In cooperation with Natural Resource Ecology Laboratory, Colorado State University, Fort Collins, Colorado

\title{
DayCent-Chem Simulations of Ecological and Biogeochemical Processes of Eight Mountain Ecosystems in the United States
}

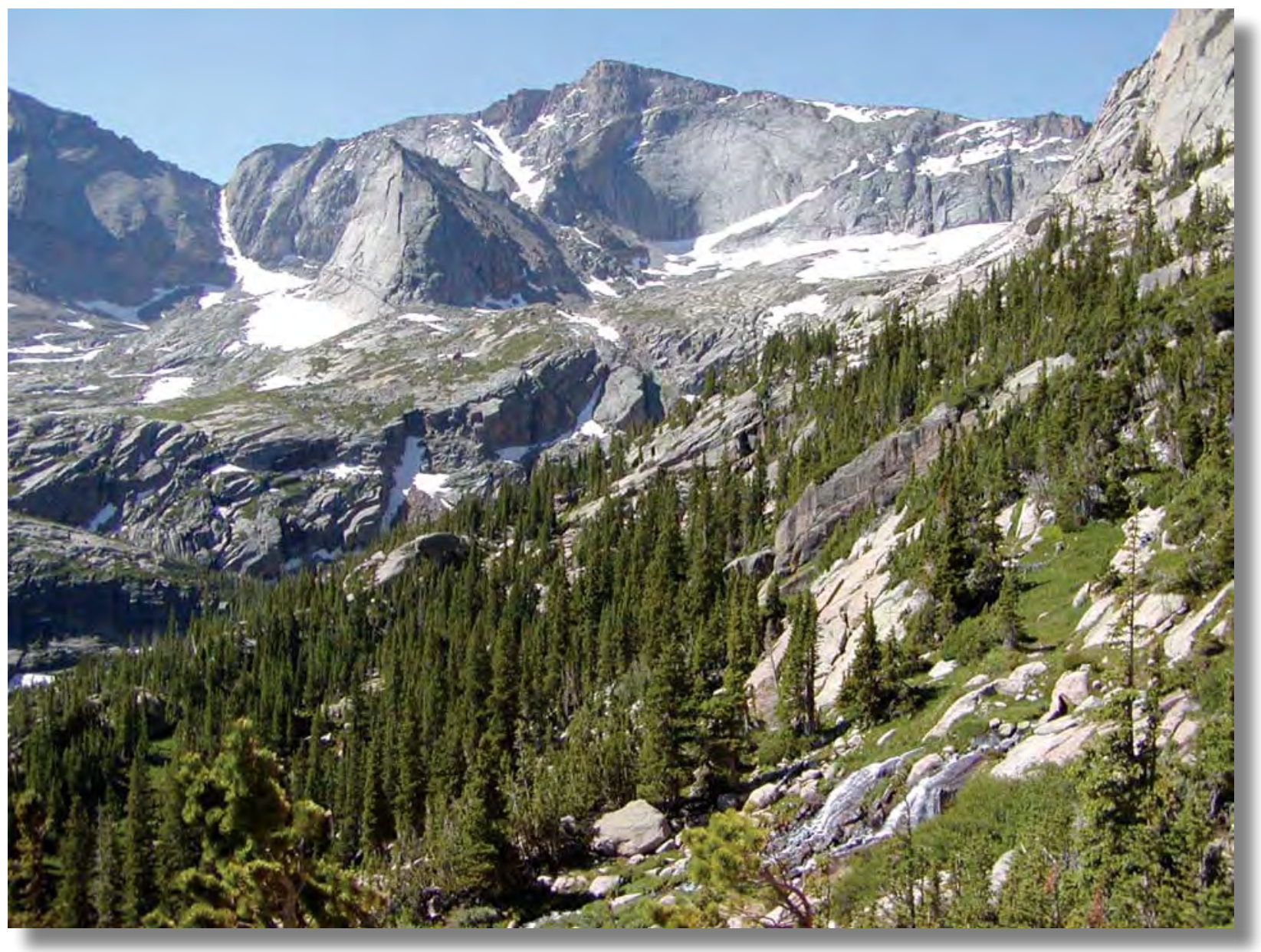

Scientific Investigations Report 2009-5150 
Photograph of a mountain forest in Rocky Mountain National Park. Photo by Melannie Hartman. 


\section{DayCent-Chem Simulations of Ecological and Biogeochemical Processes of Eight Mountain Ecosystems in the United States}

By Melannie D. Hartman, Jill S. Baron, David W. Clow, Irena F. Creed, Charles T. Driscoll, Holly A. Ewing, Bruce D. Haines, Jennifer Knoepp, Kate Lajtha, Dennis S. Ojima, William J. Parton, Jim Renfro, R. Bruce Robinson, Helga Van Miegroet, Kathleen C. Weathers, and Mark W. Williams

In cooperation with Natural Resource Ecology Laboratory, Colorado State University, Fort Collins, Colorado

Scientific Investigations Report 2009-5150 


\title{
U.S. Department of the Interior \\ KEN SALAZAR, Secretary \\ U.S. Geological Survey \\ Marcia K. McNutt, Director
}

\section{U.S. Geological Survey, Reston, Virginia: 2009}

\author{
For more information on the USGS — the Federal source for science about the Earth, its natural and living resources, \\ natural hazards, and the environment, visit http://www.usgs.gov or call 1-888-ASK-USGS \\ For an overview of USGS information products, including maps, imagery, and publications, \\ visit http://www.usgs.gov/pubprod \\ To order this and other USGS information products, visit http://store.usgs.gov
}

\begin{abstract}
Any use of trade, product, or firm names is for descriptive purposes only and does not imply endorsement by the U.S. Government.

Although this report is in the public domain, permission must be secured from the individual copyright owners to reproduce any copyrighted materials contained within this report.
\end{abstract}

Suggested citation:

Hartman, M.D., Baron, J.S., Clow, D.W., Creed, I.F., Driscoll, C.T., Ewing, H.A., Haines, B.D., Knoepp, J., Lajtha, K., Ojima, D.S., Parton, W.J., Renfro, J., Robinson, R.B., Van Miegroet, H., Weathers, K.C., and Williams, M.W., 2009, DayCent-Chem simulations of ecological and biogeochemical processes of eight mountain ecosystems in the United States: U.S. Geological Survey Scientific Investigations Report 2009-5150, 174 p. 


\section{Contents}

\section{Overview}

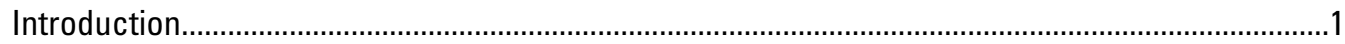

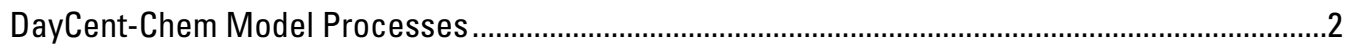

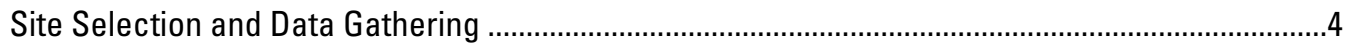

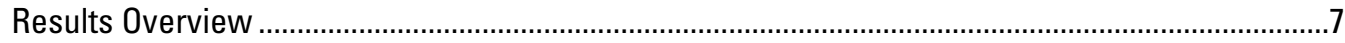

\section{Acadia National Park, Hadlock Brook Watershed, Maine}

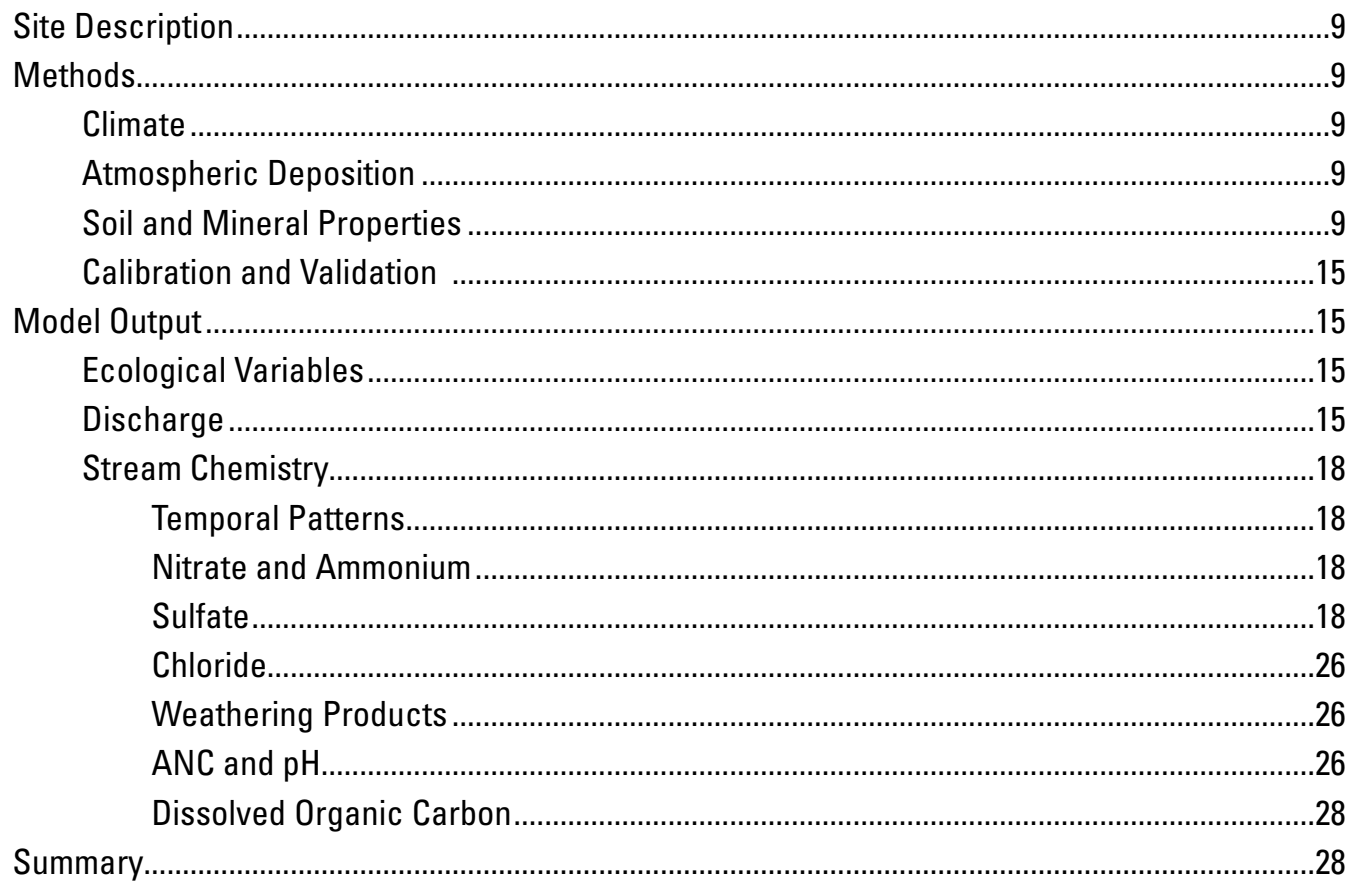

\section{Hubbard Brook Long-Term Ecological Research Site, New Hampshire}

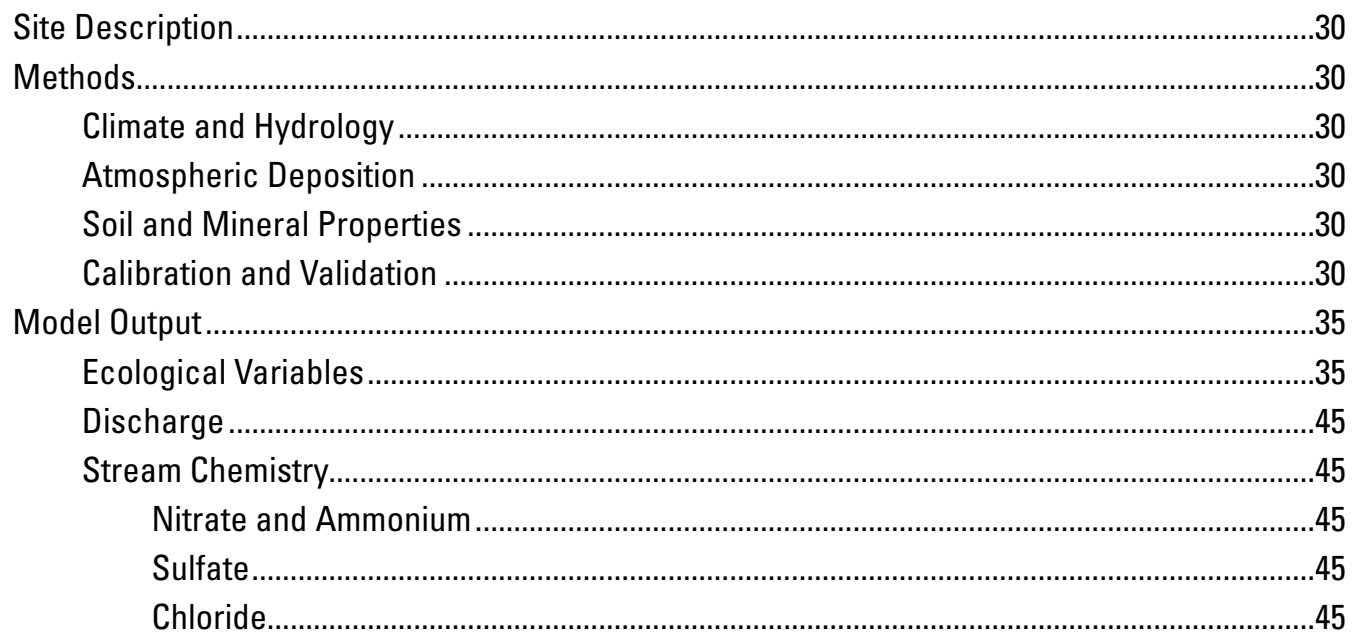




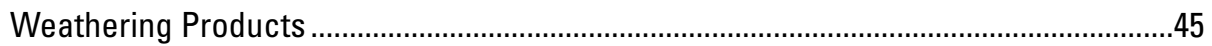

ANC and $\mathrm{pH}$

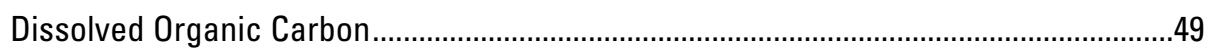

Summary

\section{Coweeta Long-Term Ecological Research Site, North Carolina}

Site Description
Methods
Climate and Hydrology
Atmospheric Deposition
Soil and Mineral Properties
Model Outputation Data
Ecological Variables
Sischarge and Stream Chemistry
$\quad$ Chloride
$\quad$ Weathering Products

\section{Great Smoky Mountains National Park, Noland Divide Watershed, North Carolina}

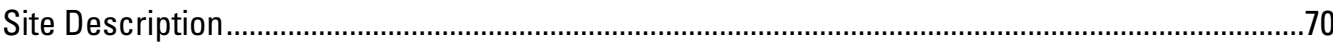

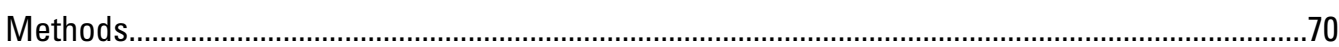

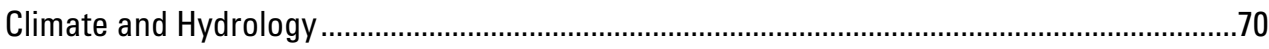

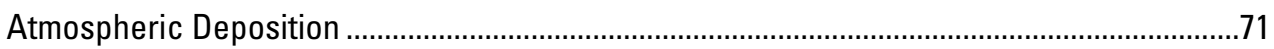

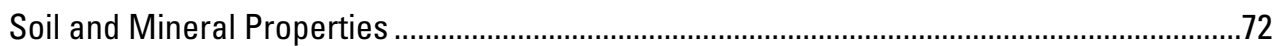

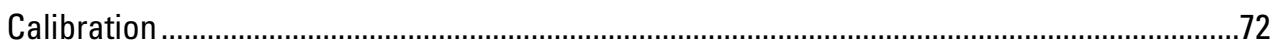

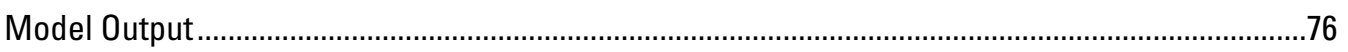

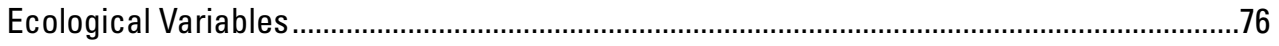

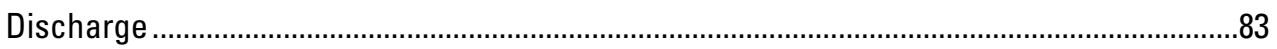

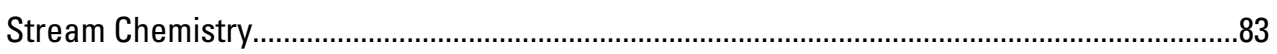

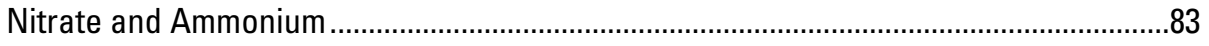

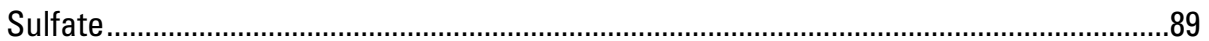

Chloride

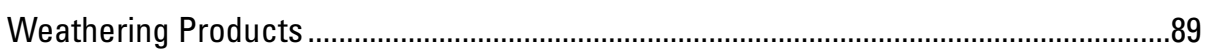

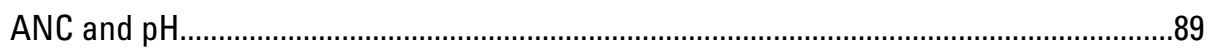

Dissolved Organic Carbon and Nitrogen ........................................................................89

Summary 


\section{Rocky Mountain National Park, Andrews Creek Watershed, Colorado}

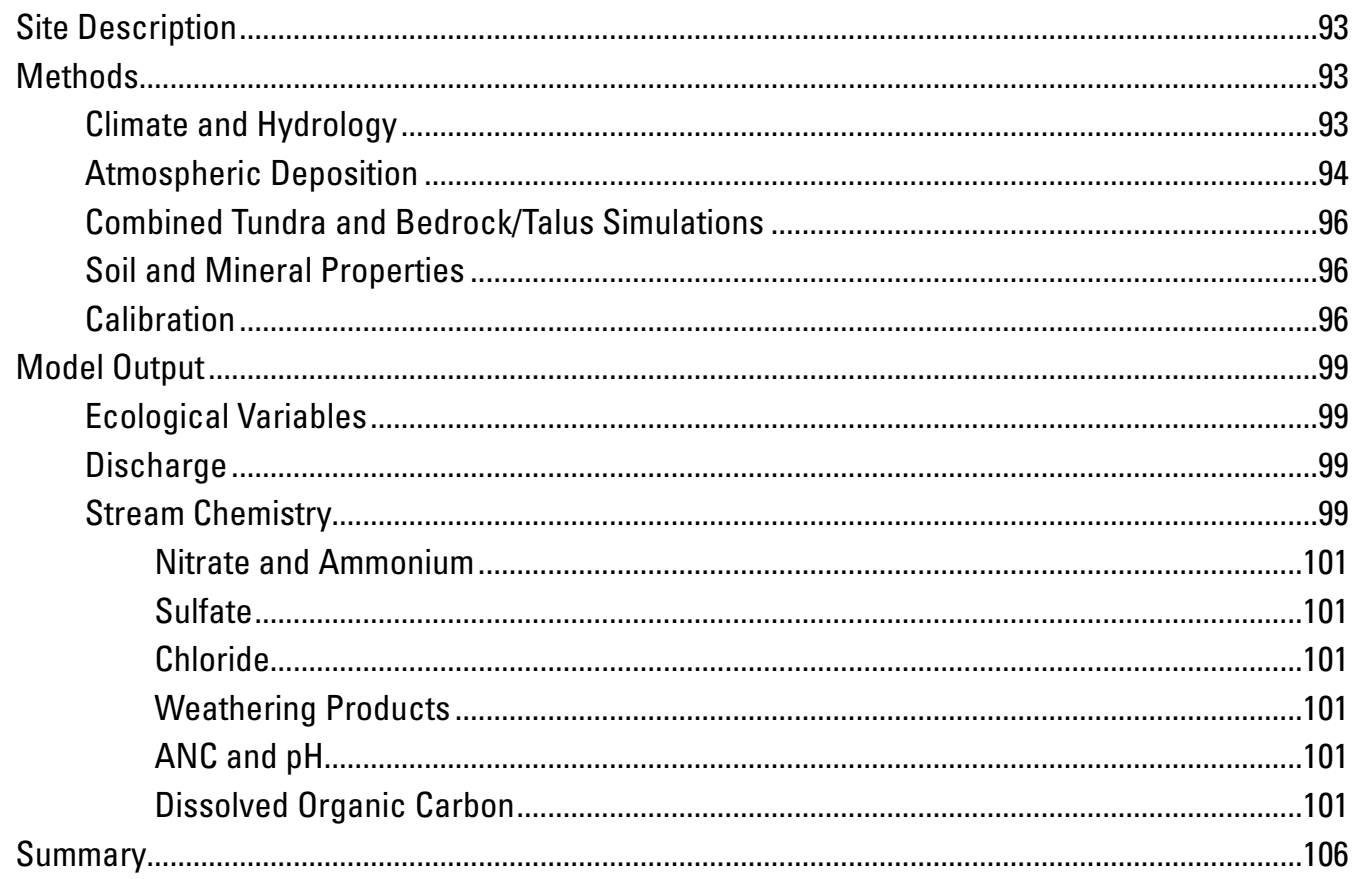

\section{Niwot Ridge Long-Term Ecological Research Site, Green Lakes Valley, Colorado}

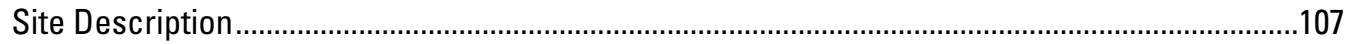

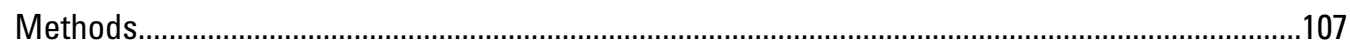

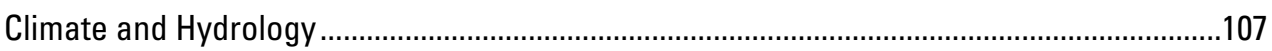

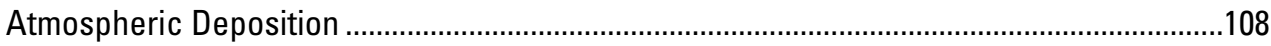

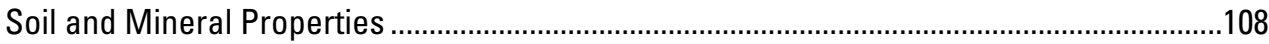

Calibration and Validation ...............................................................................................110

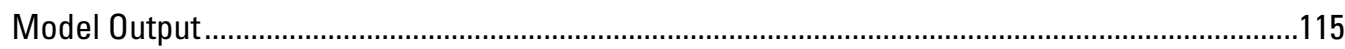

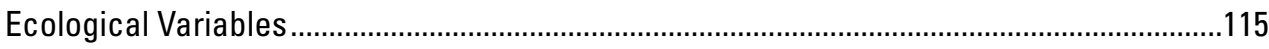

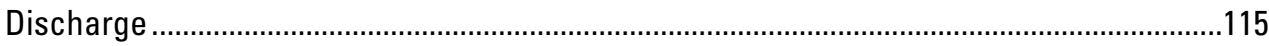

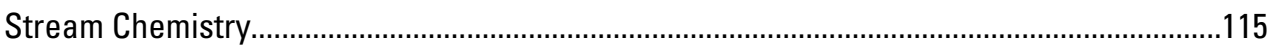

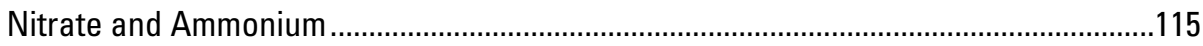

Sulfate

Chloride

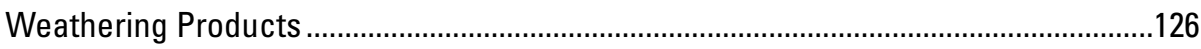

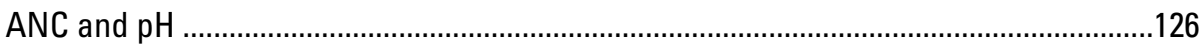

Dissolved Organic Carbon................................................................................126

Summary

\section{Mount Rainier National Park, Lake Louise Watershed, Washington}

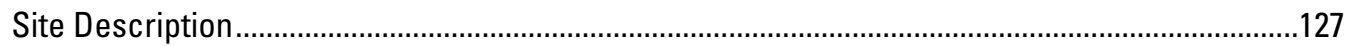

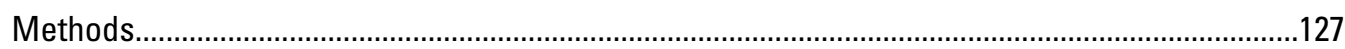




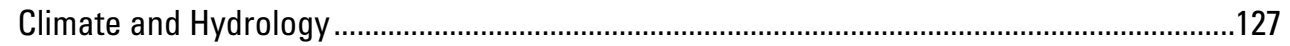

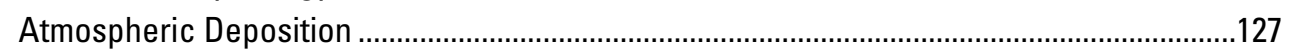

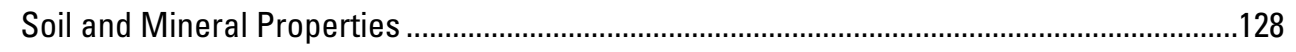

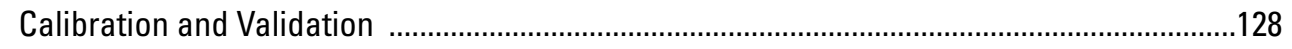

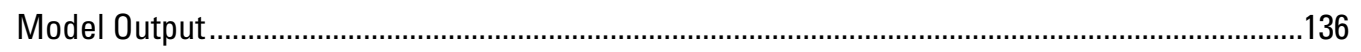

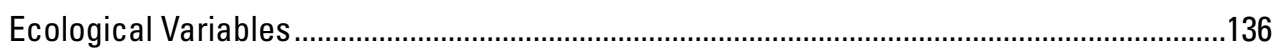

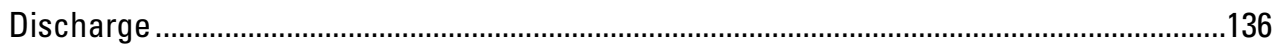

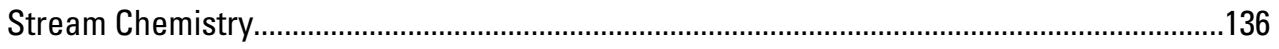

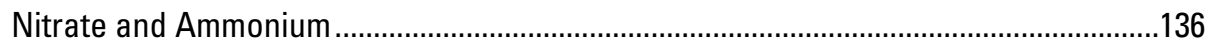

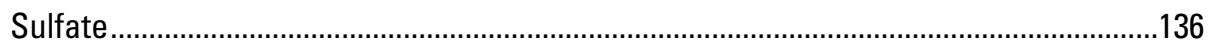

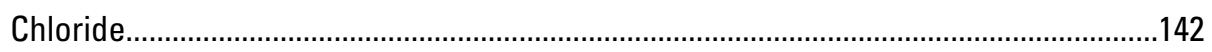

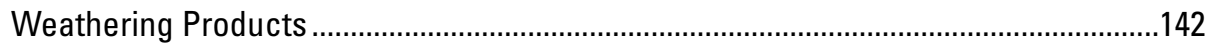

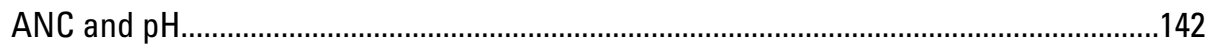

Dissolved Organic Carbon............................................................................................ 142

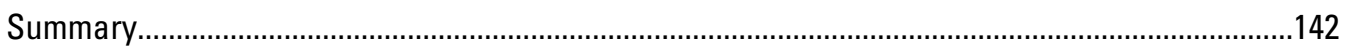

\section{H.J. Andrews Long-Term Ecological Research Site, Oregon}

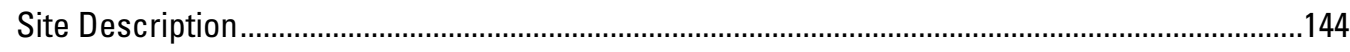

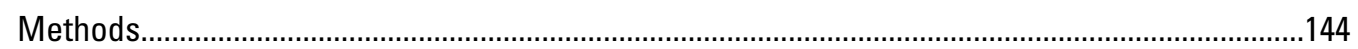

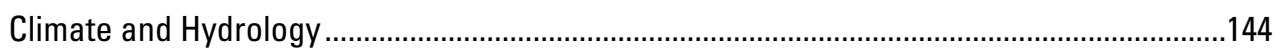

Atmospheric Deposition ....................................................................................................... 144

Soil and Mineral Properties ...................................................................................................... 144

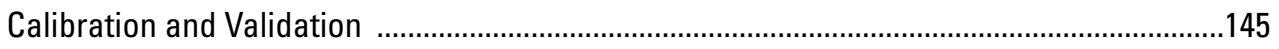

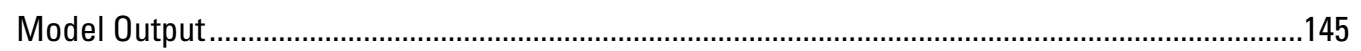

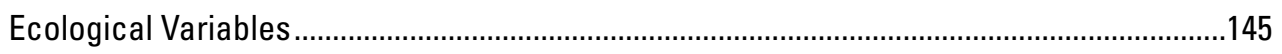

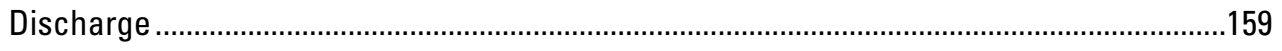

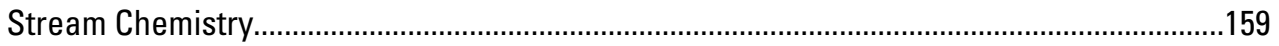

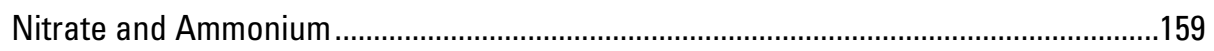

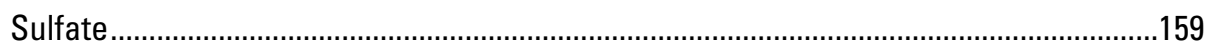

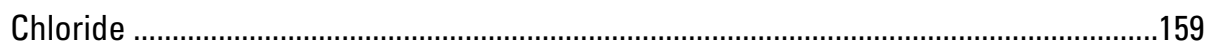

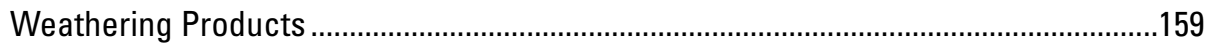

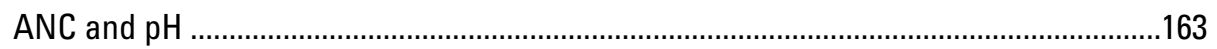

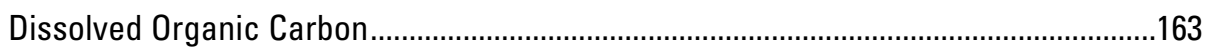

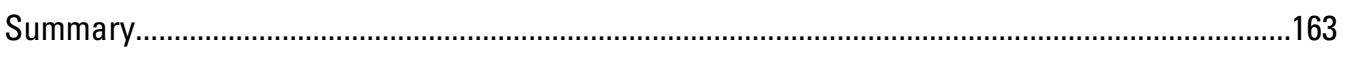

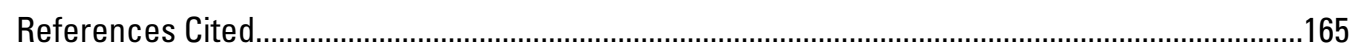

Appendix 1. Abbreviations Used in This Document. ....................................................................171

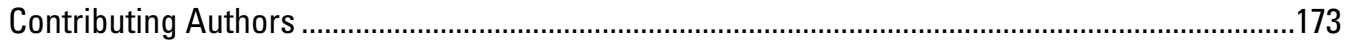




\section{Figures}

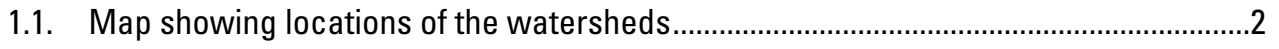

1.2. Graph showing the DayCent-Chem model processes .................................................

1.3. Photograph of participants from the first DayCent-Chem workshop held

February 2006 at Sylvan Dale Ranch, Loveland, Colorado............................................6

2.1. Map showing location of Hadlock Brook watershed in Acadia National Park, Mount Desert Island, coastal Maine .........................................................................10

2.2. Map showing vegetation in Hadlock Brook watershed and the surrounding area.....11

2.3-2.9. Graphs showing:

2.3. Meteorological statistics for Hadlock Brook watershed .......................................12

2.4. Deposition inputs to the model for Hadlock Brook watershed...............................13

2.5. Relationship between average monthly precipitation (1983-2005) and measured discharge (2000-2003) for Hadlock Brook watershed ...........................16

2.6. Simulated and observed daily discharge for Hadlock Brook watershed,

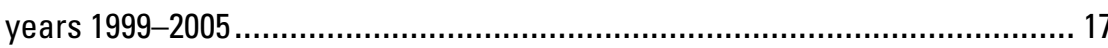

2.7. Simulated and observed discharge and volume-weighted mean stream chemistry averaged by month for Hadlock Brook watershed, years 1999-2005

2.8. Simulated and observed stream chemistry averaged by month for Hadlock Brook watershed, years 1999-2003

2.9. Simulated and observed daily stream chemistry for Hadlock Brook watershed, years 1988-1989

3.1. Map showing location of Hubbard Brook Experimental Forest in the White

Mountain National Forest, New Hampshire.

3.2-3.7. Graphs showing:

3.2. Meteorological statistics for the weather station at Hubbard Brook.

3.3. Relationship between average monthly precipitation and streamflow measured at W6, Hubbard Brook, years 1979-2004 ...........................................33

3.4. Deposition inputs to the model for Hubbard Brook .............................................34

3.5. Simulated and observed discharge and stream chemistry for W6, Hubbard Brook, years 1988-1990

3.6. Simulated and observed discharge and stream chemistry for W6, Hubbard Brook, years 2002-2004

3.7. Simulated and observed stream chemistry averaged by month for W6, Hubbard Brook, years 1979-2004.

4.1. Map showing location of Coweeta LTER in the Blue Ridge Physiographic

Province of the southern Appalachian Mountains, western North Carolina

4.2-4.7. Graphs showing:

4.2. Meteorological statistics for the weather station at Coweeta LTER

4.3. Relationship between average monthly precipitation and measured discharge for Coweeta LTER, years 1985-1995.......................................................................53

4.4. Deposition inputs to the model for Coweeta LTER

4.5. Simulated and observed daily discharge and stream chemistry for WS2, 
4.6. Simulated and observed daily discharge and stream chemistry for WS2,

Coweeta LTER, years 1988-1990

4.7. Simulated and observed stream chemistry averaged by month for WS2,

Coweeta LTER, years 1985-1995

5.1. Map showing location of Noland Divide watershed in Great Smoky Mountains National Park, North Carolina

5.2-5.7. Graphs showing:

5.2. Meteorological statistics for the weather station at Newfound Gap

5.3. Relationship between average monthly precipitation (1981-1999) and discharge for the northeast weir (1992-1999) at Noland Divide watershed.

5.4. Deposition inputs to the model for Noland Divide watershed.

5.5. Simulated and observed daily discharge and stream chemistry for Noland Divide watershed, years 1993-1995

5.6. Simulated and observed daily discharge and stream chemistry for Noland Divide watershed, years 1997-1999...

5.7. Simulated and observed discharge and volume-weighted mean stream chemistry averaged by month for Noland Divide watershed, years 1992-1999.

6.1. Map showing location of Andrews Creek watershed in Rocky Mountain National Park, Colorado.

6.2-6.5. Graphs showing:

6.2. Meteorological statistics of model inputs for Andrews Creek watershed . .95

6.3. Deposition inputs to the model for Andrews Creek watershed .

6.4. Simulated and observed daily discharge and stream chemistry for Andrews Creek watershed, years 1993-1995. 102

6.5. Simulated and observed daily discharge and stream chemistry for Andrews Creek watershed, years 2001-2003

7.1. Map showing location of Niwot Ridge LTER, approximately 35 kilometers west of Boulder, Colorado

7.2-7.8. Graphs showing:

7.2. Meteorological statistics for weather station D1 at Niwot Ridge LTER 109

7.3. Relationship between average monthly precipitation measured at Niwot Ridge LTER, weather station D1, and discharge measured at GL4, years 1989-2006.

7.4. Deposition inputs to the model for Niwot Ridge LTER . .111

7.5. Simulated and observed discharge and volume-weighted mean stream chemistry averaged by month for GL4, Niwot Ridge LTER, years 1989-2006 116

7.6. Simulated and observed daily discharge and stream chemistry for GL4, Niwot Ridge LTER, years 1993-1995.

7.7. Simulated and observed daily discharge and stream chemistry for GL4, Niwot Ridge LTER, years 1999-2006.

7.8. Simulated and measured discharge for GL4, Niwot Ridge LTER, by water year, compared with observed precipitation.

8.1. Map showing location of Lake Louise watershed in the south-central part of Mount Rainier National Park, Washington 
8.2-8.6. Graphs showing:

8.2. Meteorological statistics of model inputs for Lake Louise watershed, years 1990-2007

8.3. Relationship between average monthly precipitation (2004-2007) measured at Lake Louise watershed, and discharge (2004-2007) measured at Lake Louise........131

8.4. Deposition inputs to the model for Lake Louise watershed.....................................132

8.5. Simulated and observed daily discharge and stream chemistry for Lake Louise watershed, years 2004-2007.

8.6. Simulated and observed discharge and volume-weighted mean stream chemistry averaged by month for Lake Louise watershed, years 2004-2007

9.1. Map showing location of H.J. Andrews LTER in the western Cascade Range of Oregon

9.2-9.8. Graphs showing:

9.2. Meteorological statistics of model inputs for H.J. Andrews LTER .146

9.3. Relationship between average monthly precipitation and discharge measured at H.J. Andrews LTER, years 1981-2004.

9.4. Deposition inputs to the model for H.J. Andrews LTER . 148

9.5. Simulated and observed daily discharge and stream chemistry for WS10, H.J. Andrews LTER, years 1994-1996

9.6. Simulated and observed daily discharge and stream chemistry for WS10, H.J. Andrews LTER, years 2002-2004

9.7. Simulated and observed discharge and volume-weighted mean stream chemistry averaged by month for WS10, H.J. Andrews LTER, years 1981-2004

9.8. Measured stream $\mathrm{pH}$ versus measured stream alkalinity for seven small catchments across the United States

\section{Tables}

1.1. The names and locations of the eight watersheds included in this intersite comparison study, their ecosystem type, and working group members.

2.1. Characteristics of Hadlock Brook watershed, Acadia National Park, Maine................10

2.2. Average annual wet, dry, and total atmospheric deposition and precipitation as measured at the NADP and CASTNET sites and as simulated, years 1983-2005

2.3. Mineral phases and potential annual mineral denudation rates prescribed for the simulation $\ldots 14$

2.4. Soil layer properties used for the simulation ......................................................16

2.5. Annual average (1983-2005) simulated ecological response ........................................17

2.6. The slopes and $\mathrm{R}^{2}$ correlation coefficients from a linear regression of simulated monthly volume-weighted mean stream concentrations against measured monthly volume-weighted mean values, years 2000-2003

2.7. Annual volume-weighted mean simulated and observed stream solute concentrations and discharge, years 2000-2003

3.1. Characteristics of biogeochemical reference watershed 6 at Hubbard Brook LTER, New Hampshire. 
3.2. Average annual wet and dry plus fog deposition inputs to the model over the 1979-2004 simulation period.

3.3. Mineral weathering rates as determined by calibration ................................................35

3.4. Soil layer properties used for the simulation .............................................................35

3.5. Simulated (1979-2004) and measured ecological variables and input/output fluxes

3.6. Annual volume-weighted mean simulated and observed stream chemistry averaged over each year of the simulation.

4.1. Characteristics of Watershed 2 at Coweeta LTER, North Carolina..............................51

4.2. Average annual wet and dry plus fog deposition inputs to the model over the 1985-1995 simulation period.

4.3. Mineral phases and potential annual mineral denudation rates prescribed for the simulation

4.4. Soil layer properties used for the simulation

4.5. Simulated (1985-1995) and measured ecological variables and input/output fluxes

4.6. Annual simulated and measured mean discharge and volume-weighted mean stream chemistry averaged over each year of the simulation.

5.1. Characteristics of Noland Divide watershed in Great Smoky Mountains National Park, North Carolina

5.2. Average annual wet and dry plus fog deposition inputs to the model over the 1981-1999 simulation period.

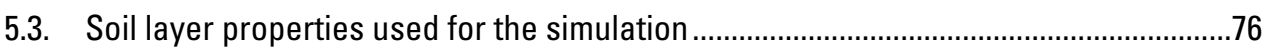

5.4. Mineral weathering rates as determined by calibration ................................................76

5.5. Simulated (1981-1999) and measured ecological variables and input/output fluxes.

5.6. Annual volume-weighted mean simulated and observed stream chemistry averaged over each year of the simulation

6.1. Characteristics of Andrews Creek watershed in Rocky Mountain National Park, Colorado

6.2. Average annual wet and dry plus fog deposition inputs to the model over the 1984-2003 simulation period

6.3. Tundra and bedrock/talus soil layer properties used for the simulation.

6.4. Mineral phases and potential annual mineral denudation rates prescribed for the alpine and bedrock/talus simulations.

6.5. Simulated and observed annual water fluxes, annual nitrogen fluxes, annual net primary production, annual range of live biomass, and average soil organic matter.

7.1. Characteristics of Green Lakes Valley catchment near Niwot Ridge LTER, Colorado

7.2. Average annual wet and dry plus fog deposition inputs to the model over the 1989-2006 simulation period

7.3. Mineral phases and potential annual mineral denudation rates prescribed for the simulation 
7.4. Soil layer properties used for the simulation

7.5. Simulated (1990-2006) and measured ecological variables and input/output fluxes

7.6. Annual volume-weighted mean simulated and observed stream chemistry averaged over each year of the simulation.

8.1. Characteristics of Lake Louise watershed in Mount Rainier National

Park, Washington.

8.2. Average annual wet and dry plus fog deposition inputs to the model over the 1990-2007 simulation period

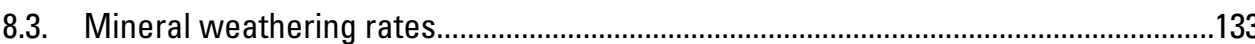

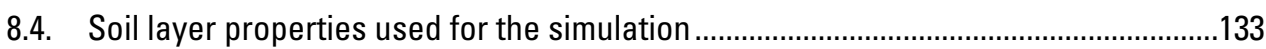

8.5. Simulated (1990-2007) and measured ecological variables and input/output fluxes

8.6. Annual volume-weighted mean simulated stream chemistry averaged over each year of the simulation.................................................................................143

9.1. Characteristics of Watershed 10 at H.J. Andrews LTER, Oregon................................145

9.2. Average annual wet and dry plus fog deposition inputs to the model over the 1981-1999 simulation period.

9.3. Mineral phases and potential annual mineral denudation rates prescribed for the simulation .149

9.4. Soil layer properties used for the simulation 149

9.5. Simulated (1981-2004) and measured ecological variables and input/output fluxes

9.6. Annual volume-weighted mean simulated and observed stream chemistry averaged over each year of the simulation. 


\section{Conversion Factors}

\section{SI to Inch/Pound}

\begin{tabular}{|c|c|c|}
\hline Multiply & By & To obtain \\
\hline \multicolumn{3}{|c|}{ Length } \\
\hline centimeter (cm) & 0.3937 & inch (in.) \\
\hline millimeter (mm) & 0.03937 & inch (in.) \\
\hline meter $(\mathrm{m})$ & 3.281 & foot $(\mathrm{ft})$ \\
\hline kilometer (km) & 0.6214 & mile (mi) \\
\hline kilometer (km) & 0.5400 & mile, nautical (nmi) \\
\hline meter $(\mathrm{m})$ & 1.094 & yard (yd) \\
\hline \multicolumn{3}{|c|}{ Area } \\
\hline square meter $\left(\mathrm{m}^{2}\right)$ & 0.0002471 & acre \\
\hline hectare (ha) & 2.471 & acre \\
\hline square kilometer $\left(\mathrm{km}^{2}\right)$ & 247.1 & acre \\
\hline square meter $\left(\mathrm{m}^{2}\right)$ & 10.76 & square foot $\left(\mathrm{ft}^{2}\right)$ \\
\hline hectare (ha) & 0.003861 & square mile $\left(\mathrm{mi}^{2}\right)$ \\
\hline square kilometer $\left(\mathrm{km}^{2}\right)$ & 0.3861 & square mile $\left(\mathrm{mi}^{2}\right)$ \\
\hline \multicolumn{3}{|c|}{ Volume } \\
\hline cubic meter $\left(\mathrm{m}^{3}\right)$ & 6.290 & barrel (petroleum, 1 barrel = 42 gal) \\
\hline liter $(\mathrm{L})$ & 33.82 & ounce, fluid (fl. oz) \\
\hline liter (L) & 2.113 & pint (pt) \\
\hline liter $(\mathrm{L})$ & 1.057 & quart (qt) \\
\hline liter (L) & 0.2642 & gallon (gal) \\
\hline cubic meter $\left(\mathrm{m}^{3}\right)$ & 264.2 & gallon (gal) \\
\hline cubic meter $\left(\mathrm{m}^{3}\right)$ & 0.0002642 & million gallons (Mgal) \\
\hline cubic centimeter $\left(\mathrm{cm}^{3}\right)$ & 0.06102 & cubic inch $\left(i^{3}\right)$ \\
\hline liter $(\mathrm{L})$ & 61.02 & cubic inch $\left(\mathrm{in}^{3}\right)$ \\
\hline cubic meter $\left(\mathrm{m}^{3}\right)$ & 35.31 & cubic foot $\left(\mathrm{ft}^{3}\right)$ \\
\hline cubic meter $\left(\mathrm{m}^{3}\right)$ & 1.308 & cubic yard $\left(\mathrm{yd}^{3}\right)$ \\
\hline cubic meter $\left(\mathrm{m}^{3}\right)$ & 0.0008107 & acre-foot (acre-ft) \\
\hline \multicolumn{3}{|c|}{ Flow rate } \\
\hline cubic meter per second $\left(\mathrm{m}^{3} \mathrm{~s}^{-1}\right)$ & 70.07 & acre-foot per day (acre-ft d ${ }^{-1}$ ) \\
\hline cubic meter per second $\left(\mathrm{m}^{3} \mathrm{~s}^{-1}\right)$ & 35.31 & cubic foot per second $\left(\mathrm{ft}^{3} \mathrm{~s}^{-1}\right)$ \\
\hline liter per second $\left(\mathrm{L} \mathrm{s}^{-1}\right)$ & 15.85 & gallon per minute (gal min ${ }^{-1}$ ) \\
\hline cubic meter per second $\left(\mathrm{m}^{3} \mathrm{~s}^{-1}\right)$ & 22.83 & $\begin{array}{l}\text { million gallons per day } \\
\left(\text { Mgal d }^{-1}\right)\end{array}$ \\
\hline centimeter per second $\left(\mathrm{cm} \mathrm{sec}^{-1}\right)$ & 0.3937 & inch per second (in sec ${ }^{-1}$ ) \\
\hline $\begin{array}{l}\text { centimeter per day }\left(\mathrm{cm} \mathrm{d}^{-1}\right) \text { or } \\
(\mathrm{cm} / \text { day })\end{array}$ & 0.3937 & inch per day (in $\mathrm{d}^{-1}$ ) \\
\hline $\begin{array}{l}\text { centimeter per month }\left(\mathrm{cm} \mathrm{mo}^{-1}\right) \\
\text { or }(\mathrm{cm} / \mathrm{mo})\end{array}$ & 0.3937 & inch per month (in mo-1) \\
\hline $\begin{array}{l}\text { centimeter per year }\left(\mathrm{cm} \mathrm{yr}^{-1}\right) \text { or } \\
(\mathrm{cm} / \mathrm{yr})\end{array}$ & 0.3937 & inch per year (in $\mathrm{yr}^{-1}$ ) \\
\hline
\end{tabular}




\begin{tabular}{|c|c|c|}
\hline \multicolumn{3}{|c|}{ Mass } \\
\hline gram (g) & 0.03527 & ounce, avoirdupois (oz) \\
\hline kilogram (kg) & 2.205 & pound avoirdupois (lb) \\
\hline megagram (Mg) & 1.102 & ton, short $(2,000 \mathrm{lb})$ \\
\hline megagram $(\mathrm{Mg})$ & 0.9842 & ton, long $(2,240 \mathrm{lb})$ \\
\hline \multicolumn{3}{|c|}{ Density } \\
\hline gram per cubic centimeter $\left(\mathrm{g} \mathrm{cm}^{-3}\right)$ & 62.4220 & pound per cubic foot $\left(\mathrm{lb} \mathrm{ft}^{-3}\right)$ \\
\hline \multicolumn{3}{|c|}{ Hydraulic conductivity } \\
\hline centimeter per sec $\left(\mathrm{cm} \mathrm{s}^{-1}\right)$ & 0.3937 & inches per sec (in $\mathrm{s}^{-1}$ ) \\
\hline meter per day $\left(\mathrm{m} \mathrm{d}^{-1}\right)$ & 3.281 & foot per day $\left(\mathrm{ft} \mathrm{d}^{-1}\right)$ \\
\hline \multicolumn{3}{|c|}{ Application rate } \\
\hline $\begin{array}{l}\text { grams per square meter per year } \\
\qquad\left(\mathrm{g} \mathrm{m}^{-2} \mathrm{yr}^{-1}\right)\end{array}$ & 0.08921 & $\begin{array}{l}\text { pounds per acre per year } \\
\quad\left(\mathrm{lb} \mathrm{acre}^{-1} \mathrm{yr}^{-1}\right)\end{array}$ \\
\hline $\begin{array}{l}\text { kilograms per hectare per year } \\
\left(\mathrm{kg} \mathrm{ha}^{-1} \mathrm{yr}^{-1}\right)\end{array}$ & 0.8921 & $\begin{array}{l}\text { pounds per acre per year } \\
\left(\mathrm{lb} \mathrm{acre}^{-1} \mathrm{yr}^{-1}\right)\end{array}$ \\
\hline
\end{tabular}

Temperature in degrees Celsius $\left({ }^{\circ} \mathrm{C}\right)$ may be converted to degrees Fahrenheit $\left({ }^{\circ} \mathrm{F}\right)$ as follows:

$$
{ }^{\circ} \mathrm{F}=\left(1.8 \times^{\circ} \mathrm{C}\right)+32
$$

Temperature in degrees Fahrenheit $\left({ }^{\circ} \mathrm{F}\right)$ may be converted to degrees Celsius $\left({ }^{\circ} \mathrm{C}\right)$ as follows:

$$
{ }^{\circ} \mathrm{C}=\left({ }^{\circ} \mathrm{F}-32\right) / 1.8
$$

Vertical coordinate information is referenced to the insert datum name (and abbreviation) here, for instance, "North American Vertical Datum of 1988 (NAVD 88)"

Horizontal coordinate information is referenced to the insert datum name (and abbreviation) here, for instance, "North American Datum of 1983 (NAD 83)"

Elevation, as used in this report, refers to meters above mean sea level (m.a.s.I.).

Concentrations of chemical constituents in water are given either in milligrams per liter ( $\mathrm{mg} / \mathrm{L}$ ) or microequivalents per liter ( $\mu \mathrm{eq} / \mathrm{L})$.

NOTE TO USGS USERS: Use of hectare (ha) as an alternative name for square hectometer $\left(\mathrm{hm}^{2}\right)$ is restricted to the measurement of small land or water areas. Use of liter $(\mathrm{L})$ as a special name for cubic decimeter $\left(\mathrm{dm}^{3}\right)$ is restricted to the measurement of liquids and gases. No prefix other than milli should be used with liter. Metric ton (t) as a name for megagram $(\mathrm{Mg})$ should be restricted to commercial usage, and no prefixes should be used with it. 


\section{Acknowledgments}

We gratefully acknowledge support from the Environmental Protection Agency, the U.S. Geological Survey, the National Park Service, and the U.S. Department of Agriculture Forest Service. Lois St. Brice-an undergraduate at Bates College who was mentored by H. Ewing, M. Hartman, and K. Weathers in exploring DayCent-Chem's performance and sensitivity for an Honor's thesis during 2006-2007-expanded these principal investigators' understanding of the model and of ecosystem dynamics at Acadia National Park. Programming, database, and statistical support were provided by Cindy Keough, Lee Casuto, and Guoming Wang. Todd Ackerman, Howard Bruner, and John Campbell assisted with the data collection. 


\title{
DayCent-Chem Simulations of Ecological and Biogeochemical Processes of Eight Mountain Ecosystems in the United States
}

\author{
By Melannie D. Hartman, Jill S. Baron, David W. Clow, Irena F. Creed, Charles T. Driscoll, Holly A. Ewing, \\ Bruce D. Haines, Jennifer Knoepp, Kate Lajtha, Dennis S. Ojima, William J. Parton, Jim Renfro, R. Bruce \\ Robinson, Helga Van Miegroet, Kathleen C. Weathers, and Mark W. Williams
}

\section{Overview}

\section{Introduction}

Agencies such as the Environmental Protection Agency (EPA), National Park Service (NPS), and U.S. Forest Service (FS) are charged with protecting, managing, and restoring ecosystems. The National Research Council recently called on agencies to work together and, with other partners, to assess the capabilities of current authorities for ecosystem protection (for example, Clean Air Act mechanisms) and implement new, innovative ecosystem protection approaches and benchmarks (National Research Council, 2004).

An important area of ecosystem protection involves developing and implementing policies and programs to control atmospheric pollutant emissions and subsequent deposition in downwind ecosystems. Atmospheric deposition patterns of nitrogen $(\mathrm{N})$ and sulfur $(\mathrm{S})$ compounds are changing across the United States, with increasing $\mathrm{N}$ emissions in some regions and decreasing $\mathrm{N}$ and $\mathrm{S}$ in others (Nilles and Conley, 2001; Butler and others, 2003; Fenn and others, 2003). Inputs of N and S cause complex responses in ecosystems, from fertilization to forest ecosystem decline, freshwater eutrophication to acidification, loss of soil base cations, and alterations of disturbance regimes (Weathers and Lovett, 1998; Baron, Rueth, and others, 2000; Driscoll and others, 2001; Weathers, Likens, and Butler, 2006; Weathers, Simkin, and others, 2006).

An essential component of policy development involves understanding the ecological impacts of potential policies. Ecosystem assessment tools should be enhanced so that they can allow agencies to better and more comprehensively assess both aquatic and terrestrial ecosystem response to sulfur and nitrogen loading. We recognize, however, that our understanding of how ecosystems respond, especially to excess $\mathrm{N}$ inputs-alone or in conjunction with $\mathrm{S}$ or other pollutants-is imperfect at best. Geochemically-based models developed during the National Acid Precipitation Assessment Program, which can be used to explore ecosystem responses to atmospheric deposition, largely ignore the dynamic biological cycling of N. Models such as PnET-BGC, NuCM, and DayCent-Chem that address both ecological response to increasing $\mathrm{N}$ availability and soil biogeochemical dynamics of strong acid anion leaching have been run successfully for different ecosystems (Johnson and others, 2000; GbondoTugbawa and others, 2001; Backx, 2004; Hartman and others, 2007). One primary difference between DayCent-Chem and PnET-BGC is model time step: DayCent-Chem operates at a daily time step, where PnET-PGC is a monthly time step model. When investigating ecosystem and surface water chemical response to episodic events such as storm flow, snowmelt, and disturbances, finer temporal resolution may be desirable. The model NuCM (Liu and others, 1991) is a stand-level model that depicts the cycling of $\mathrm{N}$, phosphorus $(\mathrm{P})$, potassium $(\mathrm{K})$, calcium $(\mathrm{Ca})$, magnesium $(\mathrm{Mg})$, and $\mathrm{S}$ on daily or monthly time scales and includes canopy processes and biological cycling of base cations that DayCent-Chem does not. Unlike DayCent-Chem, NuCM does not simulate stream chemistry, the microbial uptake of nutrients, or ecosystem carbon accumulation. Further work with these models is needed for better prediction of the ecosystem effects of different deposition scenarios.

DayCent-Chem combines ecosystem nutrient cycling and plant dynamics with an aqueous geochemical equilibrium model (Hartman and others, 2007). DayCent-Chem was developed and tested on Andrews Creek, an alpine ecosystem in Loch Vale watershed, a long-term ecological research and monitoring site in Rocky Mountain National Park since 1983 (Baron, 1992; Baron, Hartman, and others, 2000. This report presents DayCent-Chem model application procedures 
and results from Andrews Creek watershed (ANDCRK) in Rocky Mountain National Park (Chapter 6) and seven additional mountain catchments across the United States (fig. 1.1). The watersheds that were modeled represent a diverse set of vegetation.

- Hadlock Brook in Acadia National Park (ACAD) is a mixed deciduous-coniferous forest in coastal Maine (Chapter 2).

- Watershed 6 in Hubbard Brook (HBR) Long-Term Ecological Research (LTER) site, N.H., represents northern hardwood forests (Chapter 3).

- Watershed 2 in Coweeta (CWT) LTER, N.C., is vegetated with eastern deciduous forest (Chapter 4).

- Red spruce is the dominant vegetation at Noland Divide watershed in the Great Smoky Mountains National Park (GRSM) site in North Carolina (Chapter 5).

- The Green Lakes Valley of the Niwot Ridge LTER (NWT), Colo., is alpine (Chapter 7).
- Lake Louise in Mount Rainier National Park (MORA), Wash., is a subalpine coniferous forest (Chapter 8).

- Watershed 10 at the H.J. Andrews LTER (HJA), Oreg., is a maritime coniferous forest (Chapter 9).

Acronyms used in this document are defined in Appendix 1.

\section{DayCent-Chem Model Processes}

DayCent-Chem was developed to address ecosystem responses to combined atmospheric nitrogen and sulfur deposition. As sulfur dioxide emissions in the United States have decreased sharply in response to the U.S. Clean Air Act Amendments, the importance of atmospheric nitrogen species in wet and dry deposition has become apparent. In many parts of the world, nitrogen deposition is projected to rise (Galloway and others, 2008). Nitrogen is a critical nutrient for plants and microbes, and any realistic projection of effects of atmospheric deposition must consider the influence of nitrogen on biogeochemical cycling processes. Many of these ecosystem processes, such as primary productivity, decomposition rates,

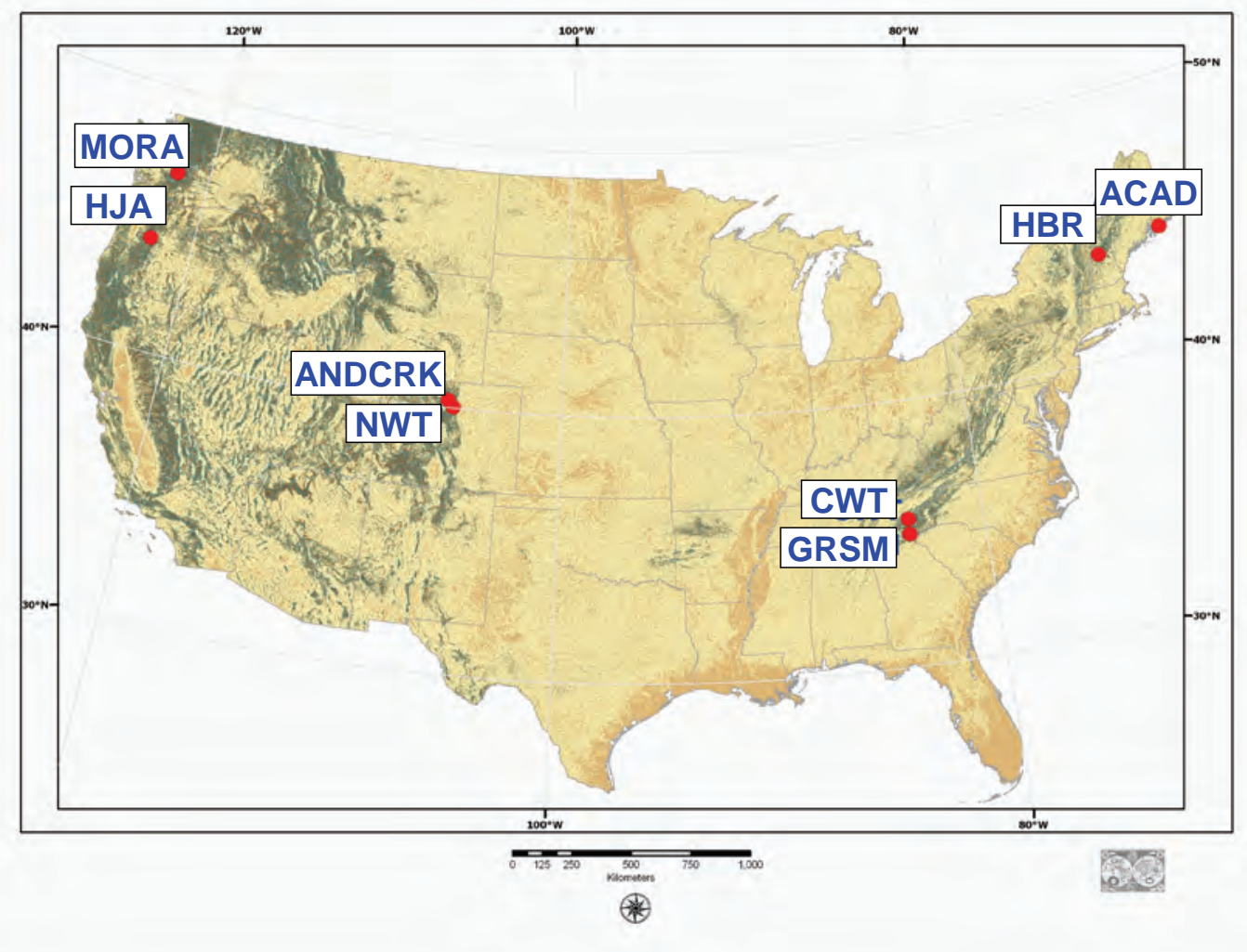

Figure 1.1. Locations of the watersheds included in this intersite comparison study: Acadia National Park (ACAD), Hubbard Brook (HBR) Long-Term Ecological Research (LTER) site, Coweeta LTER (CWT), Great Smoky Mountains National Park (GRSM), Andrews Creek watershed in Rocky Mountain National Park (ANDCRK), Niwot Ridge LTER (NWT), Mount Rainier National Park (MORA), and H.J. Andrews LTER (HJA). 
trace gas fluxes, and alteration of species assemblages, are important in their own right, and including them in the evaluation of the interaction of nitrogen deposition can inform both scientists and policy makers of changes caused by nitrogen in advance of, or coincident with, changes in water chemistry.

DayCent-Chem links together two widely accepted and tested models-(1) a daily time-step nutrient cycling and soil hydrology model, version 5 of the DayCent model (Parton and others, 1998), and (2) PHREEQC, an aqueous geochemical equilibrium model (Parkhurst and Appelo, 1999) - to form a model that simulates N, P, S, and carbon (C) ecosystem dynamics and soil and stream water acid-base chemistry (fig. 1.2). DayCent-Chem computes atmospheric deposition, soil water fluxes, snowpack and stream dynamics, plant production and uptake, soil organic matter decomposition, mineralization, nitrification, and denitrification (left side of fig. 1.2) while utilizing PHREEQC's low-temperature aqueous geochemical equilibrium calculations, including $\mathrm{CO}_{2}$ dissolution, mineral denudation, and cation exchange, to compute soil water and stream chemistry (right side of figure). DayCentChem's daily soil solution and stream water chemistry calculations make it possible to use the model to investigate the potential for episodic acidification. The full model description was published in the journal "Ecological Modeling” (Hartman and others, 2007).

Inputs to DayCent-Chem include daily precipitation amount and ionic concentrations, daily minimum and maximum air temperatures, and the daily dry:wet deposition ratios that specify the combined amount of deposition from gas, particulates, and aerosols. Annual denudation rates of common primary and secondary minerals are also model inputs, and each mineral can be dictated to dissolve only, to precipitate only, or to do either. The user specifies the distribution of minerals among the soil layers, groundwater, and stream.

Atmospheric deposition occurs in wet and dry forms. If the air temperature is cold enough, deposition and precipitation will be routed to the snowpack; otherwise, they will be

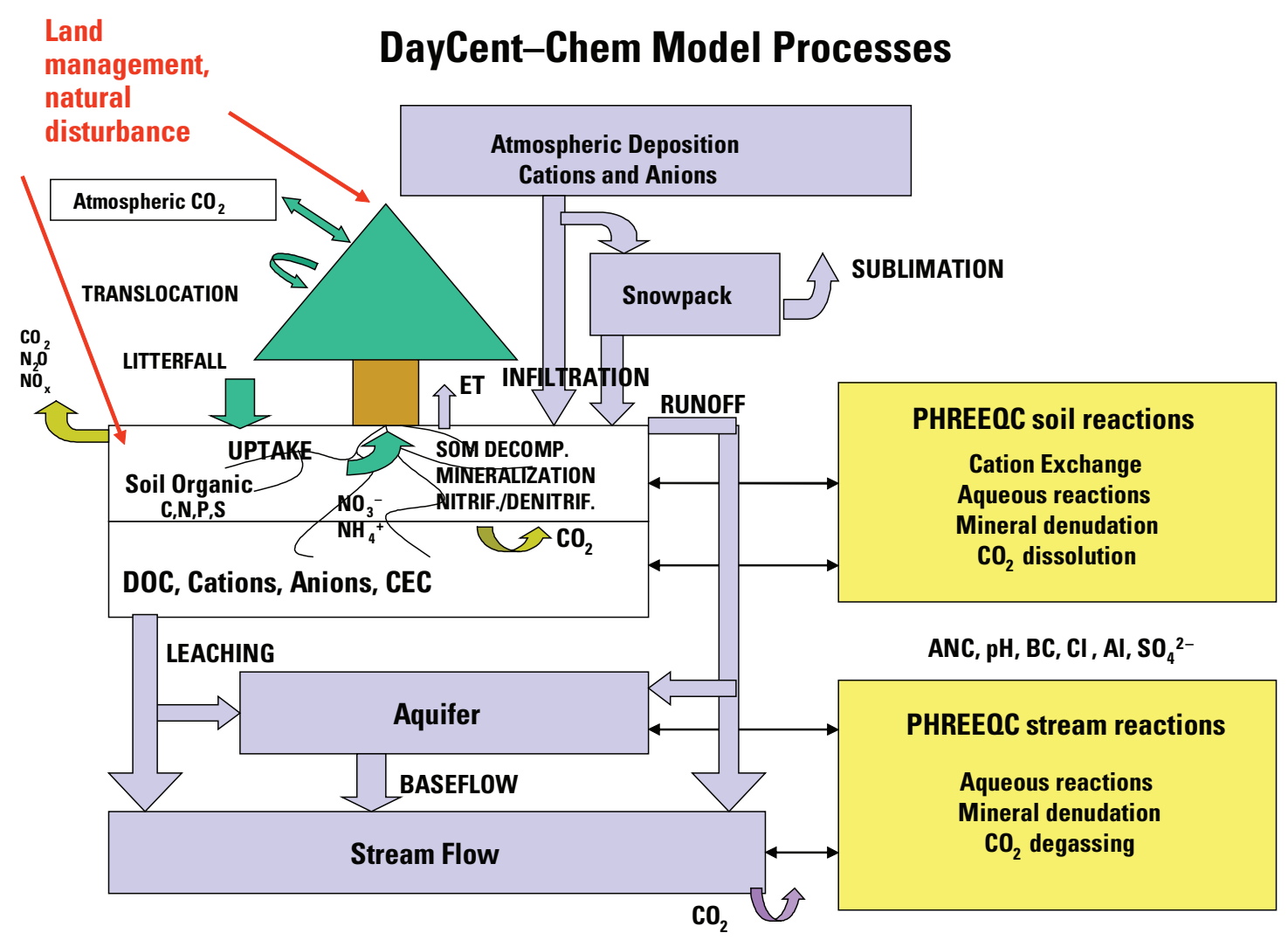

Figure 1.2. DayCent-Chem model processes. DayCent-Chem computes atmospheric deposition, soil water fluxes, snowpack and stream dynamics, plant production and uptake, soil organic matter decomposition, mineralization, nitrification, and denitrification (left side of figure) while utilizing PHREEOC's low-temperature aqueous geochemical equilibrium calculations, including $\mathrm{CO}_{2}$ dissolution, mineral denudation, and cation exchange, to compute soil water and stream chemistry (right side of figure). ET = evapotranspiration; DOC = dissolved organic carbon; $\mathrm{CEC}=$ cation exchange capacity; ANC = acid neutralizing capacity; $\mathrm{BC}$ = base cations $(\mathrm{Ca}, \mathrm{Mg}, \mathrm{K}, \mathrm{Na})$. 
DayCent-Chem Simulations of Ecological and Biogeochemical Processes of Eight Mountain Ecosystems in the U.S.

routed to the soil surface where they can infiltrate the soil, seep into groundwater, or run off directly to streamflow. Additional N, P, and S may be incorporated into the top soil layer through inorganic fertilizer or organic matter additions.

Rain and snowmelt that do not infiltrate the soil surface carry precipitation solutes to the streamflow along with dissolved organics leached from surface litter, although a fraction of surface runoff can be routed to groundwater for deferred release into the stream. Snowmelt and rainfall that infiltrate the soil move upward or downward in one dimension through a multilayered soil profile before entering the aquifer or stream. Upward movement of water (but not solutes) occurs as water evaporates directly from the soil or is transpired by plants. The downward movement of water through the soil leaches organic and inorganic species. The model directs a constant fraction of soil drainage to streamflow and to groundwater; a constant fraction of groundwater is routed to streamflow. Some of the $\mathrm{CO}_{2}$ carried from soil solutions and groundwater degasses as it encounters the lower partial pressure of the atmosphere. Geochemical reactions in streamflow and groundwater include the same aqueous reactions defined for soils, except for cation exchange.

DayCent-Chem can simulate growth of one herbaceous vegetation type, one woody vegetation type, and (or) both simultaneously, with growth depending on plant type characteristics and limits on temperature, moisture, and nutrients. Carbon is dynamically allocated to above- and below-ground plant parts according to nutrient availability, water stress, and vegetation type. Plants take up nutrients (nitrate, ammonium, $\mathrm{P}$, and S) from soil as needed to maintain carbon:nutrient ratios in the range specified for the plant. Nutrients from senescing leaves are translocated to plant storage at the end of the growing season. Dead plant material remains standing or is dropped onto the soil surface. Some plant types are able to reduce their mineral $\mathrm{N}$ demand by symbiotically fixing nitrogen. Because the DayCent model simulates only C, N, P, and S dynamics, there is no assimilation of base cations ( $\mathrm{Ca}, \mathrm{Mg}, \mathrm{K}, \mathrm{Na}$ ) by plants in the linked model; we assume that annual plant uptake of these four nutrients equals the amount released through decomposition of plant material. This assumption may hold for undisturbed ecosystems, but not for recently disturbed areas or relatively young forests.

Organic matter is incorporated into the soil through decay of litter and roots. Decomposing organic matter is redistributed among active, passive, and slow pools while $\mathrm{N}, \mathrm{P}$, and $\mathrm{S}$ are either mineralized or immobilized. The $\mathrm{CO}_{2}$ produced by heterotrophic respiration is dissolved in soil solutions. Nitrification and denitrification produce $\mathrm{N}_{2}, \mathrm{~N}_{2} \mathrm{O}$, and $\mathrm{NO}_{x}$ through oxidation and reduction of ammonium and nitrate, respectively. Rainfall and snowmelt infiltrating the litter leach dissolved organic C, N, P, and S. Both inorganic and organic species are transported downward with water that further leaches organic and mineral soil. A portion of dissolved organic carbon (DOC) is organic acid that reacts with other species in soil and stream solutions to influence their chemistry.

Dissolution of primary and secondary minerals releases base cations, aluminum ( $\mathrm{Al})$ hydroxides, bicarbonate $\left(\mathrm{HCO}_{3}^{-}\right.$ or $\mathrm{HCO}_{3}$ ), metallic cations, hydrogen $(\mathrm{H})$ ions, silica (Si), sulfate $\left(\mathrm{SO}_{4}{ }^{2-}\right.$ or $\left.\mathrm{SO}_{4}\right)$, and other inorganic species into soil layer, groundwater, and stream solutions. The maximum amount of any mineral that can be dissolved within a solution on a given day is calculated by dividing its annual denudation rate by 365. The dissolution of minerals described in the PHREEQC database is assumed to be complete without intermediate weathering products. Minerals can dissolve until they reach equilibrium with the solution, or until the maximum daily amount has been dissolved, whichever comes first. No kinetically limited mineral dissolution reactions are considered. Minerals precipitate when their components are oversaturated in solution. For some sites, we allowed minerals such as gibbsite and kaolinite to precipitate or dissolve to account for incomplete dissolution.

Cations in solution are adsorbed and desorbed from permanent, negatively charged exchange sites $\left(\mathrm{X}^{-}\right)$. During simulation the amount of exchangeable cations in each soil layer is updated based on solute concentrations in soil solution. Sulfate adsorption is calculated as a Langmuir isotherm.

Acid-neutralizing capacity (ANC) was calculated as the sum of $\mathrm{H}^{+}$acceptors, $\mathrm{HCO}_{3}$, Al-hydroxides, and the organic analog anion in soil solution $\left(\mathrm{Org}^{3-}\right)$, minus the sum of $\mathrm{H}^{+}$ donors (equation 1).

$$
\begin{aligned}
\mathrm{ANC} & =\left[\mathrm{HCO}_{3}^{-}\right]+2\left[\mathrm{CO}_{3}{ }^{2-}\right]+\left[\mathrm{OH}^{-}\right]-\left[\mathrm{H}^{+}\right]+\left[\mathrm{Al}(\mathrm{OH})_{2}^{+}\right. \\
& +3\left[\mathrm{Al}(\mathrm{OH})_{4}^{-}\right]+\left[\mathrm{HOrg}^{2-}\right]+2\left[\mathrm{Org}^{3-}\right]+[\mathrm{AlOrg}]
\end{aligned}
$$

\section{Site Selection and Data Gathering}

Site selection was based on sites of interest to the NPS and EPA; a gradient of $\mathrm{N}$ deposition across locales, from relatively pristine (HJA, MORA) to N-saturated (GRSM); a variety of ecosystem types and climates; availability of data to parameterize the model; and the interest of participating scientists (table 1.1, fig. 1.3). Data were gathered from site databases, literature surveys, and expert judgment. For MORA and ACAD, samples were collected specifically to support the modeling effort. The mechanism for this work included intensive modeling efforts interspersed with workshops to evaluate results, calibrate the model, and develop deposition scenarios.

Model algorithms for several different processes and model output were iteratively refined through a series of workshops and meetings that took place from February 2006 to March 2007 (fig. 1.3). In addition to improving the model, the meetings resulted in a cumulative enthusiasm for the capabilities of a model such as DayCent-Chem, a growing awareness 
Table 1.1. The names and locations of the eight watersheds included in this intersite comparison study, their ecosystem type, and working group members.

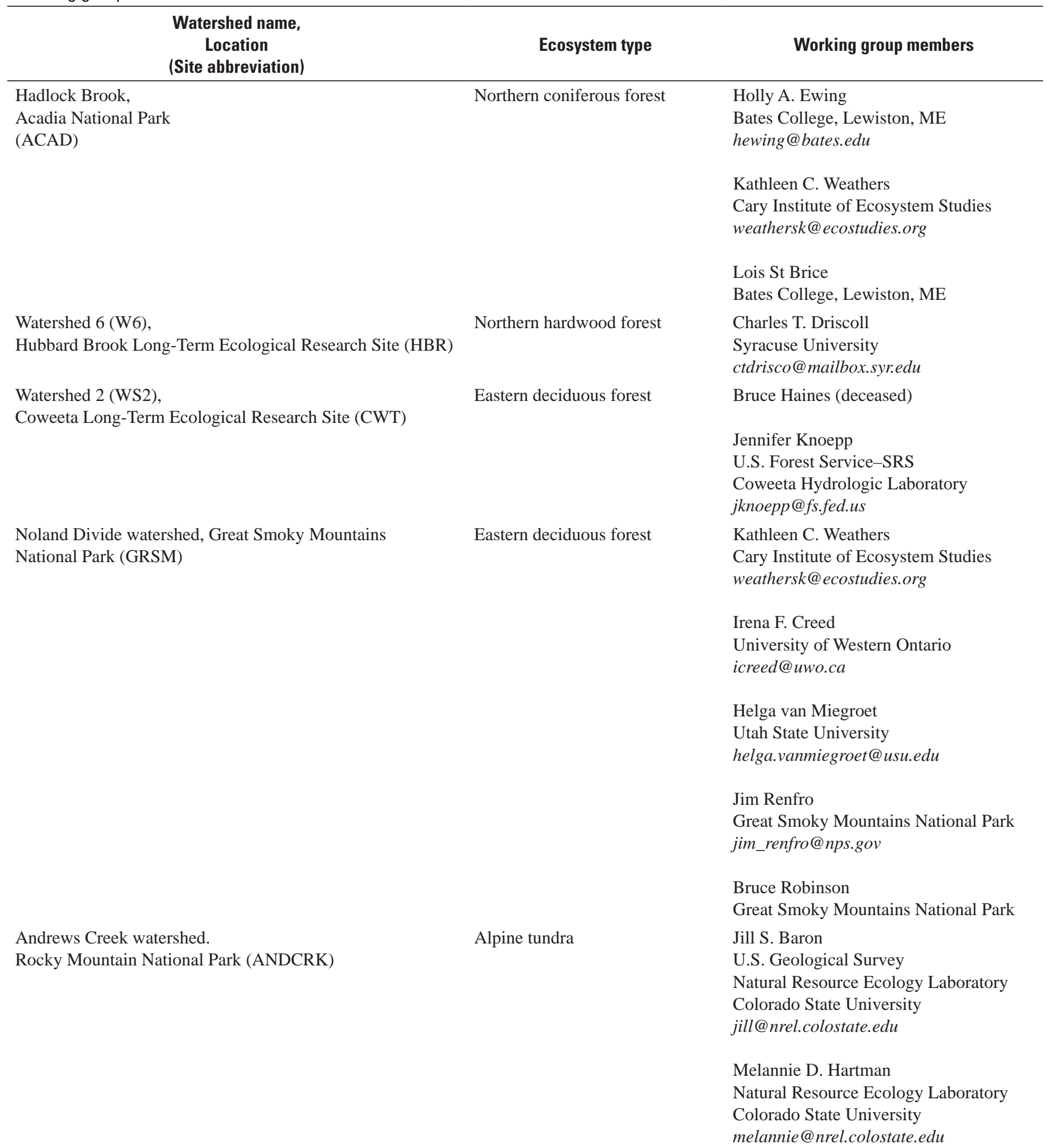


Table 1.1. The names and locations of the eight watersheds included in this intersite comparison study, their ecosystem type, and working group members.-Continued

\begin{tabular}{|c|c|c|}
\hline $\begin{array}{l}\text { Watershed name, } \\
\text { Location } \\
\text { (Site abbreviation) }\end{array}$ & Ecosystem type & Working group members \\
\hline $\begin{array}{l}\text { Green Lakes Valley, } \\
\text { Niwot Ridge Long-Term Ecological Research Site } \\
\text { (NWT) }\end{array}$ & Alpine tundra & $\begin{array}{l}\text { Mark Williams } \\
\text { INSTAAR } \\
\text { University of Colorado-Boulder } \\
\text { markw@culter@colorado.edu }\end{array}$ \\
\hline $\begin{array}{l}\text { Lake Louise watershed, } \\
\text { Mount Rainier National Park (MORA) }\end{array}$ & Subalpine forest & $\begin{array}{l}\text { Dave Clow } \\
\text { Colorado Water Science Center } \\
\text { U.S. Geological Survey-Water } \\
\text { Resources Discipline } \\
\text { dwclow@usgs.gov }\end{array}$ \\
\hline $\begin{array}{l}\text { Watershed } 10 \text { (WS10), } \\
\text { H.J. Andrews Long-Term Ecological Research Site (HJA) }\end{array}$ & Northwest coniferous forest & $\begin{array}{l}\text { Kate Lajtha } \\
\text { Oregon State University } \\
\text { lajthak@science.oregonstate.edu }\end{array}$ \\
\hline
\end{tabular}

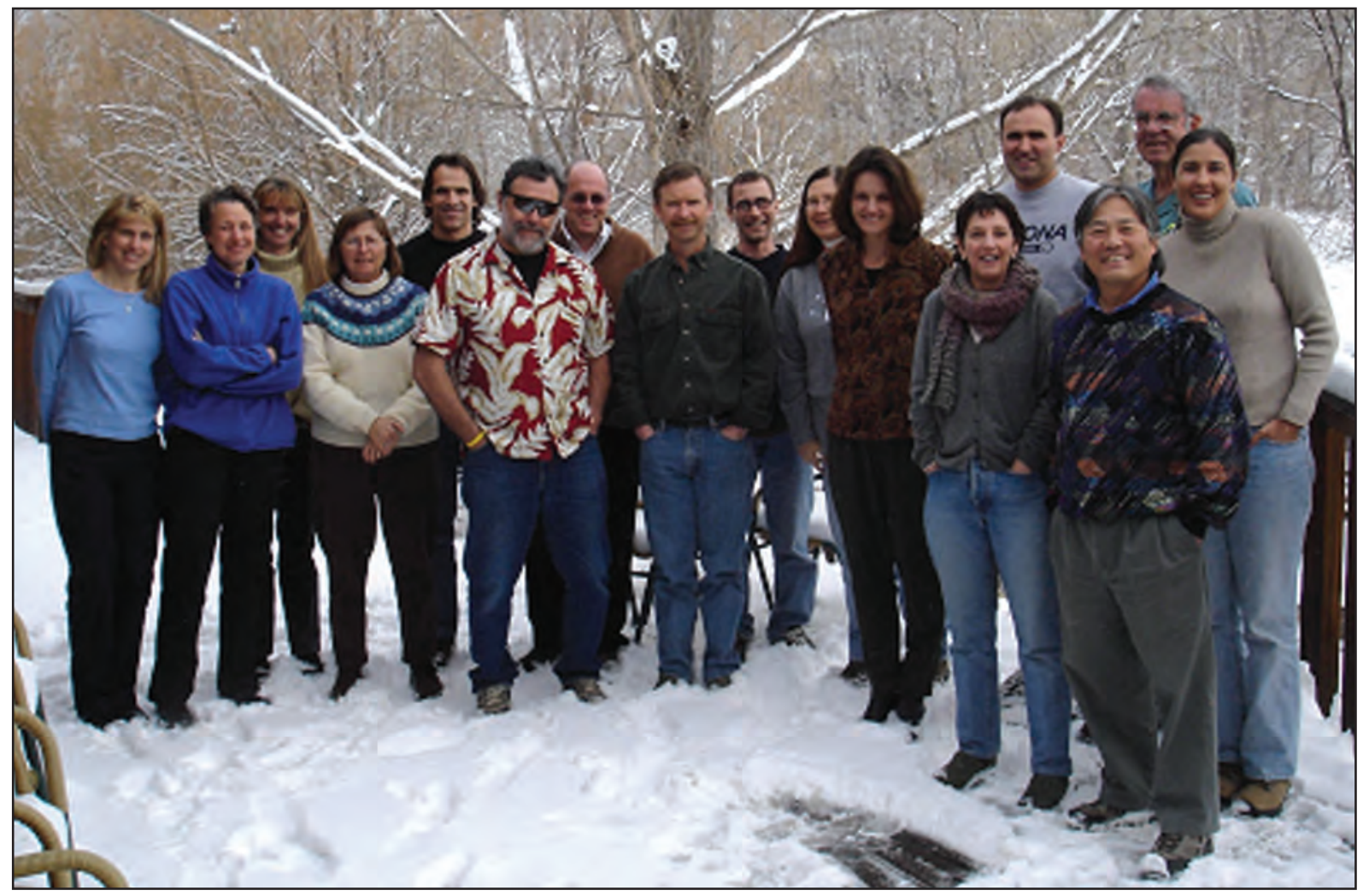

Figure 1.3. Participants from the first DayCent-Chem workshop held February 2006 at Sylvan Dale Ranch, Loveland, Colorado. From left to right: Kate Lajtha, Kathleen Weathers, Tamara Blett, Edie Allen, Rick Haeuber, Mark Williams, Charles Driscoll, David Clow, Todd Ackerman, Cindy Keough, Melannie Hartman, Jill Baron (front), Tom Meixner (back), Dennis Ojima (front), Bruce Haines (back), and Leela Rao (back) 
of the types of information needed to conduct these kinds of analyses, and the beginnings of efforts to train others to use the model.

With model parameterization now complete and results documented in this report, our next goals are as follows:

1. Better understand biogeochemical processes related to atmospheric deposition. For example, what are the consequences of changing atmospheric deposition on ecosystems? How do combined inputs of $\mathrm{S}$ and $\mathrm{N}$ affect plant productivity, C and N storage/cycling, soil base cations, stream water acid-neutralizing capacity, acidity, and major ion concentrations?

2. Explore biogeochemical responses to changing atmospheric deposition caused by emissions reductions or increases. How much atmospheric $\mathrm{N}$ deposition is needed, alone or in conjunction with sulfate $\left(\mathrm{SO}_{4}\right)$ deposition, to acidify surface waters, alter soil chemistry, and influence forest or tundra productivity? What are ecosystem responses to reductions of atmospheric $\mathrm{N}$ and $\mathrm{S}$ deposition?

3. Use DayCent-Chem to assist in the formulation and evaluation of new, innovative ecosystem protection approaches and benchmarks: for example, formulation of critical loads of atmospheric $\mathrm{N}$ and $\mathrm{S}$ deposition for assessing nitrogen saturation, acidification or eutrophication of ecosystems. Can DayCent-Chem identify potential indicators/metrics for measurement across many sites and, ultimately, regions to detect ecosystem condition related to deposition?

\section{Results Overview}

Model performance varied among sites. Overall the model performed best in predicting stream chemistry for snowmelt-dominated sites, particularly Andrews Creek (ANDCRK, Chapter 6) where soils were also very shallow. Predicting daily stream chemistry for watersheds with deep soils (for example, CWT, Chapter 4), high amounts of atmospheric deposition (for example, ACAD, Chapter 2, and GRSM, Chapter 5), and a large degree of spatial heterogeneity (for example, ACAD, Chapter 2) was more difficult. In some cases a paucity of empirical data to drive and test the model hindered modeling efforts (ACAD, Chapter 2; MORA, Chapter 8; HJA, Chapter 9). Regardless of the modeling challenges, this intersite comparison exercise provided insight about important and possibly not well understood processes at each site.

Across this range of study catchments, DayCent-Chem did well in representing plant and soil carbon and nitrogen pools and fluxes, though there was a large discrepancy in the amount and types of available data between sites. Model output compared well with observed and reported values for net primary production (NPP), soil organic matter and plant carbon pools, and nitrogen mineralization. Exceptions included GRSM, where simulated overstory NPP was 1.8 times the amount of measured overstory $\mathrm{C}$ sequestration and simulated ecosystem $\mathrm{N}$ was 55-70 percent of measured values, and CWT, where simulated soil organic matter $\mathrm{C}$ was underestimated by 24 percent and simulated soil organic matter $\mathrm{N}$, tree biomass $\mathrm{N}$, and total ecosystem $\mathrm{N}$ were underestimated by 40 percentDaily discharge was well represented by the model for most sites. Simulated and measured daily discharge had the greatest correlation for CWT (Chapter 4) and HJA (Chapter 9), where snowmelt and accumulation had the least influence on stream dynamics. Simulated discharge did not correlate strongly with measured discharge for GRSM, where a roadcut and diversion may affect stream dynamics (Chapter 5). For some years, modeled discharge deviated from measured values for ANDCRK and NWT (Chapters 6 and 7) because of contributions of glacial meltwater to flow, a process not included in the model. The model could not predict accurately daily discharge for MORA (Chapter 8), where snowfall was greater than it was at the other sites and where there was an insufficient discharge record to parameterize and test the model.

Modeled stream nitrate $\left(\mathrm{NO}_{3}\right)$ and ammonium $\left(\mathrm{NH}_{4}\right)$ concentrations compared well with measurements at all sites, with few exceptions. The model did well in predicting the timing and magnitude of stream $\mathrm{NO}_{3}$ concentrations from about 1979 through 1991 at Hubbard Brook, but it did not capture the overall decline in stream $\mathrm{NO}_{3}$ concentrations that have been observed since the early 1990s (Chapter 3, this volume; Aber and others, 2002; Goodale and others, 2003; Bernhardt and others, 2005). Another ecosystem model (PnET) was able to reproduce much of the interannual variability in stream $\mathrm{NO}_{3}$ concentrations for the 1980s, but, like DayCent-Chem, it was not able to predict the extremely low values in the 1990s (Aber and Driscoll, 1997; Aber and others, 2002; Goodale and others, 2003; Bernhardt and others, 2005).

Simulated daily stream $\mathrm{SO}_{4}$ concentrations compared well to measured values for sites where $\mathrm{SO}_{4}$ deposition has been low and where $\mathrm{SO}_{4}$ adsorption/desorption reactions did not seem to be important (ANDCRK, Chapter 6; NWT, Chapter 7; MORA, Chapter 8; and HJA, Chapter 9). The model could not explain the high stream $\mathrm{SO}_{4}$ concentrations that were measured at ACAD; prior data and ecological knowledge about the system suggested that the dry and fog depositions of $\mathrm{Cl}, \mathrm{SO}_{4}$, and the base cations may be much greater than wet deposition of these solutes at ACAD (Chapter 2). The simulated stream $\mathrm{SO}_{4}$ values for HBR (Chapter 3), Coweeta (Chapter 4), and GRSM (Chapter 5) were greater than reported values, for instance, possibly because DayCent-Chem could not represent the degree of S-adsorption occurring in these soils.

DayCent-Chem did not accurately predict weathering products for some catchments. This was especially true for HJA (Chapter 9), for which very high stream base cation concentrations were measured. Our model is not unique in this respect; Johnson and others (2000) encountered and noted 
difficulties in simulating the leaching of base cations. The concentrations of base cations and silica in streams are highly dependent on the geochemistry and weathering rates of minerals in each catchment, yet these were rarely, if ever, known. Additionally, few data were available for exchangeable cations in the soil or the magnitude of base cation deposition as a result of dry and fog inputs.

For some catchments, DayCent-Chem did not accurately predict stream ANC and $\mathrm{pH}$, two measures that depend on concentrations of many solutes. The uncertainties related to weathering reactions, deposition, soil cation exchange capacity, and groundwater contributions influenced how well the simulated ANC and pH estimates compared to observed values. Whereas simulated $\mathrm{HCO}_{3}$ concentrations were close to measured alkalinity for many sites, simulated stream ANC was too high for a few sites because Al-hydroxides were overestimated. The exceptions were ANDCRK and ACAD, where simulated ANC was close to measurements.

The following chapters describe the parameterization for each site and summarize model results for ecosystem variables, stream discharge, and stream chemistry. The results presented below will be used in subsequent manuscripts to address the questions posed above regarding consequences of atmospheric $\mathrm{N}$ and $\mathrm{S}$ deposition. 


\section{Acadia National Park, Hadlock Brook Watershed, Maine}

\section{Site Description}

Hadlock Brook watershed is located in Acadia National Park on Mount Desert Island in coastal Maine (table 2.1, fig. 2.1). The watershed encompasses 47.2 ha and extends from 137 to $380 \mathrm{~m}$ in elevation with an average slope of 20 percent (Nelson, 2002). Paleoecological records indicate that the watershed has been dominated by red spruce (Picea rubens) and balsam fir (Abies balsamea) for 500 years or more and has not burned recently or been cleared substantially (Schauffler and others, 2007). The upper portion has polished bedrock surfaces, a result of continental glaciations that ended about 14,000 years ago, with patches of low-lying spruce fir and subalpine scrub (fig. 2.2) (Schauffler and others, 2007). The underlying bedrock is Cadillac granite (Gilman and others, 1988) and the soils are coarse-loamy Haplorthods composed primarily of glacial till with depths and organic matter thicknesses that range widely throughout the watershed (Jordan, 1998; H.A. Ewing, Bates College, Lewiston, Maine, personal commun., 2007). As a result of its location along the Maine coast and a topography that causes orographic precipitation effects, Acadia National Park is subjected to significant atmospheric pollution (Weathers and others, 1986; Weathers and others, 1988; Amirbahman and others, 2004; Weathers, Simkin, and others, 2006).

\section{Methods}

\section{Climate}

Daily precipitation and minimum and maximum daily air temperatures measured at Acadia National Park, McFarland Hill (44.3739 $\mathrm{N}, 68.2606^{\circ} \mathrm{W}$, elevation $129 \mathrm{~m}$ ), from 1983 through 2005 were used as input data to the model (fig. 2.3). This weather station is outside the Hadlock Brook watershed, further inland, and at a lower elevation. Precipitation for January 1, 1983, through December 20, 2005, was retrieved from National Atmospheric Deposition Program (NADP) site ME98 (http://nadp.sws.uiuc.edu, accessed 22 September 2006). Precipitation for December 21, 2005, through December 31, 2005, and air temperature for January 1, 1983, through December 31, 2005, were retrieved from the National Oceanic and Atmospheric Administration's (NOAA) National Climate Data Center (http://www1.ncdc.noaa.gov/, accessed 22 September 2006). This weather station received less precipitation than Hadlock Brook for the same time period, likely because of orographic effects (Lovett and Kinsman, 1990); to account for this, precipitation inputs to the model were enhanced by 12.5 percent annually. From 1983 to 2005, mean annual temperature input to the model was 7.6 (std. dev. 0.7) ${ }^{\circ} \mathrm{C}$ and average annual precipitation was 152 (std. dev. 32) $\mathrm{cm} \mathrm{yr}^{-1}$. Average annual temperature increased $0.04{ }^{\circ} \mathrm{C} \mathrm{yr}^{-1}$.

\section{Atmospheric Deposition}

Daily wet deposition inputs to the model for the period 1983-2005 were derived from weekly solute concentrations measured at NADP/National Trend Network (NTN) site ME98, Acadia National Park-McFarland Hill (44.3772 $\mathrm{N}$, $68.2608^{\circ} \mathrm{W}$, elevation $150 \mathrm{~m}$ ) (fig. 2.4). We assumed that daily concentrations for each day during the week were the same as the weekly measurement. The amount of wet deposition each day was calculated as the product of that day's precipitation input to the model and the daily estimated concentration.

Dry deposition measurements for $\mathrm{NH}_{4}, \mathrm{NO}_{3}$, and $\mathrm{SO}_{4}$ for the period 1998-2005 were available from CASTNet site ACA416 in Acadia National Park, $0.3 \mathrm{~km}$ from the NADP site at an elevation of $158 \mathrm{~m}$. Both the CASTNet site and the NADP/NTN site were outside of Hadlock Brook.

Initially we derived dry:wet ratios for $\mathrm{NH}_{4}, \mathrm{NO}_{3}$, and $\mathrm{SO}_{4}$ from CASTNET and NADP data (which excluded fog deposition) (table 2.2). Using these dry:wet ratios, we calculated total $\mathrm{N}$ deposition at $4.45 \mathrm{~kg} \mathrm{~N} \mathrm{ha}^{-1} \mathrm{yr}^{-1}$ and total S deposition at $6.50 \mathrm{~kg} \mathrm{~S} \mathrm{ha}^{-1} \mathrm{yr}^{-1}$. These calculated amounts were about half of those estimated after Weathers, Simkin, and others (2006) as average deposition for the period 2001-2004 (9-11 kg N ha ${ }^{-1} \mathrm{yr}^{-1}$ and 11-14 $\mathrm{kg} \mathrm{S} \mathrm{ha}^{-1} \mathrm{yr}^{-1}$ ).

We increased $\mathrm{N}$ and $\mathrm{S}$ deposition in the model by increasing the dry:wet ratios for $\mathrm{NH}_{4}, \mathrm{NO}_{3}$, and $\mathrm{SO}_{4}$ until annual deposition rates were approximately equal to those measured by Weathers, Simkin, and others (2006). Since we had no measured values for base cation and $\mathrm{Cl}$ deposition, we adjusted dry:wet ratios for these species so that simulated annual volume-weighted mean (VWM) stream concentrations were close to measured values and to achieve cation/anion balance of all inputs species (table 2.2).

\section{Soil and Mineral Properties}

We prescribed the dissolution of three minerals common to granite: albite, anorthite, and biotite (table 2.3). We initially set the mineral denudation rates equal to those determined for the Loch Vale subalpine forest (Hartman and others, 2007) and adjusted them until simulated stream Si concentrations 
Table 2.1. Characteristics of Hadlock Brook watershed, Acadia National Park, Maine.

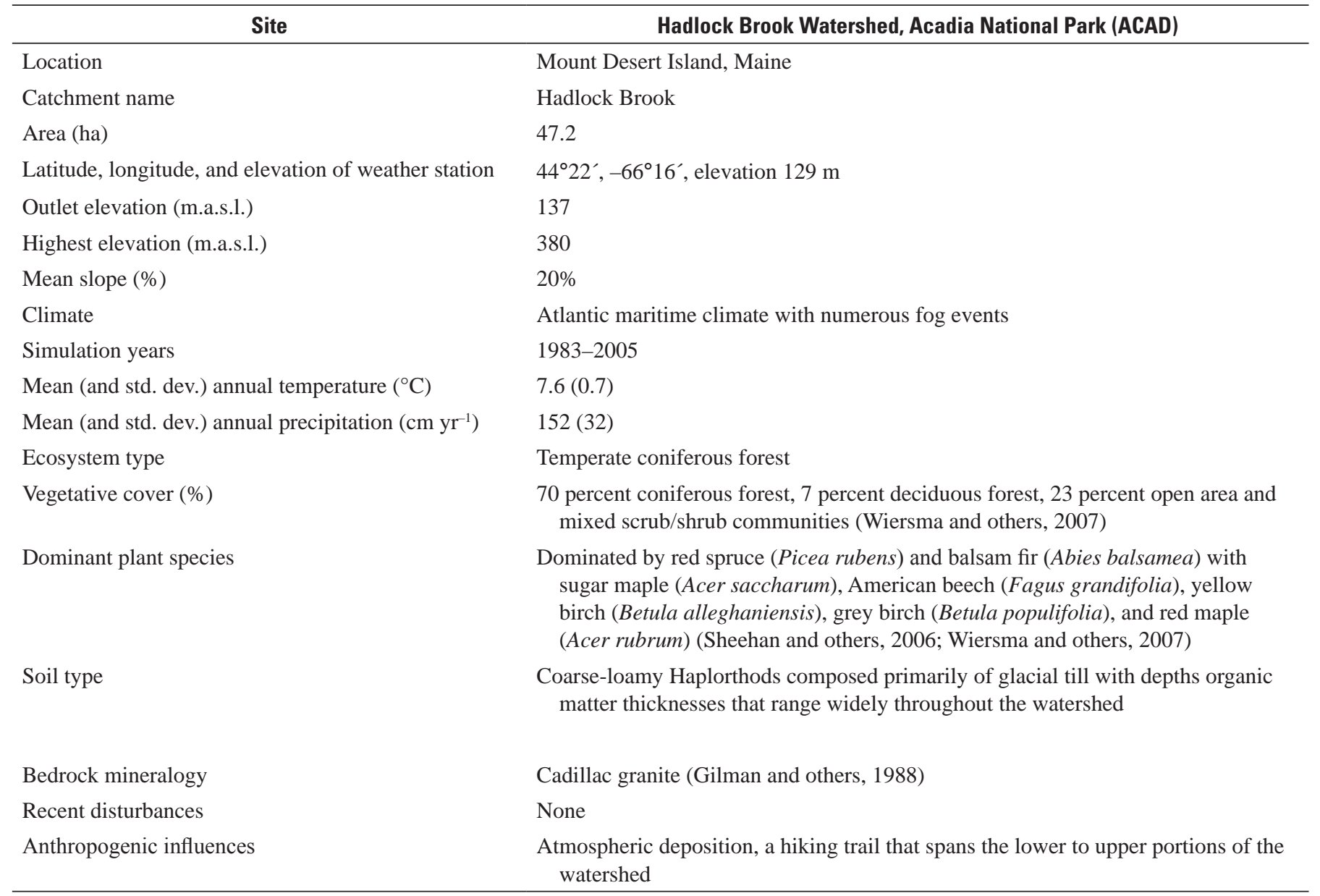

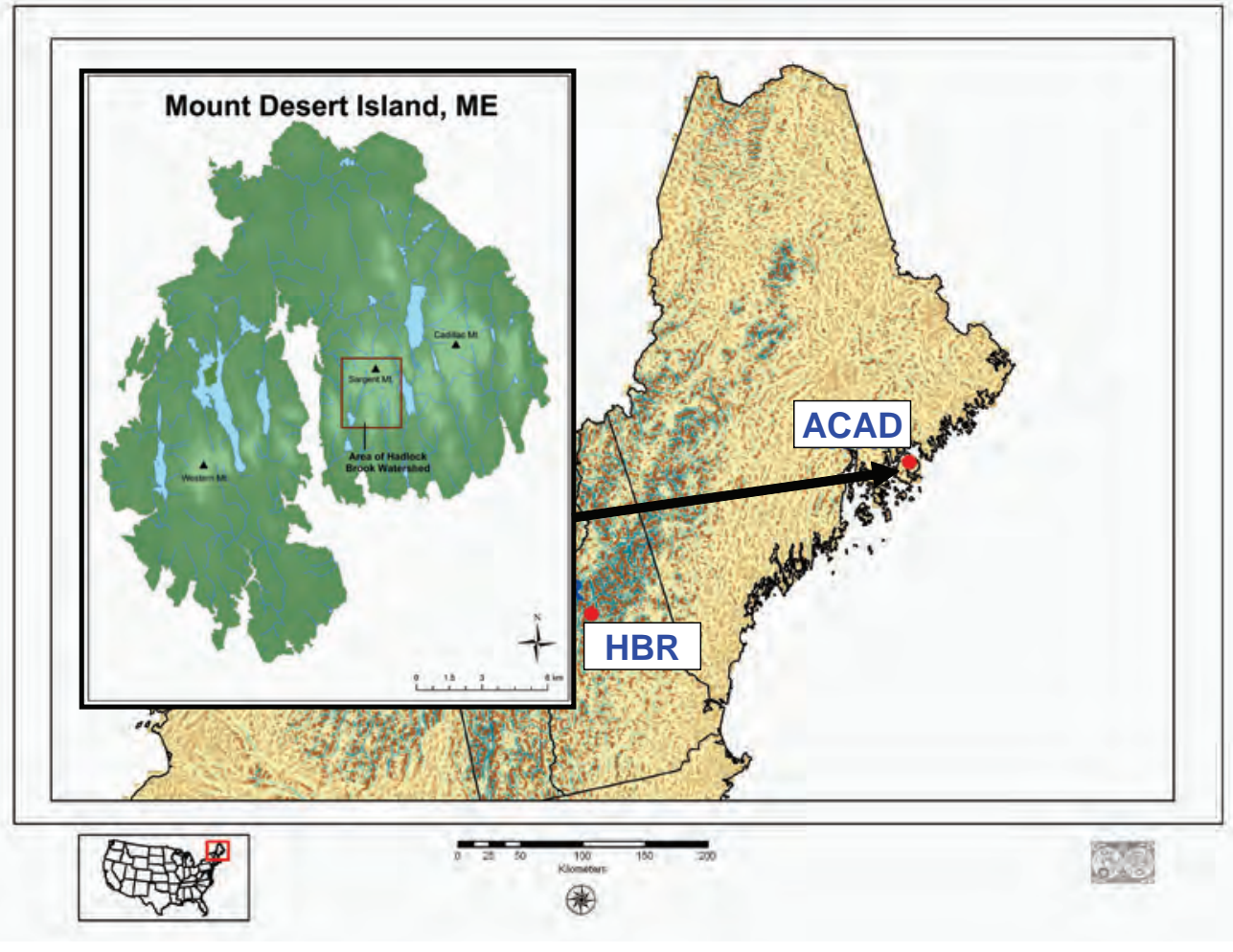

Figure 2.1. Hadlock Brook watershed is located in Acadia National Park (ACAD) on Mount Desert Island (inset) in coastal Maine. Hubbard Brook (HBR; Chapter 3 ) is to the southwest in New Hampshire. 


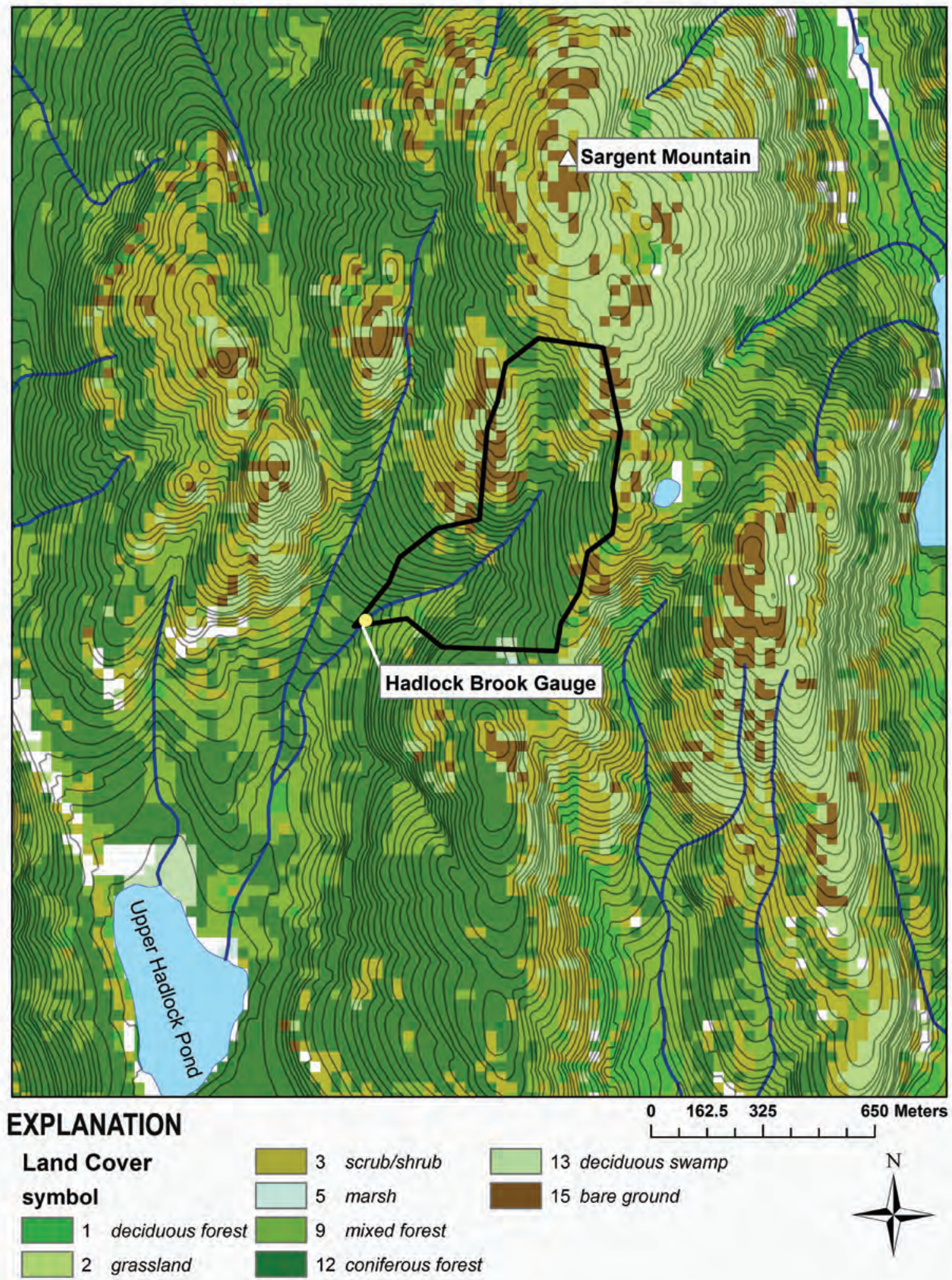

Figure 2.2. Vegetation in Hadlock Brook watershed and the surrounding area. 

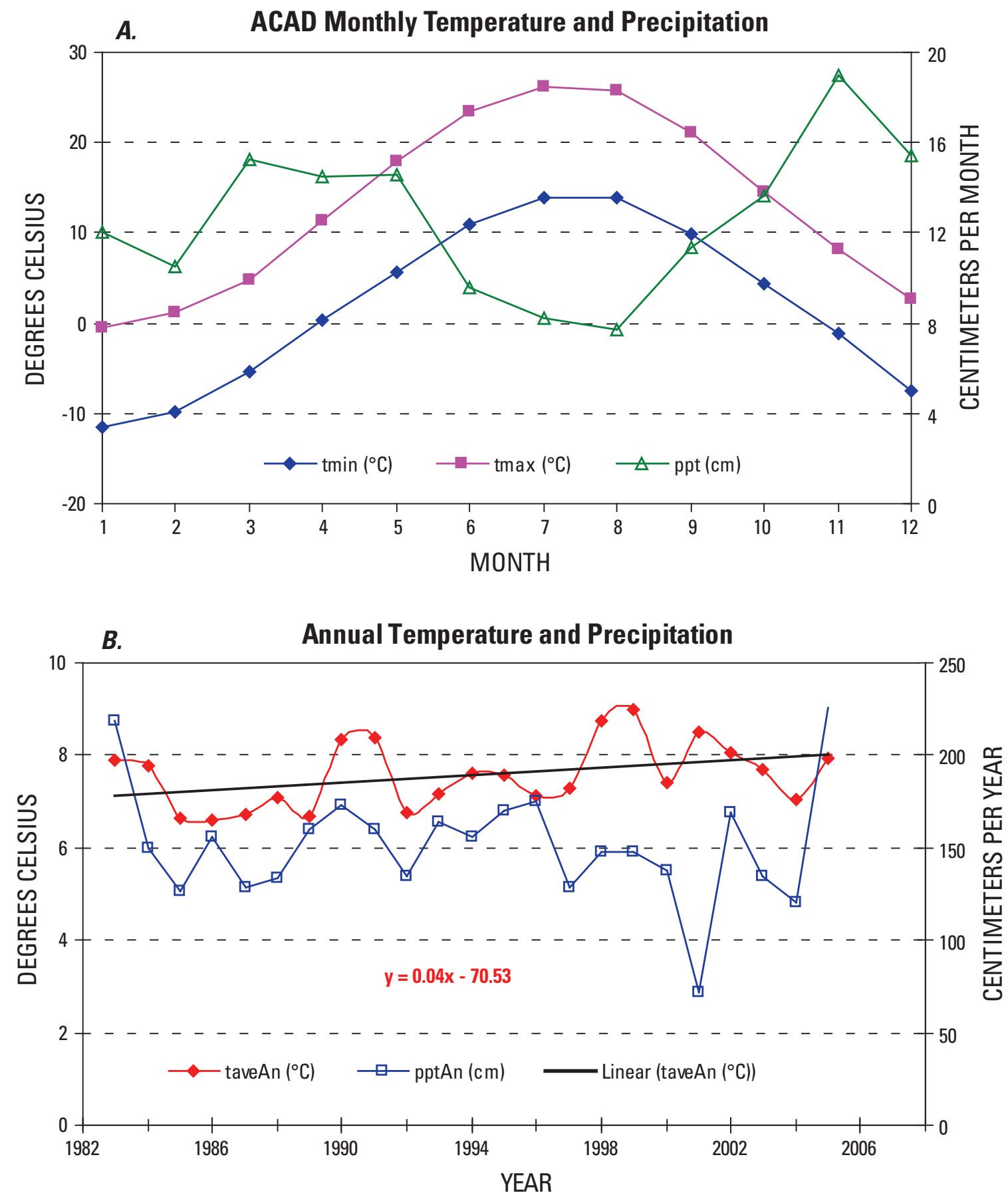

Figure 2.3. Meteorological statistics for Hadlock Brook watershed. $A$, Average monthly minimum air temperatures (tmin), maximum air temperatures (tmax), and precipitation (ppt), years 1983-2005. B, Mean annual temperature (taveAn) and annual precipitation (pptAn), years 1983-2005. Mean annual temperature was 7.6 (std. dev. 0.7) ${ }^{\circ} \mathrm{C}$, and average annual precipitation was 152 (std. dev. 32) $\mathrm{cm} \mathrm{yr}^{-1}$. Average annual temperature increased $0.04^{\circ} \mathrm{C} \mathrm{yr}^{-1}$. 

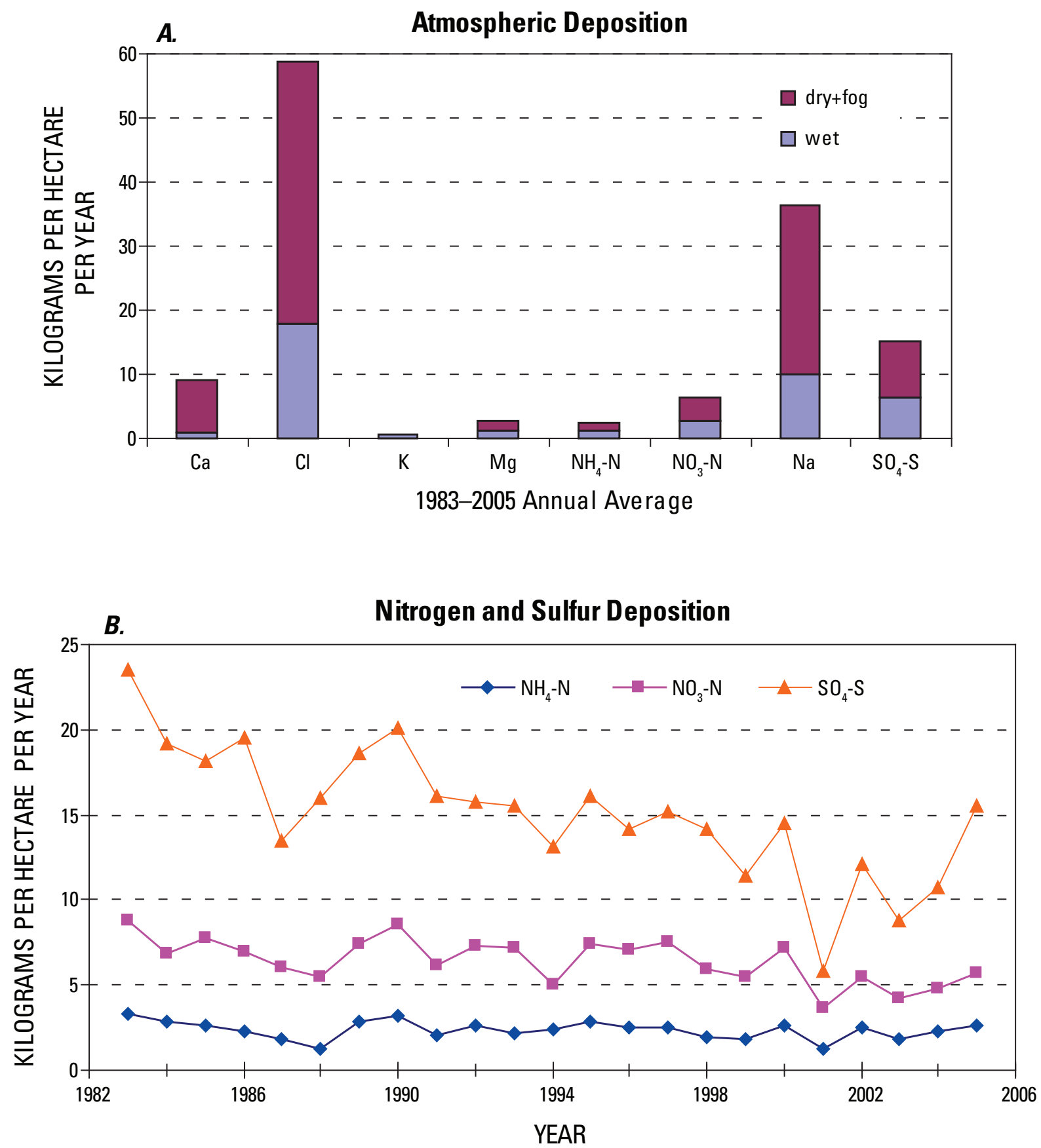

Figure 2.4. Deposition inputs to the model for Hadlock Brook watershed. $A$, The 1983-2005 average annual wet and dry plus fog deposition. $B$, Annual $\mathrm{NH}_{4}-\mathrm{N}_{1} \mathrm{NO}_{3}-\mathrm{N}$, and $\mathrm{SO}_{4}-\mathrm{S}$ deposition over the simulation period. Wet deposition inputs to the model for the period 1983-2005 were derived from weekly solute concentrations measured at NADP/NTN site ME98. Dry plus fog deposition was calculated from dry deposition measurements available from CASTNet site ACA416 in Acadia National Park, from throughfall measurements (Weathers, Simkin, and others, 2006), and by calibration. 
Table 2.2. Average annual wet, dry, and total atmospheric deposition $\left(\mathrm{kg} \mathrm{ha}^{-1} \mathrm{yr}^{-1}\right)$ and precipitation $\left(\mathrm{cm} \mathrm{yr}^{-1}\right)$ as measured at the

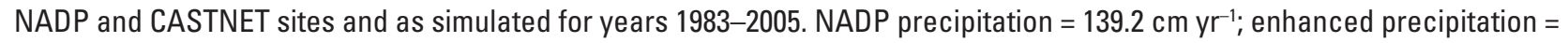
$152 \mathrm{~cm} \mathrm{yr}^{-1}$.

\begin{tabular}{|c|c|c|c|c|c|c|c|c|c|}
\hline NADP/CASTNET & $\mathrm{NH}_{4}-\mathrm{N}$ & $\mathrm{NO}_{3}-\mathrm{N}$ & $\mathbf{N}$ & $\mathrm{SO}_{4}-\mathrm{S}$ & Cl & $\mathrm{Ca}$ & Mg & $\mathrm{Na}$ & K \\
\hline Average wet & 1.14 & 2.33 & 3.48 & 5.62 & 16.15 & 0.85 & 1.10 & 9.10 & 0.48 \\
\hline $\begin{array}{l}\text { Average dry } \\
\quad(2000-2004)\end{array}$ & 0.12 & 0.84 & 0.97 & 0.88 & - & - & - & - & - \\
\hline Average total & 1.26 & 3.17 & 4.45 & 6.50 & - & - & - & - & - \\
\hline Dry+fog:wet ratio & 0.11 & 0.36 & 0.28 & 0.16 & - & - & - & - & - \\
\hline Average wet & 1.3 & 2.8 & 4.1 & 6.4 & 17.8 & 1.0 & 1.2 & 10.1 & 0.5 \\
\hline $\begin{array}{l}\text { Average dry } \\
\quad(2000-2004)\end{array}$ & 1.0 & 3.6 & 4.6 & 8.7 & 41.0 & 8.1 & 1.5 & 26.2 & 0 \\
\hline Average total & 2.4 & 6.4 & 8.8 & 15.1 & 58.8 & 9.1 & 2.7 & 36.3 & 0.5 \\
\hline
\end{tabular}

Table 2.3. Mineral phases and potential annual mineral denudation rates prescribed for the simulation. All minerals were allowed only to dissolve except for kaolinite, which was allowed to both precipitate and dissolve.

\begin{tabular}{llc}
\hline Mineral phases & $\mathbf{m o l ~ m}^{-\mathbf{2}} \mathbf{y r}^{-\mathbf{1}}$ & $\begin{array}{c}\mathbf{1}=\text { dissolve, } \\
\mathbf{0}=\text { precipitate } \\
\text { or dissolve }\end{array}$ \\
\hline Albite & 0.023489 & 1 \\
Anorthite & 0.008683 & 1 \\
Phlogopite & 0.002084 & 1 \\
Kaolinite & 0.0 & 0 \\
\hline
\end{tabular}


were close to measured values. For Hadlock Brook, the annual rates of dissolution for albite, anorthite, and biotite were set at 234.89, 86.83, $20.84 \mathrm{~mol} \mathrm{ha}^{-1} \mathrm{yr}^{-1}$, respectively. We allowed kaolinite to precipitate or dissolve to account for incomplete dissolution. The mineral reactions are summarized below.

Albite: $\mathrm{NaAlSi}_{3} \mathrm{O}_{8}+8 \mathrm{H}_{2} \mathrm{O}=\mathrm{Na}^{+}+\mathrm{Al}(\mathrm{OH})_{4}^{-}+3 \mathrm{H}_{4} \mathrm{SiO}_{4}$ Anorthite: $\mathrm{CaAl}_{2} \mathrm{Si}_{2} \mathrm{O}_{8}+8 \mathrm{H}_{2} \mathrm{O}=\mathrm{Ca}^{2+}+2 \mathrm{Al}(\mathrm{OH})_{4}^{-}+2$ $\mathrm{H}_{4} \mathrm{SiO}_{4}$

Phlogopite: $\mathrm{KMg}_{3} \mathrm{AlSi}_{3} \mathrm{O}_{10}(\mathrm{OH})_{2}+10 \mathrm{H}^{+}=\mathrm{K}^{+}+3 \mathrm{Mg}^{2+}+$ $\mathrm{Al}^{3+}+3 \mathrm{H}_{4} \mathrm{SiO}_{4}$

Kaolinite: $\mathrm{Al}_{2} \mathrm{Si}_{2} \mathrm{O}_{5}(\mathrm{OH})_{4}+6 \mathrm{H}^{+}=\mathrm{H}_{2} \mathrm{O}+2 \mathrm{H}_{4} \mathrm{SiO}_{4}+2 \mathrm{Al}^{3+}$

Soil properties for Acadia National Park were derived from unpublished work of Ivan Fernandez, Holly Ewing, and Colin Hollister (H.A. Ewing, Bates College, Lewiston, Maine, personal commun., 2007). These properties include soil texture, exchangeable cations, and soil solution $\mathrm{pH}$ (table 2.4). Hydraulic conductivity, field capacity, and wilting point were estimated from soil texture (Reynolds and others, 2000). The model was initialized with measured cation exchange capacities (H.A. Ewing, Bates College, Lewiston, Maine, personal commun., 2007).

\section{Calibration and Validation}

Daily stream discharge was measured at U.S. Geological Survey (USGS) site 01022860 using stage height and relationships with stream profile. Discharge data were available for April 1999-December 2005 (U.S. Geological Survey, 2008). There were three periods of stream chemistry measurements (http://www.umaine.edu/sparc/ACAD/Research_catchments. $\mathrm{htm}$, accessed 28 May 2007). The first included 15 samples collected between February 1983 and November 1984 as part of the Acadia Stream Chemistry-1980s Baseline Data and Assessment. The second included 57 weekly or bimonthly samples between May 1988 and December 1989 as part of the Hadlock Watershed Episodic Acidification Study. For the third period, discharge-weighted monthly mean chemistry was available from April 1999 through September 2003 as part of the Paired Research Watersheds Study carried out at Acadia National Park (Kahl, 2005).

We calibrated modeled streamflow by visually comparing simulated daily and annual stream discharge to measured values for years 2000-2003, the only full years daily discharge was available. Once discharge was calibrated, we tuned the model for stream chemistry by visually comparing simulated daily and monthly VWM concentrations with monthly mean observations for 1999-2003, and simulated annual VWM solute concentrations with observed annual means for 2000-2003. Measured stream samples for 1983-1984 and 1988-1989 were used for validation, and simulated daily concentrations for these two 2-year time periods were emergent from predetermined parameterization.
Discharge at Hadlock Brook was regulated by snow accumulation and melt, and by evapotranspiration in the summer (fig. 2.5). Measured discharge showed two seasonal peaks each year, one in March/April and the other in October/November, coinciding with periods of high precipitation (March-May and October-December). Discharge was less than precipitation in the winter months and was greater than precipitation during the spring thaw. Evapotranspiration from June through September reduces discharge to less than 50 percent of precipitation.

\section{Model Output}

\section{Ecological Variables}

Simulated soil organic matter carbon, 7,706 (std. dev. 72) g C m${ }^{-2}$, and soil organic matter nitrogen, 319 (std. dev. 1) g N $\mathrm{m}^{-2}$, were greater than measured values from Hadlock Brook, 7,100 (std. dev. 1,630) g C m${ }^{-2}$ and 208.8 (std. dev. 1.6) g N $\mathrm{m}^{-2}$, respectively (table 2.5) (Parker and others, 2001). Simulated net $\mathrm{N}$ mineralization, 5.6 (std. dev. 0.3) $\mathrm{g} \mathrm{N} \mathrm{m}^{-2} \mathrm{yr}^{-1}$, was slightly greater than $\mathrm{O}$ horizon plus upper mineral horizon net $\mathrm{N}$ mineralization estimated as part of the study at Bear Brook watershed, which is inland but within $60 \mathrm{~km}$ of the Hadlock Brook watershed (East Bear Brook $=5.0 \mathrm{~g} \mathrm{~N} \mathrm{~m}^{-2} \mathrm{yr}^{-1}$; Jefts and others, 2004). The model suggested that ecosystem retention of atmospherically deposited $\mathrm{N}$ plus internally fixed $\mathrm{N}$ was 62 percent, though no measurement of $\mathrm{N}$ retention was available to verify this estimate.

\section{Discharge}

The model was able to replicate the timing and magnitude of daily discharge for much of the simulation period (fig. 2.6). Measured daily discharge showed a wider range of values than simulated discharge (the $\mathrm{R}^{2}$ correlation between measured and modeled daily discharge was 0.50 ; fig. 2.6). Simulated monthly discharge showed a strong correlation with measured monthly discharge (the $\mathrm{R}^{2}$ correlation was 0.75 ; table 2.6 , fig. 2.7). Simulated annual discharge was underestimated five of the six years between 2000 and 2005 by about 8 percent annually. For this time period, measured discharge averaged $116 \mathrm{~cm} \mathrm{yr}^{-1}$ and simulated discharge $108 \mathrm{~cm} \mathrm{yr}^{-1}$. The model suggested that snow accumulation and melt regulate discharge in the winter. Simulations showed intermittent snow cover in November, December, and March and relatively continuous snow cover in January and February. Average vapor water loss calculated by the model was $36 \mathrm{~cm} \mathrm{yr}^{-1}$, or about 25 percent of precipitation. We are not sure of the magnitude of groundwater flow or how this contribution to discharge changes seasonally. 
Table 2.4. Soil layer properties used for the simulation. Initial cation exchange capacity (CEC) values correspond to the beginning of simulation year 1983, whereas final CEC values correspond to the end of simulation year 2005. Ksat is saturated hydraulic conductivity, and the mineral dissolution fraction (Minrl dissoln) is the fraction of total mineral dissolution that occurred in each layer. Wilting point and field capacity are expressed as volumetric soil water content. Exchangeable cations are expressed as milliequivalents per 100 grams of soil (meq/100 g). Organic soil made up the top $10 \mathrm{~cm}$.

\begin{tabular}{|c|c|c|c|c|c|c|c|c|c|c|}
\hline Layer & $\begin{array}{c}\text { Thickness } \\
\text { cm }\end{array}$ & pH & $\begin{array}{c}\text { Sand } \\
\text { percent }\end{array}$ & $\begin{array}{c}\text { Silt } \\
\text { percent }\end{array}$ & $\begin{array}{c}\text { Clay } \\
\text { percent }\end{array}$ & $\begin{array}{c}\text { Bulk } \\
\text { density } \\
\text { g cm }^{-3}\end{array}$ & $\begin{array}{c}\text { Wilting } \\
\text { point } \\
\text { cm sec }^{-1}\end{array}$ & $\begin{array}{c}\text { Field } \\
\text { capacity } \\
\text { percent }\end{array}$ & $\begin{array}{c}\text { Ksat } \\
\text { percent }\end{array}$ & $\begin{array}{c}\text { Minrl } \\
\text { dissoln } \\
\text { fraction }\end{array}$ \\
\hline 2 & 3 & 3.725 & 54 & 30 & 16 & 1.2 & 0.02 & 23 & 11 & 0.4 \\
\hline 3 & 8 & 3.919 & 54 & 30 & 16 & 1.47 & 0.02 & 23 & 11 & 0.4 \\
\hline 1 & 4.303 & 3.649 & 1.037 & 0.605 & 0 & 0 & 0 & 10.264 & 0 & 0 \\
\hline 2 & 0.101 & 0.113 & 0.071 & 0.057 & 0 & 0 & 0 & 1.08 & 0 & 0 \\
\hline 3 & 0.106 & 0.088 & 0.082 & 0.066 & 0 & 0 & 0 & 0.572 & 0 & 0 \\
\hline $\begin{array}{c}\text { Final } \\
\text { CEC }\end{array}$ & $\mathrm{CaX}_{2}$ & $\mathrm{MgX}_{2}$ & KX & $\mathrm{NaX}$ & $\mathrm{AlOHX}_{2}$ & $\mathrm{AlX}_{3}$ & $\mathrm{FeX}_{2}$ & $H X$ & $\mathrm{MnX}_{2}$ & $\mathrm{NH}_{4} \mathrm{X}$ \\
\hline 3 & 0.029 & 0.019 & 0.027 & 0.008 & 0.001 & 0.801 & 0.000 & 0.027 & 0 & 0.004 \\
\hline
\end{tabular}

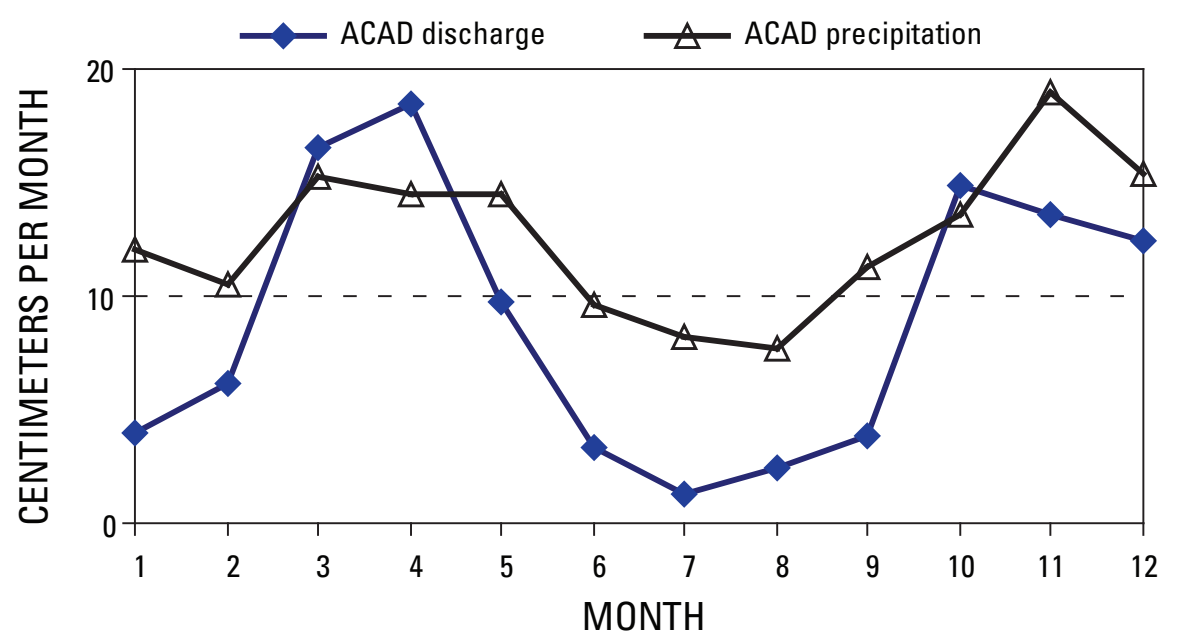

Figure 2.5. Relationship between average monthly precipitation (1983-2005) and measured discharge (2000-2003) for Hadlock Brook watershed. 
Table 2.5. Annual average simulated ecological response. The simulated values are means for years 1983-2005. Standard deviations are in parentheses.

\begin{tabular}{|c|c|c|c|}
\hline & Simulated & Observed & Data sources \\
\hline $\mathrm{NPP}\left(\mathrm{g} \mathrm{C} \mathrm{m}^{-2} \mathrm{yr}^{-1}\right)$ & $567(35)$ & & \\
\hline Above ground NPP & $329(20)$ & & \\
\hline Below ground NPP & $238(15)$ & & \\
\hline $\mathrm{Rh}\left(\mathrm{g} \mathrm{C} \mathrm{m}^{-2} \mathrm{yr}^{-1}\right)$ & $417(17)$ & & \\
\hline Litterfall ( $\left.\mathrm{g} \mathrm{C} \mathrm{m}^{-2} \mathrm{yr}^{-1}\right)$ & $247(6)$ & & \\
\hline $\operatorname{NEP}\left(\mathrm{g} \mathrm{C} \mathrm{m}^{-2} \mathrm{yr}^{-1}\right)$ & $150(37)$ & & \\
\hline SOM-C ( $\mathrm{g} \mathrm{C} \mathrm{m}^{-2}$ ) & $7706(72)$ & $7100(1630)$ & (Parker and others, 2001) \\
\hline SOM-N $\left(\mathrm{g} \mathrm{N} \mathrm{m}^{-2}\right)$ & $319(1)$ & $208.8(1.6)$ & (Parker and others, 2001) \\
\hline AET $\left(\mathrm{cm} \mathrm{yr}^{-1}\right), \%$ of precipitation & 36 (3), $25 \%$ & & \\
\hline $\mathrm{Q}\left(\mathrm{cm} \mathrm{yr}^{-1}\right)$ & $115(29)$ & & \\
\hline Total stream N ( $\left.\mathrm{g} \mathrm{N} \mathrm{m}^{-2} \mathrm{yr}^{-1}\right)$ & $0.35(0.11)$ & & \\
\hline Stream $\mathrm{NH}_{4}-\mathrm{N}$ & 0.00 & & \\
\hline Stream $\mathrm{NO}_{3}-\mathrm{N}$ & 0.21 & & \\
\hline Stream DON & 0.14 & & \\
\hline Total stream S ( $\left.\mathrm{g} \mathrm{S} \mathrm{m}^{-2} \mathrm{yr}^{-1}\right)$ & $1.46(0.42)$ & & \\
\hline N-uptake ( $\mathrm{g} \mathrm{N} \mathrm{m}^{-2} \mathrm{yr}^{-1}$ ) & $6.0(0.3)$ & & \\
\hline S-uptake $\left(\mathrm{g} \mathrm{S} \mathrm{m}^{-2} \mathrm{yr}^{-1}\right)$ & $0.7(0.04)$ & & \\
\hline $\mathrm{N}$-mineralization $\left(\mathrm{g} \mathrm{N} \mathrm{m}^{-2} \mathrm{yr}^{-1}\right)$ & $5.6(0.3)$ & 5.0 & (Jefts and others, 2004) \\
\hline S-mineralization $\left(\mathrm{g} \mathrm{S} \mathrm{m}^{-2} \mathrm{yr}^{-1}\right)$ & $1.3(0.1)$ & & \\
\hline
\end{tabular}

Hadlock Brook Daily Discharge

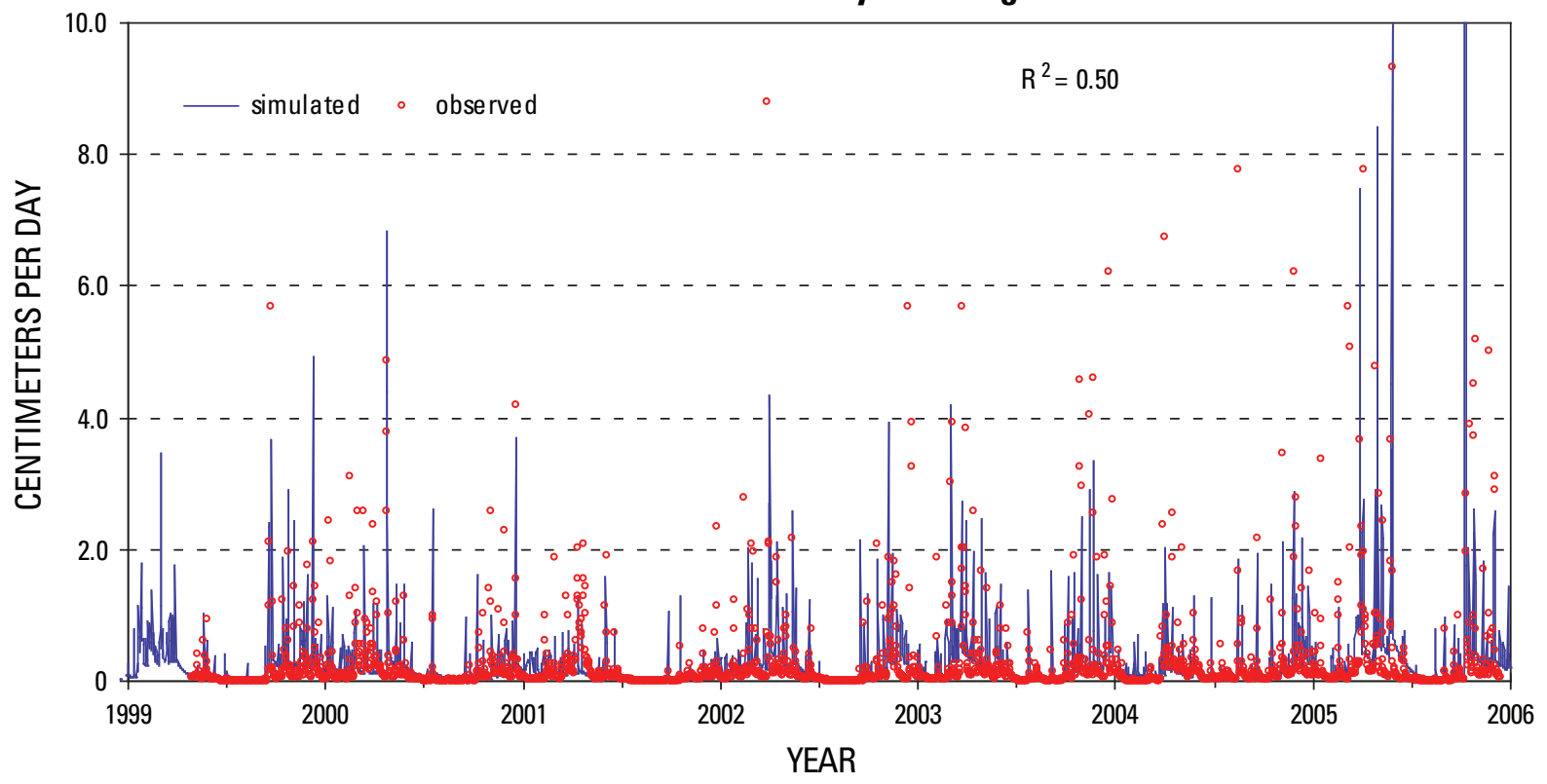

Figure 2.6. Simulated and observed daily discharge for Hadlock Brook watershed, years 1999-2005. The $\mathrm{R}^{2}$ correlation between measured and modeled daily discharge was 0.50 . 
Table 2.6. The slopes $(\mathrm{m})$ and $\mathrm{R}^{2}$ correlation coefficients from a linear regression of simulated monthly volume-weighted mean (VWM) stream concentrations against measured monthly VWM values, years 2000-2003. These relations are based on the monthly graphs (fig. 2.7). $\mathrm{BC}=$ the sum of base cations ( $\mathrm{Ca}, \mathrm{Mg}$, $\mathrm{K}, \mathrm{Na})$.

\begin{tabular}{lcc}
\hline \multicolumn{1}{c}{ Monthly } & $\mathbf{~ m}$ & $\mathbf{R}^{2}$ \\
\hline Discharge & 1.09 & 0.75 \\
$\mathrm{pH}$ & 0.01 & 0.00 \\
$\mathrm{ANC}$ & 0.08 & 0.02 \\
$\mathrm{BC}$ & 0.26 & 0.16 \\
$\mathrm{Ca}$ & 0.16 & 0.03 \\
$\mathrm{Mg}$ & 0.19 & 0.15 \\
$\mathrm{~K}$ & -0.03 & 0.00 \\
$\mathrm{Na}$ & 0.29 & 0.23 \\
$\mathrm{NH}_{4}$ & 0.01 & 0.06 \\
$\mathrm{NO}_{3}$ & 0.32 & 0.49 \\
$\mathrm{SO}_{4}$ & 0.09 & 0.06 \\
$\mathrm{Cl}_{\mathrm{Si}}$ & 0.29 & 0.20 \\
$\mathrm{DOC}$ & 0.13 & 0.18 \\
\hline
\end{tabular}

\section{Stream Chemistry}

\section{Temporal Patterns}

To better understand the general trends in seasonal measured and simulated stream solute concentrations, we computed multi-year VWM concentrations for each month of the year using values from April 1999 to September 2003 (fig. 2.8). The graphs in figure 2.8 demonstrate the degree to which the model matches observations for some months and not others, or whether it consistently underestimates or overestimates stream concentrations.

The correlations between monthly simulated versus observed stream solute concentrations were strongest for $\mathrm{NO}_{3}$, $\mathrm{Cl}, \mathrm{Si}, \mathrm{Na}, \mathrm{Mg}$, and the sum of base cations (table 2.6). There were no strong negative correlations for any ions. Correlation coefficients for $\mathrm{pH}$, acid neutralizing capacity (ANC), $\mathrm{SO}_{4}$, $\mathrm{Ca}, \mathrm{K}$, dissolved organic carbon (DOC), and $\mathrm{NH}_{4}$ were not high even though the model replicated measured concentrations at least part of the year (fig. 2.8).

\section{Nitrate and Ammonium}

Model predictions of stream $\mathrm{NO}_{3}$ concentrations showed the same seasonal patterns as measured values but had higher peak concentrations. The model showed a slight decline in annual VWM simulated $\mathrm{NO}_{3}$ concentrations over the simulation period, and observed annual means (2000-2003) showed a comparable decline. Measured and simulated annual VWM $\mathrm{NO}_{3}$ concentrations were within $11 \mu \mathrm{eq} \mathrm{L} \mathrm{L}^{-1}$ of each other (table 2.7). Measured monthly stream $\mathrm{NO}_{3}$ concentrations peaked each year at just under $20 \mu \mathrm{eq} \mathrm{\textrm {L } ^ { - 1 }}$ in January or February and were generally less than $5 \mu \mathrm{eq} \mathrm{L}{ }^{-1}$ between April and November. Simulated monthly VWM stream $\mathrm{NO}_{3}$ concentrations were positively correlated with measured values $\left(\mathrm{R}^{2}=0.49\right)$, with peak February concentrations of 31-47 $\mu$ eq $\mathrm{L}^{-1}$ (fig. 2.7). Simulated daily stream $\mathrm{NO}_{3}$ concentrations from 1983 to 1985 were greater than values measured during that time period, but 1988-1989 simulated daily $\mathrm{NO}_{3}$ concentrations were close to measured values (fig. 2.9). Concentrations of $\mathrm{NH}_{4}$ in stream water were usually below detection, and simulated values were also very low (figs. 2.7, 2.8).

\section{Sulfate}

The model showed declining annual VWM stream $\mathrm{SO}_{4}$ concentrations over the simulation period, and observed annual means (2000-2003) showed a comparable decline. The

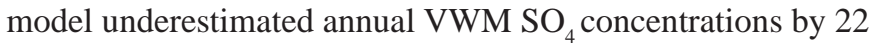
to $42 \mu \mathrm{eq} \mathrm{L} \mathrm{L}^{-1}$ (table 2.7) or by $23-46$ percent. For the 1980s, the model showed a wider range of daily $\mathrm{SO}_{4}$ concentrations than what measured values showed (fig. 2.9). For years 1999 2003, monthly measured VWM stream $\mathrm{SO}_{4}$ concentrations 

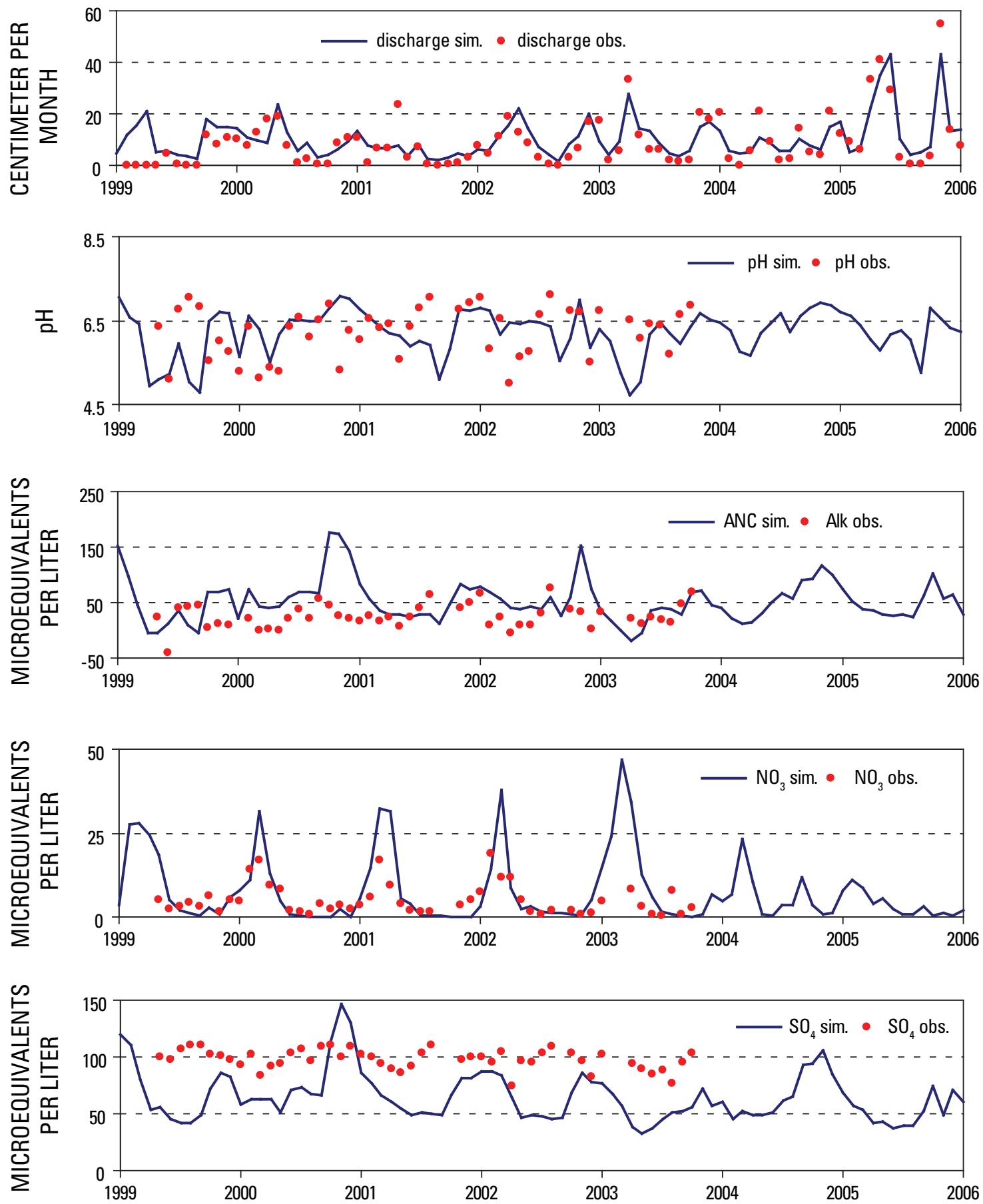

Figure 2.7. Simulated (sim) and observed (obs) discharge and volume-weighted mean (VWM) stream chemistry averaged by month for Hadlock Brook watershed, years 1999-2005 (x axis). 

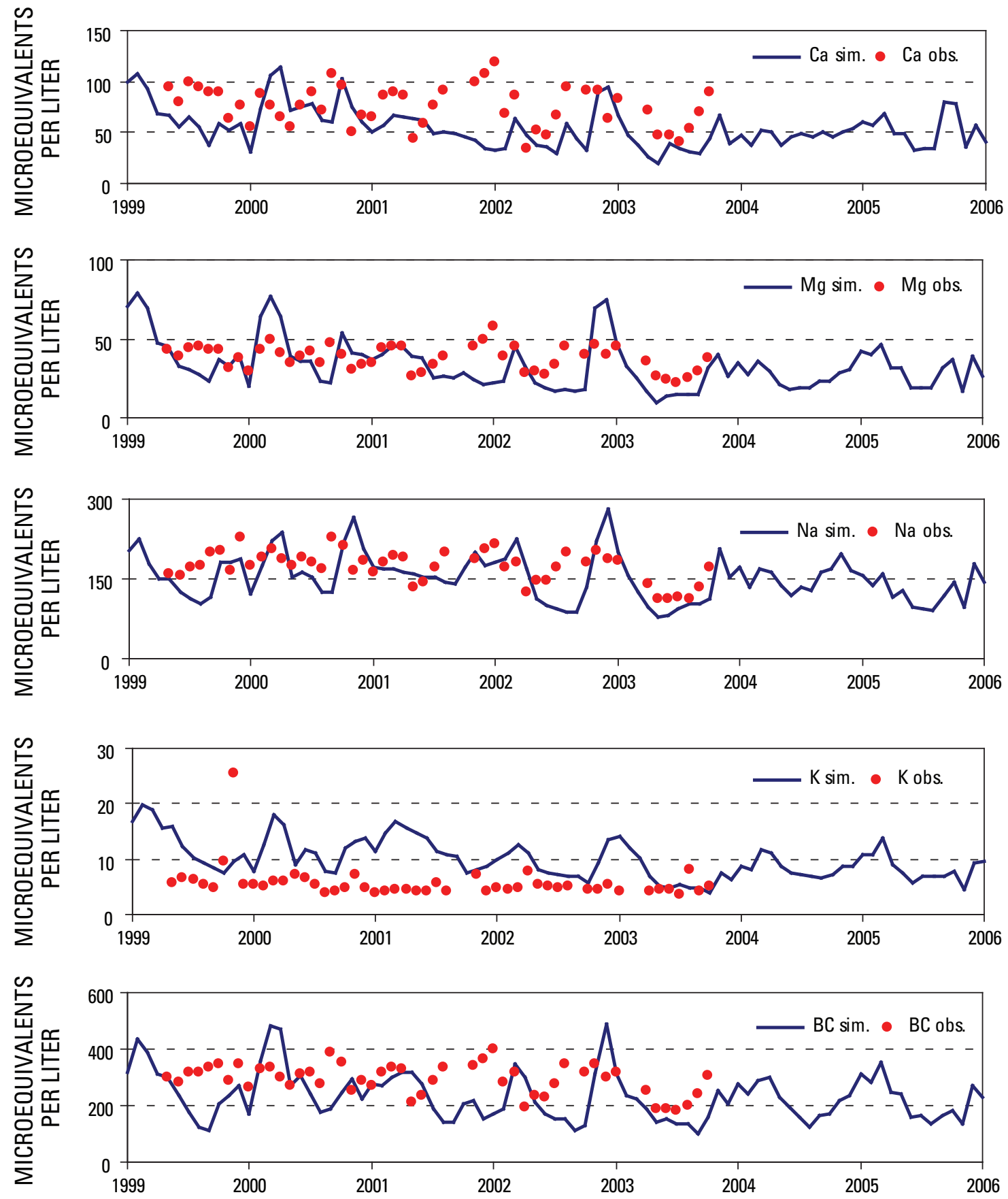

Figure 2.7. Simulated (sim) and observed (obs) discharge and volume-weighted mean (VWM) stream chemistry averaged by month for Hadlock Brook watershed, years 1999-2005 (x axis).-Continued 

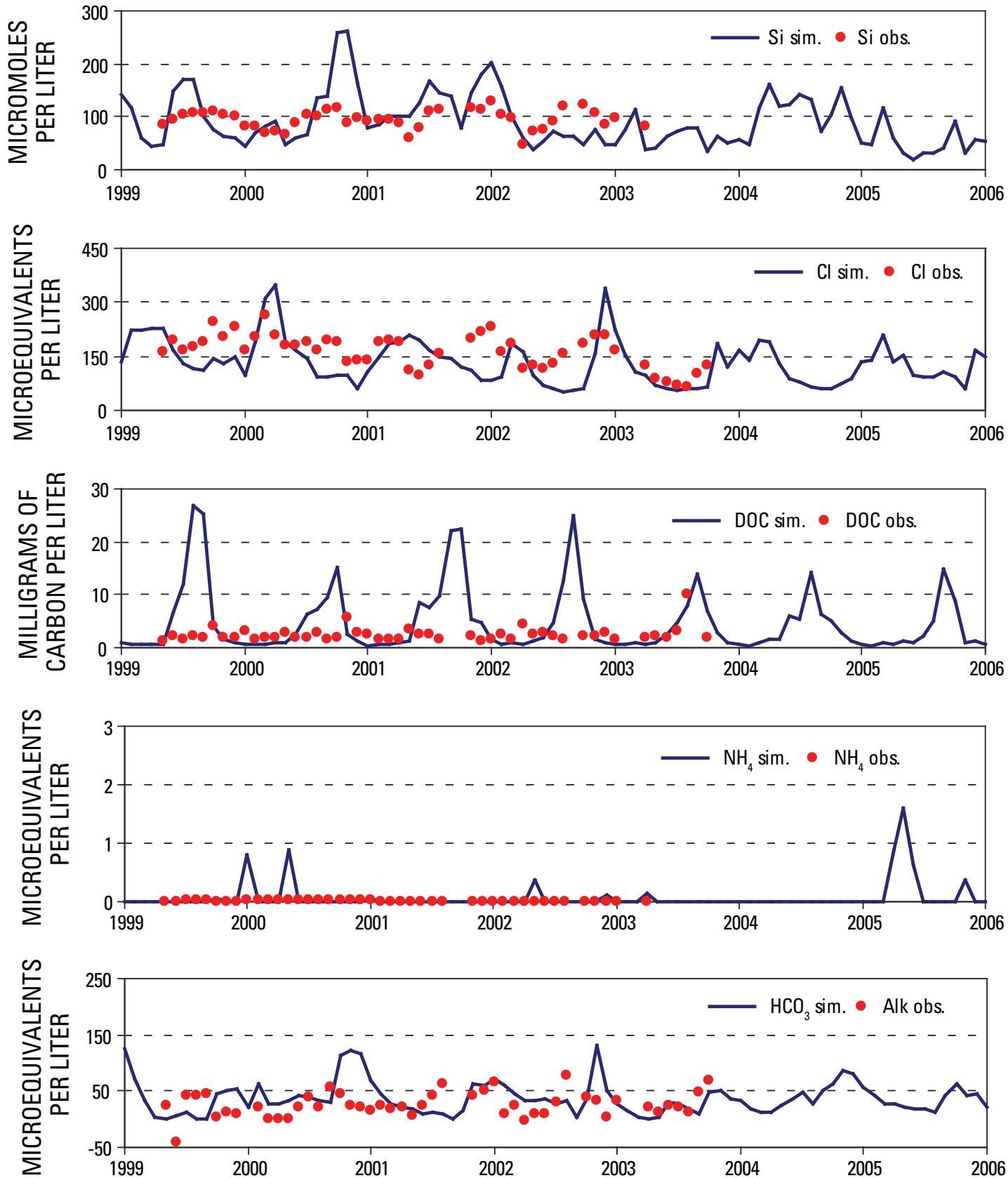

Figure 2.7. Simulated (sim) and observed (obs) discharge and volume-weighted mean (VWM) stream chemistry averaged by month for Hadlock Brook watershed, years 1999-2005 (x axis).-Continued 

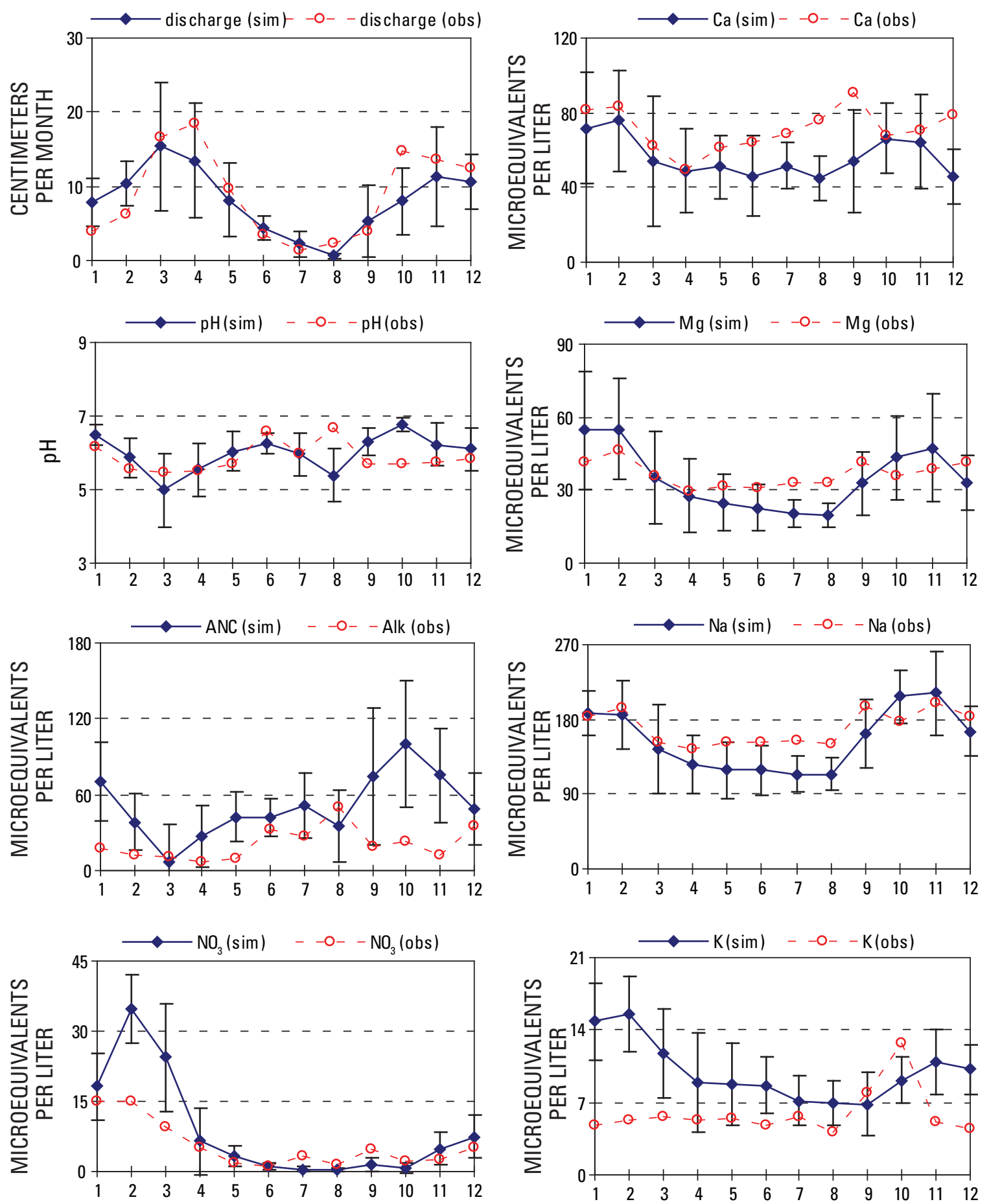

Figure 2.8. Simulated (sim) and observed (obs) stream chemistry averaged by month ( $x$ axis) for Hadlock Brook watershed, years 1999-2003. The vertical bars on the simulated values represent plus and minus one standard deviation from the simulated mean. 

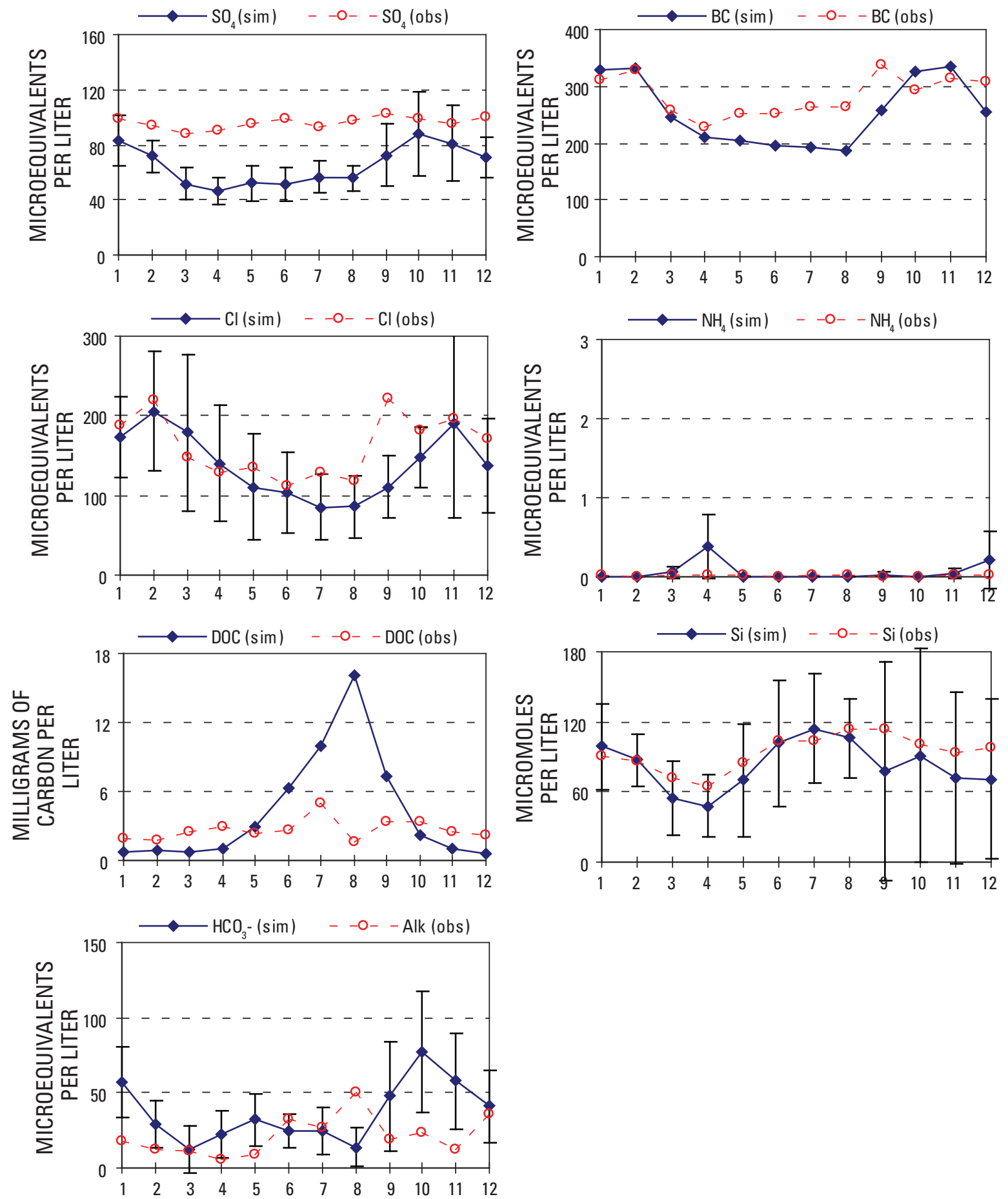

Figure 2.8. Simulated (sim) and observed (obs) stream chemistry averaged by month (x axis) for Hadlock Brook watershed, years 1999-2003. The vertical bars on the simulated values represent plus and minus one standard deviation from the simulated mean.-Continued 

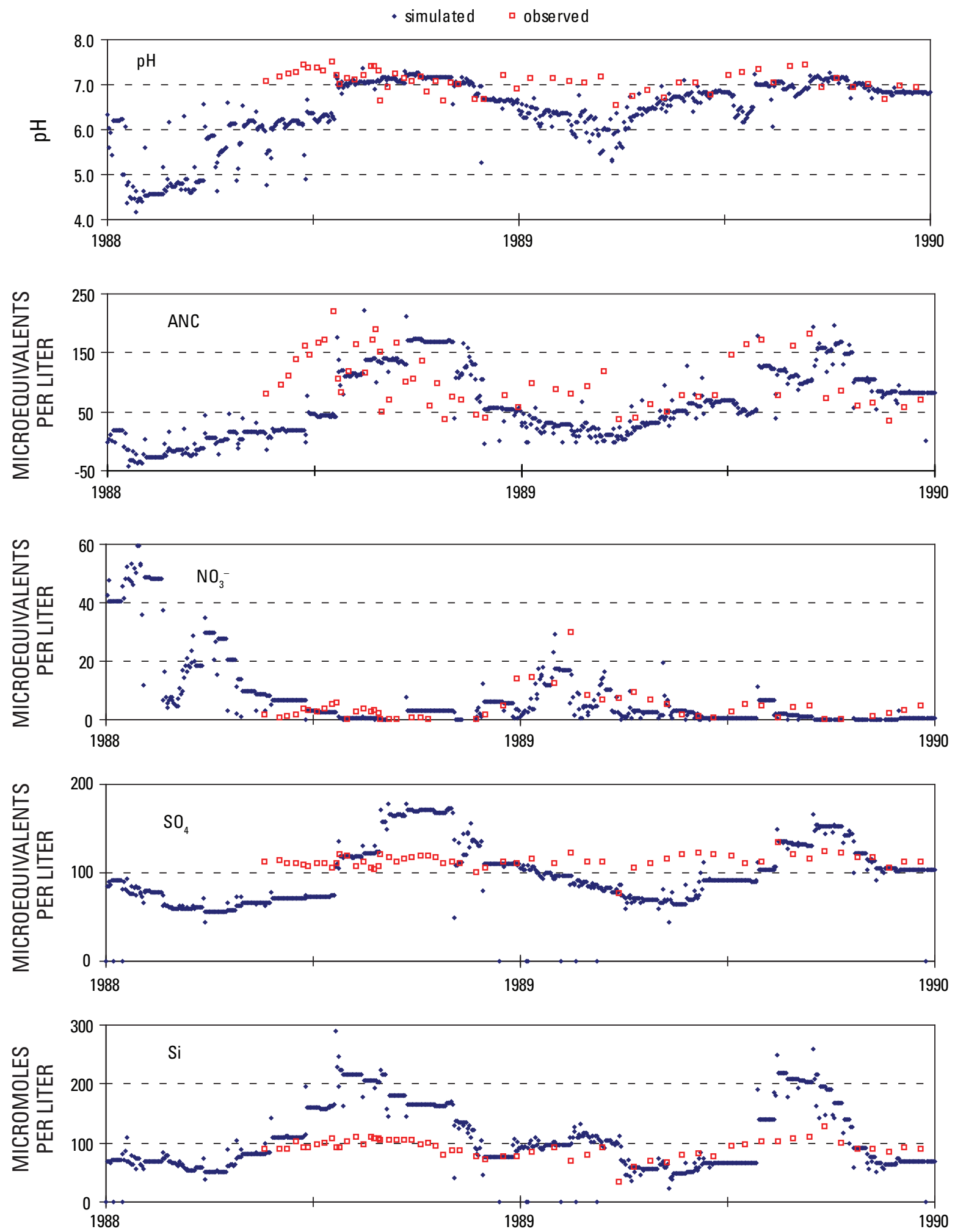

Figure 2.9. Simulated and observed daily stream chemistry for Hadlock Brook watershed, years 1988-1989 (x axis). 

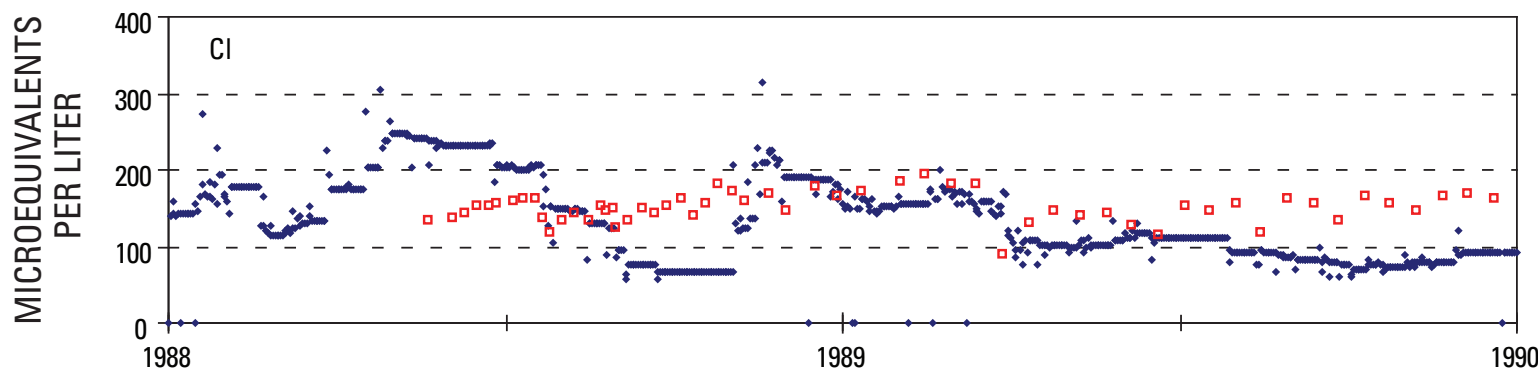

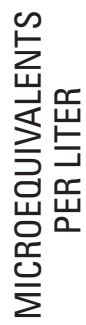

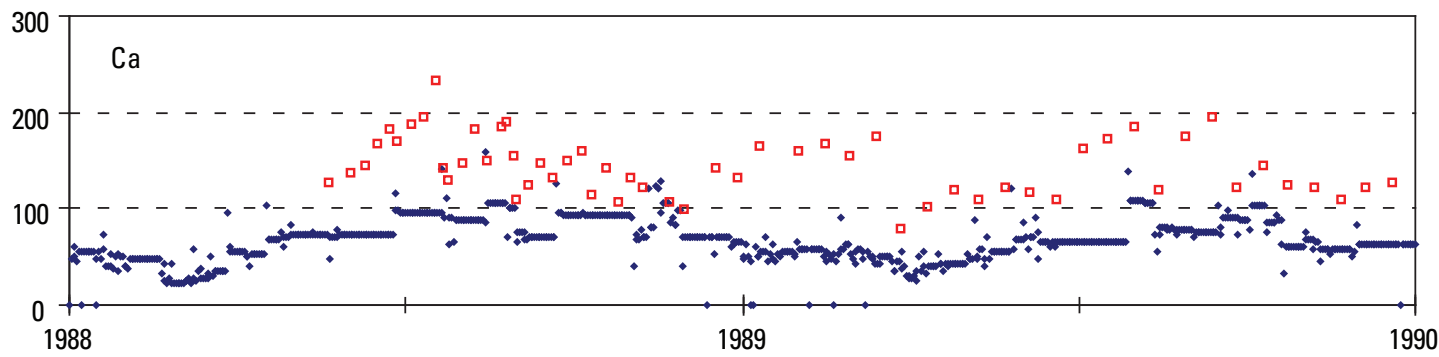

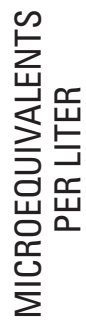

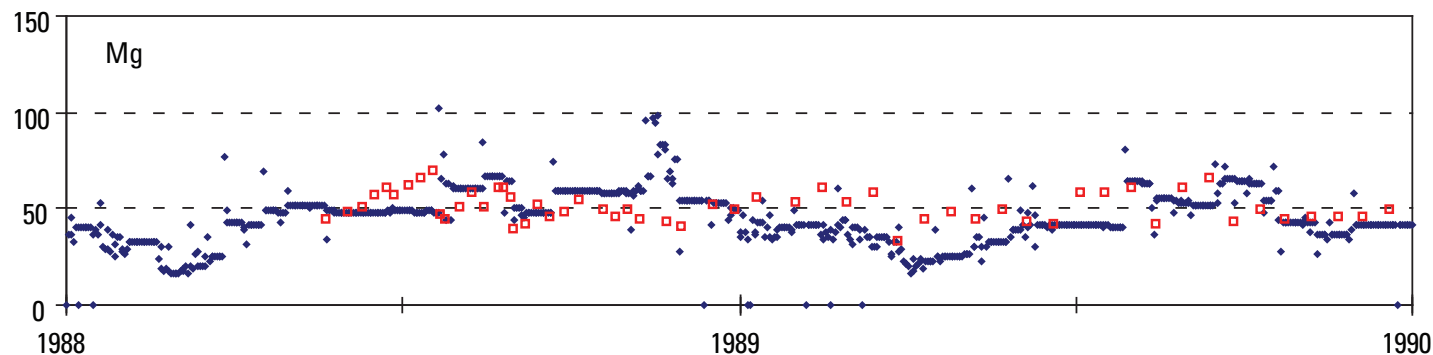

点
岸出
品品
品
号
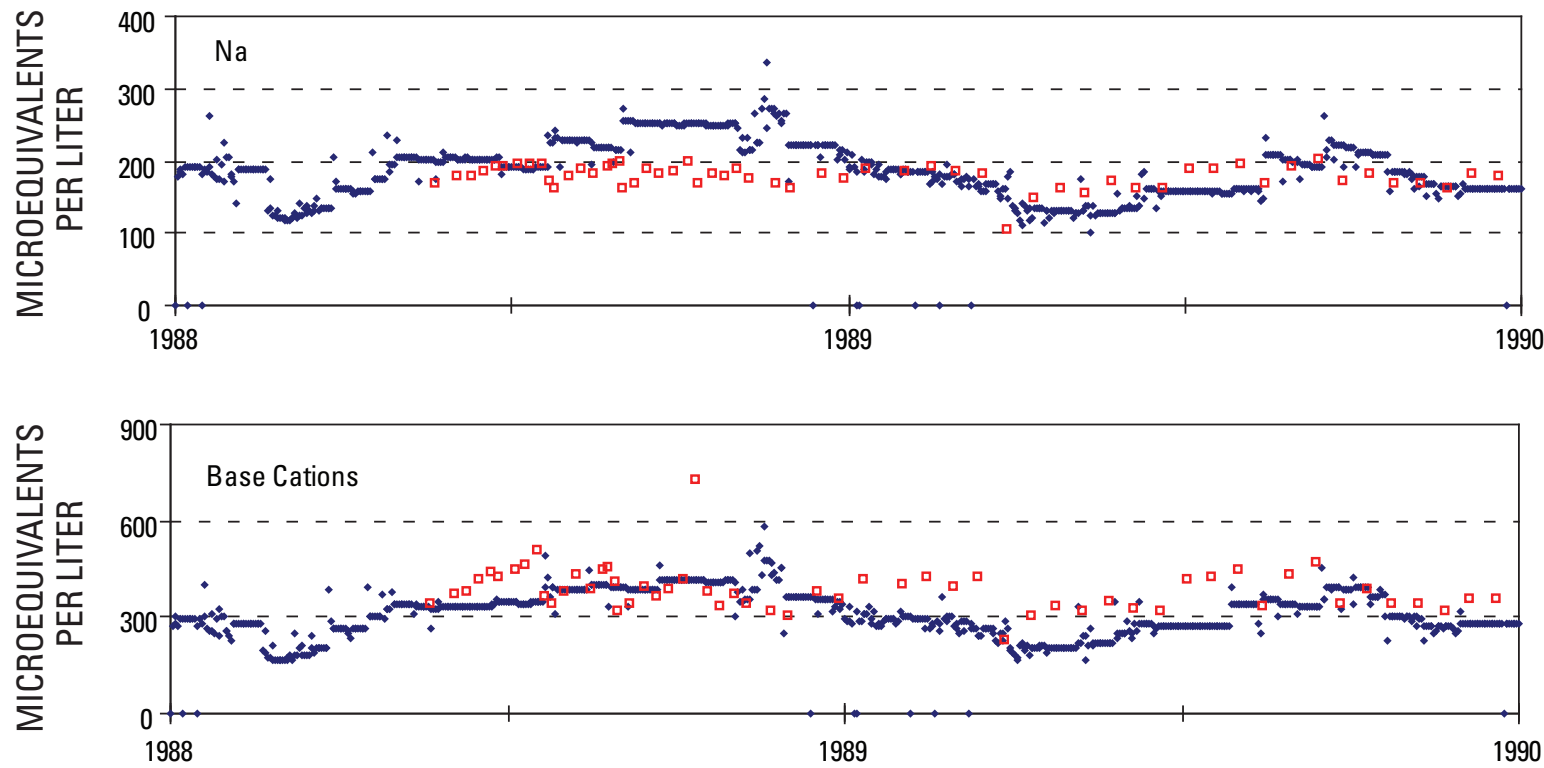

Figure 2.9. Simulated and observed daily stream chemistry for Hadlock Brook watershed, years 1988-1989 (x axis).-Continued 
were between 75 and $110 \mu \mathrm{eq} \mathrm{L}^{-1}$, varying from most diluted during late winter and early spring when discharge was highest to most concentrated during the summer when discharge was lowest (fig. 2.7). Simulated monthly stream $\mathrm{SO}_{4}$ concentrations for 1999-2003, ranging between 28 and $150 \mu \mathrm{eq} \mathrm{L}^{-1}$, were underestimated throughout the year except for autumn (figs. 2.7, 2.8). The rise and fall of simulated $\mathrm{SO}_{4}$ concentrations were partially out of phase with measured concentrations $\left(\mathrm{R}^{2}=0.06\right.$; table 2.6). Simulated stream $\mathrm{SO}_{4}$ concentrations were greatest on the rising limb of hydrographs and were lowest for the summer months, suggesting that simulated stream $\mathrm{SO}_{4}$ concentrations were regulated by soil flushing (fig. 2.7). We do not know why the model underestimated annual VWM stream $\mathrm{SO}_{4}$ concentrations. We set $\mathrm{SO}_{4}$ deposition as high as we could justify given measures of $\mathrm{SO}_{4}$ deposition at Acadia National Park (Weathers, Simkin, and others, 2006). Additionally, simulated S-mineralization was greater than simulated S-uptake (table 2.5), thus allowing for net loss of S from organic material in the soil (table 2.5). Nevertheless, the model still underestimated $\mathrm{SO}_{4}$ export into stream water.

\section{Chloride}

Measured monthly stream Cl concentrations (64 to $263 \mu \mathrm{eq} \mathrm{L}^{-1}$ ) were high at Hadlock Brook, reflecting a heavy sea salt contribution (fig. 2.7). Monthly simulated $\mathrm{Cl}$ concentrations (50 to $350 \mu \mathrm{eq} \mathrm{L}^{-1}$ ) were positively correlated with measured values $\left(\mathrm{R}^{2}=0.20\right.$; table 2.6$)$ and showed similar seasonal patterns for most months of the year except September (fig. 2.8). Simulated annual VWM Cl concentration was very close to the observed mean (table 2.7). The range of simulated daily values for the 1980s was greater than the measured range (fig. 2.9).

\section{Weathering Products}

The model estimated annual VWM stream $\mathrm{Na}, \mathrm{Mg}$, and total base cation concentrations within 2 percent of measured values (table 2.7). The magnitude and temporal patterns of simulated daily $\mathrm{Na}, \mathrm{Mg}$, and total base cation concentrations were similar to measured values (fig. 2.9). Despite very high inputs of dry plus fog Ca deposition to the model, the model underestimated annual VWM stream Ca concentrations by about 16 percent (table 2.7). Daily and monthly stream Ca concentrations also were underestimated most of the year (figs. 2.8, 2.9). Though dry plus fog $\mathrm{K}$ deposition inputs to the model were zero, model estimates of annual VWM stream K concentrations were high but within $6 \mu \mathrm{eq} \mathrm{L}^{-1}$ of measured values. Neither the pattern nor amount of $\mathrm{K}$ in stream water was captured by the model (figs. 2.7, 2.8). Seasonal simulated and measured patterns of stream $\mathrm{Ca}, \mathrm{Mg}$, and $\mathrm{Na}$ were similar, though in general the model underestimated summer stream water concentrations of all three elements (figs. 2.7, 2.8). This suggests that the high summer concentrations of base cations could originate in groundwater. Monthly simulated total base cation concentrations showed some correlation with measured values $\left(\mathrm{R}^{2}=0.16\right.$ ), with positive correlations for $\mathrm{Mg}$ and $\mathrm{Na}$ and no correlation for Ca and K (table 2.6). The model cannot account for biological cycling of base cations that may have an influence on $\mathrm{Ca}$ and $\mathrm{K}$ concentrations in the stream.

Many simulated monthly Si concentrations (36 to $261 \mu \mathrm{mol} \mathrm{L}^{-1}$ ) for years 1999-2004 were close to those measured concentrations (47 to $128 \mu \mathrm{mol} \mathrm{L}^{-1}$; fig. 2.7), and simulated values were positively correlated with measured values $\left(\mathrm{R}^{2}=0.18\right.$; table 2.6$)$. Seasonal patterns and concentrations of Si were very similar for predictions and observations (fig. 2.8). Simulated annual VWM Si concentrations also were very close to the observed means (table 2.7). For the late 1980s, many daily simulated Si concentrations were close to

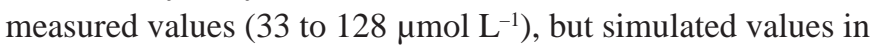
the summer and fall were greater than measured values (modeled as up to $300 \mu \mathrm{mol} \mathrm{L}^{-1}$ ) and again showed more variation than was observed in the field (fig. 2.9). Often stream silica is influenced by instream biologic activity, and DayCent-Chem does not account for instream processing.

\section{$\mathrm{ANC}$ and $\mathrm{pH}$}

Simulated stream $\mathrm{pH}$ and ANC followed measured $\mathrm{pH}$ and alkalinity dynamics from January through August, then showed a marked increase from September through November, whereas measured values of $\mathrm{pH}$ and alkalinity showed a decline (fig. 2.8). Measured monthly concentrations of alkalinity for years 1999-2003 ranged between -40 $\mu$ eq $\mathrm{L}^{-1}$ in May 1999 to $77 \mu$ eq $\mathrm{L}^{-1}$ in July 2002 and were less than $20 \mu$ eq $\mathrm{L}^{-1}$ for about one-third of the time, particularly during February through May. Several measured values showed that Hadlock Brook was episodically acidic in the winter or early spring. Simulated monthly ANC jumped to more than $150 \mu$ eq $\mathrm{L}^{-1}$ for a few autumn months when measured values declined (figs. 2.7, 2.8). Simulated $\mathrm{HCO}_{3}$ concentrations (which do not include Al-hydroxides) showed the same seasonal pattern as ANC but with a smaller magnitude of variability (fig. 2.8). The model overestimated annual VWM ANC by an average $31 \mu$ eq $\mathrm{L}^{-1}$ per year (table 2.7$)$. The majority of simulated daily ANC

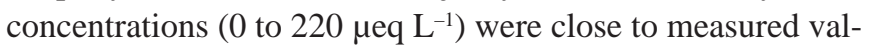
ues for 1988-1989 (34 to $220 \mu \mathrm{eq} \mathrm{L}{ }^{-1}$ ) and patterns were also similar, though measured alkalinity peaked earlier in the summer/fall of 1988 than the modeled ANC (fig. 2.9). Monthly simulated and measured VWM pH fluctuated by two units and were within the same range (5.0 to 7.0; fig. 2.7), and simulated and measured annual VWM pH also were close (table 2.7). For years 1988-1989, simulated maximum daily $\mathrm{pH}$ values were close to measured values, but minimum simulated $\mathrm{pH}$ was about 1.0 to 1.5 units less than measured values (fig. 2.9). 
Table 2.7. Annual volume-weighted mean simulated (sim) and observed (obs) stream solute concentrations and discharge, years 2000-2003. The mean is the 4-year average value. The mean "sim-obs" value is the average error (AE). Min and max are the 4-year minimum and maximum in each row. The normalized average error (NAE) is the AE divided by the observed mean. $B C=$ the sum of base cations ( $\mathrm{Ca}, \mathrm{Mg}, \mathrm{K}, \mathrm{Na}) ; 0$ = discharge. Units are $\mu \mathrm{eq} \mathrm{L}^{-1}$ except where indicated.

\begin{tabular}{|c|c|c|c|c|c|c|c|c|}
\hline & 2000 & 2001 & 2002 & 2003 & Mean & Min & Max & NAE \\
\hline pH (sim) & 6.23 & 6.23 & 6.24 & 5.21 & 5.70 & 5.21 & 6.24 & \\
\hline $\mathrm{pH}$ (obs) & 5.48 & 5.92 & 5.54 & 6.39 & 5.71 & 5.48 & 6.39 & \\
\hline sim-obs & 0.75 & 0.31 & 0.71 & -1.18 & -0.01 & -1.18 & 0.75 & $-0.08 \%$ \\
\hline $\mathrm{H}^{+}(\operatorname{sim})$ & 0.59 & 0.59 & 0.57 & 6.19 & 1.98 & 0.57 & 6.19 & \\
\hline $\mathrm{H}^{+}$(obs) & 3.34 & 1.20 & 2.90 & 0.41 & 1.96 & 0.41 & 3.34 & \\
\hline sim-obs & -2.75 & -0.61 & -2.33 & 5.78 & 0.02 & -2.75 & 5.78 & $1.11 \%$ \\
\hline $\mathrm{Ca}^{2+}(\operatorname{sim})$ & 76.04 & 55.24 & 56.26 & 36.83 & 56.09 & 36.83 & 76.04 & \\
\hline $\mathrm{Ca}^{2+}$ (obs) & 67.31 & 73.39 & 64.35 & 61.43 & 66.62 & 61.43 & 73.39 & \\
\hline sim-obs & 8.73 & -18.15 & -8.08 & -24.60 & -10.53 & -24.60 & 8.73 & $-15.80 \%$ \\
\hline $\mathrm{Mg}^{2+}(\operatorname{sim})$ & 46.25 & 35.71 & 39.22 & 22.68 & 35.97 & 22.68 & 46.25 & \\
\hline $\mathrm{Mg}^{2+}$ (obs) & 38.50 & 37.33 & 37.05 & 31.16 & 36.01 & 31.16 & 38.50 & \\
\hline sim-obs & 7.75 & -1.62 & 2.17 & -8.48 & -0.04 & -8.48 & 7.75 & $-0.12 \%$ \\
\hline $\mathrm{K}^{+}(\operatorname{sim})$ & 12.15 & 13.31 & 10.21 & 6.92 & 10.65 & 6.92 & 13.31 & \\
\hline $\mathrm{K}^{+}$(obs) & 5.90 & 4.58 & 5.40 & 4.45 & 5.08 & 4.45 & 5.90 & \\
\hline sim-obs & 6.24 & 8.73 & 4.81 & 2.48 & 5.56 & 2.48 & 8.73 & $109.46 \%$ \\
\hline $\mathrm{Na}^{+}(\operatorname{sim})$ & 181.55 & 166.93 & 176.24 & 124.07 & 162.20 & 124.07 & 181.55 & \\
\hline $\mathrm{Na}^{+}$(obs) & 183.24 & 169.03 & 166.49 & 131.12 & 162.47 & 131.12 & 183.24 & \\
\hline sim-obs & -1.69 & -2.11 & 9.74 & -7.05 & -0.28 & -7.05 & 9.74 & $-0.17 \%$ \\
\hline BC (sim) & 315.98 & 271.19 & 281.93 & 190.50 & 264.90 & 190.50 & 315.98 & \\
\hline BC (obs) & 294.95 & 284.33 & 273.29 & 228.15 & 270.18 & 228.15 & 294.95 & \\
\hline sim-obs & 21.03 & -13.14 & 8.64 & -37.65 & -5.28 & -37.65 & 21.03 & $-1.95 \%$ \\
\hline $\mathrm{NH}_{4}^{+}(\operatorname{sim})$ & 0.19 & 0.00 & 0.09 & 0.03 & 0.08 & 0.00 & 0.19 & \\
\hline $\mathrm{NH}_{4}^{+}$(obs) & 0.02 & 0.01 & 0.01 & 0.01 & 0.01 & 0.01 & 0.02 & \\
\hline sim-obs & 0.17 & -0.01 & 0.08 & 0.02 & 0.07 & -0.01 & 0.17 & $564.85 \%$ \\
\hline $\mathrm{NO}_{3}^{-}(\operatorname{sim})$ & 7.41 & 12.85 & 8.42 & 15.82 & 11.12 & 7.41 & 15.82 & \\
\hline $\mathrm{NO}_{3}^{-}$(obs) & 7.70 & 6.07 & 6.23 & 5.32 & 6.33 & 5.32 & 7.70 & \\
\hline sim-obs & -0.30 & 6.78 & 2.19 & 10.50 & 4.80 & -0.30 & 10.50 & $75.76 \%$ \\
\hline $\mathrm{SO}_{4}^{2-}(\operatorname{sim})$ & 74.93 & 66.45 & 66.22 & 49.40 & 64.25 & 49.40 & 74.93 & \\
\hline $\mathrm{SO}_{4}{ }^{2-}(\mathrm{obs})$ & 97.01 & 92.94 & 92.54 & 91.42 & 93.48 & 91.42 & 97.01 & \\
\hline sim-obs & -22.08 & -26.49 & -26.32 & -42.03 & -29.23 & -42.03 & -22.08 & $-31.27 \%$ \\
\hline ANC (sim) & 72.07 & 44.56 & 58.10 & 21.79 & 49.13 & 21.79 & 72.07 & \\
\hline Alk (obs) & 10.78 & 26.15 & 14.88 & 22.32 & 18.53 & 10.78 & 26.15 & \\
\hline sim-obs & 61.28 & 18.41 & 43.22 & -0.52 & 30.60 & -0.52 & 61.28 & $165.11 \%$ \\
\hline $\mathrm{Cl}^{-}(\operatorname{sim})$ & 177.11 & 159.53 & 161.78 & 108.60 & 151.75 & 108.60 & 177.11 & \\
\hline $\mathrm{Cl}^{-}$(obs) & 185.39 & 154.22 & 158.59 & 104.80 & 150.75 & 104.80 & 185.39 & \\
\hline sim-obs & -8.28 & 5.30 & 3.19 & 3.79 & 1.00 & -8.28 & 5.30 & $0.66 \%$ \\
\hline
\end{tabular}


Table 2.7. Annual volume-weighted mean simulated (sim) and observed (obs) stream solute concentrations and discharge, years 2000-2003. The mean is the 4-year average value. The mean "sim-obs" value is the average error (AE). Min and max are the 4-year minimum and maximum in each row. The normalized average error (NAE) is the AE divided by the observed mean. $B C=$ the sum of base cations $(\mathrm{Ca}, \mathrm{Mg}, \mathrm{K}, \mathrm{Na}) ; \mathrm{O}=$ discharge. Units are $\mu$ eq $\mathrm{L}^{-1}$ except where indicated. —Continued

\begin{tabular}{|c|c|c|c|c|c|c|c|c|}
\hline & 2000 & 2001 & 2002 & 2003 & Mean & Min & Max & NAE \\
\hline $\mathrm{Si}\left(\operatorname{sim}, \mu \mathrm{mol} \mathrm{L} \mathrm{L}^{-1}\right)$ & 92.20 & 122.21 & 61.99 & 56.93 & 83.33 & 56.93 & 122.21 & \\
\hline Si (obs, $\mu \mathrm{mol} \mathrm{L} \mathrm{L}^{-1}$ ) & 80.53 & 87.44 & 83.38 & 83.33 & 83.67 & 80.53 & 87.44 & \\
\hline sim-obs & 11.68 & 34.77 & -21.39 & -26.39 & -0.33 & -26.39 & 34.77 & $-0.40 \%$ \\
\hline DOC (sim, mg L L & 2.02 & 3.31 & 1.84 & 1.83 & 2.25 & 1.83 & 3.31 & \\
\hline DOC (obs, mg L-1) & 2.59 & 2.50 & 2.69 & 2.33 & 2.53 & 2.33 & 2.69 & \\
\hline sim-obs & -0.57 & 0.82 & -0.85 & -0.50 & -0.28 & -0.85 & 0.82 & $-10.93 \%$ \\
\hline $\mathrm{Q}(\mathrm{sim}, \mathrm{cm})$ & 96.73 & 47.18 & 115.36 & 118.18 & 94.36 & 47.18 & 118.18 & \\
\hline Q (obs, cm) & 99.90 & 60.69 & 104.10 & 130.38 & 98.77 & 60.69 & 130.38 & \\
\hline sim-obs & -3.17 & -13.51 & 11.26 & -12.20 & -4.41 & -13.51 & 11.26 & $-4.46 \%$ \\
\hline
\end{tabular}

\section{Dissolved Organic Carbon}

Measured annual VWM DOC from 2000 to 2003 showed little interannual variability ( 2.3 to $2.7 \mathrm{mg} \mathrm{C} \mathrm{L}^{-1}$ ), whereas simulated concentrations ranged from 1.8 to $3.3 \mathrm{mg} \mathrm{C} \mathrm{L}^{-1}$ during the same time period (table 2.7). Simulated monthly DOC concentrations were inversely related to discharge, diluted to less than $1 \mathrm{mg} \mathrm{C} \mathrm{L}^{-1}$ during the wet winter and spring months and highly concentrated during the drier summer months (figs. 2.7, 2.8). Measured monthly DOC concentrations changed little with discharge, showed no regular seasonal pattern, and remained elevated above $1.4 \mathrm{mg} \mathrm{C} \mathrm{L}^{-1}$.

\section{Summary}

At Hadlock Brook, where fog immersion may be frequent, total atmospheric deposition of base cations, chloride, and sulfate is likely to be many times greater than wet deposition, possibly due to sea salts deposited by marine fog (Weathers and others, 1986; Kimball and others, 1988; Weathers and others, 1988; Jagels and others, 1989; Weathers, Likens, and others, 2006). In addition, dry deposition is not easy to estimate in complex terrain (Weathers, Simkin, and others, 2006). The model could not explain many stream solute concentrations measured at Hadlock Brook without simulating fog deposition inputs in addition to wet plus dry deposition inputs.

The model was able to replicate the timing and magnitude of daily discharge for much of the simulation period, though the model underestimated some high flow events.
Simulated annual discharge was within 5 percent of measured annual discharge. Simulated monthly discharge showed a strong correlation with measured discharge.

The model was able to estimate the mass balance of most stream solutes. Annual volume-weighted mean concentrations produced by the model were within 11 percent of the mean measured values or were within $5 \mu \mathrm{eq} \mathrm{L}{ }^{-1}$ of mean measured values for eleven of fourteen measures $\left(\mathrm{pH}, \mathrm{H}^{+}, \mathrm{Mg}, \mathrm{K}, \mathrm{Na}\right.$, sum of base cations, $\mathrm{NH}_{4}, \mathrm{NO}_{3}, \mathrm{Cl}, \mathrm{Si}$, and DOC). The largest discrepancies between simulated and observed annual means were for $\mathrm{Ca}$, ANC, and $\mathrm{SO}_{4}$.

The temporal patterns of most solutes were replicated by the model for at least part of the year. The correlations between monthly simulated and observed stream solute concentrations were strongest for $\mathrm{NO}_{3}, \mathrm{Na}, \mathrm{Cl}, \mathrm{Si}, \mathrm{Mg}$, and the sum of base cations. The differences between the temporal patterns of observed and simulated stream concentrations may be related to the rate of soil flushing in the model. For most solutes, the model concentrated solutes in soil solution during dry periods and flushed them out during wet periods, showing a wider range of concentrations than what was observed. At Hadlock Brook there appeared to be more opportunity for subsurface waters to mix, possibly due to longer hydrologic pathways that the model represented. Additionally, the model does not account for biological cycling of any elements except $\mathrm{C}, \mathrm{N}, \mathrm{P}$, and $\mathrm{S}$, and biological processes may be influencing the concentrations of other biologically active elements such as Ca and K. Furthermore, the model could not account for groundwater flow that may contribute high base cation concentrations in the summer and fall, and instream biological activity that may consume dissolved silica.

The high stream Ca concentrations at Hadlock Brook could not be explained by the model, despite high inputs of $\mathrm{Ca}$ 
deposition to the model. The growing season (May-September) was the time of greatest underestimate by the model and corresponded to underestimates of stream water $\mathrm{Na}$ and $\mathrm{Mg}$ at the same time. There may be sources of these base cations from mineral dissolution, decomposing organic matter, release from the soil exchange complex, or from groundwater that was not accounted for in the model.

The model was not able to replicate the high stream $\mathrm{SO}_{4}$ concentrations that were observed. Like many areas in the northeastern United States, Acadia National Park has had a longer history of $\mathrm{N}$ and $\mathrm{S}$ deposition than sites in other regions. We speculate that the ecosystem is a source of $\mathrm{SO}_{4}$ through soil organic matter mineralization and (or) desorption of $\mathrm{SO}_{4}$. We do not believe that there is a significant source of $\mathrm{SO}_{4}$ from mineral dissolution (for example, pyrite); however, it is possible that our $\mathrm{S}$ deposition estimates are too low. 


\section{Hubbard Brook Long-Term Ecological Research Site, New Hampshire}

\section{Site Description}

The Hubbard Brook Experimental Forest (HBR), a 3,160 ha reserve located in the White Mountain National Forest, N.H., is administered by the U.S. Forest Service (table 3.1, fig. 3.1). It has been a long-term ecological research site since 1963.

For this modeling exercise we focused on the 13.2-ha biogeochemical reference watershed (W6) in HBR. The area has been relatively free of human disturbance except for intensive logging that took place in 1909 and 1917. The watershed also was damaged by a hurricane in 1938 and an ice storm in January 1998 (Aber and others, 2002).

The vegetation at HBR is characteristic of northern mixed hardwood forest consisting of deciduous American beech, sugar maple, and yellow birch, and coniferous balsam fir and red spruce (table 3.1).

The soils are well-drained sandy loam with a high infiltration capacity and are classified as Spodosols (Haplorthods). The surface is rough, encouraging infiltration, and virtually all incident water from rain and snowmelt percolates through the soil even in the largest storms. Bedrock is composed of granite and schist. The geologic substrate is relatively watertight, and export of water from deep seepage or lateral transport across watershed boundaries is limited. Water is transported downhill to the stream bed via subsurface interflow. Soils usually remain unfrozen during the winter because of a thick humus layer and deep snow cover (Likens and Bormann, 1995).

\section{Methods}

\section{Climate and Hydrology}

Daily meteorological data were retrieved from the Hubbard Brook website (http://www.hubbardbrook.org/, accessed 17 July 2006). From 1979 through 2004, mean annual temperature at HBR was 4.4 (std. dev. 0.8$)^{\circ} \mathrm{C}$ and increased by $0.05^{\circ} \mathrm{C} \mathrm{yr}^{-1}$. The average annual precipitation was 142 (std. dev. 20) $\mathrm{cm} \mathrm{yr}^{-1}$ (fig. 3.2). Daily stream discharge measurements and monthly VWM stream concentrations were available from the Hubbard Brook website.

Precipitation inputs were evenly distributed throughout the year (fig. 3.3). Discharge was regulated by snow accumulation and melt and was greatest in spring during snowmelt. Discharge was lowest during the summer due to high evapotranspiration. Despite large differences in annual precipitation, evapotranspiration at HBR was relatively constant from year to year; discharge was correlated to precipitation. Seasonal streamflow varied by orders of magnitude, but annual streamflow varied twofold or less.

\section{Atmospheric Deposition}

Wet deposition concentration inputs to the model were measured at the NADP/NTN Hubbard Brook site (NH02). Dry:wet deposition ratios were determined from previous modeling studies (table 3.2) (Gbondo-Tugbawa and others, 2001; Backx, 2004). From 1979 through 2004, annual S deposition declined steeply, and $\mathrm{NO}_{3}-\mathrm{N}$ deposition also declined, but $\mathrm{NH}_{4}-\mathrm{N}$ deposition rates did not change (fig. 3.4).

\section{Soil and Mineral Properties}

Mineral weathering rates were initially set to match mineral cation and Si fluxes determined from a previous study (Gbondo-Tugbawa and others, 2001). We had to lower these rates by about 50 percent to better reproduce the measured stream chemistry (table 3.3). The mineral reactions are summarized below.

$$
\begin{aligned}
& \text { Albite: } \quad \mathrm{NaAlSi}_{3} \mathrm{O}_{8}+8 \mathrm{H}_{2} \mathrm{O}=\mathrm{Na}^{+}+\mathrm{Al}(\mathrm{OH})_{4}^{-}+3 \mathrm{H}_{4} \mathrm{SiO}_{4} \\
& \text { Anorthite: } \mathrm{CaAl} 2 \mathrm{Si}_{2} \mathrm{O}_{8}+8 \mathrm{H}_{2} \mathrm{O}=\mathrm{Ca}^{2+}+2 \mathrm{Al}(\mathrm{OH})_{4} \\
& +2 \mathrm{H}_{4} \mathrm{SiO}_{4} \\
& \text { Phlogopite: } \mathrm{KMg}_{3} \mathrm{AlSi}_{3} \mathrm{O}_{10}(\mathrm{OH})_{2}+10 \mathrm{H}^{+}=\mathrm{K}^{+} \\
& +3 \mathrm{Mg}^{2+}+\mathrm{Al}^{3+}+3 \mathrm{H}_{4} \mathrm{SiO}_{4}
\end{aligned}
$$

Soil properties of five layers, including horizon thickness and exchangeable cations, were obtained from Johnson, Johnson, and others (1991) (table 3.4). Other soil properties were calibrated.

\section{Calibration and Validation}

We represented the forest as 65 percent deciduous and 35 percent evergreen. To parameterize the model for Hubbard Brook, we first adjusted vegetation and soil parameters until 
Table 3.1. Characteristics of biogeochemical reference watershed 6 (W6) at Hubbard Brook LTER, New Hampshire.

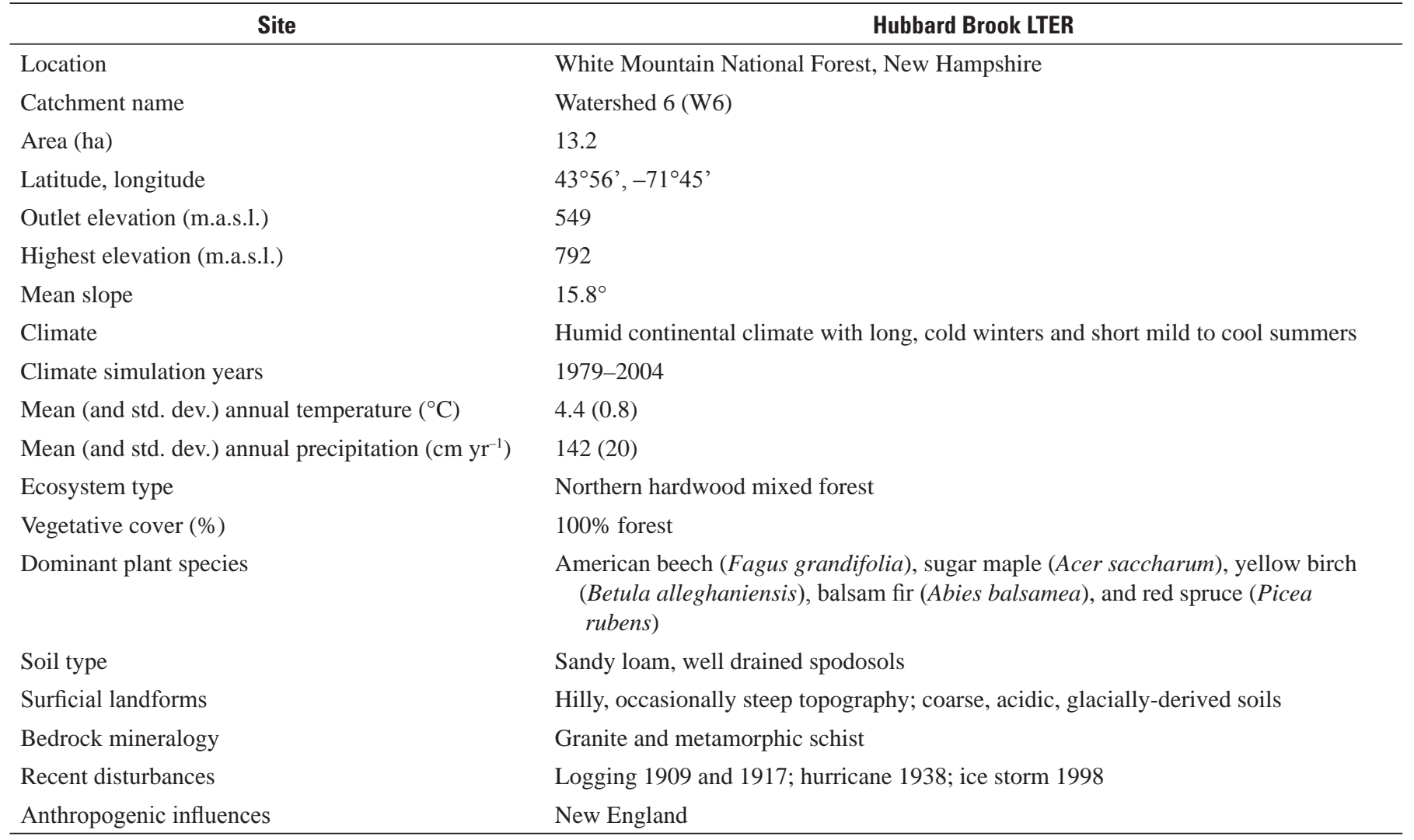

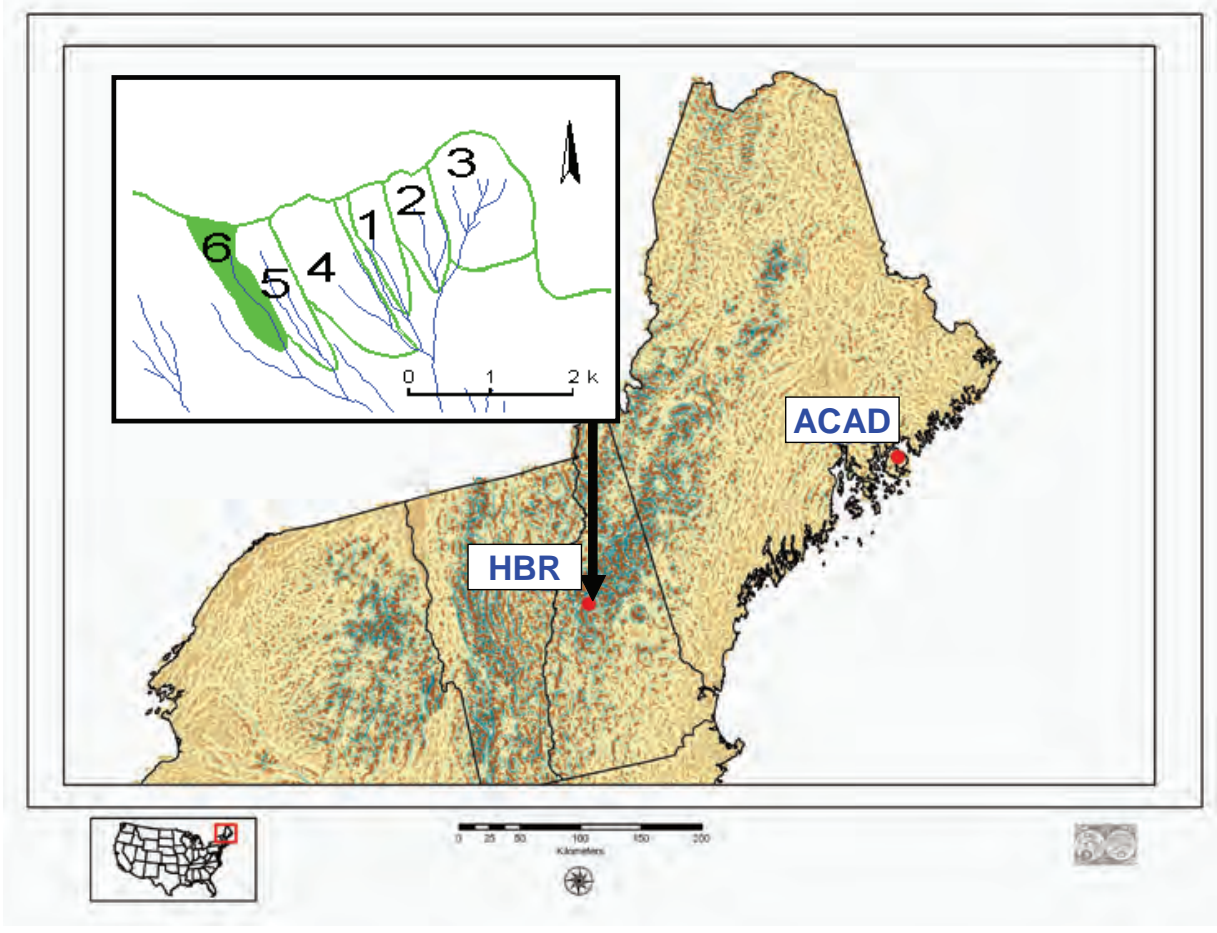

Figure 3.1. Hubbard Brook Experimental Forest (HBR) is located in the White Mountain National Forest, New Hampshire. Watershed 6 (W6; inset) is the biogeochemical reference watershed at HBR. 

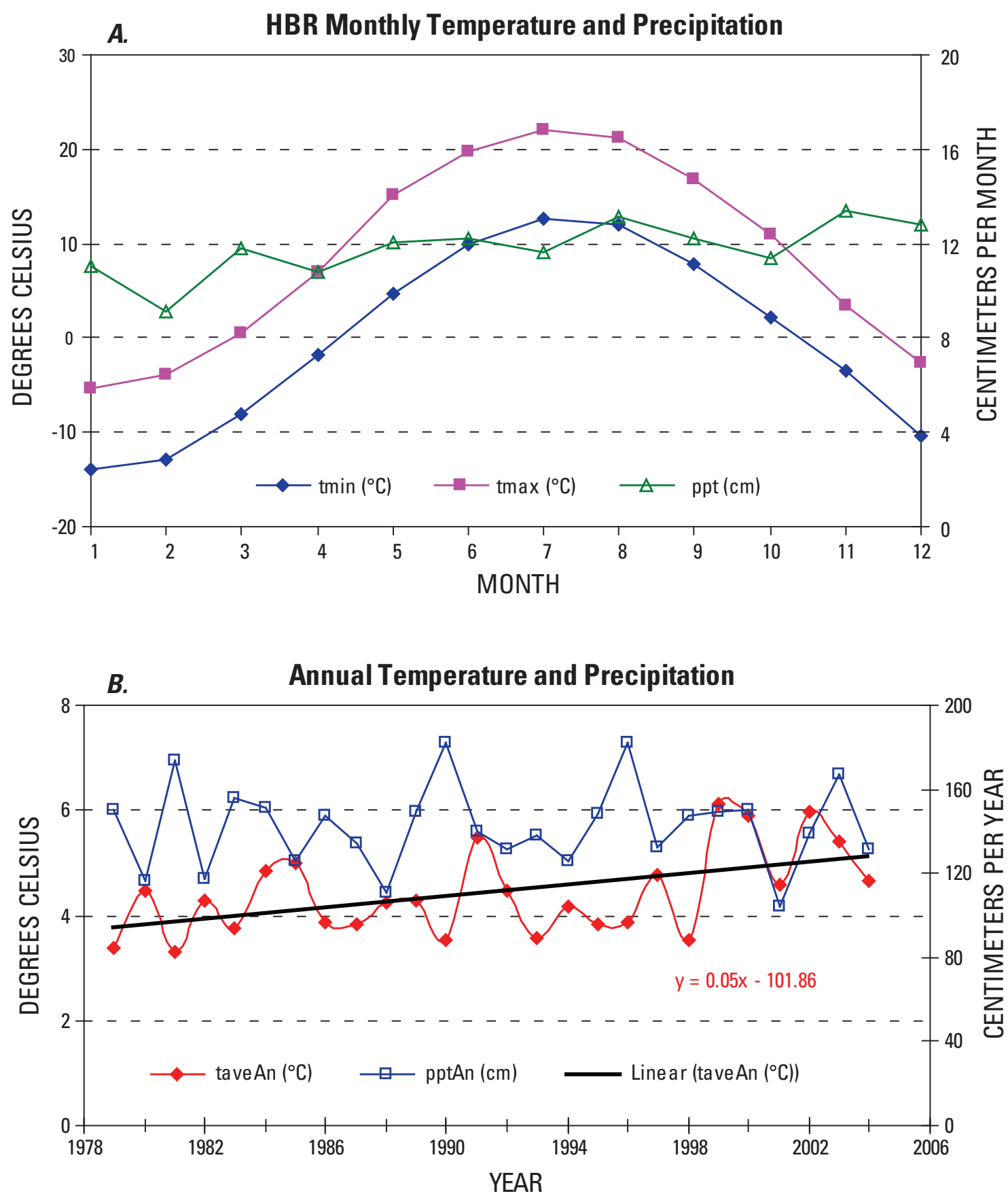

Figure 3.2. Meteorological statistics for the weather station at Hubbard Brook (HBR). A, Average monthly minimum air temperatures (tmin), maximum air temperatures (tmax), and precipitation (ppt), years 19792004. B, Mean annual temperature (taveAn) and annual precipitation (pptAn), years 1979-2004. Average annual temperature showed an increase of $0.05^{\circ} \mathrm{C} \mathrm{yr}^{-1}$. 


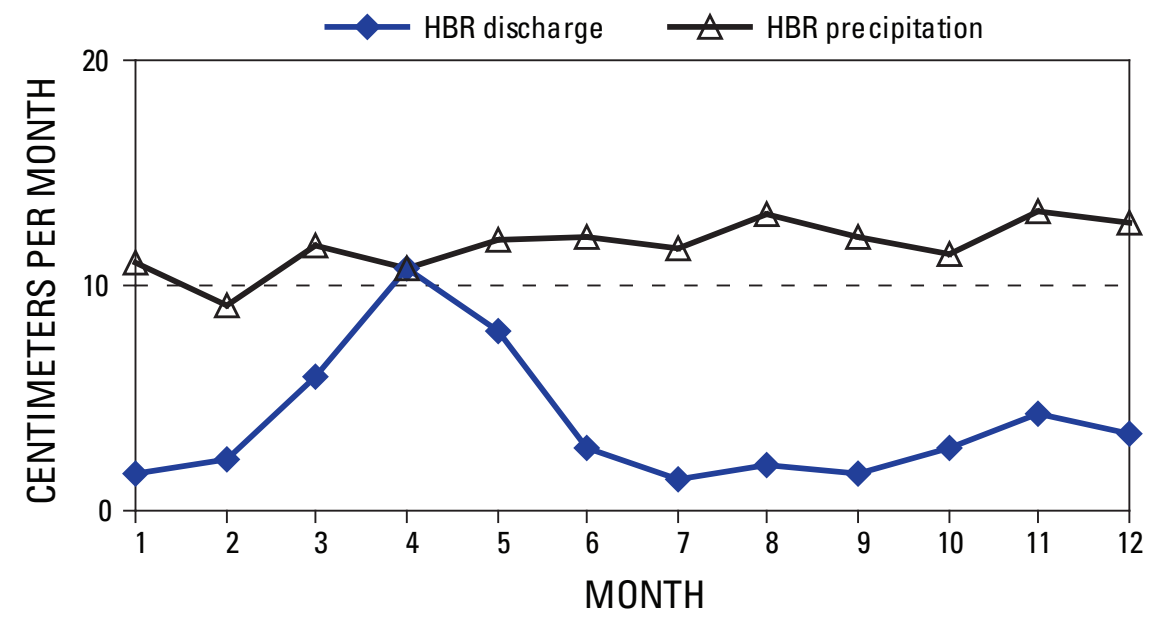

Figure 3.3. Relationship between average monthly precipitation and streamflow measured at W6, Hubbard Brook, years 1979-2004. Precipitation inputs are evenly distributed over the year. Stream outflow is low in the summer due to high evapotranspiration and high in the spring due to snowmelt.

Table 3.2. Average annual wet and dry plus fog deposition inputs $\left(\mathrm{kg} \mathrm{ha}^{-1} \mathrm{yr}^{-1}\right)$ to the model over the 1979-2004 simulation period.

\begin{tabular}{lccc}
\hline & Wet & Dry + Fog & Total \\
\hline $\mathrm{Ca}$ & 0.99 & 1.18 & 2.17 \\
$\mathrm{Cl}$ & 2.45 & 1.23 & 3.68 \\
$\mathrm{~K}$ & 0.22 & 0.07 & 0.28 \\
$\mathrm{Mg}$ & 0.28 & 0.34 & 0.62 \\
$\mathrm{NH}_{4}-\mathrm{N}$ & 1.90 & 0.21 & 2.10 \\
$\mathrm{NO}_{3}-\mathrm{N}$ & 4.39 & 0.53 & 4.91 \\
$\mathrm{Na}_{\mathrm{SO}_{4}-\mathrm{S}}$ & 1.52 & 0.45 & 1.97 \\
\hline
\end{tabular}



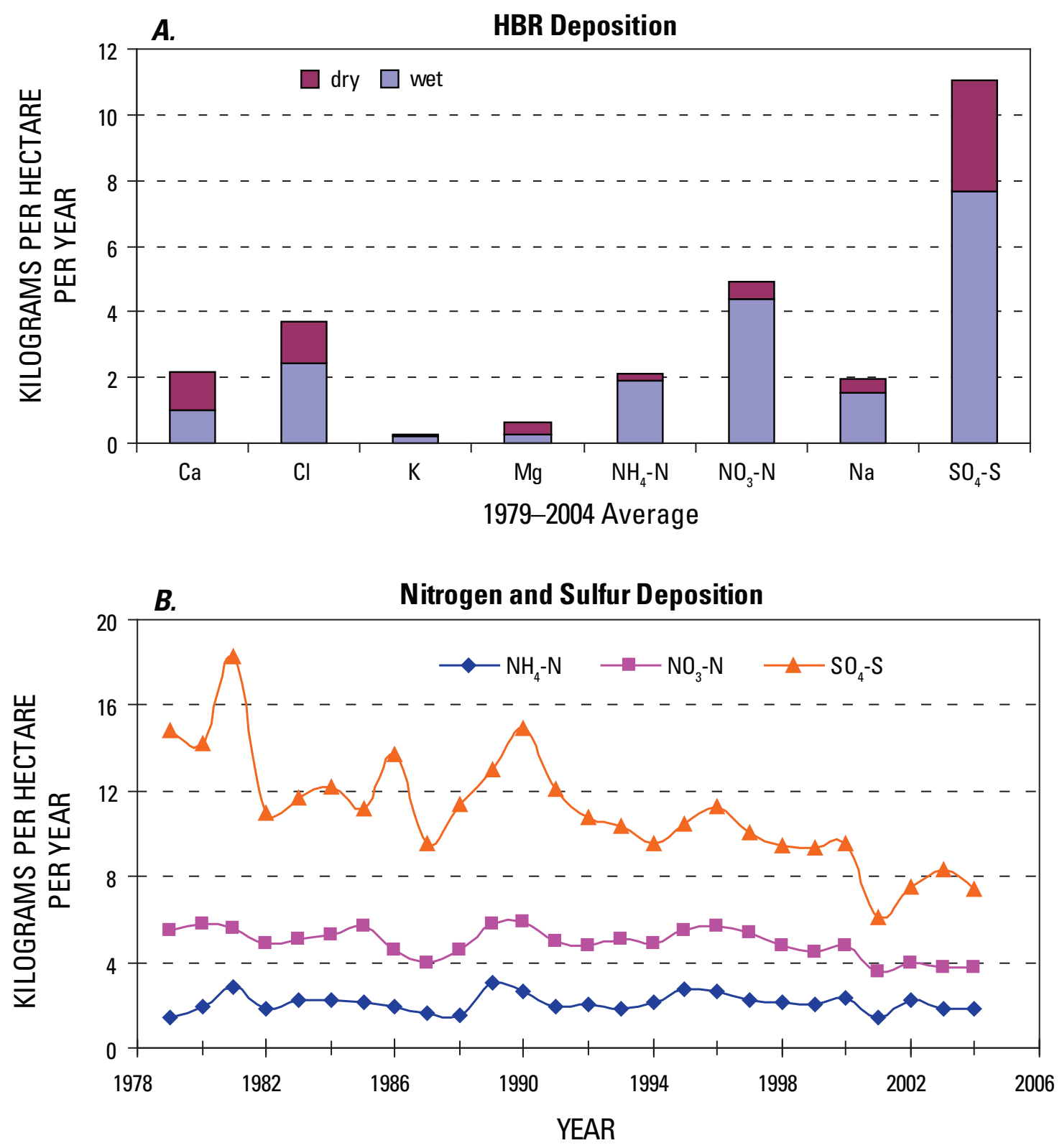

Figure 3.4. Deposition inputs to the model for Hubbard Brook (HBR). A, The 1979-2004 average annual wet and dry deposition. $B$, The time series of $\mathrm{N}$ and $\mathrm{S}$ deposition over the simulation period. 
Table 3.3. Mineral weathering rates as determined by calibration. All minerals were allowed only to dissolve.

\begin{tabular}{llc}
\hline \multicolumn{1}{c}{ Mineral phases } & mol m$^{-2} \mathbf{~ r r ~}^{-\mathbf{1}}$ & $\begin{array}{c}\mathbf{1}=\text { dissolve, } \\
\mathbf{0}=\text { precipitate or dissolve }\end{array}$ \\
\hline Albite & 0.013422 & 1 \\
Anorthite & 0.004962 & 1 \\
Phlogopite & 0.001042 & 1 \\
\hline
\end{tabular}

Table 3.4. Soil layer properties used for the simulation. Ksat is saturated hydraulic conductivity, and the mineral dissolution fraction (Minrl dissoln) is the fraction of total mineral dissolution that occurred in each layer. Wilting point and field capacity are expressed as volumetric soil water content. Exchangeable cations are expressed as milliequivalents per 100 grams of soil (meq/100 g). Total soil depth was $58 \mathrm{~cm}$, and organic soil made up the top $20 \mathrm{~cm}$.

\begin{tabular}{|c|c|c|c|c|c|c|c|c|c|}
\hline Layer & Thickness & Sand & Silt & Clay & $\begin{array}{c}\text { Bulk } \\
\text { density }\end{array}$ & $\begin{array}{c}\text { Wilting } \\
\text { point }\end{array}$ & $\begin{array}{c}\text { Field } \\
\text { capacity }\end{array}$ & $\begin{array}{c}\text { Ksat } \\
\text { cm }\end{array}$ & $\begin{array}{c}\text { Minrl } \\
\text { dissoln }\end{array}$ \\
\hline & $\mathbf{c m}$ & fraction & fraction & fraction & $\mathrm{g} \mathrm{cm}^{-3}$ & fraction & fraction & $\sec ^{-1}$ & fraction \\
\hline 0 & 7 & 0.39 & 0.49 & 0.12 & 1.0 & 0.0839 & 0.2674 & 0.00145 & 0.25 \\
\hline 1 & 9 & 0.39 & 0.49 & 0.12 & 1.1 & 0.0839 & 0.2674 & 0.00145 & 0.25 \\
\hline 2 & 9 & 0.39 & 0.49 & 0.12 & 1.2 & 0.0839 & 0.2674 & 0.00145 & 0.25 \\
\hline 3 & 15 & 0.39 & 0.49 & 0.12 & 1.2 & 0.0839 & 0.2674 & 0.00145 & 0.25 \\
\hline 4 & 18 & 0.39 & 0.49 & 0.12 & 1.2 & 0.0839 & 0.2674 & 0.00145 & 0.00 \\
\hline Layer & $\begin{array}{c}\mathrm{CaX}_{2} \\
\mathrm{meq} / 100 \mathrm{~g}\end{array}$ & $\begin{array}{c}\mathrm{MgX}_{2} \\
\mathrm{meq} / 100 \mathrm{~g}\end{array}$ & $\begin{array}{c}\mathrm{KX} \\
\mathrm{meq} / 100 \mathrm{~g}\end{array}$ & $\begin{array}{c}\mathrm{NaX} \\
\mathrm{meq} / 100 \mathrm{~g}\end{array}$ & $\begin{array}{c}\mathrm{AlOHX}_{2} \\
\mathrm{meq} / 100 \mathrm{~g}\end{array}$ & $\begin{array}{c}\mathrm{AlX}_{3} \\
\mathrm{meq} / 100 \mathrm{~g}\end{array}$ & $\begin{array}{c}\mathrm{FeX}_{2} \\
\mathrm{meq} / 100 \mathrm{~g}\end{array}$ & $\begin{array}{c}\mathrm{HX} \\
\mathrm{meq} / 100 \mathrm{~g}\end{array}$ & $\begin{array}{c}\mathrm{NH}_{4} \mathrm{X} \\
\mathrm{meq} / 100 \mathrm{~g}\end{array}$ \\
\hline 0 & 6.67 & 1.22 & 0.8 & 0.26 & 0.0 & 2.79 & 0.28 & 5.87 & 0.55 \\
\hline 1 & 0.79 & 0.21 & 0.18 & 0.04 & 0.0 & 6.34 & 0.4 & 1.57 & 0.00 \\
\hline 2 & 0.36 & 0.10 & 0.09 & 0.04 & 0.0 & 6.90 & 0.22 & 0.62 & 0.00 \\
\hline 3 & 0.19 & 0.04 & 0.05 & 0.05 & 0.0 & 4.52 & 0.08 & 0.46 & 0.00 \\
\hline 4 & 0.19 & 0.04 & 0.05 & 0.05 & 0.0 & 4.52 & 0.08 & 0.46 & 0.00 \\
\hline
\end{tabular}

simulated ecological variables were close to reported values (table 3.5).

Stream discharge and monthly chemistry were calibrated using data from years 1979-1998, and results from years 1999-2004 were emergent from existing parameterization.

We show two 3-year periods of stream discharge and chemistry. The first period (1988-1991) was chosen because these were the last three years before modeled stream nitrate diverged from observations (fig. 3.5). We chose the other years (2002-2004) because they were the most recent of the simulation and were included in the validation period (fig. 3.6).

\section{Model Output}

\section{Ecological Variables}

Simulated total net primary production (NPP) was 414 (std. dev. 58) $\mathrm{g} \mathrm{C} \mathrm{m}^{-2} \mathrm{yr}^{-1}$ and fell within the range of previous measurements (Pregitzer and Euskirchen, 2004) (table 3.5). The simulated above ground NPP of 302 (std. dev. 34) g C $\mathrm{m}^{-2} \mathrm{yr}^{-1}$ was slightly lower than the measured value of 354 $\mathrm{g} \mathrm{C} \mathrm{m}^{-2} \mathrm{yr}^{-1}$ (Fahey and others, 2005). The model predicted less heterotrophic respiration, 290 (std. dev. 15) $\mathrm{g} \mathrm{C} \mathrm{m}^{-2} \mathrm{yr}^{-1}$, lower total litterfall values, 242 (std. dev. 14) $\mathrm{g} \mathrm{C} \mathrm{m}^{-2} \mathrm{yr}^{-1}$, and greater net ecosystem production (NEP), 124 (std. dev. 52) g $\mathrm{C} \mathrm{m}^{-2} \mathrm{yr}^{-1}$, than what has been measured (383, 389, and $20 \mathrm{~g} \mathrm{C}$ $\mathrm{m}^{-2} \mathrm{yr}^{-1}$, respectively; table 3.5).

The simulated total soil organic matter of 4,137 (std. dev. 82) g C m${ }^{-2}$ was at the high end of a reported range, 1,5004,200 g C m${ }^{-2}$ (Pregitzer and Euskirchen, 2004) (table 3.5). Live biomass carbon for leaves was very close to a previously reported value, and large wood was underestimated by 20 percent, while coarse roots and fine roots were overestimated by 9 and 80 percent, respectively. Modeled total ecosystem carbon, $18,642 \mathrm{~g} \mathrm{C} \mathrm{m}^{-2}$, was slightly less than a previously reported value of 21,000 $\mathrm{g} \mathrm{C} \mathrm{m}^{-2}$ (Pregitzer and Euskirchen, 2004). 
Table 3.5. Simulated (1979-2004) and measured ecological variables and input/output fluxes. Standard deviations are shown in parentheses and represent interannual variation for annual fluxes and monthly variations for state variables. NPP = Net primary production; NEP = net ecosystem production; $\mathrm{Rh}=$ heterotrophic respiration; $\mathrm{PET}=$ potential evapotranspiration; $\mathrm{AET}=\mathrm{actual}$ evapotranspiration; and $\mathrm{DOC}=$ dissolved organic carbon. To convert units reported by data sources, it was assumed that $2.25 \mathrm{~g}$ biomass equals 1 gram $C$.

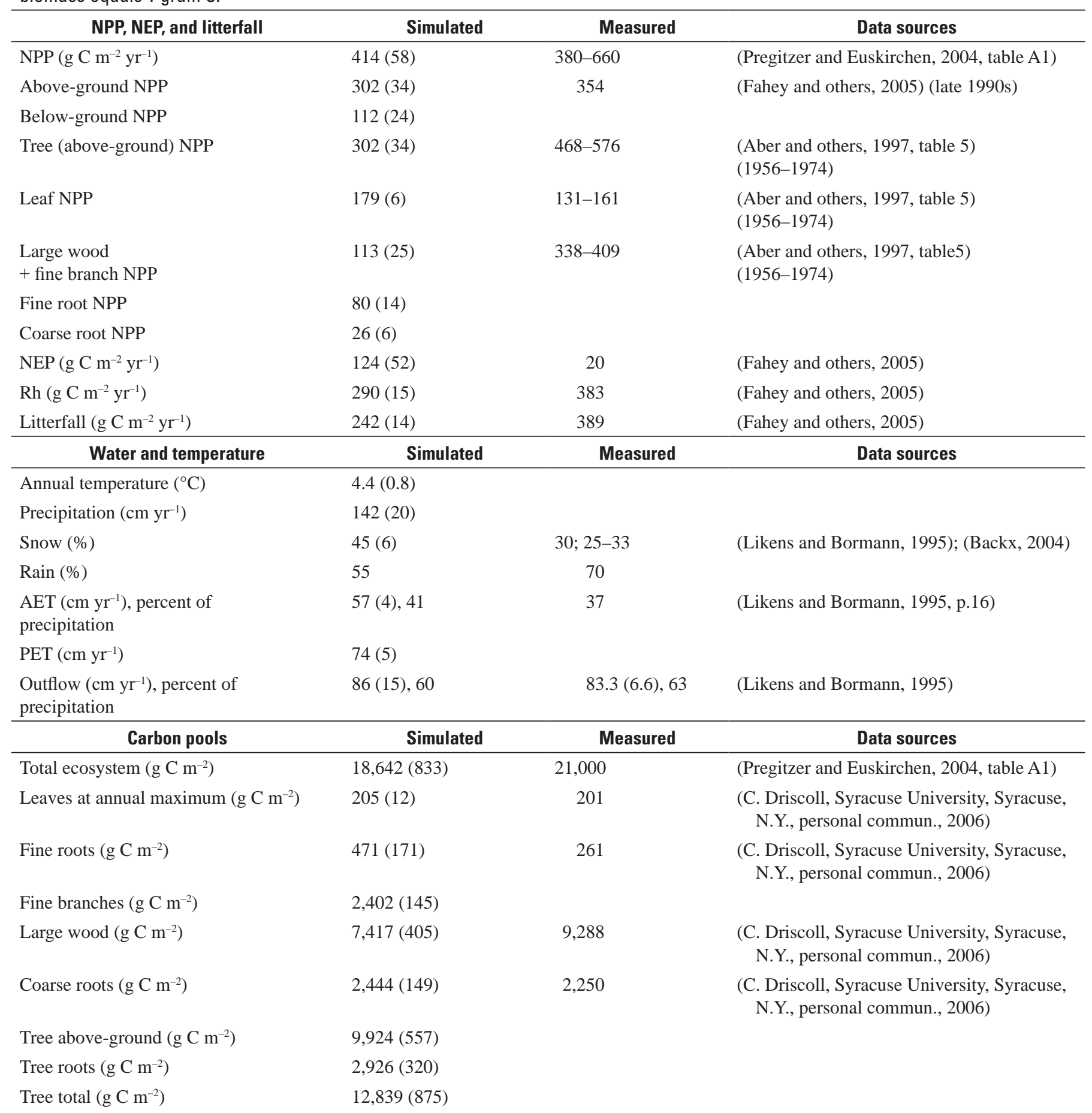


Table 3.5. Simulated (1979-2004) and measured ecological variables and input/output fluxes. Standard deviations are shown in parentheses and represent interannual variation for annual fluxes and monthly variations for state variables. NPP = Net primary production; NEP = net ecosystem production; $\mathrm{Rh}=$ heterotrophic respiration; $\mathrm{PET}=$ potential evapotranspiration; $\mathrm{AET}=$ actual evapotranspiration; and DOC = dissolved organic carbon. To convert units reported by data sources, it was assumed that $2.25 \mathrm{~g}$ biomass equals 1 gram C.-Continued

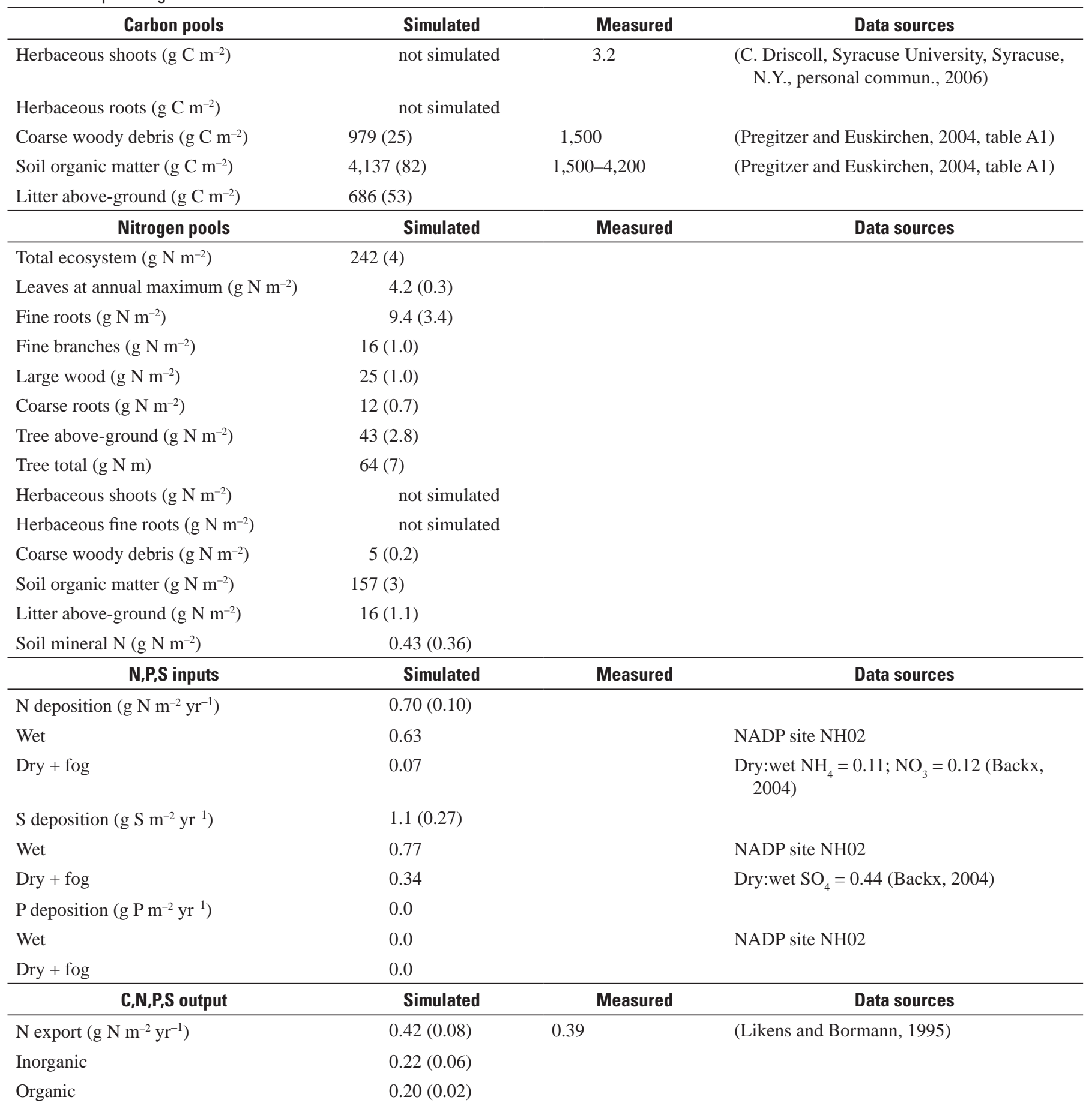


Table 3.5. Simulated (1979-2004) and measured ecological variables and input/output fluxes. Standard deviations are shown in parentheses and represent interannual variation for annual fluxes and monthly variations for state variables. NPP = Net primary production; NEP = net ecosystem production; $\mathrm{Rh}=$ heterotrophic respiration; $\mathrm{PET}=$ potential evapotranspiration; $\mathrm{AET}=\mathrm{actual}$ evapotranspiration; and DOC = dissolved organic carbon. To convert units reported by data sources, it was assumed that $2.25 \mathrm{~g}$ biomass equals 1 gram $\mathrm{C}$.-Continued

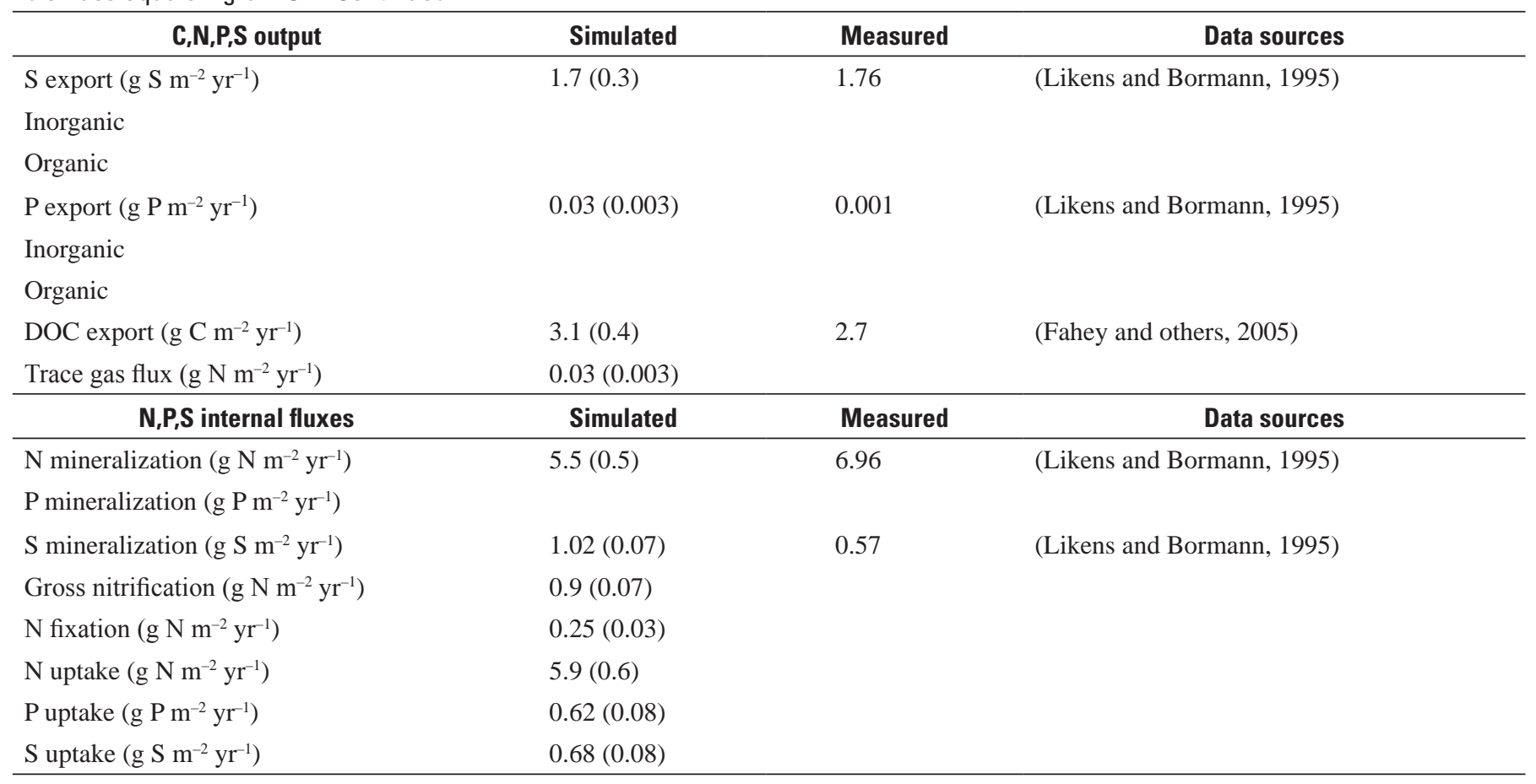



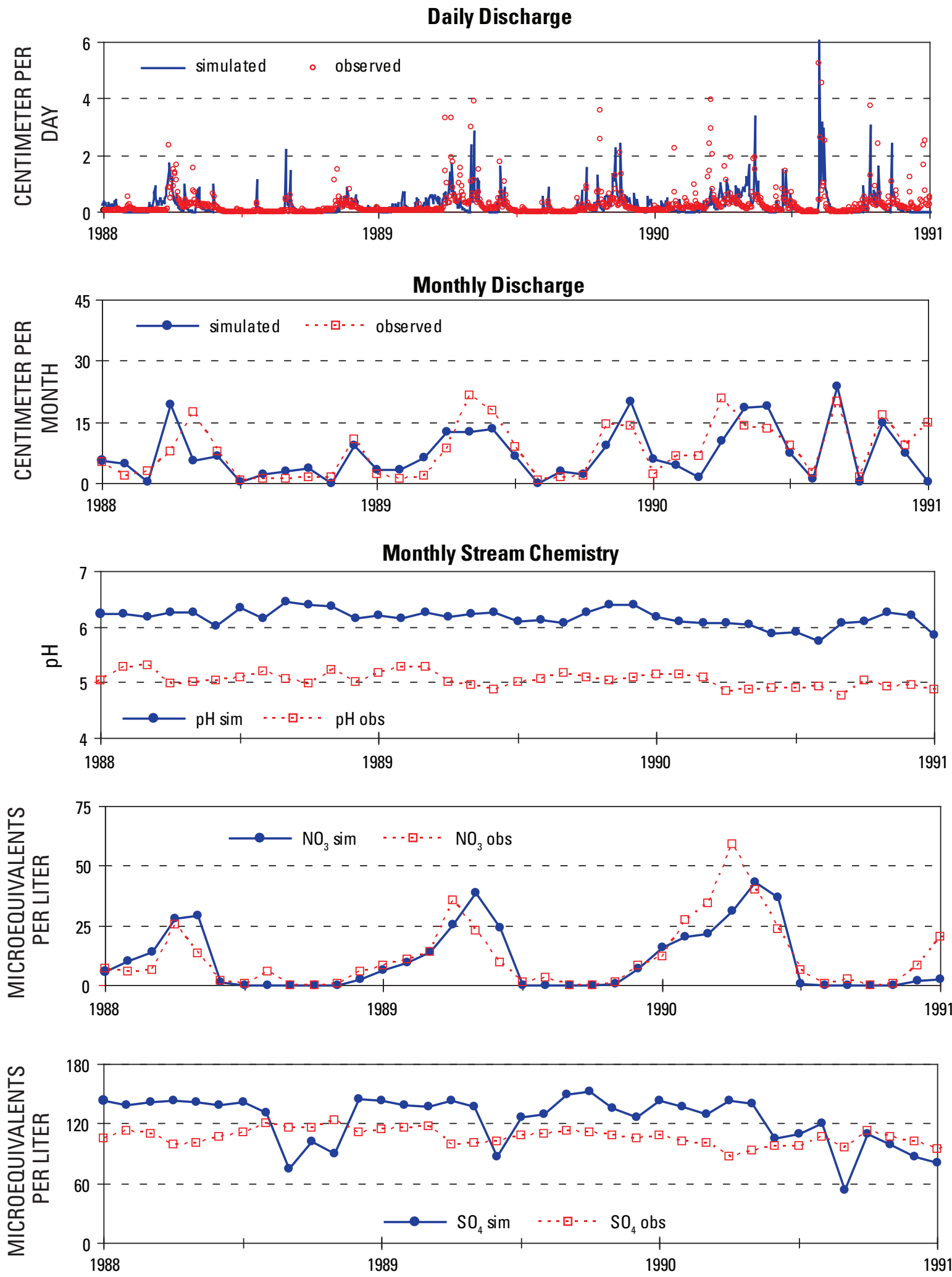

Figure 3.5. Simulated (sim) and observed (obs) discharge and stream chemistry for W6, Hubbard Brook, years 1988-1990 ( $\mathrm{x}$ axis). Measured DOC and ANC were not available. 


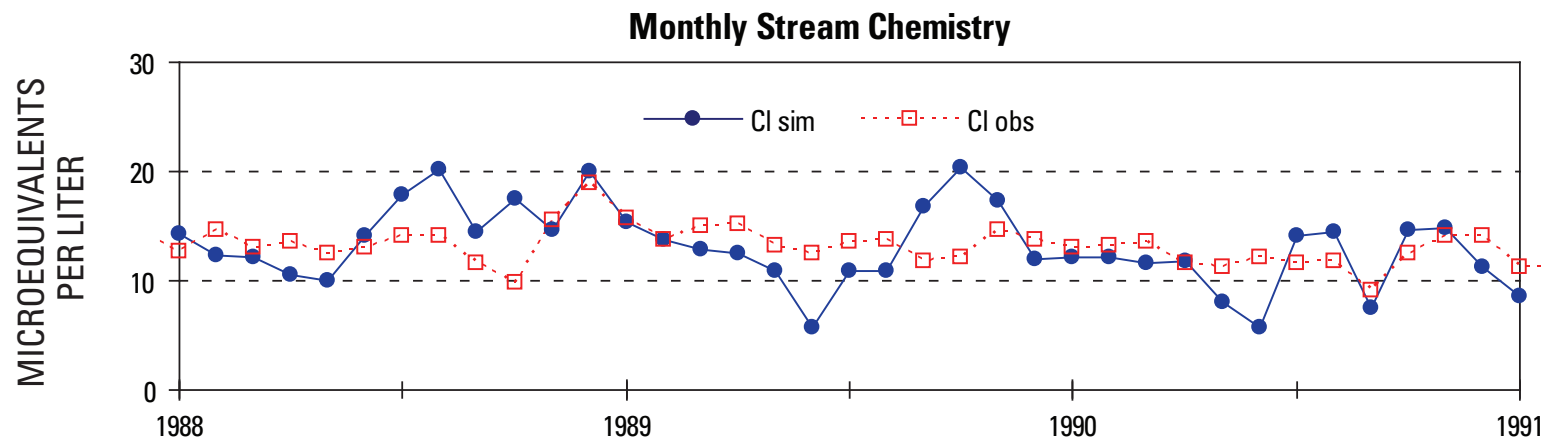

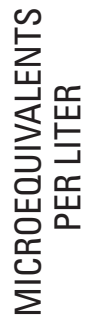
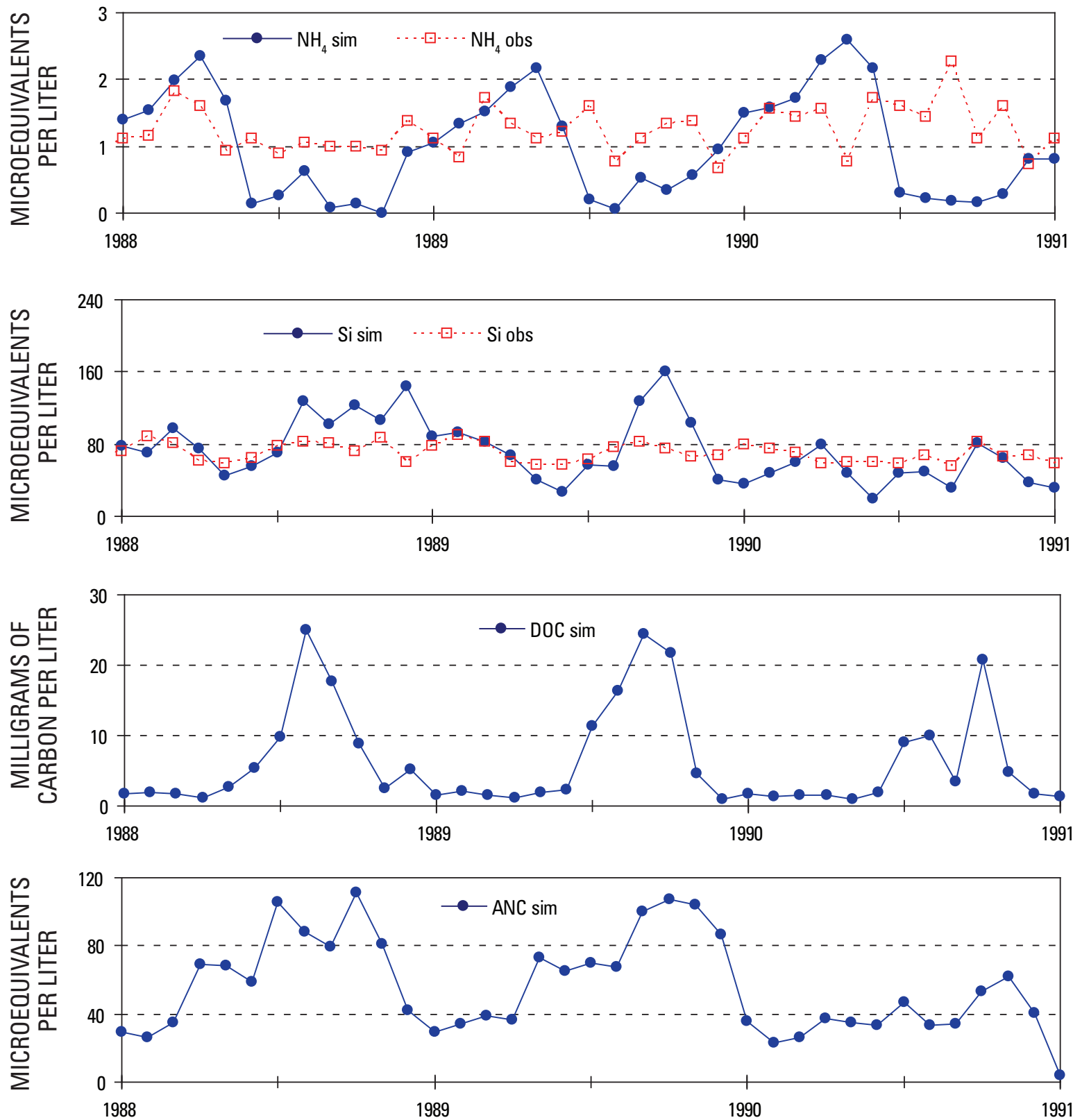

Figure 3.5. Simulated (sim) and observed (obs) discharge and stream chemistry for W6, Hubbard Brook, years 1988-1990 (x axis). Measured DOC and ANC were not available.-Continued 

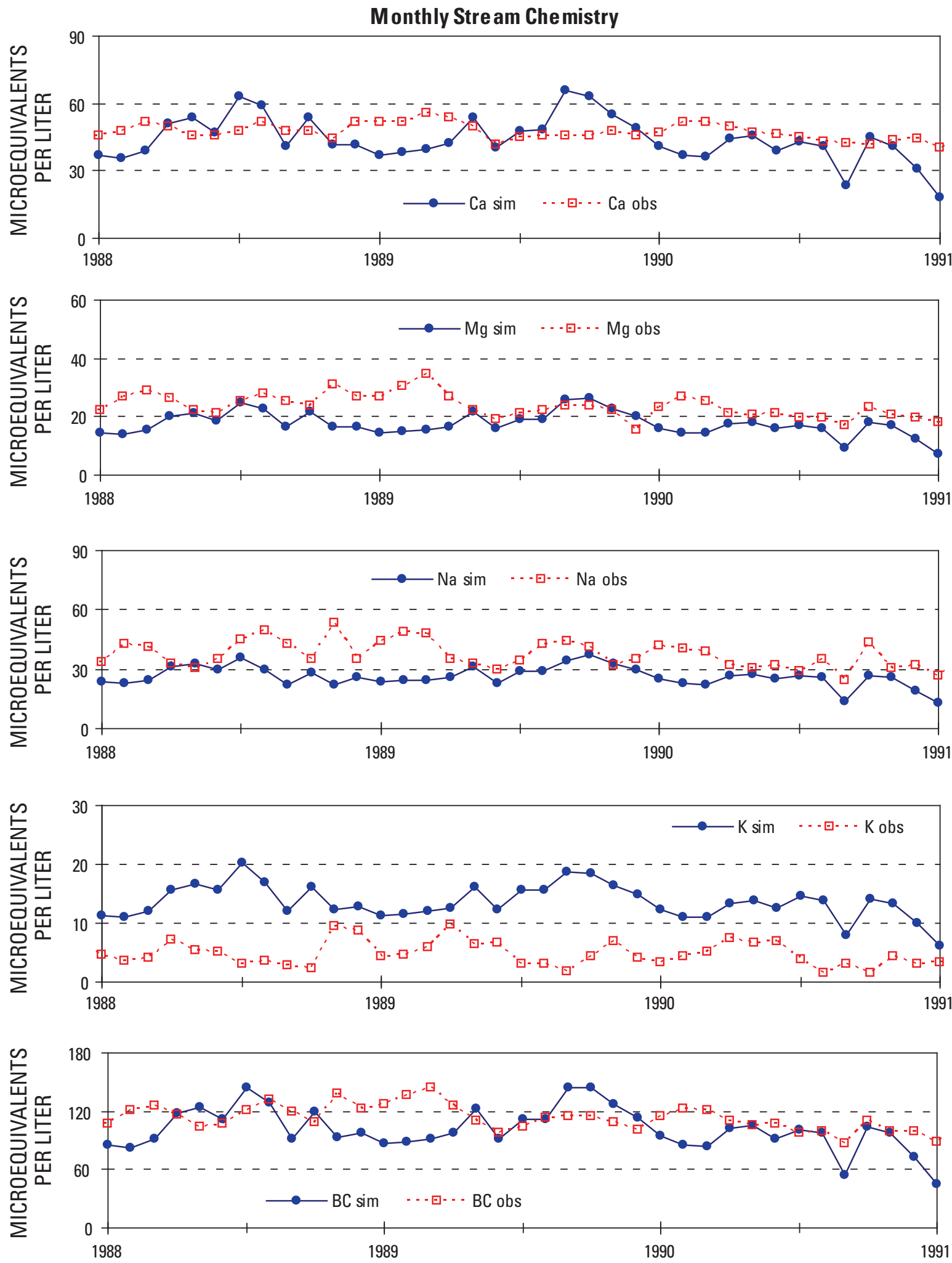

Figure 3.5. Simulated (sim) and observed (obs) discharge and stream chemistry for W6, Hubbard Brook, years 1988-1990 (x axis). Measured DOC and ANC were not available.-Continued 

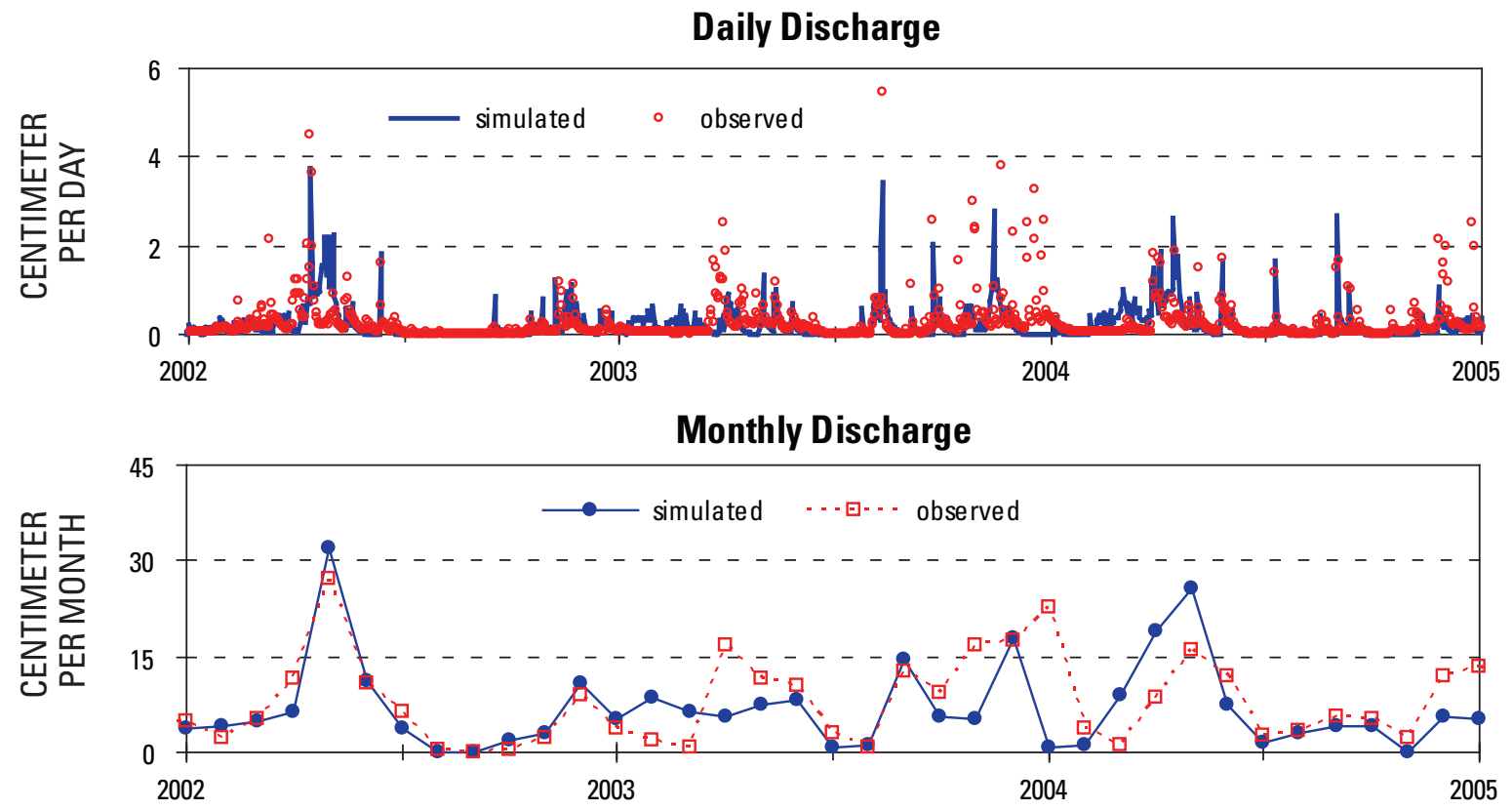

Monthly Stream Chemistry
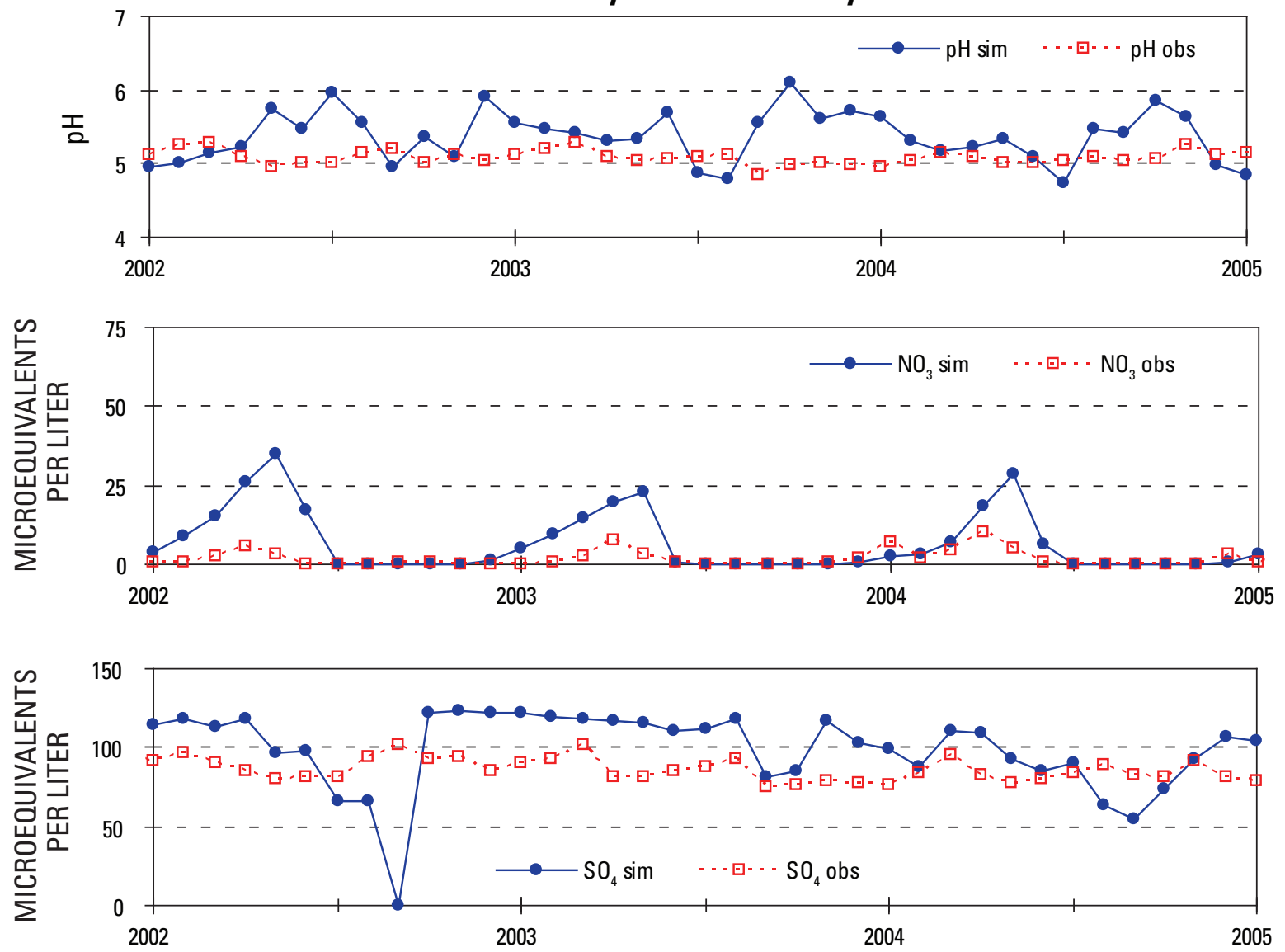

Figure 3.6. Simulated (sim) and observed (obs) discharge and stream chemistry for W6, Hubbard Brook, years 2002-2004 (x axis). Measured DOC and ANC were not available. 

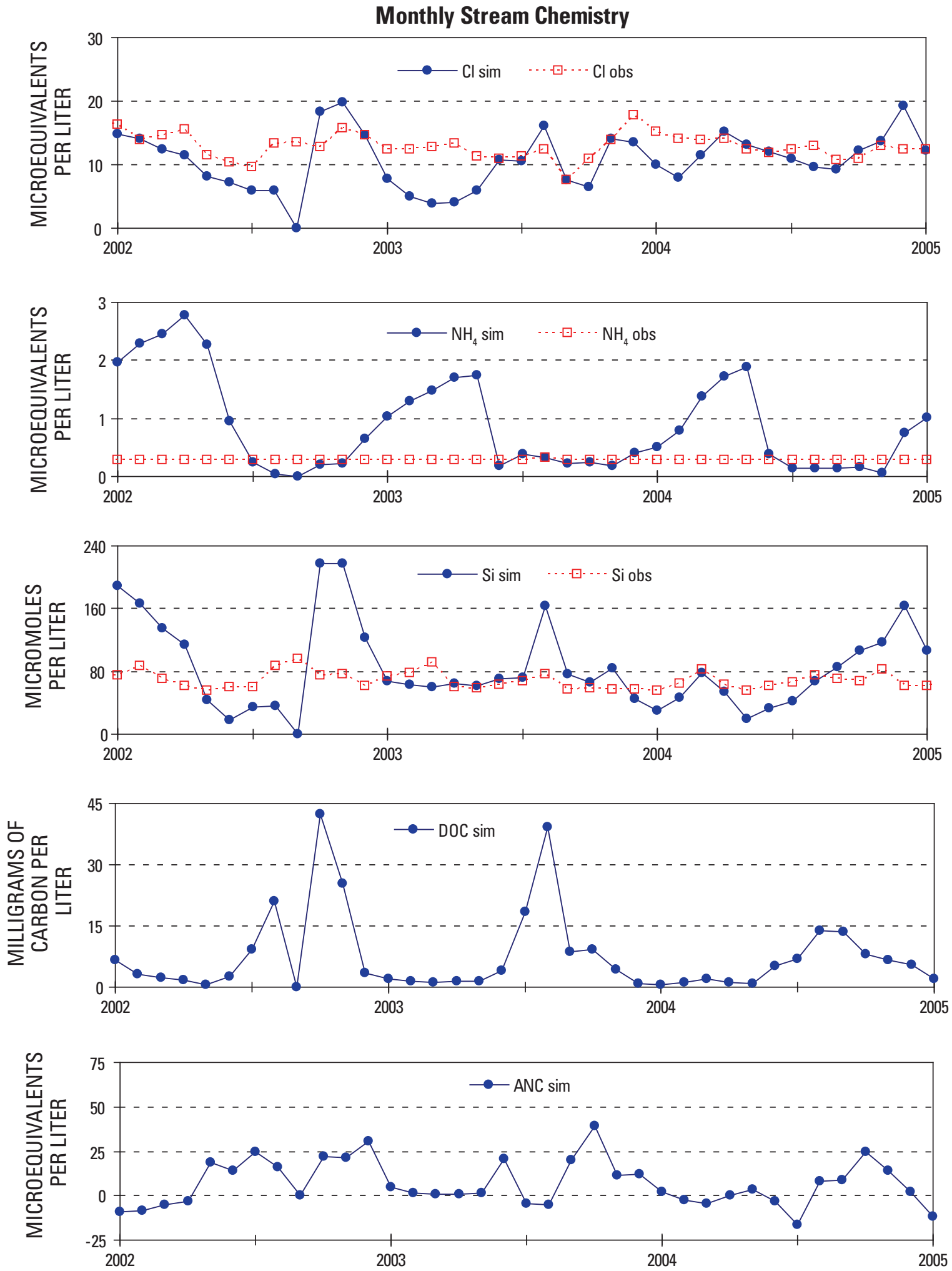

Figure 3.6. Simulated (sim) and observed (obs) discharge and stream chemistry for W6, Hubbard Brook, years 2002-2004 (x axis). Measured DOC and ANC were not available.-Continued 

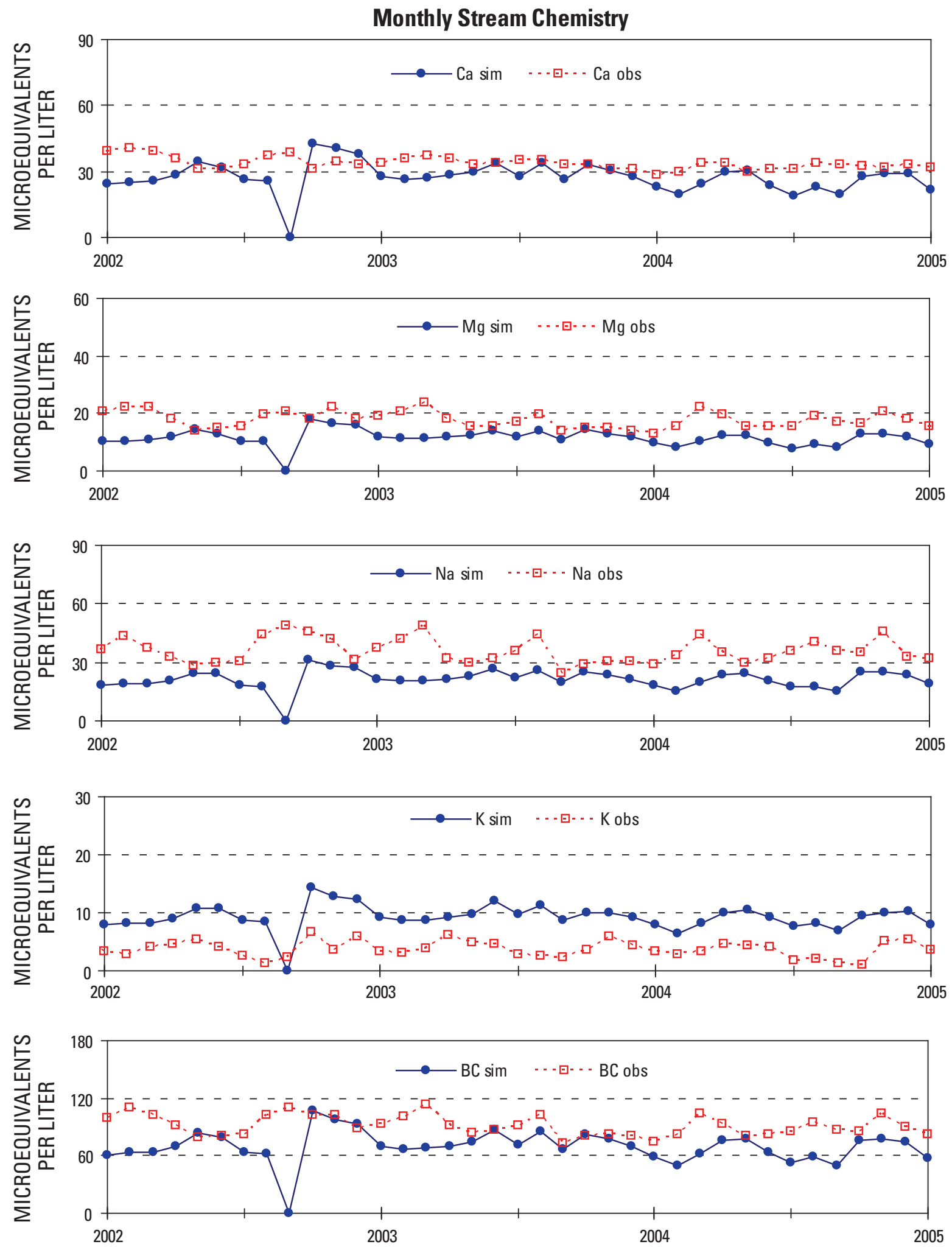

Figure 3.6. Simulated (sim) and observed (obs) discharge and stream chemistry for W6, Hubbard Brook, years 2002-2004 (x axis). Measured DOC and ANC were not available.-Continued 
Estimated net $\mathrm{N}$ mineralization, $5.5 \mathrm{~g} \mathrm{~N} \mathrm{~m}^{-2} \mathrm{yr}^{-1}$, was lower than previously reported values, $6.96 \mathrm{~g} \mathrm{~N} \mathrm{~m}^{-2} \mathrm{yr}^{-1}$ (Likens and Bormann, 1995) (table 3.5). The model estimated that total stream N flux, $0.42 \mathrm{~g} \mathrm{~N} \mathrm{~m}^{-2} \mathrm{yr}^{-1}$, was 49 percent dissolved organic nitrogen (DON) and 47 percent $\mathrm{NO}_{3}-\mathrm{N}$. This distribution of stream $\mathrm{N}$ species in the model somewhat underestimates the relative contribution of DON in a high-elevation spruce-fir-beech forest at Hubbard Brook (87 and 64 percent for the growing season and nongrowing season, respectively), but it closely estimates the relative contribution of DON in high- and low-elevation hardwood forests at Hubbard Brook (54-56 percent in the growing season and 34-37 percent in the nongrowing season; Dittman and others, 2007). Gaseous loss, $0.04 \mathrm{~g} \mathrm{~N} \mathrm{~m}^{-2} \mathrm{yr}^{-1}$, was small. The model suggested that ecosystem retention of atmospherically deposited $\mathrm{N}$ plus internally fixed $\mathrm{N}$ was 52 percent, though no measurement of $\mathrm{N}$ retention was available to verify this estimate.

\section{Discharge}

Predicted stream discharge was close to measurements most times of the year, but the model missed some larger discharge events (the $\mathrm{R}^{2}$ correlation between daily measured and modeled discharge was 0.21 ; figs. $3.5,3.6$ ). Monthly simulated stream discharge was in better agreement with measured discharge, with an $\mathrm{R}^{2}$ correlation between monthly measured and modeled discharge of 0.39 (figs. 3.5, 3.6).

\section{Stream Chemistry}

\section{Nitrate and Ammonium}

From 1979 through 2004, total N deposition at HBR decreased $0.053 \mathrm{~kg} \mathrm{ha}^{-1} \mathrm{yr}^{-1}$, mostly a result of decreasing $\mathrm{NO}_{3}$ deposition. Observed stream $\mathrm{NO}_{3}$ concentrations also decreased by about $0.5 \mu$ eq $\mathrm{L}^{-1} \mathrm{yr}^{-1}$ over the entire period of record, but they were temporarily elevated for multi-year periods following an extremely cold winter in 1989-1990 and a severe ice storm in January 1998. Prior to 1992, HBR showed periodic $\mathrm{NO}_{3}$ loss during the growing season, but since 1992 monthly stream $\mathrm{NO}_{3}$ concentrations were very low (less than $2 \mu \mathrm{eq} \mathrm{L}{ }^{-1}$ ) for most months from May through November. The model did well at predicting the temporal patterns of stream $\mathrm{NO}_{3}$ and concentrations for most months of the year, but after 1991 it overpredicted monthly concentrations in April, and to a lesser extent in March and May (figs. 3.5-3.7). Predicted annual VWM stream $\mathrm{NO}_{3}$ concentration over the entire simulation (16.6 $\left.\mu \mathrm{eq} \mathrm{L}^{-1}\right)$ was greater than the observed mean (9.3 $\mu$ eq $\mathrm{L}^{-1}$; table 3.6). Though measured and predicted annual VWM stream $\mathrm{NH}_{4}$ concentrations never exceeded 3 peq L ${ }^{-1}$, measured $\mathrm{NH}_{4}$ concentrations declined after 1993 and the model was unable to represent this decline (fig. 3.6).

\section{Sulfate}

Hubbard Brook had high stream sulfate concentrations, approximately $100 \mu \mathrm{eq} \mathrm{L} \mathrm{L}^{-1}$. From 1979 through 2004 average wet plus dry $\mathrm{S}$ deposition declined by about $0.25 \mathrm{~kg}$ $\mathrm{ha}^{-1} \mathrm{yr}^{-1}$, and annual VWM stream $\mathrm{SO}_{4}$ concentrations also decreased by about $1.5 \mu \mathrm{eq} \mathrm{L}^{-1} \mathrm{yr}^{-1}$. The model showed this same decreasing trend of stream $\mathrm{SO}_{4}$ concentrations; however, simulated annual VWM (116 $\mu$ eq $\left.\mathrm{L}^{-1}\right)$ was somewhat greater than that of measured values ( $97 \mu$ eq $\mathrm{L}^{-1}$; table 3.6). There was little seasonal variation in monthly measured stream $\mathrm{SO}_{4}$ concentrations, whereas the simulated values responded more to changes in precipitation and discharge (figs. 3.5-3.7). Both simulated and measured $\mathrm{SO}_{4}$ export were greater than $\mathrm{SO}_{4}-\mathrm{S}$ deposition. Hubbard Brook has a long history of elevated atmospheric $\mathrm{SO}_{4}$ deposition, and the high stream $\mathrm{S}$ flux has been attributed to the desorption of $\mathrm{SO}_{4}$ from mineral soil and mineralization of high sulfur organic matter that was formed during periods of higher $\mathrm{S}$ deposition (Likens and others, 2002).

\section{Chloride}

Simulated annual VWM stream $\mathrm{Cl}$ concentrations were within $0.6 \mu \mathrm{eq} \mathrm{L}^{-1}$ of measured values (table 3.6). Monthly measured values showed less seasonal variation than simulated values. Measured stream $\mathrm{Cl}$ concentrations were most concentrated in the winter, whereas simulated values were most concentrated in autumn (figs. 3.5-3.7). There is some evidence for soil $\mathrm{Cl}$ adsorption at HBR (Lovett and others, 2005).

\section{Weathering Products}

Measured and observed annual VWM Si concentrations were the same (63 $\mu \mathrm{mol} \mathrm{L}^{-1}$; table 3.6). The range of simulated monthly Si concentrations was greater than the measured values, with the model underestimating stream Si concentrations April-June and overestimating them September-November (figs. 3.5-3.7). Measured stream $\mathrm{Ca}$ and $\mathrm{Mg}$ concentrations declined 30-40 percent from 1979 to 2004, a result of the decline in deposition of both $\mathrm{Ca}$ and $\mathrm{Mg}$ and soil base cation depletion (Likens and others, 1996). Simulated annual VWM stream sum of base cation concentrations also declined and were 10 percent below measured values. Mean $\mathrm{Ca}, \mathrm{Mg}$, and Na concentrations were below observations, while the mean stream K concentrations were overestimated (table 3.6). Monthly simulated stream $\mathrm{Ca}, \mathrm{Mg}$, and Na concentrations were close to measured concentrations in all months except January-March (figs. 3.5-3.7).

\section{ANC and $\mathrm{pH}$}

Stream water at HBR was acidic, with a range of 4.8-5.4. Measured annual VWM pH increased slightly from 1979 

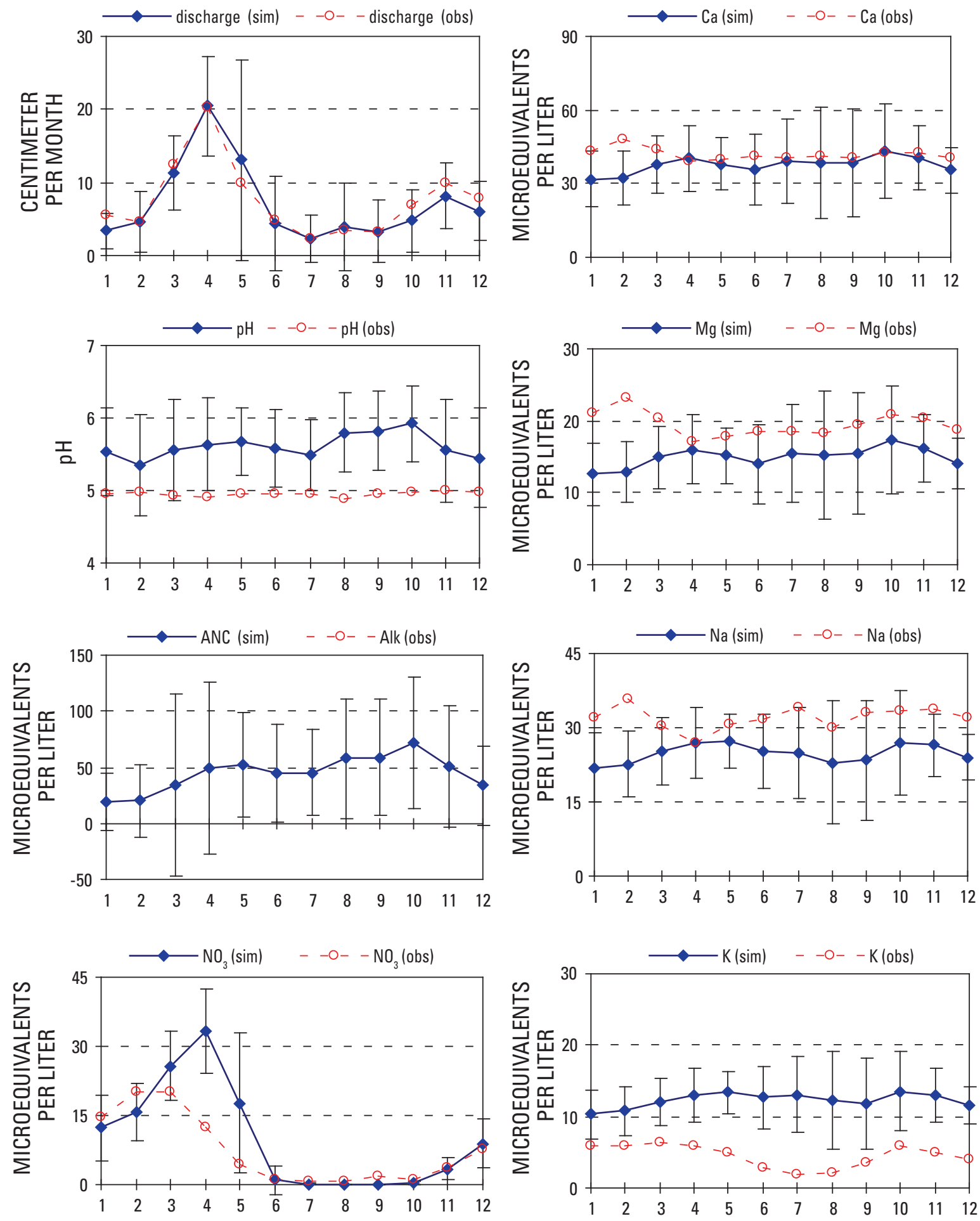

Figure 3.7. Simulated (sim) and observed (obs) stream chemistry averaged by month (x axis) for W6, Hubbard Brook, years 1979-2004. The vertical bars on the simulated values represent plus and minus one standard deviation from the simulated mean. Measured DOC and ANC were not available. 

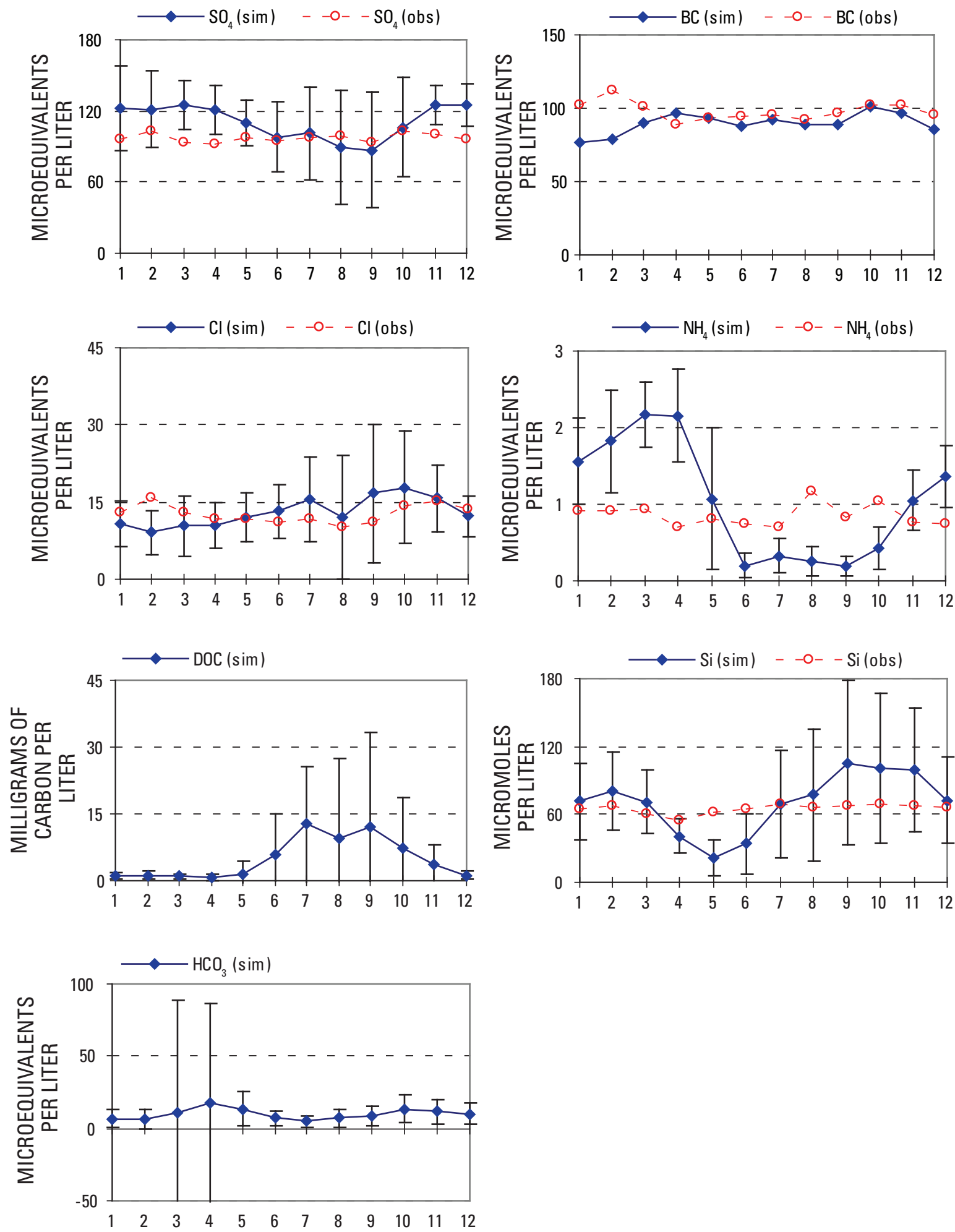

Figure 3.7. Simulated (sim) and observed (obs) stream chemistry averaged by month (x axis) for W6, Hubbard Brook, years 1979-2004. The vertical bars on the simulated values represent plus and minus one standard deviation from the simulated mean. Measured DOC and ANC were not available.-Continued 
Table 3.6. Annual volume-weighted mean simulated and observed stream chemistry averaged over each year of the simulation (1979-2004). Pmean = predicted mean; Omean = observed mean; $A E=$ absolute error (Pmean - Omean); NAE = normalized absolute error (AE/Omean); N/A = not available.

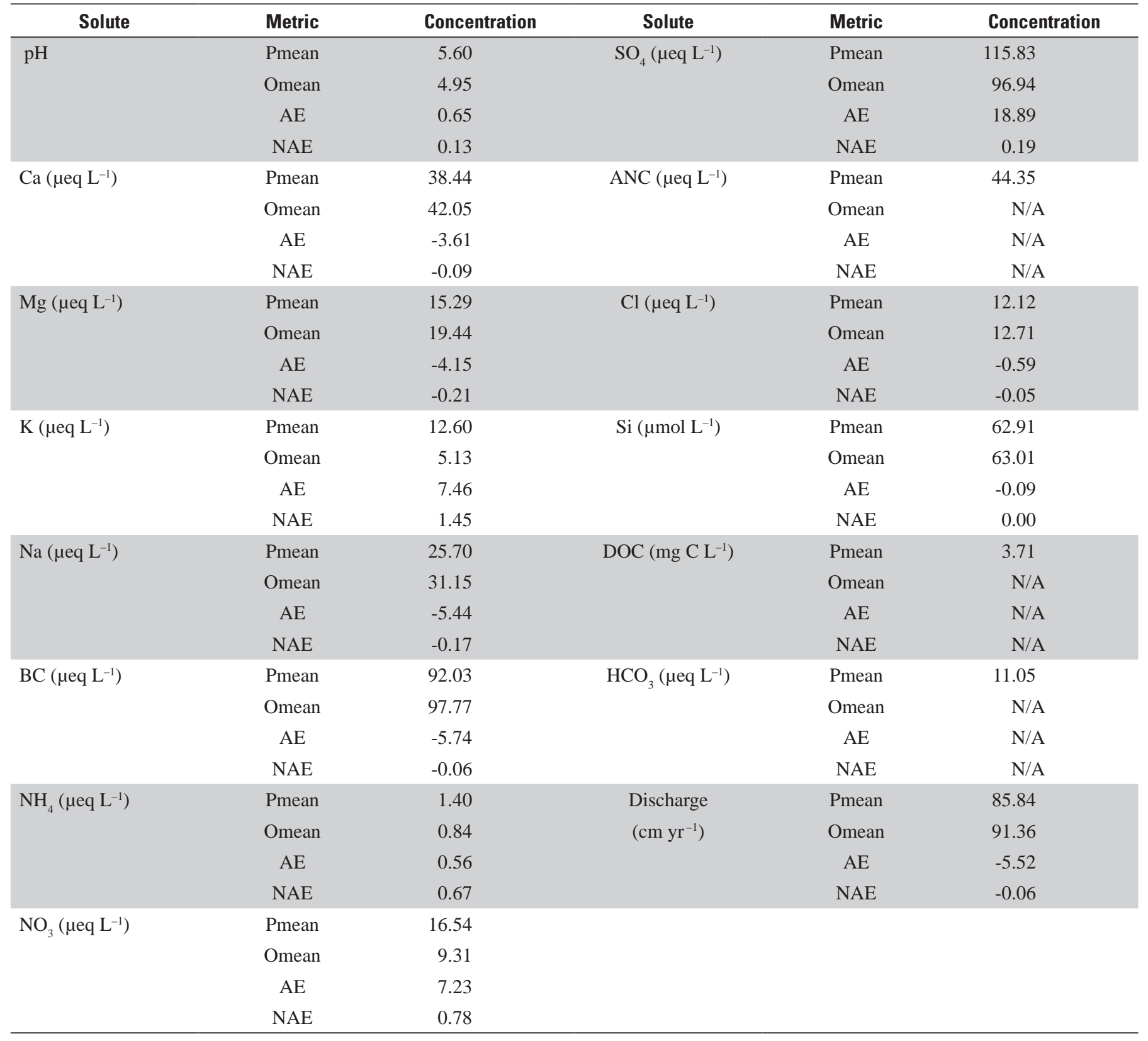


and was close to 5.0, but the model predicted much higher pH (annual VWM 5.8; table 3.6). Monthly simulated pH values were closer to measured values for simulation years 2002-2004 than for years 1988-1990 (figs. 3.5, 3.6). Monthly measured stream $\mathrm{pH}$ varied within 0.5 units a year, while the model produced up to 1.0 units of intra-annual variability. The simulated annual VWM $\mathrm{HCO}_{3}$ concentration was $11 \mu \mathrm{eq} \mathrm{L}^{-1}$, and simulated annual VWM acid neutralizing capacity (ANC), which included Al-hydroxide buffers, was $44 \mu$ eq $\mathrm{L}^{-1}$ (table 3.6, fig. 3.7). Measured alkalinity for HBR was not available, though it is known to be close to zero (C. Driscoll, Syracuse University, Syracuse, N.Y., personal commun., 2007). Simulated annual VWM ANC values that were $56 \mu \mathrm{eq} \mathrm{L}^{-1}$ for the 1988-1990 period were only $9 \mu \mathrm{eq} \mathrm{L}^{-1}$ for the 2002-2004 period (figs. 3.5, 3.6). The model may have overestimated stream concentrations of Al-hydroxides, particularly during the early simulation years, as the model was still reaching a geochemical equilibrium with the cation exchange complex.

\section{Dissolved Organic Carbon}

Simulated dissolved organic carbon (DOC) concentrations for May through July (figs. 3.5, 3.6) were much greater than measured growing season concentrations for low- and high-elevation hardwood forests at Hubbard Brook (2.2 and $4.0 \mathrm{mg} \mathrm{C} \mathrm{L} \mathrm{L}^{-1}$, respectively), but were closer growing season concentrations for a high-elevation spruce-fir-beech forest (19.2 $\mathrm{mg} \mathrm{C} \mathrm{L}^{-1}$ ) (Dittman and others, 2007). Simulated DOC concentrations outside of the growing season ranged from 1.0 to $5.0 \mathrm{mg} \mathrm{C} \mathrm{L}^{-1}$ (figs. 3.5, 3.6) and were close to measured values for high- and low-elevation hardwood forests at Hub-

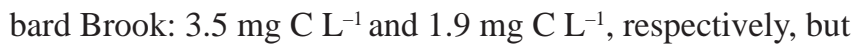
measured values for a high-elevation spruce-fir-beech forest were much greater: 14.5 mg C L ${ }^{-1}$ (Dittman and others, 2007).

\section{Summary}

The model did well in predicting the timing and magnitude of stream $\mathrm{NO}_{3}$ concentrations from about 1979 through 1991, but it did not capture the overall decline in stream $\mathrm{NO}_{3}$ concentrations that have been observed since the early 1990 s. There has been a decline in stream $\mathrm{NO}_{3}$ concentrations and export at HBR (and other long-term monitoring watersheds in New England) over the past few decades, despite forest aging, which cannot be explained by changes in atmospheric deposition or biomass assimilation (Goodale and others, 2003; Bernhardt and others, 2005). The declining trend has been partially explained by changes in instream $\mathrm{NO}_{3}$ uptake (Bernhardt and others, 2005), but the role of climate is uncertain (Goodale and others, 2003). Another ecosystem model (PnET) computed climate-driven variation in $\mathrm{N}$ cycling and was able to reproduce much of the interannual variability in stream $\mathrm{NO}_{3}$ concentrations for the 1980s, but like DayCent-Chem it was not able to predict the extremely low values in the 1990s (Aber and Driscoll, 1997; Aber and others, 2002).

Model predictions of stream $\mathrm{SO}_{4}$ concentrations were slightly greater and more variable than measured values. Both simulated and measured $\mathrm{SO}_{4}$ export were greater than $\mathrm{SO}_{4}-\mathrm{S}$ deposition, suggesting that $\mathrm{HBR}$ has an internal source of $\mathrm{SO}_{4}$, possibly from desorption of $\mathrm{SO}_{4}$ and mineralization of organic matter.

All stream base cation concentrations except $\mathrm{K}$ were underestimated by about 10-20 percent. The model closely predicted annual stream $\mathrm{Si}$ and $\mathrm{Cl}$ concentrations, but it showed a wider range of monthly values than what was measured. A question that remains is why measured stream $\mathrm{pH}$ is about a unit less than simulated $\mathrm{pH}$. 


\section{Coweeta Long-Term Ecological Research Site, North Carolina}

\section{Site Description}

Coweeta LTER (CWT) is located in the Blue Ridge Physiographic Province of the southern Appalachian Mountains in western North Carolina (fig. 4.1). Watershed 2 (WS2), which encompasses 12 ha of mature, mixed mesophytic hardwood forest with a rhododendron understory (http://coweeta. ecology.uga.edu/webdocs/1/ws/ws2.html, accessed 22 January 2008; table 4.1), has been a reference watershed since 1934.

A hurricane occurred at the site in 1837, but no anthropogenic disturbance has occurred since logging in 1923 (Lindberg and others, 1992). The watershed was included in the Integrated Forest Study "Coweeta Hardwood (CH)” site of Johnson and Lindberg (1992). This was one of 17 sites across the United States that were studied as part of the National Integrated Forest study to determine the effects of acidic atmospheric deposition on forest ecosystems from 1986 to 1989.

The Coweeta basin is quite rugged with an average slope of about 45 percent (or 23) (Velbel, 1985a). Soils are mostly Ultisols and Inceptisols (Velbel, 1988), and bedrock in the area of WS2 is metamorphic biotite paragniess and biotite schists (Hatcher, 1988). Saprolite mantles the landscape at Coweeta, and the average weathering profile (saprolite plus soil) at Coweeta is approximately $6 \mathrm{~m}$ thick (Price and others, 2005); the soil pedon depth averages less than $1 \mathrm{~m}$.

Baseflow is sustained by prolonged drainage of moist unsaturated soil and saprolite (Hibbert and Troendle, 1988). No permanent saturated ground water table exists (Velbel, 1985b). Displacement of stored water in deep subsurface saprolite, not interflow or overland flow, sustains perennial streamflow. During periods of high rainfall and runoff, rapid water displacement occurs.

\section{Methods}

\section{Climate and Hydrology}

Eleven years of daily weather data (1985-1995) were available for CWT (J. Knoepp, U.S. Forest Service-SRS, Coweeta Hydrologic Laboratory, Otto, N.C., personal commun., 2006). During this time period precipitation averaged 177 (std. dev. 41) $\mathrm{cm} \mathrm{yr}^{-1}$. Mean annual temperature was 13.5 (std. dev. 0.7) ${ }^{\circ} \mathrm{C}$, increasing about $0.09{ }^{\circ} \mathrm{C} \mathrm{yr}^{-1}$ (fig. 4.2).

Patterns of discharge partially reflect seasonal patterns of precipitation (fig. 4.3). The months with the greatest precipitation occurred in winter and spring. The greatest flow occurred from January to March when precipitation was also high, but discharge was substantially reduced by evapotranspiration the remainder of the year.

\section{Atmospheric Deposition}

We used wet deposition measured at the NADP/NTN Coweeta (NC25) site (35.0605,$-83.4305^{\circ}$, elevation 868 $\mathrm{m})$ and dry deposition measured at CASTNet site COW137 (35.0608,$-83.4306^{\circ}$, elevation $686 \mathrm{~m}$ ) to compute total deposition (table 4.2). For 1985 to 1995, $\mathrm{SO}_{4}$ was the dominant ion in wet plus dry atmospheric deposition (8.7 $\mathrm{kg} \mathrm{S} \mathrm{ha}^{-1} \mathrm{yr}^{-1}$ ), and total $\mathrm{N}$ deposition was $5.2 \mathrm{~kg} \mathrm{~N} \mathrm{ha}^{-1} \mathrm{yr}^{-1}$. During the time period 1985-1995, $\mathrm{NH}_{4}-\mathrm{N}, \mathrm{NO}_{3}-\mathrm{N}$, and $\mathrm{S}$ deposition reached a maximum in 1989 then declined. After 1989, S deposition declined about $0.5 \mathrm{~kg} \mathrm{ha}^{-1} \mathrm{yr}^{-1}$, whereas $\mathrm{N}$ deposition declined about $0.1 \mathrm{~g} \mathrm{ha}^{-1} \mathrm{yr}^{-1}$ (fig. 4.4).

\section{Soil and Mineral Properties}

We describe mineral weathering of plagioclase (Ca:Na $=0.32: 0.68$ ), biotite, and almandine as previously reported (Velbel, 1988; Velbel, 1995) (table 4.3). In order to account for incomplete dissolution of primary minerals, secondary minerals gibbsite and kaolinite were allowed to precipitate or dissolve. The mineral reactions are summarized below.

$$
\begin{aligned}
& \text { Albite: } \mathrm{NaAlSi}_{3} \mathrm{O}_{8}+8 \mathrm{H}_{2} \mathrm{O}=\mathrm{Na}^{+}+\mathrm{Al}(\mathrm{OH})_{4} \\
& +3 \mathrm{H}_{4} \mathrm{SiO}_{4} \\
& \text { Anorthite: } \mathrm{CaAl} 2 \mathrm{Si}_{2} \mathrm{O}_{8}+8 \mathrm{H}_{2} \mathrm{O}=\mathrm{Ca}^{2+}+2 \mathrm{Al}(\mathrm{OH})_{4} \\
& +2 \mathrm{H}_{4} \mathrm{SiO}_{4} \\
& \text { Biotite: } \mathrm{KMg}_{1.5} \mathrm{Fe}_{1.5} \mathrm{AlSi}_{3} \mathrm{O}_{10}(\mathrm{OH})_{2}+6 \mathrm{H}^{+} \\
& +4 \mathrm{H}_{2} \mathrm{O}=\mathrm{K}^{+}+1.5 \mathrm{Mg}^{2+} \\
& +1.5 \mathrm{Fe}^{2+}+\mathrm{Al}(\mathrm{OH})_{4}^{-}+3 \mathrm{H}_{4} \mathrm{SiO}_{4} \\
& \text { Almandine: } \mathrm{Ca}_{0.2} \mathrm{Mg}_{0.5} \mathrm{Mn}_{0.2} \mathrm{Fe}_{2.1} \mathrm{Al}_{2} \mathrm{Si}_{3} \mathrm{O}_{12} \\
& +0.625 \mathrm{O}_{2}+9.3 \mathrm{H}^{+}+3.95 \mathrm{H}_{2} \mathrm{O}+0.4 \mathrm{e}^{-} \\
& =2 \mathrm{Fe}^{3+}+0.1 \mathrm{Fe}(\mathrm{OH})_{2}^{+}+\mathrm{Al}(\mathrm{OH})_{3} \\
& +\mathrm{Al}(\mathrm{OH})_{2}^{+}+3 \mathrm{H}_{4} \mathrm{SiO}_{4} \\
& +0.5 \mathrm{Mg}^{2+}+0.2 \mathrm{Ca}^{2+}+0.2 \mathrm{Mn}^{2+}
\end{aligned}
$$

Gibbsite: $\mathrm{Al}(\mathrm{OH})_{3}+3 \mathrm{H}^{+}=\mathrm{Al}^{3+}+3 \mathrm{H}_{2} \mathrm{O}$

Kaolinite: $\mathrm{Al}_{2} \mathrm{Si}_{2} \mathrm{O}_{5}(\mathrm{OH})_{4}+6 \mathrm{H}^{+}=\mathrm{H}_{2} \mathrm{O}+2 \mathrm{H}_{4} \mathrm{SiO}_{4}+2 \mathrm{Al}^{3+}$

The soil representation for CWT was deep (200 cm) and highly weathered (USDA National Resource Conservation Service, 2006) (table 4.4). 


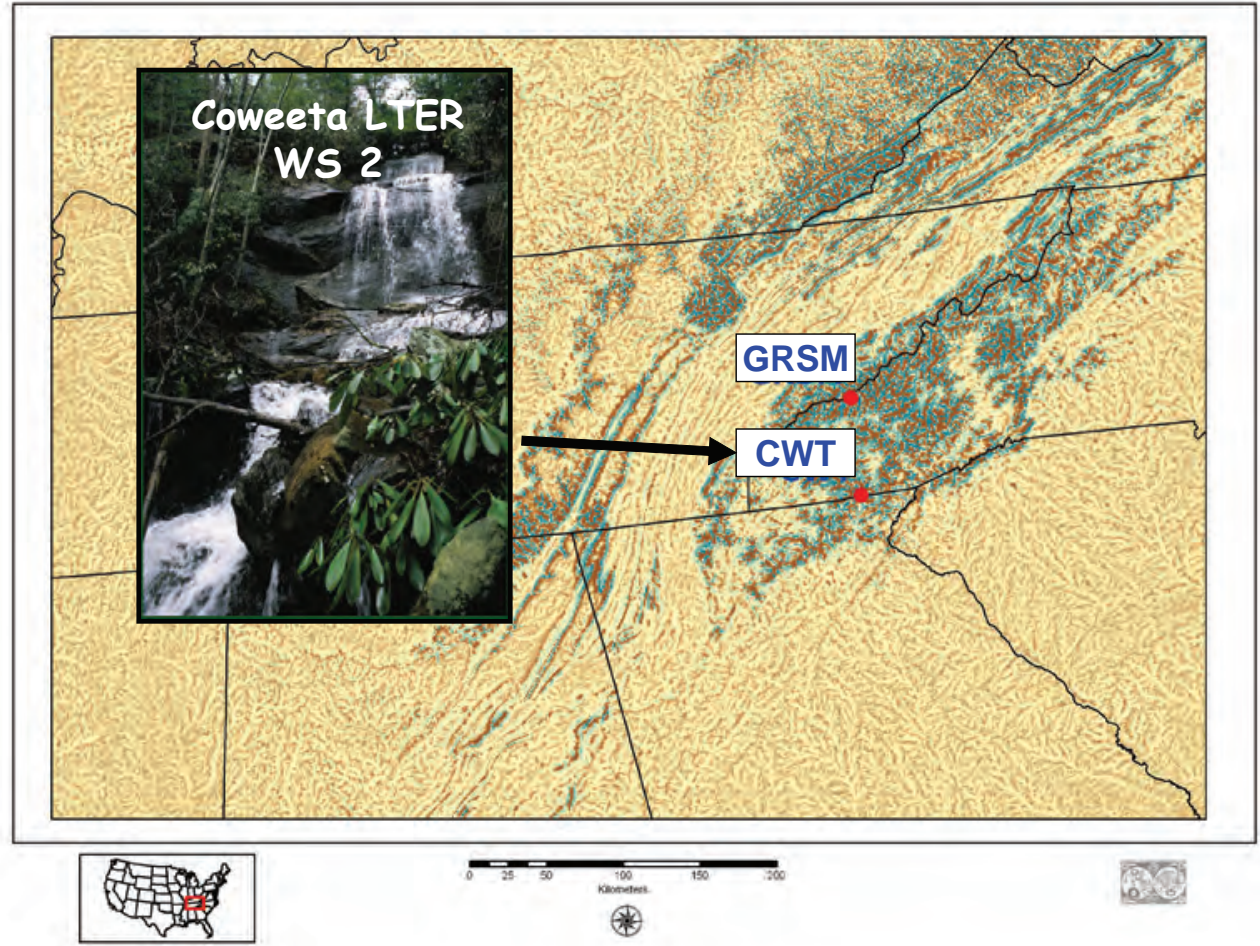

Figure 4.1. Coweeta LTER (CWT) is located in the Blue Ridge Physiographic Province of the southern Appalachian Mountains in western North Carolina. Great Smoky Mountains National Park (GRSM) is to the north (see Chapter 5).

Table 4.1. Characteristics of Watershed 2 (WS2) at Coweeta LTER, North Carolina.

\begin{tabular}{|c|c|}
\hline Site & Coweeta LTER (CWT) \\
\hline Location & North Carolina \\
\hline Catchment name & WS2 \\
\hline Latitude, longitude & $35^{\circ} 00^{\prime},-83^{\circ} 30^{\prime}$ \\
\hline Outlet elevation (m.a.s.l.) & 709 \\
\hline Climate & Marine, humid temperate \\
\hline Climate simulation years & 1985-1995 \\
\hline Mean (and std. dev.) annual temperature $\left({ }^{\circ} \mathrm{C}\right)$ & $13.5(0.7)$ \\
\hline Mean (and std. dev.) annual precipitation $\left(\mathrm{cm} \mathrm{yr}^{-1}\right)$ & $177(41)$ \\
\hline Surficial landforms & Mountainous \\
\hline Bedrock mineralogy & Plagioclase, biotite, almadine (Velbel, 1985a) \\
\hline Recent disturbances & Hurricane in 1837; some logging prior to 1923 \\
\hline Anthropogenic influences & Nearby feedlots and agriculture \\
\hline
\end{tabular}



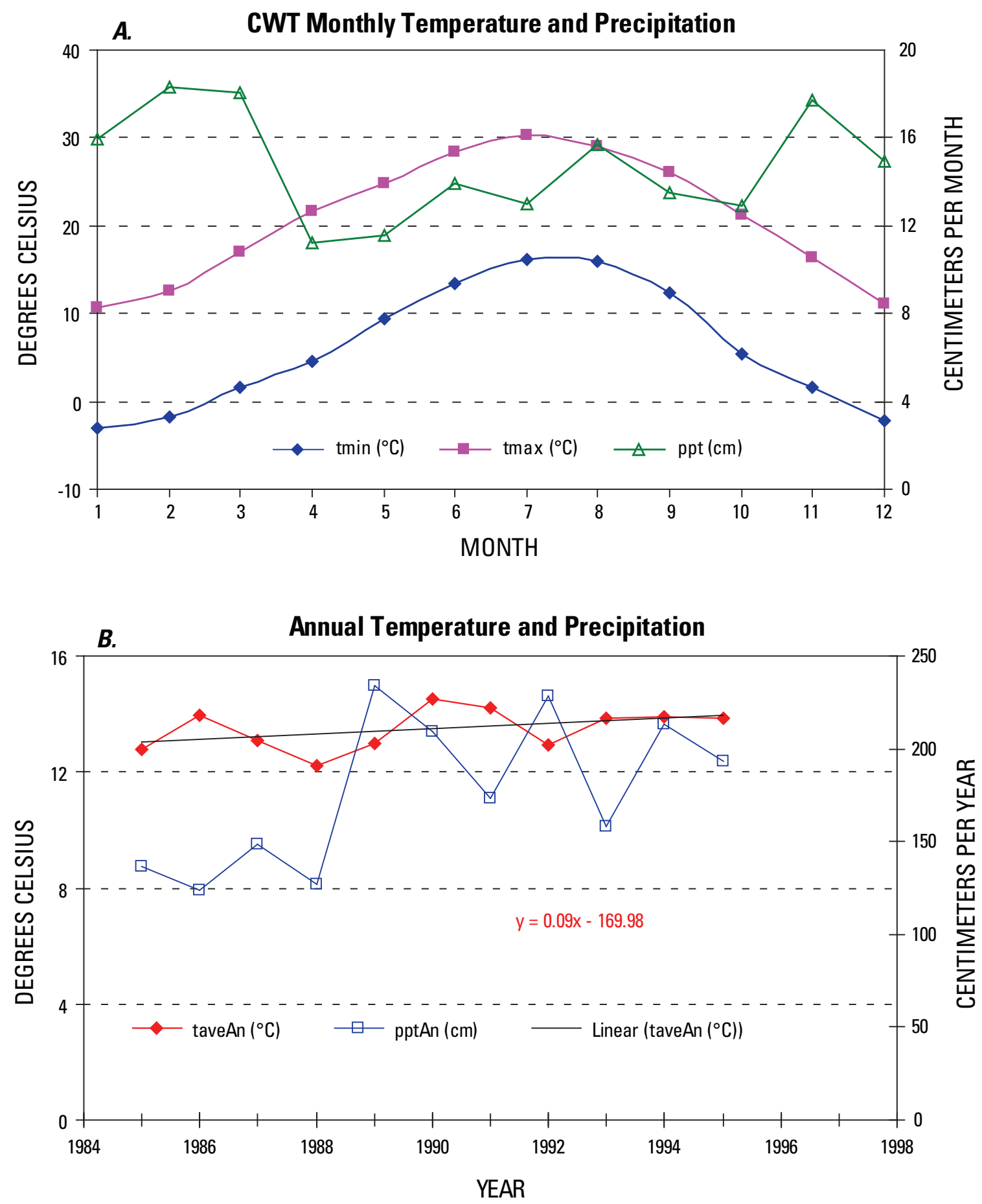

Figure 4.2. Meteorological statistics for the weather station at Coweeta LTER (CWT). A, Average monthly minimum air temperatures (tmin), maximum air temperatures (tmax), and precipitation (ppt), years 1985-1995. B, Mean annual temperature (taveAn) and annual precipitation (pptAn), years 1985-1995.

Mean annual temperature was -13.5 (std. dev. 0.7) ${ }^{\circ} \mathrm{C}$, and average annual precipitation was 177 (std. dev.

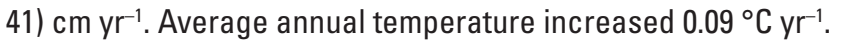




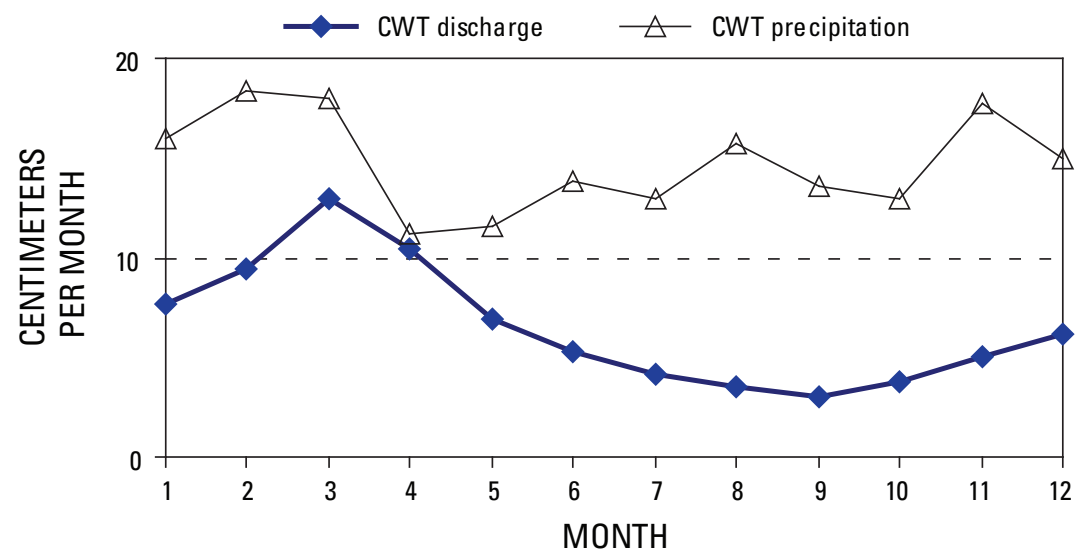

Figure 4.3. Relationship between average monthly precipitation and measured discharge for Coweeta LTER, years 1985-1995.

Table 4.2. Average annual wet and dry plus fog deposition inputs $\left(\mathrm{kg} \mathrm{ha}^{-1} \mathrm{yr}^{-1}\right)$ to the model over the 1985-1995 simulation period.

\begin{tabular}{llll}
\hline & Wet & Dry + Fog & Total \\
\hline $\mathrm{Ca}$ & 1.07 & 0.47 & 1.54 \\
$\mathrm{Cl}$ & 3.05 & 0.41 & 3.46 \\
$\mathrm{~K}$ & 0.37 & 0.40 & 0.77 \\
$\mathrm{Mg}$ & 0.30 & 0.12 & 0.41 \\
$\mathrm{NH}_{4}-\mathrm{N}$ & 1.97 & 0.22 & 2.19 \\
$\mathrm{NO}_{3}-\mathrm{N}$ & 2.93 & 0.06 & 2.99 \\
$\mathrm{Na}$ & 1.81 & 0.30 & 2.11 \\
$\mathrm{SO}_{4}-\mathrm{S}$ & 7.77 & 0.97 & 8.73 \\
\hline
\end{tabular}

\section{Calibration Data}

To parameterize the model for Coweeta, we first tuned vegetation and soil parameters until simulated ecological variables were close to long-term data collected at Coweeta (Johnson and Lindberg, 1992; Swank and others, 1992; Shure and others, 2006) (table 4.5). We then used stream discharge (1985-1995) and chemistry (1985-1995) for WS2 (Coweeta Hydrologic Laboratory, U.S. Forest Service, written commun., 2006) to tune hydrogeochemical model parameters. Validation runs were not conducted because of an insufficient number of years of weather, discharge, and water quality data.

\section{Model Output}

\section{Ecological Variables}

Simulated net primary production (NPP) values and plant carbon pools were close to measured values, whereas simulated soil carbon and ecosystem nitrogen pool values were generally lower than measured values. Simulated aboveground NPP, 388 (std. dev. 52) g C m ${ }^{-2} \mathrm{yr}^{-1}$, was the same as measured above-ground NPP (Shure and others, 2006), but simulated below-ground NPP, 201 (std. dev. 36) g C m ${ }^{-2}$ 

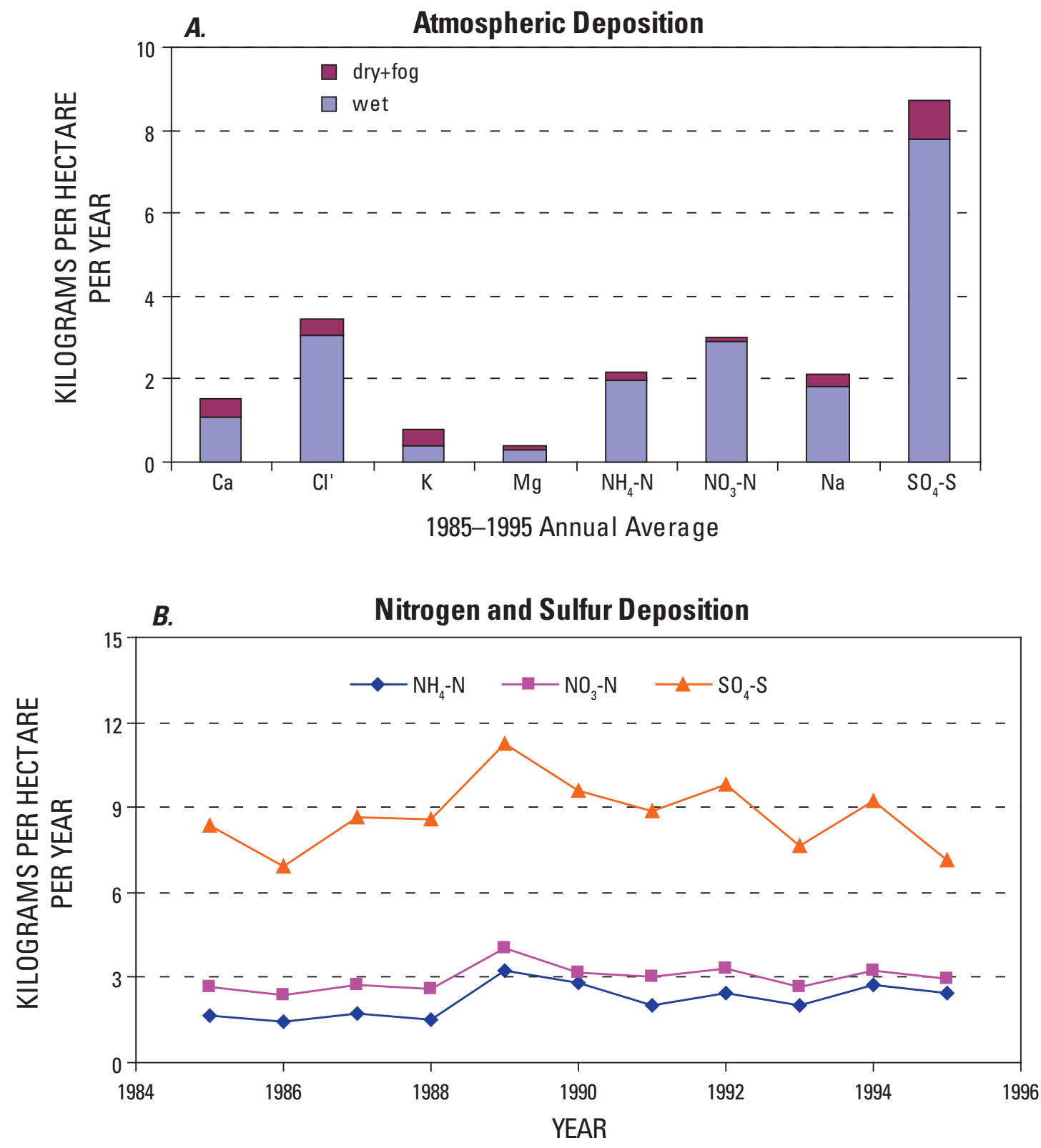

Figure 4.4. Deposition inputs to the model for Coweeta LTER. A, The 1985-1995 average annual wet and dry deposition. $B$, Annual $\mathrm{N}$ and $\mathrm{S}$ deposition over the simulation period. Wet deposition was measured at the NADP/NTN Coweeta (NC25) site, and dry deposition was measured at CASTNet site COW137. 
Table 4.3. Mineral phases and potential annual mineral denudation rates prescribed for the simulation. All minerals were allowed only to dissolve, except for gibbsite and kaolinite, which were allowed to both precipitate and dissolve (Velbel, 1985a). The dissolution rates of plagioclase ( $\mathrm{Ca}: \mathrm{Na}=0.32: 0.68$ ), biotite, and almandine are reported in Velbel (1995). Plagioclase was represented as albite and anorthite.

\begin{tabular}{llcc}
\hline $\begin{array}{c}\text { Mineral } \\
\text { phases }\end{array}$ & $\mathbf{m o l ~ m}^{-\mathbf{2}} \mathbf{y r}^{-\mathbf{1}}$ & $\begin{array}{c}\mathbf{1} \text { = dissolve, } \\
\mathbf{0}=\mathbf{\text { precipitate }} \\
\text { or dissolve }\end{array}$ & $\begin{array}{c}\text { mol ha }^{-\mathbf{2}} \mathbf{~ r ~}^{-\mathbf{1}} \\
\text { (Velbel, 1995) }\end{array}$ \\
\hline Albite & 0.03856 & 1 & $567 * 0.68$ \\
Anorthite & 0.01814 & 1 & $567 * 0.32$ \\
Biotite & 0.0432 & 1 & 432 \\
Almandine & 0.0240 & 1 & 240 \\
Gibbsite & 0 & 0 & \\
Kaolinite & 0 & 0 & \\
\hline
\end{tabular}

Table 4.4. Soil layer properties used for the simulation (USDA National Resource Conservation Service, 2006). Ksat is saturated hydraulic conductivity, and the mineral dissolution fraction (Minrl dissoln) is the fraction of total mineral dissolution that occurred in each layer. Wilting point and field capacity are expressed as volumetric soil water content. Exchangeable cations are expressed as milliequivalents per 100 grams of soil $(\mathrm{meq} / 100 \mathrm{~g})$. Total soil depth was $200 \mathrm{~cm}$, and organic soil made up the top $20 \mathrm{~cm}$ of soil.

\begin{tabular}{|c|c|c|c|c|c|c|c|c|c|}
\hline Layer & $\begin{array}{c}\text { Thickness } \\
\text { cm }\end{array}$ & $\begin{array}{c}\text { Sand } \\
\text { fraction }\end{array}$ & $\begin{array}{c}\text { Silt } \\
\text { fraction }\end{array}$ & $\begin{array}{c}\text { Clay } \\
\text { fraction }\end{array}$ & $\begin{array}{c}\text { Bulk } \\
\text { density } \\
\mathrm{g} \mathrm{cm}^{-3}\end{array}$ & $\begin{array}{l}\text { Wilting } \\
\text { point } \\
\text { fraction }\end{array}$ & $\begin{array}{c}\text { Field } \\
\text { capacity } \\
\text { fraction }\end{array}$ & $\begin{array}{c}\text { Ksat } \\
\mathrm{cm} \mathrm{sec}^{-1}\end{array}$ & $\begin{array}{l}\text { Minrl } \\
\text { dissoln } \\
\text { fraction }\end{array}$ \\
\hline 0 & 13 & 0.389 & 0.294 & 0.317 & 1.34 & 0.162 & 0.37 & 0.001 & 0.25 \\
\hline 1 & 17 & 0.384 & 0.188 & 0.428 & 1.38 & 0.206 & 0.34 & 0.001 & 0.25 \\
\hline 2 & 23 & 0.536 & 0.189 & 0.275 & 1.42 & 0.154 & 0.31 & 0.001 & 0.25 \\
\hline 3 & 31 & 0.638 & 0.283 & 0.079 & 1.36 & 0.087 & 0.21 & 0.0005 & 0.00 \\
\hline 4 & 40 & 0.649 & 0.283 & 0.068 & 1.26 & 0.081 & 0.26 & 0.00005 & 0.00 \\
\hline 5 & 36 & 0.704 & 0.243 & 0.053 & 1.60 & 0.073 & 0.30 & 0.0005 & 0.00 \\
\hline 6 & 40 & 0.669 & 0.27 & 0.061 & 1.60 & 0.079 & 0.30 & 0.0005 & 0.00 \\
\hline Layer & $\begin{array}{c}\mathrm{CaX}_{2} \\
\mathrm{meq} / 100 \mathrm{~g}\end{array}$ & $\begin{array}{c}\mathrm{MgX}_{2} \\
\mathrm{meq} / 100 \mathrm{~g}\end{array}$ & $\begin{array}{c}\mathrm{KX} \\
\mathrm{meq} / 100 \mathrm{~g}\end{array}$ & $\begin{array}{c}\mathrm{NaX} \\
\mathrm{meq} / 100 \mathrm{~g}\end{array}$ & $\begin{array}{c}\mathrm{AlOHX}_{2} \\
\mathrm{meq} / 100 \mathrm{~g}\end{array}$ & $\begin{array}{c}\mathrm{AlX}_{3} \\
\mathrm{meq} / 100 \mathrm{~g}\end{array}$ & $\begin{array}{c}\mathrm{FeX}_{2} \\
\mathrm{meq} / 100 \mathrm{~g}\end{array}$ & $\begin{array}{c}\mathrm{HX} \\
\mathrm{meq} / 100 \mathrm{~g}\end{array}$ & $\begin{array}{c}\mathrm{NH}_{4} \mathrm{X} \\
\mathrm{meq} / 100 \mathrm{~g}\end{array}$ \\
\hline 0 & 7.5 & 4.3 & 0.7 & 0.1 & 0.6 & 0.0 & 0.0 & 9.6 & 0.0 \\
\hline 1 & 0.9 & 1.3 & 0.1 & 0.1 & 0.6 & 1.6 & 0.0 & 9.6 & 0.0 \\
\hline 2 & 0.6 & 1.4 & 0.1 & 0.1 & 0.5 & 0.7 & 0.0 & 5.9 & 0.0 \\
\hline 3 & 0.1 & 0.8 & 0.0 & 0.0 & 0.3 & 0.9 & 0.0 & 4.8 & 0.0 \\
\hline 4 & 0.1 & 0.6 & 0.0 & 0.0 & 0.3 & 1.2 & 0.0 & 3.7 & 0.0 \\
\hline 5 & 0.1 & 0.2 & 0.0 & 0.1 & 0.3 & 1.0 & 0.0 & 3.8 & 0.0 \\
\hline 6 & 0.1 & 0.3 & 0.0 & 0.0 & 0.3 & 1.0 & 0.0 & 3.7 & 0.0 \\
\hline
\end{tabular}


DayCent-Chem Simulations of Ecological and Biogeochemical Processes of Eight Mountain Ecosystems in the U.S.

$\mathrm{yr}^{-1}$, was double the measured NPP, $98 \mathrm{~g} \mathrm{C} \mathrm{m}^{-2} \mathrm{yr}^{-1}$ (Swank and others, 1992) (table 4.5). Simulated soil organic matter (SOM), 5,361 (std. dev. 22) g C m ${ }^{-2}$, was 24 percent lower than the measured value of 7,076 $\mathrm{g} \mathrm{C} \mathrm{m}^{-2}$ (Swank and others, 1992). Simulated values for all live plant carbon pools except fine branches were very close to reported values, while total live tree biomass $C$ was 5 percent less than the measured value (Swank and others, 1992) (table 4.5). Total simulated ecosystem biomass $\mathrm{C}, 19,626 \mathrm{~g} \mathrm{C} \mathrm{m}^{-2}$, was underestimated by 13 percent. The simulated soil organic matter $\mathrm{N}$, total live tree $\mathrm{N}$, and total ecosystem $\mathrm{N}$ were each about 60 percent of measured values (table 4.5).

Biologic processes consume or transform almost all inorganic $\mathrm{N}$ deposition. Although $\mathrm{N}$ deposition at CWT was about $0.52 \mathrm{~g} \mathrm{~N} \mathrm{~m}^{-2} \mathrm{yr}^{-1}$, both measurements and the model showed that WS2 lost only small amounts of inorganic $\mathrm{N}$ in solution. The model showed that almost all of the total stream $\mathrm{N}$ flux $\left(0.18 \mathrm{~g} \mathrm{~N} \mathrm{~m}^{-2} \mathrm{yr}^{-1}\right)$ was dissolved organic nitrogen (DON) and that gaseous loss $\left(0.16 \mathrm{~g} \mathrm{~N} \mathrm{~m}^{-2} \mathrm{yr}^{-1}\right)$ was almost as great as stream $\mathrm{N}$ flux. Ecosystem retention of atmospherically deposited $\mathrm{N}$ plus internally fixed $\mathrm{N}$ as predicted by the model was 35 percent, though no measurement of $\mathrm{N}$ retention was available to verify this estimate.

\section{Discharge and Stream Chemistry}

We show two 3-year periods of daily discharge and chemistry. Years 1988-1990 cover a range of moisture conditions, with 1988 being very dry and the other two years being relatively wet (fig. 4.5). Results from years 1993-1995 will be examined (when possible) for all sites in an intersite model comparison (fig. 4.6).

The model did especially well in simulating the timing and magnitude of daily discharge for CWT (the $\mathrm{R}^{2}$ correlation between measured and modeled discharge was 0.72 ), missing only a few measured high flows (figs. 4.5, 4.6). Over the simulation period (1985-1995), the model overestimated mean annual discharge by 12 percent (table 4.6).

\section{Nitrate and Ammonium}

The watershed had very low measured stream $\mathrm{NO}_{3}$ concentrations (less than $5 \mu \mathrm{eq} \mathrm{L} \mathrm{L}^{-1}$ ) year-round. Both measured and simulated annual VWM stream $\mathrm{NO}_{3}$ concentrations were less than $1 \mu \mathrm{eq} \mathrm{L} \mathrm{L}^{-1}$ (table 4.6). Daily simulated stream $\mathrm{NO}_{3}$ concentration was close to measured values for most of the year. Exceptions were greater simulated than measured $\mathrm{NO}_{3}$ concentrations during the wettest part of the year, JanuaryMarch, and lower simulated than measured stream $\mathrm{NO}_{3}$ during summer months (figs. 4.5-4.7). The model did not predict any $\mathrm{NH}_{4}$ in daily stream flow, and the vast majority of measured $\mathrm{NH}_{4}$ concentrations were less than $1.0 \mu \mathrm{eq} \mathrm{L} \mathrm{L}^{-1}$.

\section{Sulfate}

The deep soils at CWT appeared to play a strong role in regulating stream $\mathrm{SO}_{4}$. Though CWT had relatively high $\mathrm{S}$ deposition rates (approx. $\left.8.7 \mathrm{~kg} \mathrm{~S} \mathrm{ha}^{-1} \mathrm{yr}^{-1}, 1985-1995\right)$, stream $\mathrm{SO}_{4}$ concentrations were relatively low, with an annual VWM concentration of $12 \mu \mathrm{eq} \mathrm{L} \mathrm{L}^{-1}$. This suggested that soils at CWT have a large $\mathrm{SO}_{4}$ adsorption capacity. DayCent-Chem did not account for enough $\mathrm{SO}_{4}$ adsorption, so stream $\mathrm{SO}_{4}$ concentrations were overestimated year-round. Simulated annual VWM stream $\mathrm{SO}_{4}\left(29 \mu \mathrm{eq} \mathrm{\textrm {L } ^ { - 1 }}\right)$ was more than double the observed mean (table 4.6). Measured annual VWM stream $\mathrm{SO}_{4}$ decreased after 1988, but simulated values generally increased after 1990. Measured values showed little seasonal variation in stream $\mathrm{SO}_{4}$, whereas simulated stream $\mathrm{SO}_{4}$ concentrations showed seasonal differences and increased with soil flushing (figs. 4.5-4.7).

\section{Chloride}

Simulated annual VWM steam $\mathrm{Cl}$ concentrations were $12 \mu$ eq $\mathrm{L}^{-1}$. This was 42 percent less than the mean measured $\mathrm{Cl}$ concentration (table 4.6, fig. 4.7). The daily simulated stream $\mathrm{Cl}$ concentrations deviated most from measured values during low flow periods (figs. 4.5, 4.6). Since simulated discharge matched well with measured discharge, deposition of $\mathrm{Cl}$, particularly dry or fog deposition, might be underestimated for CWT (table 4.2). There are no known weatherable minerals in the watershed that may act as a source of $\mathrm{Cl}$ (Velbel, 1988)

\section{Weathering Products}

The deep saprolite and soil of CWT moderate interannual variability in concentrations of weathering products more than the model was able to replicate. Despite parameterizing the model with published mineral denudation rates for CWT (table 4.3), DayCent-Chem predicted annual VWM stream Si concentrations (316 $\mu \mathrm{eq} \mathrm{L}^{-1}$ ) were twice the measured mean value of $153 \mu \mathrm{eq} \mathrm{L}^{-1}$. Daily model output matched poorly with observations (figs. 4.5, 4.6). Observed stream Si concentrations were relatively constant, becoming slightly diluted during high flow in the spring and slightly concentrated during low flow in the autumn (fig. 4.7). Simulated stream Si concentrations displayed more seasonality. The largest differences between simulated and measured stream Si concentrations were during the wettest months. Although the model overestimated stream $\mathrm{Si}$ concentrations, stream $\mathrm{Ca}, \mathrm{Mg}$, and $\mathrm{Na}$ concentrations were underestimated (table 4.6). These results suggest that there may be an additional source of base cations for CWT, aside from mineral denudation and deposition, or that the model overestimated total base cation adsorption capacity in soils. Simulated daily K concentrations matched well with measured concentrations. 
Table 4.5. Simulated (1985-1995) and measured ecological variables and input/output fluxes. Standard deviations are shown in parentheses and represent interannual variation for annual fluxes and monthly variations for state variables. NPP = net primary production; NEP = net ecosystem production; $\mathrm{Rh}=$ heterotrophic respiration; $\mathrm{PET}=$ potential evapotranspiration; $\mathrm{AET}=$ actual evapotranspiration; DOC = dissolved organic carbon. To convert units reported by data sources, it was assumed that 2.25 grams biomass equals 1 gram $C$.

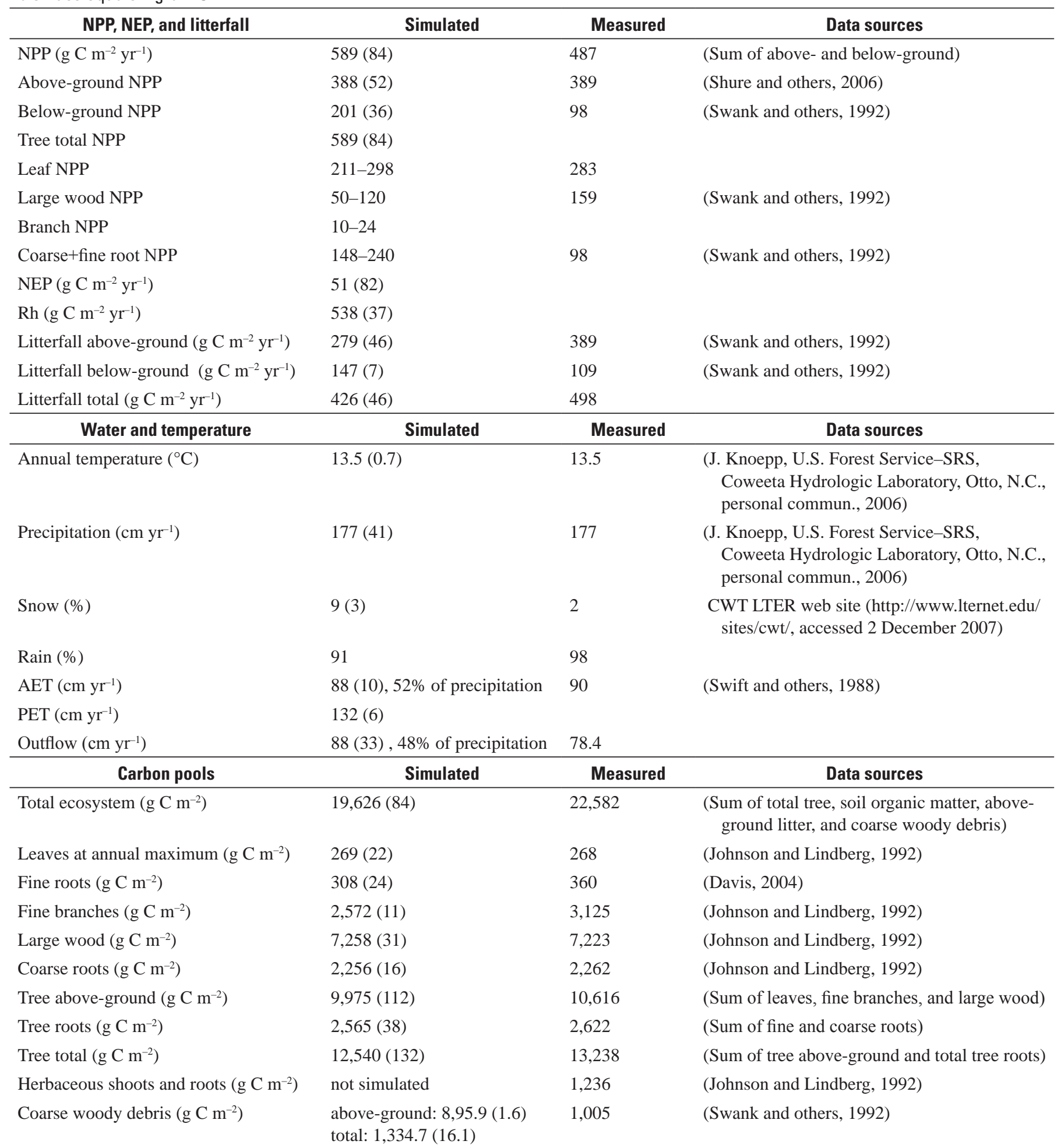


Table 4.5. Simulated (1985-1995) and measured ecological variables and input/output fluxes. Standard deviations are shown in parentheses and represent interannual variation for annual fluxes and monthly variations for state variables. NPP $=$ net primary production; NEP = net ecosystem production; $\mathrm{Rh}=$ heterotrophic respiration; $\mathrm{PET}=$ potential evapotranspiration; $\mathrm{AET}=\mathrm{actual}$ evapotranspiration; DOC = dissolved organic carbon. To convert units reported by data sources, it was assumed that 2.25 grams biomass equals 1 gram C.-Continued

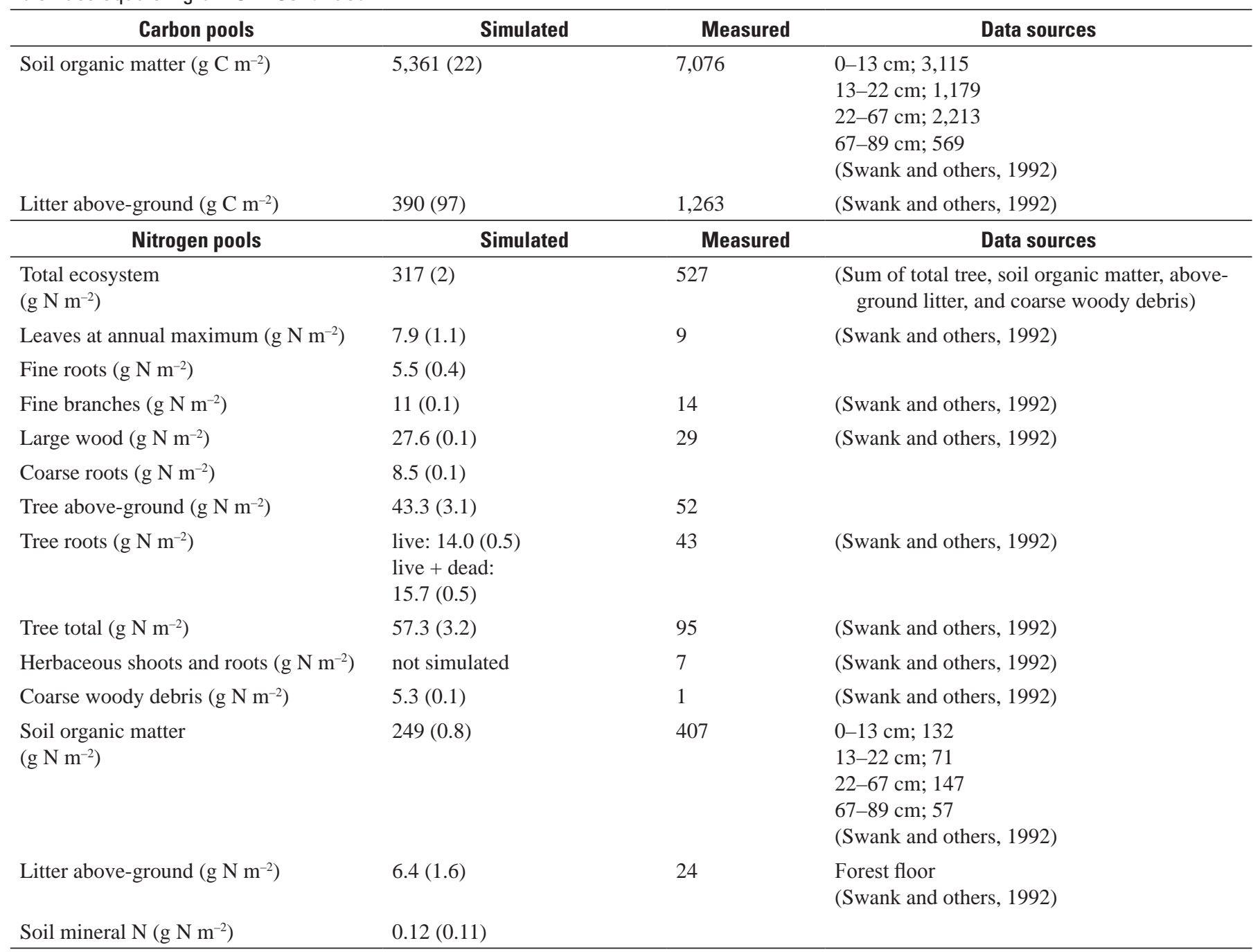

\begin{tabular}{|c|c|c|c|}
\hline N,P,S inputs & Simulated & Measured & Data sources \\
\hline Dry+fog & 0.03 & & CASTNET site COW137 \\
\hline $\mathrm{S}$ deposition $\left(\mathrm{g} \mathrm{S} \mathrm{m}^{-2} \mathrm{yr}^{-1}\right.$ ) & $0.87(0.12)$ & & \\
\hline $\mathrm{P}$ deposition ( $\mathrm{g} \mathrm{P} \mathrm{m}^{-2} \mathrm{yr}^{-1}$ ) & 0 & & \\
\hline Wet & 0 & & NADP site NC25 \\
\hline Dry+fog & 0 & & CASTNET site COW137 \\
\hline C,N,P,S outputs & Simulated & Measured & Data sources \\
\hline
\end{tabular}


Table 4.5. Simulated (1985-1995) and measured ecological variables and input/output fluxes. Standard deviations are shown in parentheses and represent interannual variation for annual fluxes and monthly variations for state variables. NPP = net primary production; NEP = net ecosystem production; $\mathrm{Rh}=$ heterotrophic respiration; $\mathrm{PET}=$ potential evapotranspiration; $\mathrm{AET}$ = actual evapotranspiration; DOC = dissolved organic carbon. To convert units reported by data sources, it was assumed that 2.25 grams biomass equals 1 gram C.-Continued

\begin{tabular}{|c|c|c|c|}
\hline C,N,P,S outputs & Simulated & Measured & Data sources \\
\hline Inorganic & $0.01(0.01)$ & 0.006 & $\begin{array}{l}\text { Coweeta Hydrologic Laboratory, U.S. Forest } \\
\text { Service, written commun., } 2006\end{array}$ \\
\hline Organic & $0.17(0.05)$ & 0.02 & (Qualls and others, 2002) \\
\hline \multicolumn{4}{|l|}{ S export } \\
\hline$\left(\mathrm{g} \mathrm{S} \mathrm{m}^{-2} \mathrm{yr}^{-1}\right)$ & $0.44(0.2)$ & & \\
\hline Inorganic & $0.41(0.2)$ & 0.14 & $\begin{array}{l}\text { Coweeta Hydrologic Laboratory, U.S. Forest } \\
\text { Service, written commun., } 2006\end{array}$ \\
\hline Organic & $0.02(0.01)$ & & \\
\hline \multicolumn{4}{|l|}{ P export } \\
\hline$\left(\mathrm{g} \mathrm{P} \mathrm{m}^{-2} \mathrm{yr}^{-1}\right)$ & $0.03(0.01)$ & & \\
\hline Inorganic & & 0.001 & $\begin{array}{l}\text { Coweeta Hydrologic Laboratory, U.S. Forest } \\
\text { Service, written commun., } 2006\end{array}$ \\
\hline Organic & & 0.0011 & (Qualls and others, 2002) \\
\hline \multicolumn{4}{|l|}{ DOC export } \\
\hline$\left(\mathrm{g} \mathrm{C} \mathrm{m}^{-2} \mathrm{yr}^{-1}\right)$ & $2.7(0.9)$ & 0.41 & (Qualls and others, 2002) \\
\hline \multicolumn{4}{|l|}{ Trace gas flux } \\
\hline$\left(\mathrm{g} \mathrm{N} \mathrm{m}^{-2} \mathrm{yr}^{-1}\right)$ & $0.16(0.06)$ & $\begin{array}{l}0.30 \text { (denitrifi- } \\
\text { cation) }\end{array}$ & $\begin{array}{l}\text { (Barton and others, 1999), undisturbed decidu- } \\
\text { ous }\end{array}$ \\
\hline $\mathrm{N}, \mathrm{P}, \mathrm{S}$ internal fluxes & Simulated & Measured & Data sources \\
\hline $\mathrm{N}$ mineralization $\left(\mathrm{g} \mathrm{N} \mathrm{m}^{-2} \mathrm{yr}^{-1}\right)$ & $7.6(0.6)$ & 5.8 & $\begin{array}{l}\text { Potential N mineralization from laboratory } \\
\text { measurement-1999 (J. Knoepp, U.S. } \\
\text { Forest Service-SRS, Coweeta Hydrologic } \\
\text { Laboratory, Otto, N.C., personal commun., } \\
\text { 2008) }\end{array}$ \\
\hline \multicolumn{4}{|l|}{ P mineralization ( $\mathrm{g} \mathrm{P} \mathrm{m}^{-2} \mathrm{yr}^{-1}$ ) } \\
\hline $\mathrm{S}$ mineralization $\left(\mathrm{g} \mathrm{S} \mathrm{m}^{-2} \mathrm{yr}^{-1}\right)$ & $1.9(0.2)$ & & \\
\hline Gross nitrification $\left(\mathrm{g} \mathrm{N} \mathrm{m}^{-2} \mathrm{yr}^{-1}\right)$ & $1.5(0.2)$ & & \\
\hline $\mathrm{N}$ fixation $\left(\mathrm{g} \mathrm{N} \mathrm{m}^{-2} \mathrm{yr}^{-1}\right)$ & $0.04(0.00)$ & & \\
\hline $\mathrm{N}$ uptake $\left(\mathrm{g} \mathrm{N} \mathrm{m}^{-2} \mathrm{yr}^{-1}\right)$ & $7.7(0.6)$ & & \\
\hline P uptake ( $\left.\mathrm{g} \mathrm{P} \mathrm{m}^{-2} \mathrm{yr}^{-1}\right)$ & $1.1(0.1)$ & & \\
\hline S uptake $\left(\mathrm{g} \mathrm{S} \mathrm{m}^{-2} \mathrm{yr}^{-1}\right)$ & $1.1(0.1)$ & & \\
\hline
\end{tabular}




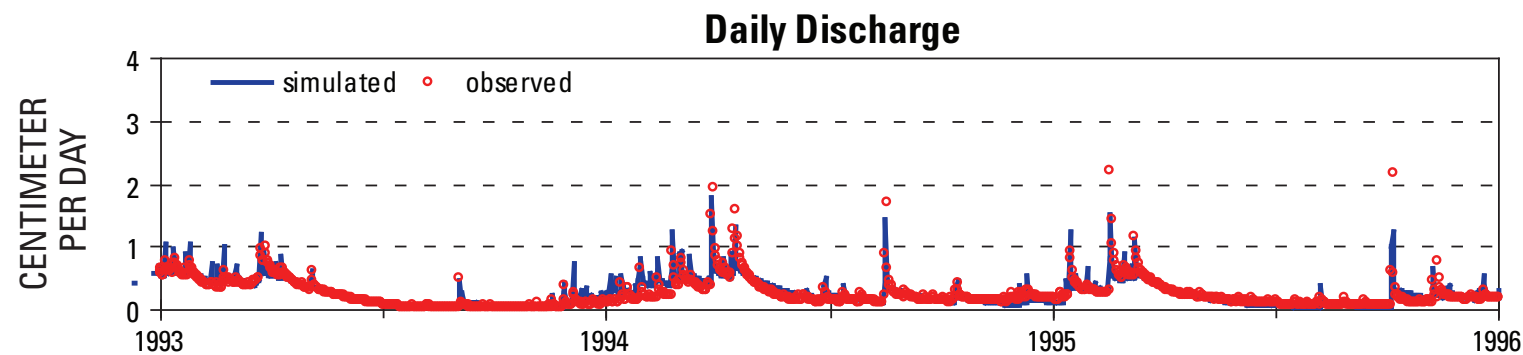

Stream Chemistry
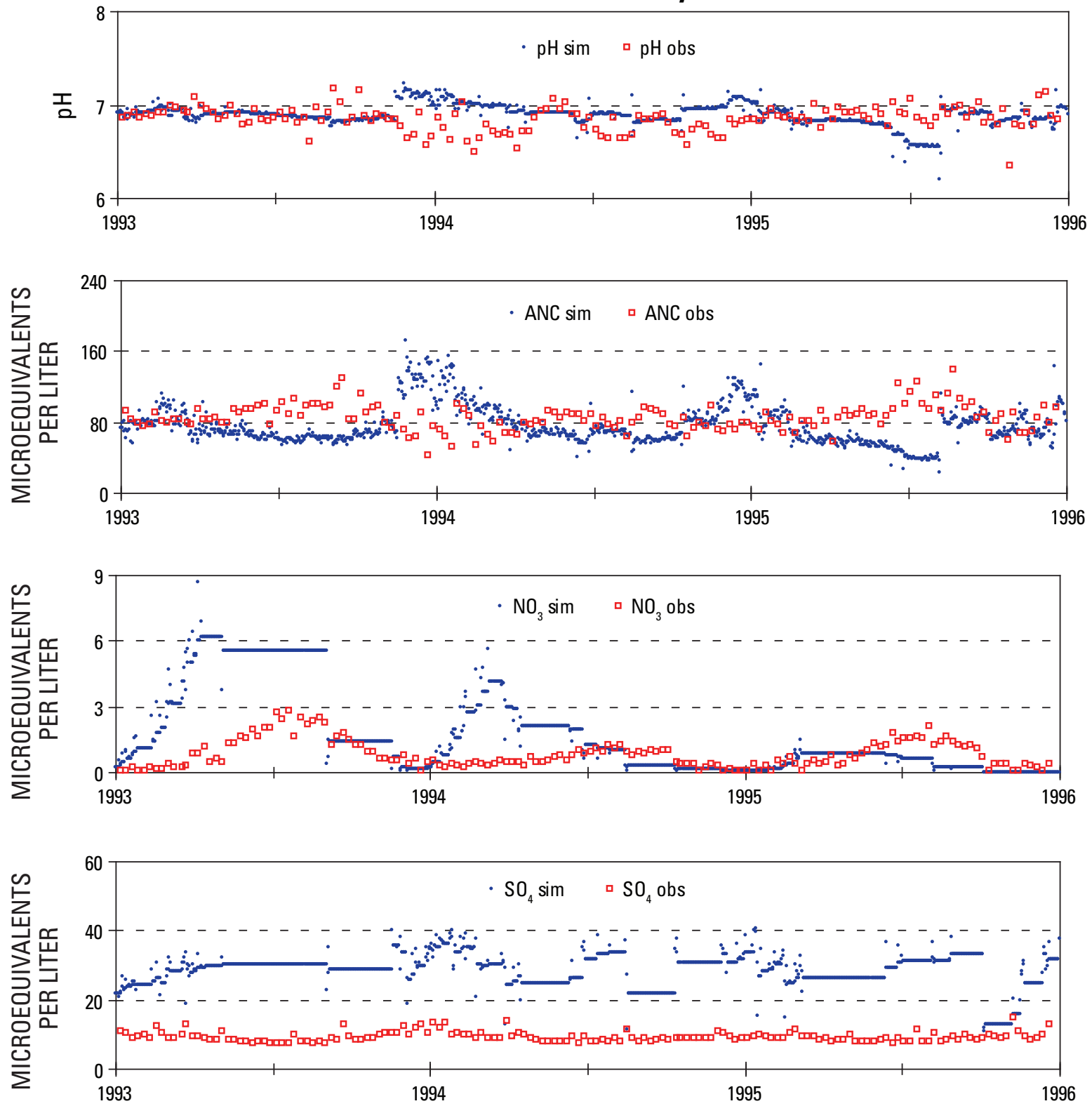

Figure 4.5. Simulated (sim) and observed (obs) daily discharge and stream chemistry for WS2, Coweeta LTER, years 1993-1995 (x axis). Measured DOC was not available. 

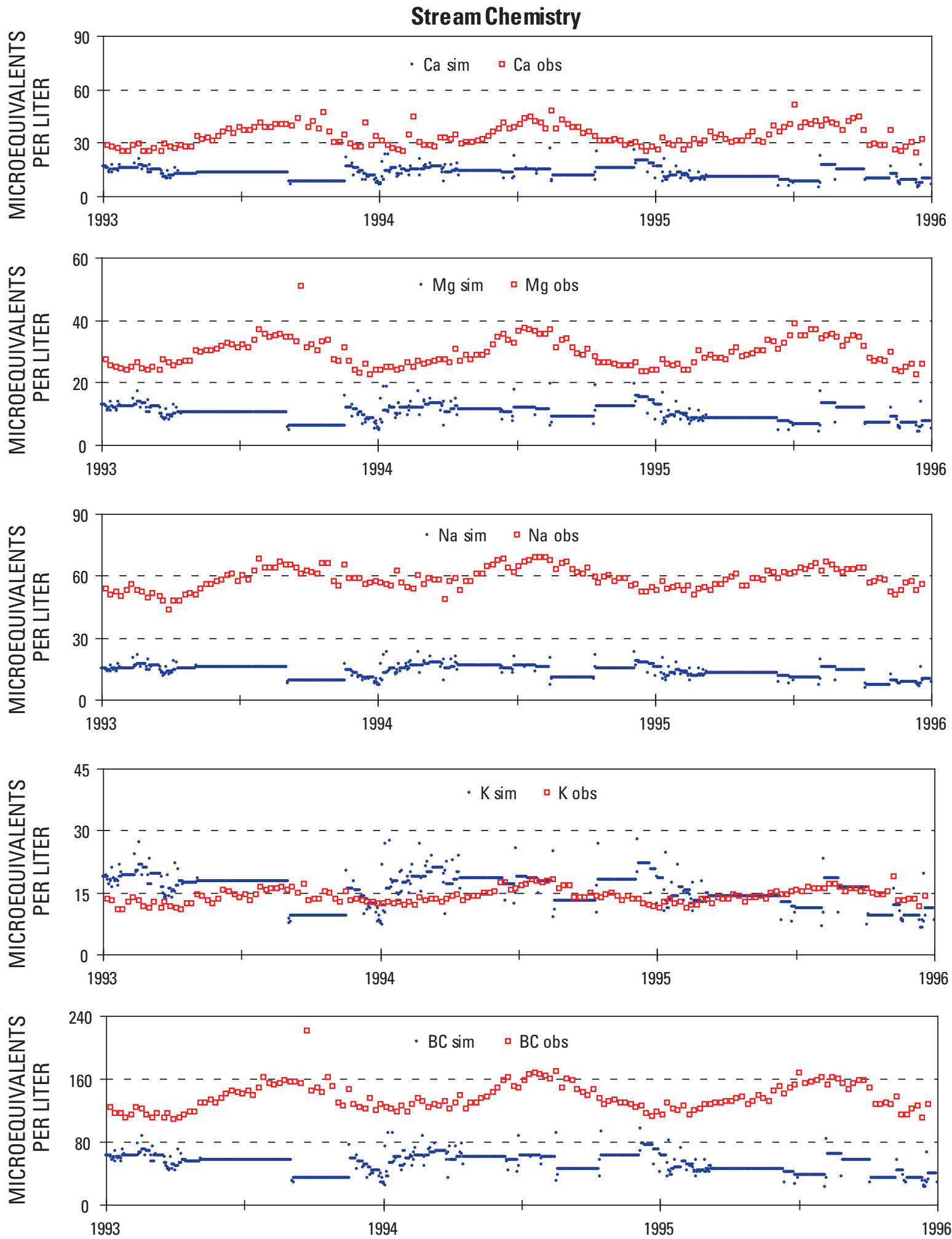

Figure 4.5. Simulated (sim) and observed (obs) daily discharge and stream chemistry for WS2, Coweeta LTER, years 1993-1995 (x axis). Measured DOC was not available.-Continued 

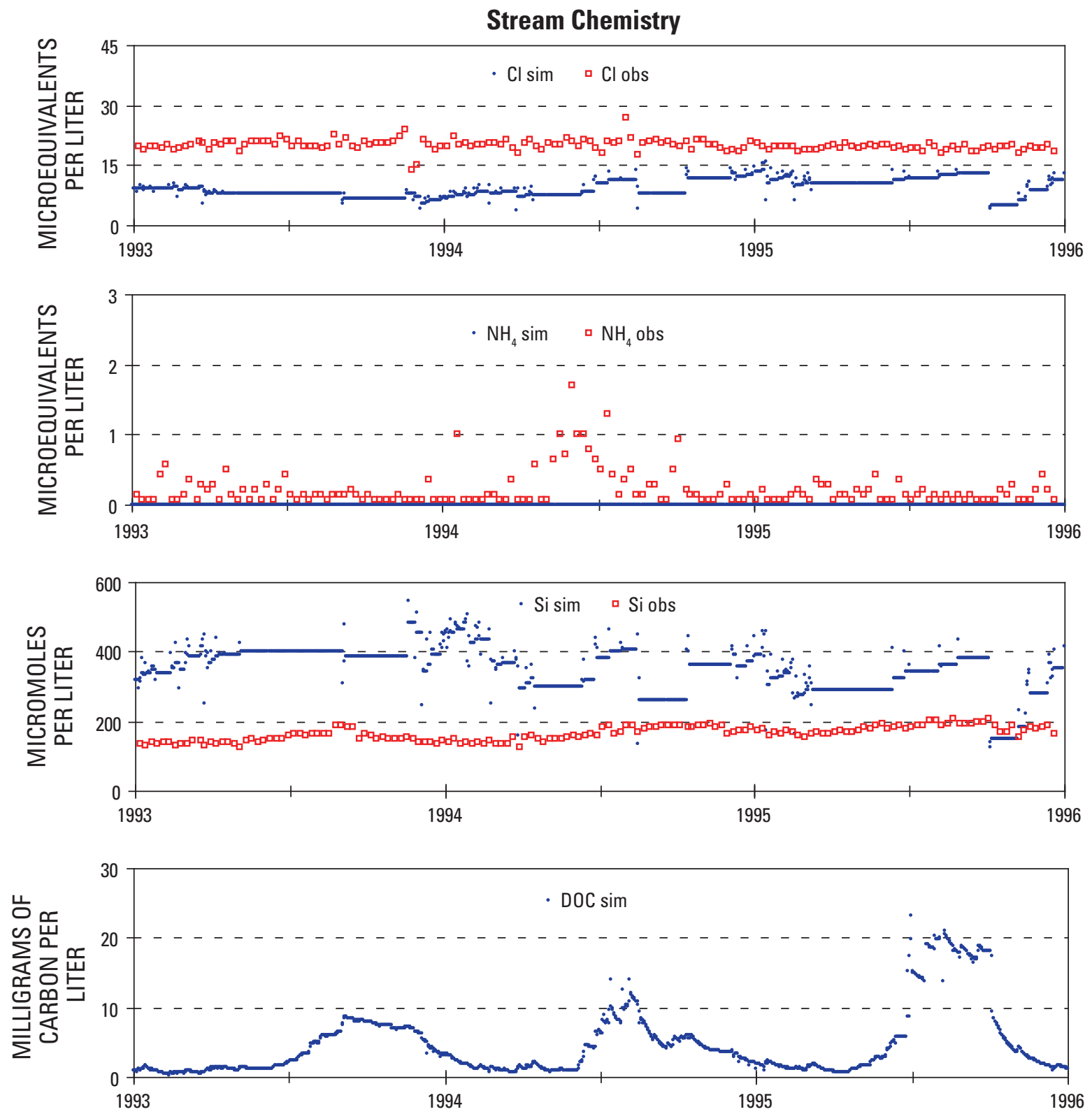

Figure 4.5. Simulated (sim) and observed (obs) daily discharge and stream chemistry for WS2, Coweeta LTER, years 1993-1995 (x axis). Measured DOC was not available.-Continued 


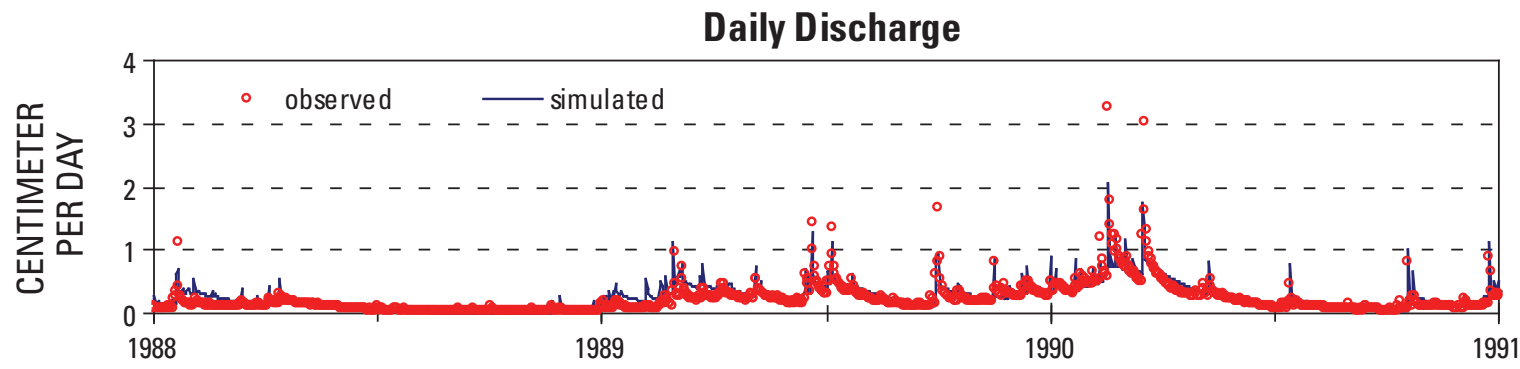

Stream Chemistry

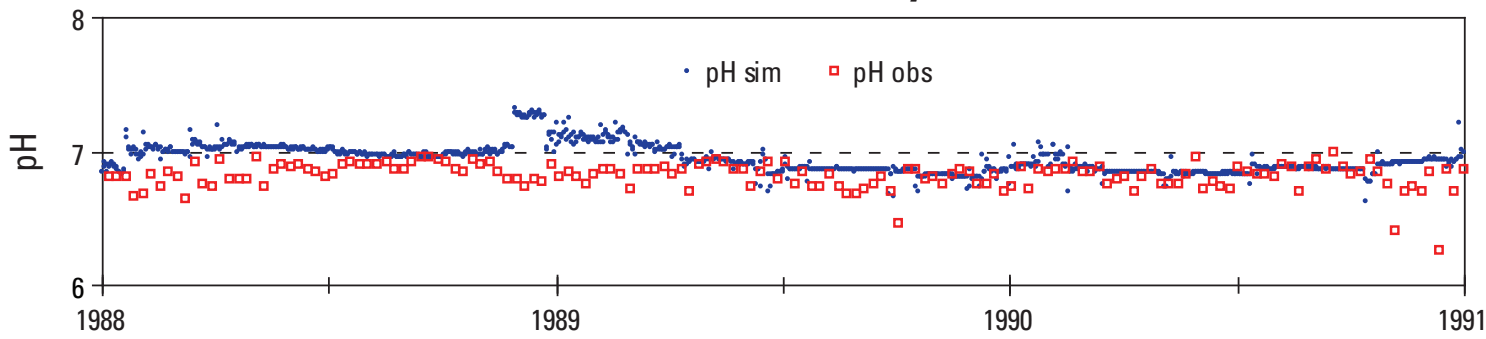

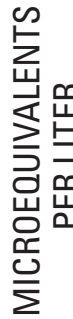

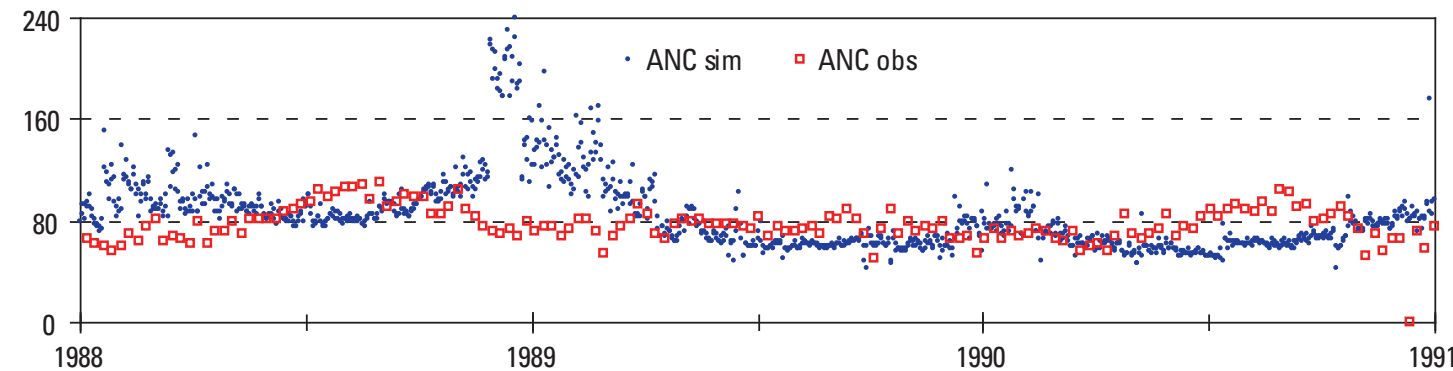

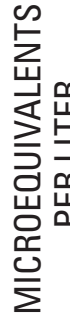
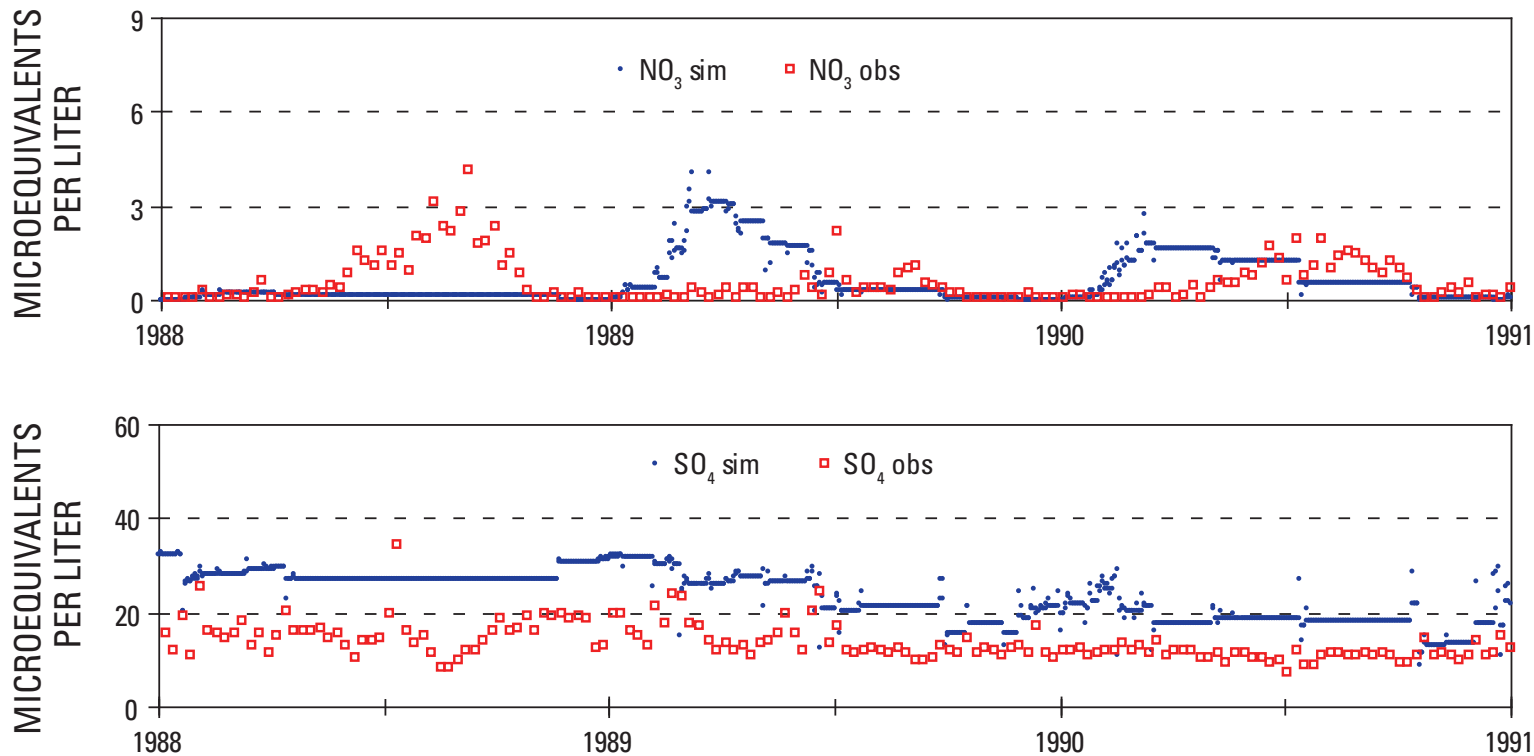

Figure 4.6. Simulated (sim) and observed (obs) daily discharge and stream chemistry for WS2, Coweeta LTER, years 1988-1990 ( $x$ axis). Measured DOC was not available. 

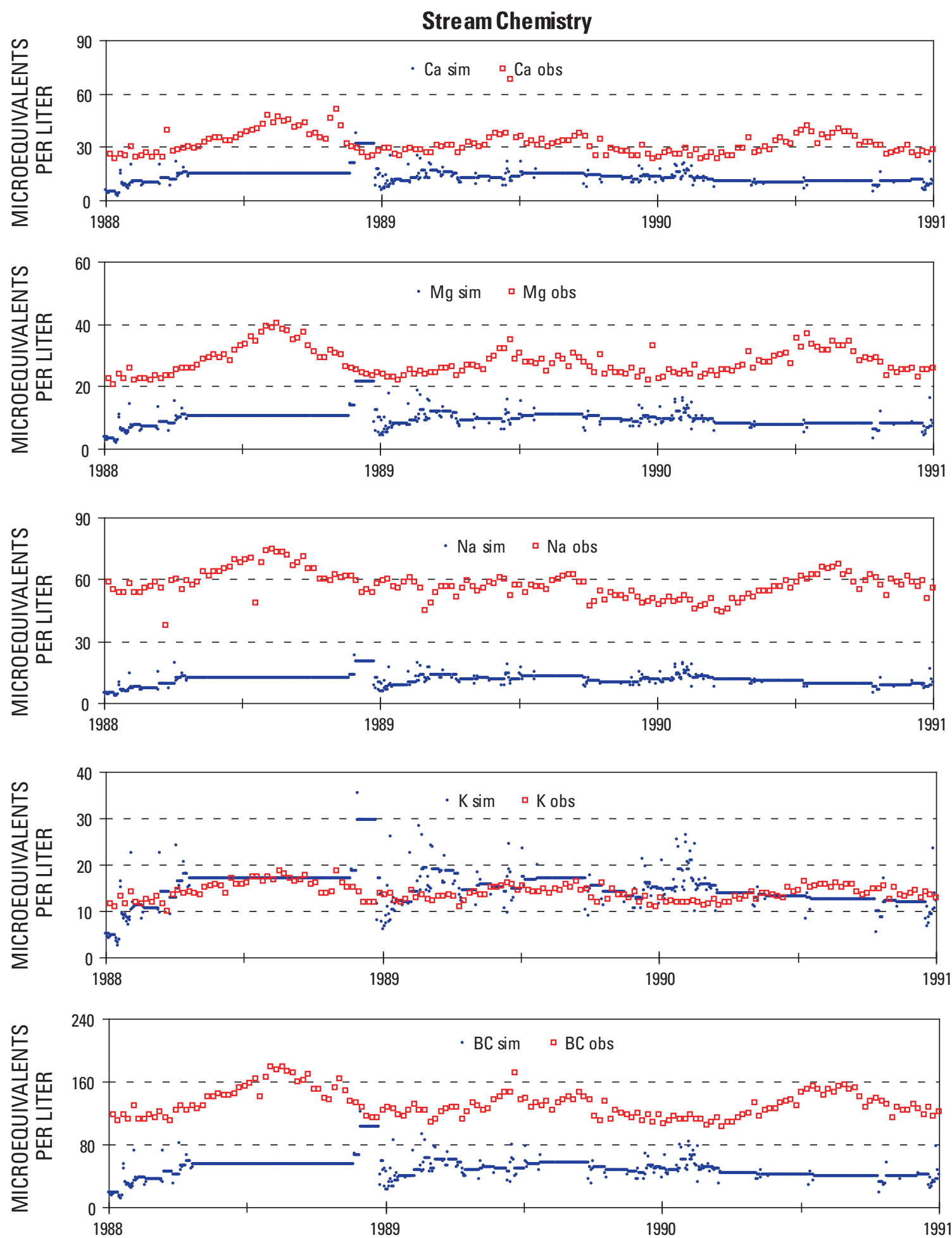

Figure 4.6. Simulated (sim) and observed (obs) daily discharge and stream chemistry for WS2, Coweeta LTER, years 1988-1990 ( $\mathrm{x}$ axis). Measured DOC was not available.-Continued 

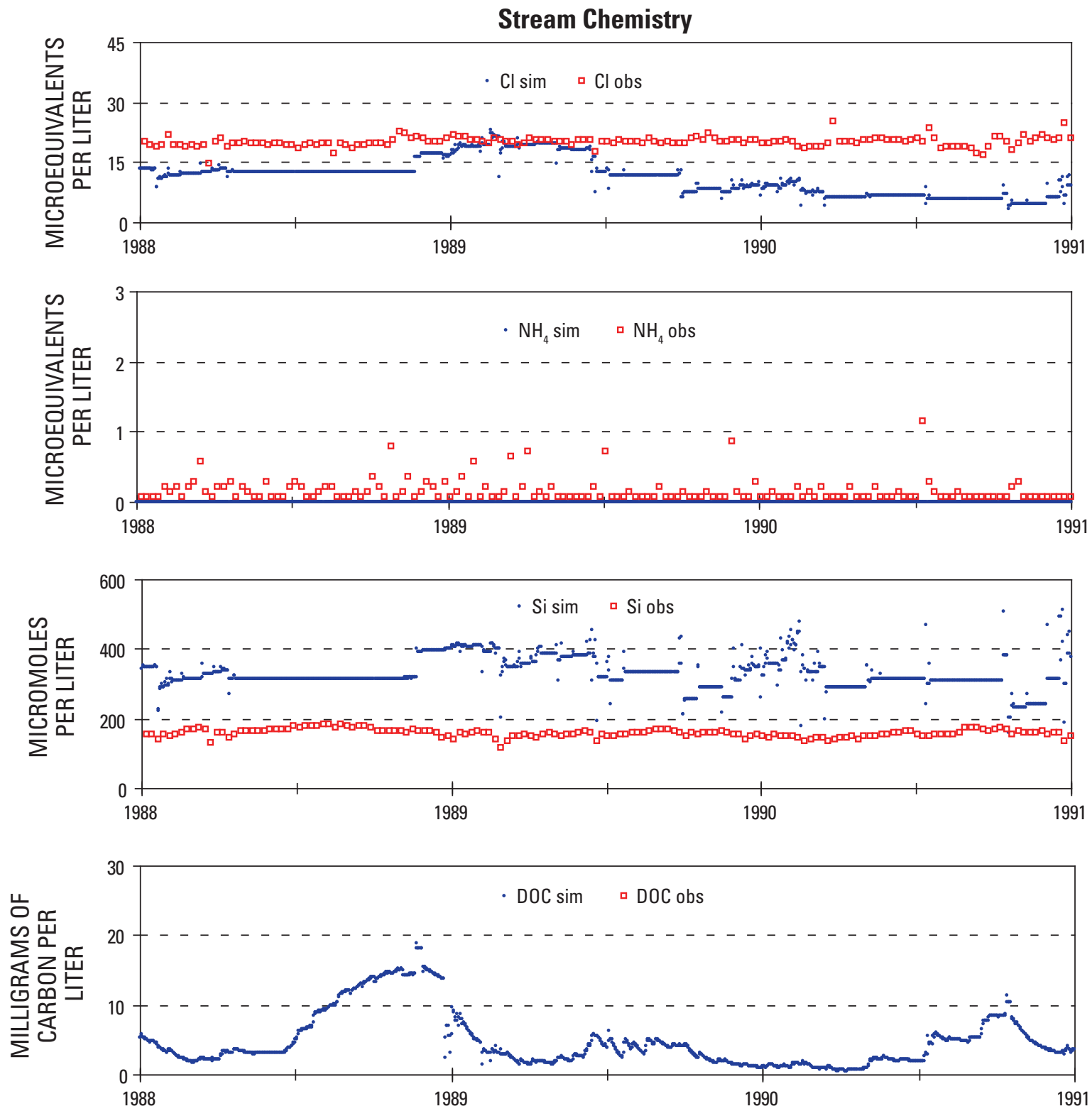

Figure 4.6. Simulated (sim) and observed (obs) daily discharge and stream chemistry for WS2, Coweeta LTER, years 1988-1990 (x axis). Measured DOC was not available.-Continued 
Table 4.6. Annual simulated and measured mean discharge and volume-weighted mean stream chemistry averaged over each year of the simulation. Pmean = predicted mean; Omean = observed mean; $A E=$ absolute error (Pmean Omean); $\mathrm{NAE}=$ normalized absolute error (AE/Omean); $\mathrm{BC}=$ sum of base cations $(\mathrm{Ca}, \mathrm{Mg}, \mathrm{K}, \mathrm{Na})$.

\begin{tabular}{|c|c|c|c|c|c|}
\hline Constituent & Metric & Value & Constituent & Metric & Value \\
\hline \multirow[t]{4}{*}{ Discharge $\left(\mathrm{cm} \mathrm{yr}^{-1}\right)$} & Pmean & 87.65 & $\mathrm{NH}_{4}\left(\mu\right.$ еq $\left.\mathrm{L}^{-1}\right)$ & Pmean & 0.00 \\
\hline & Omean & 78.40 & & Omean & 0.17 \\
\hline & $\mathrm{AE}$ & 9.25 & & $\mathrm{AE}$ & -0.17 \\
\hline & NAE & 0.12 & & NAE & -1.00 \\
\hline \multirow[t]{4}{*}{$\mathrm{pH}$} & Pmean & 6.90 & $\mathrm{NO}_{3}(\mu \mathrm{eq} \mathrm{L}-1)$ & Pmean & 0.92 \\
\hline & Omean & 6.84 & & Omean & 0.46 \\
\hline & $\mathrm{AE}$ & 0.06 & & $\mathrm{AE}$ & 0.46 \\
\hline & NAE & 0.01 & & NAE & 1.01 \\
\hline \multirow[t]{4}{*}{ Ca $\left(\mu \mathrm{eq} \mathrm{L} \mathrm{L}^{-1}\right)$} & Pmean & 13.19 & $\mathrm{SO}_{4}\left(\mu \mathrm{eq} \mathrm{L}{ }^{-1}\right)$ & Pmean & 29.37 \\
\hline & Omean & 30.41 & & Omean & 11.67 \\
\hline & $\mathrm{AE}$ & -17.22 & & $\mathrm{AE}$ & 17.69 \\
\hline & NAE & -0.57 & & NAE & 1.52 \\
\hline \multirow[t]{4}{*}{$\operatorname{Mg}\left(\mu \mathrm{eq} \mathrm{L}^{-1}\right)$} & Pmean & 10.01 & ANC $\left(\mu\right.$ eq $\left.L^{-1}\right)$ & Pmean & 80.08 \\
\hline & Omean & 26.79 & & Omean & 78.42 \\
\hline & $\mathrm{AE}$ & -16.78 & & $\mathrm{AE}$ & 1.66 \\
\hline & NAE & -0.63 & & NAE & 0.02 \\
\hline \multirow[t]{4}{*}{$\mathrm{K}\left(\right.$ неq $\left.\mathrm{L}^{-1}\right)$} & Pmean & 15.70 & $\mathrm{Cl}\left(\mu \mathrm{eq} \mathrm{L}^{-1}\right)$ & Pmean & 11.60 \\
\hline & Omean & 13.40 & & Omean & 19.86 \\
\hline & $\mathrm{AE}$ & 2.30 & & $\mathrm{AE}$ & -8.26 \\
\hline & NAE & 0.17 & & NAE & -0.42 \\
\hline \multirow[t]{4}{*}{ Na $\left(\mu e q L^{-1}\right)$} & Pmean & 13.13 & $\mathrm{Si}\left(\mu \mathrm{mol} \mathrm{L}{ }^{-1}\right)$ & Pmean & 316.08 \\
\hline & Omean & 55.93 & & Omean & 152.73 \\
\hline & $\mathrm{AE}$ & -42.79 & & $\mathrm{AE}$ & 163.35 \\
\hline & NAE & -0.77 & & NAE & 1.07 \\
\hline \multirow[t]{5}{*}{ BC $\left(\mu\right.$ eq $\left.L^{-1}\right)$} & Pmean & 52.03 & $\mathrm{DOC}\left(\mathrm{mg} \mathrm{C} \mathrm{L} \mathrm{L}^{-1}\right)$ & Pmean & 3.30 \\
\hline & Omean & 126.52 & & Omean & N/A \\
\hline & $\mathrm{AE}$ & -74.49 & & $\mathrm{AE}$ & N/A \\
\hline & NAE & -0.59 & & NAE & N/A \\
\hline & & & $\mathrm{HCO}_{3}\left(\mu \mathrm{eq} \mathrm{L} \mathrm{L}^{-1}\right)$ & Pmean & 75.55 \\
\hline
\end{tabular}



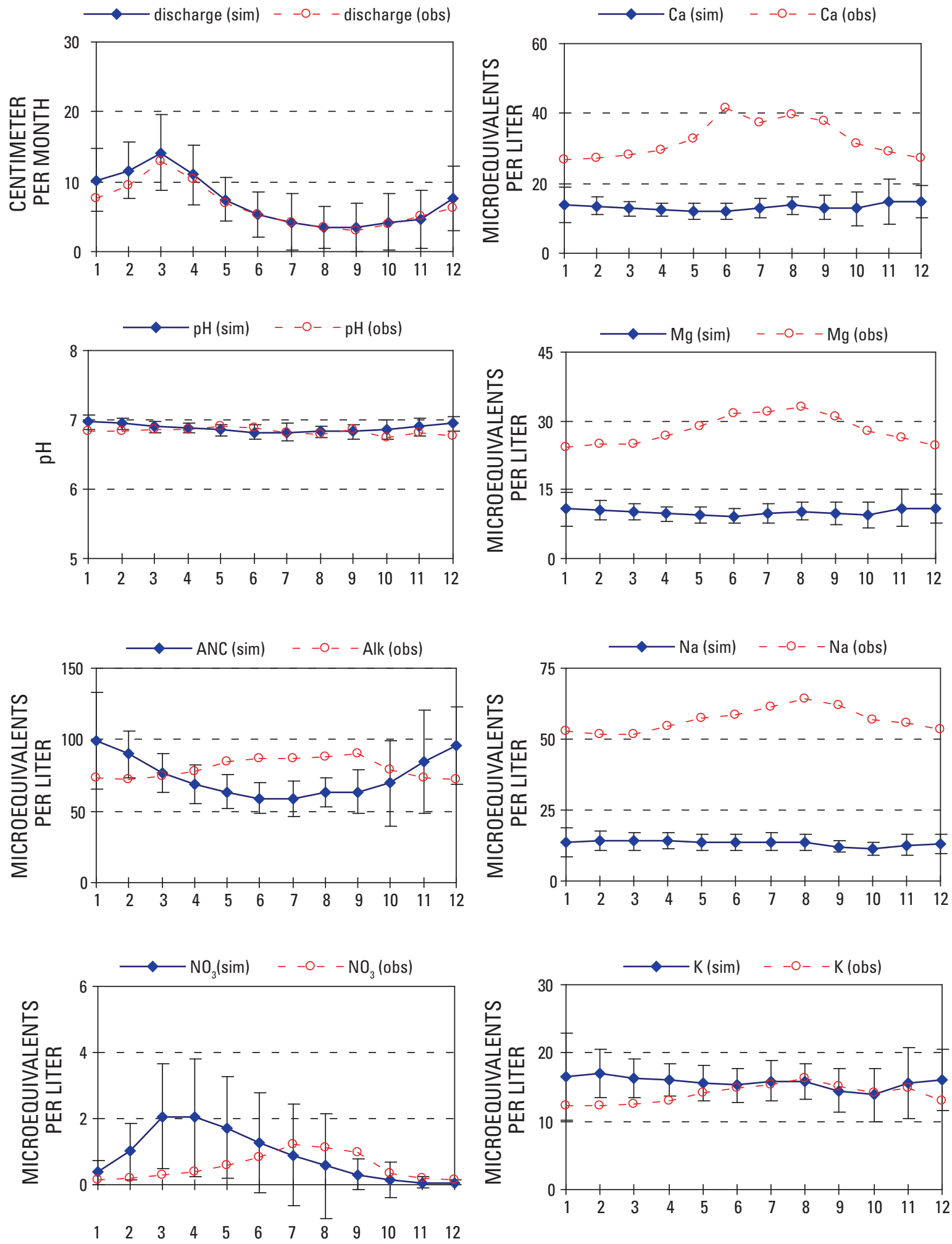

Figure 4.7. Simulated (sim) and observed (obs) stream chemistry averaged by month (x axis) for WS2, Coweeta LTER, years 1985-1995. The vertical bars on the simulated values represent plus and minus one standard deviation from the simulated mean. Measured DOC was not available. 

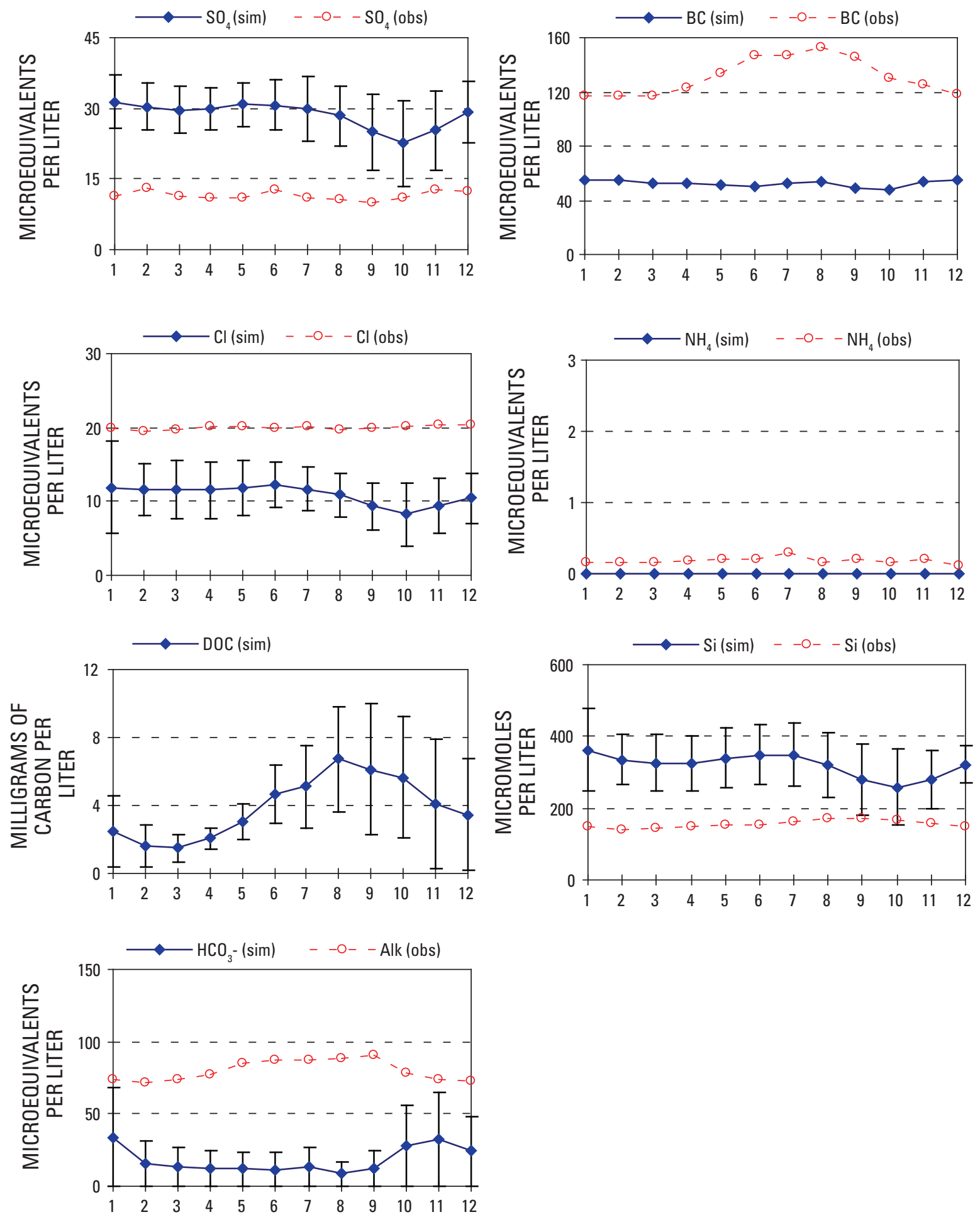

Figure 4.7. Simulated (sim) and observed (obs) stream chemistry averaged by month (x axis) for WS2, Coweeta LTER, years 1985-1995. The vertical bars on the simulated values represent plus and minus one standard deviation from the simulated mean. Measured DOC was not available.-Continued 


\section{ANC and $\mathrm{pH}$}

Measured stream alkalinity ranged from about $125 \mu \mathrm{eq}$ $\mathrm{L}^{-1}$ in the summer to about $50 \mu \mathrm{eq} \mathrm{L}^{-1}$ in December or January. Stream ANC predictions were in the same range as what was measured but were out of phase with observed temporal patterns, particularly for simulation years 1993-1995 (figs. 4.5-4.7). Both the model and the measurements showed that stream $\mathrm{pH}$ was only slightly acidic, and they showed little seasonal variation, hovering around 6.8.

\section{Dissolved Organic Carbon}

Simulated daily stream dissolved organic carbon (DOC) ranged from 0 to $15 \mathrm{mg} \mathrm{C} \mathrm{L}^{-1}$ throughout the simulation, with the lowest concentrations during the winter and the highest concentrations in July and August (figs. 4.5, 4.6). Measured stream DOC during the study period was not available.

\section{Summary}

DayCent-Chem did well in representing tree carbon pools but underestimated soil carbon pools and most nitrogen pools. Simulated soil organic matter $\mathrm{C}$ and simulated total ecosystem C were underestimated by 24 and 13 percent, respectively, though total tree biomass was within 6 percent of the measured value. Simulated soil organic matter N, tree biomass $\mathrm{N}$, and total ecosystem $\mathrm{N}$ were underestimated by 40 percent. Simulated above-ground NPP values were the same as measured values, whereas simulated below-ground NPP values were double the measured values.

The model did very well in simulating the timing and magnitude of daily discharge, though it slightly overestimated annual mean discharge and underestimated some high flow events. Simulated daily concentrations and temporal patterns of stream $\mathrm{pH}, \mathrm{NO}_{3}$, and $\mathrm{K}$ were similar to observations. The deep soils at CWT appeared to play a strong role in regulating stream $\mathrm{SO}_{4}$, base cations, and silica export, but the model was not able to replicate watershed controls on these solutes; it underestimated stream base cation concentrations and overestimated stream $\mathrm{Si}$ and $\mathrm{SO}_{4}$ concentrations. 


\section{Great Smoky Mountains National Park, Noland Divide Watershed, North Carolina}

\section{Site Description}

Noland Divide watershed (NDW) is a 17.4-ha watershed in Great Smoky Mountains National Park (GRSM), N.C., with elevation extending from 1,678 to $1,921 \mathrm{~m}$ (table 5.1, fig. 5.1). The spruce-fir forest that covers the watershed receives among the highest atmospheric N and S inputs in North America (Johnson and Lindberg, 1992).

At the onset of a vegetation study in 1993, the live basal area of the forest was dominated by red spruce (Picea rubens; 77 percent), with lesser amounts of yellow birch (Betula alleghaniensis; 19 percent) and Fraser fir (Abies fraseri; 2.5 percent); with increasing elevation, the relative abundance of fir increased and that of yellow birch decreased (Van Miegroet and others, 2001). Noland Divide watershed includes the Integrated Forest Study (IFS) "Smokies Tower" site of Johnson and Lindberg (1992). It was one of 17 sites across the United States studied as part of the National IFS to determine the effects of acidic atmospheric deposition on forest ecosystems from 1986 to 1989.

The soils of NDW are Inceptisols with spodic characteristics classified as Dystrochrepts or Haplumbrepts (Johnson, Van Miegroet, and others, 1991; Van Miegroet and others, 1993) and underlain by the Thunderhead Sandstone formation (King and others, 1968). They have low $\mathrm{pH}$, low base status, high exchangeable Al, and a silt loam to sandy loam texture (Johnson, Van Miegroet, and others, 1991; Van Miegroet and others, 2001). Estimated soil depths range from less than 50 cm (Van Miegroet and others, 2001) to 60-65 cm (Johnson and Lindberg, 1992).

There has been no known logging or fire at NDW, but there have been a number of other disturbances to the watershed. Clingmans Dome is a major tourist attraction in GRSM, and the paved Clingmans Dome Road across the upper Noland Divide watershed at 1,808-1,826 m was constructed in 1935. The watershed has been affected by rates of $\mathrm{N}$ and $\mathrm{S}$ deposition that have been as great as $30 \mathrm{~kg} \mathrm{~N} \mathrm{yr}^{-1}$ (Van Miegroet and others, 2001) and $35 \mathrm{~kg} \mathrm{~S} \mathrm{yr}^{-1}$ (Johnson and Lindberg, 1992). The invasion by the exotic balsam woolly adelgid (BWA; Adelges piceae), which started in 1977 at NDW, caused the death of mature Fraser fir, creating a heterogeneous forest structure with gaps and large variation in stand age, the number of live and dead standing trees, and amount of coarse woody debris (CWD) on the forest floor (Nicholas and others, 1992; Pauley and others, 1996). As of 1992 the initial wave of BWA-caused mortality of Fraser fir was nearly complete
(Nicholas and others, 1992). Currently, Fraser fir is making a rapid recovery (Moore and others, 2008). There were two hurricanes, Hurricane Andrew in August 1992 and Hurricane Opal in October 1995, and a severe ice storm in the winter of 1995 that caused a significant downing of live and dead trees and a large accumulation of CWD (Van Miegroet and others, 2001). However, standing live biomass of overstory trees is no longer in decline, and standing biomass values are similar to those measured before the BWA invasion (Moore and others, 2008).

\section{Methods}

\section{Climate and Hydrology}

Meteorological data used to drive the model were measured at two nearby weather stations. Weather records that began in 1974 were available from the Newfound Gap (NFG) weather station, $7 \mathrm{~km}$ to the northeast of NDW and 1,536 m.a.s.l. (National Weather Service, written commun., 2006). Data from Clingman's Dome weather station $\left(35.5619^{\circ}\right.$, $\left.-83.4981^{\circ}\right), 1.6 \mathrm{~km}$ from NDW at 2,021 m.a.s.l., has been collected from May to October each year since 1993 (National Park Service Air Resources Division, http://12.45.109.6/ pls/portal/data_request.mainfile, accessed 26 January 2007; fig. 5.2). The elevation difference between the NFG station and NDW was great enough to change basic hydrology model inputs. For simulation years 1981-1999, we used daily minimum and maximum air temperature from the NFG weather station. For simulation years 1993-1999 we used daily precipitation measured at Clingmans Dome for the months it operates, approximately May-October each year, and precipitation for all other times was from the NFG station. Mean annual temperature for 1981-1999 was 8.6 (std. dev. 0.6) ${ }^{\circ} \mathrm{C}$ and increased $0.02{ }^{\circ} \mathrm{C} \mathrm{yr}^{-1}$. Precipitation averaged 232 (std. dev. 39) $\mathrm{cm} \mathrm{yr}^{-1}$ during the period 1981-1999. The greatest precipitation occurred in the winter months, and the driest months were in early autumn. The watershed is frequently immersed in fog, which accounts for a large portion of atmospheric deposition plus water inputs, measured at 41 $\mathrm{cm} \mathrm{yr}^{-1}$ (Johnson and Lindberg, 1992).

Two adjacent first-order streams originate from NDW and flow into Noland Creek at the outlet of the watershed. Stream flow from NDW is measured using two V-notched weirs that 
Table 5.1. Characteristics of Noland Divide watershed in Great Smoky Mountains National Park, North Carolina.

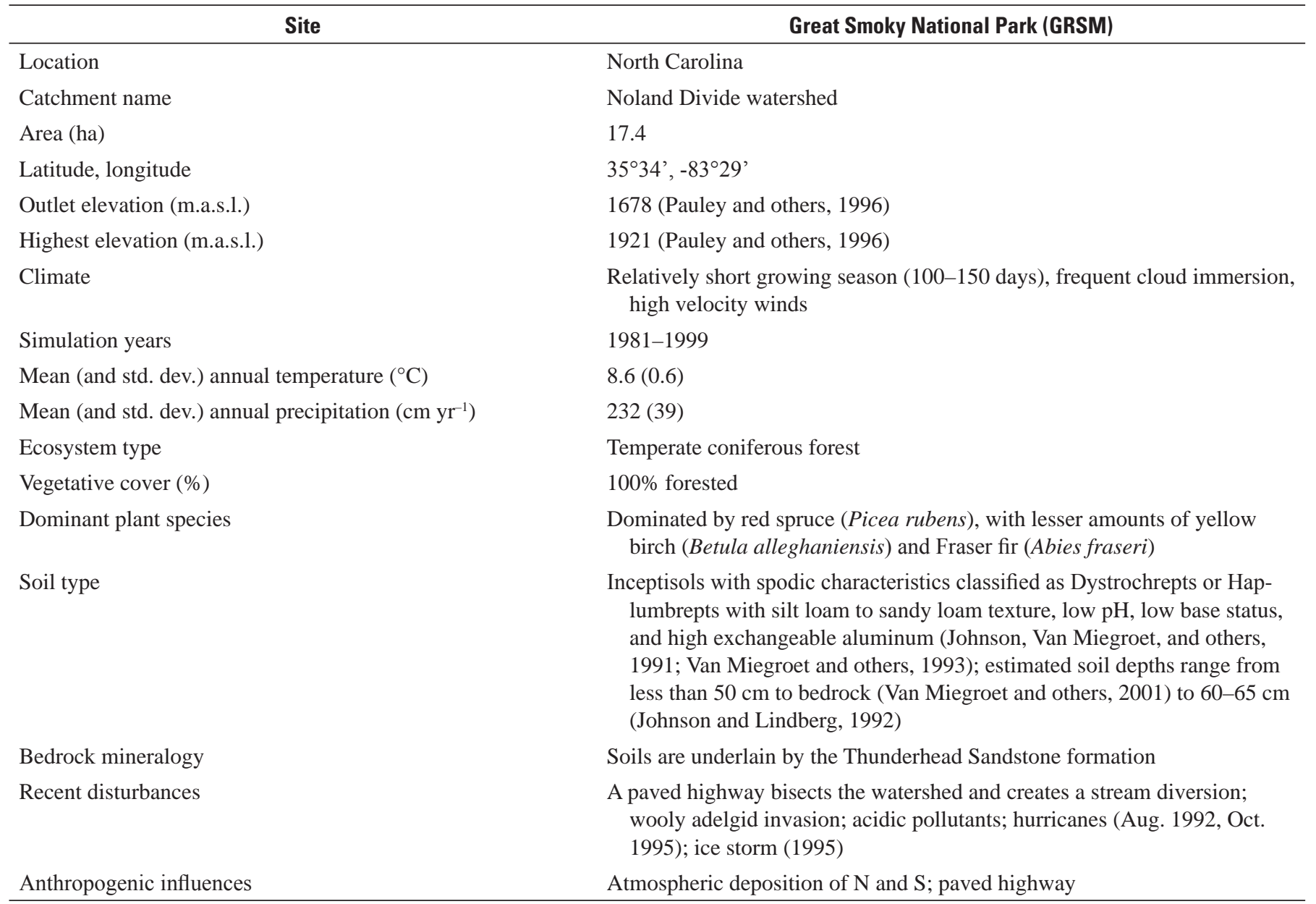

were installed in 1991. Stream chemical sampling occurred at both the southwest and northeast weirs. Discharge and stream chemistry from both weirs was available for simulation years 1992-1999 and several years beyond (NPS data collected by the University of Tennessee, written commun., 2006). A culvert along the Clingman's Dome Road diverts some flow out of the NDW, reducing the effective drainage area (Loscher, 2006). Based on a manual delineation of NDW using contours generated from topographic survey, the contributing area of the southwest stream (3.66 ha) was smaller than that of the northeast stream (12.96 ha) (Loscher, 2006).

Measured precipitation (1981-1999) plotted against streamflow measured at the northeast weir at Noland Divide (1992-1999; NPS data collected by the University of Tennessee, written commun., 2006) showed that discharge generally varied synchronously with precipitation, and the largest difference between the two occurred when evapotranspiration was high in the summer months (fig. 5.3).

\section{Atmospheric Deposition}

We derived wet plus dry atmospheric deposition inputs from a combination of sources (table 5.2, fig. 5.4). For years 1981-1990 we used NADP/NTN data from the TN11Elkmont, Tenn., site (latitude $35.6645^{\circ}$, longitude $-83.5903^{\circ}$, elevation $640 \mathrm{~m}$ ), and for years 1991-1999 we used Noland Divide Open Site throughfall data (NPS data collected by the University of Tennessee, written commun., 2006). The $\mathrm{N}$ and $S$ wet:dry:fog ratios were available from the IFS (Johnson and Lindberg, 1992), and $\mathrm{N}$ ratios were available from Van Miegroet and others (2001). Measured wet:dry:fog ratios for base cations were not available, so these were calibrated to better approximate stream concentrations of these solutes.

Atmospheric deposition from 1981-1999 for both $\mathrm{N}$ and $\mathrm{S}$ was very high (greater than $30 \mathrm{~kg} \mathrm{~N} \mathrm{ha}^{-1} \mathrm{yr}^{-1}$ and greater than $30 \mathrm{~kg} \mathrm{~S} \mathrm{ha}^{-1} \mathrm{yr}^{-1}$ ). During this period $\mathrm{NO}_{3}-\mathrm{N}$ deposition decreased, but $\mathrm{NH}_{4}-\mathrm{N}$ deposition increased such that total $\mathrm{N}$ 


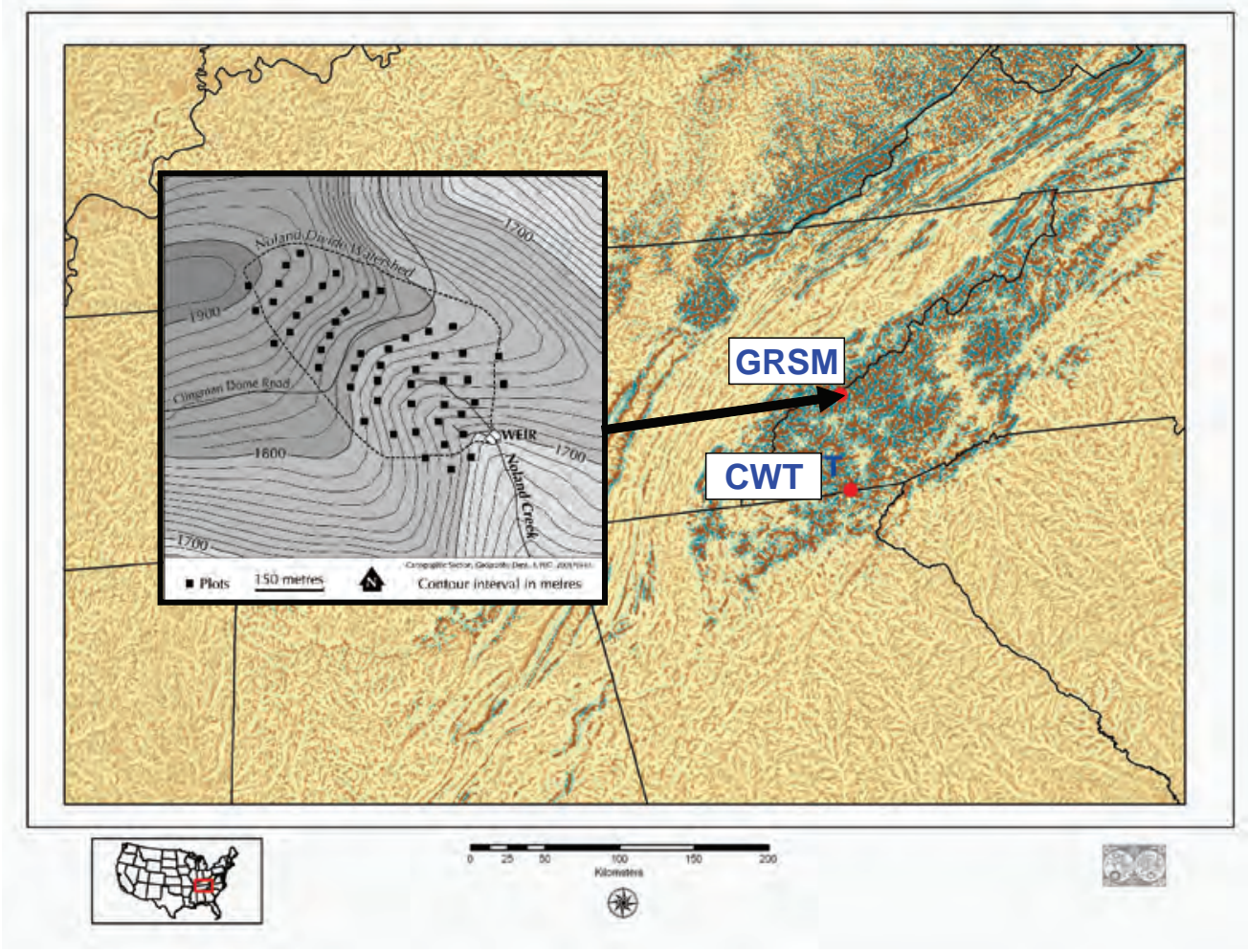

Figure 5.1. Noland Divide watershed (inset) is located in Great Smoky Mountains National Park (GRSM) in North Carolina. Coweeta LTER (CWT, Chapter 4) is to the south.

deposition increased. During the same time, $\mathrm{SO}_{4}$-S deposition declined (fig. 5.4B).

\section{Soil and Mineral Properties}

Soil properties used for input to the model were derived from several data sources (table 5.3). Sand, silt, and clay fractions were characteristic of silt to sandy loam. Soil layer thicknesses were based on the IFS Smokies Tower Plot 1 data (Johnson and Lindberg, 1992), since the depth of the soil at that plot $(55 \mathrm{~cm})$ was close to the watershed average of about $50 \mathrm{~cm}$ (Van Miegroet and others, 2001). Saturated hydraulic conductivity (Ksat) was the mean for plots reported by Loscher (2006). Bulk density values were the average of upper and lower elevation values determined from eight intensive plots in NDW (Van Miegroet and others, 2007). Wilting point and field capacity were computed by the model based on soil texture and bulk density. Initial exchangeable cations (table 5.3) were determined by calibration, repeatedly running the model and updating the initial cation exchange values with the end of simulation values until there were no steep increases or decreases in exchangeable cations over the simulation period.

The soil mineral inputs to the model, plagioclase (albite and anorthite) and biotite, were included in minerals commonly present in soils at IFS sites (April and Newton, 1992) and were the same as those found at Coweeta LTER (Velbel, 1995), a nearby site in North Carolina (see Chapter 4). We started with the mineral weathering rates measured at Coweeta but reduced weathering rates by 50 percent during calibration (table 5.4). The minerals gibbsite and kaolinite were allowed to precipitate to simulate incomplete silicate dissolution. The mineral reactions are summarized below.

Albite: $\mathrm{NaAlSi}_{3} \mathrm{O}_{8}+8 \mathrm{H}_{2} \mathrm{O}=\mathrm{Na}^{+}+\mathrm{Al}(\mathrm{OH})_{4}^{-}+3 \mathrm{H}_{4} \mathrm{SiO}_{4}$ Anorthite: $\mathrm{CaAl}_{2} \mathrm{Si}_{2} \mathrm{O}_{8}+8 \mathrm{H}_{2} \mathrm{O}=\mathrm{Ca}^{2+}+2 \mathrm{Al}(\mathrm{OH})_{4}^{-}$ $+2 \mathrm{H}_{4} \mathrm{SiO}_{4}$

Biotite: $\mathrm{KMg}_{1.5} \mathrm{Fe}_{1.5} \mathrm{AlSi}_{3} \mathrm{O}_{10}(\mathrm{OH})_{2}+6 \mathrm{H}^{+}+4 \mathrm{H}_{2} \mathrm{O}=\mathrm{K}^{+}$ $+1.5 \mathrm{Mg}^{2+}+1.5 \mathrm{Fe}^{2+}+\mathrm{Al}(\mathrm{OH})_{4}^{-}+3 \mathrm{H}_{4} \mathrm{SiO}_{4}$

Gibbsite: $\mathrm{Al}(\mathrm{OH})_{3}+3 \mathrm{H}^{+}=\mathrm{Al}^{3+}+3 \mathrm{H}_{2} \mathrm{O}$

Kaolinite: $\mathrm{Al}_{2} \mathrm{Si}_{2} \mathrm{O}_{5}(\mathrm{OH})_{4}+6 \mathrm{H}^{+}=\mathrm{H}_{2} \mathrm{O}$ $+2 \mathrm{H}_{4} \mathrm{SiO}_{4}+2 \mathrm{Al}^{3+}$

\section{Calibration}

To prepare the model for the GRSM simulation, DayCent-Chem was run in two stages. The first simulation, years 1501-1980, was a spin-up run to initialize model state variables. The results presented in this report are from a second run, simulation years 1981-1999, the years when both 

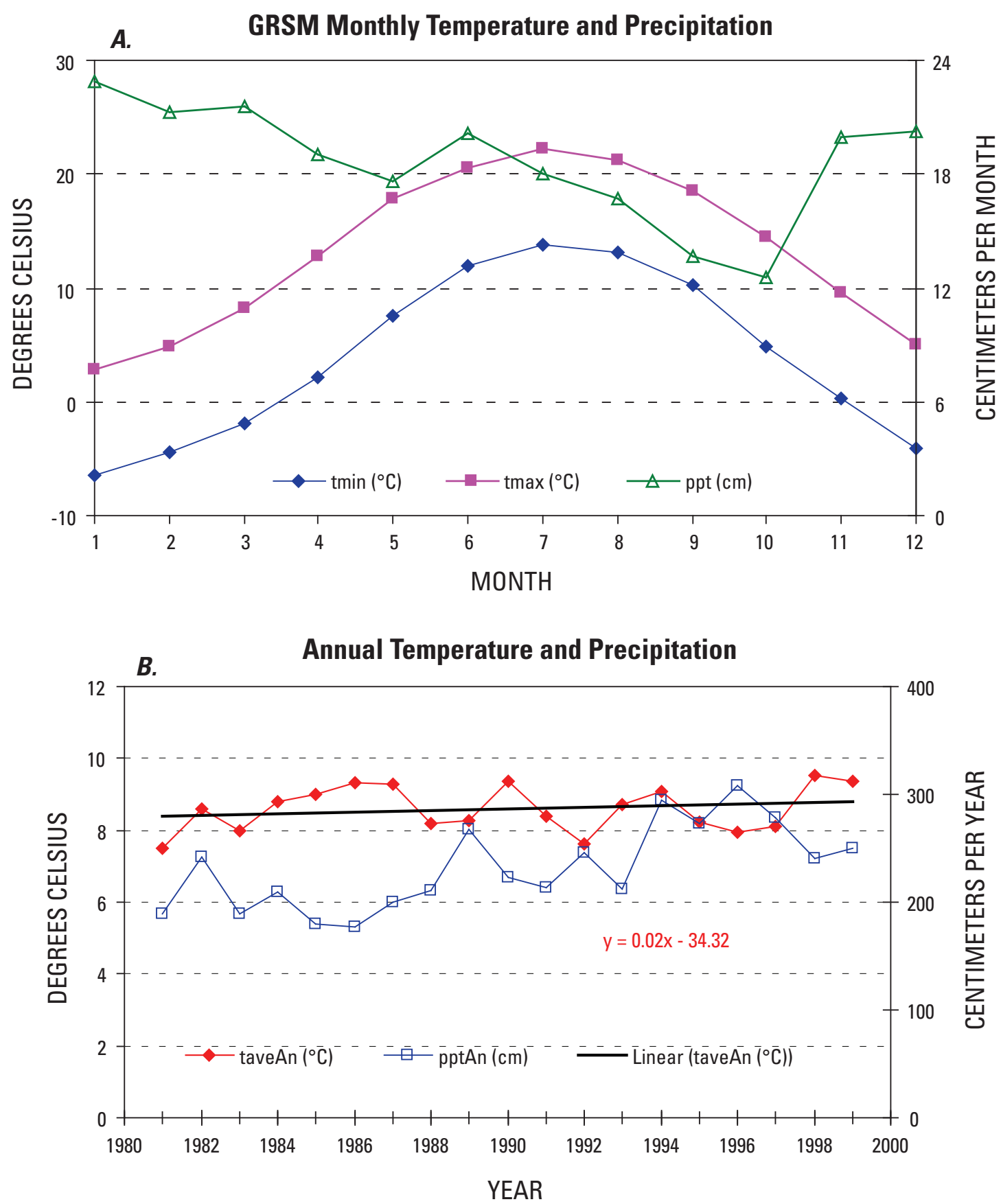

Figure 5.2. Meteorological statistics for the weather station at Newfound Gap (elevation 1,540 $\mathrm{m}), 7 \mathrm{~km}$ to the northeast of Noland Divide in Great Smoky Mountains National Park (GRSM). $A$, Average monthly minimum air temperatures (tmin), maximum air temperatures (tmax), and precipitation (ppt), years 1981-1999. $B$, The time series of mean annual temperature (taveAn) and annual precipitation (pptAn), years 1981-1999. Mean annual temperature showed an increase of $0.02{ }^{\circ} \mathrm{C}^{-1}$. 


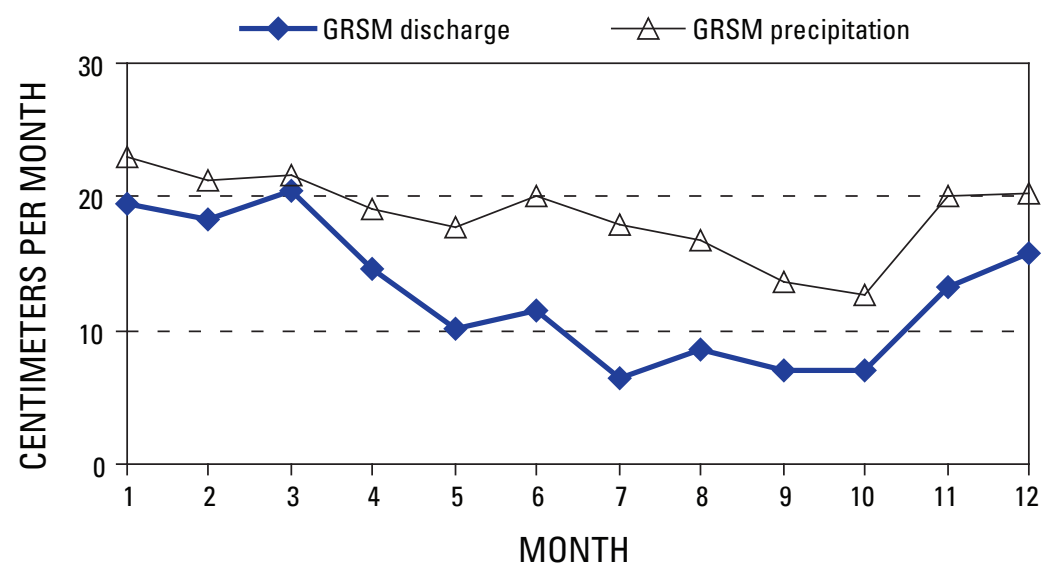

Figure 5.3. Relationship between average monthly precipitation (1981-1999) and discharge for the northeast weir (1992-1999) at Noland Divide watershed.

Table 5.2. Average annual wet and dry plus fog deposition inputs $\left(\mathrm{kg} \mathrm{ha}^{-1} \mathrm{yr}^{-1}\right)$ to the model over the 1981-1999 simulation period.

\begin{tabular}{lccr}
\hline & Wet & Dry + Fog & Total \\
\hline $\mathrm{Ca}$ & 3.99 & 7.98 & 11.98 \\
$\mathrm{Cl}$ & 7.39 & 3.70 & 11.09 \\
$\mathrm{~K}$ & 8.30 & 0.00 & 8.30 \\
$\mathrm{Mg}$ & 0.68 & 1.36 & 2.04 \\
$\mathrm{NH}_{4}-\mathrm{N}$ & 4.09 & 6.97 & 11.06 \\
$\mathrm{NO}_{3}-\mathrm{N}$ & 4.59 & 14.91 & 19.49 \\
$\mathrm{Na}$ & 2.67 & 1.33 & 4.00 \\
$\mathrm{SO}_{4}-\mathrm{S}$ & 12.08 & 19.27 & 31.35 \\
\hline
\end{tabular}



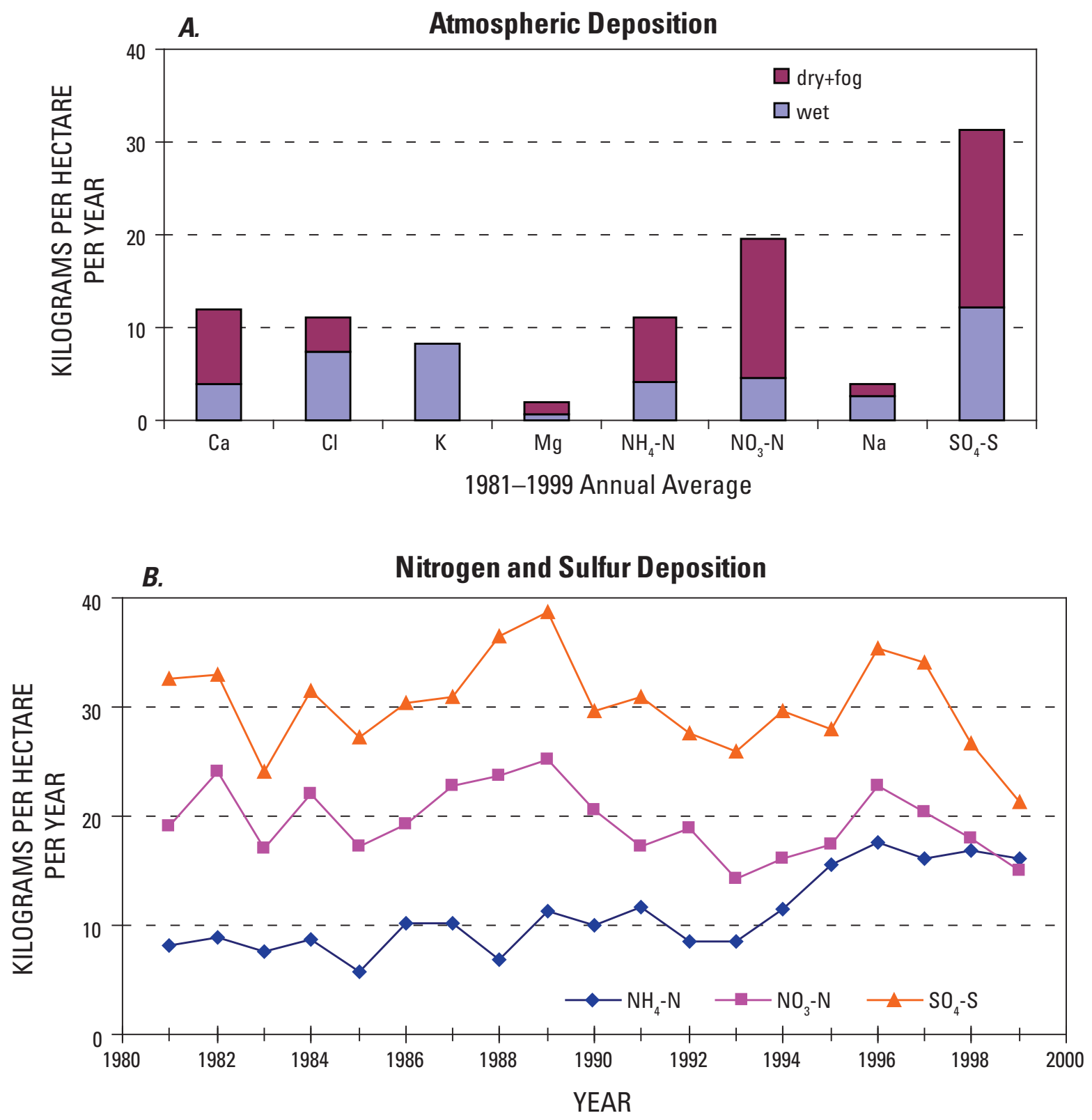

Figure 5.4. Deposition inputs to the model for Noland Divide watershed. $A$, The 1981-1999 average annual wet and dry plus fog deposition. $B$, The time series of $\mathrm{N}$ and $\mathrm{S}$ deposition over the simulation period. 
Table 5.3. Soil layer properties used for the simulation. Ksat is saturated hydraulic conductivity, and the mineral dissolution (Minrl dissoln) fraction is the fraction of total mineral dissolution that occurred in each layer. Wilting point and field capacity are expressed as volumetric soil water content. Exchangeable cations are expressed as milliequivalents per $100 \mathrm{grams}$ of soil (meq/100 g). Soil layer thicknesses were based on the IFS Smokies Tower Plot 1 data (Johnson and Lindberg, 1992). Sand, silt, and clay fractions are characteristic of a silt loam to sandy loam. Ksat was the mean for plots reported by Loscher (2006). Bulk density values were the average of upper and lower elevation values determined from eight intensive plots in NDW (Van Miegroet and others, 2007). Wilting point and field capacity were computed by the model based on soil texture and bulk density. Total soil depth was $55 \mathrm{~cm}$ and organic matter made up the top $21 \mathrm{~cm}$.

\begin{tabular}{|c|c|c|c|c|c|c|c|c|c|}
\hline Layer & $\begin{array}{c}\text { Thickness } \\
\text { cm }\end{array}$ & $\begin{array}{c}\text { Sand } \\
\text { fraction }\end{array}$ & $\begin{array}{c}\text { Silt } \\
\text { fraction }\end{array}$ & $\begin{array}{c}\text { Clay } \\
\text { fraction }\end{array}$ & $\begin{array}{c}\text { Bulk } \\
\text { density } \\
\mathrm{g} \mathrm{cm}^{-3}\end{array}$ & $\begin{array}{c}\text { Wilting } \\
\text { point } \\
\text { fraction }\end{array}$ & $\begin{array}{c}\text { Field } \\
\text { capacity } \\
\text { fraction }\end{array}$ & $\begin{array}{c}\text { Ksat } \\
\mathrm{cm} \mathrm{sec}^{-1}\end{array}$ & $\begin{array}{c}\text { Minrl } \\
\text { dissoln } \\
\text { fraction }\end{array}$ \\
\hline 0 & 4.0 & 0.50 & 0.40 & 0.10 & 1.0 & 0.078 & 0.241 & 0.0105 & 0.2 \\
\hline 1 & 5.0 & 0.50 & 0.40 & 0.10 & 1.0 & 0.078 & 0.241 & 0.0105 & 0.2 \\
\hline 2 & 12.0 & 0.50 & 0.40 & 0.10 & 1.1 & 0.078 & 0.241 & 0.0105 & 0.2 \\
\hline 3 & 17.0 & 0.50 & 0.40 & 0.10 & 1.1 & 0.078 & 0.241 & 0.0105 & 0.2 \\
\hline Layer & $\begin{array}{c}\mathrm{CaX}_{2} \\
\mathrm{meq} / 100 \mathrm{~g}\end{array}$ & $\begin{array}{c}\mathrm{MgX}_{2} \\
\mathrm{meq} / 100 \mathrm{~g}\end{array}$ & $\begin{array}{c}\mathrm{KX} \\
\mathrm{meq} / 100 \mathrm{~g}\end{array}$ & $\begin{array}{c}\mathrm{NaX} \\
\mathrm{meq} / 100 \mathrm{~g}\end{array}$ & $\begin{array}{c}\mathrm{AlOHX}_{2} \\
\mathrm{meq} / 100 \mathrm{~g}\end{array}$ & $\begin{array}{c}\mathrm{AlX}_{3} \\
\mathrm{meq} / 100 \mathrm{~g}\end{array}$ & $\begin{array}{c}\mathrm{FeX}_{2} \\
\mathrm{meq} / 100 \mathrm{~g}\end{array}$ & $\begin{array}{c}\mathrm{HX} \\
\mathrm{meq} / 100 \mathrm{~g}\end{array}$ & $\begin{array}{c}\mathrm{NH}_{4} \mathrm{X} \\
\mathrm{meq} / 100 \mathrm{~g}\end{array}$ \\
\hline 0 & 1.0 & 0.5 & 0.2 & 0.1 & 0.0 & 0.0 & 0.0 & 0.0 & 16.6 \\
\hline 1 & 0.9 & 0.4 & 0.1 & 0.0 & 0.0 & 14.0 & 0.0 & 1.2 & 1.6 \\
\hline
\end{tabular}

meteorological and atmospheric deposition records were available to drive the model. The initial values of the state variables for the 1981-1999 simulation were sensitive to deposition inputs of the spin-up run. For simulation years 1501-1900, we input background $\mathrm{N}$ and $\mathrm{S}$ deposition amounts $\left(0.1 \mathrm{~g} \mathrm{~m}^{-2}\right.$ $\mathrm{yr}^{-1}$ ) to the model. Then, for simulation years 1901-1980, we ramped up $\mathrm{N}$ and $\mathrm{S}$ deposition inputs exponentially until they reached 1981 values.

To parameterize the model for Noland Divide, we first tuned vegetation and soil parameters until simulated ecological variables were close to observations. We then compared measured stream chemistry and discharge measured at the northeast weir at Noland Divide against model results. The northeast weir at Noland Divide collects flow from the full upper to lower reaches of the watershed, whereas the southwest weir collects flow from a small portion of the lower watershed. Data from years 1992-1996 were used to calibrate the model. Model output for years 1997-1999 were emergent from the resulting model parameterization. We show two 3-year periods of daily discharge and chemistry. Results from years 1993-1995 include a range of moisture conditions (figs. 5.2B, 5.5) and will be examined (when possible) for all sites in an intersite model comparison. Years 1997-1999 showed average or slightly above average precipitation (figs. 5.2B, 5.6).

To compute discharge volume $\left(\mathrm{cm} \mathrm{day}^{-1}\right)$ from discharge measurements (cfs) from the northeast weir, we used a watershed area of 12.98 ha, based on a manual delineation of the
Table 5.4. Mineral weathering rates as determined by calibration. All minerals were allowed only to dissolve except gibbsite and kaolinite, which were allowed to both precipitate and dissolve.

\begin{tabular}{|c|c|c|}
\hline $\begin{array}{c}\text { Mineral } \\
\text { phases }\end{array}$ & $\mathrm{mol} \mathrm{m}^{-2} \mathrm{yr}^{-1}$ & $\begin{array}{c}1 \text { = dissolve, } \\
0=\text { precipitate } \\
\text { or dissolve }\end{array}$ \\
\hline Albite & 0.019 & 1 \\
\hline Anorthite & 0.009 & 1 \\
\hline Biotite & 0.010 & 1 \\
\hline Gibbsite & 0 & 0 \\
\hline Kaolinite & 0 & 0 \\
\hline
\end{tabular}

northeast basin that excludes the portion watershed area that feeds the diversion (Loscher, 2006).

\section{Model Output}

\section{Ecological Variables}

There have been many measurements of vegetation and ecosystem fluxes at Noland Divide and other parts of GRSM, and the model results were close to some of them (table 5.5). In general, the model showed greater NPP and NEP than 


\section{Daily Discharge}

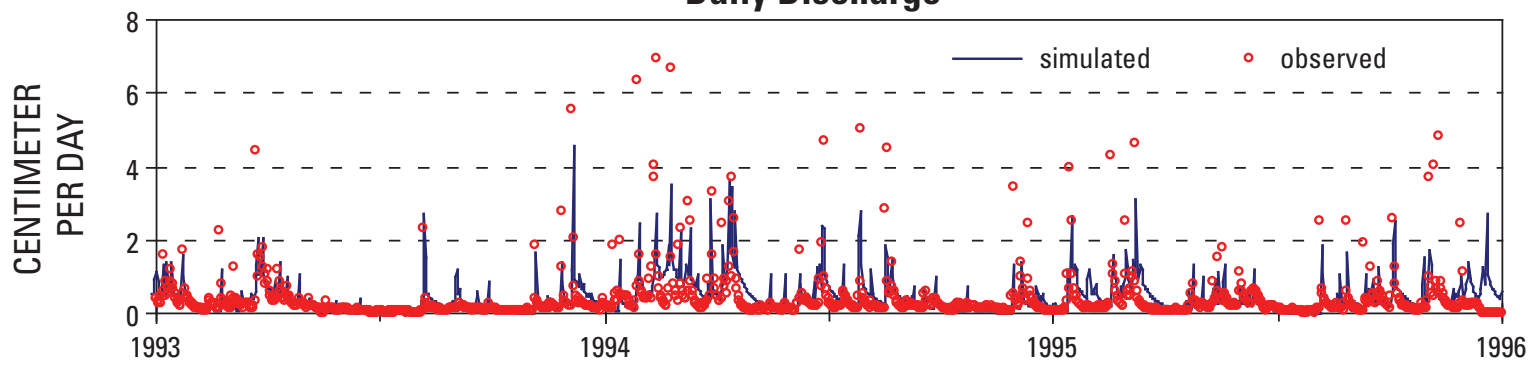

Stream Chemistry
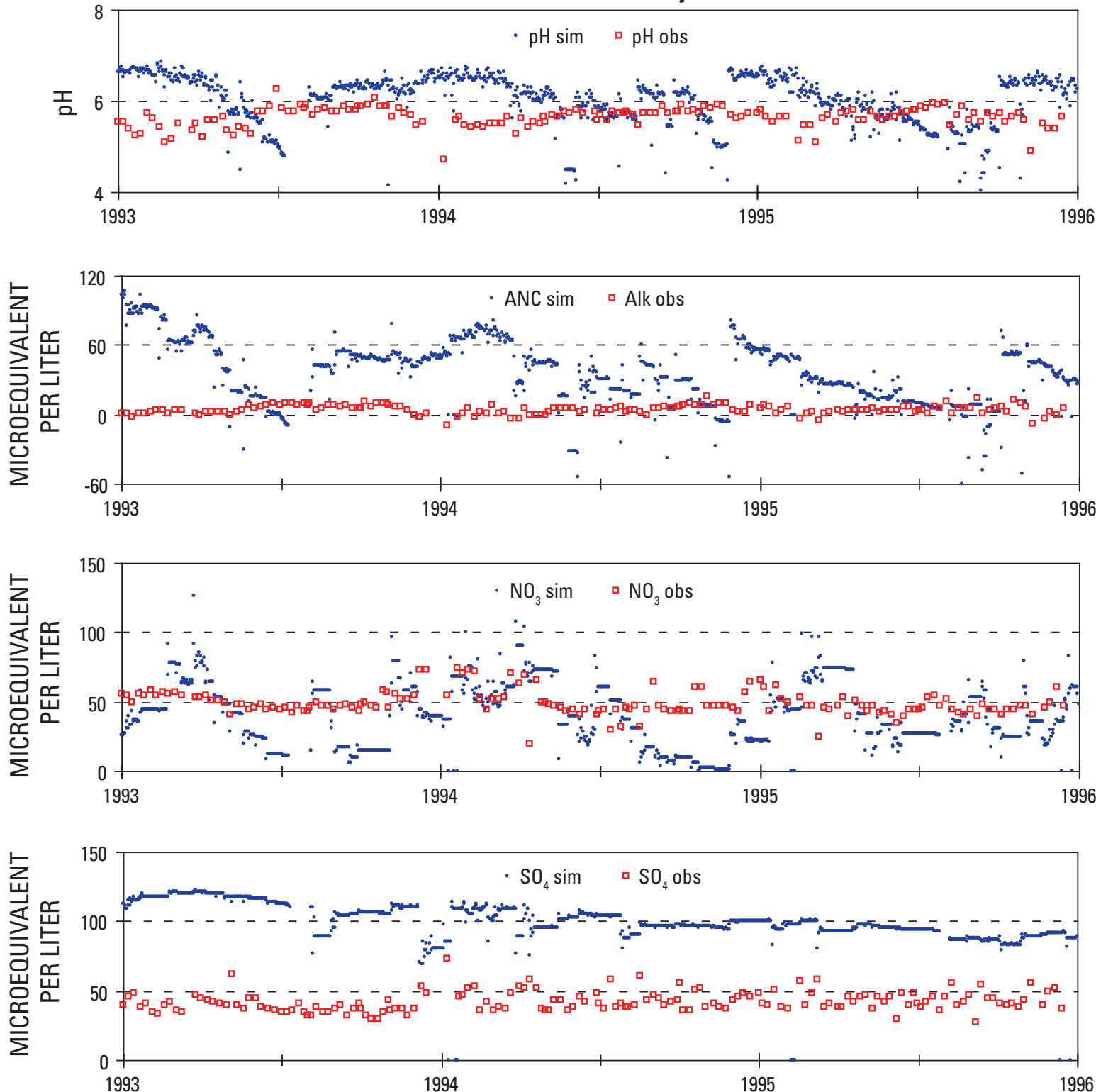

Figure 5.5. Simulated (sim) and observed (obs) daily discharge and stream chemistry for Noland Divide watershed, years 1993-1995 (x axis). Simulated concentrations are not shown for days when simulated discharge was extremely low $\left(<0.01 \mathrm{~cm} \mathrm{day}^{-1}\right)$. Measured DOC was not available. 

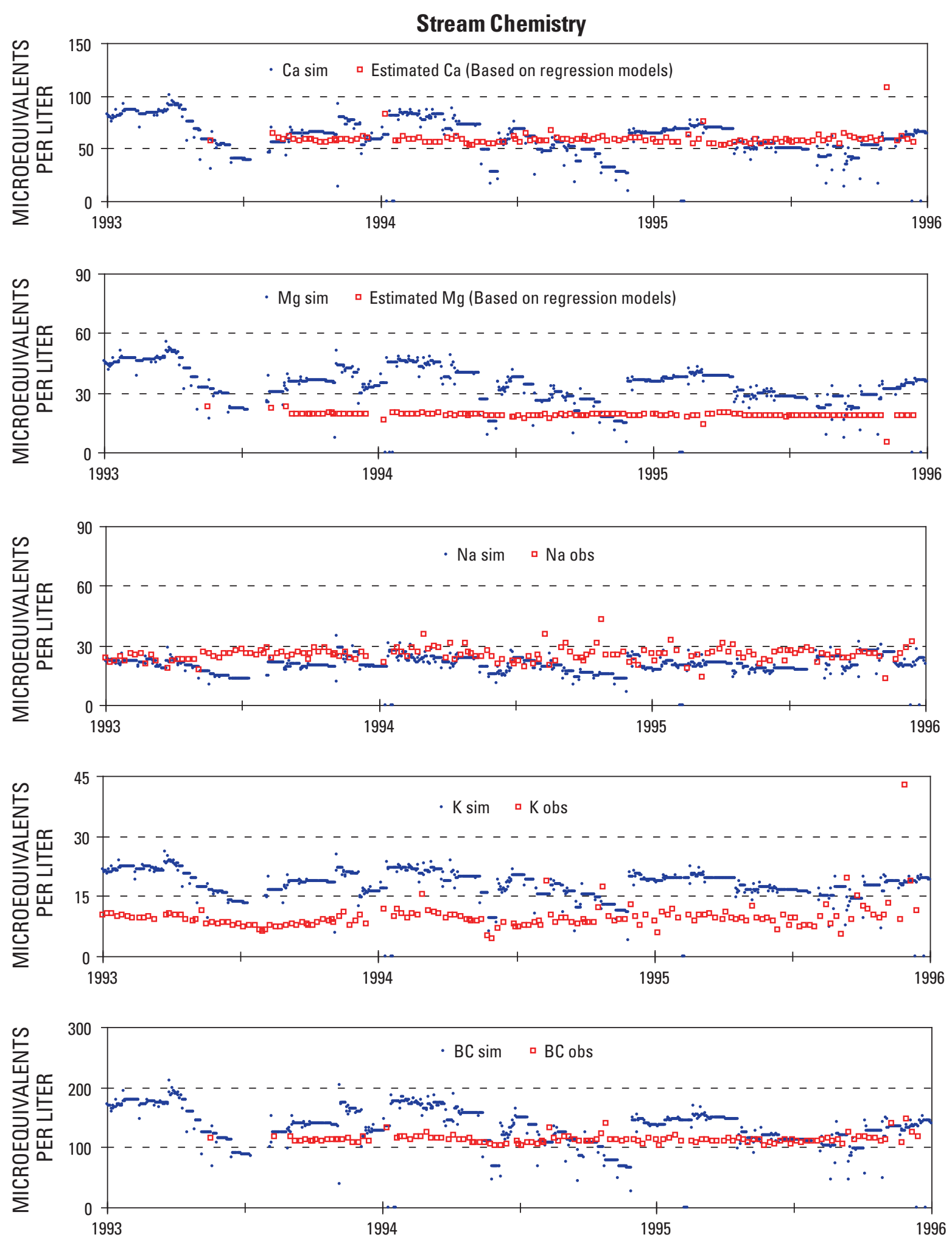

Figure 5.5. Simulated (sim) and observed (obs) daily discharge and stream chemistry for Noland Divide watershed, years 1993-1995 (x axis). Simulated concentrations are not shown for days when simulated discharge was extremely low $\left(<0.01 \mathrm{~cm} \mathrm{day}^{-1}\right)$. Measured DOC was not available.-Continued 

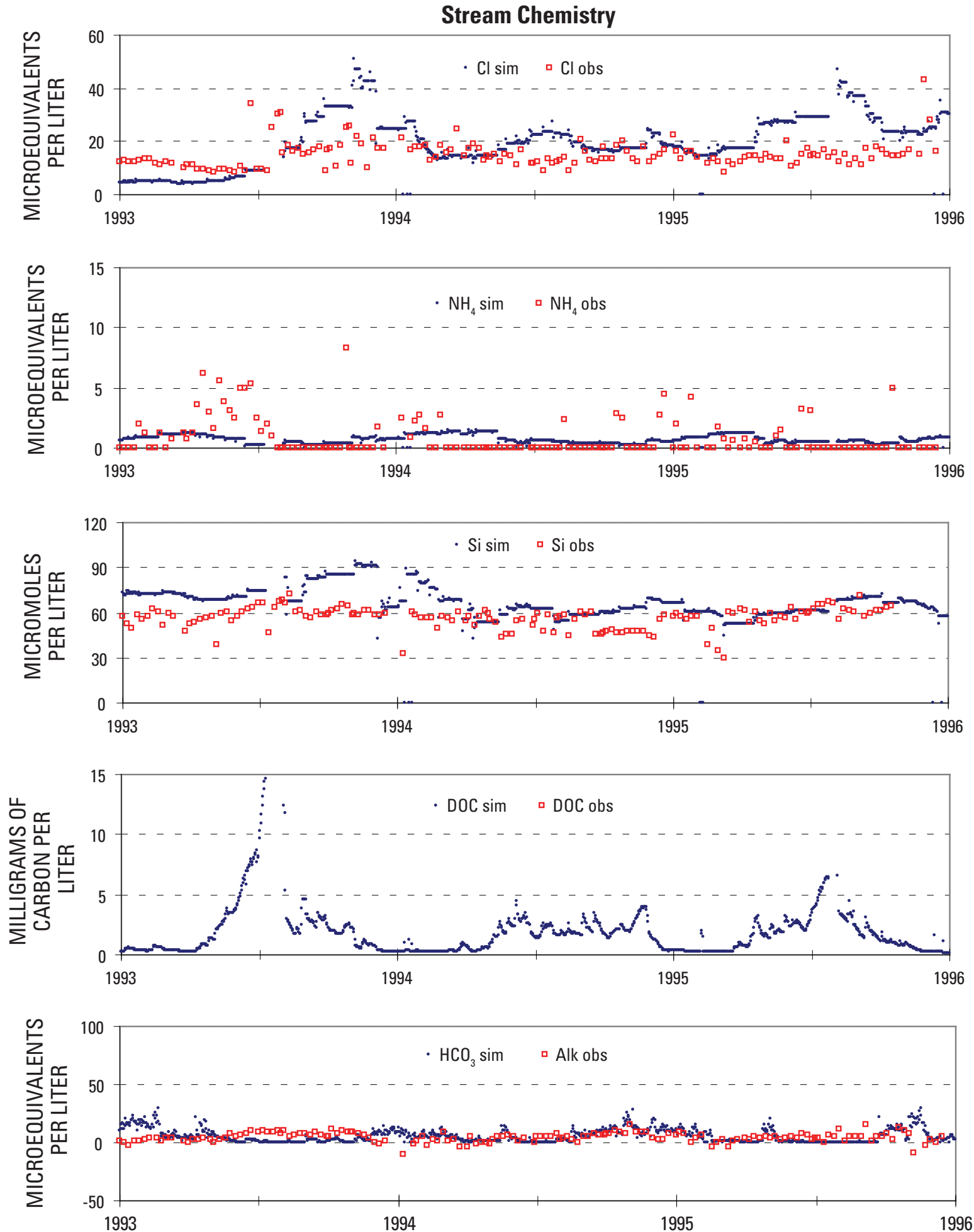

Figure 5.5. Simulated (sim) and observed (obs) daily discharge and stream chemistry for Noland Divide watershed, years 1993-1995 (x axis). Simulated concentrations are not shown for days when simulated discharge was extremely low $\left(<0.01 \mathrm{~cm} \mathrm{day}^{-1}\right)$. Measured DOC was not available.-Continued 

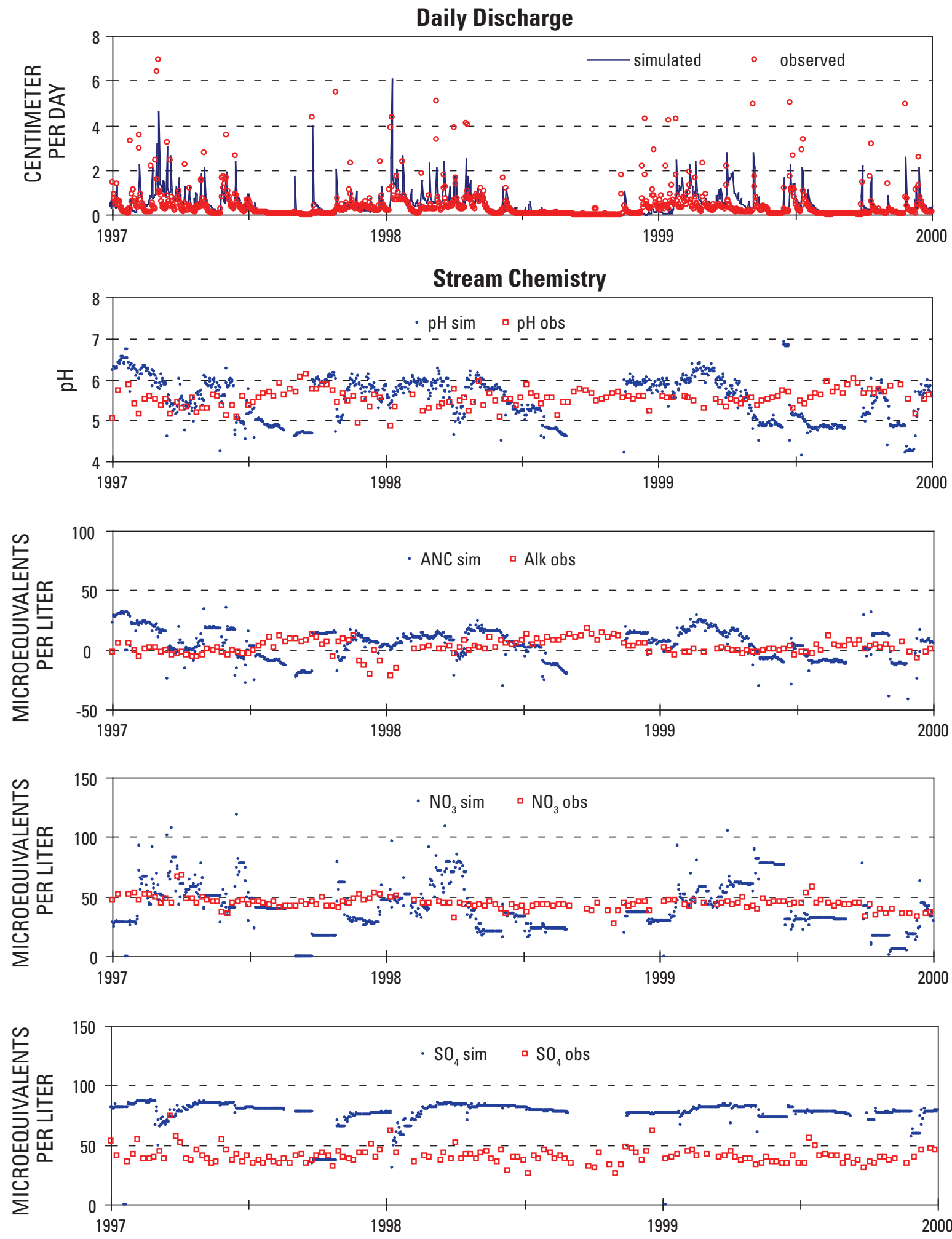

Figure 5.6. Simulated (sim) and observed (obs) daily discharge and stream chemistry for Noland Divide watershed, years 1997-1999 (x axis). Simulated concentrations are not shown for days when simulated discharge was extremely low (less than $0.01 \mathrm{~cm} \mathrm{day}^{-1}$ ). Measured DOC and Si were not available. 

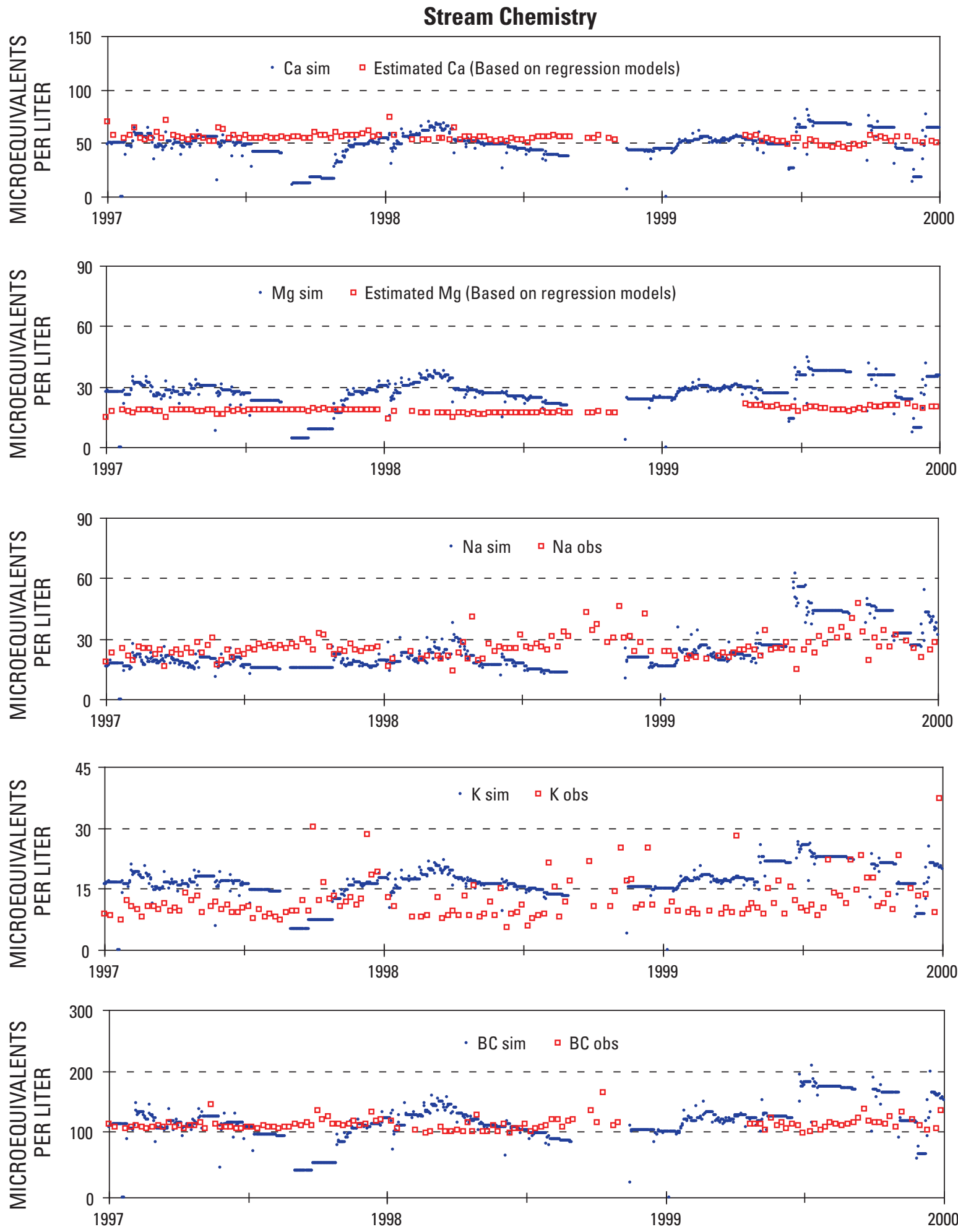

Figure 5.6. Simulated (sim) and observed (obs) daily discharge and stream chemistry for Noland Divide watershed, years 1997-1999 (x axis). Simulated concentrations are not shown for days when simulated discharge was extremely low (less than $0.01 \mathrm{~cm}^{\text {day }}{ }^{-1}$ ). Measured DOC and Si were not available.-Continued 

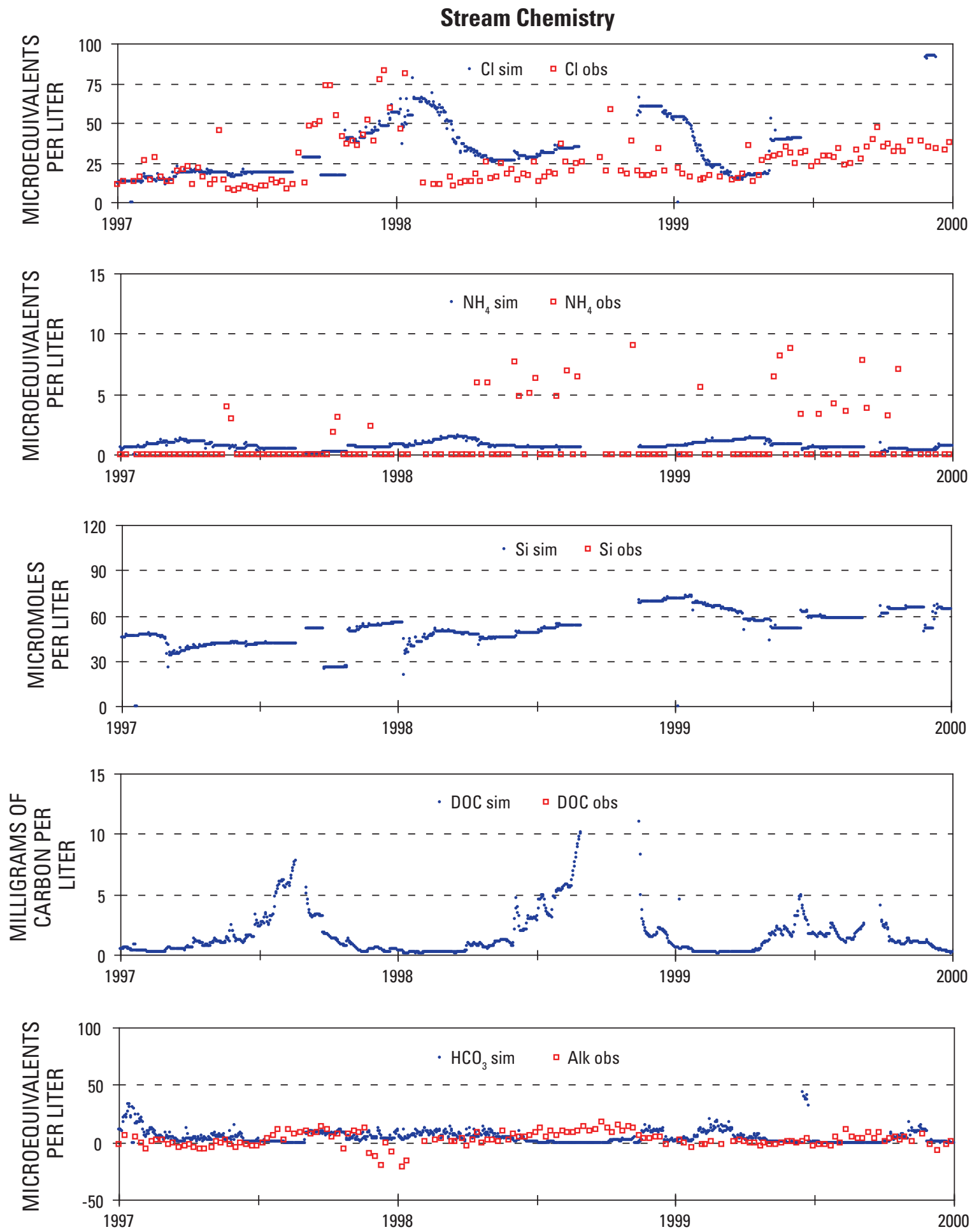

Figure 5.6. Simulated (sim) and observed (obs) daily discharge and stream chemistry for Noland Divide watershed, years 1997-1999 (x axis). Simulated concentrations are not shown for days when simulated discharge was extremely low (less than $0.01 \mathrm{~cm}^{-19 y^{-1}}$ ). Measured DOC and Si were not available.-Continued 
measured values showed, but soil organic carbon and plant biomass values were similar. The model also showed greater plant biomass $\mathrm{N}$, but less $\mathrm{N}$ in soil organic matter (SOM) and forest floor litter than measured values and less ecosystem $\mathrm{N}$ overall.

DayCent-Chem's prediction of overstory NPP, 461 (std. dev. 61) $\mathrm{g} \mathrm{C} \mathrm{m}^{-2} \mathrm{yr}^{-1}$, was greater than values measured at the lower and upper elevations of NDW, 263.7 (std. dev. 67.2) and 259.0 (std. dev. 91.7) g C m${ }^{-2} \mathrm{yr}^{-1}$, respectively (Van Miegroet and others, 2007). Similarly, the model's predicted NEP, which was NPP minus $\mathrm{C}$ flux from decomposition, was greater and opposite in sign compared to the ecosystem $\mathrm{C}$ balance measured at the lower and upper elevations of NDW, -56.5 and $-39.2 \mathrm{~g} \mathrm{C} \mathrm{m}^{-2} \mathrm{yr}^{-1}$, respectively (Van Miegroet and others, 2007). The model predicted much greater soil $\mathrm{C}$ flux than was measured at NDW (621 vs. $120-183 \mathrm{~g} \mathrm{C} \mathrm{m}^{-2} \mathrm{yr}^{-1}$ ), but much less $\mathrm{C}$ loss from decomposition than was measured (31 vs. 156.4 and $160.9 \mathrm{~g} \mathrm{C} \mathrm{m}^{-2} \mathrm{yr}^{-1}$ for the lower and upper elevations of NDW, respectively; table 5.5).

Simulated total ecosystem biomass, 41,707 (std. dev. 239) $\mathrm{g} \mathrm{C} \mathrm{m}^{-2}$, was very close to measured values from NDW that ranged from 37,000 to $41,900 \mathrm{~g} \mathrm{C} \mathrm{m}^{-2}$ (table 5.5). Simulated tree overstory biomass, 16,494 (std. dev. 655) g C m ${ }^{-2}$, was also within the range of measured values from NDW, 9,773-17,500 g C m${ }^{-2}$. Overall, model results for leaf biomass and root biomass were within the range of measured values, fine branch biomass was underestimated, and large wood biomass was overestimated. Simulated dead standing and downed wood, 9,728 (std. dev. 698) g C m${ }^{-2}$, was within the range of measured values, 9,068-24,100 g C m².

According to measured values, understory biomass (including woody and herbaceous plants) was $2-5$ percent of total plant biomass. The model cannot simulate two woody species simultaneously, therefore it could not simulate a woody understory, and it simulated only a small herbaceous understory. The model's estimate of above-ground herbaceous understory biomass, $7 \mathrm{~g} \mathrm{C} \mathrm{m}^{-2}$, was much lower than measured values, 103 and $134 \mathrm{~g} \mathrm{C} \mathrm{m}^{-2}$ for lower and upper NDW, respectively (Van Miegroet and others, 2007).

The model's estimate of above-ground litterfall, 189 (std. dev. 9) $\mathrm{g} \mathrm{C} \mathrm{m}^{-2} \mathrm{yr}^{-1}$, was within range of measured values, 78.7-240.7 $\mathrm{g} \mathrm{C} \mathrm{m}^{-2} \mathrm{yr}^{-1}$, but estimates of accumulated litter and SOM were generally low (table 5.5). Simulated aboveground litter biomass, 1,087 (std. dev. 27) g C m${ }^{-2}$, was lower than measured values, $1,820-3,590 \mathrm{~g} \mathrm{C} \mathrm{m}^{-2}$, and simulated SOM, 11,746 (162) g C m${ }^{-2}$, was on the low end of measured values, 9,058-24,100 g C m${ }^{-2}$.

Despite high $\mathrm{N}$ deposition (3.1 $\left.\mathrm{g} \mathrm{N} \mathrm{m}^{-2} \mathrm{yr}^{-1}\right)$ and a history of chronic $\mathrm{N}$ deposition, the model suggested that GRSM retained 57 percent of atmospheric $\mathrm{N}$ inputs plus internally fixed $\mathrm{N}$, though no measurement of $\mathrm{N}$ retention was available to verify this estimate. Dissolved organic nitrogen (DON) accounted for 7 percent of stream $\mathrm{N}$ export and $\mathrm{NO}_{3}-\mathrm{N}$ accounted for 92 percent. High rainfall and moderate temperatures at NDW could favor $\mathrm{N}$ gas loss by nitrification and denitrification, but the actual amount of gaseous $\mathrm{N}$ loss that occurs there is uncertain. The model predicted that $0.13 \mathrm{~g} \mathrm{~N}$ $\mathrm{m}^{-2} \mathrm{yr}^{-1}$ was volatilized in soils, but this estimate could be low. Barton and others (1999) reported a loss of $0.24 \mathrm{~g} \mathrm{~N} \mathrm{~m}^{-2}$ $\mathrm{yr}^{-1}$ from disturbed coniferous forest. Instream denitrification at NDW may be small. Martin and others (2001) reported a denitrification potential of $4.38 \mathrm{~kg} \mathrm{yr}^{-1}\left(0.025 \mathrm{~g} \mathrm{~N} \mathrm{~m}^{-2} \mathrm{yr}^{-1}\right)$ from stream sediments at NDW, which equates to about 1.5 percent of stream $\mathrm{N}$ export. According to measured values (Johnson and Lindberg, 1992; Pauley and others, 1996), the majority of ecosystem N at NDW was stored in forest floor litter and SOM, whereas the model showed a greater proportion of $\mathrm{N}$ in plant biomass (table 5.5). Additionally, simulated ecosystem N, 638 (std. dev. 9) g N m${ }^{-2}$, was much less than the range determined during the IFS study, 929.0-1,173.1 $\mathrm{g} \mathrm{N} \mathrm{m}^{-2}$ (Johnson and Lindberg, 1992). Simulated leaf N, 17 (std. dev. $0.5) \mathrm{g} \mathrm{N} \mathrm{m}^{-2}$, was higher than measured values, $8.3-15.9 \mathrm{~g} \mathrm{~N}$ $\mathrm{m}^{-2}$. Although simulated fine branch $\mathrm{N}, 4.3$ (std. dev. 0.2) g N $\mathrm{m}^{-2}$, was close to measured values, $4.7-5.5 \mathrm{~g} \mathrm{~N} \mathrm{~m}^{-2}$, simulated large wood N, 58.9 (2.3 std. dev.) g $\mathrm{N} \mathrm{m}^{-2}$, was several times greater than measured values, $13.8-16.3 \mathrm{~g} \mathrm{~N} \mathrm{~m}^{-2}$. Simulated above-ground tree biomass, 79.6 (std. dev. 2.0) $\mathrm{g} \mathrm{N} \mathrm{m}^{-2}$, was two to three times the measured values, $26.8-37.5 \mathrm{~g} \mathrm{~N} \mathrm{~m}^{-2}$. Simulated live plus dead root biomass, 26.8 (std. dev. 1.0) g N $\mathrm{m}^{-2}$, was greater than measured values, 11.0 and $22.0 \mathrm{~g} \mathrm{~N} \mathrm{~m}^{-2}$ (Johnson and Lindberg, 1992). Simulated soil organic matter $\mathrm{N}, 471.8$ (std. dev. 7.2) g N m${ }^{-2}$, was 52-65 percent of measured values, 723.7 and $904 \mathrm{~g} \mathrm{~N} \mathrm{~m}^{-2}$ (Johnson and Lindberg, 1992). Simulated forest floor litter, 24.6 (std. dev. 0.5) g N $\mathrm{m}^{-2}$, was a magnitude smaller than $\mathrm{N}$ measured in the forest $\mathrm{O}$ horizon, 144 and $208 \mathrm{~g} \mathrm{~N} \mathrm{~m}^{-2}$ (Johnson and Lindberg, 1992).

\section{Discharge}

The model reproduced daily discharge most of the year but periodically missed some of the higher flows (figs. 5.5, 5.6). The $\mathrm{R}^{2}$ correlation between measured and modeled discharge was 0.38 . Mean annual simulated discharge was within 5 percent of mean annual observed discharge (table 5.6). The discrepancy between model predictions and observations could be due, in part, to the road cut and diversion in the watershed or to the distance between the watershed and weather station.

\section{Stream Chemistry}

\section{Nitrate and Ammonium}

Measured stream $\mathrm{NO}_{3}$ concentrations reached $75 \mu \mathrm{eq} \mathrm{L}-1$ and were frequently over $40 \mu \mathrm{eq} \mathrm{L}^{-1}$, even during the growing season. Simulated daily $\mathrm{NO}_{3}$ concentrations had a wider range of values than were measured because the model was more sensitive to soil flushing events (figs. 5.5, 5.6). The model showed the greatest $\mathrm{NO}_{3}$ concentrations when discharge was high in the early spring and the lowest $\mathrm{NO}_{3}$ concentrations 
Table 5.5. Simulated (1981-1999) and measured ecological variables and input/output fluxes. Standard deviations are shown in parentheses and represent interannual variation for annual fluxes and monthly variations for state variables. NPP = net primary production; CWD = above-ground coarse woody debris; $\mathrm{Rh}=$ heterotrophic respiration; NEP = net ecosystem production (NPP - Rh); $\mathrm{PET}$ = potential evapotranspiration; $\mathrm{AET}=$ actual evapotranspiration; $\mathrm{DOC}=$ dissolved organic carbon. To convert units reported by data sources, it was assumed that 2.25 grams biomass equals 1 gram $C$.

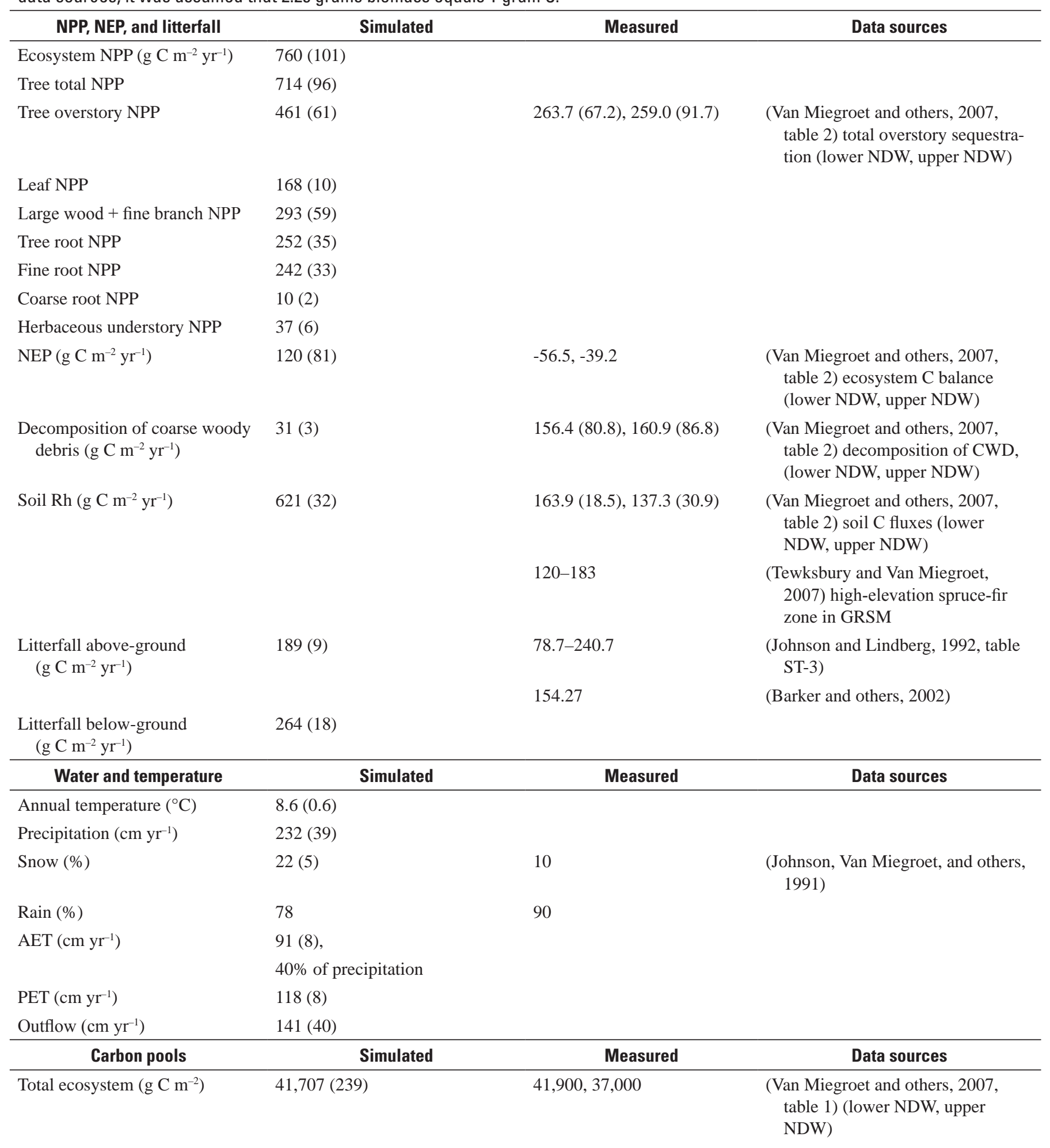


Table 5.5. Simulated (1981-1999) and measured ecological variables and input/output fluxes. Standard deviations are shown in parentheses and represent interannual variation for annual fluxes and monthly variations for state variables. NPP = net primary production; CWD = above-ground coarse woody debris; $\mathrm{Rh}$ = heterotrophic respiration; NEP = net ecosystem production (NPP - Rh); $\mathrm{PET}=$ potential evapotranspiration; $\mathrm{AET}=$ actual evapotranspiration; $\mathrm{DOC}=$ dissolved organic carbon. To convert units reported by data sources, it was assumed that 2.25 grams biomass equals 1 gram C.-Continued

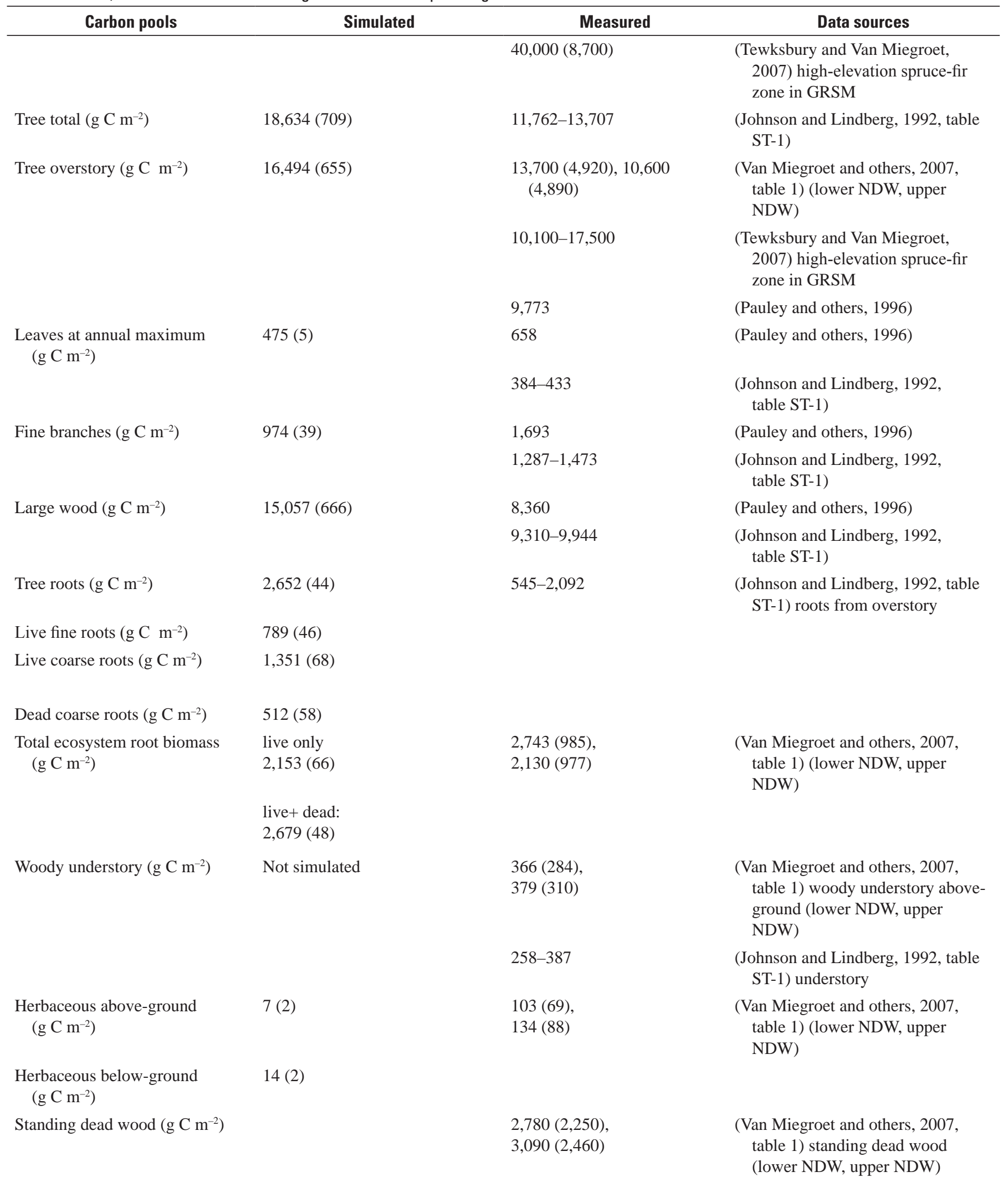


Table 5.5. Simulated (1981-1999) and measured ecological variables and input/output fluxes. Standard deviations are shown in parentheses and represent interannual variation for annual fluxes and monthly variations for state variables. NPP = net primary production; CWD = above-ground coarse woody debris; $\mathrm{Rh}=$ heterotrophic respiration; NEP = net ecosystem production (NPP - Rh); $\mathrm{PET}$ = potential evapotranspiration; $\mathrm{AET}=$ actual evapotranspiration; $\mathrm{DOC}=$ dissolved organic carbon. To convert units reported by data sources, it was assumed that 2.25 grams biomass equals 1 gram C. - Continued

\begin{tabular}{|c|c|c|c|}
\hline Carbon pools & Simulated & Measured & Data sources \\
\hline \multirow[t]{2}{*}{$\begin{array}{l}\text { Standing dead wood + downed } \\
\quad \text { wood }\left(\mathrm{g} \mathrm{C} \mathrm{m}^{-2}\right)\end{array}$} & \multirow[t]{2}{*}{$9,728(698)$} & $\begin{array}{l}5,800 \\
6,840\end{array}$ & $\begin{array}{l}\text { Van Miegroet and others, 2007) } \\
\text { stand dead + downed wood (lower } \\
\text { NDW, upper NDW) }\end{array}$ \\
\hline & & 724-889 & $\begin{array}{l}\text { (Johnson and Lindberg, 1992, } \\
\text { table ST-1) }\end{array}$ \\
\hline \multirow[t]{2}{*}{ Soil organic matter $\left(\mathrm{g} \mathrm{C} \mathrm{m}^{-2}\right)$} & \multirow[t]{2}{*}{$11,746(162)$} & $\begin{array}{l}19,100(4,620), 16,800 \\
\quad(4,000)\end{array}$ & $\begin{array}{l}\text { (Van Miegroet and others, } 2007 \text {, } \\
\text { table 1) total soil C (lower NDW, } \\
\text { upper NDW) }\end{array}$ \\
\hline & & $9,068-13,294$ & $\begin{array}{l}\text { (Johnson and Lindberg, 1992, table } \\
\text { ST-1) }\end{array}$ \\
\hline \multirow[t]{2}{*}{$\begin{array}{l}\text { Total above-ground litter } \\
\qquad\left(\mathrm{g} \mathrm{C} \mathrm{m}^{-2}\right)\end{array}$} & \multirow[t]{2}{*}{$1,087(27)$} & $\begin{array}{l}2,160(678) \\
1,820(513)\end{array}$ & $\begin{array}{l}\text { (Van Miegroet and others, 2007, } \\
\text { table 1, forest floor (O) (lower } \\
\text { NDW, upper NDW) }\end{array}$ \\
\hline & & $1,630-3,590$ & $\begin{array}{l}\text { (Tewksbury and Van Miegroet, } \\
\text { 2007) high-elevation spruce-fir } \\
\text { zone in GRSM }\end{array}$ \\
\hline Nitrogen pools & Simulated & Measured & Data sources \\
\hline \multirow[t]{2}{*}{ Fine branches ( $\mathrm{g} \mathrm{N} \mathrm{m}^{-2}$ ) } & \multirow[t]{2}{*}{$4.3(0.2)$} & $4.7-5.5$ & (Johnson and Lindberg, 1992) \\
\hline & & 5.4 & (Pauley and others, 1996) \\
\hline \multirow[t]{2}{*}{ Large wood ( $\mathrm{g} \mathrm{N} \mathrm{m}^{-2}$ ) } & \multirow[t]{2}{*}{$58.6(2.3)$} & $13.8-15.4$ & (Johnson and Lindberg, 1992) \\
\hline & & 16.3 & (Pauley and others, 1996) \\
\hline Tree roots $\left(\mathrm{g} \mathrm{N} \mathrm{m}^{-2}\right.$ ) & $26.8(1.1)$ & $11.0-22.0$ & $\begin{array}{l}\text { (Johnson and Lindberg, 1992, table } \\
\text { ST-1) roots from overstory }\end{array}$ \\
\hline Live fine roots $\left(\mathrm{g} \mathrm{N} \mathrm{m}^{-2}\right)$ & $16.1(1.1)$ & & \\
\hline Live coarse roots $\left(\mathrm{g} \mathrm{N} \mathrm{m}^{-2}\right.$ ) & $7.7(0.4)$ & & \\
\hline Dead coarse roots $\left(\mathrm{g} \mathrm{N} \mathrm{m}^{-2}\right.$ ) & $3.0(0.3)$ & & \\
\hline Herbaceous shoots $\left(\mathrm{g} \mathrm{N} \mathrm{m}^{-2}\right.$ ) & $0.4(0.1)$ & & \\
\hline Herbaceous fine roots $\left(\mathrm{g} \mathrm{N} \mathrm{m}^{-2}\right)$ & $0.2(0.0)$ & & \\
\hline Coarse woody debris $\left(\mathrm{g} \mathrm{N} \mathrm{m}^{-2}\right.$ ) & $38.0(3.6)$ & & \\
\hline
\end{tabular}


Table 5.5. Simulated (1981-1999) and measured ecological variables and input/output fluxes. Standard deviations are shown in parentheses and represent interannual variation for annual fluxes and monthly variations for state variables. NPP = net primary production; CWD = above-ground coarse woody debris; Rh = heterotrophic respiration; NEP = net ecosystem production (NPP - Rh); $\mathrm{PET}=$ potential evapotranspiration; $\mathrm{AET}=$ actual evapotranspiration; $\mathrm{DOC}=$ dissolved organic carbon. To convert units reported by data sources, it was assumed that 2.25 grams biomass equals 1 gram C.-Continued

\begin{tabular}{|c|c|c|c|}
\hline Nitrogen pools & Simulated & Measured & Data sources \\
\hline Soil organic matter ( $\mathrm{g} \mathrm{N} \mathrm{m}^{-2}$ ) & $471.8(7.2)$ & & \\
\hline N,P,S inputs & Simulated & Measured & Data sources \\
\hline \multirow[t]{2}{*}{$\mathrm{N}$ deposition ( $\mathrm{g} \mathrm{N} \mathrm{m}^{-2} \mathrm{yr}^{-1}$ ) } & $3.06(0.46)$ & 2.8 & (Barker and others, 2002) \\
\hline & $\begin{array}{l}1993-1997: \\
3.20(0.69)\end{array}$ & $\begin{array}{l}\text { 1993-1997: } \\
3.22\end{array}$ & (Van Miegroet and others, 2001) \\
\hline Wet & 0.87 & & NADP site TN11, NDW Open Site \\
\hline Dry + fog & 2.19 & & (Van Miegroet and others, 2001) \\
\hline $\mathrm{S}$ deposition ( $\mathrm{g} \mathrm{S} \mathrm{m}^{-2} \mathrm{yr}^{-1}$ ) & $3.02(0.43)$ & & \\
\hline Dry + fog & 1.81 & & \\
\hline $\mathrm{P}$ deposition ( $\mathrm{g} \mathrm{P} \mathrm{m}^{-2} \mathrm{yr}^{-1}$ ) & 0 & & \\
\hline Wet & 0 & & NADP site TN11, NDW Open Site \\
\hline Dry + fog & 0 & & \\
\hline C,N,P,S outputs & Simulated & Measured & Data sources \\
\hline $\mathrm{N}$ export (g N m${ }^{-2} \mathrm{yr}^{-1}$ ) & $1.2(0.4)$ & & \\
\hline \multirow[t]{2}{*}{ Inorganic } & $1.1(0.4)$ & & \\
\hline & $\begin{array}{l}\text { 1993-1997: } \\
1.3(0.3)\end{array}$ & 1.5 & $\begin{array}{l}\text { (Van Miegroet and others, 2001), } \\
\text { years 1993-1997 }\end{array}$ \\
\hline \multicolumn{4}{|l|}{ Inorganic } \\
\hline \multicolumn{4}{|l|}{ Organic } \\
\hline DOC export ( $\left.\mathrm{g} \mathrm{C} \mathrm{m}^{-2} \mathrm{yr}^{-1}\right)$ & $1.5(0.3)$ & & \\
\hline Trace gas flux $\left(\mathrm{g} \mathrm{N} \mathrm{m}^{-2} \mathrm{yr}^{-1}\right)$ & $0.13(0.02)$ & 0.24 & $\begin{array}{l}\text { (Barton and others, 1999), denitri- } \\
\text { fication in disturbed coniferous } \\
\text { forest }\end{array}$ \\
\hline N,P,S internal fluxes & Simulated & Measured & Data sources \\
\hline $\mathrm{N}$ mineralization $\left(\mathrm{g} \mathrm{N} \mathrm{m}^{-2} \mathrm{yr}^{-1}\right.$ ) & $9.4(1.1)$ & 10.7 & (Joslin and others, 1992, table 5) \\
\hline \multicolumn{4}{|l|}{$\mathrm{P}$ mineralization $\left(\mathrm{g} \mathrm{P} \mathrm{m}^{-2} \mathrm{yr}^{-1}\right)$} \\
\hline S mineralization $\left(\mathrm{g} \mathrm{S} \mathrm{m}^{-2} \mathrm{yr}^{-1}\right.$ ) & $2.6(0.4)$ & & \\
\hline Gross nitrification $\left(\mathrm{g} \mathrm{N} \mathrm{m}^{-2} \mathrm{yr}^{-1}\right)$ & $2.1(0.3)$ & & \\
\hline $\mathrm{N}$ fixation $\left(\mathrm{g} \mathrm{N} \mathrm{m}^{-2} \mathrm{yr}^{-1}\right)$ & $0.01(0.01)$ & & \\
\hline
\end{tabular}


Table 5.5. Simulated (1981-1999) and measured ecological variables and input/output fluxes. Standard deviations are shown in parentheses and represent interannual variation for annual fluxes and monthly variations for state variables. NPP = net primary production; CWD = above-ground coarse woody debris; $\mathrm{Rh}$ = heterotrophic respiration; NEP = net ecosystem production (NPP - Rh); $\mathrm{PET}$ = potential evapotranspiration; $\mathrm{AET}=$ actual evapotranspiration; $\mathrm{DOC}=$ dissolved organic carbon. To convert units reported by data sources, it was assumed that 2.25 grams biomass equals 1 gram C.-Continued

\begin{tabular}{llllr}
\multicolumn{1}{c}{ N,P,S internal fluxes } & \multicolumn{1}{c}{ Simulated } & Measured & Data sources \\
\hline $\mathrm{N}$ uptake $\left(\mathrm{g} \mathrm{N} \mathrm{m}^{-2} \mathrm{yr}^{-1}\right)$ & $10.5(1.2)$ & 0.7 & (Barker and others, 2002), spruce-fir \\
$\mathrm{P}$ uptake $\left(\mathrm{g} \mathrm{P} \mathrm{m}^{-2} \mathrm{yr}^{-1}\right)$ & $1.1(0.1)$ & & \\
$\mathrm{S}$ uptake $\left(\mathrm{g} \mathrm{S} \mathrm{m}^{-2} \mathrm{yr}^{-1}\right)$ & $2.1(0.3)$ & & \\
\hline
\end{tabular}

Table 5.6. Annual volume-weighted mean (VWM) simulated and observed stream chemistry averaged over each year of the simulation. Pmean = predicted mean; Omean = observed mean; $A E=$ absolute error $($ Pmean - Omean); NAE = normalized absolute error (AE/Omean); N/A = not available.

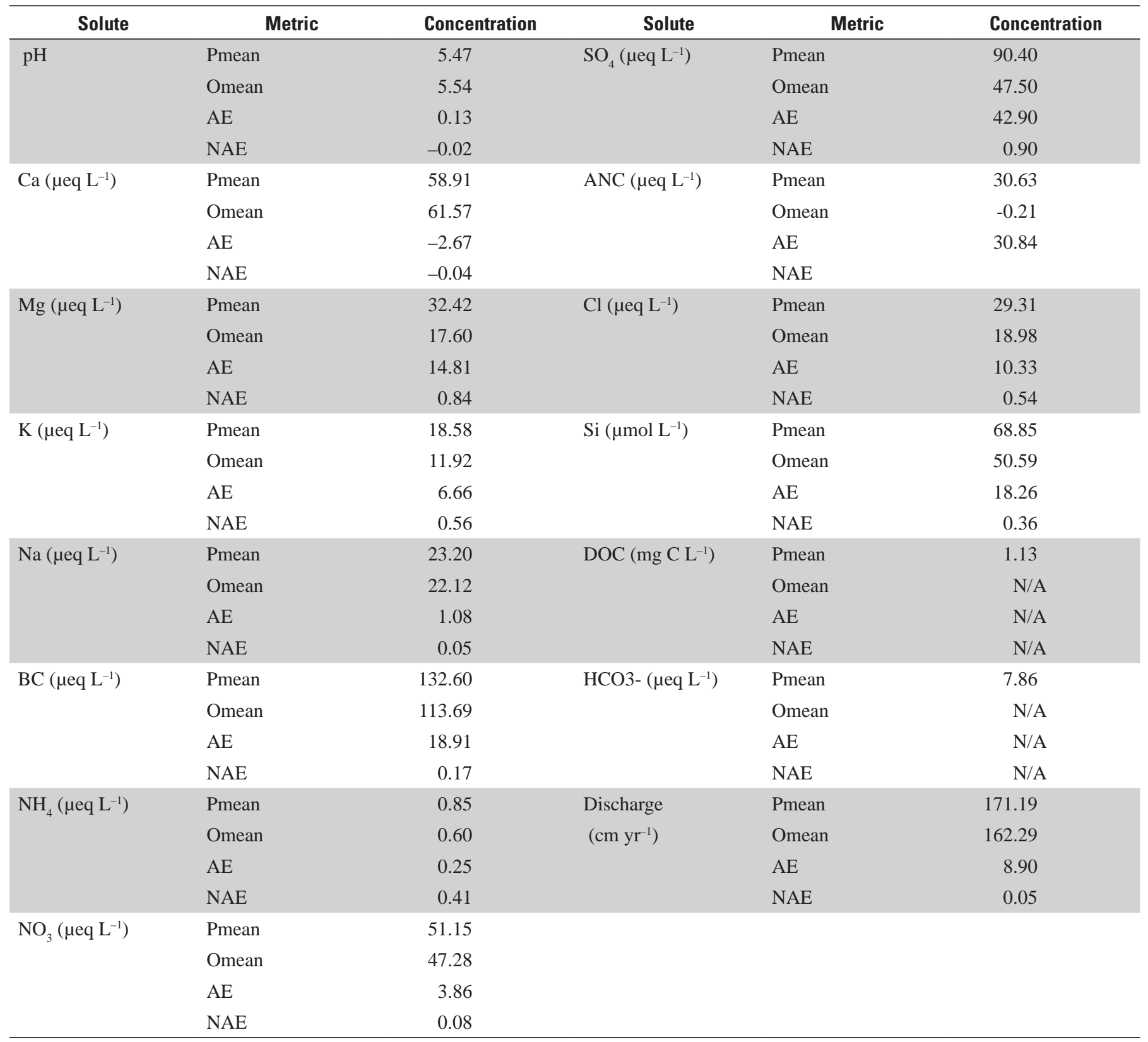


during the fall and winter months (fig. 5.7). Despite the differences in patterns of daily simulated and observed concentrations, the model approximated the annual $\mathrm{NO}_{3}$ loss since simulated annual VWM NO${ }_{3}$ concentration ( $51 \mu \mathrm{eq} \mathrm{L} \mathrm{L}^{-1}$ ) was close to the measured concentration (47 $\mu \mathrm{eq} \mathrm{L}^{-1}$; table 5.6). Simulated daily stream $\mathrm{NH}_{4}$ concentrations cycled between 0.0 $\mu$ eq $\mathrm{L}^{-1}$ during the growing season and $2 \mu \mathrm{eq} \mathrm{L}^{-1}$ in the early spring. Most measured stream $\mathrm{NH}_{4}$ concentrations were close to $0 \mu \mathrm{eq} \mathrm{L}^{-1}$, but there were also a few dozen measurements between 1 and $10 \mu \mathrm{eq} \mathrm{L} \mathrm{L}^{-1}$ and a few between 10 and $20 \mu \mathrm{eq}$ $\mathrm{L}^{-1}$. Despite the occasional high $\mathrm{NH}_{4}$ measurements, modeled and measured annual VWM NH 4 concentrations were within 1 $\mu$ eq $\mathrm{L}^{-1}$ of each other for all simulation years (table 5.6).

\section{Sulfate}

Daily simulated stream $\mathrm{SO}_{4}$ concentrations were generally greater than measurements throughout the simulation (figs. 5.5-5.7). Simulated annual VWM stream $\mathrm{SO}_{4}$ concentration was 90 percent greater than the observed mean, 90 versus 48 peq L ${ }^{-1}$ (table 5.6). DayCent-Chem may not have accounted for enough $\mathrm{SO}_{4}$ adsorption, causing predicted stream $\mathrm{SO}_{4}$ concentrations to be overestimated.

\section{Chloride}

The model overestimated annual VWM stream Cl concentrations by $10 \mu \mathrm{eq} \mathrm{L} \mathrm{L}^{-1}$, or 54 percent (table 5.6). Daily predicted stream $\mathrm{Cl}$ concentrations were close to measured values for most of the year, with the model overestimating stream $\mathrm{Cl}$ concentrations in June and July (figs. 5.5-5.7). Simulated daily stream $\mathrm{Cl}$ concentrations showed a large spike (up to 200 $\mu$ eq $\mathrm{L}^{-1}$ ) during June and July 1999 (off the scale in fig. 5.6), the same time that the throughfall measurements used to drive the model showed extremely high concentrations. It did not appear that these throughfall measurements were representative of $\mathrm{Cl}$ deposition across the entire watershed. This shortterm spike in predicted $\mathrm{Cl}$ concentrations skewed seasonal calculations for June and July (fig. 5.7), making the model appear much farther from measurements than if year 1999 had been excluded from the calculation.

\section{Weathering Products}

Simulated daily stream Si concentrations were close to the measured values for all but the winter months, when simulated concentrations were greater; seasonal averaged modeled and measured concentrations also were similar for the nonwinter months (figs. 5.5, 5.7). The model overestimated annual VWM stream Si concentrations for GRSM by $18 \mu \mathrm{mol} \mathrm{L}^{-1}$, or 36 percent (table 5.6 ).

The model did well in predicting seasonal changes in $\mathrm{Na}$ and Ca concentrations, but it overestimated seasonal Mg and K concentrations for most of the year (fig. 5.7). Simulated daily Na concentrations followed observations closely, whereas simulated daily Ca concentrations showed a wider range of values (figs. 5.5, 5.6). For all base cations except $\mathrm{Na}$, the modeled daily concentrations had greater variation than observations (figs. 5.5, 5.6). The annual VWM concentrations of $\mathrm{Na}$ and Ca were within 1 and 5 percent of the observed means, respectively (table 5.6). The simulated annual VWM $\mathrm{Mg}$ concentration was overestimated by $15 \mu \mathrm{eq} \mathrm{L} \mathrm{L}^{-1}$, or 54 percent, and K was overestimated by $7 \mu \mathrm{eq} \mathrm{L}^{-1}$, or 56 percent, making the simulated annual VWM sum of base cation concentrations $19 \mu \mathrm{eq} \mathrm{L}^{-1}$, or 17 percent, greater than the observed mean (table 5.6).

\section{ANC and $\mathrm{pH}$}

Daily measured pH at GRSM was acidic, with seasonal averages ranging from 5.1 to 5.7 (fig. 5.7). The modeled daily $\mathrm{pH}$ showed a wider range of values than was observed (figs. 5.5, 5.6), although simulated annual volume-weighted stream pH was very close to the observed mean (table 5.6).

Measured alkalinity also was low, with all monthly averages less than $10 \mu \mathrm{eq} \mathrm{L}^{-1}$ and less than $0 \mu \mathrm{eq} \mathrm{L}^{-1}$ for December-June (fig. 5.7). Model calculated acid neutralizing capacity (ANC), which included both $\mathrm{HCO}_{3}$ and Al-hydroxides, was much greater and showed a wider range of values than measured alkalinity (figs. 5.5-5.7). However, daily and seasonal simulated $\mathrm{HCO}_{3}$ concentrations were very close to measured alkalinity and showed similar daily and seasonal variations (fig. 5.7). The simulated annual VWM $\mathrm{HCO}_{3}$ concentration was only $8 \mu \mathrm{eq} \mathrm{L}^{-1}$ greater than observed mean

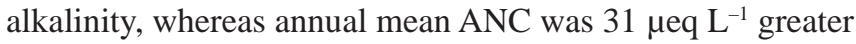
than observed mean alkalinity (table 5.6).

\section{Dissolved Organic Carbon and Nitrogen}

Simulated daily stream dissolved organic carbon (DOC) ranged from 0 to $20 \mathrm{mg} \mathrm{C} \mathrm{L}^{-1}$ throughout the simulation, with the lowest concentrations in winter and the highest concentrations after rain events in the summer (figs. 5.5, 5.6). Simulated daily stream DON ranged from 0 to $1.0 \mathrm{mg} \mathrm{C} \mathrm{L}^{-1}$ and followed seasonal patterns similar to DOC. The simulated annual VWM DOC concentration was $1.3 \mathrm{mg} \mathrm{C} \mathrm{L}^{-1}$ and the mean annual flux was 1.5 (std. dev. 0.3) $\mathrm{g} \mathrm{C} \mathrm{m}^{-2} \mathrm{yr}^{-1}$. The simulated mean annual DON flux was 0.08 (std. dev. 0.02) $\mathrm{g} \mathrm{N} \mathrm{m}^{-2} \mathrm{yr}^{-1}$. There were no measured stream DOC or DON concentrations for NDW from the simulated period. Measured DOC from the northeast stream for June 2001 through December 2003 ranged from 0.5 to $5.0 \mathrm{mg} \mathrm{C} \mathrm{L}^{-1}$, while measured DON for the same time period ranged from 0.0 to $0.5 \mathrm{mg} \mathrm{N} \mathrm{L}^{-1}$ (H. Van Miegroet, unpub. data, 2008). For the last three years of the simulation, 1997-1999, simulated DOC ranged from 0 to 14

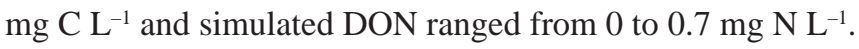



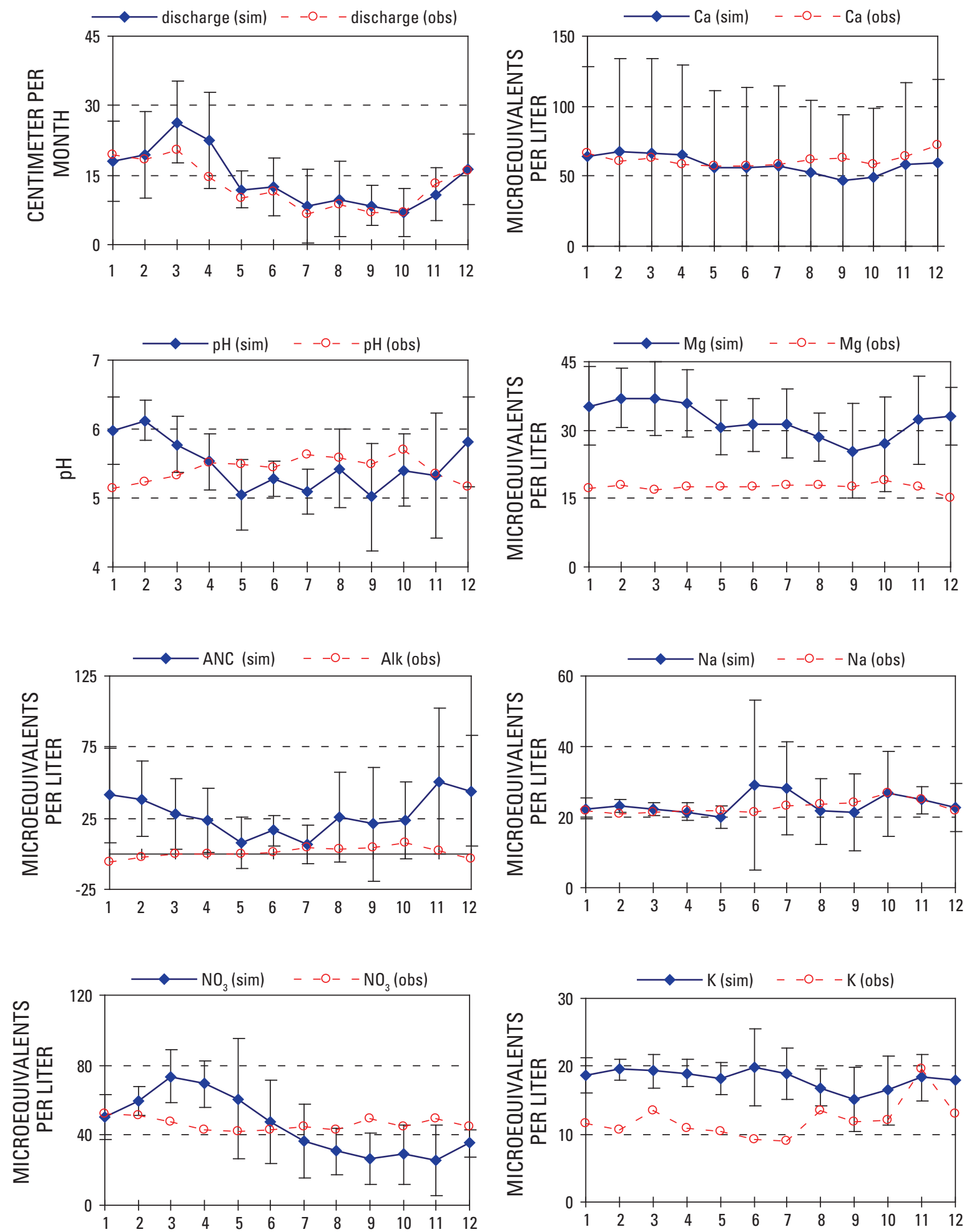

Figure 5.7. Simulated (sim) and observed (obs) discharge and volume-weighted mean (VWM) stream chemistry averaged by month (x axis) for Noland Divide watershed, years 1992-1999. The vertical bars are plus and minus one standard deviation from the simulated mean. Measured DOC was not available. 

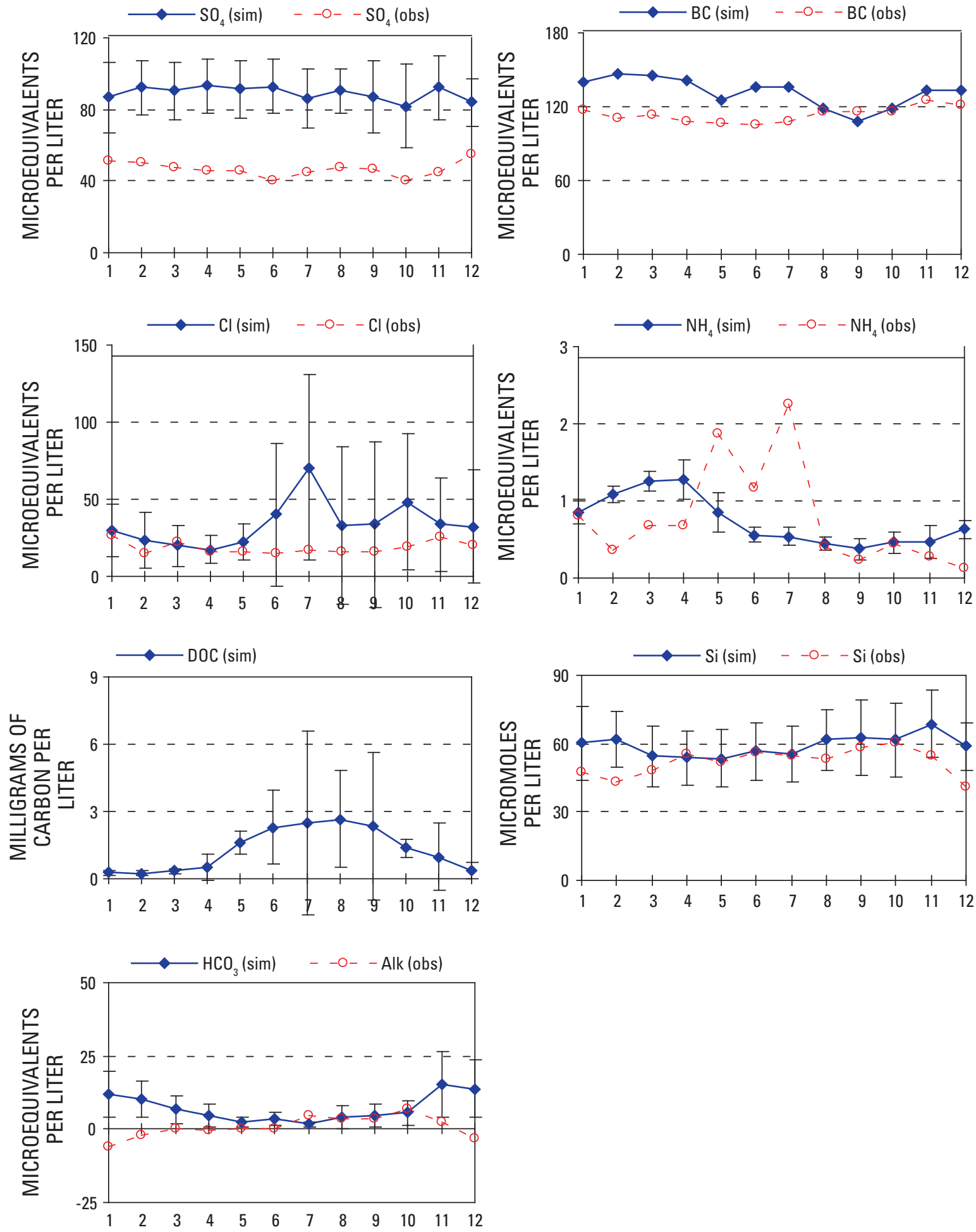

Figure 5.7. Simulated (sim) and observed (obs) discharge and volume-weighted mean (VWM) stream chemistry averaged by month (x axis) for Noland Divide watershed, years 1992-1999. The vertical bars are plus and minus one standard deviation from the simulated mean. Measured DOC was not available.-Continued 


\section{Summary}

In general, the model produced greater net primary production, greater net ecosystem production, and similar soil organic carbon and plant biomass than observed values. Simulated total ecosystem biomass was very close to measured values from NDW, but simulated ecosystem $\mathrm{N}$ was 55 to 70 percent of measured values. The majority of ecosystem $\mathrm{N}$ at NDW was stored in forest floor litter and soil organic matter, whereas the model showed a greater proportion of $\mathrm{N}$ in plant biomass.

DayCent-Chem was able to replicate daily discharge most of the year but periodically missed some of the higher flows. Mean annual simulated discharge was within 5 percent of mean annual observed discharge. The discrepancy between model predictions and observations could be due, in part, to the road cut and diversion in the watershed or to the linear distances (1.6-7 km) and elevational differences between the watershed and the two weather stations that provided the meteorological data.

Of all solutes, the model did best in predicting the magnitude and temporal dynamics of stream $\mathrm{NH}_{4}, \mathrm{Si}, \mathrm{Cl}$, $\mathrm{Ca}$, and $\mathrm{Na}$ concentrations. Additionally, simulated annual VWM stream $\mathrm{NH}_{4}, \mathrm{NO}_{3}$, Ca, and $\mathrm{Na}$ were within either 10 percent or $1 \mu \mathrm{eq} \mathrm{L}^{-1}$ of the observed annual means. Simulated daily concentrations of $\mathrm{pH}, \mathrm{ANC}, \mathrm{NO}_{3}$, $\mathrm{Ca}$, and $\mathrm{Mg}$ had a wider range of values than observations. Modeled solute concentrations are sensitive to soil flushing events that influence predicted stream chemistry. We believe that DayCent-Chem may not have accounted for enough $\mathrm{SO}_{4}$ adsorption, causing predicted stream $\mathrm{SO}_{4}$ concentrations to be overestimated.

Simulated daily stream $\mathrm{HCO}_{3}$ concentrations were much closer to measured alkalinity than simulated ANC, which includes Al-hydroxide buffers as well as $\mathrm{HCO}_{3}$. Simulated annual VWM ANC was on average $31 \mu \mathrm{eq} \mathrm{L}^{-1}$ greater than mean observed alkalinity, and daily ANC had greater variability than daily $\mathrm{HCO}_{3}$ concentrations.

The solutes that are largely influenced by cation exchange, and mineral dissolution reactions were difficult to predict. Minerals and their dissolution rates were largely uncertain, as were exchangeable base cations, and both influence calculated stream $\mathrm{pH}$ and base cation, aluminum hydroxide, and ANC concentrations. 


\section{Rocky Mountain National Park, Andrews Creek Watershed, Colorado}

\section{Site Description}

Andrews Creek is a 183-ha alpine watershed located on the eastern side of the Continental Divide in Rocky Mountain National Park, Colo., about $80 \mathrm{~km}$ northwest of Denver (fig. 6.1, table 6.1). It ranges in elevation from 3,215 to 4,000 $\mathrm{m}$ and makes up the northwest portion of the larger Loch Vale watershed (LVWS), a long-term ecological research and monitoring since 1983 (Baron, 1992).

Andrews Creek watershed is dominated by bedrock (57 percent) and talus (31 percent) with alpine tundra soils comprising 11 percent. Andrews Glacier (10 ha) and a small tarn comprise the remaining land cover fractions of the Andrews Creek watershed (Meixner and others, 2000). Andrews Glacier, a remnant of Quaternary glaciation characterized as a drift glacier (Outcalt and MacPhail, 1980), persists as a result of the contribution of blowing snow from alpine areas west of LVWS and the adjacent towering valley walls that minimize direct sunlight.
The tundra of Andrews Creek watershed has dry to moist perennial sedge meadows with moderately deep soils classified as a Cryochrept (Baron, Walthall, and others, 1992). The bedrock and talus slopes are composed of biotite gneiss and Silver Plume granite, both Precambrain in age. Small amounts of calcite are found along hydrothermically altered zones in gniess and along grain boundaries and microfractures in mineralogically unaltered granite (Mast and others, 1990).

\section{Methods}

\section{Climate and Hydrology}

Daily minimum and maximum air temperatures and precipitation data were taken from the LVWS weather station (http://www.nrel.colostate.edu/projects/lvws/pages/homepage. htm, accessed February 2009), co-located with NADP/NTN

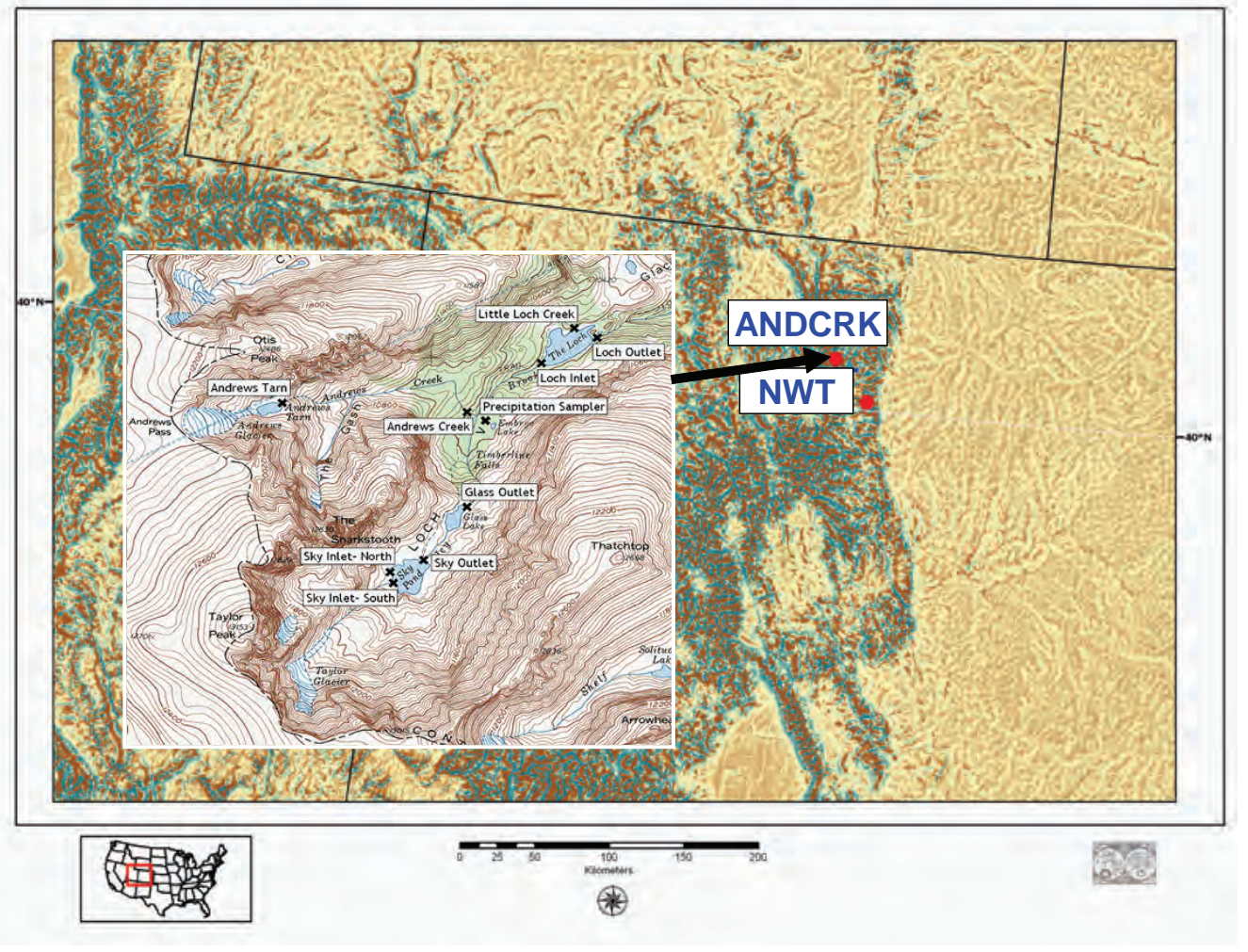

Figure 6.1. Andrews Creek watershed (ANDCRK) is located in Rocky Mountain National Park, Colorado. The watershed is 30 kilometers northwest of Niwot Ridge Long-Term Ecological Research site (NWT; see Chapter 7). Andrews Creek watershed drains the northwest portion of Loch Vale watershed (inset). The outlet of Andrews Creek, along with other stream gages and water sampling locations in Loch Vale watershed, are labeled. The National Atmospheric Deposition Network station (C098) and the main Loch Vale weather station are located at the Precipitation Sampler. 
Table 6.1. Characteristics of Andrews Creek watershed in Rocky Mountain National Park, Colorado.

\begin{tabular}{|c|c|}
\hline Site & Andrews Creek, Rocky Mountain National Park \\
\hline Location & Colorado Front Range, Rocky Mountain National Park \\
\hline Catchment name & Andrews Creek \\
\hline Area (ha) & 183 \\
\hline Latitude, longitude of outlet & $40^{\circ} 17^{\prime} 24^{\prime \prime},-105^{\circ} 40^{\prime} 00^{\prime \prime}$ \\
\hline Outlet elevation (m.a.s.l.) & 3,215 \\
\hline Highest elevation (m.a.s.l.) & 4,000 \\
\hline Climate & Continental, high mountain \\
\hline Simulation years & 1984-2003 \\
\hline Mean (and std. dev.) annual temperature $\left({ }^{\circ} \mathrm{C}\right)$ & $-1.1(0.5)$ \\
\hline Mean (and std. dev.) annual precipitation ( $\mathrm{cm} \mathrm{yr}^{-1}$ ) & $106(18)$ \\
\hline Ecosystem type & Alpine tundra \\
\hline Vegetative cover (\%) & Bedrock (57\%), talus (31\%), alpine tundra soils (11\%) \\
\hline Dominant plant species & Alpine grasses \\
\hline Soil type & Tundra soils: Cryochrept (Baron, Walthall, and others, 1992) \\
\hline Surficial landforms & $\begin{array}{l}\text { Mountainous peaks, talus and block slopes, Andrews glacier } \\
\text { (10 ha) and small tarn }\end{array}$ \\
\hline Bedrock mineralogy & Granite with microcrystalline calcite, gneiss \\
\hline Recent disturbances & None \\
\hline Anthropogenic influences & $\begin{array}{l}\text { Adjacent to Front Range urban corridor, with nearby agriculture and animal } \\
\text { feedlots; climate change }\end{array}$ \\
\hline
\end{tabular}

site CO98 $\left(40.2878^{\circ},-105.6628^{\circ}\right.$, elevation 3,159 m) (http:// nadp.sws.uiuc.edu, accessed January 2005) (fig. 6.1). The median elevation of Andrews Creek basin is $400 \mathrm{~m}$ higher than the weather station, so we applied an environmental lapse rate of $6^{\circ} \mathrm{C}$ per $1,000 \mathrm{~m}$ (Daly and others, 2002) to account not only for the higher elevation of Andrews Creek basin, but also for the shadowing effect of cliff faces and northerly aspect of the catchment that limits solar heating during much of the year (Campbell and others, 1995). Both weekly and daily precipitation amounts were measured at the NADP/NTN site. Weekly measurements often were available when daily precipitation values were missing, particularly during the snow season. In this case, we adjusted daily precipitation uniformly for each missing value during the week, so that the weekly sum was equal to the measured weekly amount. When neither daily nor weekly values were recorded, daily precipitation was set to 0.0. Data from a second weather station in Andrews Creek basin and linear regression equations were used to fill in missing temperature data.

The climate is cold and windy with a short growing season (fig. 6.2). Average annual precipitation from 1984 to 2003 measured at the Loch Vale weather station was 106 (std. dev 18) $\mathrm{cm}$, approximately 65 percent of which was snow (http:// nadp.sws.uiuc.edu, accessed January 2005). The mean annual temperature input to the model was -1.1 (std. dev. 0.5) ${ }^{\circ} \mathrm{C}$. Annual average temperature decreased $0.4^{\circ} \mathrm{C} \mathrm{yr}^{-1}$ (fig. 6.2B).
The hydrology is dominated by annual winter snow that melts during the spring and summer. Discharge appeared to be augmented by glacier and permafrost bedrock/talus. Talus slopes in LVWS are the primary groundwater reservoir, with a maximum storage capacity equal to or greater than annual discharge (Clow and others, 2003). Groundwater flowing from talus can account for $\geq 75$ percent of streamflow in Andrews Creek during storms and the winter baseflow period. Ice stored as permafrost (including glaciers) is the second largest groundwater reservoir in LVWS (Clow and others, 2003).

\section{Atmospheric Deposition}

Weekly precipitation chemistry is collected for wet-only deposition at the Loch Vale NADP/NTN CO98 site; data are available at http://nadp.sws.uiuc.edu/ (accessed August 2008). Daily wet deposition concentrations were derived from weekly concentrations by assuming individual precipitation events had the same concentrations as the week-long sample. Field $\mathrm{pH}$ values were used when available; otherwise, lab $\mathrm{pH}$ values were substituted. Missing concentrations of any solute for a particular day of year were assigned the multi-year average concentration for that same day of year.

The composition and proportion of dry deposition varied seasonally and spatially in LVWS. To calculate seasonal 

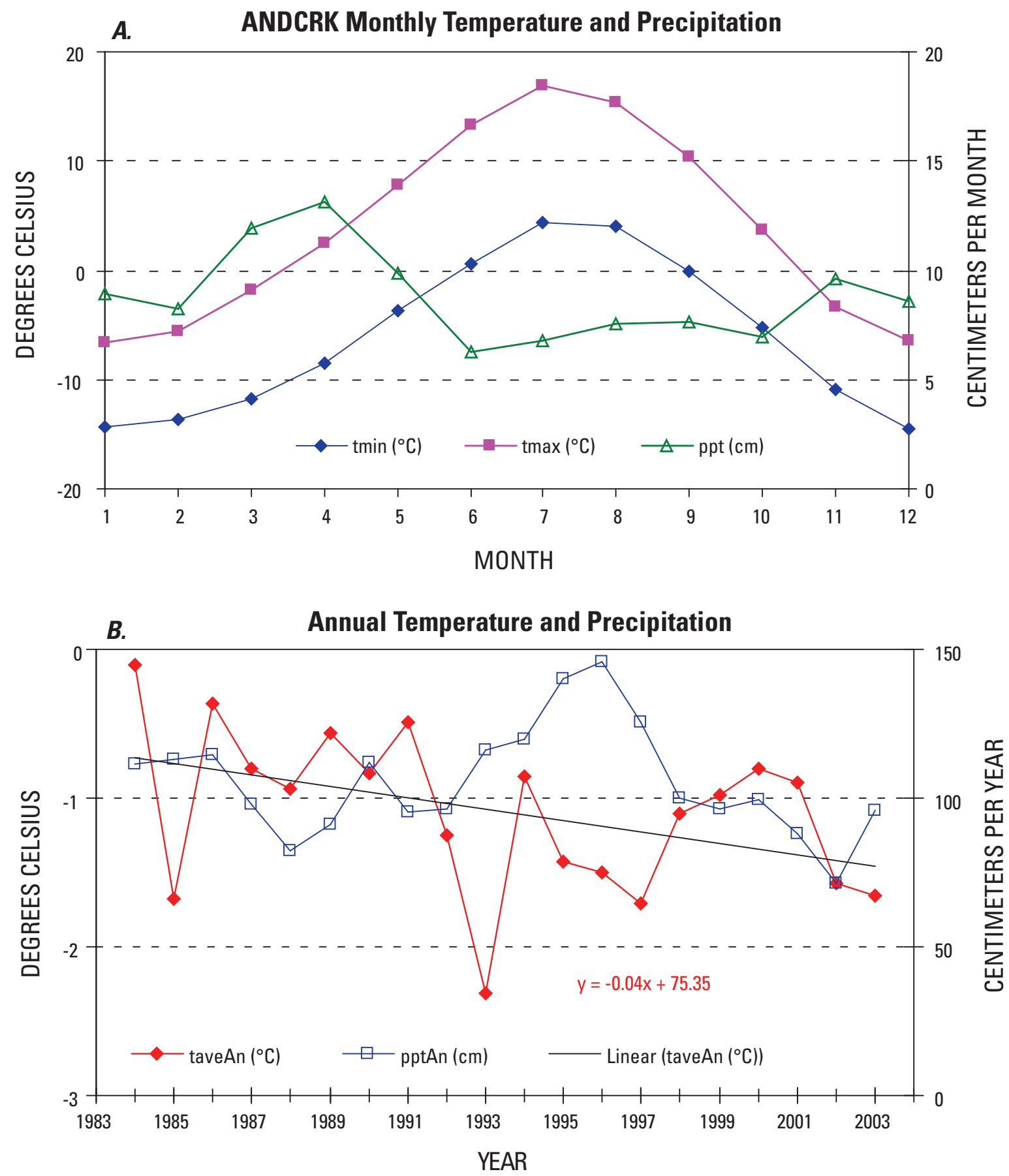

Figure 6.2. Meteorological statistics of model inputs for Andrews Creek watershed. A, Average monthly minimum air temperatures (tmin), maximum air temperatures (tmax), and precipitation (ppt), years 1984-2003. $B$, The time series of mean annual temperature (taveAn) and annual precipitation (pptAn), years 1984-2003. Unlike all other sites that had an increase in mean annual temperature, Andrews Creek showed a decrease of $0.04^{\circ} \mathrm{C} \mathrm{yr}^{-1}$. 
DayCent-Chem Simulations of Ecological and Biogeochemical Processes of Eight Mountain Ecosystems in the U.S.

dry:wet deposition ratios of $\mathrm{NO}_{3}, \mathrm{NH}_{4}$, and $\mathrm{S}\left(\mathrm{SO}_{2}\right.$ plus $\left.\mathrm{SO}_{4}\right)$, we used the 1995-2002 quarterly dry deposition measurements for site ROM406 of the Clean Air Status and Trends Network $\left(40.2778^{\circ},-105.5453^{\circ}\right.$, elevation 2,743 m; CASTNet, U.S. Environmental Protection Agency, Washington, D.C., 2003, http://www.epa.gov/castnet/) and the corresponding quarterly wet deposition measurements from NADP/NTN site CO98 in LVWS. The ROM406 site is located within a forest approximately $10 \mathrm{~km}$ southeast of and $416 \mathrm{~m}$ lower than NADP/NTN site CO98. Because N deposition is affected by upslope conditions (Baron, Denning, and others, 1992), we assumed the treeless high elevation areas of LVWS do not capture as much dryfall nitrogen as forests because of their smaller leaf area index (LAI) and relative position upslope of forests. Additionally, the dry:wet ratios for $\mathrm{NO}_{3}$ and $\mathrm{NH}_{4}$, derived from Clow and Mast (1995) for a treeless area in the summer, were much lower than CASTNET/NADP derived ratios, while dry:wet $\mathrm{SO}_{4}$ ratios were similar. We estimated dry:wet ratios for base cations and $\mathrm{Cl}$ using bulk deposition measurements from two sources (Campbell and others, 1995; Clow and Mast, 1995). Annual average dry deposition estimates for $\mathrm{Ca}, \mathrm{Mg}$, and $\mathrm{K}$ were greater than or equal to the amount of wet deposition of these cations (table 6.2, fig. 6.3). A more detailed explanation of how seasonal dry deposition was calculated is included in Hartman and others (2007).

\section{Combined Tundra and Bedrock/Talus Simulations}

The inaugural application of the DayCent-Chem model was for Andrews Creek watershed, and results summarized in this chapter were initially presented in Hartman and others (2007). Unlike for the other sites (Chapters 2-5 and 7-9), for which a single simulation was set up to represent the entire watershed, the Andrews Creek model simulated separate bedrock/talus and tundra sites and combined their results to derive total watershed response. The contribution of each site to total discharge quantity and quality was weighted by the percentage

Table 6.2. Average annual wet and dry plus fog deposition inputs $\left(\mathrm{kg} \mathrm{ha}^{-1} \mathrm{yr}^{-1}\right)$ to the model over the 1984-2003 simulation period.

\begin{tabular}{lccc}
\hline & Wet & Dry + Fog & Total \\
\hline $\mathrm{Ca}$ & 1.76 & 3.49 & 5.25 \\
$\mathrm{Cl}$ & 0.90 & 0.09 & 1.00 \\
$\mathrm{~K}$ & 0.24 & 0.49 & 0.73 \\
$\mathrm{Mg}$ & 0.24 & 0.64 & 0.87 \\
$\mathrm{NH}_{4}-\mathrm{N}$ & 1.15 & 0.08 & 1.23 \\
$\mathrm{NO}_{3}-\mathrm{N}$ & 1.83 & 0.46 & 2.28 \\
$\mathrm{Na}$ & 0.70 & 0.11 & 0.81 \\
$\mathrm{SO}_{4}-\mathrm{S}$ & 2.01 & 0.53 & 2.54 \\
\hline
\end{tabular}

of the watershed occupied by each area represented. The combined bedrock/talus and tundra simulation, hereafter referred to as the combined run, had an 89 percent contribution from bedrock/talus and an 11 percent contribution from tundra. The bedrock/talus simulation represented solid metamorphic and igneous bedrock surfaces and cliffs, talus slopes, and block slopes with a small amount of perennial vegetation. The tundra simulation represented a vegetated alpine meadow with moderately deep soils. Tundra vegetation and soil organic matter parameters for DayCent were obtained from a nearby alpine research site, Niwot Ridge (Conley and others, 2000). Neither the glacier nor the tarn was included in the modeling effort.

\section{Soil and Mineral Properties}

Soil layer thickness, $\mathrm{pH}$, clay content, organic matter percentage, and exchangeable cations for tundra were initialized with data for a Cryochrept (table 6.3A) (Baron, Walthall, and others, 1992). For the bedrock/talus simulation, we created a single shallow dense soil layer with very low cation exchange capacity (table 6.3B). Because measured sulfate adsorption in LVWS was less than $1.2 \mathrm{mmol} \mathrm{kg}{ }^{-1}$ and soil $\mathrm{PO}_{4}$ concentrations were low (Baron, Denning, and others, 1992), sulfate and other anion adsorption reactions were not included in Andrews Creek simulations.

We prescribed different weathering rates to bedrock/talus and tundra (table 6.4). Primary mineral weathering reactions in LVWS have been quantified using a combination of traditional mass-balance calculation methods and strontium isotope mixing calculations (Mast and others, 1990; Clow, 1992; Mast, 1992). Calcite weathering occurs in fresh talus surfaces, but is unlikely to occur in older, more weathered soils (Walthall, 1985; Clow and Sueker, 2000). Silicate mineral weathering has a strong influence on tundra waters (Clow and Sueker, 2000), and the influence of sulfide-bearing minerals is significant in Andrews Creek (Campbell and others, 1995). Oligoclase ( $\mathrm{Na}: \mathrm{Ca}=73: 27)$ was represented as albite and anorthite in the same ratio. The kinetically limited dissolution of crystalline minerals cannot account for the regulation of $\mathrm{SiO}_{2}$ in LVWS stream waters, and faster reacting amorphous aluminosilicates may play an important role in regulating $\mathrm{SiO}_{2}$ concentrations in alpine soils (Clow, 1992; Campbell and others, 1995). We prescribed amorphous silica dissolution in tundra soils and bedrock/talus to better estimate stream silica concentrations.

\section{Calibration}

DayCent-Chem was calibrated using Andrews Creek stream chemistry and discharge data for years 1992-1999; years 2000-2003 were used for evaluation. Model calibration required several steps: (1) match simulated net primary production, soil organic matter content, and nitrogen mineralization rates with corresponding observed values; (2) match 

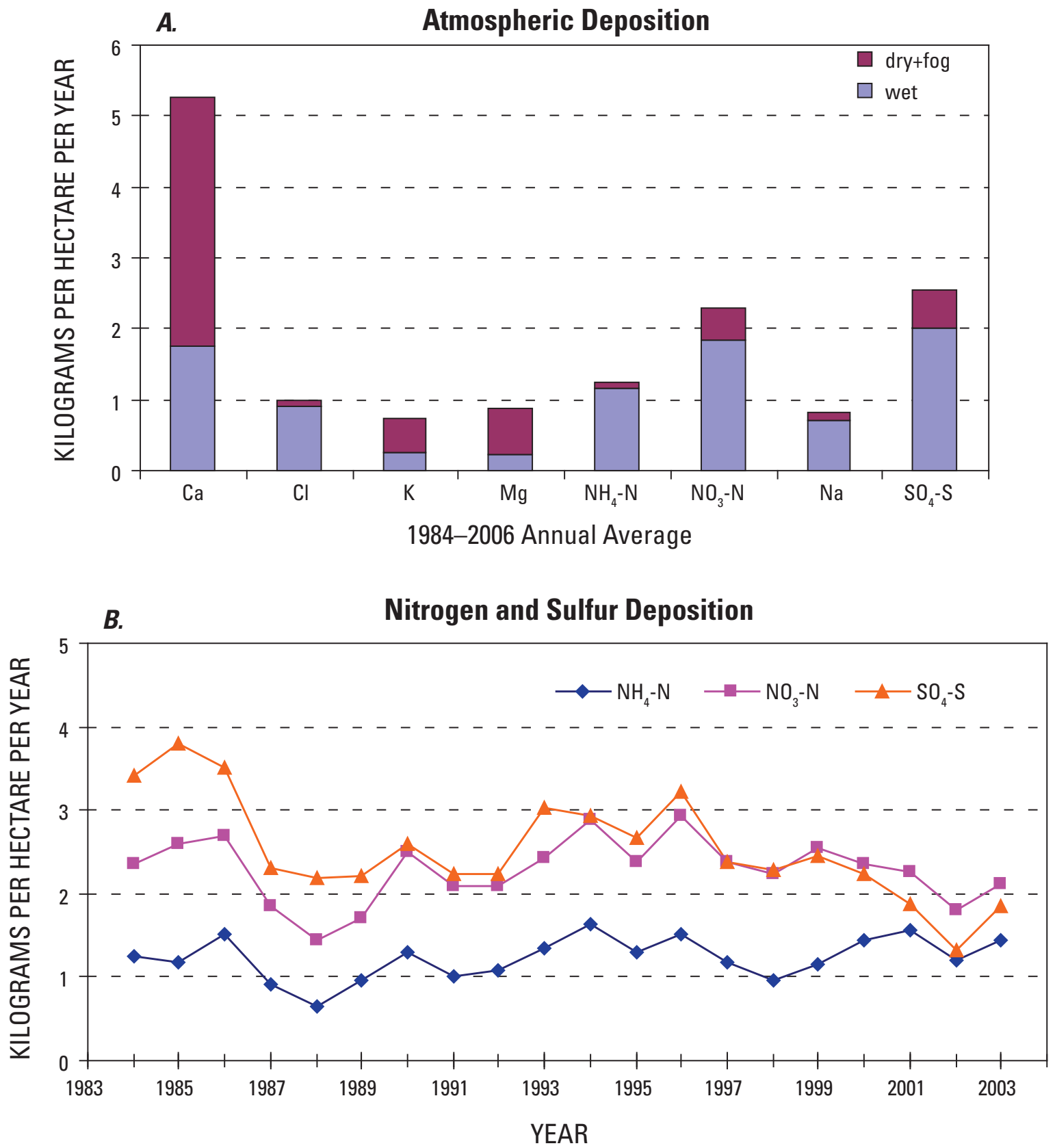

Figure 6.3. Deposition inputs to the model for Andrews Creek watershed. A, The 1984-2003 average annual wet and dry plus fog deposition. $B$, The time series of $\mathrm{N}$ and $\mathrm{S}$ deposition over the simulation period. 
Table 6.3. Tundra and bedrock/talus soil layer properties used for the simulation. $A$, Tundra soil layer properties and initial exchangeable cations, based on measured values for a Cryochrept (Baron, Walthall, and others, 1992). Ksat is saturated hydraulic conductivity, and the mineral dissolution fraction (Minrl dissoln) is the fraction of total mineral dissolution that occurred in each layer. Wilting point and field capacity are expressed as volumetric soil water content. Exchangeable cations are expressed as milliequivalents per 100 grams of soil (meq/100 g). Total soil depth was $32 \mathrm{~cm}$ and organic soil comprised the top $5 \mathrm{~cm}$. $B$, Bedrock/ talus soil layer properties and initial exchangeable cations (meq/100 g). All numbers were estimated.

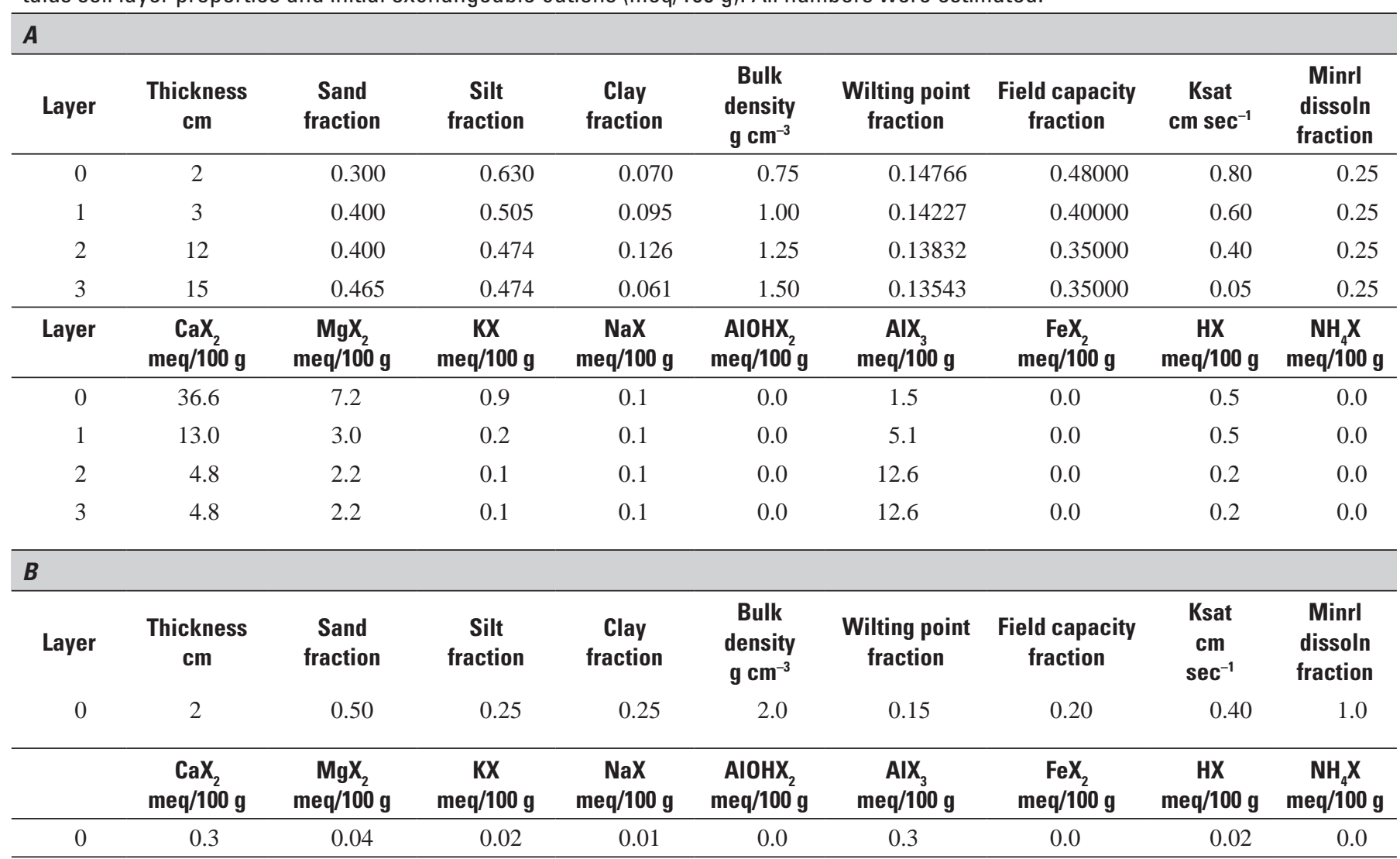

Table 6.4. Mineral phases and potential annual mineral denudation rates prescribed for the alpine and bedrock/talus simulations (Hartman and others, 2007). Minerals could only dissolve, except for kaolinite and smectite, which could both precipitate and dissolve.

\begin{tabular}{|c|c|c|c|}
\hline $\begin{array}{c}\text { Mineral } \\
\text { phases }\end{array}$ & $\begin{array}{c}\text { Alpine } \\
\mathrm{mol} \mathrm{m}^{-2} \mathrm{yr}^{-1}\end{array}$ & $\begin{array}{l}\text { Bedrock/talus } \\
\mathrm{mol} \mathrm{m}^{-2} \mathrm{yr}^{-1}\end{array}$ & $\begin{array}{c}1 \text { = dissolve, } \\
0 \text { = precipitate } \\
\text { or dissolve }\end{array}$ \\
\hline Calcite & 0 & 0.0129 & 1 \\
\hline Albite & 0.02169 & 0.0047 & 1 \\
\hline Anorthite & 0.00801 & 0.0017 & 1 \\
\hline Biotite & 0.0087 & 0.0019 & 1 \\
\hline Kaolinite & 0 & 0 & 0 \\
\hline Chlorite & 0.0021 & 0.0005 & 1 \\
\hline Pyrite & 0.0018 & 0.0004 & 1 \\
\hline Smectite & 0 & 0 & 0 \\
\hline $\mathrm{SiO}_{2}$ & 0.0153 & 0.0153 & 1 \\
\hline
\end{tabular}


daily and annual total discharge with measured amounts; and (3) match daily and annual volume-weighted stream chemistry with measured concentrations.

Since the model's geochemical calculations are computationally intensive, DayCent was brought to an equilibrium state without utilizing PHREEQC. First, we ran the model for 400 years using background (pre-industrial) inputs of nitrogen (0.04 $\mathrm{g} \mathrm{N} \mathrm{m}^{-2} \mathrm{yr}^{-1}$; Galloway and others, 1996). Next, we ran the model for 30 years with current average deposition rates $\left(0.35 \mathrm{~g} \mathrm{~N} \mathrm{~m}^{-2} \mathrm{yr}^{-1}\right)$ that varied from year to year as a linear function of precipitation. Finally, we ran the model for years 1984-2003 with the geochemical model calculations. All runs used daily 1984-2003 weather, repeated if necessary. We tuned the model on uncertain values, such as the fraction of mineral denudation in each soil layer, elution parameters, parameters that control watershed average discharge, and $\mathrm{pCO}_{2}$ of stream water and soil water to represent measured 1992-1999 daily stream discharge and stream chemistry (Hartman and others, 2007). Stream concentration calibrations were made by visually comparing daily and annual simulated and measured stream discharge and species concentrations. Our goals were to constrain the simulated concentrations within the range of measured concentrations and capture the timing and patterns of flow dilution and flow concentration for each solute. The $\mathrm{pH}$ of soil and stream solutions was computed as a charge balance in solution. Three separate performance measures were calculated for discharge and each stream solute to evaluate the model (Hartman and others, 2007).

\section{Model Output}

\section{Ecological Variables}

Model estimates of NPP and live biomass for tundra were lower than but close to measured values from nearby Niwot Ridge $\left(40^{\circ} 03^{\prime} \mathrm{N} 105^{\circ} 35^{\prime} \mathrm{W}\right.$, approximately $30 \mathrm{~km}$ southeast of LVWS; table 6.5). Actual average annual production rates for LVWS tundra are probably lower than those at Niwot Ridge because of shallower soils and steeper slopes at LVWS (Arthur, 1992). Simulated above-ground NPP for tundra, $43 \mathrm{~g} \mathrm{C} \mathrm{m}^{-2} \mathrm{yr}^{-1}$, was at the low end of that measured at Niwot Ridge, 44-135 g C m-2 $\mathrm{yr}^{-1}$ (Bowman and Fisk, 2001), whereas total NPP, $95 \mathrm{~g} \mathrm{C} \mathrm{m}^{-2}$, was less than measured values, 149-219 g C m ${ }^{-2}$ (Bowman and Fisk, 2001). Year-long simulated above-ground live biomass, $0.0-63.8 \mathrm{~g} \mathrm{C} \mathrm{m}^{-2}$, was at the low end of Niwot measurements, $60-117 \mathrm{~g} \mathrm{C} \mathrm{m}^{-2}$ (Bowman and Fisk, 2001), whereas below-ground live biomass, 425$515 \mathrm{~g} \mathrm{Cm}^{-2}$, was in the middle of the measured range, 225$929 \mathrm{~g} \mathrm{C} \mathrm{m}^{-2}$ (Bowman and Fisk, 2001). The model's above- to below-ground biomass ratio at the peak of the growing season was about 1:8, whereas measured above- to below-ground biomass ratios ranged from 1:3.7 to 1:12 (Bowman and Fisk, 2001).
The model did well in estimating $\mathrm{N}$-mineralization and total soil organic matter, but underestimated total evapotranspiration (ET) for tundra (table 6.5). Simulated $\mathrm{N}$-mineralization rates $\left(2.1 \mathrm{~g} \mathrm{~N} \mathrm{~m}^{-2}\right.$ year $\left.^{-1}\right)$ were very close to those observed on Niwot Ridge (approx. $2.0 \mathrm{~g} \mathrm{~N} \mathrm{~m}^{-2}$ year $^{-1}$; Bowman, 1992) and soil organic matter $\left(9,550 \mathrm{~g} \mathrm{C} \mathrm{m}^{-2}\right)$ was within the range observed: $6,700 \mathrm{~g} \mathrm{Cm}^{-2}$ for dry alpine sedge meadows at Niwot Ridge (Seastedt, 2001) and 13,000 $\mathrm{g} \mathrm{C} \mathrm{m}^{-2}$ (Conley and others, 2000). Simulated tundra ET, $6.1 \mathrm{~cm} \mathrm{yr}^{-1}$, was about 26 percent of a previously approximated amount, $23.4 \mathrm{~cm} \mathrm{yr}^{-1}$, and sublimation, $26.5 \mathrm{~cm} \mathrm{yr}^{-1}$, was at the low end of the expected range, 26-88 cm (Baron and Denning 1992).

The model suggested that the tundra $\mathrm{N}$ losses through streamflow and trace gas emissions were greater than $\mathrm{N}$ inputs via deposition and internal $\mathrm{N}$ fixation, and that bedrock/talus retained about 10 percent of atmospherically deposited $\mathrm{N}$. There were no measurements available to verify theses estimates of $\mathrm{N}$ retention for either tundra or bedrock/talus.

\section{Discharge}

The model performed the same for calibration years 1993-1995 as it did for evaluation years 2001-2003 (the $\mathrm{R}^{2}$ correlation between measured and modeled discharge was 0.72 for both 3 -year periods; figs. 6.4, 6.5). Daily simulated discharge followed the hydrographs of measured discharge for Andrews Creek with an $\mathrm{R}^{2}$ of 0.64 over a longer simulation period (1992-2003). The model best captured total annual flow through 1997, but after 1997 the model underestimated annual totals. This underestimate of annual total discharge is reflected in the daily hydrographs on the falling limb of years 2001-2003, when simulated flow is below measured flow (fig. 6.5). For most years, the simulated onset of snowmelt and the amount and timing of peak flow were close to measured values. There was a large spike in simulated discharge for late August 1994 (fig. 6.4), and this simulated discharge spike has been problematic for at least two other hydrologic models applied to LVWS (Hartman and others, 1999; Meixner and others, 2000). The overestimation of the summer rainfall discharge peak has been attributed to either incorrect precipitation measurements as input to the models or insufficient soil zone storage within the models.

\section{Stream Chemistry}

Evaluation years corresponded to some of the driest years in Andrews Creek. Overall, model results compared better to measurements for wetter-than-average years than for drier years. Precipitation was above the 1984-2003 average (106 $\mathrm{cm}$ ) during 1993-1997. Precipitation was below the average in 1992 and 1998-2003. Daily stream concentrations were close to measured concentrations for Andrews Creek during spring and summer, but the model was less capable of reproducing stream chemistry during winter when flow was very 
Table 6.5. Simulated and observed annual water fluxes, annual nitrogen fluxes, annual net primary production (NPP), annual range of live biomass, and average soil organic matter. Standard deviations are shown in parentheses. Average annual values are for years 1984-1999 except where indicated. Mean annual precipitation for years 1984-1999 was $109.8 \mathrm{~cm}$, and for years 1992-1999 was $117.5 \mathrm{~cm}$.

[n/a, not available; x, not reported]

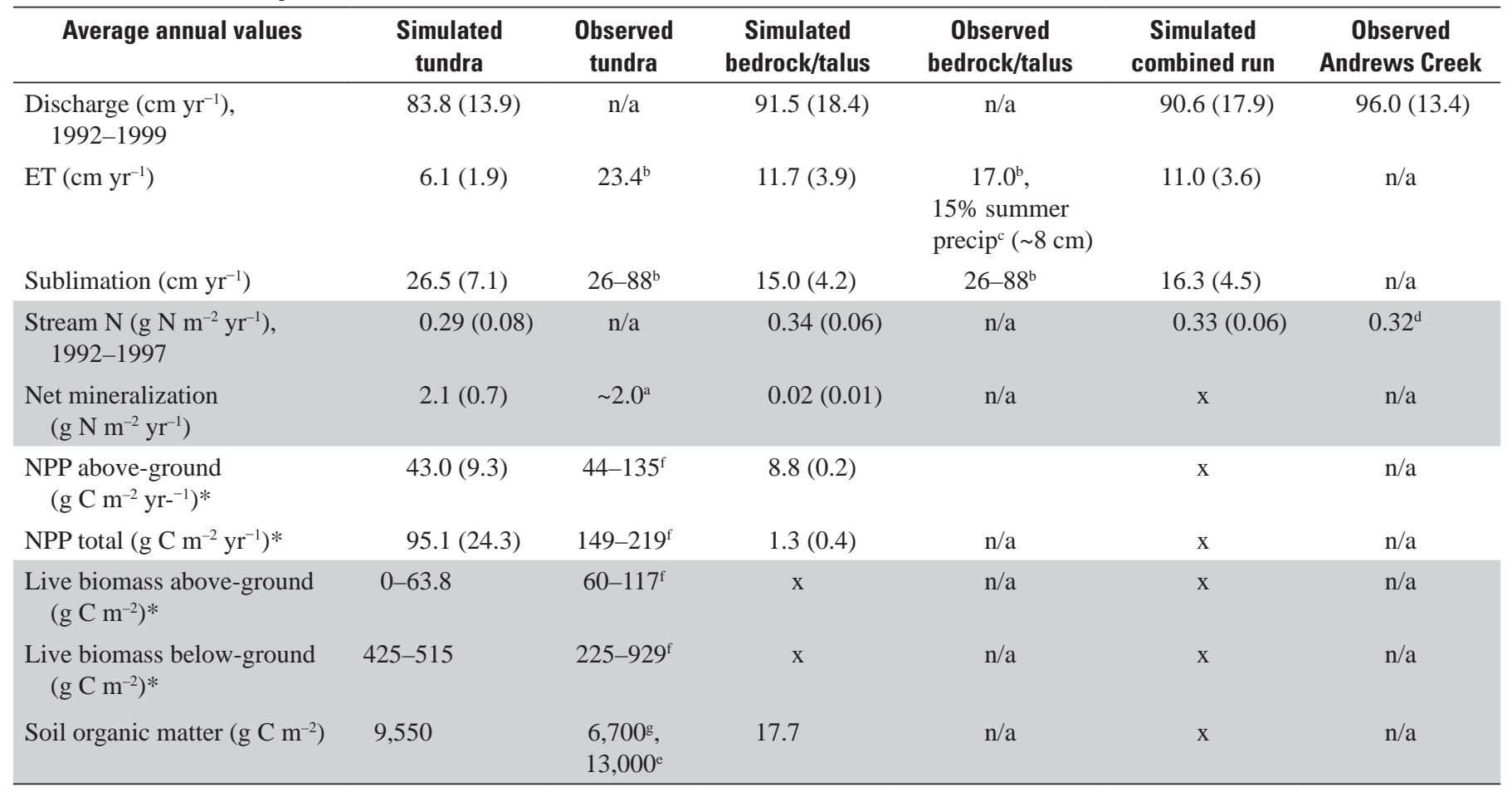

${ }^{\mathrm{a}}$ Bowman, 1992; ${ }^{\mathrm{b}}$ Baron and Denning, 1992; ${ }^{\mathrm{C}}$ Clow and Mast, 1995; ${ }^{\mathrm{d}}$ Campbell and others, 2000; ${ }^{\mathrm{e}}$ Conley and others, 2000; ${ }^{\mathrm{f}}$ Bowman and Fisk, 2001; g Seastedt, 2001.

*Observed values published in grams of biomass were divided by 2.25 to convert to grams of carbon (g C). Observed NPP and biomass for tundra include both dry and moist meadows. 
low. On days when simulated discharge was less than $0.01 \mathrm{~cm}$ $(0.02 \mathrm{cfs})$, modeled stream concentrations were filtered from the graphs (figs. 6.4, 6.5).

\section{Nitrate and Ammonium}

Measured $\mathrm{NO}_{3}$ was concentrated during initial snowmelt as a result of elution and soil and groundwater flushing, dipped to its minimum concentration during the summer when plants and microbes take up nitrogen, and gradually increased as discharge decreased through autumn. The model generally captured this pattern of observed $\mathrm{NO}_{3}$ concentrations, but it sometimes overestimated minimum concentrations, particularly for 2002 (figs. 6.4, 6.5). The simulated annual volume-weighted mean concentration of $\mathrm{NO}_{3}$ was 6 percent greater than the observed annual mean concentration (table 6.6). Simulated $\mathrm{NH}_{4}$ concentrations, like measured concentrations, lacked a strong seasonal pattern but were in the range of measured concentrations (figs. 6.4, 6.5). Both simulated and measured annual volume-weighted mean $\mathrm{NH}_{4}$ concentrations were very low and within $2 \mu \mathrm{eq} \mathrm{L}^{-1}$ of each other. Predicted mean annual 1992-1997 inorganic nitrogen export $\left(0.33 \mathrm{~g} \mathrm{~N} \mathrm{~m}^{-2} \mathrm{yr}^{-1}\right)$ was very close to the measured flux for Andrews Creek (0.32g N $\mathrm{m}^{-2} \mathrm{yr}^{-1}$; table 6.5) (Campbell and others, 2000).

\section{Sulfate}

Like $\mathrm{NO}_{3}$, simulated and measured $\mathrm{SO}_{4}$ concentrations were greatest during snowmelt and were at a minimum during the summer. The model did especially well in capturing observed daily trends in sulfate concentrations, particularly for years 1993-1995 (figs. 6.4, 6.5). Simulated daily $\mathrm{SO}_{4}$ concentrations for the late summer and autumn of 2002 were greater than measured concentrations; discharge was underestimated during this time. Simulated annual volume-weighted mean concentrations of $\mathrm{SO}_{4}$ did not become more concentrated for drier years, as was observed in measured values, and on average were underestimated by $8 \mu \mathrm{eq} \mathrm{L}^{-1}$ (table 6.6).

\section{Chloride}

Measured $\mathrm{Cl}$ concentrations followed seasonal patterns similar to $\mathrm{NO}_{3}$ and $\mathrm{SO}_{4}$, concentrating during initial snowmelt, diluting through June or July, and gradually concentrating the remaining months of the year (figs. 6.4, 6.5). Simulated daily concentrations of $\mathrm{Cl}$ followed this pattern reasonably well except during 1994 and in autumn 2002, when simulated concentrations were much higher than observed. The simulated and observed annual volume-weighted mean concentrations of Cl were within $1 \mu \mathrm{eq} \mathrm{L} \mathrm{L}^{-1}$ of each other all years except 1994 (table 6.6). The 1994 spikes in simulated daily concentrations (fig. 6.4) resulted from a suspiciously high concentration (and deposition) of $\mathrm{Cl}$ in the NADP weekly record for November 30-December 7, 1993. This high input of $\mathrm{Cl}$ to the model was stored in its snowpack and did not show up in simulated streamflow until the onset of snowmelt in 1994. We do not know why measured stream chemistry did not reflect the high $\mathrm{Cl}$ input that was measured in wet deposition in late 1993.

\section{Weathering Products}

The daily simulated sum of base cation concentrations compared well with measured concentrations, though the model underestimated maximum base cation concentrations in spring and overestimated them in late summer/autumn 2002 (figs. 6.4, 6.5). Both simulated and observed patterns of $\mathrm{Si}$ showed flow dilution during snowmelt and flow concentration during low flow (figs. 6.4, 6.5). Simulated daily concentrations of $\mathrm{Si}$ tended to have a wider range of values than measured concentrations, and concentrations were particularly greater than observed concentrations for a one- to two-week period at the onset of snowmelt, as well as in the autumn of most years between 2001 and 2003. The simulated annual volume-weighted mean concentration of base cations was underestimated by 10 percent, and $\mathrm{Si}$ was underestimated by 17 percent (table 6.6). The simulated annual volume-weighted mean concentration of individual base cations (Ca, Mg, K, and $\mathrm{Na}$ ) were within $2 \mu \mathrm{eq} \mathrm{L}^{-1}$ or 6 percent of the measured means (table 6.6).

\section{ANC and $\mathrm{pH}$}

With the exception of a few outliers, simulated daily ANC was within the range of observed concentrations (figs. 6.4, 6.5). For most years through 1997, the model captured the observed increase in stream ANC going into winter and its subsequent dip during snowmelt. Simulated daily ANC concentrations were particularly sensitive to daily discharge estimates and were underestimated when discharge was overestimated, and visa versa. Outliers (ANC less than $10 \mu$ eq $\mathrm{L}^{-1}$ ) always occurred when there was an abrupt increase in simulated discharge that simultaneously diluted simulated stream base cation concentrations. The model overestimated daily concentrations for 2002 and 2003. The simulated annual volume-weighted mean ANC concentration

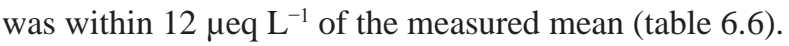

Simulated daily $\mathrm{pH}$ tracked simulated ANC and was within the range of observed values, though a few outliers occurred on days when ANC also was underestimated (figs. 6.4, 6.5). Daily simulated $\mathrm{pH}$ matched patterns of observed $\mathrm{pH}$ better for years 1993-1995 than for years 2001-2003. Simulated annual volume-weighted mean $\mathrm{pH}$ was within 0.02 units of measured $\mathrm{pH}$ (table 6.6).

\section{Dissolved Organic Carbon}

Simulated and measured daily dissolved organic carbon (DOC) concentrations had the same range of values (fig. 6.5). The simulated annual volume-weighted mean DOC concentration was lower than measured DOC (table 6.6). Infrequent 

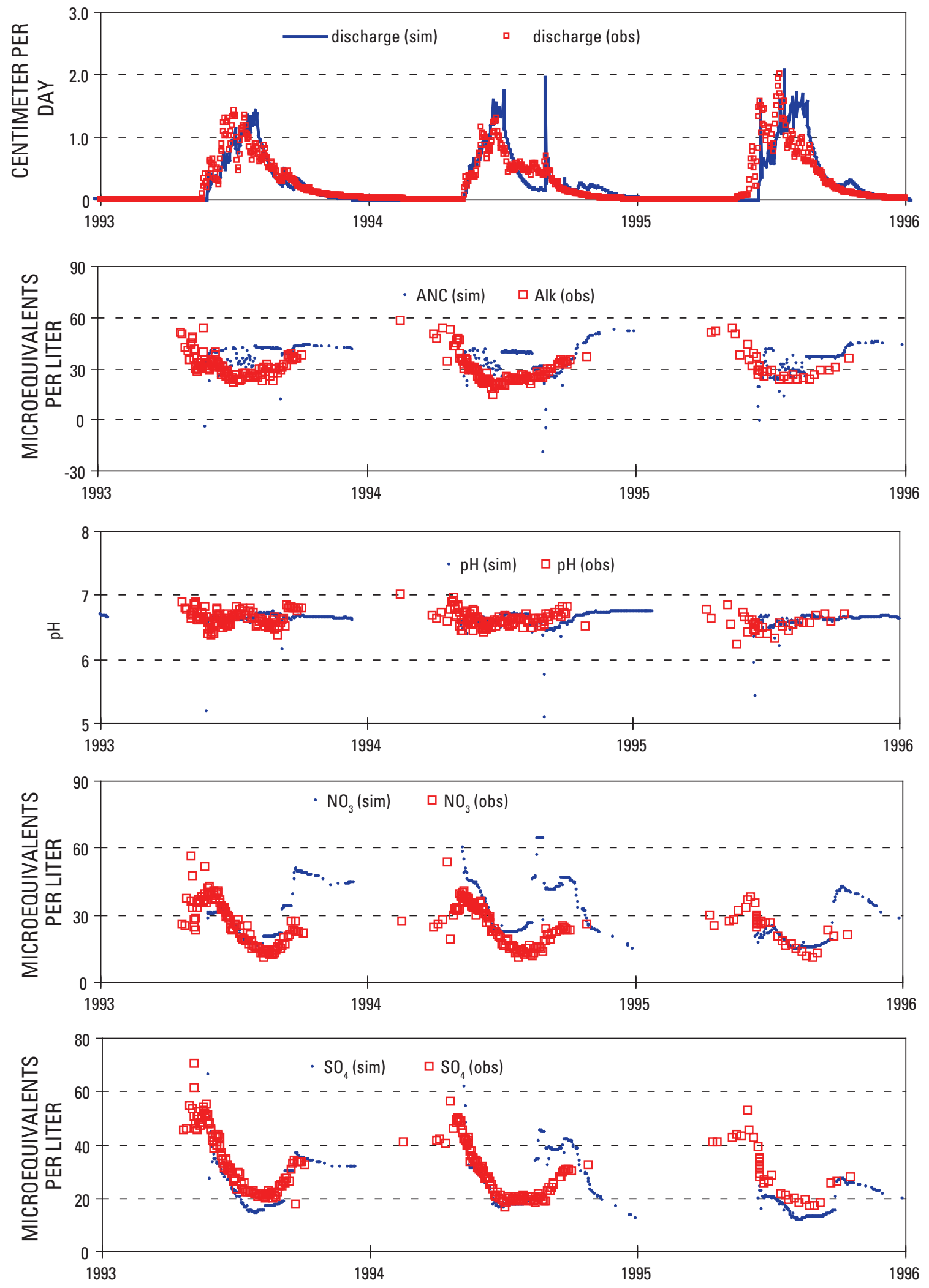

Figure 6.4. Simulated (sim) and observed (obs) daily discharge and stream chemistry for Andrews Creek watershed, years 1993-1995 (x axis). Simulated concentrations are not shown for days when simulated discharge was extremely low, less than $0.01 \mathrm{~cm} \mathrm{day}^{-1}$. Measured DOC was not available during this time period. 

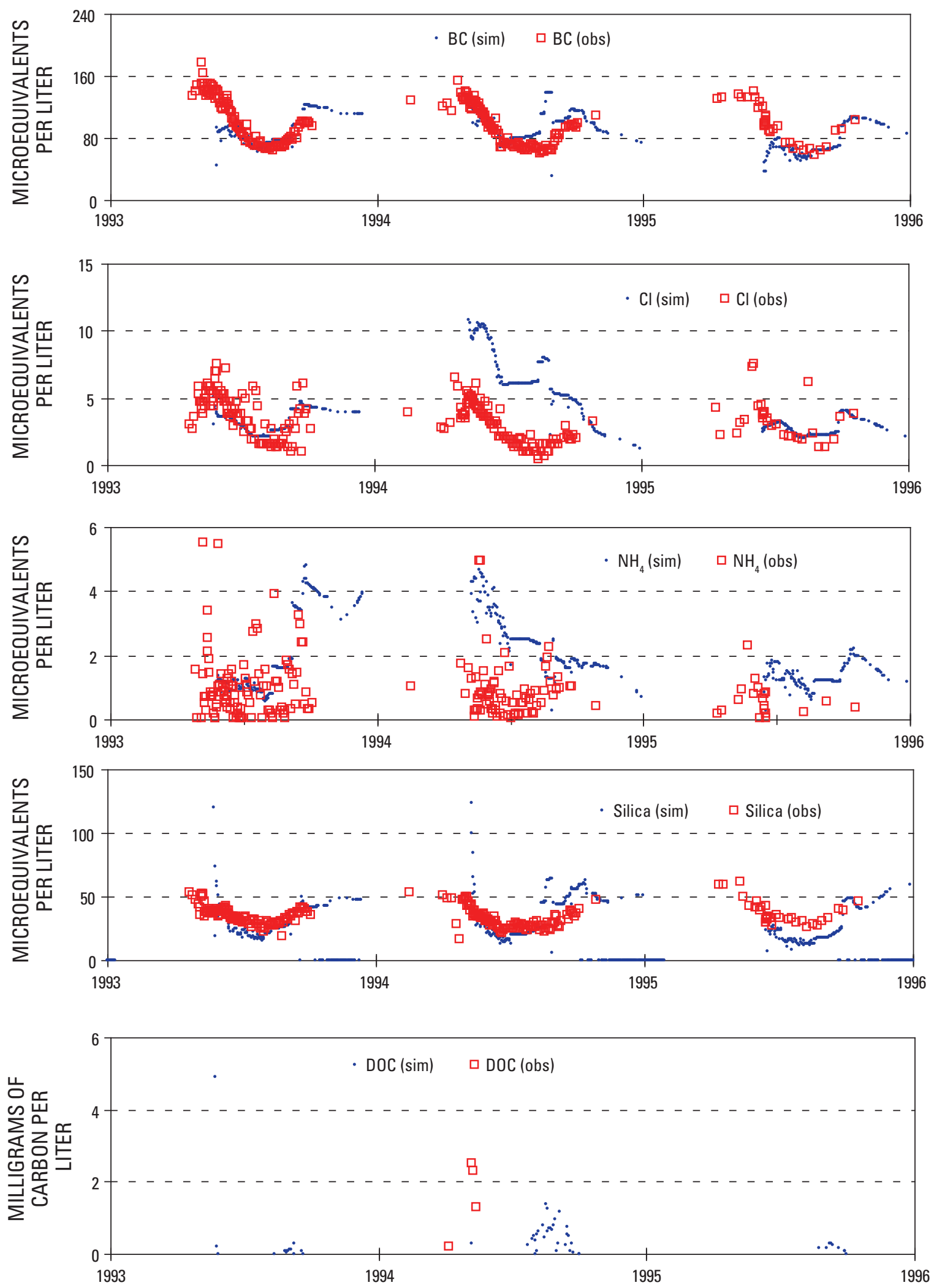

Figure 6.4. Simulated (sim) and observed (obs) daily discharge and stream chemistry for Andrews Creek watershed, years 1993-1995 (x axis). Simulated concentrations are not shown for days when simulated discharge was extremely low, less than $0.01 \mathrm{~cm} \mathrm{day}^{-1}$. Measured DOC was not available during this time period.-Continued 

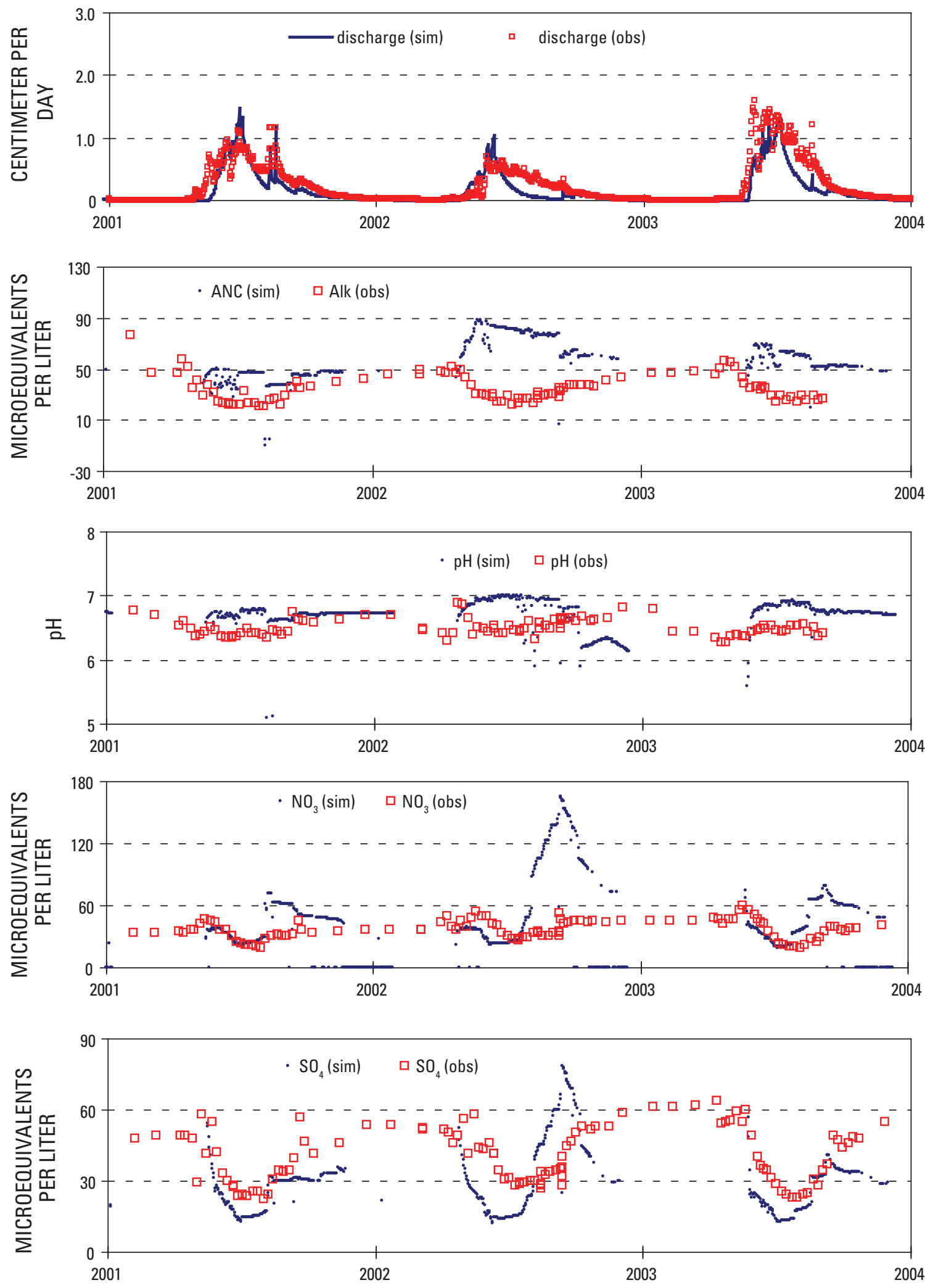

Figure 6.5. Simulated (sim) and observed (obs) daily discharge and stream chemistry for Andrews Creek watershed, years 2001-2003 (x axis). Simulated concentrations are not shown for days when simulated discharge was low, less than $0.01 \mathrm{~cm} \mathrm{day}^{-1}$. 

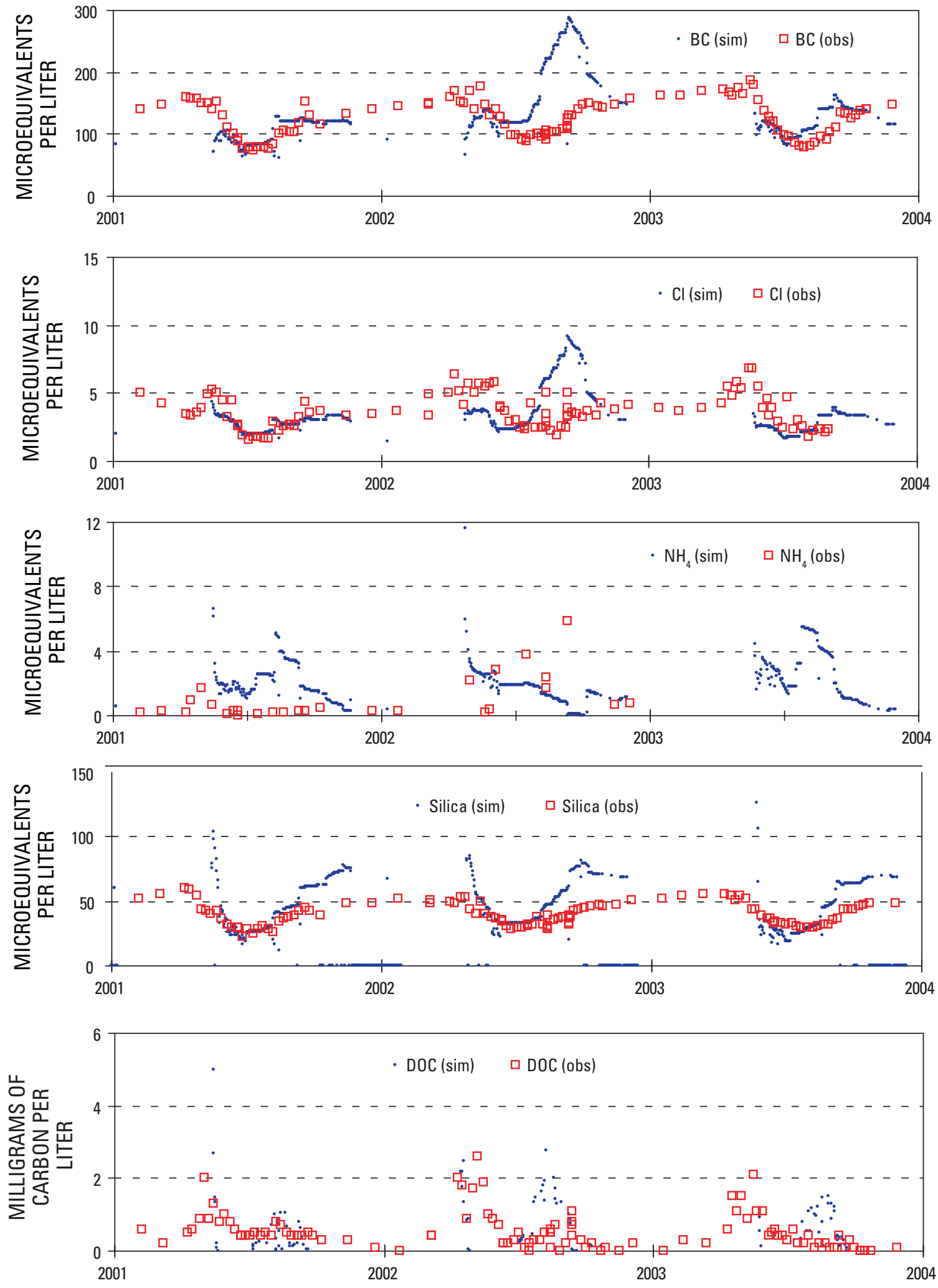

Figure 6.5. Simulated (sim) and observed (obs) daily discharge and stream chemistry for Andrews Creek watershed, years 2001-2003 (x axis). Simulated concentrations are not shown for days when simulated discharge was low, less than $0.01 \mathrm{~cm} \mathrm{day}^{-1}$. - Continued 
measurements of DOC in Andrews Creek may have made

this gap between simulated and measured annual DOC appear

larger than it actually was.

\section{Summary}

DayCent-Chem was able to replicate the seasonal and annual stream chemistry of an alpine catchment, Andrews Creek in Rocky Mountain National Park. Additionally, model estimates of net primary production, biomass, soil organic matter, and net mineralization rates for alpine tundra and subalpine forest were close to measurements.

The contributions of separate bedrock/talus and tundra simulations were aerially weighted. The combined run produced better results than bedrock/talus or tundra simulations alone. Simulated stream concentrations of many solutes matched well with observations when the model accurately predicted daily and annual discharge. The model had some difficulty accurately portraying some stream solutes during winter low flow.

DayCent-Chem replicated seasonal and annual stream chemistry and discharge for Andrews Creek in years with abundant precipitation. In warm, dry years, especially those after 1997, the simulated discharge was lower than actual discharge and solutes were more concentrated than measured values. The discrepancy appears to have more to do with melting of permanent ice in Loch Vale, a function the model does not perform, than model performance. Streamflow in Andrews Creek is generally 70-80 percent of measured annual precipitation, with the remainder lost via evapotranspiration and sublimation (Clow and others, 2003). From 1997 to 2001 the measured discharge:precipitation ratio ranged 87-101 percent and was 114 percent in 2003. Summer air temperatures in Loch Vale have been the warmest on record since 1997, so while these were years of low precipitation inputs, they were also years with temperatures high enough to raise the permafrost line and melt ice in rock and ice glaciers and permafrost (Clow and others, 2003).

Simulated stream chemistry was sensitive to the model's plant and biological soil processes. Although the tundra simulation contributed only 11 percent to the combined run, modeling plant and soil processes of tundra improved the model's ability to estimate daily runoff and seasonal stream nitrate concentrations. 


\section{Niwot Ridge Long-Term Ecological Research Site, Green Lakes Valley, Colorado}

\section{Site Description}

Niwot Ridge LTER (NWT) is located approximately $35 \mathrm{~km}$ west of Boulder, Colo., with the entire study site lying above 3,000 $\mathrm{m}$ in elevation (fig. 7.1). The 225-ha upper Green Lakes Valley is the study watershed and ranges from the Continental Divide to the outlet at Green Lake 4 (GL4). The watershed includes the 9-ha Arikaree Glacier, extensive alpine tundra, alpine lakes, and a variety of glacial landforms, including moraines, talus slopes, rock glaciers, patterned ground, and permafrost (table 7.1). The bedrock of the upper Green Lakes Valley is primarily composed of Precambrian schists, gneisses, and the Silver Plume quartz monzonite (Wallace, 1967).

Niwot Ridge is a snowmelt-dominated system where approximately 80 percent of annual precipitation enters as snow. Flow paths of water to GL4 have been studied using a multiple component end-member mixing model (Liu and others, 2004). From mid-May until early June, snowmelt water infiltrates the soil, but stream discharge is predominantly composed of old water and baseflow. From early June until
mid-July the hydrograph rises steeply and streamflow comes from multiple sources, including saturation excess overland flow, subsurface flow, and baseflow. Old water displaced from soil and groundwater by new water from snowmelt also enters the stream. Talus waters also contribute to streamflow. Snowmelt has lower solute concentrations than soil and groundwater and dilutes solute concentrations such that minimum concentrations occur just after peak discharge. From mid-July until late September, on the recession limb of the hydrograph, talus water increasingly contributes to streamflow, along with baseflow from fractured bedrock. Baseflow dominates by the end of this period (Liu and others, 2004).

\section{Methods}

\section{Climate and Hydrology}

Meteorological and streamflow data were obtained from the Niwot Ridge LTER online database (http://culter.colorado.

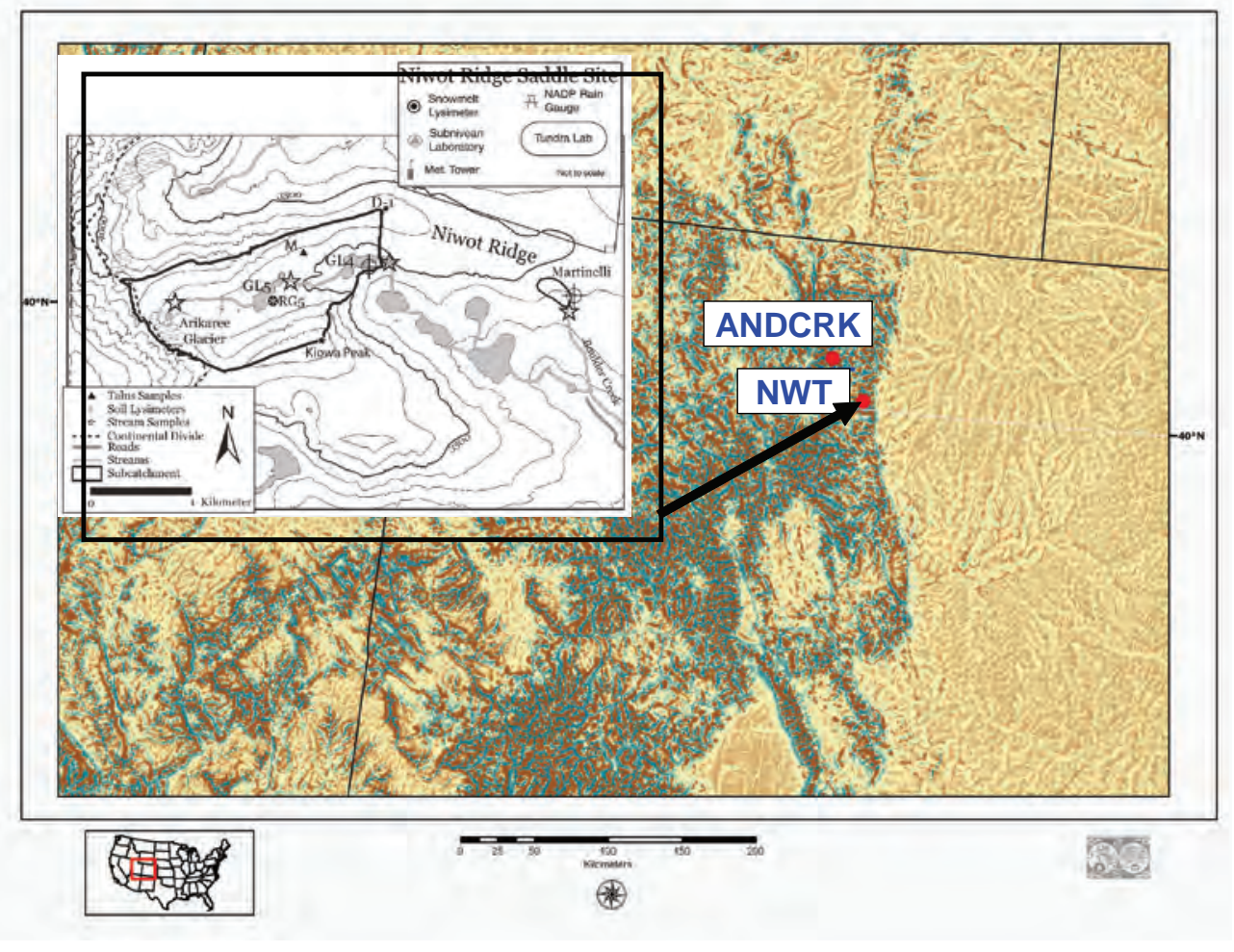

Figure 7.1. Niwot Ridge LTER is located approximately 35 kilometers west of Boulder, Colorado. The upper Green Lakes Valley is the study watershed and ranges from the Continental Divide to the outlet at Green Lake 4 (GL4). Andrews Creek watershed (ANDCRK) in Rocky Mountain National Park is about 30 kilometers to the northwest (see Chapter 6). 
Table 7.1. Characteristics of the Green Lakes Valley catchment near Niwot Ridge LTER, Colorado.

\begin{tabular}{|c|c|}
\hline Site & Green Lakes Valley, Niwot Ridge LTER (NWT) \\
\hline Location & Colorado Front Range \\
\hline Catchment name & Green Lakes Valley \\
\hline Area (ha) & 225 \\
\hline Latitude, longitude & $40^{\circ} 03^{\prime},-105^{\circ} 23^{\prime}$ \\
\hline Outlet elevation (m.a.s.l.) & 3,515 at outlet of GL4 \\
\hline Highest elevation (m.a.s.l.) & 4,084 at Continental Divide \\
\hline Climate & Continental, high mountain \\
\hline Simulation years & 1989-2006 \\
\hline Mean (and std. dev.) annual temperature $\left({ }^{\circ} \mathrm{C}\right)$ & $-3.1(0.5)$ \\
\hline Mean (and std. dev.) annual precipitation ( $\left.\mathrm{cm} \mathrm{yr}^{-1}\right)$ & $124(16)$ \\
\hline Ecosystem type & Alpine tundra \\
\hline Vegetative cover (\%) & 20 (Caine, 1995) \\
\hline Dominant plant species & Alpine grasses \\
\hline Soil type & $\begin{array}{l}\text { Cryic entisols and inceptisols on hillslopes, with histosols on wetter sections of } \\
\text { valley floor (Williams and others, 2001) }\end{array}$ \\
\hline Surficial landforms & $\begin{array}{l}\text { Bedrock (29\%), talus (33\%), soil (29\%), lakes (5\%), glacier (4\%; Caine 1995). } \\
\text { Surficial material is Holocene-aged and has accumulated since deglaciation } \\
\text { 12,000 years ago. }\end{array}$ \\
\hline Bedrock mineralogy & $\begin{array}{l}\text { Granites and quartz monzonites w/ plagioclase, quartz, biotite, hornblende, mi- } \\
\text { crocrystalline calcite (Wallace, 1967) }\end{array}$ \\
\hline Recent disturbances & None; GLV is water source for city of Boulder, public access prohibited \\
\hline Anthropogenic influences & $\begin{array}{l}\text { Adjacent to Front Range urban corridor, and nearby agriculture, feedlots; climate } \\
\text { change }\end{array}$ \\
\hline
\end{tabular}

edu/NWT/data/datmanaccess.html, accessed February 2009). Daily meteorological data from weather station D-1 (3,743 m) were used to drive the model. From 1989 through 2006, mean annual temperature at NWT was -3.1 (std. dev. 0.5) ${ }^{\circ} \mathrm{C}$, and average annual precipitation was 124 (std. dev. 16) $\mathrm{cm} \mathrm{yr}^{-1}$. During this period, mean annual temperature increased 0.0215 ${ }^{\circ} \mathrm{C} \mathrm{yr}^{-1}$ (fig. 7.2).

Stream discharge data for GL4 were available for years 1989-2006. The highest precipitation months at NWT were January-April, and the lowest precipitation occurred during the months June-August. There was little flow at NWT for November-March, and the high flow occurred during the months with the least precipitation (fig. 7.3).

\section{Atmospheric Deposition}

Wet deposition concentration inputs to DayCent-Chem were measured at the NADP/NTN CO02 site (Niwot Saddle, $40.0547^{\circ},-105.5891^{\circ}$, elevation 3,520 m) (http://nadp.sws. uiuc.edu/, accessed February 2009). Dry deposition inputs were calculated from seasonally varying dry:wet ratios. Since no dry deposition measurements for NWT were available, these dry:wet deposition ratios were the same as those determined for nearby Andrews Creek watershed in Rocky Mountain National Park (elevation 3,200 to 4,000 m, approximately $30 \mathrm{~km}$ northwest of Niwot Ridge), but without any dry deposition of $\mathrm{K}$ and $\mathrm{Na}$ (table 7.2) (Hartman and others, 2007).

Annual volume-weighted mean (VWM) concentrations of $\mathrm{NH}_{4}$ and $\mathrm{NO}_{3}$ in precipitation increased slightly from 1989 to 2006, but there was no change in total (wet plus dry) $\mathrm{NH}_{4}$ and $\mathrm{NO}_{3}$ deposition (fig. 7.4). On the contrary, both concentrations of $\mathrm{SO}_{4}$ in precipitation and total $\mathrm{SO}_{4}$ deposition decreased over the same time period.

\section{Soil and Mineral Properties}

Prescribed mineral denudation rates for primary and secondary minerals were the same as those used in a previous modeling exercise for nearby Andrews Creek watershed (Hartman and others, 2007). Minerals could only dissolve except for kaolinite, which could precipitate or dissolve (table 7.3). The mineral reactions are summarized below. 


\section{A. NWT Monthly Temperature and Precipitation}

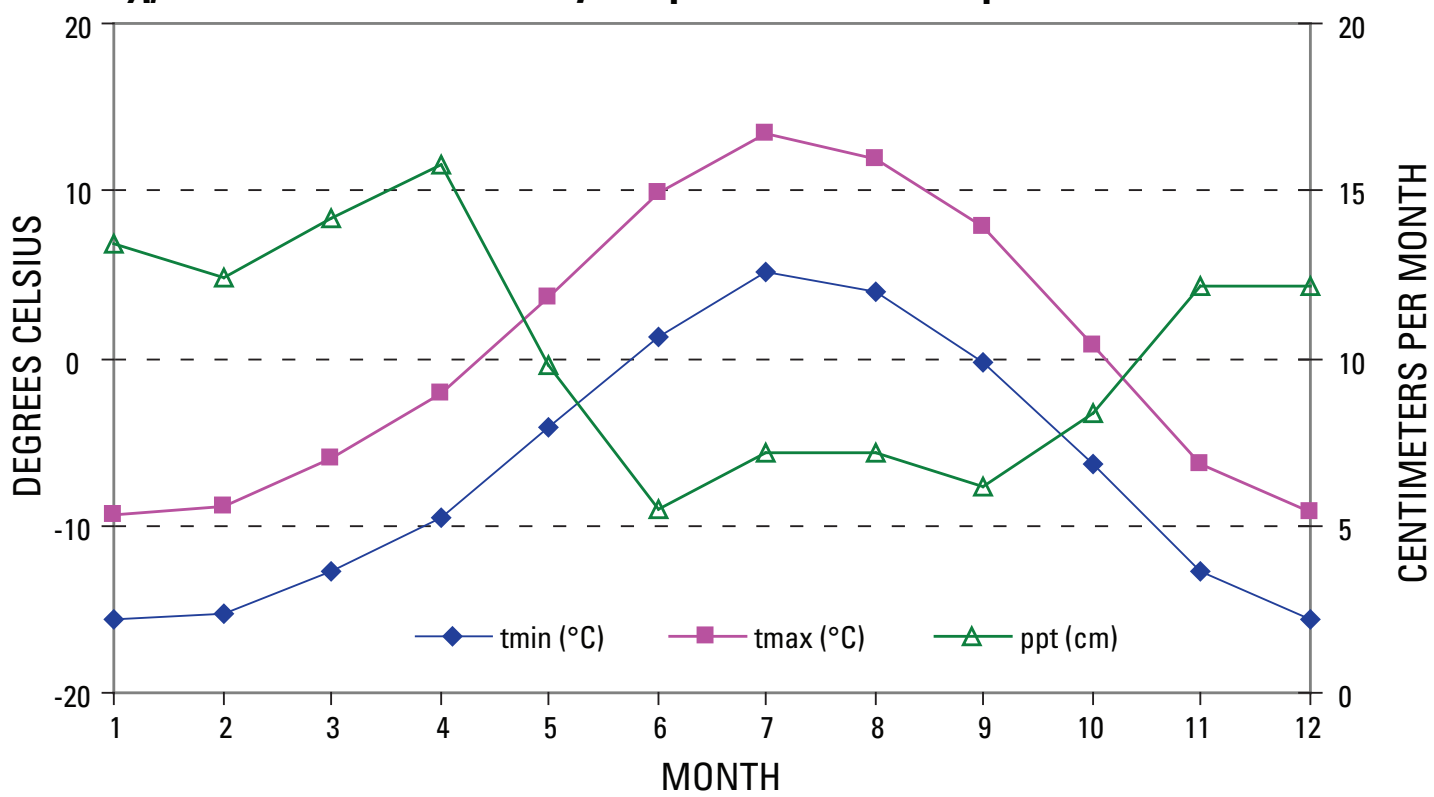

B.

Annual Temperature and Precipitation

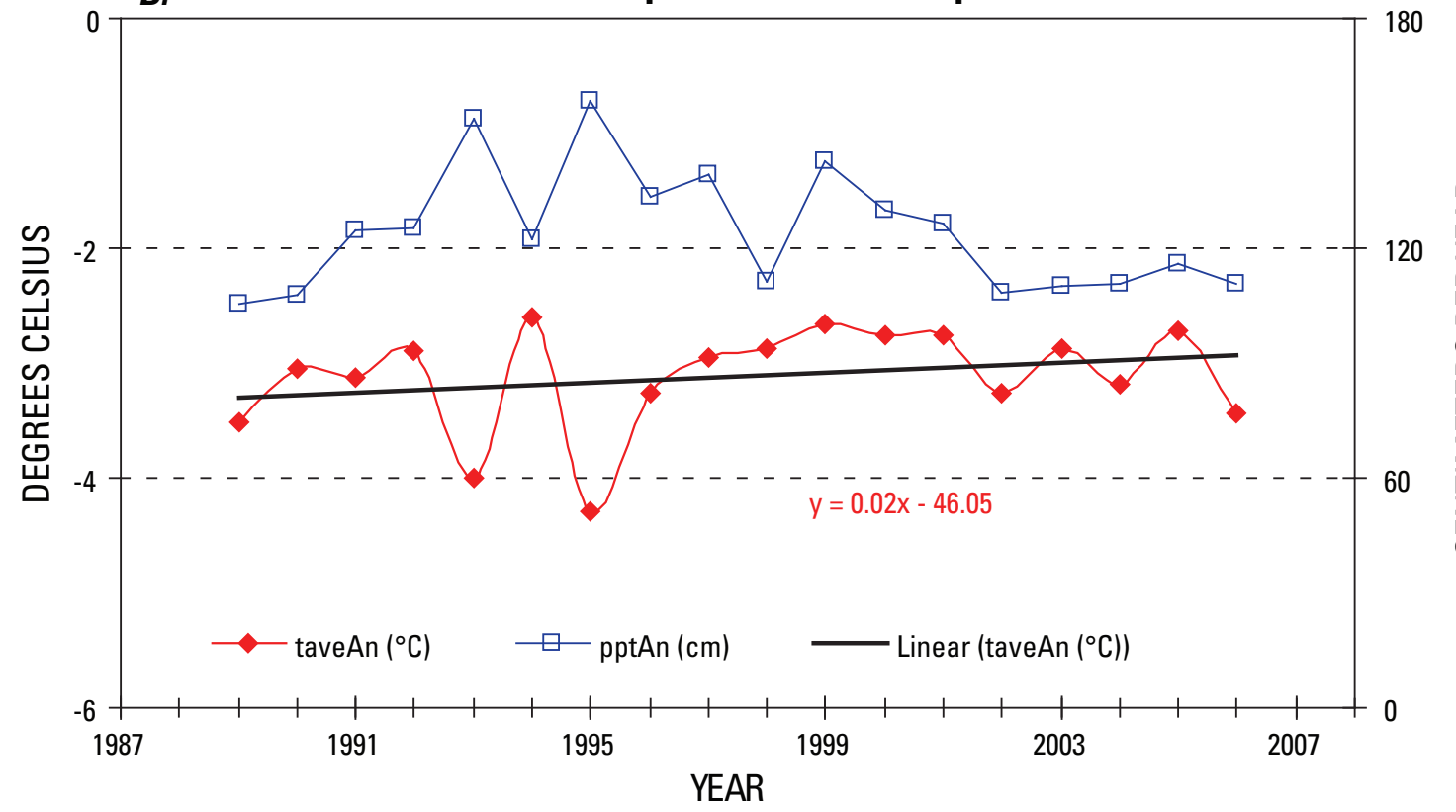

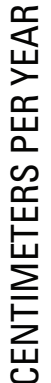

Figure 7.2. Meteorological statistics for weather station D1 at Niwot Ridge LTER. A, Monthly average minimum air temperatures (tmin), maximum air temperatures (tmax), and precipitation (ppt), years 1989-2006. $B$, The time series of mean annual air temperatures and annual precipitation, years 1989-2006. Mean annual temperature was -3.1 (std. dev. 0.5$)^{\circ} \mathrm{C}$ and average annual precipitation was 124 (std. 16) $\mathrm{cm} \mathrm{yr}^{-1}$. Average annual temperature increased $0.02{ }^{\circ} \mathrm{C} \mathrm{yr}^{-1}$. 


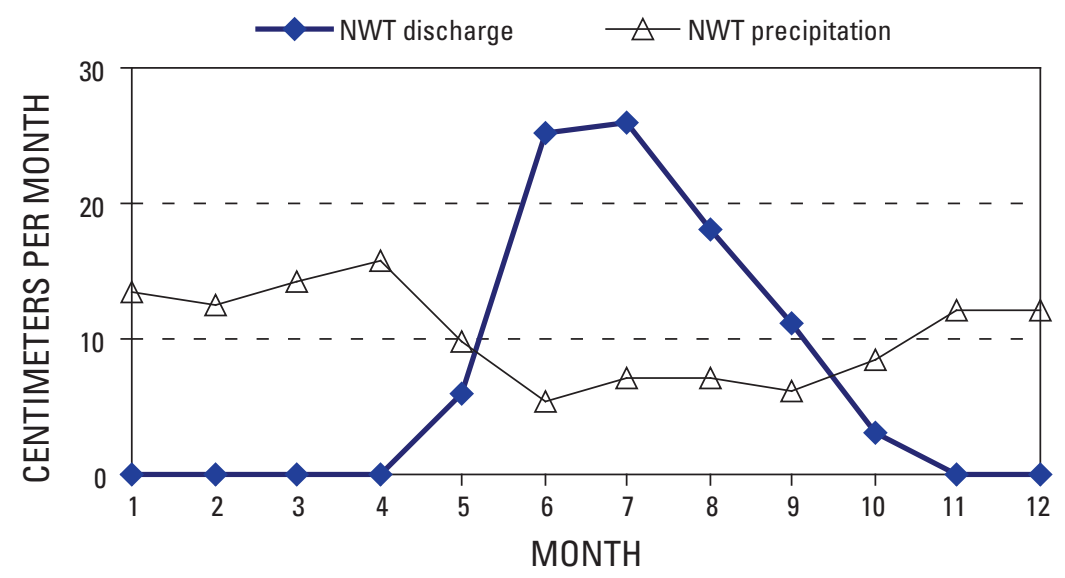

Figure 7.3. Relationship between average monthly precipitation measured at Niwot Ridge LTER, weather station D1, and discharge measured at GL4, years 1989-2006.

Table 7.2. Average annual wet and dry plus fog deposition inputs $\left(\mathrm{kg} \mathrm{ha}^{-1} \mathrm{yr}^{-1}\right)$ to the model over the 1989-2006 simulation period.

\begin{tabular}{lccc}
\hline & Wet & Dry + Fog & Total \\
\hline $\mathrm{Ca}$ & 3.00 & 6.01 & 9.00 \\
$\mathrm{Cl}$ & 1.10 & 0.12 & 1.21 \\
$\mathrm{~K}$ & 0.37 & 0.00 & 0.37 \\
$\mathrm{Mg}$ & 0.34 & 0.92 & 1.26 \\
$\mathrm{NH}_{4}-\mathrm{N}$ & 1.92 & 0.13 & 2.05 \\
$\mathrm{NO}_{3}-\mathrm{N}$ & 3.08 & 0.75 & 3.83 \\
$\mathrm{Na}$ & 0.84 & 0.00 & 0.84 \\
$\mathrm{SO}_{4}-\mathrm{S}$ & 2.68 & 0.70 & 3.39 \\
\hline
\end{tabular}

Albite: $\mathrm{NaAlSi}_{3} \mathrm{O}_{8}+8 \mathrm{H}_{2} \mathrm{O}=\mathrm{Na}^{+}+\mathrm{Al}(\mathrm{OH})_{4}^{-}+3 \mathrm{H}_{4} \mathrm{SiO}_{4}$ Anorthite: $\mathrm{CaAl} 2 \mathrm{Si}_{2} \mathrm{O}_{8}+8 \mathrm{H}_{2} \mathrm{O}=\mathrm{Ca}^{2+}+2 \mathrm{Al}(\mathrm{OH})_{4}^{-}$

$$
+2 \mathrm{H}_{4} \mathrm{SiO}_{4}
$$

Biotite: $\mathrm{KMg}_{1.5} \mathrm{Fe}_{1.5} \mathrm{AlSi}_{3} \mathrm{O}_{10}(\mathrm{OH})_{2}+6 \mathrm{H}^{+}+4 \mathrm{H}_{2} \mathrm{O}$

$$
=\mathrm{K}^{+}+1.5 \mathrm{Mg}^{2+}+1.5 \mathrm{Fe}^{2+}+\mathrm{Al}(\mathrm{OH})_{4}^{-}+3 \mathrm{H}_{4} \mathrm{SiO}_{4}
$$

Kaolinite: $\mathrm{Al}_{2} \mathrm{Si}_{2} \mathrm{O}_{5}(\mathrm{OH})_{4}+6 \mathrm{H}^{+}=\mathrm{H}_{2} \mathrm{O}+2 \mathrm{H}_{4} \mathrm{SiO}_{4}+2 \mathrm{Al}^{3+}$

Chlorite: $\mathrm{Mg}_{5} \mathrm{Al}_{2} \mathrm{Si}_{3} \mathrm{O}_{10}(\mathrm{OH})_{8}+16 \mathrm{H}^{+}$

$$
=5 \mathrm{Mg}^{2+}+2 \mathrm{Al}^{3+}+3 \mathrm{H}_{4} \mathrm{SiO}_{4}+6 \mathrm{H}_{2} \mathrm{O}
$$

Pyrite: $\mathrm{FeS}_{2}+2 \mathrm{H}^{+}+2 \mathrm{e}^{-}=\mathrm{Fe}^{2+}+2 \mathrm{HS}^{-}$

Calcite: $\mathrm{CaCO}_{3}=\mathrm{CO}_{3}{ }^{2-}+\mathrm{Ca}^{2+}$

Soil properties, including soil horizon depths, soil texture, and bulk density for Green Lakes Valley were derived from http://culter.colorado.edu/exec/.extracttoolA?soilprog. il (accessed February 2009) (table 7.4). Other soil properties, such as exchangeable cations, initially were set to those used for Andrews Creek (Hartman and others, 2007) then calibrated.

\section{Calibration and Validation}

DayCent-Chem was tuned in two steps. We first fit the model's ecological variables by comparing them against observations (table 7.5). We then calibrated stream discharge and chemistry against streamflow and surface water quality data from Green Lake 4 for years 1989-2000 (http:// culter.colorado.edu/NWT/data/datmanaccess.html, accessed February 2009). Results for years 2001-2006 were emergent from existing parameterization.

Stream chemistry was obtained from the GL4 outlet during open water conditions from June to October. Lake 

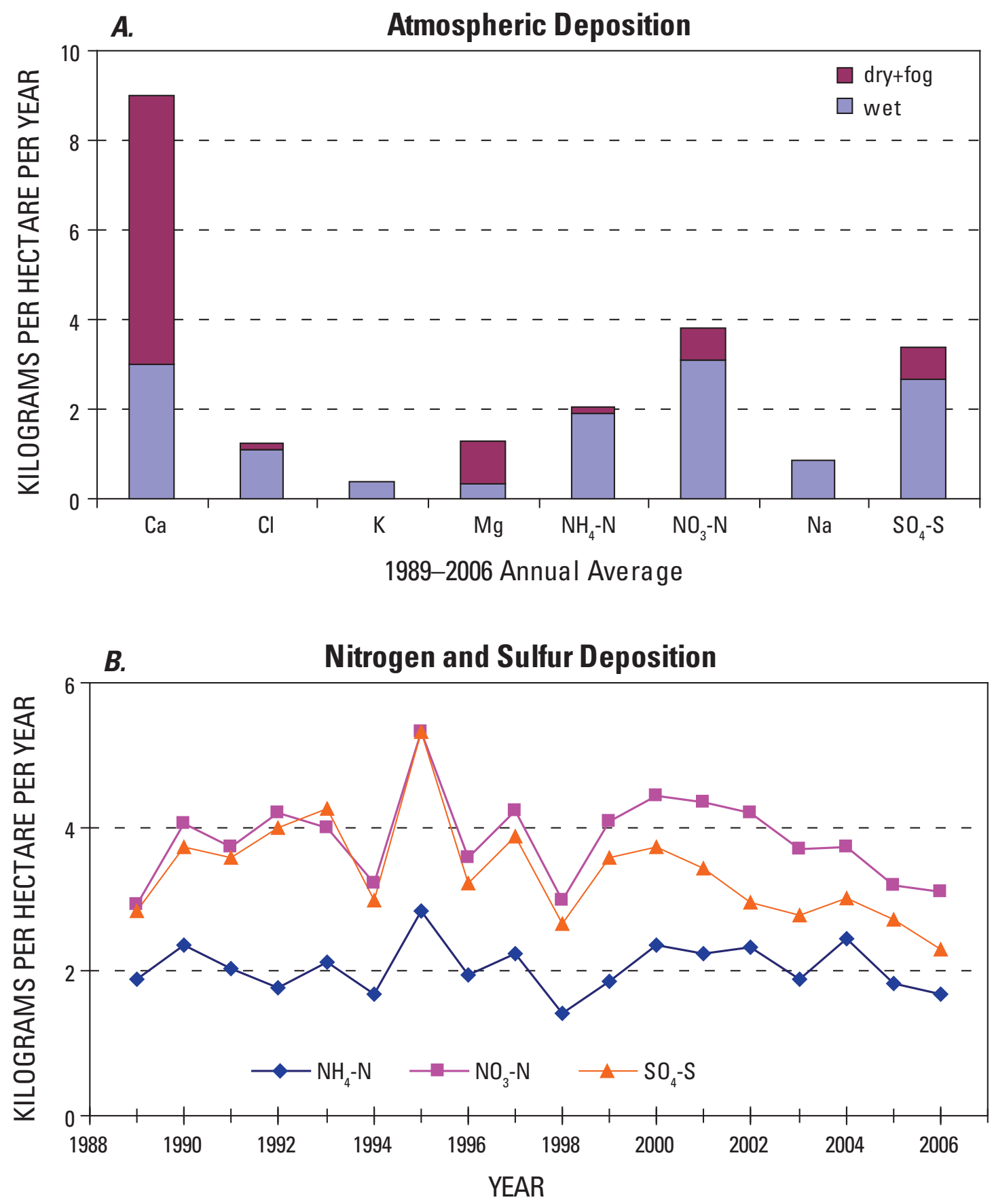

Figure 7.4. Deposition inputs to the model for Niwot Ridge LTER. $A$, The 1989-2006 average annual wet and dry deposition. $B$, The time series of $\mathrm{N}$ and $\mathrm{S}$ deposition over the simulation period. 
Table 7.3. Mineral phases and potential annual mineral denudation rates prescribed for the simulation. Mineral weathering rates were the same as those used in Hartman and others (2007). Minerals could only dissolve, except for kaolinite, which could both precipitate and dissolve.

\begin{tabular}{llc}
\hline $\begin{array}{c}\text { Mineral } \\
\text { phases }\end{array}$ & mol $\mathbf{~ m}^{-2} \mathbf{~ r ~}^{-1}$ & $\begin{array}{c}\mathbf{1}=\text { dissolve, } \\
\mathbf{0}=\text { precipitate } \\
\text { or dissolve }\end{array}$ \\
\hline Albite & 0.02169 & 1 \\
Anorthite & 0.00801 & 1 \\
Biotite & 0.0087 & 1 \\
Kaolinite & 0.0 & 0 \\
Chlorite & 0.0021 & 1 \\
Pyrite & 0.0036 & 1 \\
Calcite & 0.0129 & 1 \\
\hline
\end{tabular}

Table 7.4. Soil layer properties used for the simulation. Ksat is saturated hydraulic conductivity, and the mineral dissolution fraction (Minrl dissoln) is the fraction of total mineral dissolution that occurred in each layer. Wilting point and field capacity are expressed as volumetric soil water content. Exchangeable cations are expressed as milliequivalents per 100 grams of soil (meq/100 g). Total soil depth was $83 \mathrm{~cm}$ and organic soil made up the top $5 \mathrm{~cm}$.

\begin{tabular}{|c|c|c|c|c|c|c|c|c|c|}
\hline Layer & $\begin{array}{l}\text { Thickness } \\
\text { cm }\end{array}$ & $\begin{array}{l}\text { Sand } \\
\text { fraction }\end{array}$ & $\begin{array}{c}\text { Silt } \\
\text { fraction }\end{array}$ & $\begin{array}{l}\text { Clay } \\
\text { fraction }\end{array}$ & $\begin{array}{c}\text { Bulk } \\
\text { density } \\
\text { g cm }^{-3}\end{array}$ & $\begin{array}{l}\text { Wilting } \\
\text { point } \\
\text { fraction }\end{array}$ & $\begin{array}{c}\text { Field } \\
\text { capacity } \\
\text { fraction }\end{array}$ & $\begin{array}{c}\text { Ksat } \\
\text { cm } \\
\text { sec }^{-1}\end{array}$ & $\begin{array}{c}\text { Minrl } \\
\text { dissoln } \\
\text { fraction }\end{array}$ \\
\hline 0 & 3.0 & 0.509 & 0.285 & 0.206 & 1.66 & 0.1477 & 0.35 & 0.08 & 0.2 \\
\hline 1 & 11.0 & 0.487 & 0.337 & 0.176 & 0.97 & 0.1423 & 0.35 & 0.06 & 0.2 \\
\hline 2 & 23.0 & 0.484 & 0.321 & 0.195 & 1.39 & 0.1383 & 0.30 & 0.04 & 0.2 \\
\hline 3 & 6.0 & 0.581 & 0.329 & 0.09 & 1.45 & 0.1354 & 0.25 & 0.05 & 0.1 \\
\hline 4 & 40.0 & 0.6 & 0.35 & 0.05 & 1.5 & 0.1325 & 0.25 & 0.05 & 0.05 \\
\hline Layer & $\underset{\text { meq/100 g }}{\mathrm{CaX}_{2}}$ & $\begin{array}{c}\mathrm{MgX}_{2} \\
\mathrm{meq} / 100 \mathrm{~g}\end{array}$ & $\begin{array}{c}\mathrm{KX} \\
\mathrm{meq} / 100 \mathrm{~g}\end{array}$ & $\underset{\mathrm{meq} / 100 \mathrm{~g}}{\mathrm{NaX}}$ & $\begin{array}{c}\mathrm{AIOHX}_{2} \\
\mathrm{meq} / 100 \mathrm{~g}\end{array}$ & $\begin{array}{c}\mathrm{AlX}_{3} \\
\mathrm{meq} / 100 \mathrm{~g}\end{array}$ & $\begin{array}{c}\mathrm{FeX}_{2} \\
\mathrm{meq} / 100 \mathrm{~g}\end{array}$ & $\begin{array}{c}\mathrm{HX} \\
\mathrm{meq} / 100 \mathrm{~g}\end{array}$ & $\begin{array}{c}\mathrm{NH}_{4} \mathrm{X} \\
\mathrm{meq} / 100 \mathrm{~g}\end{array}$ \\
\hline 0 & 36.6 & 7.2 & 0.9 & 0.1 & 0 & 1.5 & 0.0 & 0.5 & 0.0 \\
\hline 1 & 13.0 & 3.0 & 0.2 & 0.1 & 0 & 5.1 & 0.0 & 0.5 & 0.0 \\
\hline 2 & 4.8 & 2.2 & 0.1 & 0.1 & 0 & 12.6 & 0.0 & 0.2 & 0.0 \\
\hline 3 & 4.8 & 2.2 & 0.1 & 0.1 & 0 & 12.6 & 0.0 & 0.2 & 0.0 \\
\hline 4 & 4.8 & 2.2 & 0.1 & 0.1 & 0 & 12.6 & 0.0 & 0.2 & 0.0 \\
\hline
\end{tabular}


Table 7.5. Simulated (1990-2006) and measured ecological variables and input/output fluxes. Standard deviations are shown in parentheses and represent interannual variation for annual fluxes and monthly variations for state variables. NPP = net primary production; NEP = net ecosystem production; Rh = heterotrophic respiration; $\mathrm{PET}=$ potential evapotranspiration; $\mathrm{AET}=$ actual evapotranspiration; DOC = dissolved organic carbon. To convert units reported by data sources, it was assumed that $2.25 \mathrm{~g}$ biomass equals 1 gram $C$.

\begin{tabular}{|c|c|c|c|}
\hline NPP, NEP, and litterfall & Simulated & Measured & Data source \\
\hline $\operatorname{NPP}\left(\mathrm{g} \mathrm{C} \mathrm{m}^{-2} \mathrm{yr}^{-1}\right)$ & $109(23)$ & 149-219 & (Bowman and Fisk, 2001) \\
\hline NPP above-ground & $51(10)$ & $44-135$ & (Bowman and Fisk, 2001) \\
\hline NPP below-ground & $58(15)$ & & \\
\hline $\operatorname{NEP}\left(\mathrm{g} \mathrm{C} \mathrm{m}^{-2} \mathrm{yr}^{-1}\right)$ & $-4(9)$ & & \\
\hline $\mathrm{Rh}\left(\mathrm{gC} \mathrm{m}^{-2} \mathrm{yr}^{-1}\right)$ & $113(27)$ & & \\
\hline $\begin{array}{l}\text { Litterfall, above- and below- } \\
\text { ground }\left(\mathrm{g} \mathrm{C} \mathrm{m}^{-2} \mathrm{yr}^{-1}\right)\end{array}$ & $106(11)$ & & \\
\hline Water and temperature & Simulated & Measured & Data source \\
\hline Annual temperature $\left({ }^{\circ} \mathrm{C}\right)$ & $-3.1(0.5)$ & & \\
\hline Precipitation $\left(\mathrm{cm} \mathrm{yr}^{-1}\right)$ & $125(16)$ & & \\
\hline Snow (\%) & $84 \%(4 \%)$ & & \\
\hline Rain (\%) & $16 \%$ & & \\
\hline $\operatorname{AET}\left(\mathrm{cm} \mathrm{yr}^{-1}\right)$ & 37 (6), 30\% of precipitation & & \\
\hline $\operatorname{PET}\left(\mathrm{cm} \mathrm{yr}^{-1}\right)$ & 26 (4) (not including sublimation) & & \\
\hline Outflow $\left(\mathrm{cm} \mathrm{yr}^{-1}\right)$ & 88 (13), $70 \%$ & & \\
\hline Carbon pools & Simulated & Measured & Data source \\
\hline Total ecosystem $\left(\mathrm{g} \mathrm{C} \mathrm{m}^{-2}\right)$ & 9,032 (18) & & \\
\hline Herbaceous shoots $\left(\mathrm{g} \mathrm{C} \mathrm{m}^{-2}\right)$ & 30-67 (peaks) & $60-117$ & (Bowman and Fisk, 2001) \\
\hline Herbaceous roots $\left(\mathrm{g} \mathrm{C} \mathrm{m}^{-2}\right)$ & $573(21)$ & 225-929 & (Bowman and Fisk, 2001) \\
\hline Soil organic matter $\left(\mathrm{g} \mathrm{C} \mathrm{m}^{-2}\right)$ & $7,446(24)$ & $6,700,13,000$ & $\begin{array}{l}\text { (Conley and others, 2000), (Seast- } \\
\text { edt, 2001) }\end{array}$ \\
\hline Litter above-ground $\left(\mathrm{g} \mathrm{C} \mathrm{m}^{-2}\right)$ & $1,006(23)$ & & \\
\hline Nitrogen pools & Simulated & Measured & Data source \\
\hline Total ecosystem $\left(\mathrm{g} \mathrm{N} \mathrm{m}^{-2}\right)$ & $390(0.5)$ & & \\
\hline Herbaceous shoots $\left(\mathrm{g} \mathrm{N} \mathrm{m}^{-2}\right.$ ) & $0.4(0.8)$ & & \\
\hline Herbaceous fine Roots $\left(\mathrm{g} \mathrm{N} \mathrm{m}^{-2}\right)$ & $12(0.3)$ & & \\
\hline Soil organic matter ( $\mathrm{g} \mathrm{N} \mathrm{m}^{-2}$ ) & $353(0.3)$ & & \\
\hline Litter above-ground ( $\mathrm{g} \mathrm{N} \mathrm{m}^{-2}$ ) & $23(0.4)$ & & \\
\hline Soil mineral $\mathrm{N}\left(\mathrm{g} \mathrm{N} \mathrm{m}^{-2}\right)$ & $0.25(0.11)$ & & \\
\hline N,P,S inputs & Simulated & Measured & Data source \\
\hline $\mathrm{N}$ deposition $\left(\mathrm{g} \mathrm{N} \mathrm{m}^{-2} \mathrm{yr}^{-1}\right)$ & $0.59(0.09)$ & 0.66 & \\
\hline Wet & 0.5 & & NADP site CO02 \\
\hline Dry + fog & 0.09 & & $\begin{array}{l}\text { CASTNET ROM406 with adjust- } \\
\text { ments like RMNP (Hartman and } \\
\text { others, 2007) }\end{array}$ \\
\hline $\mathrm{S}$ deposition $\left(\mathrm{g} \mathrm{S} \mathrm{m}^{-2} \mathrm{yr}^{-1}\right)$ & $0.34(0.07)$ & 1.08 & \\
\hline Wet & 0.27 & & NADP site CO02 \\
\hline
\end{tabular}


Table 7.5. Simulated (1990-2006) and measured ecological variables and input/output fluxes. Standard deviations are shown in parentheses and represent interannual variation for annual fluxes and monthly variations for state variables. NPP = net primary production; NEP = net ecosystem production; $\mathrm{Rh}=$ heterotrophic respiration; $\mathrm{PET}=$ potential evapotranspiration; $\mathrm{AET}=$ actual evapotranspiration; DOC = dissolved organic carbon. To convert units reported by data sources, it was assumed that $2.25 \mathrm{~g}$ biomass equals 1 gram C.-Continued

\begin{tabular}{|c|c|c|c|}
\hline N,P,S inputs & Simulated & Measured & Data source \\
\hline Dry + fog & 0.07 & & $\begin{array}{l}\text { CASTNET ROM406 with adjust- } \\
\text { ments like RMNP (Hartman and } \\
\text { others, 2007) }\end{array}$ \\
\hline C,N,P,S outputs & Simulated & Measured & Data source \\
\hline $\mathrm{N}$ export $\left(\mathrm{g} \mathrm{N} \mathrm{m}^{-2} \mathrm{yr}^{-1}\right)$ & $0.38(0.06)$ & & \\
\hline Inorganic & 0.36 & & \\
\hline Organic & 0.02 & & \\
\hline \multicolumn{4}{|l|}{$\mathrm{S}$ export $\left(\mathrm{g} \mathrm{S} \mathrm{m}^{-2} \mathrm{yr}^{-1}\right)$} \\
\hline \multicolumn{4}{|l|}{ Inorganic } \\
\hline \multicolumn{4}{|l|}{ Organic } \\
\hline P export ( $\mathrm{g} \mathrm{P} \mathrm{m}^{-2} \mathrm{yr}^{-1}$ ) & not simulated & & \\
\hline Inorganic & not simulated & & \\
\hline Organic & not simulated & & \\
\hline DOC export ( $\left.\mathrm{g} \mathrm{C} \mathrm{m}^{-2} \mathrm{yr}^{-1}\right)$ & $0.4(0.1)$ & & \\
\hline Trace gas flux $\left(\mathrm{g} \mathrm{N} \mathrm{m}^{-2} \mathrm{yr}^{-1}\right)$ & $0.16(0.02)$ & & \\
\hline $\mathrm{N}, \mathrm{P}, \mathrm{S}$ internal fluxes & Simulated & Measured & Data source \\
\hline $\mathrm{N}$ mineralization $\left(\mathrm{g} \mathrm{N} \mathrm{m}^{-2} \mathrm{yr}^{-1}\right)$ & $2.2(0.6)$ & $\sim 2.0$ & (Bowman, 1992) \\
\hline P mineralization ( $\left.\mathrm{g} \mathrm{P} \mathrm{m}^{-2} \mathrm{yr}^{-1}\right)$ & not simulated & & \\
\hline $\mathrm{S}$ mineralization $\left(\mathrm{g} \mathrm{S} \mathrm{m}^{-2} \mathrm{yr}^{-1}\right)$ & not simulated & & \\
\hline Gross nitrification $\left(\mathrm{g} \mathrm{N} \mathrm{m}^{-2} \mathrm{yr}^{-1}\right)$ & $0.44(0.09)$ & & \\
\hline $\mathrm{N}$ fixation $\left(\mathrm{g} \mathrm{N} \mathrm{m}^{-2} \mathrm{yr}^{-1}\right)$ & 0 & & \\
\hline $\mathrm{N}$ uptake (g N m${ }^{-2} \mathrm{yr}^{-1}$ ) & $2.3(0.6)$ & & \\
\hline $\mathrm{P}$ uptake ( $\left.\mathrm{g} \mathrm{P} \mathrm{m}^{-2} \mathrm{yr}^{-1}\right)$ & not simulated & & \\
\hline S uptake $\left(\mathrm{g} \mathrm{S} \mathrm{m}^{-2} \mathrm{yr}^{-1}\right)$ & not simulated & & \\
\hline
\end{tabular}


chemistry values were substituted during the winter months of the November-May period.

\section{Model Output}

\section{Ecological Variables}

The model showed that the snow-free growing season for NWT began in June or July and lasted 2 to 3 months. Simulated above-ground NPP, 51 (std. dev. 10) $\mathrm{g} \mathrm{C} \mathrm{m}^{-2} \mathrm{yr}^{-1}$, was on the low end of measured values of 44-135 $\mathrm{g} \mathrm{C} \mathrm{m}^{-2} \mathrm{yr}^{-1}$, whereas total NPP, 109 (std. dev. 23) $\mathrm{g} \mathrm{C} \mathrm{m}^{-2}$, was low compared with measured values of 149-219 $\mathrm{g} \mathrm{C} \mathrm{m}^{-2} \mathrm{yr}^{-1}$ (Bowman and Fisk, 2001) (table 7.5). Production rates for Green Lakes Valley may be lower than NPP measured at lower elevations in the tundra at Niwot Ridge because of the duration and amount of snow cover in this high elevation catchment. Simulated peak annual above-ground live biomass, 30-67 g C $\mathrm{m}^{-2}$, overlapped the lower range of measured values, $60-117 \mathrm{~g}$ $\mathrm{Cm}^{-2}$ (Bowman and Fisk, 2001), whereas below-ground live biomass, 573 (std. dev. 21) g C m${ }^{-2}$, was in the middle of the measured range, 225-929 g C m${ }^{-2}$ (Bowman and Fisk, 2001). The simulated above- to below-ground biomass ratio at the peak of the growing season ranged from 1:9 to 1:18, while measured ratios ranged from 1:3.7 to 1:12 (Bowman and Fisk, 2001). Simulated N-mineralization, 2.2 (std. dev. 0.6) g N $\mathrm{m}^{-2} \mathrm{yr}^{-1}$, was close to a previously measured value, $2.0 \mathrm{~g} \mathrm{~N}$ $\mathrm{m}^{-2} \mathrm{yr}^{-1}$ (Bowman, 1992), and simulated soil organic matter, 7,446 (std. dev. 24) $\mathrm{g} \mathrm{C} \mathrm{m}^{-2}$, was within the range of measured values: 6,700 $\mathrm{g} \mathrm{C} \mathrm{m}^{-2}$ (Seastedt, 2001) and 13,000 $\mathrm{g} \mathrm{C} \mathrm{m}^{-2}$ (Conley and others, 2000) (table 7.5).

Snowmelt releases $\mathrm{NO}_{3}$ from the snowpack and flushes it from the soil before the short summer growing season. DayCent-Chem reported that 89 percent of stream $\mathrm{N}$ flux was $\mathrm{NO}_{3}-\mathrm{N}$ and 5 percent was dissolved organic nitrogen (DON). The model suggested that ecosystem retention of atmospherically deposited $\mathrm{N}$ plus internal $\mathrm{N}$ fixation was 10 percent, but actual N-retention may be greater since the model overestimated stream $\mathrm{NO}_{3}$ concentrations. Measured stream $\mathrm{N}$ losses (including $\mathrm{NH}_{4}-\mathrm{N}, \mathrm{NO}_{3}-\mathrm{N}$, and DON) were $0.37 \mathrm{~g} \mathrm{~N} \mathrm{~m}^{-2}$ $\mathrm{yr}^{-1}$ (63 percent of $\mathrm{N}$ deposition). Calculated gaseous $\mathrm{N}$ loss from nitrification and denitrification $\left(\mathrm{N}_{2} \mathrm{O}, \mathrm{NO}_{\mathrm{x}}\right.$, and $\left.\mathrm{N}_{2}\right)$ were $0.16 \mathrm{~g} \mathrm{Nm}^{-2} \mathrm{yr}^{-1}$.

The model suggested that NWT stored the vast majority of carbon (82 percent) in soil organic matter (table 7.5). The ratio of ecosystem $\mathrm{C}$ to ecosystem $\mathrm{N}$ at NWT was about 23, and all litter inputs to the soil were nonwoody.

\section{Discharge}

Simulated daily discharge was predicted with an $\mathrm{R}^{2}$ of 0.47 for years 1989-2006. On average, the model correctly matched the timing of melt but underestimated flow in August and September (fig. 7.5). We show two periods of daily discharge and chemistry. Results from years 1993-1995 will be examined (when possible) for all sites in an inter-site model comparison (fig. 7.6). Years 1999-2006 cover a range of moisture conditions, including a period of below-normal precipitation (fig. 7.7). Water years 2000-2006 were dry with precipitation that was 84-96 percent of the 1990-2006 average (fig. 7.2B). The driest water years were 2001, 2004, and 2005. However, observed discharge did not decline commensurately with precipitation. From 1990-2006, total discharge averaged 73 percent of precipitation, but was 84 percent, 92 percent, and 103 percent of precipitation for water years 2001, 2003, and 2005 , respectively (figs. $7.8 B, C$ ). The discrepancy between simulated and measured discharge was largest for these years (2001, 2003, 2005) (fig. 7.8A), suggesting an additional source of water to the stream that was not included in the model.

\section{Stream Chemistry}

Simulated daily stream $\mathrm{pH}, \mathrm{Si}, \mathrm{Cl}$, and $\mathrm{DOC}$ were similar to measurements when streamflow was high, but not necessarily during the winter low-flow periods. The model did especially well in reproducing daily stream $\mathrm{SO}_{4}$ concentrations, except for some of the below-average precipitation years (2001-2005). The model was not able to reproduce the temporal dynamics of any base cations or ANC, and stream Ca was underestimated throughout the year while Na was overestimated. The model replicated the temporal dynamics and magnitude of stream $\mathrm{NO}_{3}$ concentrations for most early melt seasons (late spring to early summer), but it overestimated stream $\mathrm{NO}_{3}$ concentrations by as much as $25 \mu \mathrm{eq} \mathrm{L}^{-1}$ during the late summer.

\section{Nitrate and Ammonium}

Measured stream $\mathrm{NO}_{3}$ concentrations were as high as $70 \mu$ eq $\mathrm{L}^{-1}$ in May or June just before peak discharge and declined to about $5 \mu \mathrm{eq} \mathrm{L}^{-1}$ during the growing season. Model predictions for May through June were slightly greater than measured values, and the greatest discrepancy between measurements and predictions occurred primarily in July and August (figs. 7.5-7.7). The model did not capture the measured October increase in stream $\mathrm{NO}_{3}$ concentrations. Simulated annual VWM stream $\mathrm{NO}_{3}\left(27 \mu\right.$ eq $\left.\mathrm{L}^{-1}\right)$ was 67 percent greater than measurements (16 $\mu \mathrm{eq} \mathrm{L}^{-1}$; table 7.6$)$.

Both daily measurements and model predictions showed that stream $\mathrm{NH}_{4}$ concentrations ranged from 0 to $5 \mu \mathrm{eq} \mathrm{L}^{-1}$.

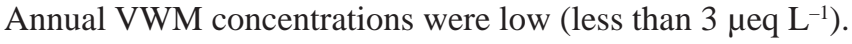
There were a few measurements at the onset of snowmelt between 1999 and 2005 when stream $\mathrm{NH}_{4}$ concentrations were between 20 and $50 \mu \mathrm{eq} \mathrm{L}^{-1}$. Though the model did not show these high $\mathrm{NH}_{4}$ concentrations, the vast majority of daily predictions were within the range measured (figs. 7.6, 7.7).

In-lake processing of $\mathrm{NO}_{3}$, such as uptake by biota or denitrification, may have affected measured stream chemistry 

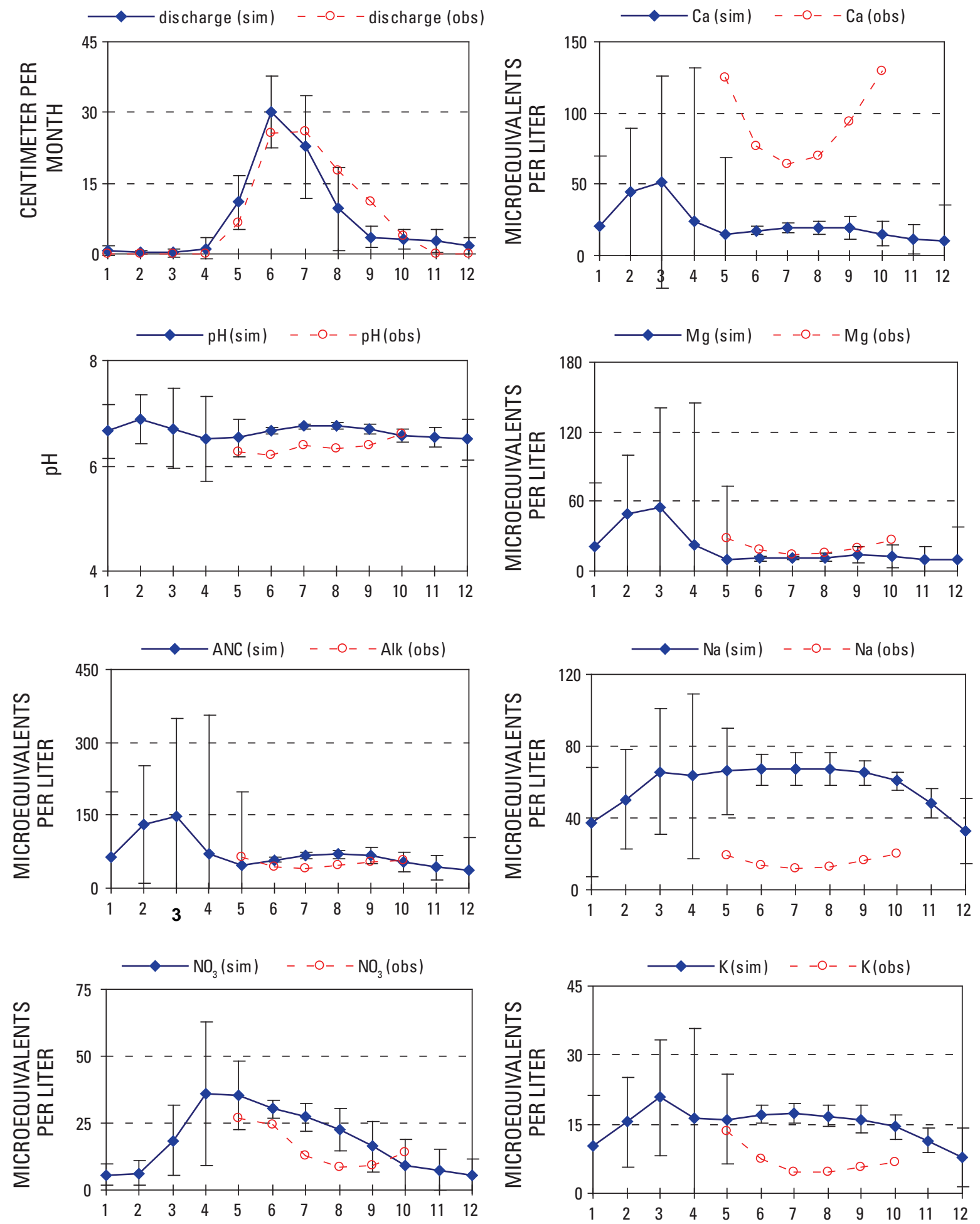

Figure 7.5. Simulated (sim) and observed (obs) discharge and volume-weighted mean (VWM) stream chemistry averaged by month (x axis) for GL4, Niwot Ridge LTER, years 1989-2006. The vertical bars on the simulated values represent plus and minus one standard deviation from the simulated mean. 

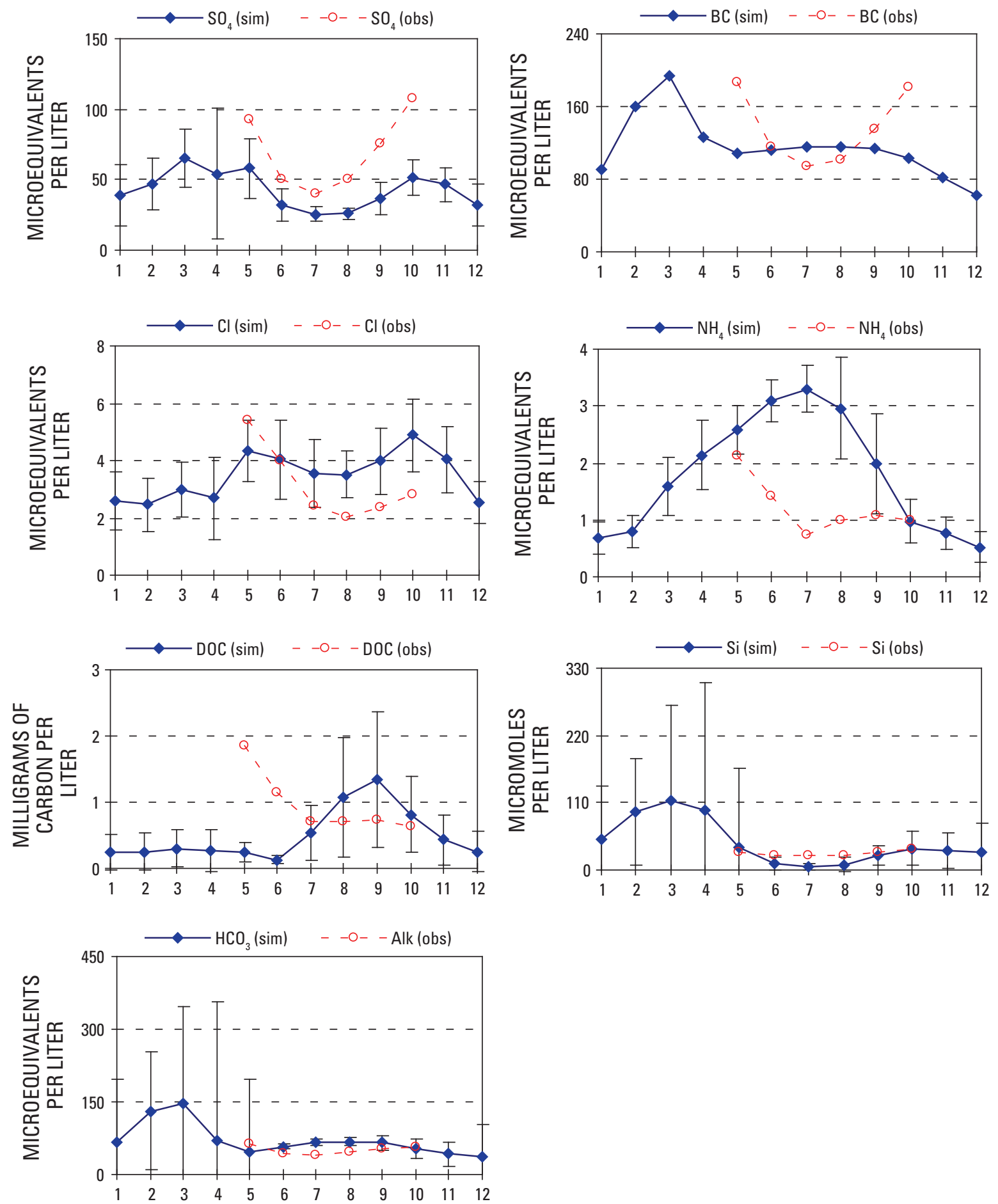

Figure 7.5. Simulated (sim) and observed (obs) discharge and volume-weighted mean (VWM) stream chemistry averaged by month (x axis) for GL4, Niwot Ridge LTER, years 1989-2006. The vertical bars on the simulated values represent plus and minus one standard deviation from the simulated mean.-Continued 

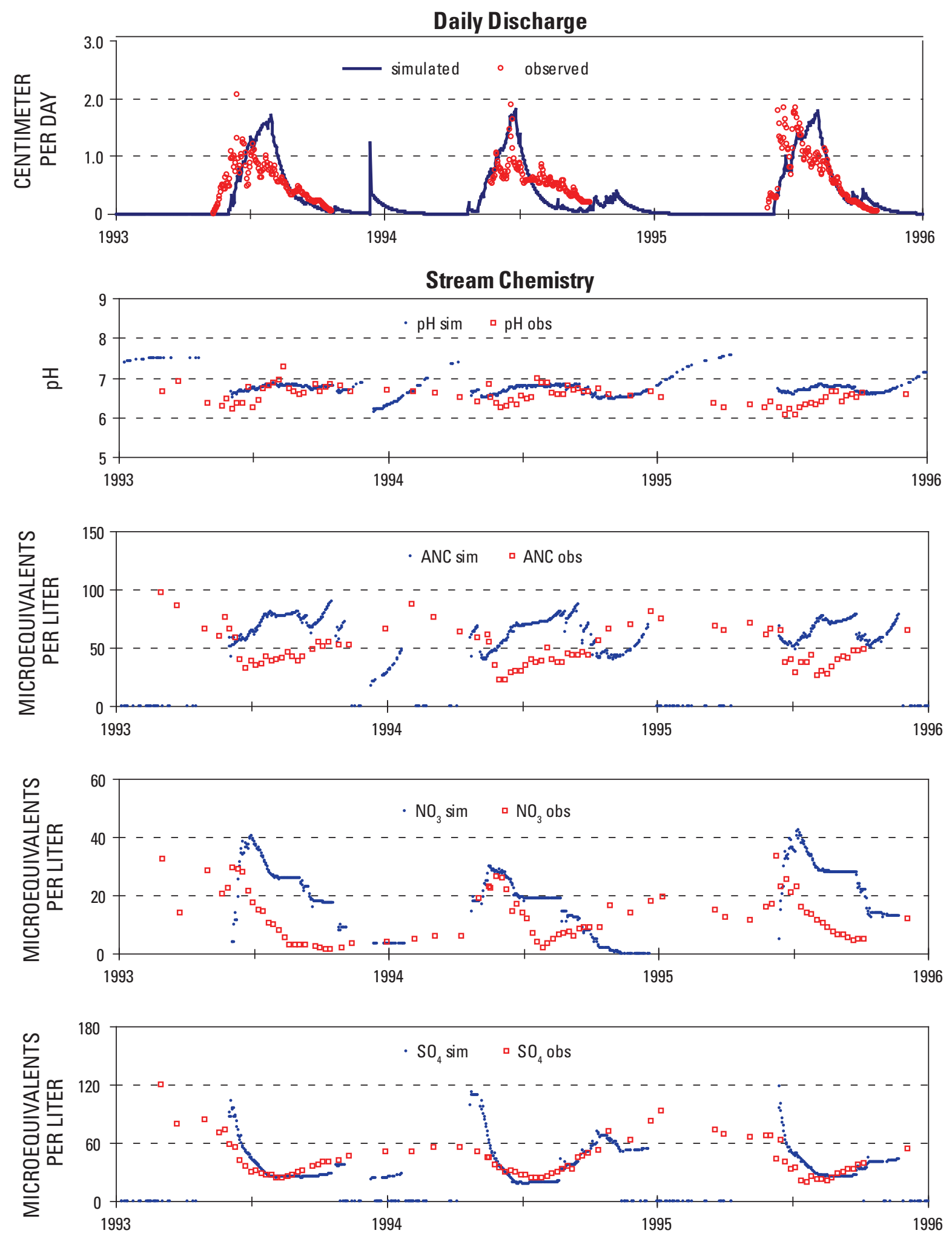

Figure 7.6. Simulated (sim) and observed (obs) daily discharge and stream chemistry for GL4, Niwot Ridge LTER, years 1993-1995. Measured DOC was not available, years 1993-1995. 

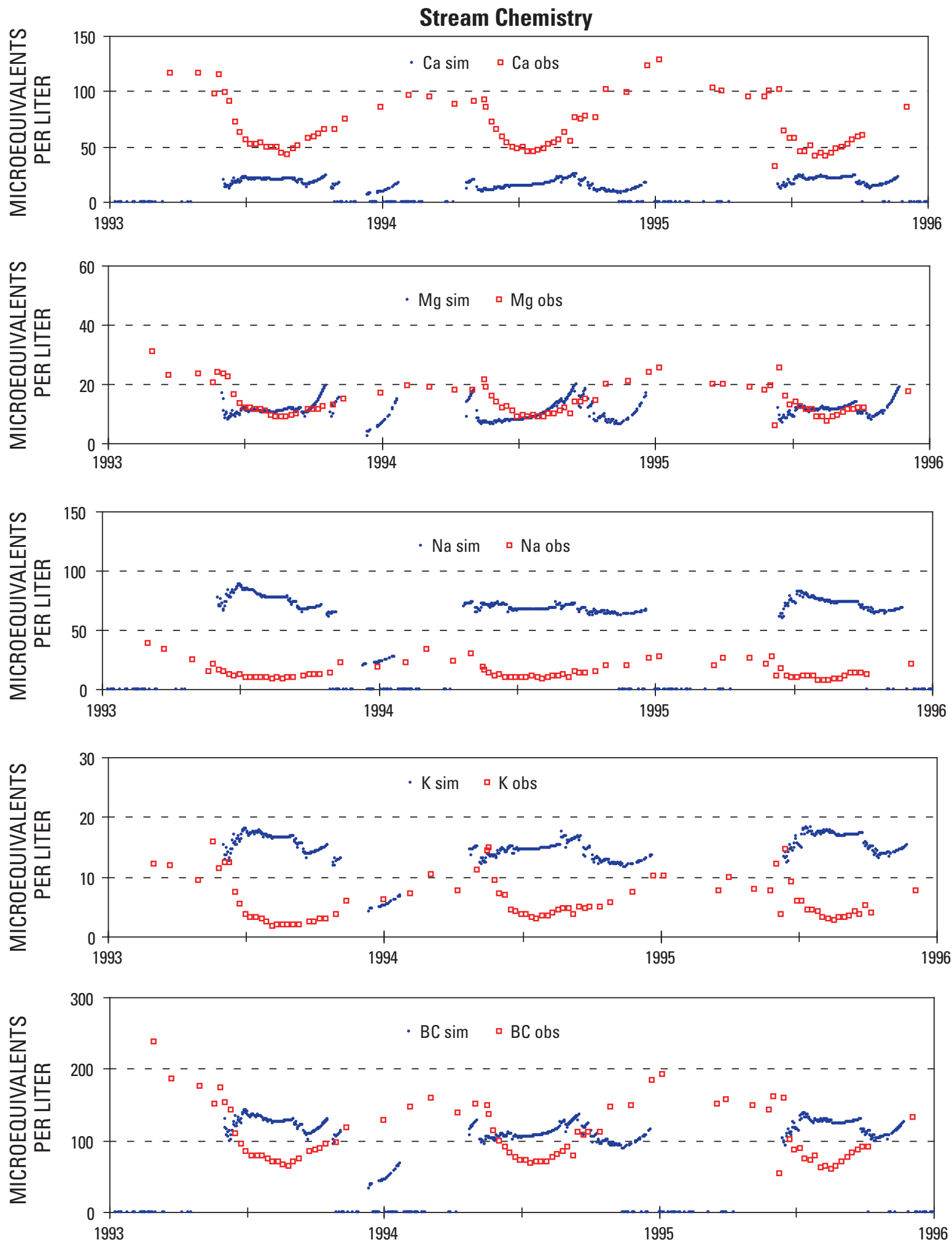

Figure 7.6. Simulated (sim) and observed (obs) daily discharge and stream chemistry for GL4, Niwot Ridge LTER, years 1993-1995. Measured DOC was not available, years 1993-1995. - Continued 

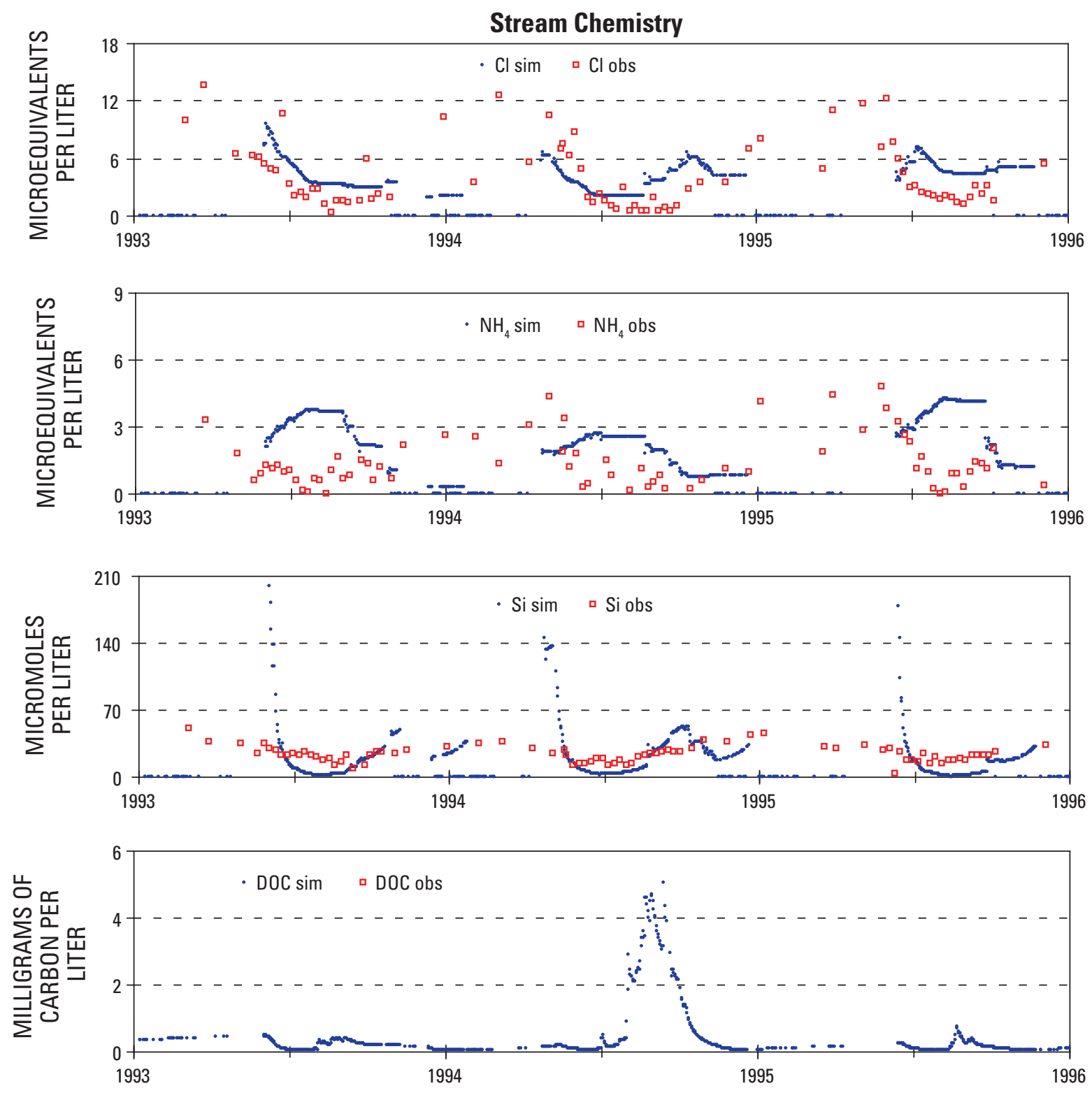

Figure 7.6. Simulated (sim) and observed (obs) daily discharge and stream chemistry for GL4, Niwot Ridge LTER, years 1993-1995. Measured DOC was not available, years 1993-1995.-Continued 


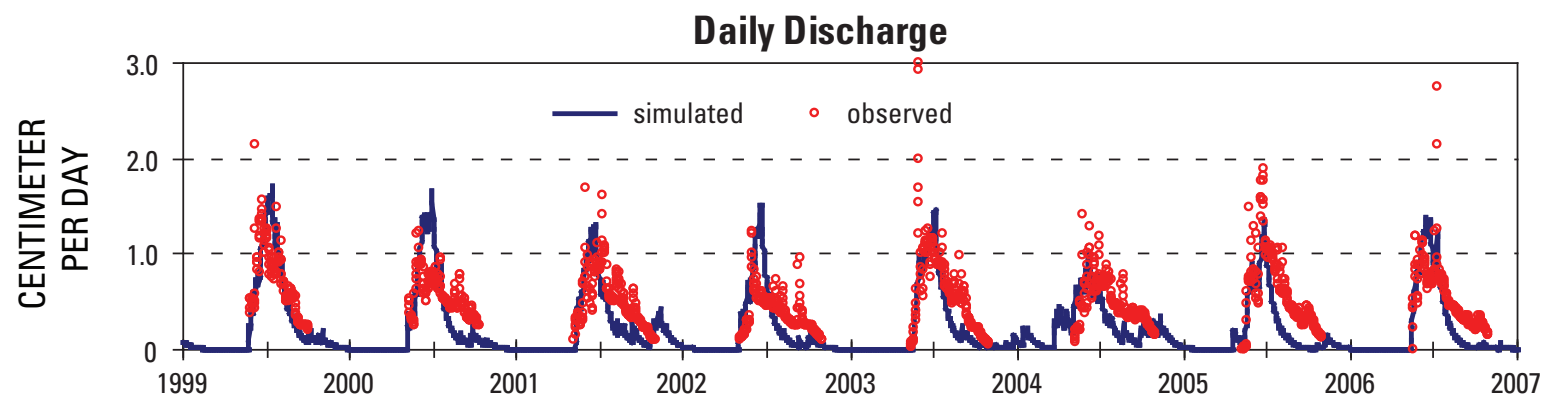

Stream Chemistry
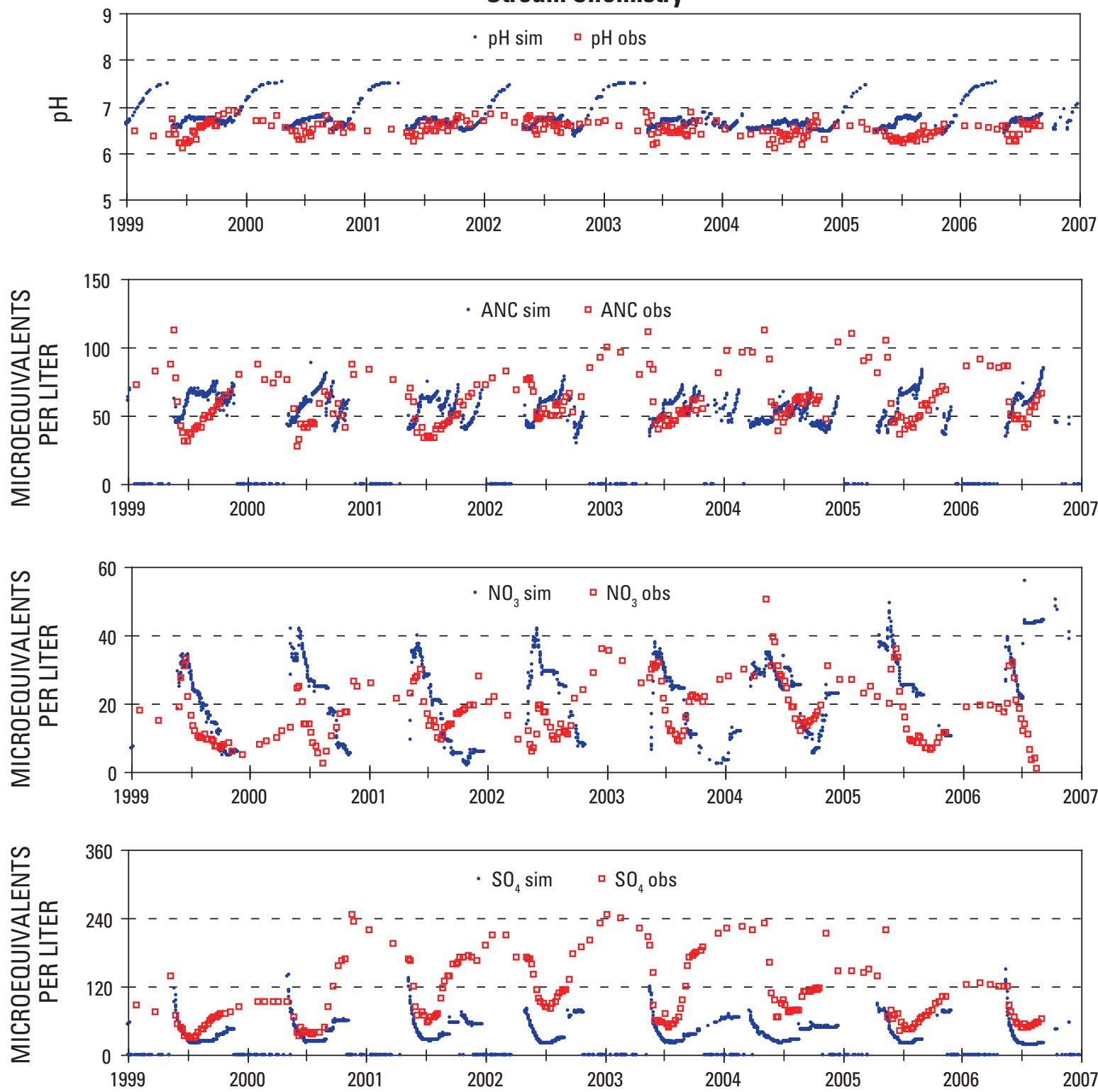

Figure 7.7. Simulated (sim) and observed (obs) daily discharge and stream chemistry for GL4, Niwot Ridge LTER, years 1999-2006. Lower-than-average precipitation occurred for years 2002-2006. 

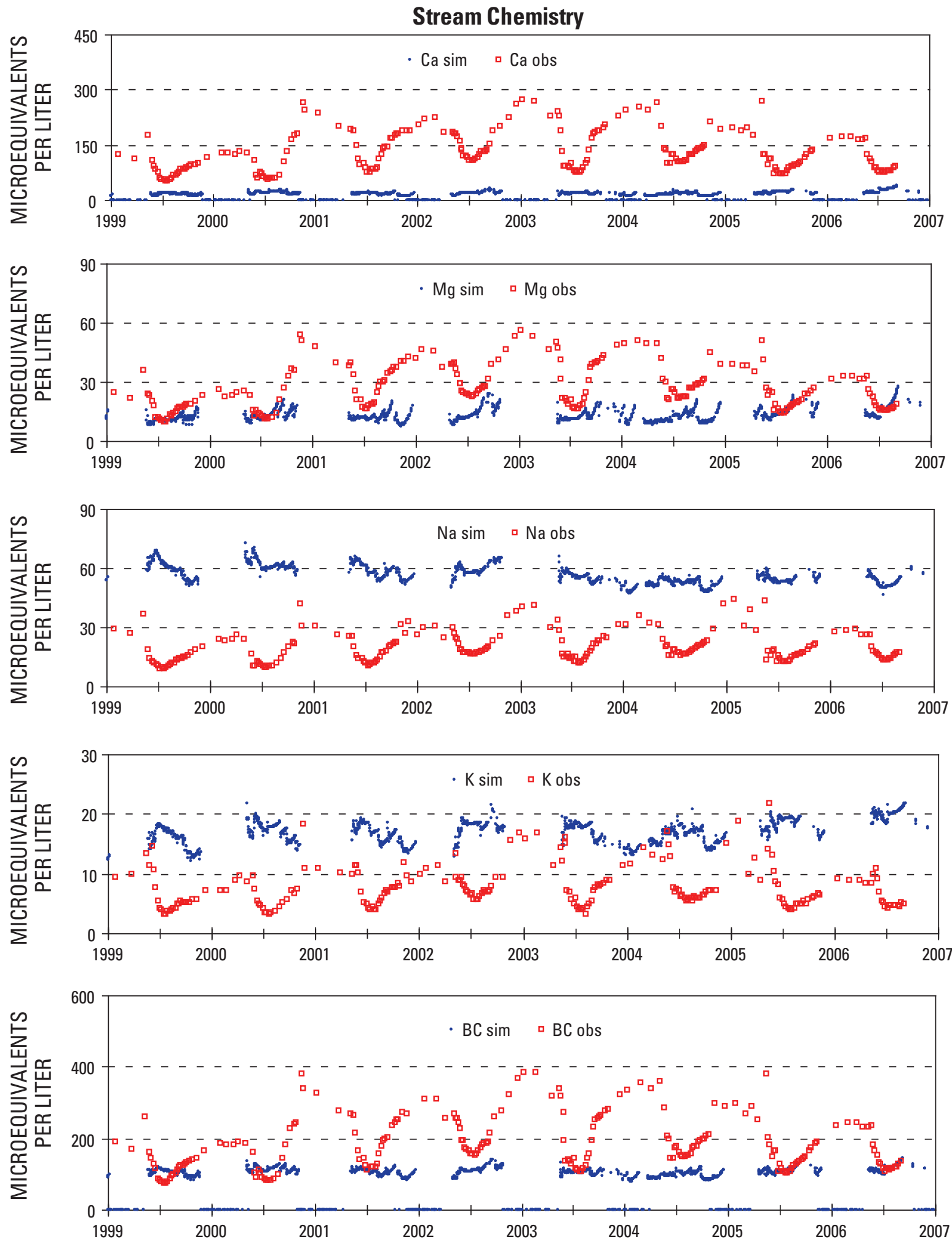

Figure 7.7. Simulated (sim) and observed (obs) daily discharge and stream chemistry for GL4, Niwot Ridge LTER, years 1999-2006. Lower-than-average precipitation occurred for years 2002-2006. - Continued 

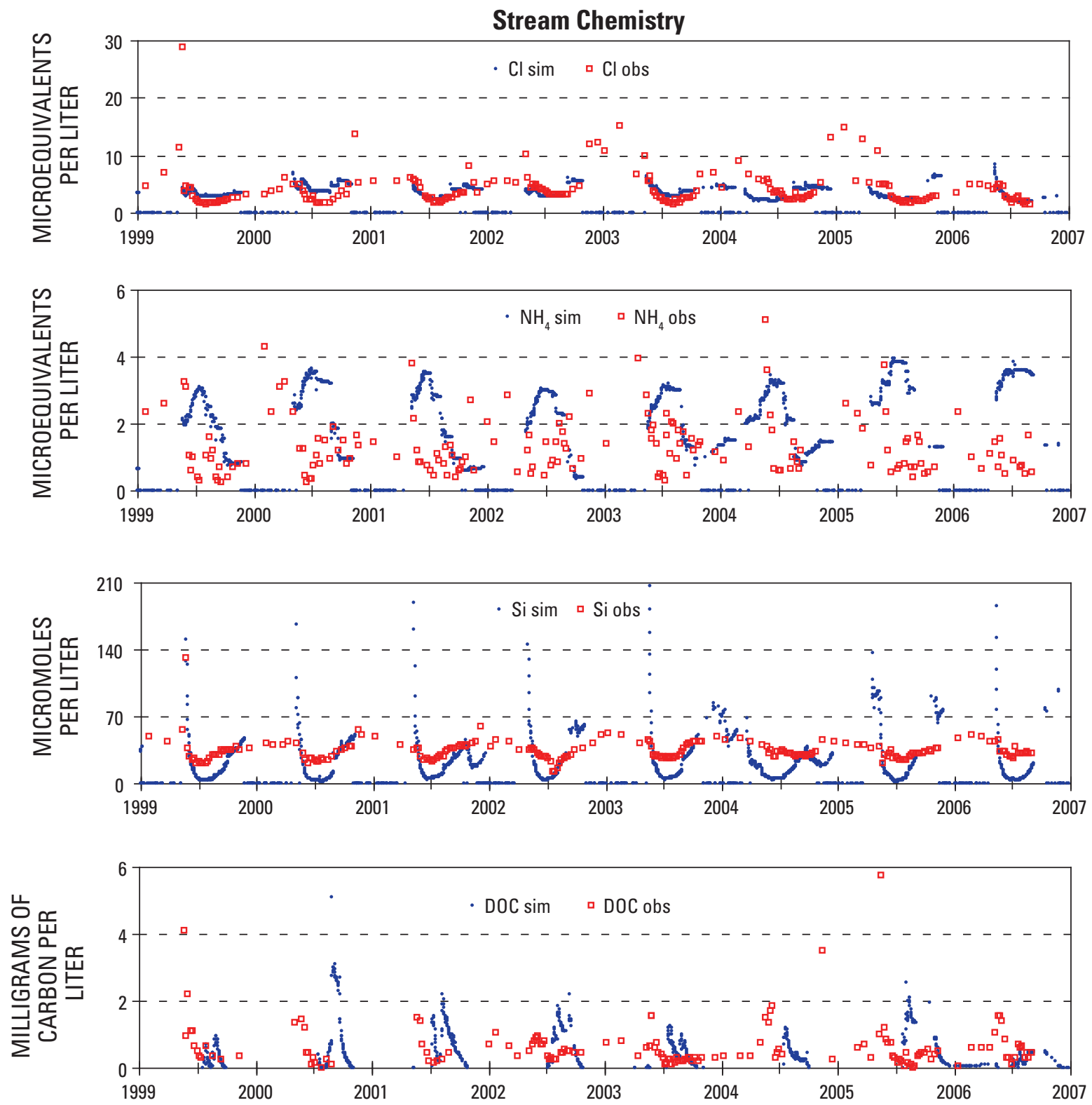

Figure 7.7. Simulated (sim) and observed (obs) daily discharge and stream chemistry for GL4, Niwot Ridge LTER, years 1999-2006. Lower-than-average precipitation occurred for years 2002-2006. - Continued 

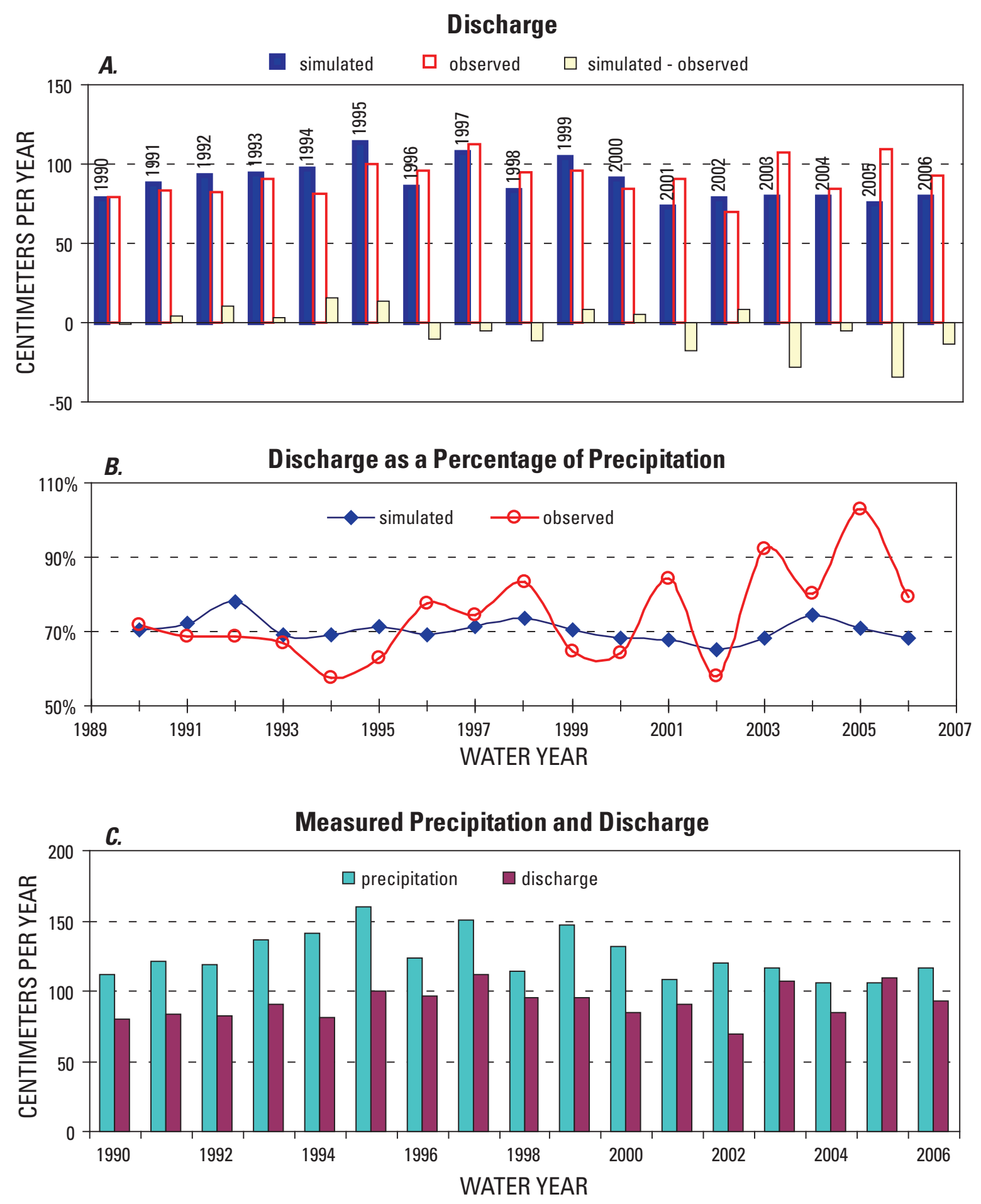

Figure 7.8. Simulated and measured discharge for GL4, Niwot Ridge LTER, by water year, compared with observed precipitation. $A$, Simulated (blue bars) and measured (red bars) total annual discharge by water year for GL4, Niwot Ridge, and the difference (simulated - observed) between the two. $B$, Simulated and observed discharge as a percentage of precipitation. $C$, Measured precipitation (light blue bars) and measured discharge (maroon bars). 
Table 7.6. Annual volume-weighted mean simulated and observed stream chemistry averaged over each year of the simulation. Pmean = predicted mean; Omean = observed mean; $\mathrm{AE}=$ absolute error $($ Pmean - Omean $) ; \mathrm{NAE}=$ normalized absolute error (AE/Omean).

\begin{tabular}{|c|c|c|c|c|c|}
\hline Solute & Metric & Concentration & Solute & Metric & Concentration \\
\hline \multirow[t]{4}{*}{$\mathrm{pH}$} & Pmean & 6.66 & $\mathrm{NO}_{3}\left(\mu\right.$ eq $\left.\mathrm{L}^{-1}\right)$ & Pmean & 26.69 \\
\hline & Omean & 6.25 & & Omean & 16.00 \\
\hline & $\mathrm{AE}$ & 0.40 & & $\mathrm{AE}$ & 10.69 \\
\hline & NAE & 0.06 & & NAE & 0.67 \\
\hline \multirow[t]{4}{*}{ Ca $\left(\mu \mathrm{eq} \mathrm{L} \mathrm{L}^{-1}\right)$} & Pmean & 18.02 & $\mathrm{SO}_{4}\left(\mu \mathrm{eq} \mathrm{L} \mathrm{L}^{-1}\right)$ & Pmean & 34.83 \\
\hline & Omean & 77.35 & & Omean & 54.29 \\
\hline & $\mathrm{AE}$ & -59.33 & & $\mathrm{AE}$ & -19.46 \\
\hline & NAE & -0.77 & & NAE & -0.36 \\
\hline \multirow[t]{4}{*}{$\operatorname{Mg}\left(\mu\right.$ eq $\left.\mathrm{L}^{-1}\right)$} & Pmean & 11.66 & ANC $\left(\mu\right.$ eq $\left.L^{-1}\right)$ & Pmean & 59.80 \\
\hline & Omean & 17.21 & & Omean & 48.64 \\
\hline & $\mathrm{AE}$ & -5.55 & & $\mathrm{AE}$ & 11.16 \\
\hline & NAE & -0.32 & & NAE & 0.23 \\
\hline \multirow[t]{4}{*}{$\mathrm{K}\left(\mu \mathrm{eq} \mathrm{L}^{-1}\right)$} & Pmean & 16.50 & $\mathrm{Cl}(\mu \mathrm{eq} \mathrm{L}-1)$ & Pmean & 3.83 \\
\hline & Omean & 6.55 & & Omean & 3.21 \\
\hline & $\mathrm{AE}$ & 9.94 & & $\mathrm{AE}$ & 0.62 \\
\hline & NAE & 1.52 & & NAE & 0.19 \\
\hline \multirow[t]{4}{*}{$\mathrm{Na}\left(\mu \mathrm{eq} \mathrm{L}^{-1}\right)$} & Pmean & 64.53 & $\operatorname{Si}\left(\mu \mathrm{mol} \mathrm{L} \mathrm{L}^{-1}\right)$ & Pmean & 17.42 \\
\hline & Omean & 13.96 & & Omean & 24.48 \\
\hline & $\mathrm{AE}$ & 50.56 & & $\mathrm{AE}$ & -7.06 \\
\hline & NAE & 3.62 & & NAE & -0.29 \\
\hline \multirow[t]{4}{*}{ BC $\left(\mu\right.$ eq $\left.\mathrm{L}^{-1}\right)$} & Pmean & 110.70 & $\mathrm{DOC}\left(\mathrm{mg} \mathrm{C} \mathrm{L} \mathrm{L}^{-1}\right)$ & Pmean & 0.51 \\
\hline & Omean & 115.08 & & Omean & 1.00 \\
\hline & $\mathrm{AE}$ & -4.38 & & $\mathrm{AE}$ & -0.50 \\
\hline & NAE & -0.04 & & NAE & -0.49 \\
\hline \multirow[t]{4}{*}{$\mathrm{NH}_{4}\left(\mu\right.$ eq $\left.\mathrm{L}^{-1}\right)$} & Pmean & 2.80 & & & \\
\hline & Omean & 1.14 & & & \\
\hline & $\mathrm{AE}$ & 1.51 & & & \\
\hline & NAE & 1.33 & & & \\
\hline
\end{tabular}

at the lake outlet, but lake processes are not included in DayCent-Chem.

\section{Sulfate}

There was strong seasonal variation in stream $\mathrm{SO}_{4}$ concentrations at NWT, and the model did well in replicating these patterns in average to above-average precipitation years (fig. 7.6). In most years stream $\mathrm{SO}_{4}$ concentrations reached a minimum of about $25 \mu \mathrm{eq} \mathrm{L}^{-1}$ in July (flow dilution) and

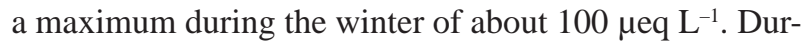
ing years 2000-2005, measured stream $\mathrm{SO}_{4}$ concentrations increased markedly, with a July minimum of $50-80 \mu \mathrm{eq} \mathrm{L} \mathrm{L}^{-1}$ and a winter maximum of $250 \mu \mathrm{eq} \mathrm{L}^{-1}$. The model did not show a corresponding increase (fig. 7.7).

\section{Chloride}

The model did fairly well in predicting annual and daily stream $\mathrm{Cl}$ concentrations (figs. 7.6, 7.7). Measured annual VWM stream Cl concentrations ( $\left.3 \mu \mathrm{eq} \mathrm{L}^{-1}\right)$ and predicted annual VWM stream $\mathrm{Cl}$ concentrations $\left(4 \mu \mathrm{eq} \mathrm{L}^{-1}\right)$ were both low (table 7.6). Both measurements and predictions showed that $\mathrm{Cl}$ was most concentrated at the onset of snowmelt, diluted during the high summer flow, and concentrated again in autumn (fig. 7.5). 


\section{Weathering Products}

For the period during which measurements were available, DayCent-Chem produced a wider range of stream Si concentrations than what was measured (figs. 7.6, 7.7). The simulated annual VWM stream Si concentrations of $17 \mu \mathrm{mol}$ $\mathrm{L}^{-1}$ were slightly lower than measured values of $24 \mu \mathrm{mol} \mathrm{\textrm {L } ^ { - 1 }}$ (table 7.6). Both observed and predicted stream Si concentrations increased at the onset of melt, were diluted during summer high flow, and increased again when flow was reduced in the autumn (fig. 7.5).

The observed stream sum of base cations showed patterns similar to observed stream Si concentrations (fig. 7.5). The model was not able to replicate the temporal dynamics of any base cations and was often out of phase with measurements (figs. 7.6, 7.7). Of all base cations, simulated daily stream $\mathrm{Mg}$ concentrations most closely followed observations, but only in average or above-average precipitation years. Daily stream Ca concentrations were underestimated throughout the year by as much as $100 \mu \mathrm{eq} \mathrm{L}^{-1}$, while stream Na concentrations were overestimated by as much as $50 \mu \mathrm{eq} \mathrm{L}^{-1}$. Daily simulated stream $\mathrm{K}$ concentrations were out of phase with observations. On an annual basis, the sum of predicted stream base cations was $115 \mu \mathrm{eq} \mathrm{L} \mathrm{L}^{-1}$, very close to the sum of measured base cations of $110 \mu \mathrm{eq} \mathrm{L}^{-1}$, but as stated above, the proportions of cations in the model output differ from those that are measured (table 7.6). The model underestimated the sum of stream base cation concentrations before and after peak discharge, but predictions were close to measurements for June through August (fig. 7.5).

\section{ANC and $\mathrm{pH}$}

Measured alkalinity and pH at NWT displayed seasonal cycles and were lowest near maximum discharge. Measured $\mathrm{pH}$ reached a minimum of about 6.0 at peak discharge and a maximum of about 7.0 in autumn or winter. On average simulated $\mathrm{pH}$ was slightly above measured values (fig. 7.5). Simulated daily $\mathrm{pH}$ was close to measurements except for being overestimated in the early winter (figs. 7.6, 7.7). Alkalinity at snowmelt plunges by about $50-60 \mu$ eq $\mathrm{L}^{-1}$ below its wintertime maximum (80-120 $\mu \mathrm{eq} \mathrm{L}^{-1}$ ). Simulated ANC was slightly greater than measured ANC and, like simulated base cation concentrations, was temporally out of phase with measured concentrations.

\section{Dissolved Organic Carbon}

Measured DOC concentrations were greatest on the rising limb of spring melt as DOC was flushed from the soils. Simulated stream DOC was in the same range as measured concentrations, but the model lagged in its DOC response, with maximum DOC occurring on the falling limb of the hydrograph (fig. 7.7).

\section{Summary}

Simulated discharge compared to measured values indicated that hydrologic inputs have been changing at NWT since 2001. Since 2001, precipitation generally decreased while measured discharge increased. Simulated versus observed annual discharge were close most years prior to 2001, after which the model underestimated discharge. The model showed that simulated discharge, as a percentage of precipitation, was relatively steady. Measured discharge as a percentage of precipitation is increasing and even exceeded 100 percent in water year 2005. Model results and measurements all indicate an additional source of water in Green Lakes Valley in recent years.

There were substantial changes in stream chemistry as well as discharge from 1989 to 2006. Trend lines showed that both measured and simulated annual VWM stream $\mathrm{NO}_{3}$ concentrations increased over this time period, with the highest concentration occurring in 2003 and 2004. At about the same time, observed stream $\mathrm{SO}_{4}$ concentrations sharply increased, from an annual VWM of $52 \mu$ eq L ${ }^{-1}$ in 2000 to $115 \mu$ eq L $\mathrm{L}^{-1}$ in 2002, the driest year at NWT. Stream $\mathrm{SO}_{4}$ concentrations remained elevated between 60 to $64 \mu \mathrm{eq} \mathrm{L}^{-1}$ in 2005 and 2006. Stream Ca and Mg concentrations showed similar dynamics. Stream Ca concentrations increased from $77 \mu \mathrm{eq} \mathrm{L}^{-1}$ in 2000 to $137 \mu \mathrm{eq} \mathrm{L} \mathrm{L}^{-1}$ in 2002, and stream Mg concentrations increased from 16 to $29 \mu \mathrm{eq} \mathrm{L}^{-1}$ during these same years; both remained elevated in 2005 and 2006. The simulation did not show a similar jump in stream $\mathrm{SO}_{4}$, $\mathrm{Ca}$, and $\mathrm{Mg}$ concentrations, indicating that some additional process may be influencing stream chemistry in at GL4. There is evidence that melt from the internal ice of rock glaciers, with high $\mathrm{NO}_{3}, \mathrm{SO}_{4}$, $\mathrm{Ca}$, and $\mathrm{Mg}$ concentrations, may be influencing stream flow and chemistry in Green Lakes Valley (Williams and others, 2006; Williams and others, 2007), and the model does not account for this source of discharge and solutes. During these drought years, measured $\mathrm{pH}$ was elevated in 2002, and ANC was elevated from 2002 to 2006, suggesting that the increased base cation flux buffered acidity from the simultaneous increase in stream $\mathrm{SO}_{4}$. 


\section{Mount Rainier National Park, Lake Louise Watershed, Washington}

\section{Site Description}

Mount Rainier National Park (MORA) is located in the Cascade Range of western Washington State, approximately $90 \mathrm{~km}$ southeast of the Seattle/Tacoma area and $100 \mathrm{~km}$ west of the Pacific Ocean (table 8.1, fig. 8.1). The most prominent peak in the park, Mount Rainier, is an active volcano that last erupted about 150 years ago.

The Lake Louise watershed is located in the south-central part of MORA (fig. 8.1). The watershed covers 211.7 ha, ranges in elevation from 1,430 to 1,844 m.a.s.l., and drains into Lake Louise near the tree line. Most of the watershed is alpine/subalpine in character (Clow and Campbell, 2008). Vegetation consists of larch (Larix spp.), whitebark pine (Pinus albicaulis), Engelmann spruce (Picea engelmannii), subalpine fir (Abies lasiocarpa), and alpine meadows (Nelson, 1991).

The alpine/subalpine areas of the Cascades were glaciated during the Holocene and late Pleistocene. The soils in the Lake Louise basin, except in wetlands and riparian areas, are predominantly Inceptisols that show poor development and have low cation-exchange capacity and high permeability (Nelson, 1991). The bedrock of the Lake Louise basin is primarily andesite and granodiorite intrusions (Fiske and others, 1964) (table 8.1).

\section{Methods}

\section{Climate and Hydrology}

Lake Louise has a temperate maritime climate with abundant orographically driven precipitation (Clow and Campbell, 2008). Prevailing winds in the Cascades are from the west, and storms are primarily frontal systems originating in the Pacific Ocean (Nelson, 1991). The basin receives the vast majority of precipitation in the winter and has warm, dry summers (fig. 8.2A). About $3 \mathrm{~m}$ of precipitation falls annually, two-thirds of which is snow. The maximum snowpack depth is around $5 \mathrm{~m}$. The nearest weather station, the Paradise SNOTEL (SNOwpack TELemetry) site (46 $46^{\prime},-121^{\circ} 44^{\prime}$, elevation 1,560 m), is $2 \mathrm{~km}$ from Lake Louise and is operated by the National Resource Conservation Service (NRCS;
http://www.wcc.nrcs.usda.gov/snotel/Washington/washington. html) (fig. 8.1). From 1990 through 2007, mean annual temperature was 4.5 (std. dev. 0.5$)^{\circ} \mathrm{C}$ and average annual precipitation was 298 (std. dev. 61) $\mathrm{cm} \mathrm{yr}^{-1}$. During this period, mean annual temperature increased $0.05^{\circ} \mathrm{C} \mathrm{yr}^{-1}$ (fig. 8.2B).

Discharge data were collected at the Lake Louise stream gage located approximately $20 \mathrm{~m}$ downstream of the lake outlet; data were available for September 2004 through August 2007 (Clow and Campbell, 2008). Stream chemistry data collected at the stream gage were available for the same time period (Clow and Campbell, 2008).

Discharge was controlled by snow accumulation and subsequent melting of deep seasonal snowpacks (Clow and Campbell, 2008). From 2004 through 2007, Lake Louise had two equivalent seasonal high flows, one in NovemberJanuary and the other in May-July, with minimum flow in September. The high winter flow was due to fall rain storms and winter rain-on-snow events, whereas the high spring flow was due to melting of the snowpack (Clow and Campbell, 2008) (fig. 8.3).

\section{Atmospheric Deposition}

For simulation years 2000-2007, we used wet deposition concentrations from the closest NADP site, Tahoma Woods (WA99; 46.7614 ${ }^{\circ},-122.1217^{\circ}$, elevation $421 \mathrm{~m}$ ). Since measurements at WA99 did not begin until October 1999, we added wet deposition concentrations from the La Grande NADP site (WA21; 46.8353ㅇ․ $-122.2867^{\circ}$, elevation $617 \mathrm{~m}$ ) for simulation years 1990-1999. Both NADP stations are outside of Mount Rainier National Park (fig. 8.1). We scaled WA21 concentrations to better match those measured at WA99, based on the differences in concentrations between these two sites where their data records overlap. We calibrated dry-plus-fog:wet deposition ratios for $\mathrm{N}$ and $\mathrm{S}$ species to better estimate stream $\mathrm{NO}_{3}$ and $\mathrm{SO}_{4}$ concentrations and to achieve a balance between cation and anion inputs. We did not simulate the dry or fog deposition of base cations and chloride (table 8.2, fig. 8.4). From 1990 to 2007, annual wet plus dry S deposition decreased while there was no trend in either $\mathrm{NH}_{4}-\mathrm{N}$ or $\mathrm{NO}_{3}-\mathrm{N}$ deposition. 
Table 8.1. Characteristics of Lake Louise watershed in Mount Rainier National Park (MORA), Washington.

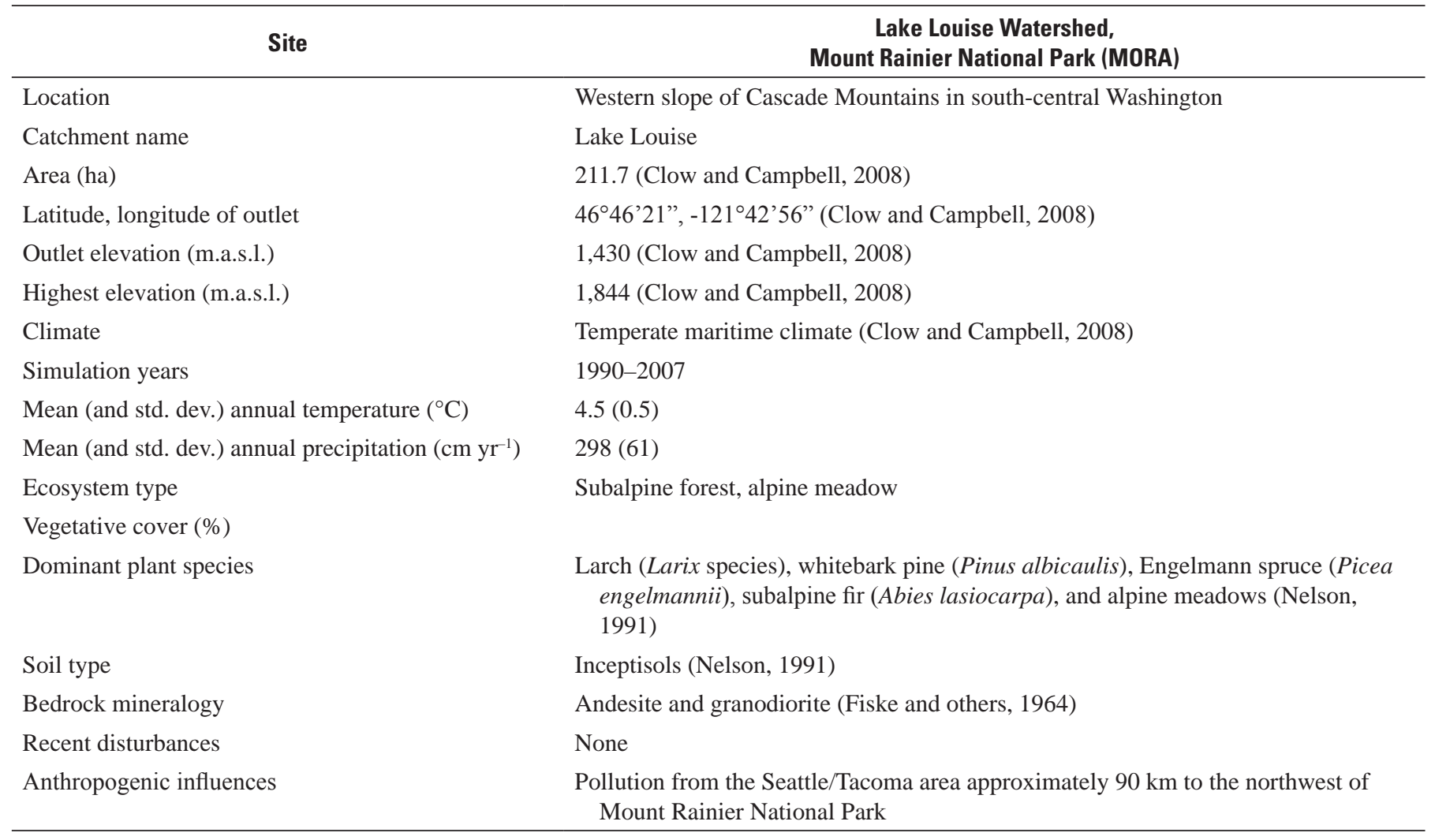

\section{Soil and Mineral Properties}

The mineralogy of the bedrock at MORA is volcanic in origin with intrusions of granitic rock (Fiske and others, 1964). Likely mineral weathering rates for the Lake Louise watershed were identified by Dave Clow through the use of inverse modeling (D.W. Clow, USGS Colorado Water Science Center, personal commun., 2006 August 23) (table 8.3). The mineral reactions are summarized below.

Albite: $\mathrm{NaAlSi}_{3} \mathrm{O}_{8}+8 \mathrm{H}_{2} \mathrm{O}=\mathrm{Na}^{+}+\mathrm{Al}(\mathrm{OH})_{4}{ }^{-}+3 \mathrm{H}_{4} \mathrm{SiO}_{4}$ Anorthite: $\mathrm{CaAl} 2 \mathrm{Si}_{2} \mathrm{O}_{8}+8 \mathrm{H}_{2} \mathrm{O}=\mathrm{Ca}^{2+}+2 \mathrm{Al}(\mathrm{OH})_{4}^{-}$ $+2 \mathrm{H}_{4} \mathrm{SiO}_{4}$

Biotite: $\mathrm{KMg}_{1.5} \mathrm{Fe}_{1.5} \mathrm{AlSi}_{3} \mathrm{O}_{10}(\mathrm{OH})_{2}+6 \mathrm{H}^{+}+4 \mathrm{H}_{2} \mathrm{O}$ $=\mathrm{K}^{+}+1.5 \mathrm{Mg}^{2+}+1.5 \mathrm{Fe}^{2+}+\mathrm{Al}(\mathrm{OH})_{4}^{-}+3 \mathrm{H}_{4} \mathrm{SiO}_{4}$

Diopside: $\mathrm{CaMgSi}_{2} \mathrm{O}_{6}+2 \mathrm{H}_{2} \mathrm{O}+4 \mathrm{H}^{+}=\mathrm{Mg}^{2+}+\mathrm{Ca}^{2+}$ $+2 \mathrm{H}_{4} \mathrm{SiO}_{4}$

To the best of our knowledge, the soil properties of the Lake Louise watershed have not been quantified. For simulation purposes, we initialized the soil properties of the Lake
Louise watershed with data from another recently glaciated subalpine forest, Loch Vale watershed in Colorado (Hartman and others, 2007) (table 8.4).

\section{Calibration and Validation}

Since there were no empirical data available for biomass and $\mathrm{C}$ and $\mathrm{N}$ fluxes from Lake Louise, we fit the model's ecological variables by comparing them against observations obtained from subalpine forest stands in Loch Vale Watershed (LVWS) in Rocky Mountain National Park (table 8.5). Compared to MORA, the subalpine forest of LVWS was located at a higher elevation (greater than 3,000 m), had slightly cooler average annual temperature $\left(1.9^{\circ} \mathrm{C}\right)$, and received less than half the precipitation (106 $\mathrm{cm} \mathrm{yr}^{-1}$ ), so we expected production and biomass values at LVWS to be lower than at MORA. After we obtained reasonable estimates of the ecological variables from the model, we calibrated discharge and stream chemistry from empirical data from 2004-2006. We ran the model for year 2007 after the model was parameterized. 

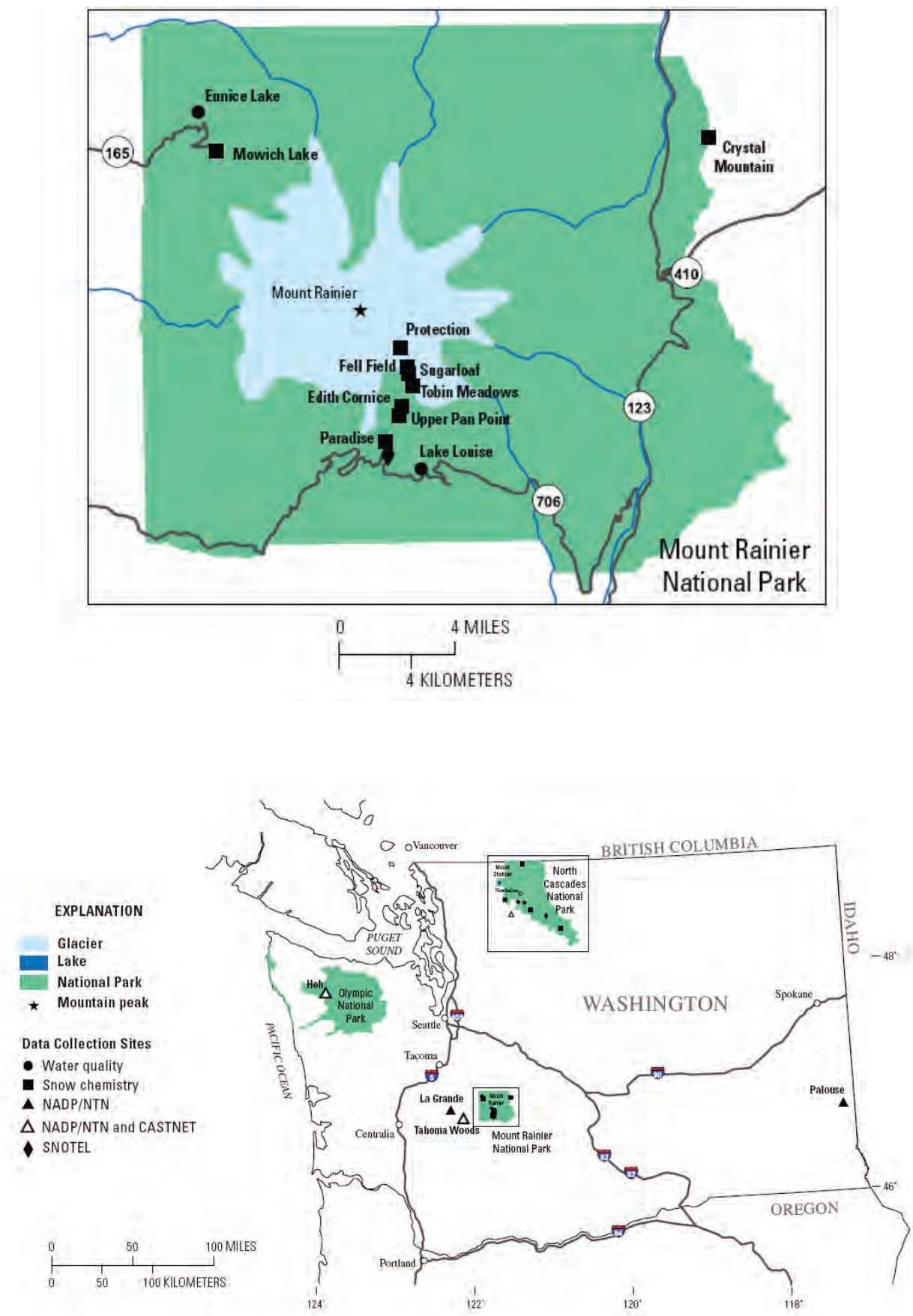

Figure 8.1. Lake Louise watershed is located in the south-central part of Mount Rainier National Park, Washington (image from Clow and Campbell, 2008). 

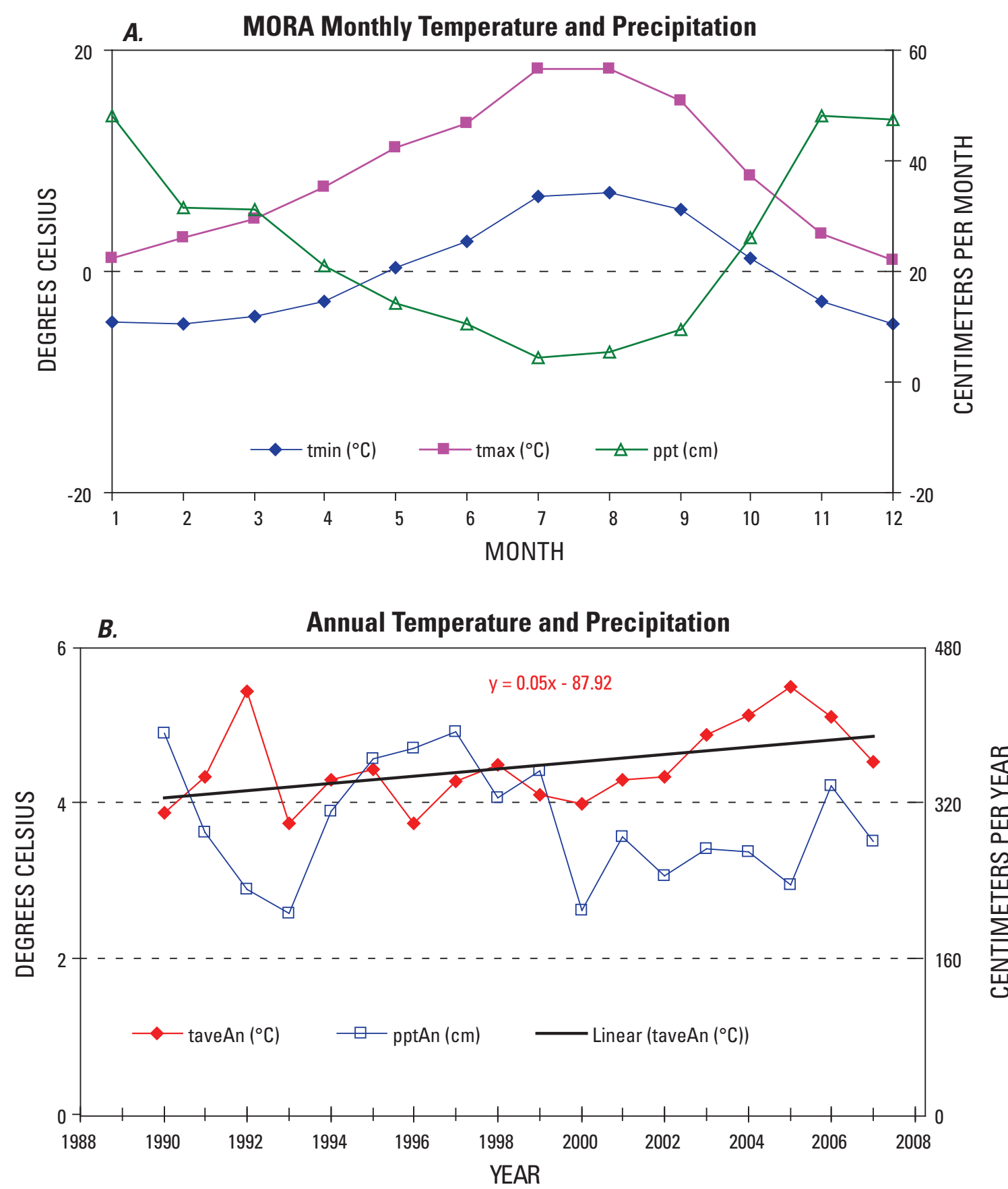

Figure 8.2. Meteorological statistics of model inputs for Lake Louise watershed. A, Average monthly minimum air temperatures (tmin), maximum air temperatures (tmax), and precipitation (ppt), years 19902007. $B$, The time series of mean annual air temperature (taveAn) and annual precipitation (pptAn), years 1990-2007. Mean annual temperature was 4.5 (std. dev. 0.5) ${ }^{\circ} \mathrm{C}$ and average annual precipitation was 298 (std. dev. 61) $\mathrm{cm} \mathrm{yr}^{-1}$. Average annual temperature increased $0.05^{\circ} \mathrm{C} \mathrm{yr}^{-1}$. 


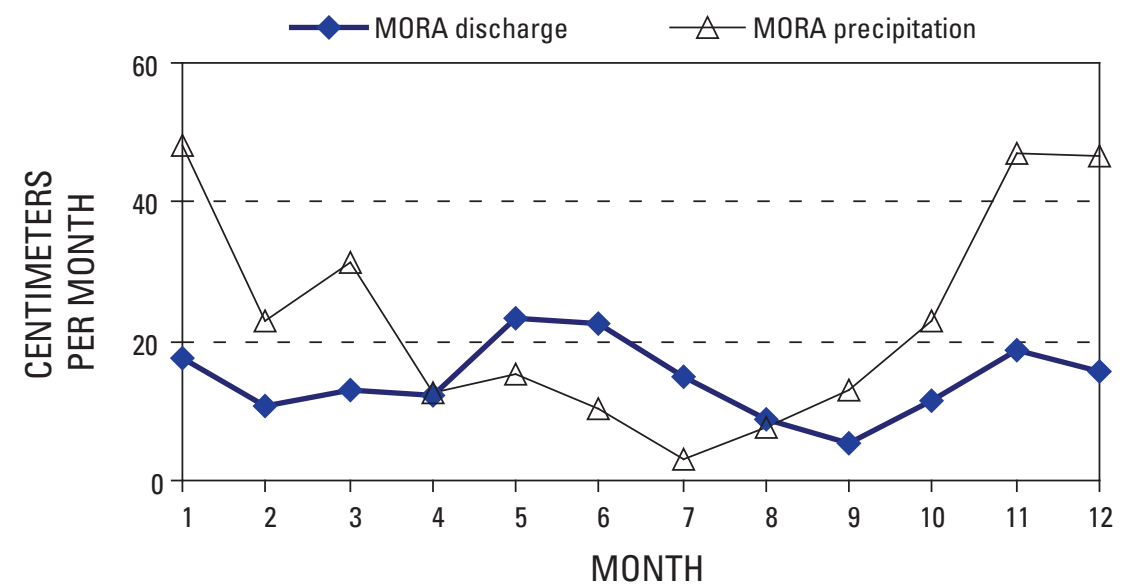

Figure 8.3. Relationship between average monthly precipitation (2004-2007) measured at Lake Louise watershed and discharge (2004-2007) measured at Lake Louise.

Table 8.2. Average annual wet and dry plus fog deposition inputs $\left(\mathrm{kg} \mathrm{ha}^{-1} \mathrm{yr}^{-1}\right)$ to the model over the 1990-2007 simulation period.

\begin{tabular}{lrcr}
\hline & Wet & Dry + Fog & \multicolumn{1}{c}{ Total } \\
\hline $\mathrm{Ca}$ & 0.84 & 0.00 & 0.84 \\
$\mathrm{Cl}$ & 10.35 & 0.00 & 10.35 \\
$\mathrm{~K}$ & 0.38 & 0.00 & 0.38 \\
$\mathrm{Mg}$ & 0.65 & 0.00 & 0.65 \\
$\mathrm{NH}_{4}-\mathrm{N}$ & 0.69 & 0.07 & 0.76 \\
$\mathrm{NO}_{3}-\mathrm{N}$ & 1.46 & 1.46 & 2.92 \\
$\mathrm{Na}$ & 5.71 & 0.00 & 5.71 \\
$\mathrm{SO}_{4}-\mathrm{S}$ & 2.52 & 1.01 & 3.52 \\
\hline
\end{tabular}



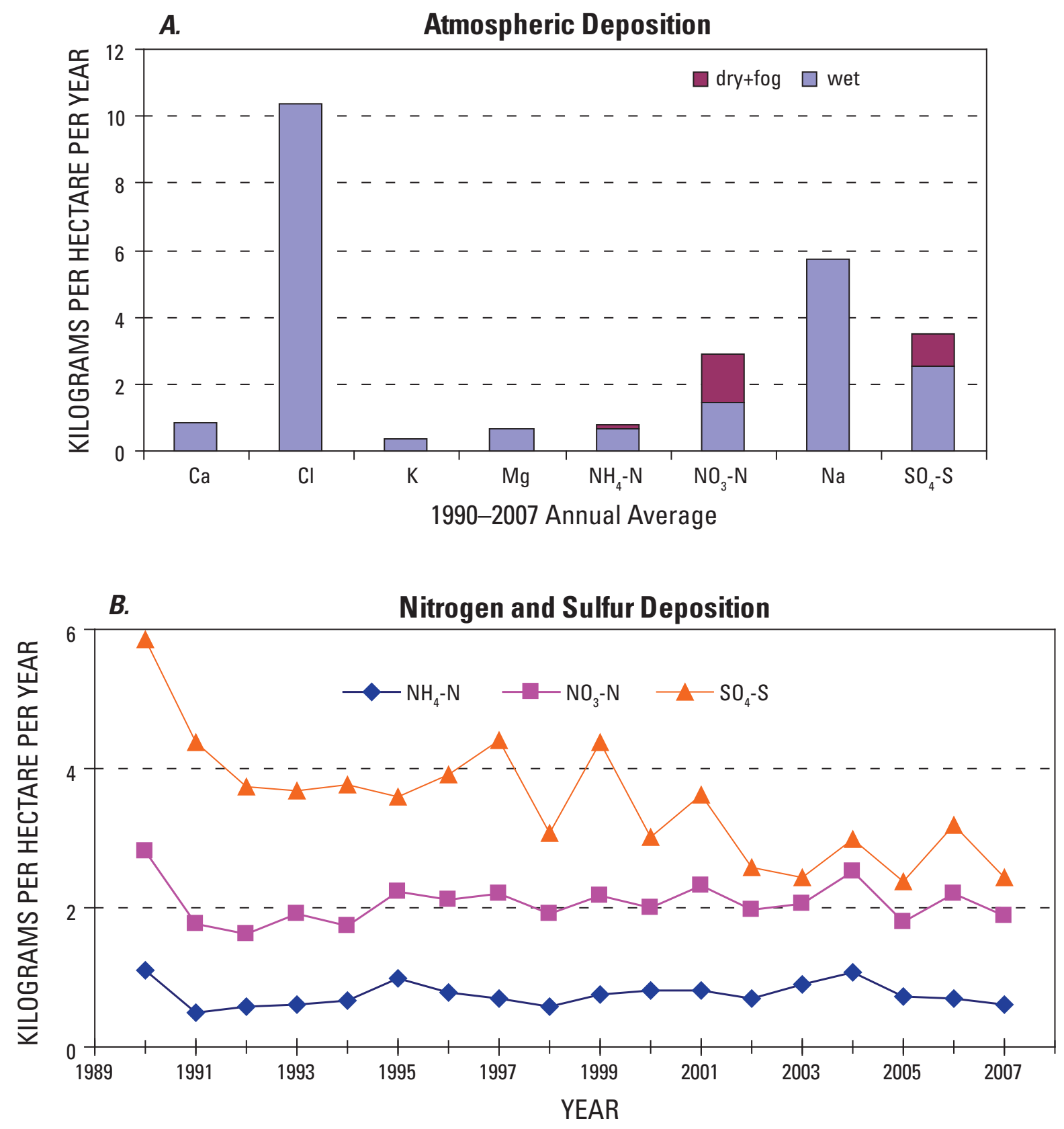

Figure 8.4. Deposition inputs to the model for Lake Louise watershed. $A$, The 1990-2007 average annual wet and dry deposition. $B$, The time series of $\mathrm{NH}_{4}-\mathrm{N}, \mathrm{NO}_{3}-\mathrm{N}$, and $\mathrm{SO}_{4}-\mathrm{S}$ deposition over the simulation period. 
Table 8.3. Mineral weathering rates (D.W. Clow, USGS Colorado Water Science Center, personal commun., 23 August 2006). Minerals were allowed to dissolve, but not precipitate. Minerals prescribed for the simulation (Prescribed mineral phases) were those in the data base closest in composition to the actual minerals. Andesine was represented as 39 percent anorthite and 61 percent albite.

\begin{tabular}{|c|c|c|c|c|c|}
\hline $\begin{array}{c}\text { Prescribed } \\
\text { mineral phases }\end{array}$ & $\mathrm{mol} \mathrm{m}^{-2} \mathrm{yr}^{-1}$ & $\begin{array}{c}1=\text { dissolve, } \\
0=\begin{array}{c}\text { precipitate or } \\
\text { dissolve }\end{array}\end{array}$ & $\mathrm{mol} \mathrm{ha}^{-2} \mathrm{yr}^{-1}$ & $\begin{array}{c}\text { Actual } \\
\text { minerals }\end{array}$ & Comments \\
\hline Albite & 0.038003 & 1 & 623 & Andesine & Plagioclase \\
\hline Anorthite & 0.024297 & 1 & & & An39 \\
\hline Biotite & 0.0016 & 1 & 16 & Biotite & \\
\hline Diopside & 0.0033 & 1 & 33 & Augite & Use diopside \\
\hline
\end{tabular}

Table 8.4. Soil layer properties used for the simulation. Ksat is saturated hydraulic conductivity, and the mineral dissolution fraction (Minrl dissoln) is the fraction of total mineral dissolution that occurred in each layer. Wilting point and field capacity are expressed as volumetric soil water content. Exchangeable cations are expressed as milliequivalents per $100 \mathrm{grams}$ of soil (meq/100 g). Total soil depth was $55 \mathrm{~cm}$ and organic soil made up the top $10 \mathrm{~cm}$.

\begin{tabular}{|c|c|c|c|c|c|c|c|c|c|}
\hline Layer & $\begin{array}{c}\text { Thickness } \\
\text { cm }\end{array}$ & $\begin{array}{l}\text { Sand } \\
\text { fraction }\end{array}$ & $\begin{array}{c}\text { Silt } \\
\text { fraction }\end{array}$ & $\begin{array}{l}\text { Clay } \\
\text { fraction }\end{array}$ & $\begin{array}{c}\text { Bulk } \\
\text { density } \\
\mathrm{g} \mathrm{cm}^{-3}\end{array}$ & $\begin{array}{l}\text { Wilting point } \\
\text { fraction }\end{array}$ & $\begin{array}{l}\text { Field } \\
\text { capacity } \\
\text { fraction }\end{array}$ & $\begin{array}{l}\text { Ksat } \\
\text { cm } \\
\text { sec }^{-1}\end{array}$ & $\begin{array}{c}\text { Minrl } \\
\text { dissoln } \\
\text { fraction }\end{array}$ \\
\hline 0 & 5 & 0.1 & 0.85 & 0.05 & 0.75 & 0.1512 & 0.40 & 0.00463 & 0.25 \\
\hline 1 & 5 & 0.1 & 0.85 & 0.05 & 1.0 & 0.1437 & 0.35 & 0.00463 & 0.25 \\
\hline 2 & 10 & 0.1 & 0.705 & 0.195 & 1.1 & 0.1386 & 0.35 & 0.00463 & 0.25 \\
\hline 3 & 15 & 0.1 & 0.617 & 0.283 & 1.3 & 0.1351 & 0.30 & 0.00086 & 0.25 \\
\hline 4 & 20 & 0.1 & 0.738 & 0.162 & 1.5 & 0.1319 & 0.30 & 0.00086 & 0.00 \\
\hline Layer & $\begin{array}{c}\mathrm{CaX}_{2} \\
\mathrm{meq} / 100 \mathrm{~g}\end{array}$ & $\underset{\text { meq/100 g }}{\mathrm{MgX}_{2}}$ & $\begin{array}{c}\mathrm{KX} \\
\mathrm{meq} / 100 \mathrm{~g}\end{array}$ & $\begin{array}{c}\mathrm{NaX} \\
\mathrm{meq} / \mathbf{1 0 0} \mathrm{g}\end{array}$ & $\begin{array}{c}\mathrm{AlOHX}_{2} \\
\mathrm{meq} / 100 \mathrm{~g}\end{array}$ & $\begin{array}{c}\mathrm{AlX}_{3} \\
\mathrm{meq} / 100 \mathrm{~g}\end{array}$ & $\begin{array}{c}\mathrm{FeX}_{2} \\
\mathrm{meq} / 100 \mathrm{~g}\end{array}$ & $\begin{array}{c}\mathrm{HX} \\
\mathrm{meq} / 100 \mathrm{~g}\end{array}$ & $\begin{array}{c}\mathrm{NH}_{4} \mathrm{X} \\
\text { meq/100 g }\end{array}$ \\
\hline 0 & 20.0 & 4.0 & 0.7 & 0.05 & 1.0 & 9.0 & 0.0 & 0.01 & 0.5 \\
\hline 1 & 20.0 & 4.0 & 0.7 & 0.05 & 1.0 & 9.0 & 0.0 & 0.01 & 0.5 \\
\hline 2 & 5.0 & 1.5 & 0.2 & 0.05 & 1.0 & 15.0 & 0.0 & 0.01 & 0.5 \\
\hline 3 & 4.0 & 1.0 & 0.1 & 0.05 & 1.0 & 20.0 & 0.0 & 0.01 & 0.5 \\
\hline 4 & 3.0 & 1.0 & 0.05 & 0.05 & 1.0 & 15.0 & 0.0 & 0.01 & 0.5 \\
\hline
\end{tabular}


Table 8.5. Simulated (1990-2007) and measured ecological variables and input/output fluxes. Standard deviations are shown in parentheses and represent interannual variation for annual fluxes and monthly variations for state variables. NPP = net primary production; NEP = net ecosystem production; $\mathrm{Rh}=$ heterotrophic respiration; $\mathrm{PET}=$ potential evapotranspiration; $\mathrm{AET}=\mathrm{actual}$ evapotranspiration; DOC = dissolved organic carbon; LVWS = Loch Vale Watershed. To convert units reported by data sources, it was assumed that 2.25 grams biomass equals 1 gram $C$.

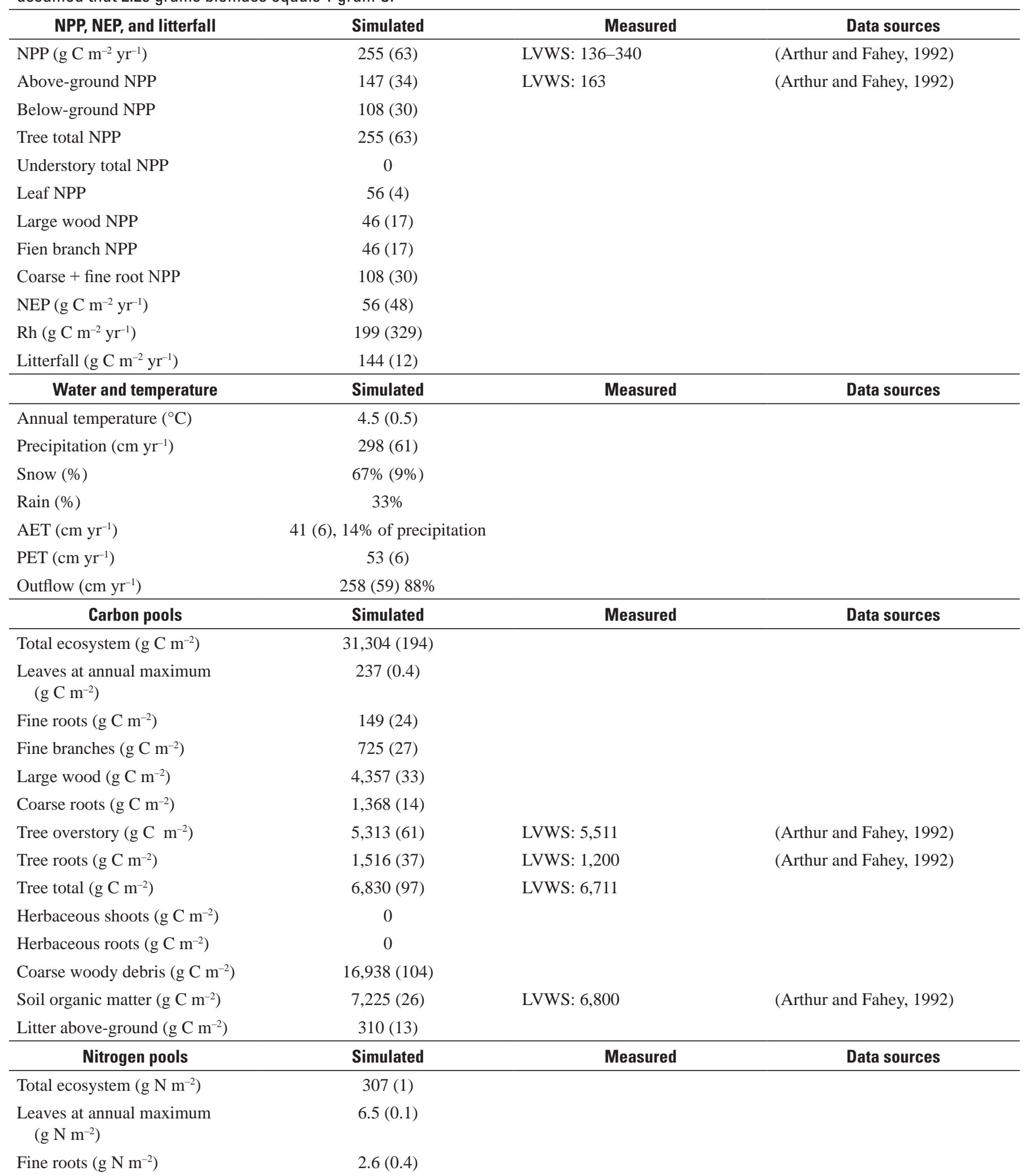


Table 8.5. Simulated (1990-2007) and measured ecological variables and input/output fluxes. Standard deviations are shown in parentheses and represent interannual variation for annual fluxes and monthly variations for state variables. NPP = net primary production; NEP = net ecosystem production; Rh = heterotrophic respiration; $\mathrm{PET}=$ potential evapotranspiration; $\mathrm{AET}=$ actual evapotranspiration; DOC = dissolved organic carbon; LVWS = Loch Vale Watershed. To convert units reported by data sources, it was assumed that 2.25 grams biomass equals $1 \mathrm{gram} \mathrm{C.-Continued}$

\begin{tabular}{|c|c|c|c|}
\hline Nitrogen pools & Simulated & Measured & Data sources \\
\hline Fine branches $\left(\mathrm{g} \mathrm{N} \mathrm{m}^{-2}\right)$ & $1.9(0.1)$ & & \\
\hline Large wood ( $\mathrm{g} \mathrm{N} \mathrm{m}^{-2}$ ) & $9.9(0.1)$ & & \\
\hline Coarse roots ( $\mathrm{g} \mathrm{N} \mathrm{m}^{-2}$ ) & $3.6(0.4)$ & & \\
\hline Tree above-ground ( $\mathrm{g} \mathrm{N} \mathrm{m}^{-2}$ ) & $18.1(0.3)$ & & \\
\hline Tree total $\left(\mathrm{g} \mathrm{N} \mathrm{m}^{-2}\right)$ & $24.4(0.7)$ & & \\
\hline Herbaceous shoots ( $\mathrm{g} \mathrm{N} \mathrm{m}^{-2}$ ) & 0 & & \\
\hline Herbaceous fine roots $\left(\mathrm{g} \mathrm{N} \mathrm{m}^{-2}\right)$ & 0 & & \\
\hline Coarse woody debris $\left(\mathrm{g} \mathrm{N} \mathrm{m}^{-2}\right.$ ) & $30.8(0.4)$ & & \\
\hline Soil organic matter $\left(\mathrm{g} \mathrm{N} \mathrm{m}^{-2}\right)$ & $245(0.4)$ & & \\
\hline Litter above-ground ( $\left.\mathrm{g} \mathrm{N} \mathrm{m}^{-2}\right)$ & $6.9(0.3)$ & & \\
\hline Soil mineral N $\left(\mathrm{g} \mathrm{N} \mathrm{m}^{-2}\right)$ & $0.15(0.17)$ & & \\
\hline N,P,S inputs & Simulated & Measured & Data sources \\
\hline $\mathrm{N}$ deposition $\left(\mathrm{g} \mathrm{N} \mathrm{m}^{-2} \mathrm{yr}^{-1}\right)$ & $0.28(0.04)$ & & \\
\hline Wet & 0.22 & & $\begin{array}{l}\text { NADP site WA99 (2000-2005), } \\
\text { WA21 (1984-1999) }\end{array}$ \\
\hline Dry + fog & 0.07 & & \\
\hline $\mathrm{S}$ deposition $\left(\mathrm{g} \mathrm{S} \mathrm{m}^{-2} \mathrm{yr}^{-1}\right)$ & $0.35(0.08)$ & & \\
\hline Wet & 0.25 & & $\begin{array}{l}\text { NADP site WA99 (2000-2005), } \\
\quad \text { WA21 (1984-1999) }\end{array}$ \\
\hline Dry + fog & 0.10 & & \\
\hline \multicolumn{4}{|l|}{$\mathrm{P}$ deposition $\left(\mathrm{g} \mathrm{P} \mathrm{m}^{-2} \mathrm{yr}^{-1}\right)$} \\
\hline Wet & not simulated & & $\begin{array}{l}\text { NADP site WA99 (2000-2005), } \\
\text { WA21 (1984-1999) }\end{array}$ \\
\hline Dry + fog & not simulated & & \\
\hline C,N,P,S outputs & Simulated & Measured & Data sources \\
\hline $\mathrm{N}$ export $\left(\mathrm{g} \mathrm{N} \mathrm{m}^{-2} \mathrm{yr}^{-1}\right)$ & $0.11(0.05)$ & & \\
\hline Inorganic & $0.06(0.05)$ & & \\
\hline Organic & $0.05(0.01)$ & & \\
\hline $\mathrm{S}$ export (g S m-2 $\left.\mathrm{yr}^{-1}\right)$ & $0.35(0.08)$ & & \\
\hline Inorganic & $0.35(0.08)$ & & \\
\hline Organic & not simulated & & \\
\hline P export ( $\mathrm{g} \mathrm{P} \mathrm{m}^{-2} \mathrm{yr}^{-1}$ ) & not simulated & & \\
\hline Inorganic & not simulated & & \\
\hline Organic & not simulated & & \\
\hline DOC export ( $\left.\mathrm{g} \mathrm{C} \mathrm{m}^{-2} \mathrm{yr}^{-1}\right)$ & $1.0(0.2)$ & & \\
\hline Trace gas flux $\left(\mathrm{g} \mathrm{N} \mathrm{m}^{-2} \mathrm{yr}^{-1}\right)$ & $0.03(0.01)$ & 0.03 (denitrification) & $\begin{array}{l}\text { (Barton and others, 1999), undis- } \\
\text { turbed coniferous forest }\end{array}$ \\
\hline
\end{tabular}


Table 8.5. Simulated (1990-2007) and measured ecological variables and input/output fluxes. Standard deviations are shown in parentheses and represent interannual variation for annual fluxes and monthly variations for state variables. NPP = net primary production; NEP = net ecosystem production; $\mathrm{Rh}=$ heterotrophic respiration; $\mathrm{PET}=$ potential evapotranspiration; $\mathrm{AET}=$ actual evapotranspiration; DOC = dissolved organic carbon; LVWS = Loch Vale Watershed. To convert units reported by data sources, it was assumed that 2.25 grams biomass equals 1 gram C.-Continued

\begin{tabular}{lccc}
\multicolumn{1}{c}{$\mathbf{N}, \mathbf{P}, \mathbf{S}$ internal fluxes } & Simulated & Measured & Data sources \\
\hline $\mathrm{N}$ mineralization $\left(\mathrm{g} \mathrm{N} \mathrm{m}^{-2} \mathrm{yr}^{-1}\right)$ & $3.0(0.5)$ & LVWS: 2.0-3.0 & (Arthur and Fahey, 1992) \\
$\mathrm{P}$ mineralization $\left(\mathrm{g} \mathrm{P} \mathrm{m}^{-2} \mathrm{yr}^{-1}\right)$ & not simulated & & \\
$\mathrm{S}$ mineralization $\left(\mathrm{g} \mathrm{S} \mathrm{m}^{-2} \mathrm{yr}^{-1}\right)$ & not simulated & & \\
Gross nitrification $\left(\mathrm{g} \mathrm{N} \mathrm{m}^{-2} \mathrm{yr}^{-1}\right)$ & $0.4(0.06)$ & & \\
$\mathrm{N}$ fixation $\left(\mathrm{g} \mathrm{N} \mathrm{m}^{-2} \mathrm{yr}^{-1}\right)$ & $0.06(0.02)$ & & \\
$\mathrm{N}$ uptake $\left(\mathrm{g} \mathrm{N} \mathrm{m}^{-2} \mathrm{yr}^{-1}\right)$ & $3.1(0.5)$ & & \\
\hline
\end{tabular}

\section{Model Output}

\section{Ecological Variables}

Carbon accumulation and biomass estimated by the model for MORA were similar to or greater than measured values from LVWS. Simulated total net primary production (NPP) was 255 (std. dev. 63) g C m${ }^{-2} \mathrm{yr}^{-1}$ compared to an average $230 \mathrm{~g} \mathrm{C} \mathrm{m}^{-2} \mathrm{yr}^{-1}$ measured at LVWS (Arthur and Fahey, 1992). Simulated above-ground live biomass, 5,313 (std. dev. 61) $\mathrm{g} \mathrm{C} \mathrm{m}^{-2}$, below-ground live biomass, 1,516 (std. dev. 37) g $\mathrm{C} \mathrm{m}^{-2}$, and total live biomass, 6,830 (std. dev. 97) $\mathrm{g} \mathrm{C} \mathrm{m}^{-2}$, were close to measurements made at LVWS $(5,511,1,200$, and 6,711 $\mathrm{g} \mathrm{C} \mathrm{m}^{-2} \mathrm{yr}^{-1}$, respectively). The model showed that MORA stored approximately equal portions of carbon in vegetation and soil organic matter (SOM). Simulated SOM, 7,225 (std. dev. 26) g C m², was greater than that measured at LVWS, 6,800 g C m${ }^{-2}$.

Ecosystem retention of atmospherically deposited $\mathrm{N}$ plus internal $\mathrm{N}$ fixation as predicted by the model was 59 percent, though no measurement of $\mathrm{N}$ retention was available to verify this estimate. Simulated net N mineralization, 3.0 (std. dev. $0.5) \mathrm{g} \mathrm{N} \mathrm{m}^{-2} \mathrm{yr}^{-1}$, was at the high end of the range measured at LVWS, 2-3 $\mathrm{g} \mathrm{N} \mathrm{m}^{-2} \mathrm{yr}^{-1}$. Simulated $\mathrm{N}$ uptake by plants, 3.1 (std. dev. 0.5) g N m${ }^{-2} \mathrm{yr}^{-1}$, was equal to net $\mathrm{N}$ mineralization. Modeled stream N losses, including $\mathrm{NH}_{4}-\mathrm{N}_{2} \mathrm{NO}_{3}-\mathrm{N}$, and dissolved organic nitrogen (DON), were $0.11 \mathrm{~g} \mathrm{~N} \mathrm{~m}^{-2} \mathrm{yr}^{-1}$ (40 percent of $\mathrm{N}$ deposition), with 43 percent of $\mathrm{N}$-export as DON. Calculated gaseous $\mathrm{N}$ loss from nitrification and denitrification $\left(\mathrm{N}_{2} \mathrm{O}, \mathrm{NO}_{\mathrm{x}}\right.$, and $\left.\mathrm{N}_{2}\right)$ were $0.03 \mathrm{~g} \mathrm{~N} \mathrm{~m}^{-2} \mathrm{yr}^{-1}$.

\section{Discharge}

Only three years of stream chemistry and discharge, from October 2004 through August 2007, were available to calibrate the model for MORA, and there were no stream chemistry samples taken in the late autumn and early winter.
DayCent-Chem performed fairly in reproducing measured daily discharge but missed some high flow events (the $\mathrm{R}^{2}$ correlation between measured and modeled discharge was 0.27 ), and the model better matched observations prior to water year 2007 (fig. 8.5). DayCent-Chem overestimated discharge from about April through September but was close for all other months (fig. 8.6). The weather used for the MORA simulation was measured at a station 2-3 km from Lake Louise and in mountainous terrain, where orographic effects can lead to large differences in weather over short distances.

\section{Stream Chemistry}

\section{Nitrate and Ammonium}

Measured $\mathrm{NO}_{3}$ concentrations at MORA were less than $5 \mu$ eq $\mathrm{L}^{-1}$. For the time period that measurements were available, model predictions matched measurements closely except for March, when simulated stream $\mathrm{NO}_{3}$ exceeded observed values by about $10 \mu$ eq $\mathrm{L}^{-1}$ (figs. 8.5, 8.6). Measured daily stream $\mathrm{NH}_{4}$ concentrations were close to $0 \mu \mathrm{eq} \mathrm{L}^{-1}$, and model predictions agreed except for a few measurements that were 1-3 $\mu$ eq $\mathrm{L}^{-1}$. Although more data are required to make generalizations, MORA did not appear to lose any $\mathrm{NO}_{3}$ downstream during the growing season.

\section{Sulfate}

Measured and simulated daily stream $\mathrm{SO}_{4}$ concentrations were less than $15 \mu \mathrm{eq} \mathrm{L}^{-1}$ (figs. 8.5, 8.6). Measurements showed that stream $\mathrm{SO}_{4}$ concentrations were negatively correlated to discharge. $\mathrm{SO}_{4}$ was diluted when discharge increased and concentrated during low flow, although the highest concentration occurred at the onset of spring melt. Simulated $\mathrm{SO}_{4}$ concentrations showed a lesser increase at snowmelt but were close to measured values for May-July and 


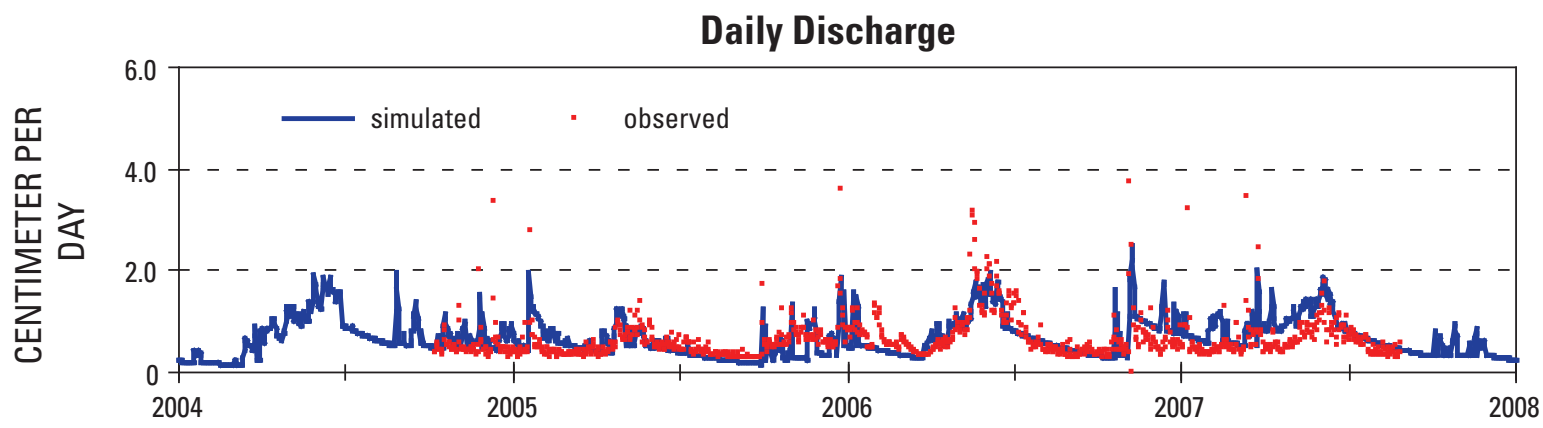

\section{Stream Chemistry}

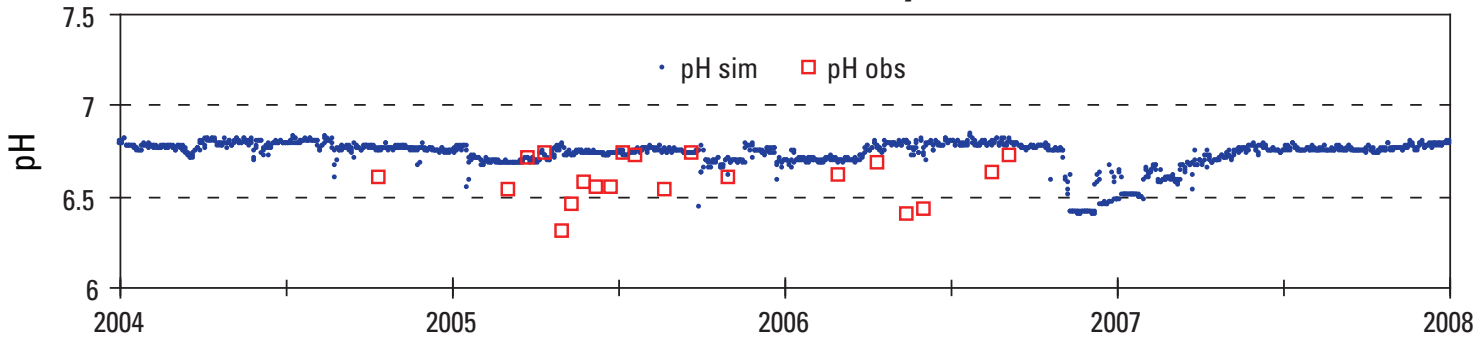

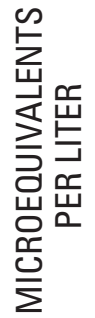
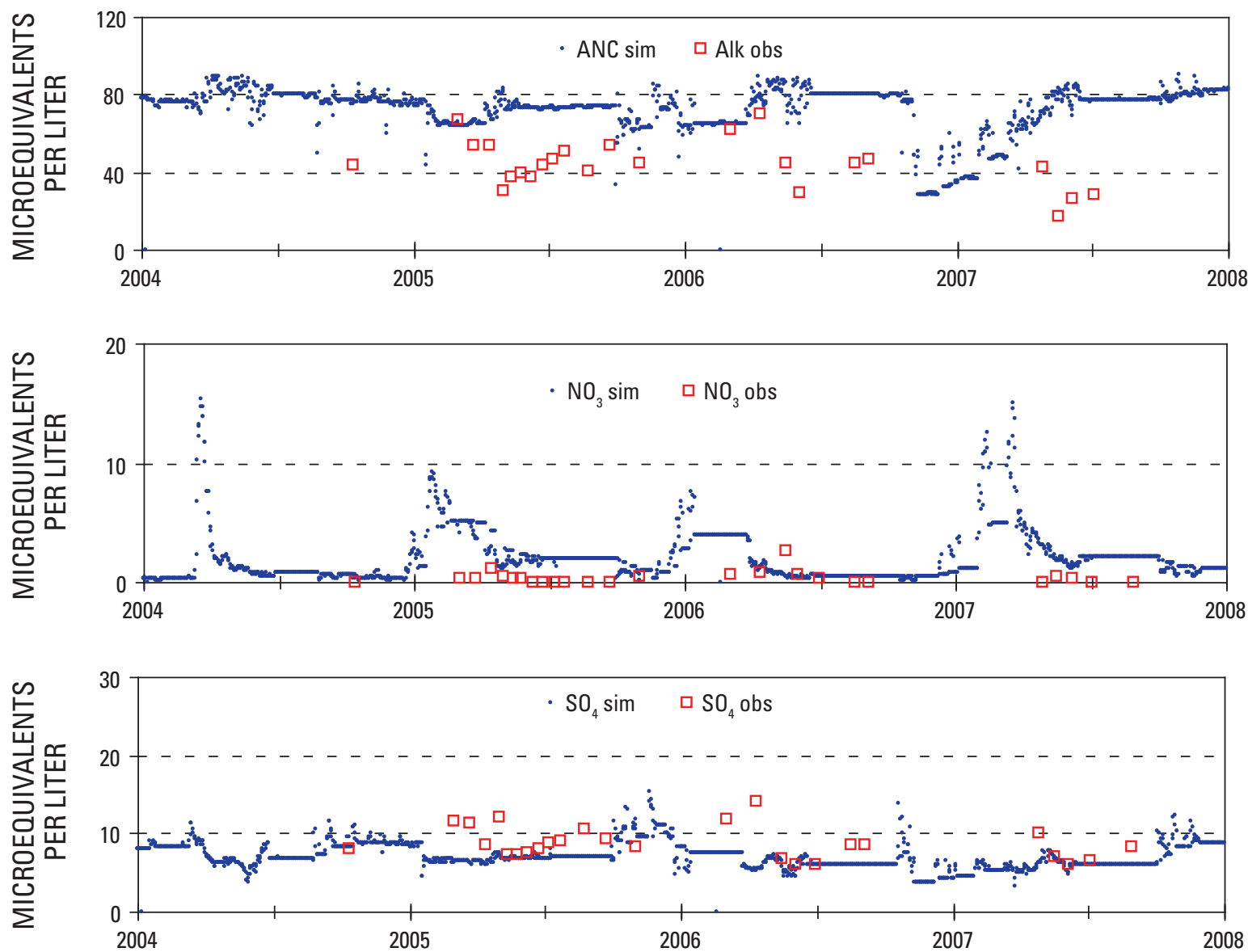

Figure 8.5. Simulated (sim) and observed (obs) daily discharge and stream chemistry for Lake Louise watershed, years 2004-2007. 

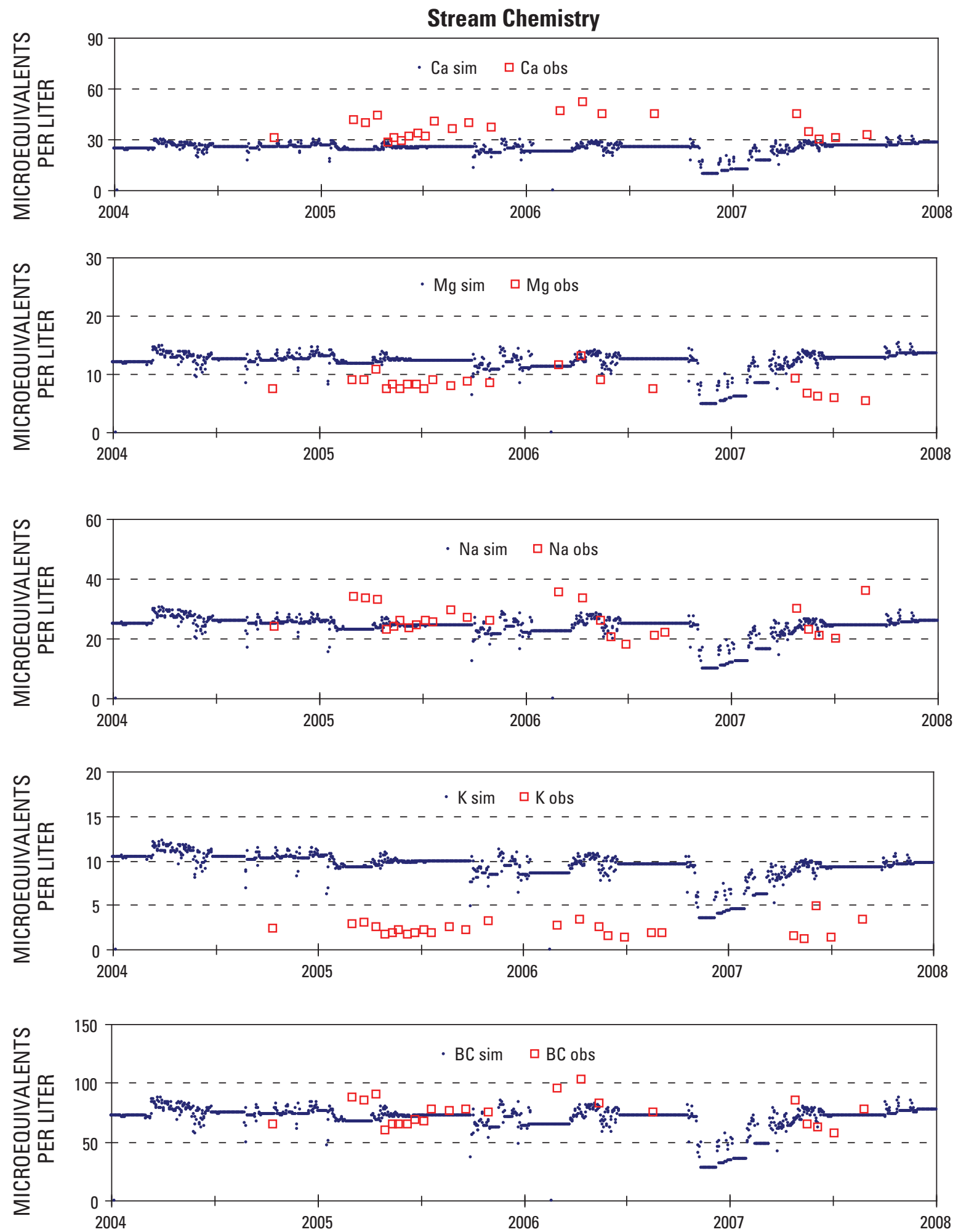

Figure 8.5. Simulated (sim) and observed (obs) daily discharge and stream chemistry for Lake Louise watershed, years 2004-2007.-Continued 

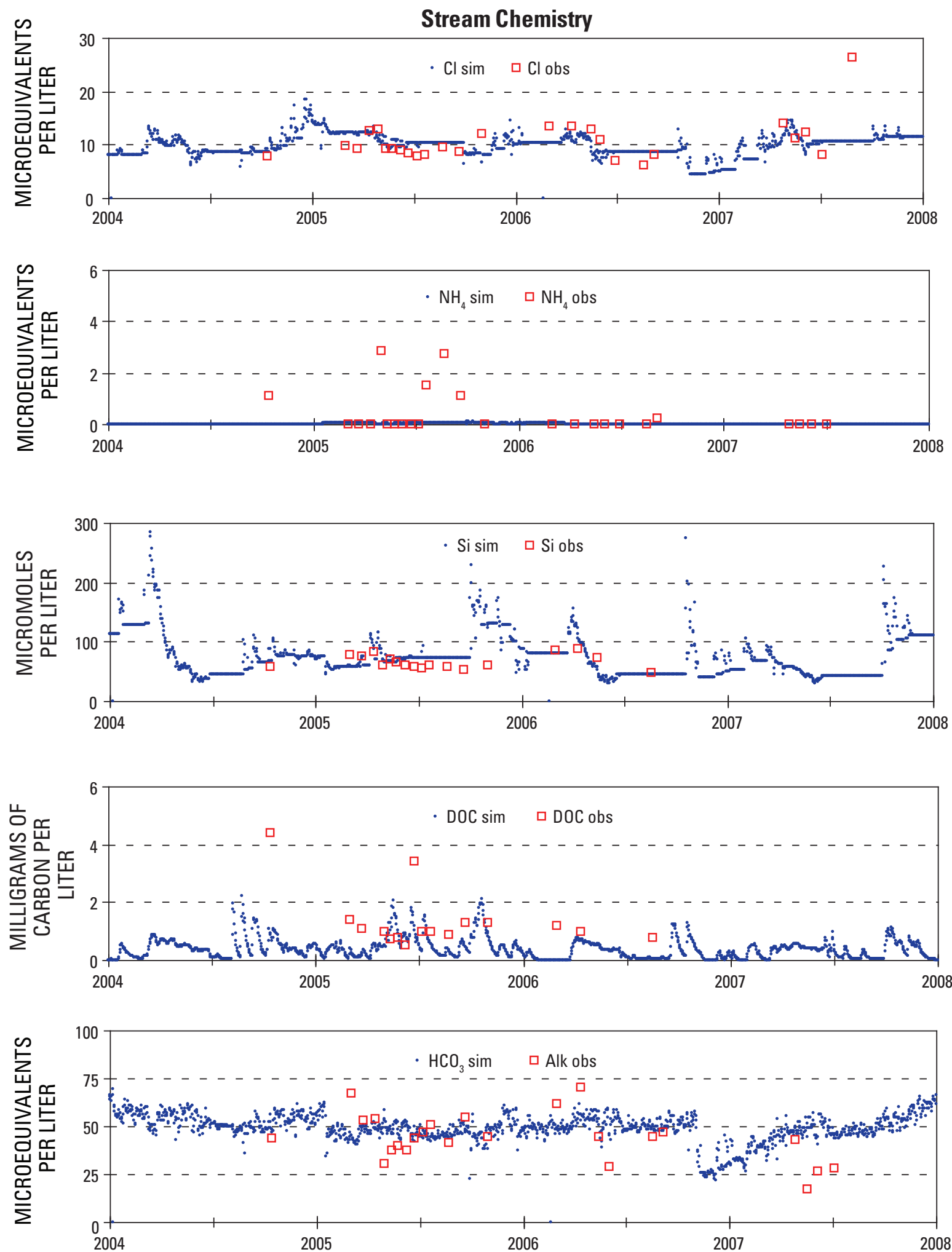

Figure 8.5. Simulated (sim) and observed (obs) daily discharge and stream chemistry for Lake Louise watershed, years 2004-2007.-Continued 

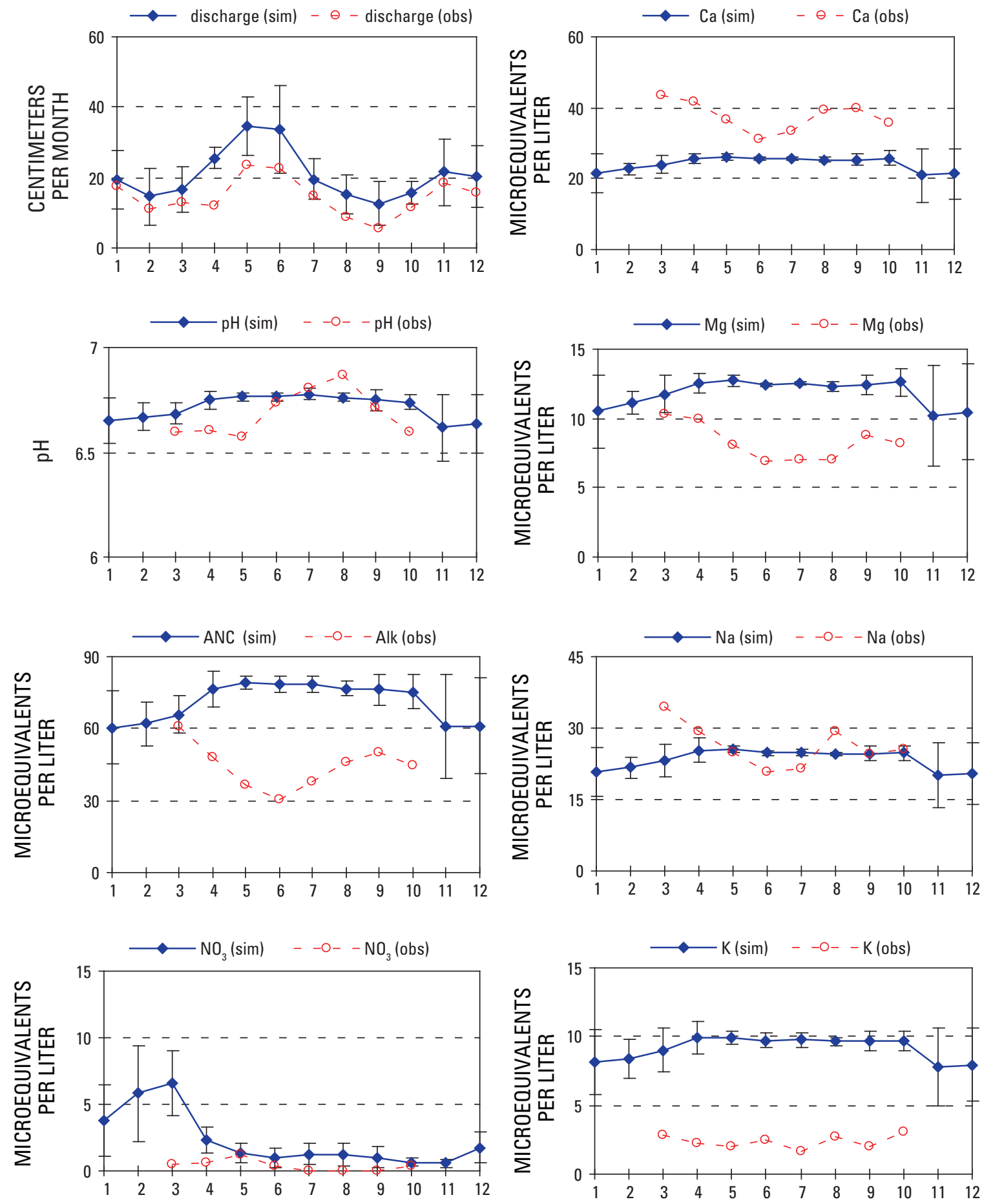

Figure 8.6. Simulated (sim) and observed (obs) discharge and volume-weighted mean (VWM) stream chemistry averaged by month (x axis) for Lake Louise watershed, years 2004-2007. The vertical bars on the simulated values represent plus and minus one standard deviation from the monthly mean. 

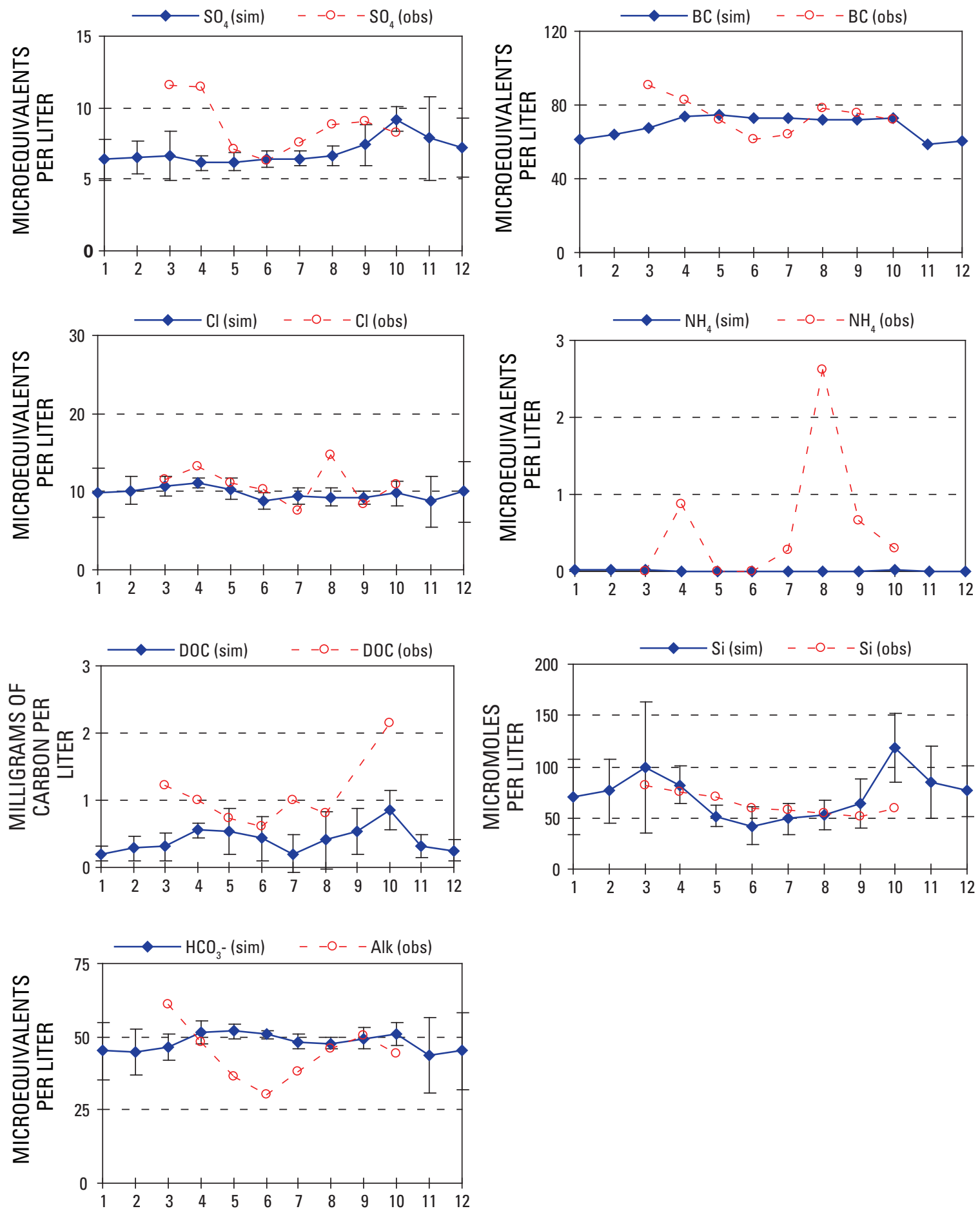

Figure 8.6. Simulated (sim) and observed (obs) discharge and volume-weighted mean (VWM) stream chemistry averaged by month ( $x$ axis) for Lake Louise watershed, years 2004-2007. The vertical bars on the simulated values represent plus and minus one standard deviation from the monthly mean.-Continued 
again in September. Sulfate behaved conservatively in both the model and observations, as $\mathrm{SO}_{4}$ inputs were roughly equal to $\mathrm{SO}_{4}$ outputs.

\section{Chloride}

The model was able to represent seasonal and daily stream $\mathrm{Cl}$ concentrations (figs. 8.5, 8.6). All simulated daily values were within a few $\mu$ eq $\mathrm{L}^{-1}$ of measured values except for one higher measured concentration in August 2007.

\section{Weathering Products}

The model predicted more seasonal variation in stream $\mathrm{Si}$ concentrations than was measured (figs. 8.5, 8.6). Though simulated monthly averaged Si concentrations were significantly close to measured values most of the year, DayCent-Chem underestimated Si concentrations during the summer months when discharge was overestimated. In contrast, the model overestimated stream Si concentrations at the onset of melt. Though the model underestimated stream Ca concentrations and overestimated stream Mg and K concentrations, simulated $\mathrm{Na}$ concentrations and the sum of base cation concentrations were close to observations (figs. 8.5, 8.6). Measured concentrations of $\mathrm{Ca}, \mathrm{Mg}$, and $\mathrm{Na}$ generally showed more seasonal variation than simulated values and were greatest at the onset of melt (March and April) and in late summer/early autumn and were lowest during the summer.

\section{$\mathrm{ANC}$ and $\mathrm{pH}$}

Stream pH at MORA varied between 6.3 and 6.7, and measured alkalinity varied between 30 and $70 \mu$ eq $\mathrm{L}^{-1}$. Simulated daily stream $\mathrm{pH}$ was slightly greater and less variable than measured $\mathrm{pH}$. Simulated $\mathrm{HCO}_{3}$ concentrations were close to measured alkalinity, but simulated ANC, which includes Alhydroxide buffers as well as $\mathrm{HCO}_{3}$, was greater than measured alkalinity, particularly for the summer months (figs. 8.5, 8.6). Simulated annual volume-weighted mean ANC was $18 \mu \mathrm{eq} \mathrm{\textrm {L } ^ { - 1 }}$ greater than simulated annual volume-weighted mean $\mathrm{HCO}_{3}$ concentrations (table 8.6). The model may have overestimated stream concentrations of Al-hydroxides.

\section{Dissolved Organic Carbon}

Simulated daily stream dissolved organic carbon (DOC) was in the range of measured DOC, although there were slightly different temporal patterns because modeled values were responsive to simulated soil flushing events.

\section{Summary}

There were insufficient data for MORA to adequately parameterize DayCent-Chem and evaluate the model's performance. Input drivers that were obtained from distant meteorological and NADP stations created difficulty in getting the model to portray observations. The period of record for measured discharge and stream chemistry was only three years.

DayCent-Chem performed fairly in matching patterns in measured daily discharge before water year 2007, a validation year. The model did well in predicting the magnitude of daily stream $\mathrm{NO}_{3}, \mathrm{NH}_{4}, \mathrm{Si}, \mathrm{Cl}, \mathrm{Na}$, and the sum of base cation concentrations, but it missed some of the temporal patterns. The model underestimated stream Ca concentrations and overestimated stream $\mathrm{Mg}$ and $\mathrm{K}$ concentrations. Simulated daily stream ANC was overestimated, but $\mathrm{HCO}_{3}$ concentrations were close to measured alkalinity. The model may have overestimated stream concentrations of Al-hydroxides that contribute to simulated ANC. In-lake processes, such as uptake of nutrients and silica, may affect stream chemistry measured at the lake outlet, but these processes are not represented by DayCent-Chem.

Though we were not able to attain measured values for ecosystem biomass and C and N fluxes, simulated NPP and biomass values were close to or slightly greater than those measured at a colder and drier subalpine forest in the Rocky Mountains. 
Table 8.6. Annual volume-weighted mean simulated stream chemistry averaged over each year of the simulation (1990-2007). Annual statistics for observed chemistry were not available due to the short data record. Pmean $=$ predicted mean; Omean = observed mean; $A E=$ absolute error $($ Pmean - Omean); NAE $=$ normalized absolute error (AE/Omean); N/A = not available.

\begin{tabular}{|c|c|c|c|c|c|}
\hline Solute & Metric & Concentration & Solute & Metric & Concentration \\
\hline \multirow[t]{4}{*}{$\mathrm{pH}$} & Pmean & 6.71 & $\mathrm{NO}_{3}\left(\mu\right.$ eq $\left.\mathrm{L}^{-1}\right)$ & Pmean & 1.91 \\
\hline & Omean & N/A & & Omean & N/A \\
\hline & $\mathrm{AE}$ & N/A & & $\mathrm{AE}$ & N/A \\
\hline & NAE & N/A & & NAE & N/A \\
\hline \multirow[t]{4}{*}{ Сa $\left(\mu \mathrm{eq} \mathrm{L} \mathrm{L}^{-1}\right)$} & Pmean & 21.97 & $\mathrm{SO}_{4}\left(\mu \mathrm{eq} \mathrm{L} \mathrm{L}^{-1}\right)$ & Pmean & 8.76 \\
\hline & Omean & N/A & & Omean & N/A \\
\hline & $\mathrm{AE}$ & N/A & & $\mathrm{AE}$ & N/A \\
\hline & NAE & N/A & & NAE & N/A \\
\hline \multirow[t]{4}{*}{$\mathrm{Mg}\left(\mu \mathrm{eq} \mathrm{L} \mathrm{L}^{-1}\right)$} & Pmean & 10.81 & ANC $\left(\mu\right.$ еq $\left.L^{-1}\right)$ & Pmean & 63.63 \\
\hline & Omean & N/A & & Omean & N/A \\
\hline & $\mathrm{AE}$ & N/A & & $\mathrm{AE}$ & N/A \\
\hline & NAE & N/A & & NAE & N/A \\
\hline \multirow[t]{4}{*}{$\mathrm{K}\left(\right.$ нeq $\left.\mathrm{L}^{-1}\right)$} & Pmean & 11.09 & $\mathrm{HCO}_{3}\left(\mu \mathrm{eq} \mathrm{L} \mathrm{L}^{-1}\right)$ & Pmean & 45.88 \\
\hline & Omean & N/A & & Omean & N/A \\
\hline & $\mathrm{AE}$ & N/A & & $\mathrm{AE}$ & N/A \\
\hline & NAE & N/A & & NAE & N/A \\
\hline \multirow[t]{4}{*}{$\mathrm{Na}\left(\mu \mathrm{eq} \mathrm{L} \mathrm{L}^{-1}\right)$} & Pmean & 25.47 & $\mathrm{Cl}\left(\mu \mathrm{eq} \mathrm{L} \mathrm{L}^{-1}\right)$ & Pmean & 11.37 \\
\hline & Omean & N/A & & Omean & N/A \\
\hline & $\mathrm{AE}$ & N/A & & $\mathrm{AE}$ & N/A \\
\hline & NAE & N/A & & NAE & N/A \\
\hline \multirow[t]{4}{*}{ BC $\left(\mu\right.$ eq $\left.\mathrm{L}^{-1}\right)$} & Pmean & 69.34 & $\mathrm{Si}\left(\mu \mathrm{mol} \mathrm{L} \mathrm{L}^{-1}\right)$ & Pmean & 68.23 \\
\hline & Omean & N/A & & Omean & N/A \\
\hline & $\mathrm{AE}$ & N/A & & $\mathrm{AE}$ & N/A \\
\hline & NAE & N/A & & NAE & N/A \\
\hline \multirow[t]{4}{*}{$\mathrm{NH}_{4}\left(\mu \mathrm{eq} \mathrm{L}{ }^{-1}\right)$} & Pmean & 0.01 & $\mathrm{DOC}\left(\mathrm{mg} \mathrm{C} \mathrm{L} \mathrm{L}^{-1}\right)$ & Pmean & 0.79 \\
\hline & Omean & N/A & & Omean & N/A \\
\hline & $\mathrm{AE}$ & N/A & & $\mathrm{AE}$ & N/A \\
\hline & NAE & N/A & & NAE & N/A \\
\hline
\end{tabular}




\section{H.J. Andrews Long-Term Ecological Research Site, Oregon}

\section{Site Description}

H.J. Andrews LTER (HJA) is situated in the western Cascade Range of Oregon (fig. 9.1). The study watershed (WS10) is 10 ha of an aggrading Douglas fir (Pseudotsuga menziesii) forest that was clear-cut in 1975 and ranges from $473 \mathrm{~m}$ to 679 $\mathrm{m}$ in elevation (table 9.1). Soils underlying the H.J. Andrews site formed in poorly sorted colluvium and alluvium derived from basaltic/andesitic tuffs and breccias and are classified as Hapludands (Lajtha and others, 2005).

\section{Methods}

\section{Climate and Hydrology}

Daily meteorological variables were obtained from McKee (2007) (fig. 9.2). For years 1981-2004, precipitation averaged 219 (std. dev. 44) $\mathrm{cm} \mathrm{yr}^{-1}$ and mean annual temperature was 10.2 (std. dev. 0.8$)^{\circ} \mathrm{C}$, increasing approximately $0.0532{ }^{\circ} \mathrm{C} \mathrm{yr}^{-1}$. The climate is marine temperate. Precipitation is greatest during the winter months of November through March and very little precipitation occurs between June 1 and September 30. Since winter temperatures are commonly at or slightly above freezing, most moisture falls as rain. Measured discharge for WS10 varied with precipitation; it was greatest during the winter and near zero during the summer (Rothacher, 2007) (fig. 9.3).

\section{Atmospheric Deposition}

Wet deposition was measured at the NADP/NTN H.J. Andrews site (OR10; elevation 436 m). We estimated dryplus-fog:wet deposition ratios by calibration (table 9.2, fig. 9.4). There was more than $3 \mathrm{~kg} \mathrm{ha}^{-1} \mathrm{yr}^{-1} \mathrm{~S}$ deposition for 1981-1983, which decreased thereafter to values mostly less than $2 \mathrm{~kg} \mathrm{~S} \mathrm{ha}^{-1} \mathrm{yr}^{-1}$. There was no trend in $\mathrm{NH}_{4}-\mathrm{N}, \mathrm{NO}_{3}-\mathrm{N}$, or total $\mathrm{N}$ deposition over time.

\section{Soil and Mineral Properties}

The study watershed, WS10, is underlain by andesitic and basaltic lava flows (Swanson and James, 1975). Andesites contain crystals composed primarily of plagioclase feldspar

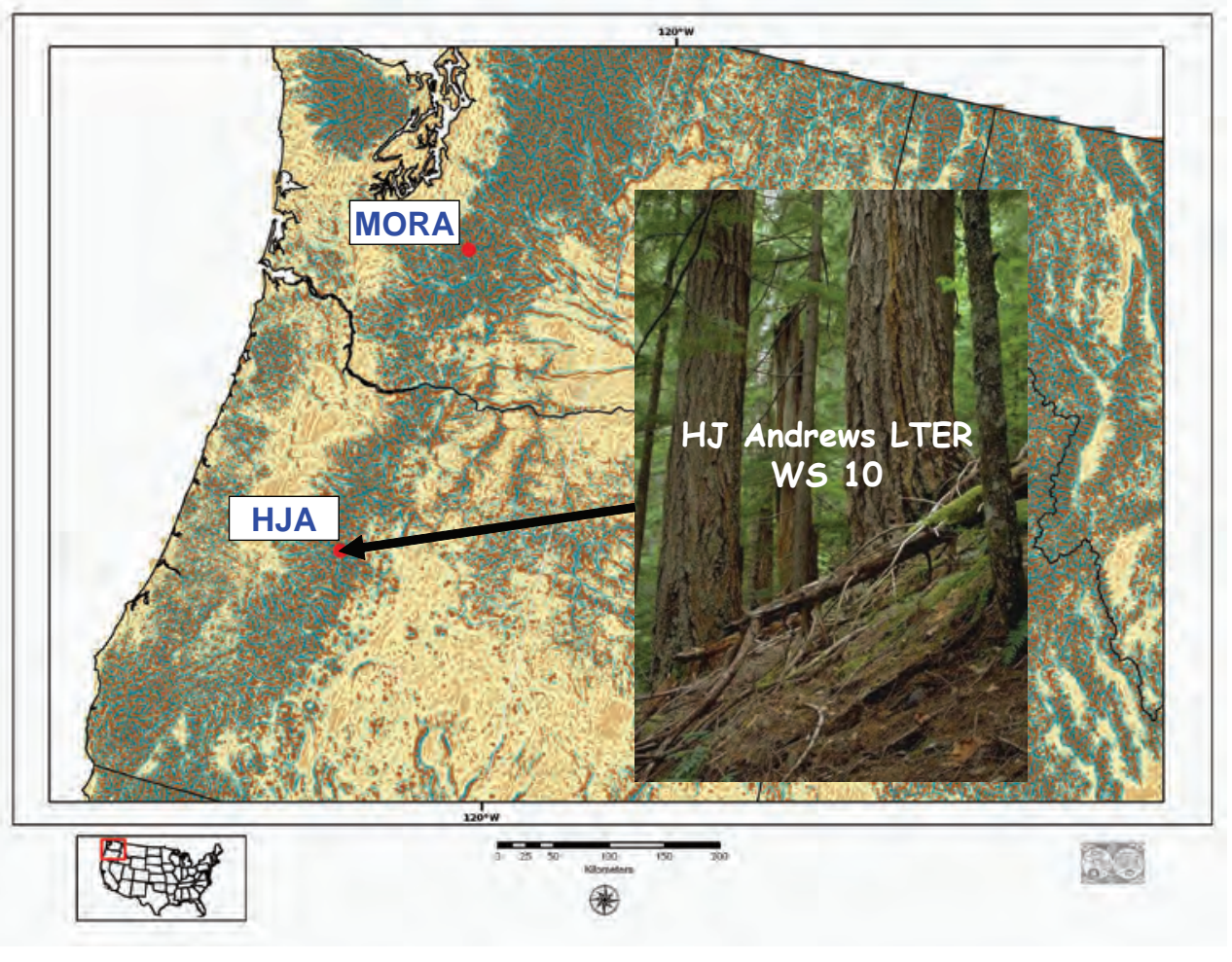

Figure 9.1. H.J. Andrews LTER (HJA) is situated in the western Cascade Range of Oregon. Mount Rainier National Park (MORA, see Chapter 8) is to the North. 
Table 9.1. Characteristics of Watershed 10 (WS10) at H.J. Andrews LTER, Oregon.

\begin{tabular}{ll}
\hline \multicolumn{1}{c}{ Site } & \multicolumn{1}{c}{ H.J. Andrews LTER } \\
\hline Location & Cascade Range of Oregon \\
Catchment name & WS10 \\
Area (ha) & 10 \\
Latitude, longitude & $44^{\circ} 13^{\prime}, 122^{\circ} 15^{\prime}$ \\
Outlet elevation (m.a.s.l.) & 473 \\
Highest elevation (m.a.s.l.) & 679 \\
Climate & Marine temperate \\
Climate simulation years & $1981-2004$ \\
Mean (and std. dev.) annual temperature $\left({ }^{\circ} \mathrm{C}\right)$ & $10.2(0.8)$ \\
Mean (and std. dev.) annual precipitation $\left(\mathrm{cm} \mathrm{yr}^{-1}\right)$ & $219(44)$ \\
Ecosystem type & Maritime coniferous forest \\
Vegetative cover (\%) & $100 \%$ forest \\
Dominant plant species & Douglas-fir (Pseudotsuga menziesii) \\
Soil type & Andisols \\
Bedrock mineralogy & Andesite lava flows \\
Recent disturbances & $100 \%$ clearcut in 1975 \\
Anthropogenic influences & Low amounts of atmospheric deposition \\
\hline
\end{tabular}

(represented as albite and anorthite) with one or more pyroxene minerals (represented as diopside) and lesser amounts of hornblende (not represented). Biotite is a common accessory mineral. Since these minerals were similar to the ones we determined for Mount Rainier (see Chapter 8), we started with the mineral dissolution rates (moles ha-1) we used for the Mount Rainier simulation, then adjusted the rates to better match simulated and observed stream base cation and silica concentrations (table 9.3). The mineral reactions are summarized below.

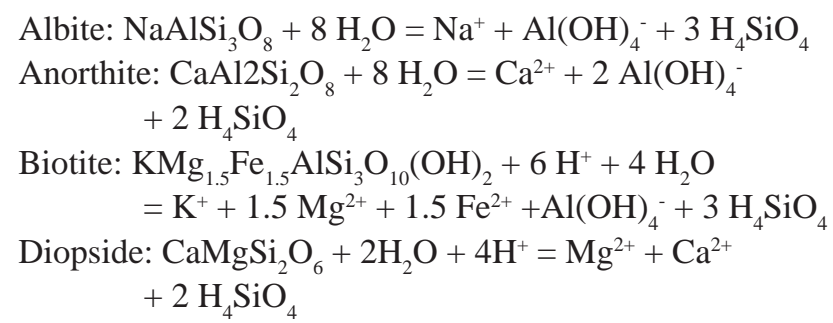

Few measurements of soil properties were available, so these model inputs were borrowed from other sites or determined by calibrating for stream discharge and chemistry (table 9.4).

\section{Calibration and Validation}

To parameterize the model for HJA, we first tuned vegetation and soil parameters until values of simulated ecological variables were close to those that were measured (table 9.5). We then compared measured stream chemistry and discharge for WS10 (Fredriksen, 2007; Rothacher, 2007) to model results. Data for years 1981-2000 (fig. 9.5) were used to calibrate the model, and model output for years 2001-2004 (fig. 9.6) were emergent from the resulting model parameterization.

We show two 3-year periods of daily discharge and chemistry. Results from about 1994-1996 will be examined (when possible) for all sites in an intersite model comparison. For HJA, the period 1994-1996 included a below-average precipitation year, an average year, and an above-average year (figs. 9.2B, 9.5). Years 2002-2004 included two belowaverage precipitation years and one above-average year (figs. 9.2B, 9.6).

\section{Model Output}

\section{Ecological Variables}

H.J. Andrews WS10 was clear-cut in 1975 and represents an aggrading forest. Since there were no post-harvest biomass measurements available, we simulated the forests of two adjacent watersheds (WS8 and WS9) where data were available but forests are mature (table 9.5, columns 5 and 6). Simulated leaf biomass (639 $\mathrm{g} \mathrm{C} \mathrm{m}^{-2}$ ), large wood biomass (23,359 g C $\left.\mathrm{m}^{-2}\right)$, and coarse root biomass $\left(6,953 \mathrm{~g} \mathrm{C} \mathrm{m}^{-2}\right)$ were lower than 

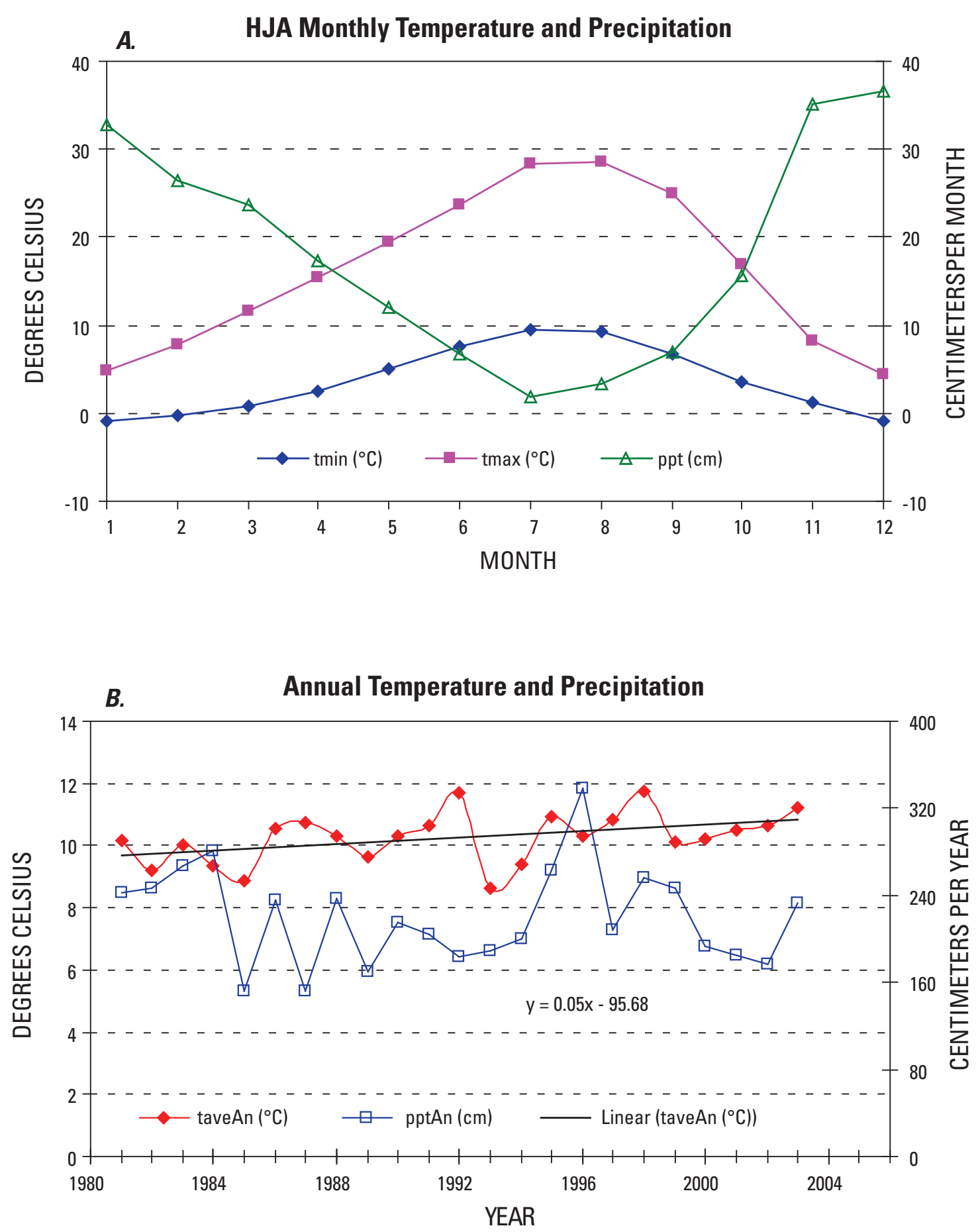

Figure 9.2. Meteorological statistics of model inputs for H.J. Andrews LTER. A, Monthly average precipitation and minimum and maximum air temperatures, years 1981-2004. $B$, The time series of annual average precipitation and temperature, years 1981-2004. Average annual temperature showed an increase of $0.05^{\circ} \mathrm{C}$ year ${ }^{-1}$. 


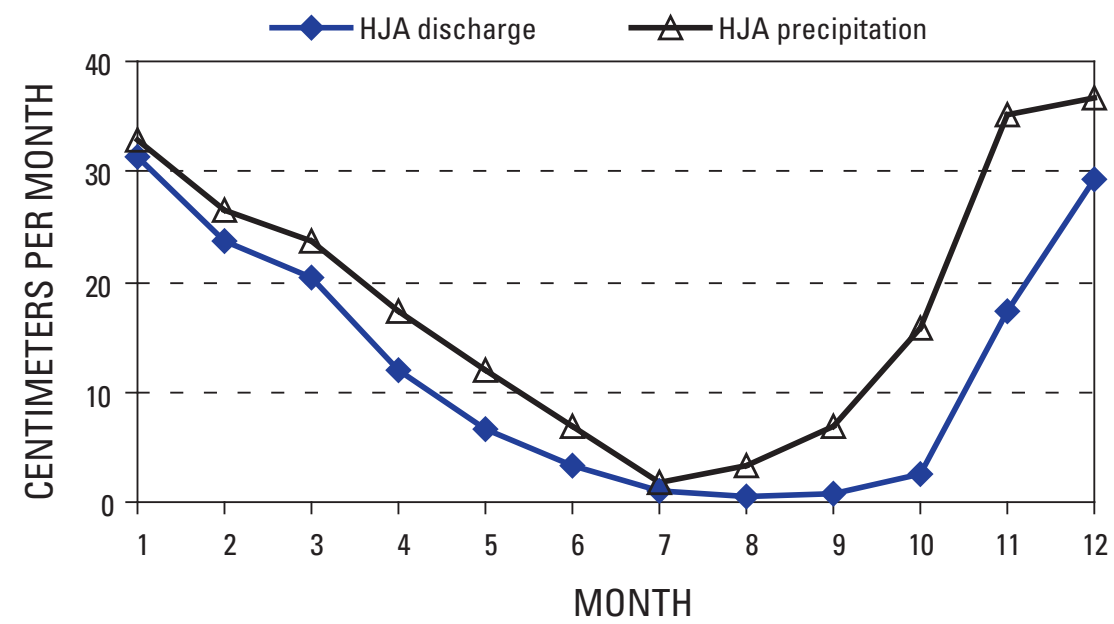

Figure 9.3. Relationship between average monthly precipitation and discharge measured at H.J. Andrews LTER (HJA), years 1981-2004.

Table 9.2. Average annual wet and dry plus fog deposition inputs $\left(\mathrm{kg} \mathrm{ha}^{-1} \mathrm{yr}^{-1}\right)$ to the model over the 1981-1999 simulation period.

\begin{tabular}{llcc}
\hline & Wet & Dry + Fog & Total \\
\hline $\mathrm{Ca}$ & 0.67 & 2.68 & 3.35 \\
$\mathrm{Cl}$ & 7.11 & 14.22 & 21.33 \\
$\mathrm{~K}$ & 0.26 & 0.00 & 0.26 \\
$\mathrm{Mg}$ & 0.51 & 0.51 & 1.02 \\
$\mathrm{NH}_{4}-\mathrm{N}$ & 0.49 & 0.12 & 0.62 \\
$\mathrm{NO}_{3}-\mathrm{N}$ & 0.70 & 0.17 & 0.87 \\
$\mathrm{Na}$ & 4.10 & 12.31 & 16.41 \\
$\mathrm{SO}_{4}-\mathrm{S}$ & 1.50 & 0.37 & 1.87 \\
\hline
\end{tabular}



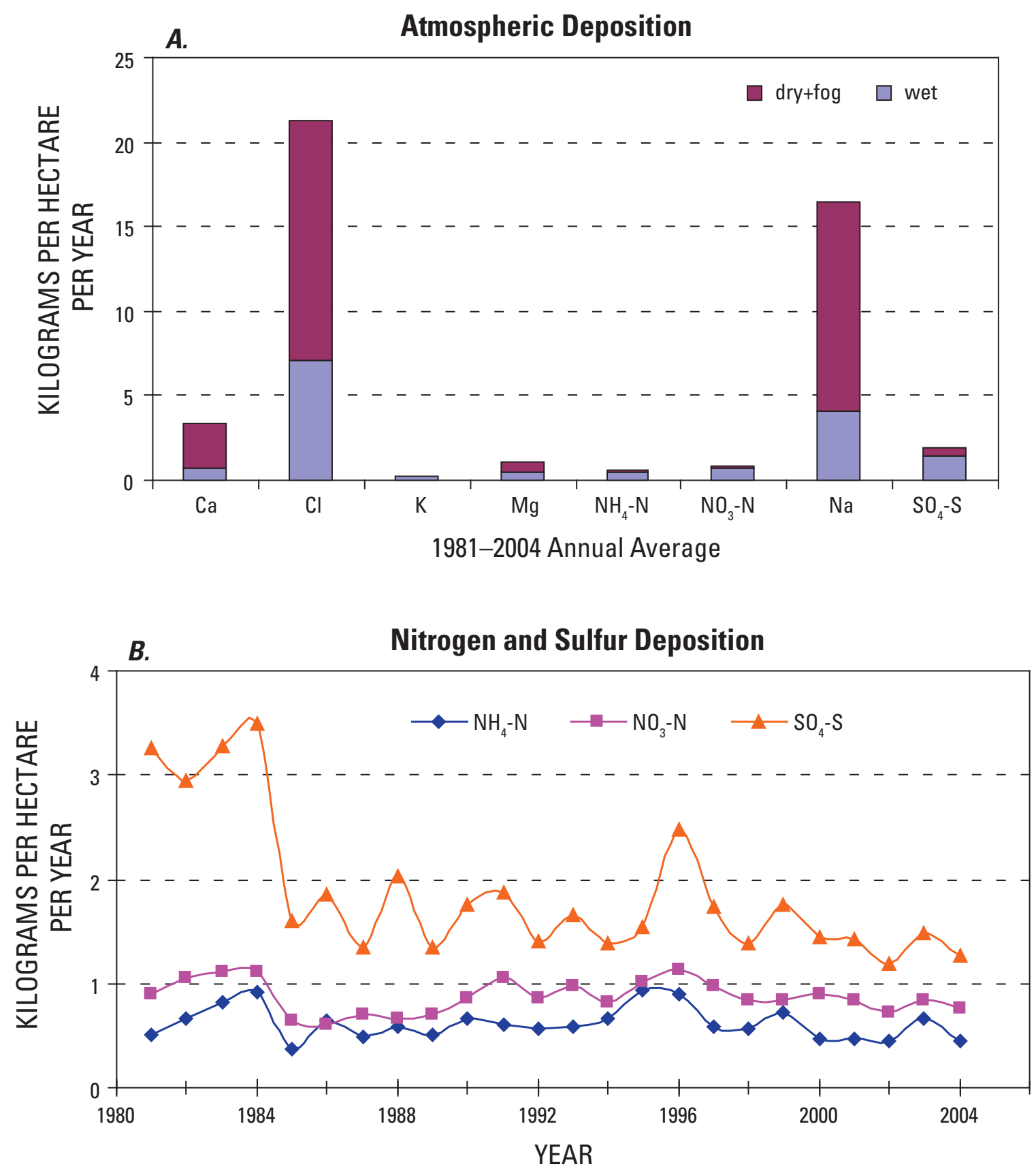

Figure 9.4. Deposition inputs to the model for H.J. Andrews LTER (HJA). A, The 1981-2004 average annual wet and dry deposition. $B$, The time series of $\mathrm{N}$ and $\mathrm{S}$ deposition over the simulation period. 
Table 9.3. Mineral phases and potential annual mineral denudation rates prescribed for the simulation. All minerals were allowed only to dissolve.

\begin{tabular}{|c|c|c|}
\hline $\begin{array}{c}\text { Mineral } \\
\text { phases }\end{array}$ & $\mathrm{mol} \mathrm{m}^{-2} \mathrm{yr}^{-1}$ & $\begin{array}{c}1 \text { = dissolve, } \\
0 \text { = precipitate } \\
\text { or dissolve }\end{array}$ \\
\hline Albite & 0.152012 & 1 \\
\hline Anorthite & 0.097188 & 1 \\
\hline Biotite & 0.0064 & 1 \\
\hline Diopside & 0.165 & 1 \\
\hline
\end{tabular}

Table 9.4. Soil layer properties used for the simulation. Ksat is saturated hydraulic conductivity, and the mineral dissolution fraction (Minrl dissoln) is the fraction of total mineral dissolution that occurred in each layer. Wilting point and field capacity are expressed as volumetric soil water content. Exchangeable cations are expressed as milliequivalents per $100 \mathrm{grams}$ of soil (meq/100 g). Total soil depth was $70 \mathrm{~cm}$ and organic soil made up the top $20 \mathrm{~cm}$.

\begin{tabular}{|c|c|c|c|c|c|c|c|c|c|}
\hline Layer & $\begin{array}{c}\text { Thickness } \\
\text { cm }\end{array}$ & $\begin{array}{c}\text { Sand } \\
\text { fraction }\end{array}$ & $\begin{array}{c}\text { Silt } \\
\text { fraction }\end{array}$ & $\begin{array}{c}\text { Clay } \\
\text { fraction }\end{array}$ & $\begin{array}{c}\text { Bulk } \\
\text { density } \\
\mathrm{g} \mathrm{cm}^{-3}\end{array}$ & $\begin{array}{l}\text { Wilting } \\
\text { point } \\
\text { fraction }\end{array}$ & $\begin{array}{c}\text { Field } \\
\text { capacity } \\
\text { fraction }\end{array}$ & $\begin{array}{c}\text { Ksat } \\
\text { cm sec }^{-1}\end{array}$ & $\begin{array}{c}\text { Minrl } \\
\text { dissoln } \\
\text { fraction }\end{array}$ \\
\hline 0 & 2 & 0.22 & 0.34 & 0.44 & 1.25 & 0.211 & 0.423 & 0.00014 & 0.2 \\
\hline 1 & 3 & 0.22 & 0.34 & 0.44 & 1.25 & 0.211 & 0.423 & 0.00014 & 0.4 \\
\hline 2 & 5 & 0.22 & 0.34 & 0.44 & 1.25 & 0.211 & 0.423 & 0.00014 & 0.4 \\
\hline 5 & 15 & 0.22 & 0.34 & 0.44 & 1.25 & 0.211 & 0.423 & 0.00014 & 0.0 \\
\hline 6 & 20 & 0.22 & 0.34 & 0.44 & 1.25 & 0.211 & 0.423 & 0.00014 & 0.0 \\
\hline Layer & $\begin{array}{c}\mathrm{CaX}_{2} \\
\mathrm{meq} / 100 \mathrm{~g}\end{array}$ & $\begin{array}{c}\mathrm{MgX}_{2} \\
\mathrm{meq} / 100 \mathrm{~g}\end{array}$ & $\begin{array}{c}\mathrm{KX} \\
\mathrm{meq} / 100 \mathrm{~g}\end{array}$ & $\begin{array}{c}\mathrm{NaX} \\
\mathrm{meq} / 100 \mathrm{~g}\end{array}$ & $\begin{array}{c}\mathrm{AlOHX}_{2} \\
\mathrm{meq} / 100 \mathrm{~g}\end{array}$ & $\begin{array}{c}\mathrm{AlX}_{3} \\
\mathrm{meq} / 100 \mathrm{~g}\end{array}$ & $\begin{array}{c}\mathrm{FeX}_{2} \\
\mathrm{meq} / 100 \mathrm{~g}\end{array}$ & $\begin{array}{c}\mathrm{HX} \\
\mathrm{meq} / 100 \mathrm{~g}\end{array}$ & $\begin{array}{c}\mathrm{NH}_{4} \mathrm{X} \\
\mathrm{meq} / 100 \mathrm{~g}\end{array}$ \\
\hline 3 & 6.01 & 1.92 & 0.17 & 0.16 & 3.18 & 17.18 & 0.00 & 0.00 & 0.11 \\
\hline 4 & 3.59 & 0.87 & 0.07 & 0.06 & 1.62 & 12.87 & 0.00 & 0.00 & 0.02 \\
\hline 5 & 4.00 & 0.93 & 0.08 & 0.06 & 1.50 & 12.68 & 0.00 & 0.00 & 0.00 \\
\hline 6 & 4.14 & 0.95 & 0.08 & 0.05 & 1.22 & 13.19 & 0.00 & 0.00 & 0.00 \\
\hline
\end{tabular}


Table 9.5. Simulated (1981-2004) and measured ecological variables and input/output fluxes. In order to have more empirical data for ecological variables, we showed model results from two simulations: one with a clear cut in 1975 and one without a clear cut. Standard deviations are shown in parentheses and represent interannual variation for annual fluxes and monthly variations for state variables. NPP = net primary production; NEP = net ecosystem production; $\mathrm{Rh}=$ heterotrophic respiration; $\mathrm{PET}=$ potential evapotranspiration; $A E T$ = actual evapotranspiration; $D O C$ = dissolved organic carbon. To convert units reported by data sources, it was assumed that 2.25 grams biomass equals 1 gram $C$.

\begin{tabular}{|c|c|c|c|c|c|}
\hline $\begin{array}{l}\text { NPP, NEP, and } \\
\text { litterfall }\end{array}$ & $\begin{array}{l}\text { Simulated with } \\
1975 \text { clear cut }\end{array}$ & $\begin{array}{l}\text { Measured with } \\
1975 \text { clear cut }\end{array}$ & Data sources & $\begin{array}{l}\text { Simulated without } \\
\text { clear cut }\end{array}$ & $\begin{array}{l}\text { Measured without } \\
\text { clear cut }\end{array}$ \\
\hline $\mathrm{NPP}\left(\mathrm{g} \mathrm{C} \mathrm{m}^{-2} \mathrm{yr}^{-1}\right)$ & 408 (35) & & & 482 (45) & \\
\hline Below-ground NPP & 177 (19) & & & $203(27)$ & \\
\hline Tree total NPP & 404 (35) & & & $480(45)$ & \\
\hline Large wood NPP & $92(12)$ & & & 102 (19) & \\
\hline Fine branch NPP & $29(4)$ & & & $32(6)$ & \\
\hline Fine root NPP & 93 (9) & & & 109 (14) & \\
\hline Coarse root NPP & $69(9)$ & & & 77 (14) & \\
\hline $\begin{array}{l}\text { Water and } \\
\text { temperature }\end{array}$ & $\begin{array}{c}\text { Simulated with } 1975 \\
\text { clear cut }\end{array}$ & $\begin{array}{c}\text { Measured with } 1975 \\
\text { clear cut }\end{array}$ & Data sources & $\begin{array}{c}\text { Simulated without } \\
\text { clear cut }\end{array}$ & $\begin{array}{l}\text { Measured without } \\
\text { clear cut }\end{array}$ \\
\hline $\begin{array}{l}\text { Annual temperature } \\
\quad\left({ }^{\circ} \mathrm{C}\right)\end{array}$ & $10.2(0.8)$ & & & $10.2(0.8)$ & \\
\hline $\begin{array}{l}\text { Precipitation } \\
\qquad\left(\mathrm{cm} \mathrm{yr}^{-1}\right)\end{array}$ & $219(44)$ & & & $219(44)$ & \\
\hline Snow (\%) & $5 \%(5 \%)$ & & & $5 \%(5 \%)$ & \\
\hline Rain (\%) & $95 \%$ & & & $95 \%$ & \\
\hline $\begin{array}{l}\text { Leaves at annual } \\
\text { maximum } \\
\qquad\left(\mathrm{g} \mathrm{C} \mathrm{m}^{-2}\right)\end{array}$ & $461(40)$ & & & $639(1)$ & 695 \\
\hline Fine roots $\left(\mathrm{g} \mathrm{C} \mathrm{m}^{-2}\right)$ & $596(91)$ & & & $780(40)$ & 565 \\
\hline $\begin{array}{l}\text { Fine branches } \\
\qquad\left(\mathrm{g} \mathrm{C} \mathrm{m}^{-2}\right)\end{array}$ & $682(191)$ & & & $6,504(71)$ & \\
\hline $\begin{array}{l}\text { Large wood } \\
\qquad\left(\mathrm{g} \mathrm{C} \mathrm{m}^{-2}\right)\end{array}$ & 2,314 (616) & & & 23,359 (261) & 35,225 \\
\hline $\begin{array}{l}\text { Coarse roots } \\
\qquad\left(\mathrm{g} \mathrm{C} \mathrm{m}^{-2}\right)\end{array}$ & $3,746(248)$ & & & 6,953 (98) & 7,065 \\
\hline
\end{tabular}


Table 9.5. Simulated (1981-2004) and measured ecological variables and input/output fluxes. In order to have more empirical data for ecological variables, we showed model results from two simulations: one with a clear cut in 1975 and one without a clear cut. Standard deviations are shown in parentheses and represent interannual variation for annual fluxes and monthly variations for state variables. NPP = net primary production; NEP = net ecosystem production; $\mathrm{Rh}=$ heterotrophic respiration; $\mathrm{PET}=$ potential evapotranspiration; $\mathrm{AET}$ = actual evapotranspiration; $\mathrm{DOC}=$ dissolved organic carbon. To convert units reported by data sources, it was assumed that 2.25 grams biomass equals 1 gram C.-Continued

\begin{tabular}{|c|c|c|c|c|c|}
\hline Carbon pools & $\begin{array}{c}\text { Simulated with } 1975 \\
\text { clear cut }\end{array}$ & $\begin{array}{l}\text { Measured with } 1975 \\
\text { clear cut }\end{array}$ & Data sources & $\begin{array}{l}\text { Simulated without } \\
\text { clear cut }\end{array}$ & $\begin{array}{l}\text { Measured without } \\
\text { clear cut }\end{array}$ \\
\hline $\begin{array}{l}\text { Tree above-ground } \\
\qquad\left(\mathrm{g} \mathrm{C} \mathrm{m}^{-2}\right)\end{array}$ & 3,445 (846) & & & 30,485 (334) & \\
\hline Tree total $\left(\mathrm{g} \mathrm{C} \mathrm{m}^{-2}\right)$ & $7,787(1,181)$ & & & 38,218 (466) & $\begin{array}{l}\text { 12,020-62,810 } \\
\text { (biomass) }\end{array}$ \\
\hline $\begin{array}{l}\text { Above-ground coarse } \\
\text { woody debris ( } \mathrm{g} \\
\mathrm{C} \mathrm{m}^{-2} \text { ) }\end{array}$ & 1,994 (160) & & & 5,066 (17) & \\
\hline $\begin{array}{l}\text { Soil organic matter } \\
\quad\left(\mathrm{g} \mathrm{C} \mathrm{m}^{-2}\right)\end{array}$ & 4,936 (86) & & $\begin{array}{l}\text { (Pregitzer and } \\
\text { Euskirchen, 2004, } \\
\text { table A1) }\end{array}$ & 5,205 (16) & 9,900-19,100 \\
\hline $\begin{array}{l}\text { Litter above-ground } \\
\qquad\left(\mathrm{g} \mathrm{C} \mathrm{m}^{-2}\right)\end{array}$ & $153(22)$ & & & $223(21)$ & \\
\hline Nitrogen pools & $\begin{array}{c}\text { Simulated with } 1975 \\
\text { clear cut }\end{array}$ & $\begin{array}{l}\text { Measured with } 1975 \\
\text { clear cut }\end{array}$ & Data sources & $\begin{array}{c}\text { Simulated without } \\
\text { clear cut }\end{array}$ & $\begin{array}{l}\text { Measured without } \\
\text { clear cut }\end{array}$ \\
\hline $\begin{array}{l}\text { Total ecosystem } \\
\qquad\left(\mathrm{g} \mathrm{N} \mathrm{m}^{-2}\right)\end{array}$ & $239(2)$ & & & 317 (2) & \\
\hline $\begin{array}{l}\text { Leaves at annual } \\
\text { maximum } \\
\left(\mathrm{g} \mathrm{N} \mathrm{m}^{-2}\right)\end{array}$ & $11(1)$ & & & $15(0)$ & \\
\hline Fine roots $\left(\mathrm{g} \mathrm{N} \mathrm{m}^{-2}\right)$ & $8(1)$ & & & $11(0.6)$ & \\
\hline $\begin{array}{l}\text { Fine branches } \\
\qquad\left(\mathrm{g} \mathrm{N} \mathrm{m}^{-2}\right)\end{array}$ & $4(1)$ & & & $39(0.4)$ & \\
\hline $\begin{array}{l}\text { Large wood } \\
\qquad\left(\mathrm{g} \mathrm{N} \mathrm{m}^{-2}\right)\end{array}$ & $3(0.7)$ & & & $28(0.3)$ & \\
\hline $\begin{array}{l}\text { Coarse roots } \\
\qquad\left(\mathrm{g} \mathrm{N} \mathrm{m}^{-2}\right)\end{array}$ & $8(0.5)$ & & & $15(0.2)$ & \\
\hline $\begin{array}{l}\text { Tree above-ground } \\
\qquad\left(\mathrm{g} \mathrm{N} \mathrm{m}^{-2}\right)\end{array}$ & $17(2.8)$ & & & $81(1)$ & \\
\hline Tree total $\left(\mathrm{g} \mathrm{N} \mathrm{m}^{-2}\right.$ ) & $33(5)$ & & & $107(2)$ & \\
\hline $\begin{array}{l}\text { Above-ground coarse } \\
\text { woody debris } \\
\left(\mathrm{g} \mathrm{N} \mathrm{m}^{-2}\right)\end{array}$ & $2.6(0.2)$ & & & $7.3(0.1)$ & \\
\hline $\begin{array}{l}\text { Soil organic matter } \\
\qquad\left(\mathrm{g} \mathrm{N} \mathrm{m}^{-2}\right)\end{array}$ & $186(1.6)$ & & & $189(0.3)$ & \\
\hline $\begin{array}{l}\text { Litter above-ground } \\
\qquad\left(\mathrm{g} \mathrm{N} \mathrm{m}^{-2}\right)\end{array}$ & $2.8(0.4)$ & & & $4.3(0.5)$ & \\
\hline $\begin{array}{l}\text { Soil mineral } \mathrm{N} \\
\qquad\left(\mathrm{g} \mathrm{N} \mathrm{m}^{-2}\right)\end{array}$ & $0.07(0.09)$ & & & $0.11(0.14)$ & \\
\hline$N, P, S$ inputs & $\begin{array}{c}\text { Simulated with } 1975 \\
\text { clear cut }\end{array}$ & $\begin{array}{l}\text { Measured with } 1975 \\
\text { clear cut }\end{array}$ & Data sources & $\begin{array}{l}\text { Simulated without } \\
\text { clear cut }\end{array}$ & $\begin{array}{l}\text { Measured without } \\
\text { clear cut }\end{array}$ \\
\hline $\begin{array}{l}\text { N deposition } \\
\quad\left(\mathrm{g} \mathrm{N} \mathrm{m}^{-2} \mathrm{yr}^{-1}\right)\end{array}$ & $0.15(0.03)$ & 0.21 & & $0.15(0.03)$ & 0.21 \\
\hline Wet & 0.12 & & NADP site OR10 & 0.12 & \\
\hline Dry + fog & 0.03 & & & 0.03 & \\
\hline
\end{tabular}


Table 9.5. Simulated (1981-2004) and measured ecological variables and input/output fluxes. In order to have more empirical data for ecological variables, we showed model results from two simulations: one with a clear cut in 1975 and one without a clear cut. Standard deviations are shown in parentheses and represent interannual variation for annual fluxes and monthly variations for state variables. NPP = net primary production; $\mathrm{NEP}=$ net ecosystem production; $\mathrm{Rh}=$ heterotrophic respiration; $\mathrm{PET}=$ potential evapotranspiration; AET = actual evapotranspiration; DOC = dissolved organic carbon. To convert units reported by data sources, it was assumed that 2.25 grams biomass equals 1 gram C.-Continued

\begin{tabular}{|c|c|c|c|c|c|}
\hline$N, P, S$ inputs & $\begin{array}{c}\text { Simulated with } 1975 \\
\text { clear cut }\end{array}$ & $\begin{array}{c}\text { Measured with } 1975 \\
\text { clear cut }\end{array}$ & Data sources & $\begin{array}{c}\text { Simulated without } \\
\text { clear cut }\end{array}$ & $\begin{array}{l}\text { Measured without } \\
\text { clear cut }\end{array}$ \\
\hline $\begin{array}{l}\text { S deposition } \\
\quad\left(\mathrm{g} \mathrm{S} \mathrm{m}^{-2} \mathrm{yr}^{-1}\right)\end{array}$ & $0.19(0.07)$ & & & $0.19(0.07)$ & \\
\hline Wet & 0.15 & & NADP site OR10 & 0.15 & \\
\hline Dry + fog & 0.04 & & & 0.04 & \\
\hline C,N,P,S outputs & $\begin{array}{c}\text { Simulated with } 1975 \\
\text { clear cut }\end{array}$ & $\begin{array}{c}\text { Measured with } 1975 \\
\text { clear cut }\end{array}$ & Data sources & $\begin{array}{c}\text { Simulated without } \\
\text { clear cut }\end{array}$ & $\begin{array}{c}\text { Measured without } \\
\text { clear cut }\end{array}$ \\
\hline $\begin{array}{l}\text { N export } \\
\quad\left(\mathrm{g} \mathrm{N} \mathrm{m}^{-2} \mathrm{yr}^{-1}\right)\end{array}$ & $0.07(0.02)$ & & & $0.09(0.02)$ & \\
\hline Inorganic & $0.02(0.01)$ & & & $0.03(0.01)$ & \\
\hline Organic & $0.05(0.01)$ & & & $0.06(0.01)$ & \\
\hline $\begin{array}{l}\text { S export } \\
\qquad\left(\mathrm{g} \mathrm{S} \mathrm{m}^{-2} \mathrm{yr}^{-1}\right)\end{array}$ & 0.18 & & & 0.18 & \\
\hline Inorganic & 0.18 & & & 0.18 & \\
\hline Organic & not simulated & & & not simulated & \\
\hline $\begin{array}{l}\text { DOC export } \\
\qquad\left(\mathrm{g} \mathrm{C} \mathrm{m}^{-2} \mathrm{yr}^{-1}\right)\end{array}$ & $1.1(0.2)$ & & & $1.2(0.2)$ & \\
\hline $\begin{array}{l}\text { Trace gas flux } \\
\quad\left(\mathrm{g} \mathrm{N} \mathrm{m}^{-2} \mathrm{yr}^{-1}\right)\end{array}$ & $0.05(0.01)$ & 0.21 (denitrification) & $\begin{array}{l}\text { (Vermes and Myrold, } \\
\text { 1992) }\end{array}$ & $0.07(0.02)$ & $\begin{array}{l}0.3-0.24 \text { (denitrifica- } \\
\text { tion) }\end{array}$ \\
\hline $\mathbf{N}, \mathbf{P}, \mathbf{S}$ internal fluxes & $\begin{array}{c}\text { Simulated with } 1975 \\
\text { clear cut }\end{array}$ & $\begin{array}{l}\text { Measured with } 1975 \\
\text { clear cut }\end{array}$ & Data sources & $\begin{array}{c}\text { Simulated without } \\
\text { clear cut }\end{array}$ & $\begin{array}{c}\text { Measured without } \\
\text { clear cut }\end{array}$ \\
\hline $\begin{array}{l}\mathrm{N} \text { mineralization } \\
\quad\left(\mathrm{g} \mathrm{N} \mathrm{m}^{-2} \mathrm{yr}^{-1}\right)\end{array}$ & $4.3(0.4)$ & & & $5.2(0.3)$ & \\
\hline $\begin{array}{l}\text { Gross nitrification } \\
\left(\mathrm{g} \mathrm{N} \mathrm{m}^{-2} \mathrm{yr}^{-1}\right)\end{array}$ & $0.7(0.3)$ & & & $1.2(0.4)$ & \\
\hline $\begin{array}{l}\text { N fixation } \\
\qquad\left(\mathrm{g} \mathrm{N} \mathrm{m}^{-2} \mathrm{yr}^{-1}\right)\end{array}$ & $0.3(0.03)$ & & & $0.3(0.03)$ & \\
\hline $\begin{array}{l}\text { N uptake } \\
\qquad\left(\mathrm{g} \mathrm{N} \mathrm{m}^{-2} \mathrm{yr}^{-1}\right)\end{array}$ & $4.3(0.4)$ & & & $5.1(0.3)$ & \\
\hline
\end{tabular}


Daily Discharge
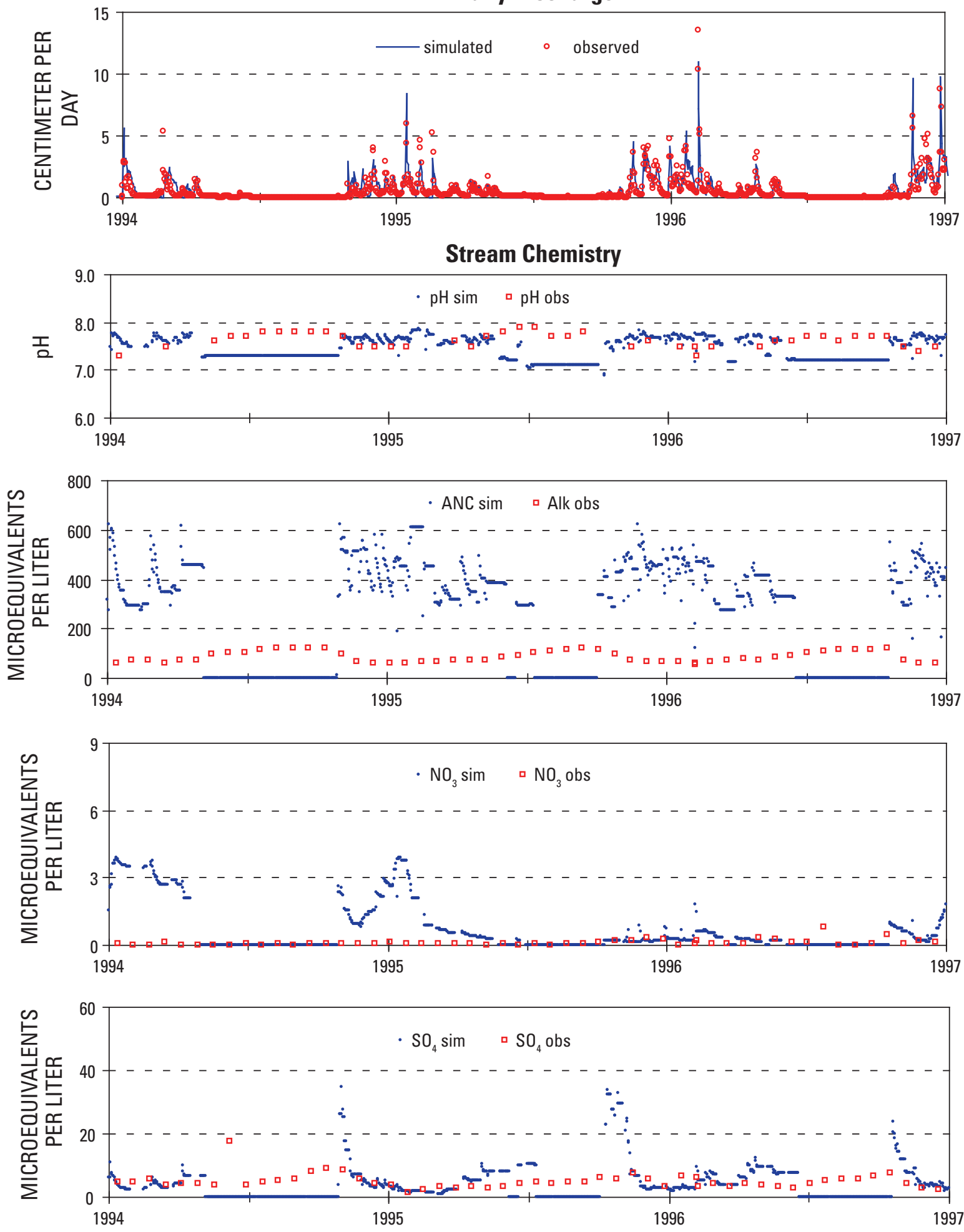

Figure 9.5. Simulated (sim) and observed (obs) daily discharge and stream chemistry for WS10, H.J. Andrews LTER (HJA), years 1994-1996 ( $x$ axis). Simulated concentrations are zero when simulated discharge is zero. Measured DOC was not available, years 1994-1996. 

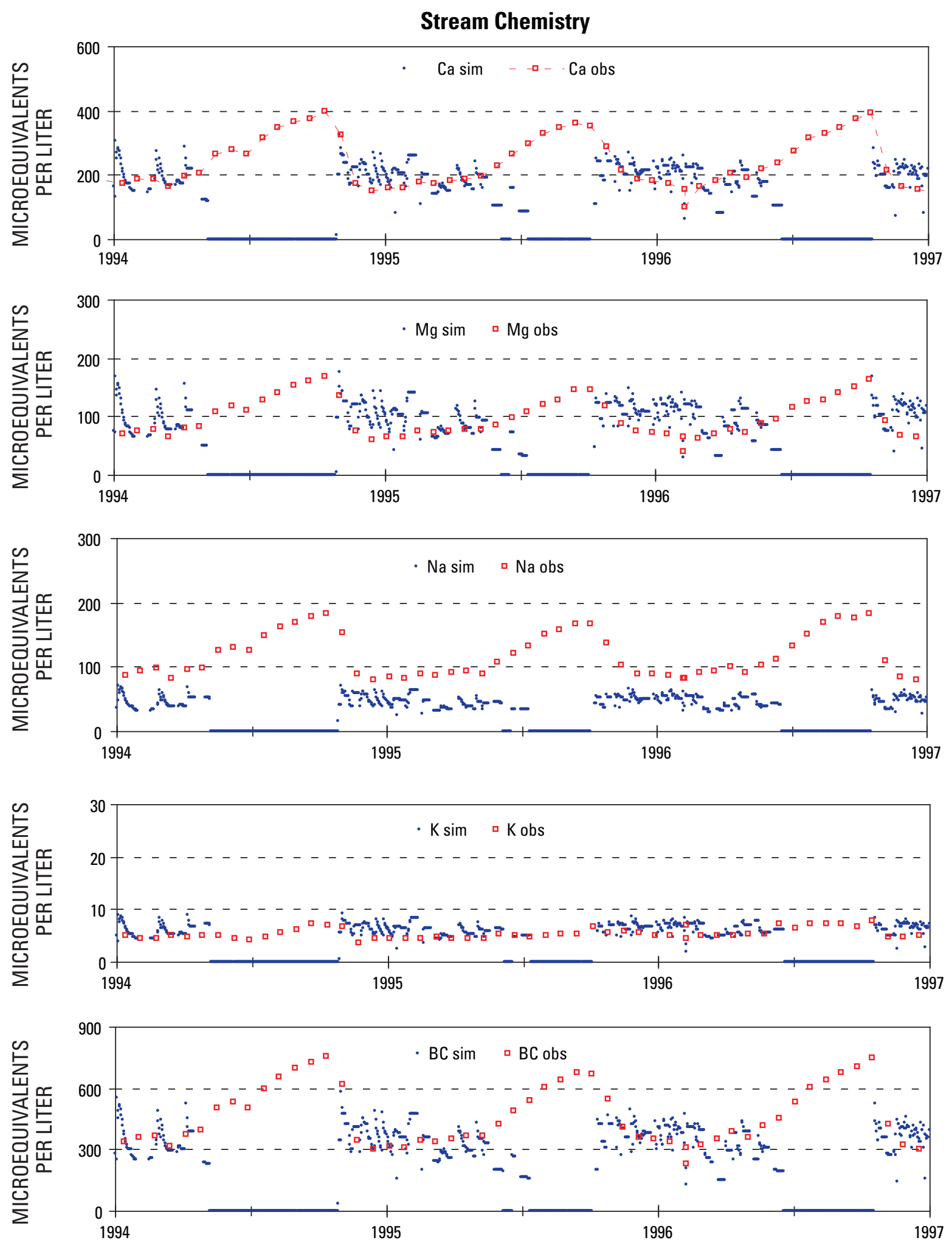

Figure 9.5. Simulated (sim) and observed (obs) daily discharge and stream chemistry for WS10, H.J. Andrews LTER (HJA), years 1994-1996 (x axis). Simulated concentrations are zero when simulated discharge is zero. Measured DOC was not available, years 1994-1996. - Continued 

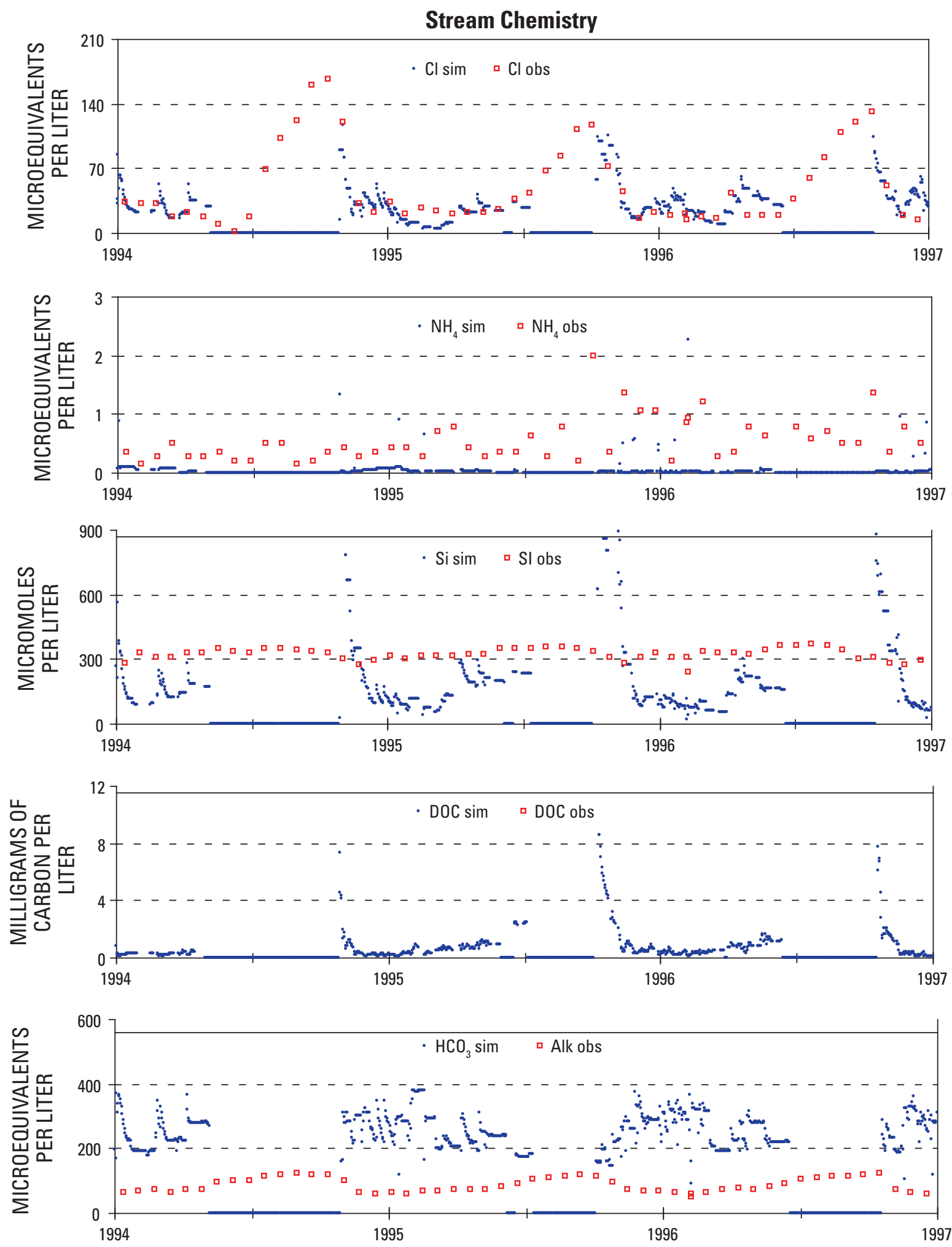

Figure 9.5. Simulated (sim) and observed (obs) daily discharge and stream chemistry for WS10, H.J. Andrews LTER (HJA), years 1994-1996 ( $x$ axis). Simulated concentrations are zero when simulated discharge is zero. Measured DOC was not available, years 1994-1996.-Continued 


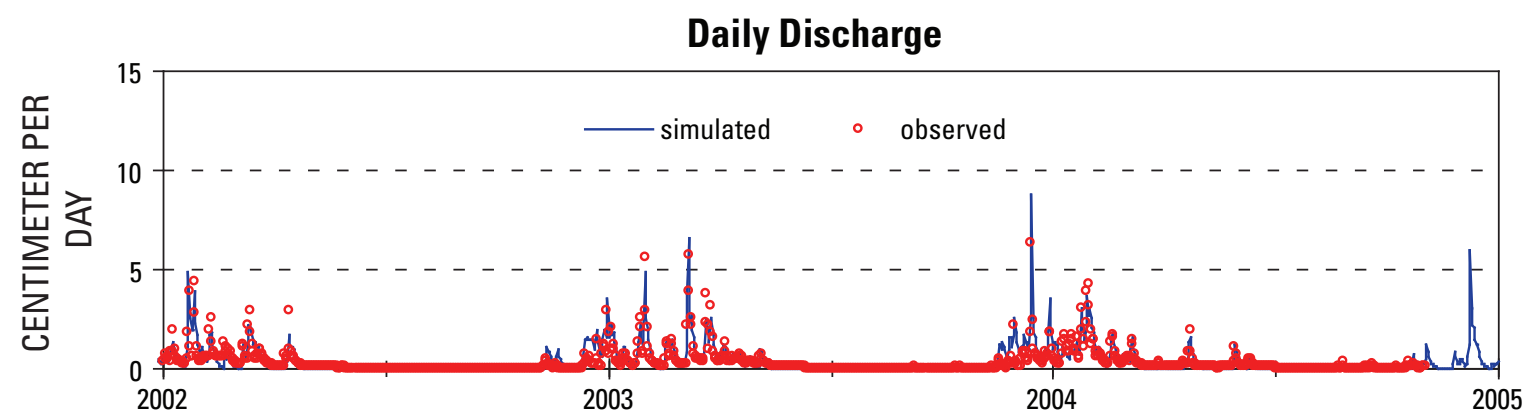

Stream Chemistry
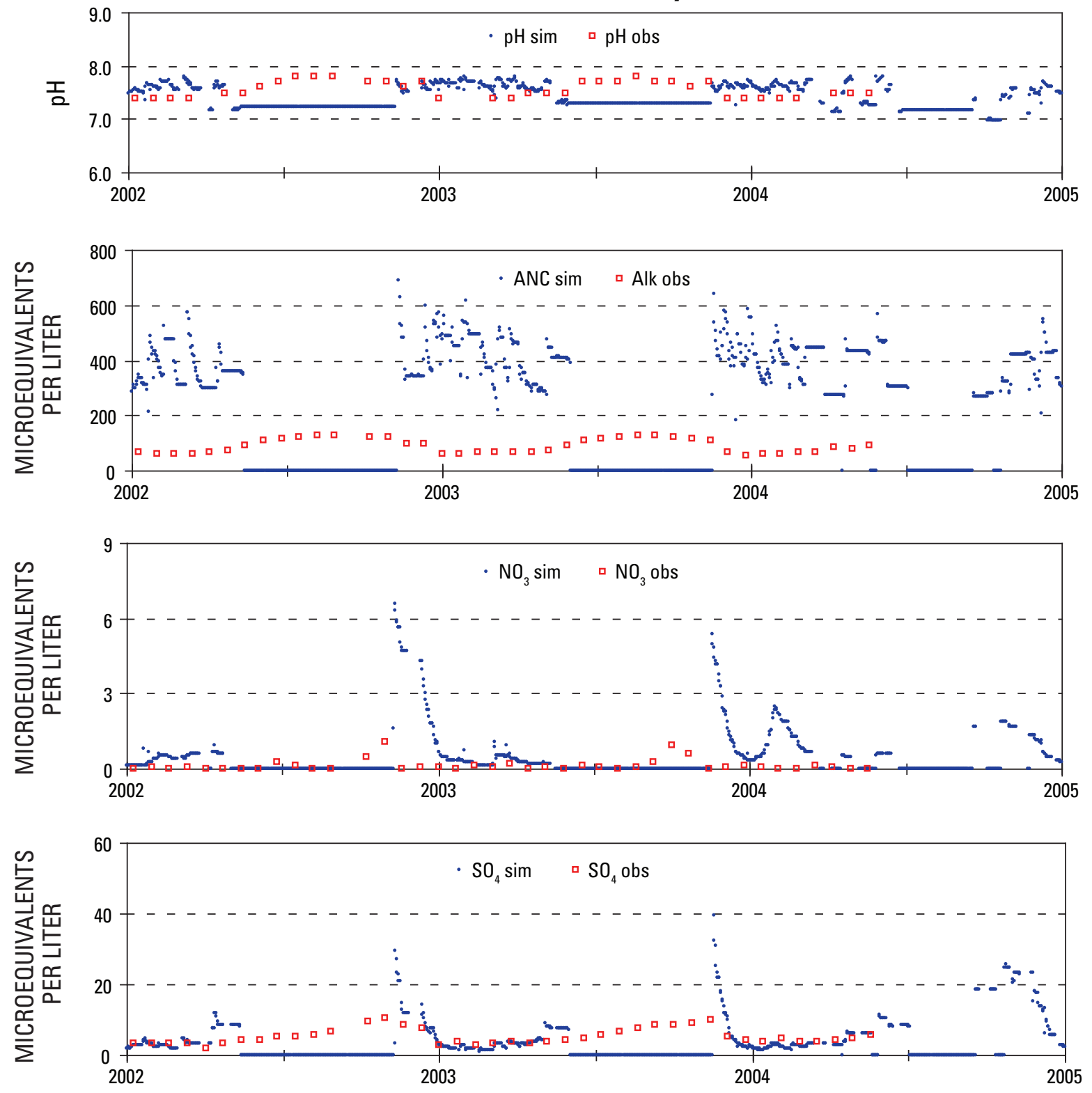

Figure 9.6. Simulated (sim) and observed (obs) daily discharge and stream chemistry for WS10, H.J. Andrews LTER (HJA), years 2002-2004 (x axis). Simulated concentrations are zero when simulated discharge is zero. 

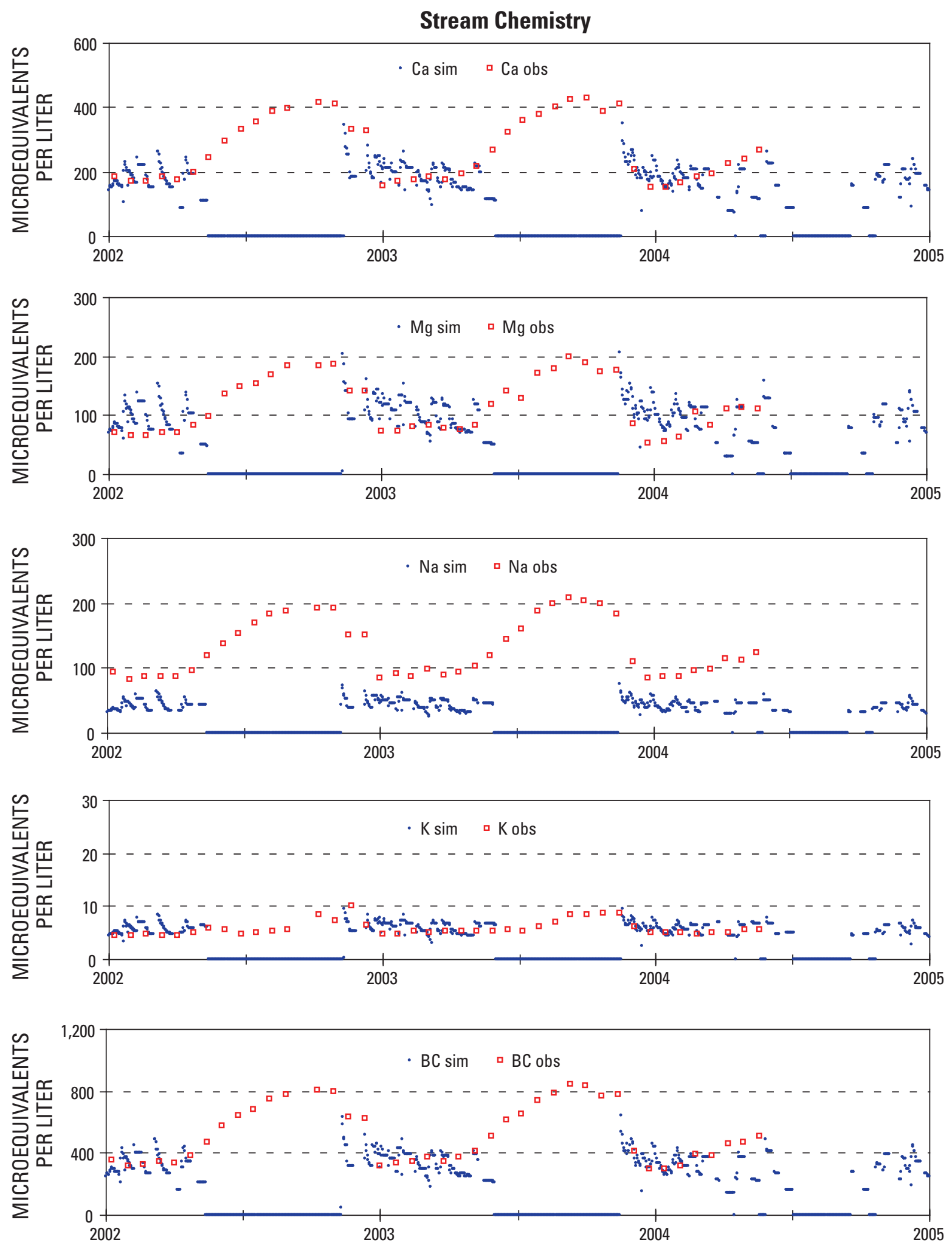

Figure 9.6. Simulated (sim) and observed (obs) daily discharge and stream chemistry for WS10, H.J. Andrews LTER (HJA), years 2002-2004 (x axis). Simulated concentrations are zero when simulated discharge is zero.-Continued 

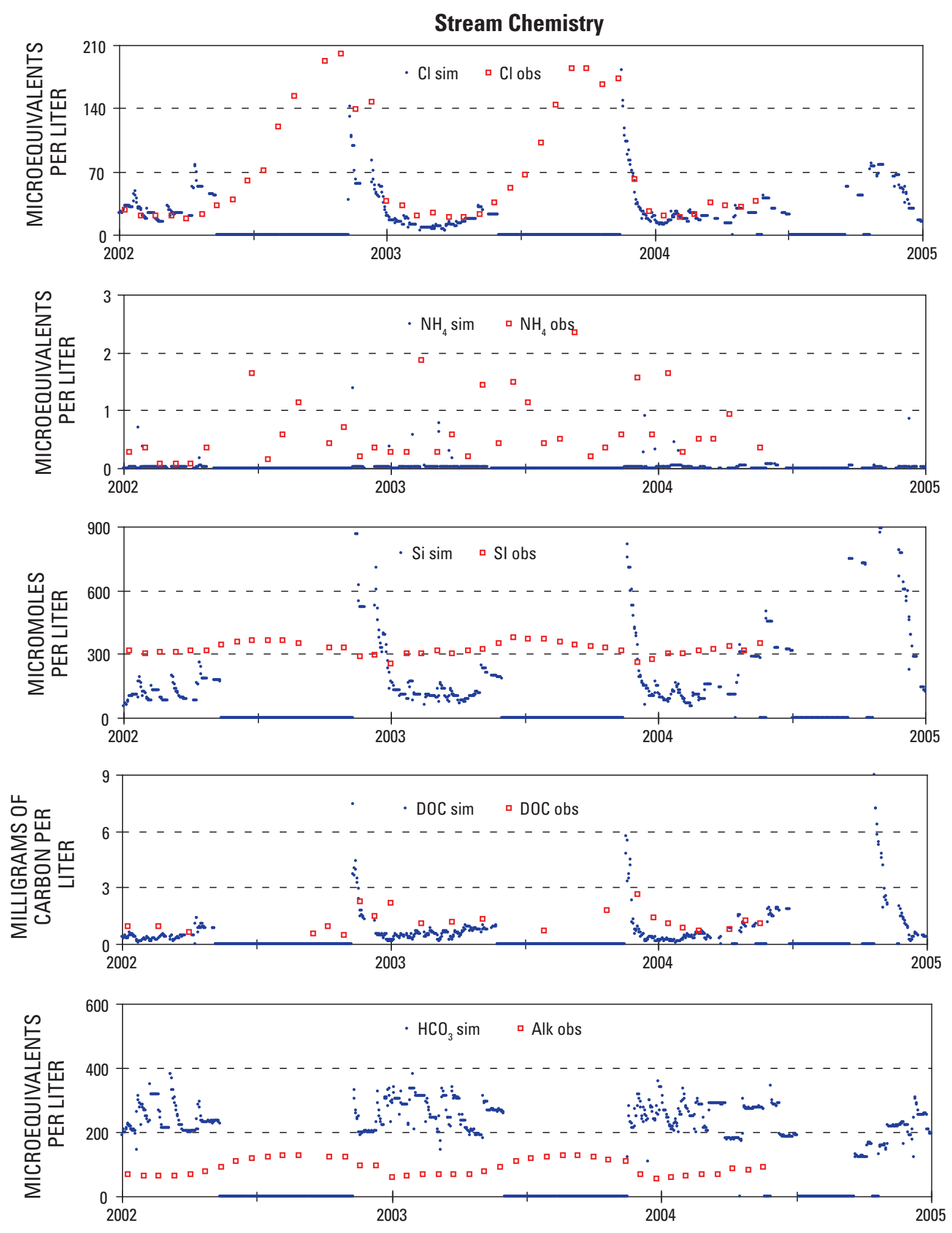

Figure 9.6. Simulated (sim) and observed (obs) daily discharge and stream chemistry for WS10, H.J. Andrews LTER (HJA), years 2002-2004 (x axis). Simulated concentrations are zero when simulated discharge is zero.-Continued 
corresponding measured values at WS8 or WS9 $\left(695 \mathrm{~g} \mathrm{C} \mathrm{m}^{-2}\right.$, $35,225 \mathrm{~g} \mathrm{C} \mathrm{m}^{-2}$, and 7,065 g C m${ }^{-2}$, respectively). Simulated fine root biomass $\left(780 \mathrm{~g} \mathrm{C} \mathrm{m}^{-2}\right.$ ) was higher than the measured value (565 $\mathrm{g} \mathrm{C} \mathrm{m}^{-2}$ ). Simulated total ecosystem carbon, $53,475 \mathrm{~g} \mathrm{C} \mathrm{m}^{-2}$, was lower than that measured at WS8 and WS9, but was in the middle of a range reported for old growth Douglas fir forest, 19,500-112,700 g C m${ }^{-2}$ (Pregitzer and Euskirchen, 2004). Simulated soil organic matter, 5,205 (std. dev. 16) $\mathrm{g} \mathrm{C} \mathrm{m}^{-2}$, was less than 50 percent of measured values from the same type of forest, 9,900-19,100 g C m${ }^{-2}$ (Pregitzer and Euskirchen, 2004).

According to DayCent-Chem, total stream $\mathrm{N}$ flux $(0.07 \mathrm{~g}$ $\mathrm{N} \mathrm{m}^{-2} \mathrm{yr}^{-1}$ ) was about 70 percent DON and 30 percent $\mathrm{NO}_{3}-\mathrm{N}$. Gaseous loss ( $\left.0.05 \mathrm{~g} \mathrm{~N} \mathrm{~m}^{-2} \mathrm{yr}^{-1}\right)$ was slightly less than stream $\mathrm{N}$ flux. Accounting for the DON flux, the model suggested that ecosystem retention of atmospherically deposited $\mathrm{N}$ plus internal $\mathrm{N}$ fixation was about 80 percent, the greatest of all sites in this intersite comparison, though no measurement of $\mathrm{N}$ retention was available to verify this estimate.

\section{Discharge}

Discharge predicted by DayCent-Chem matched the timing and magnitude of daily discharge measurements quite well (the $\mathrm{R}^{2}$ correlation was 0.70 ; figs. 9.5, 9.6). The model slightly overestimated seasonal flow in November and December (fig. 9.7).

\section{Stream Chemistry}

\section{Nitrate and Ammonium}

Measured stream $\mathrm{NO}_{3}$ concentrations at HJA were

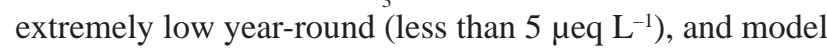
predictions were close to measurements. Measured and simulated annual VWM stream $\mathrm{NO}_{3}$ concentrations were both less than $1 \mu \mathrm{eq} \mathrm{L} \mathrm{L}^{-1}$ (table 9.6). Daily concentrations were close to observed values except in winter, particularly in September or October after the dry period when the model showed more flushing of soil $\mathrm{NO}_{3}$ after the summer dry period than was observed (figs. 9.5-9.7). The vast majority of both simulated and measured daily stream $\mathrm{NH}_{4}$ concentrations were less than $1.0 \mu \mathrm{eq} \mathrm{L}{ }^{-1}$ (figs. 9.5, 9.6), as were concentrations of observed and simulated annual $\mathrm{VWM} \mathrm{NH}_{4}$ (table 9.6). Measurements showed a small amount of $\mathrm{NH}_{4}$ in the stream during the growing season when predictions did not, but streamflow was extremely low at this time (figs. 9.5, 9.6).

\section{Sulfate}

Measured stream sulfate concentrations were low (annual VWM $5.2 \mu \mathrm{eq} \mathrm{L}^{-1}$ ) and simulated means were only

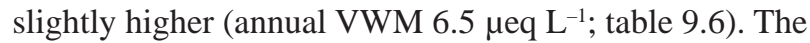

temporal patterns of daily simulated and measured stream $\mathrm{SO}_{4}$ concentrations were similar, both reaching a maximum in autumn when discharge returns after the summer dry period, and declining to a minimum in early winter after sustained high flows (figs. 9.5-9.7). Daily simulated stream $\mathrm{SO}_{4}$ concentrations fluctuated more than measured concentrations, possibly because of more rapid soil flushing by the model or the mixing of spatial variable source waters in the watershed. Both the model and measurements showed that $\mathrm{SO}_{4}$ behaved conservatively.

\section{Chloride}

Chloride was a dominant stream anion at HJA. Measured stream $\mathrm{Cl}$ concentrations increased rapidly from an average of $25 \mu \mathrm{mol} \mathrm{L}{ }^{-1}$ in December-June to an average peak of about $140 \mu$ eq L ${ }^{-1}$ in September (figs. 9.5-9.7). The model overestimated annual VWM by $7 \mu$ eq $\mathrm{L}^{-1}$, or 22 percent (table 9.6). Simulated daily $\mathrm{Cl}$ concentrations matched well with the temporal patterns and concentrations of measured $\mathrm{Cl}$ concentrations except during extremely dry periods when the model underestimated stream $\mathrm{Cl}$ concentrations, but this did not have a large influence on simulated annual VWM values (figs. 9.5, 9.6). When simulated flow was extremely low, as in August of each year, the model turned off stream chemistry calculations and set stream concentrations to zero (figs. 9.5-9.7).

\section{Weathering Products}

Measured stream Si and base cations at HJA were high, indicating that the watershed had high mineral weathering rates. The model predicted annual VWM sum of base cations within 3 percent but underestimated annual Si by 28 percent (table 9.6). Of the base cations, the model overestimated annual VWM Ca and Mg concentrations, underestimated annual VWM Na concentration, and predicted annual VWM stream K concentration within 1 percent (table 9.6). Measured base cations were most concentrated during low discharge that lasted from June through October, and for August through September concentrations were twice the winter concentrations. The model matched the measured daily stream base cation concentrations throughout the year, except during the summer dry period when daily stream base cations was underestimated (figs. 9.5-9.7). Likewise simulated versus observed daily concentrations for $\mathrm{Ca}$, Mg, and $\mathrm{K}$ are similar for the wetter periods, but daily stream Na concentrations were underestimated year-round.

Measured stream Si was most concentrated for May through July, as stream discharge was approaching the annual minimum. The model underestimated daily stream Si concentrations most of the year, but it overestimated them for September and October (figs. 9.5-9.7). We prescribed high mineral denudation rates in attempt to match observed base cation and Si concentrations, but the model's equilibrium reactions limited the amount of minerals that could be dissolved 

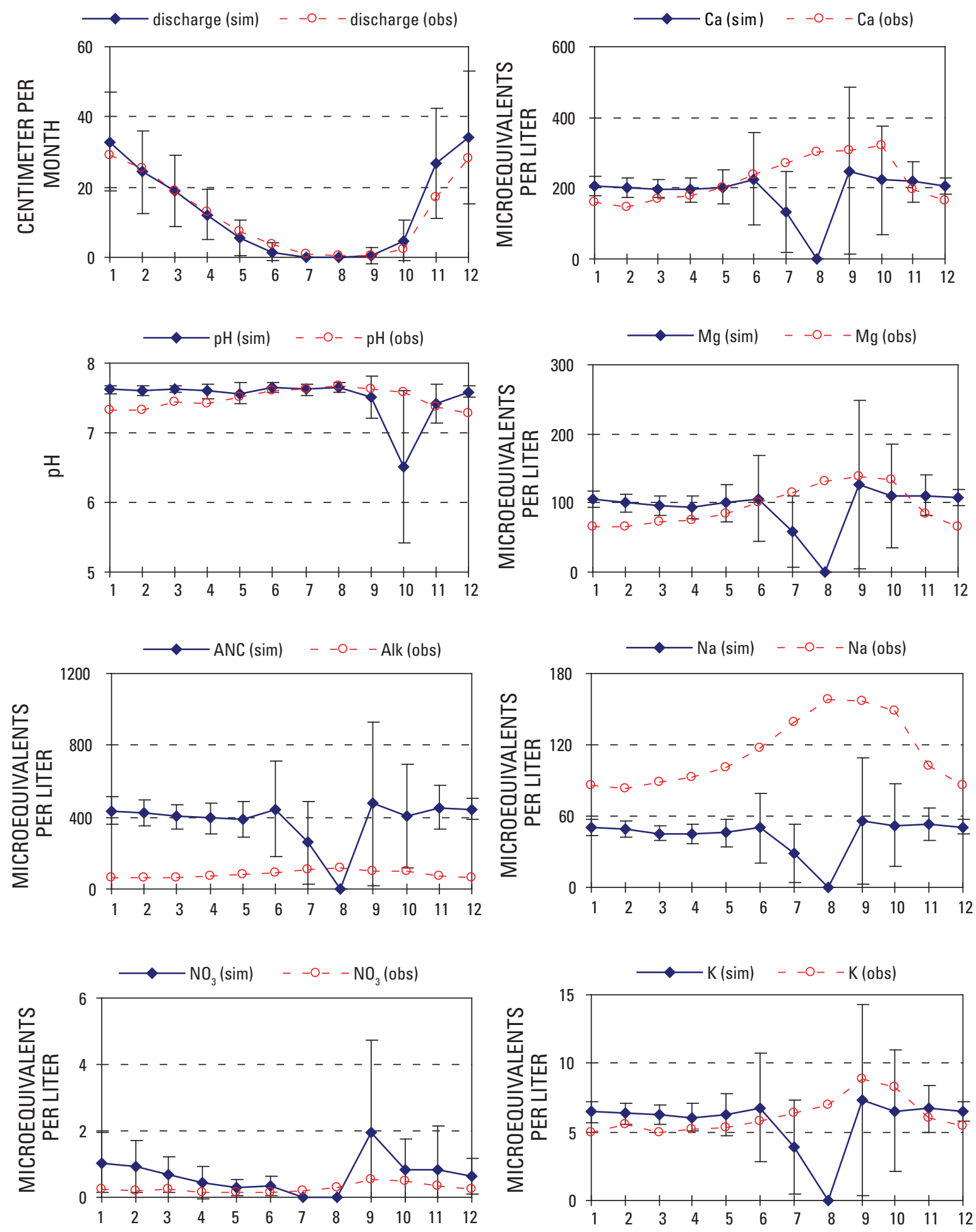

Figure 9.7. Simulated (sim) and observed (obs) discharge and volume-weighted mean (VWM) stream chemistry averaged by month (x axis) for WS10, H.J. Andrews LTER (HJA), years 1981-2004. The vertical bars on the simulated values represent plus and minus one standard deviation from the simulated mean. Simulated concentrations were zero when simulated discharge was zero for August (month 8). 

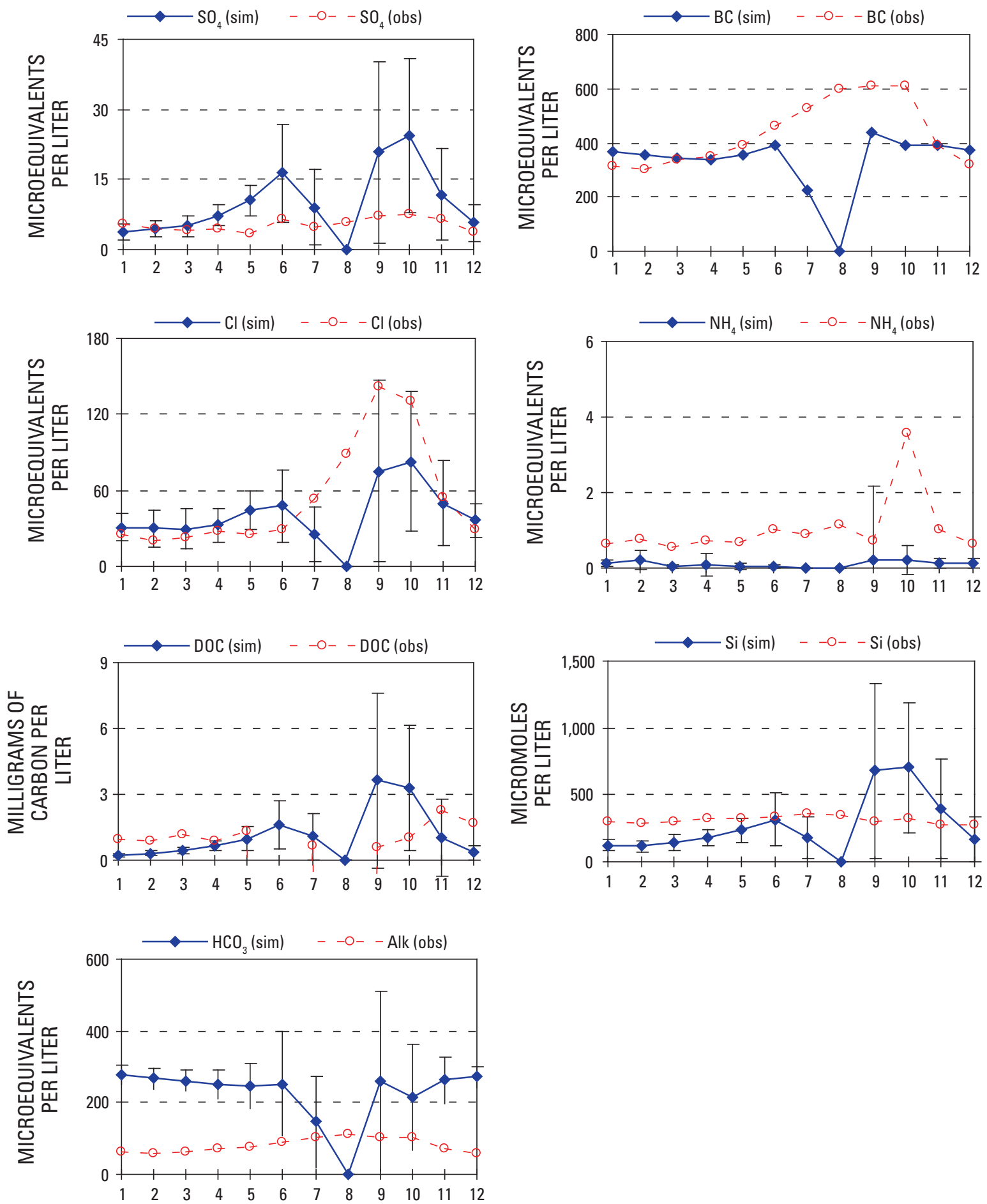

Figure 9.7. Simulated (sim) and observed (obs) discharge and volume-weighted mean (VWM) stream chemistry averaged by month (x axis) for WS10, H.J. Andrews LTER (HJA), years 1981-2004. The vertical bars on the simulated values represent plus and minus one standard deviation from the simulated mean. Simulated concentrations were zero when simulated discharge was zero for August (month 8).-Continued 
Table 9.6. Annual volume-weighted mean simulated and observed stream chemistry averaged over each year of the simulation. Pmean = predicted mean; Omean = observed mean; $A E=$ absolute error $($ Pmean - Omean); NAE = normalized absolute error (AE/Omean); N/A = Not available.

\begin{tabular}{|c|c|c|c|c|c|}
\hline Solute & Metric & Concentration & Solute & Metric & Concentration \\
\hline \multirow[t]{4}{*}{$\mathrm{pH}$} & Pmean & 7.43 & $\mathrm{NO}_{3}\left(\mu \mathrm{eq} \mathrm{L} \mathrm{L}^{-1}\right)$ & Pmean & 0.78 \\
\hline & Omean & 7.38 & & Omean & 0.23 \\
\hline & $\mathrm{AE}$ & 0.05 & & $\mathrm{AE}$ & 0.55 \\
\hline & NAE & 0.01 & & NAE & 2.43 \\
\hline \multirow[t]{4}{*}{ Ca $\left(\mu \mathrm{eq} \mathrm{L}^{-1}\right)$} & Pmean & 205.92 & $\mathrm{SO}_{4}\left(\mu \mathrm{eq} \mathrm{L}{ }^{-1}\right)$ & Pmean & 6.46 \\
\hline & Omean & 177.76 & & Omean & 5.24 \\
\hline & $\mathrm{AE}$ & 28.17 & & $\mathrm{AE}$ & 1.22 \\
\hline & NAE & 0.16 & & NAE & 0.23 \\
\hline \multirow[t]{4}{*}{$\operatorname{Mg}\left(\mu\right.$ eq $\left.L^{-1}\right)$} & Pmean & 103.72 & ANC $\left(\mu \mathrm{eq} \mathrm{L}^{-1}\right)$ & Pmean & 427.99 \\
\hline & Omean & 77.29 & & Omean & 66.56 \\
\hline & $\mathrm{AE}$ & 26.44 & & $\mathrm{AE}$ & 361.44 \\
\hline & NAE & 0.34 & & NAE & 5.43 \\
\hline \multirow[t]{4}{*}{$\mathrm{K}\left(\mu \mathrm{eq} \mathrm{L}^{-1}\right)$} & Pmean & 6.41 & $\mathrm{HCO}_{3}\left(\mu \mathrm{eq} \mathrm{L} \mathrm{L}^{-1}\right)$ & Pmean & 264.44 \\
\hline & Omean & 5.34 & & Omean & N/A \\
\hline & $\mathrm{AE}$ & 1.07 & & $\mathrm{AE}$ & N/A \\
\hline & NAE & 0.20 & & NAE & N/A \\
\hline \multirow[t]{4}{*}{ Na $\left(\mu \mathrm{eq} \mathrm{L}^{-1}\right)$} & Pmean & 49.48 & $\mathrm{Cl}\left(\mu \mathrm{eq} \mathrm{L}^{-1}\right)$ & Pmean & 36.72 \\
\hline & Omean & 92.89 & & Omean & 30.07 \\
\hline & $\mathrm{AE}$ & -43.41 & & $\mathrm{AE}$ & 6.65 \\
\hline & NAE & -0.47 & & NAE & 0.22 \\
\hline \multirow[t]{4}{*}{ BC $\left(\mu \mathrm{eq} \mathrm{L}^{-1}\right)$} & Pmean & 365.53 & Si $\left(\mu \mathrm{mol} \mathrm{L}{ }^{-1}\right)$ & Pmean & 219.93 \\
\hline & Omean & 353.28 & & Omean & 305.90 \\
\hline & $\mathrm{AE}$ & 12.26 & & $\mathrm{AE}$ & -85.97 \\
\hline & NAE & 0.03 & & NAE & -0.28 \\
\hline \multirow[t]{4}{*}{$\mathrm{NH}_{4}\left(\mu \mathrm{eq} \mathrm{L} \mathrm{L}^{-1}\right)$} & Pmean & 0.12 & DOC $\left(m g \mathrm{C} \mathrm{L}^{-1}\right)$ & Pmean & 0.64 \\
\hline & Omean & 0.75 & & Omean & 1.20 \\
\hline & $\mathrm{AE}$ & -0.63 & & $\mathrm{AE}$ & -0.57 \\
\hline & NAE & -0.84 & & NAE & -0.47 \\
\hline
\end{tabular}


in stream and soil water. In the model, any mineral added to solution in excess of its equilibrium concentration will not be dissolved in the solution.

\section{ANC and $\mathrm{pH}$}

Because base cation concentrations were so high at HJA, measured $\mathrm{pH}$ and ANC were also high, and HJA had consistently alkaline stream water. Measured stream $\mathrm{pH}$ and alkalinity had regular annual cycles, characterized as depressed during high stream flow in mid-winter and elevated in late summer when base cation concentrations are also high (figs. 9.5, 9.6). Simulated annual VWM pH was the same as measured $\mathrm{pH}$, about 7.4 (table 9.6). Simulated daily $\mathrm{pH}$ values were close to measured values when flow was high during the winter months, November-February, but the model did not represent the higher $\mathrm{pH}$ values of low flows (figs. 9.5-9.7).

The model had difficulty simulating daily and annual ANC despite being relatively close to measured stream base cations and anions. Simulated daily $\mathrm{HCO}_{3}$ concentrations were several times greater than measured alkalinity (figs. 9.5-9.7). Simulated annual VWM HCO $\mathrm{HCO}_{3}\left(264 \mu \mathrm{eq} \mathrm{L}{ }^{-1}\right.$ ) was also much greater than measured annual VWM alkalinity (67 $\mu$ eq $\mathrm{L}^{-1}$; table 9.6). Model calculated ANC (which includes Al-hydroxides as $\mathrm{H}^{+}$acceptors) was even greater than $\mathrm{HCO}_{3}$ (annual VWM $=428 \mu \mathrm{eq} \mathrm{L}^{-1}$ ) as a result of prescribing high rates of aluminosilicate dissolution. The largest component of simulated $\mathrm{ANC}$ next to $\mathrm{HCO}_{3}$ was $\mathrm{Al}(\mathrm{OH})_{4}$ - . High rates of mineral dissolution were prescribed in an effort to raise simulated base cation and Si concentrations to match measured concentrations.

Measured $\mathrm{pH}$ for HJA seemed relatively high in relation to measured alkalinity, as the relationship between $\mathrm{pH}$ and alkalinity appeared different for HJA compared to other sites we have modeled (fig. 9.8).

\section{Dissolved Organic Carbon}

Simulated stream DOC was similar to measured DOC but displayed greater amplitude and variability than the measured values (figs. 9.6, 9.7). Both measurements and simulations were greatest in late autumn when flows resumed after a dry summer, although model predictions were overestimated during this time. The model underestimated DOC in the winter during high flow.

\section{Summary}

The model captured the daily dynamics of stream $\mathrm{pH}$, $\mathrm{NO}_{3}, \mathrm{SO}_{4}, \mathrm{Cl}, \mathrm{DOC}$, and sum of base cation concentrations for most seasons. We were unable to represent high summer stream solute concentrations that accompanied low summer base flows.

Mineral dissolution appeared to be important at HJA, though simultaneously computing the correct concentrations of SI, base cations, alkalinity, and $\mathrm{pH}$ was difficult. The biggest challenge to predicting HJA stream chemistry was calculating ANC. DayCent-Chem was not able to replicate the magnitude or temporal patterns of stream alkalinity. Simulated $\mathrm{HCO}_{3}$ concentrations were several times greater than measured alkalinity, but were 62 percent of model-calculated ANC, which includes Al-hydroxides as well as $\mathrm{HCO}_{3}$. The model may have overestimated stream concentrations of $\mathrm{Al}(\mathrm{OH})_{4}^{-}$.

Although annual mean stream alkalinity was overestimated, simulated annual volume-weighted mean $\mathrm{pH}$ was the same as the observed mean. The relationship between measured $\mathrm{pH}$ and measured alkalinity suggested that measured $\mathrm{pH}$ was high relative to measured alkalinity. 


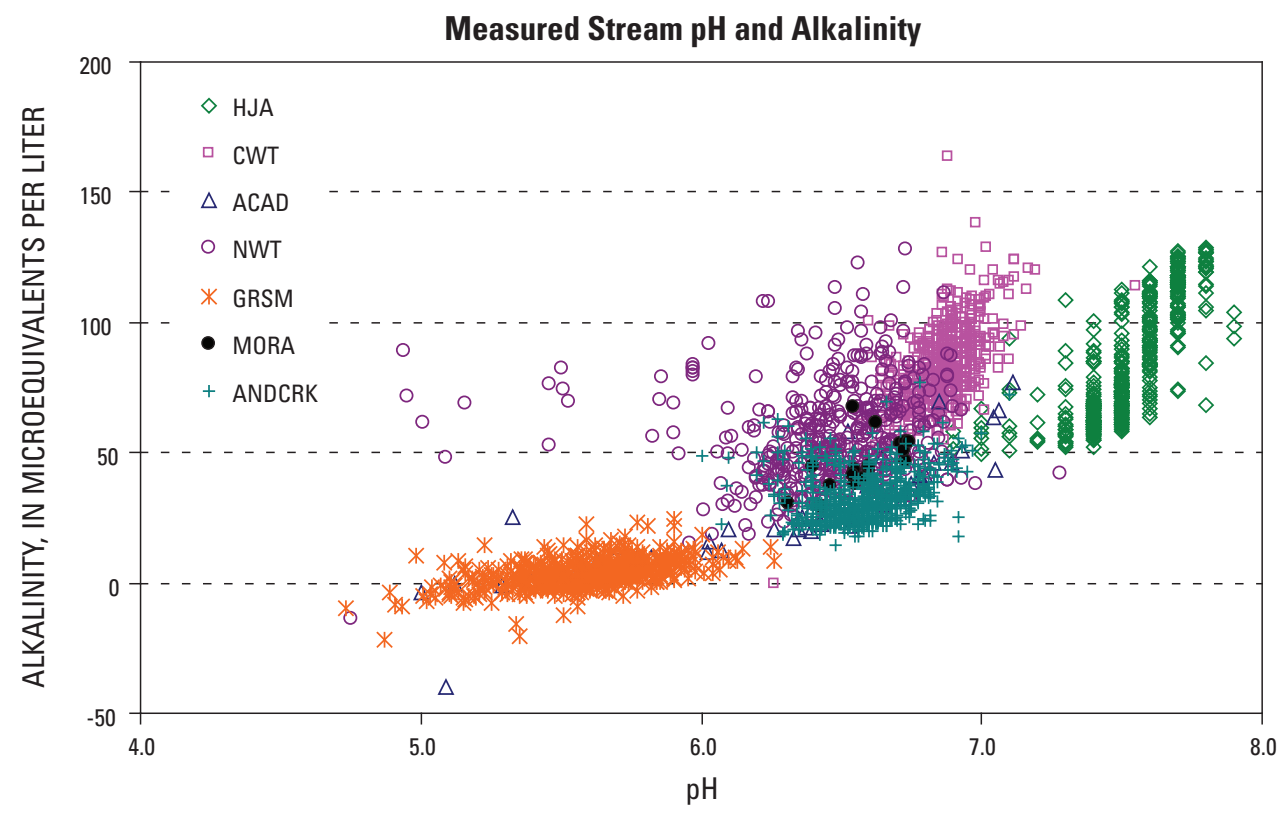

Figure 9.8. Measured stream $\mathrm{pH}$ versus measured stream alkalinity for seven small catchments across the United States: H.J. Andrews LTER (HJA), Coweeta LTER (CWT), Acadia National Park (ACAD), Niwot Ridge LTER (NWT), Great Smoky Mountains National Park (GRSM), Mount Rainier National Park (MORA), and Andrews Creek watershed Rocky Mountain National Park (ANDCRK). Compared to the $\mathrm{pH}$ versus relationships for all other sites, measured $\mathrm{pH}$ at HJA was high relative to measured stream alkalinity (hollow green diamonds). 


\section{References Cited}

Aber, J.D., and Driscoll, C.T., 1997, Effects of land use, climate variation, and $\mathrm{N}$ deposition on $\mathrm{N}$ cycling and $\mathrm{C}$ storage in northern hardwood forests: Global Biogeochemical Cycles, v. 11, no. 4, p. 639-648.

Aber, J.D., Ollinger, S.V., and Driscoll, C.T., 1997, Modeling nitrogen saturation in forest ecosystems in response to land use and atmospheric deposition: Ecological Modelling, v. 101, no. 1, p. 61-78.

Aber, J.D., Ollinger, S.V., Driscoll, C.T., Likens, G.E., Holmes, R.T., Freuder, R.J., and Goodale, C.L., 2002, Inorganic nitrogen losses from a forested ecosystem in response to physical, chemical, biotic, and climatic perturbations: Ecosystems, v. 5, no. 7, p. 648-658.

Amirbahman, A., Ruck, P.L., Fernandez, I.J., Haines, T.A., and Kahl, J.S., 2004, The effect of fire on mercury cycling in the soils of forested watersheds-Acadia National Park, Maine, USA: Water Air and Soil Pollution, v. 152, no. 1-4, p. 313-331.

April, R., and Newton, R., 1992, Mineralogy and mineral weathering, in Johnson, D.W., and Lindberg, S.E., eds., Atmospheric deposition and forest nutrient cycling-A synthesis of the Integrated Forest Study. Ecological Studies, v. 91: New York, Springer-Verlag, p. 378-425.

Arthur, M.A., 1992, Vegetation, in Baron, J., ed., Biogeochemistry of a subalpine ecosystem-Loch Vale Watershed. Ecological Studies, v. 90: New York, Springer-Verlag, p. 76-92.

Arthur, M.A., and Fahey, T.J., 1992, Biomass and nutrients in an Englemann spruce-subalpine fir forest in north central Colorado-Pools, annual production, and internal cycling: Canadian Journal of Forest Resources, v. 22, p. 315-325.

Backx, M.-A., 2004, Calculating critical loads of sulfur and nitrogen for Hubbard Brook Experimental Forest and Loch Vale Watershed using a dynamic biogeochemical model (PnET-BGC): Syracuse, N.Y., Syracuse University, 129 p.

Barker, M., Van Miegroet, H., Nicholas, N.S., and Creed, I.F., 2002, Variation in overstory nitrogen uptake in a small, high-elevation southern Appalachian spruce-fir watershed: Canadian Journal of Forest Research-Revue, v. 32, no. 10, p. $1,741-1,752$.

Baron, J., 1992, Biogeochemistry of a subalpine ecosystem: New York, Springer-Verlag, 247 p.

Baron, J., and Denning, A.S., 1992, Hydrologic budget estimates, in Baron, J., ed., Biogeochemistry of a subalpine ecosystem-Loch Vale Watershed. Ecological Studies, v. 90: New York, Springer-Verlag, p. 28-47.
Baron, J., Denning, A.S., and McLaughlin, P., 1992, Deposition, in Baron, J., ed., Biogeochemistry of a subalpine ecosystem-Loch Vale Watershed. Ecological Studies, v. 90: New York, Springer-Verlag, p. 48-75.

Baron, J., Walthall, P.M., Mast, M.A., and Arthur, M.A., 1992, Soils, in Baron, J., ed., Biogeochemistry of a subalpine ecosystem-Loch Vale Watershed. Ecological Studies, v. 90: New York, Springer-Verlag, p. 108-141.

Baron, J.S., Hartman, M.D., Band, L.E., and Lammers, R.B., 2000, Sensitivity of a high-elevation Rocky Mountain watershed to altered climate and $\mathrm{CO}_{2}$ : Water Resources Research, v. 36, no. 1, p. 89-99.

Baron, J.S., Rueth, H.M., Wolfe, A.M., Nydick, K.R., Allstott, E.J., Minear, J.T., and Moraska, B., 2000, Ecosystem responses to nitrogen deposition in the Colorado Front Range: Ecosystems, v. 3, no. 4, p. 352-368.

Barton, L., McLay, C.D.A., Schipper, L.A., and Smith, C.T., 1999, Annual denitrification rates in agricultural and forest soils-A review: Australian Journal of Soil Research, v. 37, no. 6, p. 1,073-1,093.

Bernhardt, E.S., Likens, G.E., Hall, R.O., Buso, D.C., Fisher, S.G., Burton, T.M., Meyer, J.L., McDowell, M.H., Mayer, M.S., Bowden, W.B., Findlay, S.E.G., Macneale, K.H., Stelzer, R.S., and Lowe, W.H., 2005, Can't see the forest for the stream?-In-stream processing and terrestrial nitrogen exports: Bioscience, v. 55, no. 3, p. 219-230.

Bowman, W.D., 1992, Inputs and storage of nitrogen in winter snowpack in an alpine ecosystem: Arctic Alpine Research, v. 24, p. 211-215.

Bowman, W.D., and Fisk, M.C., 2001, Primary production, in Bowman, W.D., and Seastedt, T.R., eds., Structure and function of an alpine ecosystem-Niwot Ridge, Colorado: New York, Oxford University Press, p. 177-197.

Butler, T.J., Likens, G.E., Vermeylen, F.M., and Stunder, B.J.B., 2003, The relation between $\mathrm{NO}_{x}$ emissions and precipitation $\mathrm{NO}_{3}$ - in the eastern USA: Atmospheric Environment, v. 37, no. 15, p. 2,093-2,104.

Caine, N., 1995, Snowpack influences on geomorphic processes in Green Lakes Valley, Colorado Front Range: Geographical Journal, v. 161, p. 55-68.

Campbell, D.H., Baron, J.S., Tonnessen, K.A., Brooks, P.D., and Schuster, P.F., 2000, Controls on nitrogen flux in alpine/subalpine watersheds of Colorado: Water Resources Research, v. 36, no. 1, p. 37-47.

Campbell, D.H., Clow, D.W., Ingersoll, G.P., Mast, M.A., Spahr, N.E., and Turk, J.T., 1995, Processes controlling the chemistry of 2 snowmelt-dominated streams in the Rocky Mountains: Water Resources Research, v. 31, no. 11, p. 2,811-2,821. 
Clow, D.W., 1992, Weathering rates from field and laboratory experiments on naturally weathered soils: Laramie, Wyo., University of Wyoming, Ph.D. dissertation, 116 p.

Clow, D.W., and Campbell, D.H., 2008, Atmospheric deposition and surface-water chemistry in Mount Rainierand North Cascades National Parks, U.S.A., water years 2000 and 2005-2006: U.S. Geological Survey Scientific Investigations Report 2008-5152, 37 p.

Clow, D.W., and Mast, M.A., 1995, Composition of precipitation, bulk deposition, and runoff at a granitic bedrock catchment in the Loch Vale Watershed, Colorado, USA, in Tonnessen, K.A., Williams, M.W., and Tranter, M., eds., Biogeochemistry of seasonally snow-covered catchments: Boulder, Colo., Colorado International Association of Hydrological Sciences, p. 235-242.

Clow, D.W., Schrott, L., Webb, R., Campbell, D.H., Torizzo, A., and Dornblaser, M., 2003, Ground water occurrence and contributions to streamflow in an alpine catchment, Colorado Front Range: Ground Water, v. 41, p. 937-950.

Clow, D.W., and Sueker, J.K., 2000, Relations between basin characteristics and stream water chemistry in alpine/subalpine basins in Rocky Mountain National Park, Colorado: Water Resources Research, v. 36, no. 1, p. 49-61.

Conley, A.H., Holland, E.A., Seastedt, T.R., and Parton, W.J., 2000, Simulation of carbon and nitrogen cycling in an Alpine Tundra: Arctic, Antarctic, and Alpine Research, v. 32, p. 147-154.

Daly, C., Gibson, W.P., Taylor, G.H., Johnson, G.L., and Pasteris, P., 2002, A knowledge-based approach to the statistical mapping of climate: Climate Research, v. 22, no. 2, p. 99-113.

Davis, J.P., 2004, Fine root dynamics along an elevational gradient in the southern Appalachian Mountains: Forest Ecology and Management, v. 187, p. 19-34.

Dittman, J.A., Driscoll, C.T., Groffman, P.M., and Fahey, T.J., 2007, Dynamics of nitrogen and dissolved organic carbon at the Hubbard Brook Experimental Forest: Ecology Letters, v. 88 , p. $1,153-1,166$.

Driscoll, C.T., Lawrence, G.B., Bulger, A.J., Butler, T.J., Cronan, C.S., Eagar, C., Lambert, K.F., Likens, G.E., Stoddard, J.L., and Weathers, K.C., 2001, Acidic deposition in the northeastern United States: Sources and inputs, ecosystem effects, and management strategies: Bioscience, v. 51, no. 3, p. 180-198.
Fahey, T.J., Siccama, T.G., Driscoll, C.T., Likens, G.E., Campbell, J., Johnson, C.E., Battles, J.J., Aber, J.D., Cole, J.J., Fisk, M.C., Groffman, P.M., Hamburg, S.P., Holmes, R.T., Schwarz, P.A., and Yanai, R.D., 2005, The biogeochemistry of carbon at Hubbard Brook: Biogeochemistry, v. 75, no. 1, p. 109-176.

Fenn, M.E., Baron, J.S., Allen, E.B., Rueth, H.M., Nydick, K.R., Geiser, L., Bowman, W.D., Sickman, J.O., Meixner, T., Johnson, D.W., and Neitlich, P., 2003, Ecological effects of nitrogen deposition in the western United States: Bioscience, v. 53, no. 4, p. 404-420.

Fiske, R.S., Hopson, C.A., and Waters, A.C., 1964, Geologic map and section of Mount Rainier National Park, Washington: U.S. Geological Survey Investigations Map, scale 1:62,500.

Fredriksen, R., 2007, Long-term stream chemistry concentrations and fluxes - Small watershed proportional samples in the Andrews Experimental Forest. Forest science data bank CF002 [database]: Corvallis, Oreg., Oregon State University, Andrews Experimental Forest Long-Term Ecological Research, http://andrewsforest.oregonstate.edu/ index.cfm.

Galloway, J.N., Keene, W.C., and Likens, G.E., 1996, Processes controlling the composition of precipitation at a remote southern hemispheric location-Torres del Paine National Park, Chile: Journal of Geophysical ResearchAtmospheres, v. 101, no. D3, p. 6,883-6,897.

Galloway, J.N., Townsend, A.R., Erisman, J.W., Bekunda, M., Cai, Z.C., Freney, J.R., Martinelli, L.A., Seitzinger, S.P., and Sutton, M.A., 2008, Transformation of the nitrogen cycle-Recent trends, questions, and potential solutions: Science, v. 320, no. 5878, p. 889-892.

Gbondo-Tugbawa, S.S., Driscoll, C.T., Aber, J.D., and Likens, G.E., 2001, Evaluation of an integrated biogeochemical model (PnET-BGC) at a northern hardwood forest ecosystem: Water Resources Research, v. 37, no. 4, p. $1,057-1,070$.

Gilman, R.A., Chapman, C.A., Lowell, T.V., and Borns, H.W., 1988, The geology of Mount Desert Island-A visitor's guide to the geology of Acadia National Park: Maine Geological Survey Bulletin 38.

Goodale, C.L., Aber, J.D., and Vitousek, P.M., 2003, An unexpected nitrate decline in New Hampshire streams: Ecosystems, v. 6, no. 1, p. 75-86.

Hartman, M.D., Baron, J.S., Lammers, R.B., Cline, D.W., Band, L.E., Liston, G.E., and Tague, C., 1999, Simulations of snow distribution and hydrology in a mountain basin: Water Resources Research, v. 35, no. 5, p. 1,587-1,603. 
Hartman, M.D., Baron, J.S., and Ojima, D.S., 2007, Application of a coupled ecosystem-chemical equilibrium model, DayCent-Chem, to stream and soil chemistry in a Rocky Mountain watershed: Ecological Modelling, v. 200, no. 3-4, p. $493-510$.

Hatcher, R.D., Jr., 1988, Bedrock geology and regional geologic setting of Coweeta Hydrologic Laboratory in the eastern Blue Ridge, in Swank, W.T., and Crossley, D.A., Jr., eds., Forest hydrology and ecology at Coweeta. Ecological Studies, v. 66: New York, Springer-Verlag, p. 81-92.

Hibbert, A.R., and Troendle, C.A., 1988, Streamflow generation by variable source area, in Swank, W.T., and Crossley, D.A., Jr., eds., Forest hydrology and ecology at Coweeta. Ecological Studies, v. 66: New York, Springer-Verlag, p. 111-127.

Jagels, R., Carlisle, J., Cunningham, R., Serreze, S., and Tsai, P., 1989, Impact of acid fog and ozone on coastal red spruce: Water Air and Soil Pollution, v. 48, no. 1-2, p. 193-208.

Jefts, S., Fernandez, I.J., Rustad, L.E., and Dail, D.B., 2004, Decadal responses in soil $\mathrm{N}$ dynamics at the Bear Brook Watershed in Maine, USA: Forest Ecology and Management, v. 189, no. 1-3, p. 189-205.

Johnson, C.E., Johnson, A.H., and Siccama, T.G., 1991, Whole-tree clear-cutting effects on exchangeable cations and soil acidity: Soil Science Society of America Journal, v. 55, p. 502-508.

Johnson, D.W., and Lindberg, S.E., 1992, Atmospheric deposition and forest nutrient cycling - A synthesis of the integrated forest study. Ecological Studies, v. 91: New York, Springer-Verlag, $707 \mathrm{p}$.

Johnson, D.W., Sogn, T., and Kvindesland, S., 2000, The nutrient cycling model—Lessons learned: Forest Ecology and Management, v. 138, no. 1-3, p. 91-106.

Johnson, D.W., Van Miegroet, H., Lindberg, S.E., Todd, D.E., and Harrison, R.B., 1991, Nutrient cycling in red spruce forests of the Great Smoky Mountains: Canadian Journal of Forest Research-Revue, v. 21, no. 6, p. 769-787.

Jordan, G.B., 1998, Soil survey of Hancock County area, Maine: U.S. Department of Agriculture, Natural Resources Conservation Service, 278 p.

Joslin, J.D., Kelly, J.M., and van Miegroet, H., 1992, Soil chemistry and nutrition of North American spruce-fir stands-Evidence for recent change: Journal of Environmental Quality, v. 21, no. 1, p. 12-30.
Kahl, J.S., 2005, Acadia Paired Research WatershedsMonthly Mean Chemistry (GMC): Orono, Maine, University of Maine Mitchell Center for Environmental and Watershed Research, PEARL metadata report, $h t t p: / / w w w$. pearl.maine.edu/DADataUpload/MetaData/GMC08.htm, 28 May 2007.

Kimball, K.D., Jagels, R., Gordon, G.A., Weathers, K.C., and Carlisle, J., 1988, Differences between New England coastal fog and mountain cloud water chemistry: Water Air and Soil Pollution, v. 39, no. 3-4, p. 383-393.

King, P.B., Neuman, R.B., and Hadley, J.B., 1968, Geology of the Great Smoky Mountains National Park: U.S. Geological Survey Professional Paper 587, 23 p.

Lajtha, K., Crow, S., Yano, Y., Kaushal, S., Sulzman, E., Sollins, P., and Spears, J., 2005, Detrital controls on soil solution $\mathrm{N}$ and dissolved organic matter in soils-A field experiment: Biogeochemistry v. 76, p. 261-281.

Likens, G.E., and Bormann, F.H., 1995, Biogeochemistry of a forested ecosystem (2d ed.): New York, Springer-Verlag, $159 \mathrm{p}$.

Likens, G.E., Driscoll, C.T., and Buso, D.C., 1996, Long-term effects of acid rain-Response and recovery of a forest ecosystem: Science, v. 272, no. 5259, p. 244-246.

Likens, G.E., Driscoll, C.T., Buso, D.C., Mitchell, M.J., Lovett, G.M., Bailey, S.W., Siccama, T.G., Reiners, W.A., and Alewell, C., 2002, The biogeochemistry of sulfur at Hubbard Brook: Biogeochemistry, v. 60, no. 3, p. 235-316.

Lindberg, S.E., Johnson, D.W., and Bondietti, E.A., 1992, Background on research sites and methods, in Johnson, D.W., and Lindberg, S.E., eds., Atmospheric deposition and forest nutrient cycling - A synthesis of the integrated forest study. Ecological Studies, v. 91: New York, Springer-Verlag, p. 8-26.

Liu, F.J., Williams, M.W., and Caine, N., 2004, Source waters and flow paths in an alpine catchment, Colorado Front Range, United States: Water Resources Research, v. 40, no. 9, p. 16.

Liu, S., Munson, R., Johnson, D., Gherini, S., Summers, K., Hudson, R., Wilkinson, K., and Pitelka, L., 1991, Application of a nutrient cycling model (NuCM) to a northern mixed hardwood and a southern coniferous forest: Tree Physiology, v. 9, no. 1-2, p. 173-184.

Loscher, G.C., 2006, Hydrologic analysis of a steep forested watershed using spatially distributed measurements of soil moisture and soil infiltration properties: Logan, Utah, Utah State University, 184 p. 
Lovett, G.M., and Kinsman, J.D., 1990, Atmospheric pollutant deposition to high-elevation ecosystems: Atmospheric Environment Part A-General Topics, v. 24, no. 11, p. 2,767-2,786.

Lovett, G.M., Likens, G.E., Buso, D.C., Driscoll, C.T., and Bailey, S.W., 2005, The biogeochemistry of chlorine at Hubbard Brook, New Hampshire, USA: Biogeochemistry, v. 72, no. 2, p. 191-232.

Martin, L.A., Mulholland, P.J., Webster, J.R., and Valett, H.M., 2001, Denitrification potential in sediments of headwater streams in the southern Appalachian Mountains, USA: Journal of the North American Benthological Society, v. 20, no. 4, p. 505-519.

Mast, M.A., 1992, Geochemical characteristics, in Baron, J., ed., Biogeochemistry of a subalpine ecosystem—Loch Vale Watershed. Ecological Studies, v. 90: New York, SpringerVerlag, p. 93-107.

Mast, M.A., Drever, J.I., and Baron, J., 1990, Chemical weathering in the Loch Vale Watershed, Rocky Mountain National Park, Colorado: Water Resources Research, v. 26, no. 12, p. 2,971-2,978.

McKee, W., 2007, Meteorological data from benchmark stations at the Andrews Experimental Forest. Forest science data bank MS001 [database]: Corvallis, Oreg., Oregon State University, Andrews Experimental Forest Long-Term Ecological Research, http://www.fsl.orst.edu/lter/data/ abstract.cfm?dbcode $=$ MS001.

Meixner, T., Bales, R.C., Williams, M.W., Campbell, D.H., and Baron, J.S., 2000, Stream chemistry modeling of two watersheds in the Front Range, Colorado: Water Resources Research, v. 36, no. 1, p. 77-87.

Moore, P.T., Van Miegroet, H., and Nicholas, N.S., 2008, Examination of forest recovery scenarios in a southern Appalachian Picea-Abies forest: Forestry, v. 81, no. 2, p. 183-194.

National Research Council, 2004, Air quality management in the United States: Report of the Committee on Air Quality Management in the United States, Washington, D.C., National Academies Press, 426 p.

Nelson, P.O., 1991, Cascade Mountains, in Charles, D.F., ed., Acidic deposition and aquatic ecosystems-Regional case studies: New York, Springer-Verlag, p. 531-563.

Nelson, S.J., 2002, Determining atmospheric deposition inputs to two small watersheds at Acadia National Park: Orono, Maine, University of Maine, M.S. thesis, 163 p.

Nicholas, N.S., Zedaker, S.M., and Eagar, C., 1992, A comparison of overstory community structure in 3 southern Appalachian spruce-fir forests: Bulletin of the Torrey Botanical Club, v. 119, no. 3, p. 316-332.
Nilles, M.A., and Conley, B.E., 2001, Changes in the chemistry of precipitation in the United States, 1981-1998: Water Air and Soil Pollution, v. 130, no. 1-4, p. 409-414.

Outcalt, S.I., and MacPhail, D.D., 1980, A survey of neoglaciation in the Front Range of Colorado, in Ives, J.D., ed., Geoecology of the Colorado Front Range: Boulder, Colo., Westview Press, p. 203-208.

Parker, J.L., Fernandez, I.J., Rustad, L.E., and Norton, S.A., 2001, Effects of nitrogen enrichment, wildfire, and harvesting on forest-soil carbon and nitrogen: Soil Science Society of America Journal, v. 65, no. 4, p. 1,248-1,255.

Parkhurst, D.L., and Appelo, C.A.J., 1999, User's guide to PHREEQC (Version 2)—A computer program for speciation, batch-reaction, one-dimensional transport, and inverse geochemical calculations: U.S. Geological Survey WaterResources Investigations Report 99-4259, 312 p.

Parton, W.J., Hartman, M., Ojima, D., and Schimel, D., 1998, DAYCENT and its land surface submodel-Description and testing: Global and Planetary Change, v. 19, no. 1-4, p. 35-48.

Pauley, E.F., Nodvin, S.C., Nicholas, N.S., Rose, A.K., and Coffey, T.B., 1996, Vegetation, biomass, and nitrogen pools in a spruce-fir forest of the Great Smoky Mountains National Park: Bulletin of the Torrey Botanical Club, v. 123, no. 4, p. 318-329.

Pregitzer, K.S., and Euskirchen, E.S., 2004, Carbon cycling and storage in world forests-Biome patterns related to forest age: Global Change Biology, v. 10, no. 12, p. 2,052-2,077.

Price, J.R., Velbel, M.A., and Patino, L.C., 2005, Rates and time scales of clay-mineral formation by weathering in saprolitic regoliths of the southern Appalachians from geochemical mass balance: Geological Society of America Bulletin, v. 117, no. 5-6, p. 783-794.

Qualls, R.G., Haines, B.L., Swank, W.T., and Tyler, S.W., 2002, Retention of soluble organic nutrients by a forested ecosystem: Biogeochemistry, v. 61, p. 135-171.

Reynolds, C.A., Jackson, T.J., and Rawls, W.J., 2000, Estimating soil water-holding capacities by linking the food and agriculture organization soil map of the world with global pedon databases and continuous pedotransfer functions: Water Resources Research, v. 36, no. 12, p. 3,653-3,662.

Rothacher, J., 2007, Small watershed streamflow summaries at the Andrews Experimental Forest. Forest science data bank HF004 [database]: Corvallis, Oreg., Oregon State University, Andrews Experimental Forest Long-Term Ecological Research, http://andrewsforest.oregonstate.edu. 
Schauffler, M., Nelson, S.J., Kahl, J.S., Jacobson Jr., G.L., Haines, T.A., Patterson, W.A., and Johnson, K.B., 2007, Paleoecological assessment of watershed history in PRIMENet watersheds at Acadia National Park, USA: Environmental Monitoring and Assessment, v. 126, no. 1-3, p. 39-53.

Seastedt, T.R., 2001, Soils, in Bowman, W.D., and Seastedt, T.R., eds., Structure and function of an alpine ecosystemNiwot Ridge, Colorado: New York, Oxford University Press, p. 157-173.

Sheehan, K.D., Fernandez, I.J., Kahl, J.S., and Amirbahman, A., 2006, Litterfall mercury in two forested watersheds at Acadia National Park, Maine, USA: Water Air and Soil Pollution, v. 170, no. 1-4, p. 249-265.

Shure, D.J., Phillips, D.L., and Bostick, P.E., 2006, Gap size and succession in cutover southern Appalachian forestsAn 18 year study of vegetation dynamics: Plant Ecology, v. 185, no. 2, p. 299-318.

Swank, W.T., Reynolds, L.J., and Vose, J.M., 1992, Appendix: Nutrient Flux and Content Data from the Intgrated Forest (IFS) Sites, in Johnson, D.W., and Lindberg, S.E., eds., Atmospheric deposition and forest nutrient cycling-A synthesis of the integrated forest study. Ecological Studies, v. 91: New York, Springer-Verlag, p. 610-688.

Swanson, F.J., and James, M.E., 1975, Geology and geomorphology of the H.J. Andrews Experimental Forest, western Cascades, Oregon: U.S. Department of Agriculture Forest Service, Pacific Northwest Forest and Range Experiment Station Research Paper PNW-188, 14 p.

Swift, L.W.J., Cunningham, G.B., and Douglass, J.E., 1988, Climatology and hydrology, in Swank, W.T., and Crossley, D.A., Jr., eds., Forest hydrology and ecology at Coweeta. Ecological Studies, v. 66: New York, Springer Verlag, p. 35-55.

USDA National Resource Conservation Service, 2006, U.S. General Soil Map (STATSGO2) for North Carolina: National Soil Survey Center Soil Data Mart database, http://soildatamart.nrcs.usda.gov, January 2006.

U.S. Geological Survey, 2008, USGS 01022860 Hadlock Bk nr Cedar Swamp Mtn nr Northeast Hbr, ME: U.S. Geological Survey National Water Information System, http://waterdata.usgs.gov/me/nwis/uv/?site_no $=01022860$, 22 September 2006.

Tewksbury, C.E., and Van Miegroet, H., 2007, Soil organic carbon dynamics along a climatic gradient in a southern Appalachian spruce-fir forest: Canadian Journal of Forest Research, v. 37, no. 7, p. 1,161-1,172.
Van Miegroet, H., Creed, I.F., Nicholas, N.S., Tarboton, D.G., Webster, K.L., Shubzda, J., Robinson, B., Smoot, J., Johnson, D.W., Lindberg, S.E., Lovett, G., Nodvin, S., and Moore, S., 2001, Is there synchronicity in $\mathrm{N}$ input and output fluxes at the Noland Divide Watershed, a small $\mathrm{N}$-saturated forested catchment in the Southern Appalachians?: The Scientific World, v. 1, no. S2, p. 480-492.

Van Miegroet, H., Johnson, D.W., and Todd, D.E., 1993, Foliar response of red spruce saplings to fertilization with Ca and Mg in the Great Smoky Mountains National Park: Canadian Journal of Forest Research, v. 23, no. 1, p. 89-95.

Van Miegroet, H., Moore, P.T., Tewksbury, C.E., and Nicholas, N.S., 2007, Carbon sources and sinks in high-elevation spruce-fir forests of the southeastern US: Forest Ecology and Management, v. 238, no. 1-3, p. 249-260.

Velbel, M.A., 1985a, Geochemical mass balances and weathering rates in forested watersheds of the Southern Blue Ridge: American Journal of Science, v. 285, no. 10, p. 904-930.

Velbel, M.A., 1985b, Hydrogeochemical constraints on mass balances in forested watersheds of the southern Appalachians, in Drever, J.I., ed., The chemistry of weathering: Dordrecht, The Netherlands, D. Reidel Publishing Company, p. 231-247.

Velbel, M.A., 1988, Weathering and soil-forming processes, in Swank, W.T., and Crossley, D.A. Jr., eds., Forest hydrology and ecology at Coweeta. Ecological Studies, v. 66: New York, Springer-Verlag, p. 93-102.

Velbel, M.A., 1995, Interaction of ecosystem processes and weathering processes, in Trudgill, S.T., ed., Solute modeling in catchment systems: New York, N.Y., John Wiley \& Sons Ltd., p. 193-209.

Vermes, J.F., and Myrold, D.D., 1992, Denitrification in forest soils of Oregon: Canadian Journal of Forest Research, v. 22, no. 4, p. 504-512.

Wallace, R.G., 1967, Type and rates of alpine mass movement, west edge of Boulder County, Colorado Front Range: Columbus, Ohio, Ohio State University, Ph.D. dissertation, 200 p.

Walthall, P.M., 1985, Acidic deposition and the soil environment of Loch Vale Watershed in Rocky Mountain National Park: Fort Collins, Colo., Colorado State University, Ph.D. dissertation, $148 \mathrm{p}$.

Weathers, K.C., Likens, G.E., Bormann, F.H., Eaton, J.S., Bowden, W.B., Andersen, J.L., Cass, D.A., Galloway, J.N., Keene, W.C., Kimball, K.D., Huth, P., and Smiley, D., 1986, A regional acidic cloud fog water event in the eastern United States: Nature, v. 319, no. 6055, p. 657-658. 
Weathers, K.C., Likens, G.E., Bormann, F.H., Bicknell, S.H., Bormann, B.T., Daube, B.C., Eaton, J.S., Galloway, J.N., Keene, W.C., Kimball, K.D., McDowell, W.H., Siccama, T.G., Smiley, D., and Tarrant, R.A., 1988, Cloudwater chemistry from 10 sites in North America: Environmental Science \& Technology, v. 22, no. 9, p. 1,018-1,026.

Weathers, K.C., Likens, G.E., and Butler, T.J., 2006, Acid rain, in Rom, W., ed., Environmental and occupational medicine (4th ed.): Philadelphia, Pa., Lippincott-Raven and Wilkins Publishers, p. 1,507-1,522.

Weathers, K.C., and Lovett, G.M., 1998, Acid deposition research and ecosystem science-Synergistic successes, in Pace, M.L., and Groffman, P.M., eds., Successes, limitations, and frontiers in ecosystem science. Cary Conference VII, Millbrook, N.Y., May 1997, Proceedings: New York, Springer-Verlag, p. 195-219.

Weathers, K.C., Simkin, S.M., Lovett, G.M., and Lindberg, S.E., 2006, Empirical modeling of atmospheric deposition in mountainous landscapes: Ecological Applications, v. 16, no. 4, p. 1,590-1,607.

Wiersma, G.B., Elvir, J.A., and Eckhoff, J.D., 2007, Forest vegetation monitoring and foliar chemistry of red spruce and red maple at Acadia National Park in Maine: Environmental Monitoring and Assessment, v. 126, no. 1-3, p. 27-37.

Williams, M.W., Hood, E., and Caine, N., 2001, Role of organic nitrogen in the nitrogen cycle of a high-elevation catchment, Colorado Front Range: Water Resources Research, v. 37, no. 10, p. 2,569-2,581.

Williams, M.W., Knauf, M., Caine, N., Liu, F., and Verplanck, P.L., 2006, Geochemistry and source waters of rock glacier outflow, Colorado Front Range: Permafrost and Periglacial Processes, v. 17, no. 1, p. 13-33.

Williams, M.W., Knauf, M., Cory, R., Caine, N., and Liu, F., 2007, Nitrate content and potential microbial signature of rock glacier outflow, Colorado Front Range: Earth Surface Processes and Landforms, v. 32, no. 7, p. 1,032-1,047. 


\section{Appendix 1. Abbreviations Used in This Document}

\begin{tabular}{|c|c|}
\hline Al & Aluminum \\
\hline ANC & Acid neutralizing capacity \\
\hline AET & Actual evapotranspiration \\
\hline BC & Base cations (Ca, Mg, K, Na) \\
\hline C & Carbon \\
\hline Ca & Calcium \\
\hline CASTNet & Clean Air Status and Trends Network \\
\hline CEC & Cation exchange capacity \\
\hline Cl & Chloride \\
\hline $\mathrm{CO}_{2}$ & Carbon dioxide \\
\hline $\mathrm{CO}_{3}^{2-}$ & Carbonate \\
\hline DOC & Dissolved organic carbon \\
\hline DON & Dissolved organic nitrogen \\
\hline EPA & Environmental Protection Agency \\
\hline ET & Evapotranspiration \\
\hline Fe & Iron \\
\hline FS & U.S. Forest Service \\
\hline GL4 & Green Lake 4 watershed \\
\hline H & Hydrogen \\
\hline $\mathrm{HCO}_{3}^{-}$or $\mathrm{HCO}_{3}$ & Bicarbonate \\
\hline K & Potassium \\
\hline LAI & Leaf area index \\
\hline LVWS & Loch Vale watershed \\
\hline Mg & Magnesium \\
\hline Mn & Manganese \\
\hline $\mathbf{N}$ & Nitrogen \\
\hline $\mathrm{Na}$ & Sodium \\
\hline NADP & National Atmospheric Deposition Program \\
\hline NADP/NTN & $\begin{array}{l}\text { National Atmospheric Deposition Program/National } \\
\text { Trends Network }\end{array}$ \\
\hline NOAA & National Oceanic and Atmospheric Administration \\
\hline NRCS & National Resource Conservation Service \\
\hline NTN & National Trends Network \\
\hline NEP & Net ecosystem production (NPP - Rh) \\
\hline $\mathrm{NH}_{4}^{+}$or $\mathrm{NH}_{4}$ & Ammonium \\
\hline $\mathrm{NO}_{3}^{-}$or $\mathrm{NO}_{3}$ & Nitrate \\
\hline NPP & Net primary production \\
\hline NPS & National Park Service \\
\hline $\mathbf{0}$ & Oxygen \\
\hline Org $^{3-}$ & The organic analog anion in soil solution \\
\hline $\mathbf{P}$ & Phosphorus \\
\hline PET & Potential evapotranspiration \\
\hline $\mathbf{R h}$ & Heterotrophic respiration \\
\hline
\end{tabular}


172 DayCent-Chem Simulations of Ecological and Biogeochemical Processes of Eight Mountain Ecosystems in the U.S.

S Sulfur

Si Silica

$\mathrm{SO}_{4}{ }^{2-}$ or $\mathrm{SO}_{4} \quad$ Sulfate

SNOTEL SNOwpack TELemetry

Std. dev. Standard deviation

TE

Total evapotranspiration

USGS U.S. Geological Survey

VWM Volume-weighted mean 


\section{Contributing Authors}

Melannie D. Hartman

Natural Resource Ecology Laboratory

Colorado State University

Fort Collins, CO

Jill S. Baron

Natural Resource Ecology Laboratory

Colorado State University

Fort Collins, CO

Fort Collins Science Center

U.S. Geological Survey

Fort Collins, CO

David W. Clow

Colorado Water Science Center

U.S. Geological Survey

Lakewood, CO

Irena F. Creed

University of Western Ontario

London, Ontario, Canada

Charles T. Driscoll

Syracuse University

Syracuse, NY

Holly A. Ewing

Bates College

Lewiston, ME

Bruce D. Haines (deceased)

Plant Biology Department

University of Georgia

Athens, GA

Jennifer Knoepp

Coweeta Hydrologic Laboratory

USDA Forest Service-SRS

Otto, NC

Kate Lajtha

Department of Botany and Plant Pathology

Oregon State University

Corvallis, OR
Dennis S. Ojima

The H. John Heinz III Center for Science, Economics, and the Environment

Washington, D.C.

William J. Parton

Natural Resource Ecology Laboratory

Colorado State University

Fort Collins, CO

Jim Renfro

Resource Management and Science DivisionAir Quality Branch

Great Smoky Mountains National Park

Gatlinburg, TN

R. Bruce Robinson

University of Tennessee

Knoxville, TN

Helga Van Miegroet

Departments of Wildland Resources and Watershed Sciences

Utah State University

Logan, UT

Kathleen C. Weathers

Cary Institute of Ecosystem Studies

Millbrook, NY

Mark W. Williams

INSTAAR

University of Colorado

Boulder, CO 
Publishing support provided by:

Denver Publishing Service Center

For more information concerning this publication, contact:

Center Director, USGS Fort Collins Science Center

2150 Centre Ave., Bldg. C

Fort Collins, CO 80526-8118

(970) 226-9398

Or visit the Fort Collins Science Center Web site at: http://www.fort.usgs.gov/ 


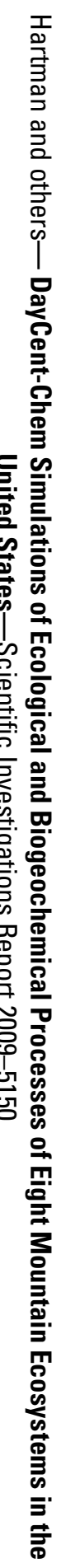

